Hiroshi Ehara · Yukio Toyoda

Dennis V. Johnson Editors

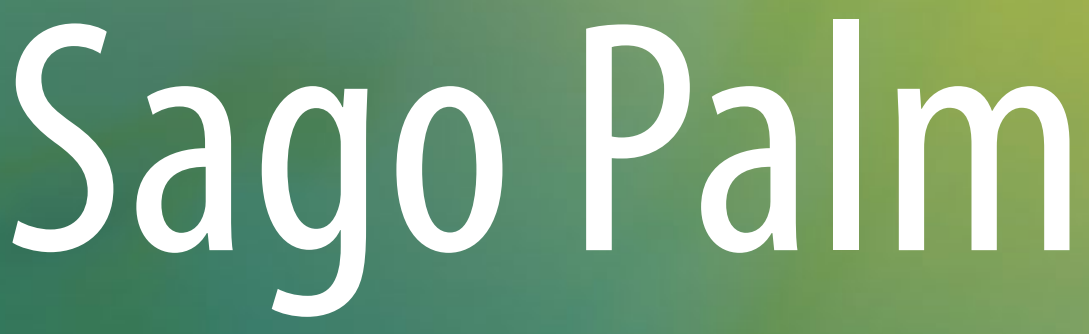

Multiple Contributions to Food Security and Sustainable Livelihoods 
Sago Palm 
Hiroshi Ehara • Yukio Toyoda

Dennis V. Johnson

Editors

\section{Sago Palm}

Multiple Contributions to Food Security and Sustainable Livelihoods

黛 Springer Open 


\section{Editors}

Hiroshi Ehara

Applied Social System Institute of Asia; International Cooperation Center for

Agricultural Education

Nagoya University

Nagoya, Japan

\section{Dennis V. Johnson \\ Cincinnati, OH, USA}

\author{
Yukio Toyoda \\ College of Tourism \\ Rikkyo University \\ Niiza, Saitama, Japan
}

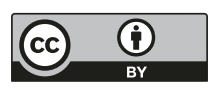

ISBN 978-981-10-5268-2 ISBN 978-981-10-5269-9 (eBook)

https://doi.org/10.1007/978-981-10-5269-9

Library of Congress Control Number: 2017954957

(C) The Editor(s) (if applicable) and The Author(s) 2018, corrected publication 2018. This book is an open access publication.

Open Access This book is licensed under the terms of the Creative Commons Attribution 4.0 International License (http://creativecommons.org/licenses/by/4.0/), which permits use, sharing, adaptation, distribution and reproduction in any medium or format, as long as you give appropriate credit to the original author(s) and the source, provide a link to the Creative Commons license and indicate if changes were made.

The images or other third party material in this book are included in the book's Creative Commons license, unless indicated otherwise in a credit line to the material. If material is not included in the book's Creative Commons license and your intended use is not permitted by statutory regulation or exceeds the permitted use, you will need to obtain permission directly from the copyright holder.

The use of general descriptive names, registered names, trademarks, service marks, etc. in this publication does not imply, even in the absence of a specific statement, that such names are exempt from the relevant protective laws and regulations and therefore free for general use.

The publisher, the authors and the editors are safe to assume that the advice and information in this book are believed to be true and accurate at the date of publication. Neither the publisher nor the authors or the editors give a warranty, express or implied, with respect to the material contained herein or for any errors or omissions that may have been made. The publisher remains neutral with regard to jurisdictional claims in published maps and institutional affiliations.

Printed on acid-free paper

This Springer imprint is published by Springer Nature

The registered company is Springer Nature Singapore Pte Ltd.

The registered company address is: 152 Beach Road, \#21-01/04 Gateway East, Singapore 189721, Singapore 


\section{Preface}

\section{Sago supports the welfare of human and the planet: Commemoration of SAGO 2015 Tokyo}

In 2015, the 12th International Sago Symposium (SAGO 2015) entitled Sago Supports Human and Planet Welfare was held in Rikkyo University, Ikebukuro, Tokyo. It was the third international symposium on sago to have been held in Japan, supported by the Japanese Society for Tropical Agriculture (JSTA); the Japanese Society of Applied Glycoscience (JSAG); United Nations of Food and Agriculture (FAO) Regional Office for Asia and the Pacific; the Ministry of Agriculture, Forestry and Fisheries of the Government of Japan (MAFF); Japan International Cooperation Agency (JICA), the Japan International Research Center for Agricultural Studies (JIRCAS), and Rikkyo University. About 120 participants including 78 sago specialists from many countries in the world came to Ikebukuro to participate in the symposium. Through the discussion during the symposium, it was concluded by the organizing committee of SAGO 2015 that a book on sago should be published by the Society of Sago Palm Studies from the viewpoint of new aspects. The society contacted Springer Publishing Company to publish a book on sago. Much of the contribution for this book was financially supported by the late Isao Nagato and Rikkyo University, which accepted the financial proposal from the society.

Sago palm (Metroxylon sagu Rottb.) can be grown in wetland swamps of Southeast Asia and the Pacific islands where other food crops cannot grow economically and produce high yield of starch. It is one of the typical indigenous food crops with very little attention and research. Since other food crops cannot be grown, sago palm has a high potential to contribute to food security and improvement of health and human welfare as an additional source of staple food without competition for the use of arable lands.

Sago palm can absorb a large amount of carbon dioxide to counteract global warming and climate change and grow up to $20 \mathrm{~m}$ in height, accumulating starch in its trunk. Few people know that Japan has imported around 20,000 mt of raw sago starch from Malaysia and Indonesia for more than 20 years. Sago starch is typically 
used as dusting starch in Japan. Sago starch granules are relatively large and uniform, making them ideal for the separation of adhesive noodles but more costly than cassava starch. Accordingly, sago starch always has a competitive price compared to cassava starch in the world trade market.

The late Dr. Isao Nagato supported sago studies based on his belief that sago palm will strongly contribute to solving the food crisis in this century and invested large sums of his funds in sago palm and related research. He established the foundations of sago palm research in Japan to promote sago palm research for young scientists. As a result, Japan has come to lead in international research on sago, even though no growing areas of sago palm naturally are present in Japan. He recognized the potential power of sago palm in vast tropical lowland areas with brackish water.

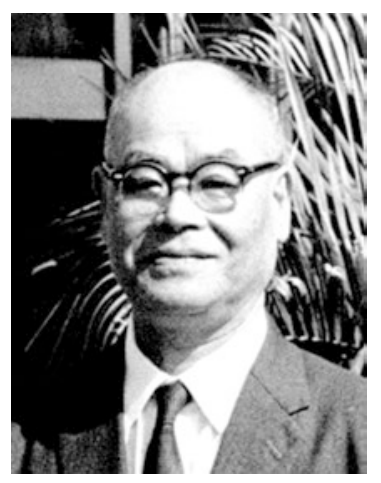

The late Dr. Isao Nagato

We acknowledge all of the contributors of this book and Springer Publishing Company and hope that this book is useful to sago researchers and serves human and planet welfare.

Nagoya, Japan

Niiza, Japan

Cincinnati, USA
Hiroshi Ehara

Yukio Toyoda

Dennis V. Johnson

Masanori Okazaki

Chair of the 12th International Sago Symposium 


\section{Contents}

\section{Part I Introduction of Sago Resources}

1 Status and Outlook of Global Food Security and the Role of Underutilized Food Resources: Sago Palm Hiroyuki Konuma

2 Growing Area of Sago Palm and Its Environment. Mochamad Hasjim Bintoro, Muhammad Iqbal Nurulhaq, Agief Julio Pratama, Fendri Ahmad, and Liska Ayulia

3 Life and Livelihood in Sago-Growing Areas Yukio Toyoda

Part II Diversity of Sago Resource in Asia and Pacific

4 Genetic Variation and Agronomic Features of Metroxylon Palms in Asia and Pacific

Hiroshi Ehara

5 Sago Palm Genetic Resource Diversity in Indonesia Barahima Abbas

Part III Sago Industry Contributes for Food Security and Rural Development in Core Producing Countries

6 An Overview of Sago Industry Development, 1980s-2015 F.S. Jong

7 Suitability of Peat Swamp Areas for Commercial Production of Sago Palms: The Sarawak Experience Roland Yong Chiew Ming, Yusup Sobeng, Fariza Zaini, and Noraini Busri 
8 Feasibility of Small-Scale Sago Industries in the Maluku

Islands, Indonesia

Wardis Girsang

9 Addressing Food Insecurity in Papua New Guinea Through

Food Safety and Sago Cropping

Aisak G. Pue, Mary T. Fletcher, Barry Blaney, Andrew R. Greenhill,

Jeffery M. Warner, Atagazli Latifa, and Jack C. Ng

10 Conservation and Sustainable Utilization

of the Fiji Sago Palm Metroxylon vitiense

Dick Watling

\section{Part IV Agricultural Botany of Sago Palm}

11 Dry Matter Production as a Basis of Starch Production in Sago Palm

Yoshinori Yamamoto

12 Morphogenesis of Sago Palm

Satoshi Nakamura

13 Morphological and Anatomical Characteristics

of Sago Palm Starch

Yoji Nitta

\section{Part V Growth Environment}

14 Soil Environment in Sago Palm Forest.

Masanori Okazaki and Yuka Sasaki

15 Microbial Interactions and Activities Affecting Sago

Palm Growth

Koki Toyota

\section{Part VI Starch Production and Utilization}

16 Sago Starch: Transformation of Extraction and Consumption Processes in Traditional Indonesian Societies

Yoshihiko Nishimura

17 Improvement of Sago Processing Machinery

Darma

18 The Structure and Characteristics of Sago Starch

Masanori Okazaki

19 Recovery of Starch from Sago Pith Waste and Waste

Water Treatment

Budi Santoso 
20 Acid Modification of Sago Hampas for Industrial Purposes

Titi Candra Sunarti, Vioni Derosya, and Indah Yuliasih

\section{Part VII New Carbohydrate Resources}

21 Starch Properties and Uses as Food for Human Health and Welfare.

Kazuko Hirao, Tomoko Kondo, Keiji Kainuma, and Setsuko Takahashi

22 Production, Purification, and Health Benefits of Sago Sugar Kopli Bujang

23 New Sago Palm Starch Resources and Starch Pith Waste Properties Takashi Mishima

\section{Part VIII Conclusion}

24 Outcomes and Recommendations from the 12th International Sago Symposium

Yoshinori Yamamoto

Erratum 


\section{Contributors}

Barahima Abbas Faculty of Agriculture, University of Papua, Manokwari, Indonesia

Fendri Ahmad Department of Agronomy and Horticulture, Faculty of Agriculture, Bogor Agricultural University, Bogor, Indonesia

Liska Ayulia Department of Agronomy and Horticulture, Faculty of Agriculture, Bogor Agricultural University, Bogor, Indonesia

Mochamad Hasjim Bintoro Department of Agronomy and Horticulture, Faculty of Agriculture, Bogor Agricultural University, Bogor, Indonesia

Barry Blaney Queensland Alliance for Agriculture and Food Innovation, University of Queensland, Coopers Plains, QLD, Australia

Kopli Bujang Centre for Sago Research, Faculty of Resource Science and Technology, Universiti Malaysia Sarawak, Kota Samarahan, Sarawak, Malaysia

Noraini Busri CRAUN Research Sdn. Bhd, Kuching, Sarawak, Malaysia

Darma Faculty of Agricultural Technology, University of Papua, Manokwari, Indonesia

Vioni Derosya Department of Agroindustrial Technology, Faculty of Agricultural Technology and Engineering, Bogor Agricultural University, Bogor, Indonesia

Hiroshi Ehara Applied Social System Institute of Asia; International Cooperation Center for Agricultural Education, Nagoya University, Nagoya, Japan

Mary T. Fletcher Queensland Alliance for Agriculture and Food Innovation, University of Queensland, Coopers Plains, QLD, Australia

Wardis Girsang Faculty of Agriculture, University of Pattimura, Ambon, Indonesia

Andrew R. Greenhill Monash University, Melbourne, VIC, Australia 
Kazuko Hirao Aikoku Gakuen Junior College, Tokyo, Japan

Muhammad Iqbal Nurulhaq Department of Agronomy and Horticulture, Faculty of Agriculture, Bogor Agricultural University, Bogor, Indonesia

F.S. Jong Formerly, P.T. Lestari Sago Papu, Jakarta, Indonesia

Keiji Kainuma Tsukuba Science Academy, Tsukuba, Japan

Tomoko Kondo Kyoritsu Women's University, Tokyo, Japan

Hiroyuki Konuma ASEAN Center, Meiji University, Tokyo, Japan

Formerly, UN FAO Regional Representative for Asia and the Pacific, Khlong Nung, Thailand

Atagazli Latifa Department of Microbiology and Immunology, School Vet and Biomed Science, James Cook University, Townsville, QLD, Australia

Takashi Mishima Graduate School of Regional Innovation Studies, Mie University, Tsu, Japan

Satoshi Nakamura School of Food Industrial Science, Miyagi University, Sendai, Japan

Jack C. Ng National Research Centre for Environmental Toxicology, University of Queensland, Coopers Plains, QLD, Australia

Yoshihiko Nishimura Formerly, Nagoya University, Nagoya, Japan

Yoji Nitta The College of Agriculture, Ibaraki University, Ami, Ibaraki, Japan

Masanori Okazaki Japan Soil Research Institute Inc., Nishitokyo, Tokyo, Japan

Agief Julio Pratama Department of Agronomy and Horticulture, Faculty of Agriculture, Bogor Agricultural University, Bogor, Indonesia

Aisak G. Pue Papua New Guinea University of Natural Resources and Environment, PMB Kokopo, Papua New Guinea

Budi Santoso Faculty of Agricultural Technology, Papua University, Manokwari, West Papua, Indonesia

Yuka Sasaki Faculty of Agriculture, Yamagata University, Tsuruoka, Yamagata, Japan

Yusup Sobeng CRAUN Research Sdn. Bhd, Kuching, Sarawak, Malaysia

Titi Candra Sunarti Department of Agroindustrial Technology, Faculty of Agricultural Technology and Engineering, Bogor Agricultural University, Bogor, Indonesia

Setsuko Takahashi Kyoritsu Women's University, Tokyo, Japan

Yukio Toyoda College of Tourism, Rikkyo University, Niiza, Saitama, Japan 
Koki Toyota Tokyo University of Agriculture and Technology, Koganei, Tokyo, Japan

Jeffery M. Warner Department of Microbiology and Immunology, School Vet and Biomed Science, James Cook University, Townsville, QLD, Australia

Dick Watling NatureFiji-MareqetiViti, Suva, Fiji

Yoshinori Yamamoto Kochi University, Nankoku, Kochi, Japan

Roland Yong Chiew Ming CRAUN Research Sdn. Bhd, Kuching, Sarawak, Malaysia

Indah Yuliasih Department of Agroindustrial Technology, Faculty of Agricultural Technology and Engineering, Bogor Agricultural University, Bogor, Indonesia

Fariza Zaini CRAUN Research Sdn. Bhd, Kuching, Sarawak, Malaysia 
Part I

Introduction of Sago Resources 


\title{
Chapter 1 \\ Status and Outlook of Global Food Security and the Role of Underutilized Food Resources: Sago Palm
}

\author{
Hiroyuki Konuma
}

\begin{abstract}
The United Nations (FAO) projected that global food production needs to be increased by $60 \%$ by 2050 to meet increasing world demands as a result of rapid population growth and per capita food consumption increase. However, there is a very little room to expand agricultural land, while water scarcity is threatening future agricultural production potential. Under the circumstances, it is predicted that nearly $90 \%$ of the food production increase should come from existing arable land through yield increase and advancement of agricultural research and innovation. On the other hand, the world is facing other serious challenges and uncertainties resulting from the stagnation of productivity growth of major cereal crops, advancement of negative impacts of climate change, and competition on the use of agricultural land and water with bioenergy crops. It is uncertain if and whether the world can meet the challenging target by 2050 . Otherwise, the world food security, peace, and stability would be seriously threatened. The situation sparked scientific interest in identifying alternative food resources, which can be grown on underutilized lands without or with less competition with existing food crops, tolerant to stress environmental conditions, and produce a substantial quantity of food or starch. FAO recognized that neglected and underutilized species play a crucial role in the fight against hunger and are a key resource for agriculture and rural development for the benefit of smallholder farmers. In addition, many neglected and underutilized species play a role in keeping cultural diversity alive. They occupy important niches, conserving traditional landscape, adapted to the risky and fragile conditions of rural communities.

Against this backdrop, sago palm (Metroxylon sagu Rottb.) was identified as one of the most promising typical underutilized food crops with very little attention and research in the past. It can be grown in underutilized wetlands and peat swamps where other food crops cannot grow economically. It produces a high yield of edible starch (about 150-300 kg of dry starch per plant), while different parts of the palm
\end{abstract}

H. Konuma $(\varangle)$

ASEAN Center, Meiji University, Tokyo, Japan

Formerly, UN FAO Regional Representative for Asia and the Pacific, Khlong Nung, Thailand e-mail: hiroyukikonuma@outlook.com

H. Ehara et al. (eds.), Sago Palm, https://doi.org/10.1007/978-981-10-5269-9_1 
tree can be utilized as roofing materials, animal feeds, sago worm production, mat and basket weaving, etc., which would contribute to promoting national and household food security and enhancing family income and employment generation at rural villages.

\subsection{Present Status of Global Food Production and Food Security}

At present, as estimated by FAO, the world produces more or less sufficient food to meet the needs of world population and maintains sufficient food stock to cover nearly $25 \%$ of estimated annual utilization. Despite the positive situation on the supply side, FAO's estimation in 2014-2016 indicated that, globally, 795 million people were unable to meet their dietary energy requirements. Thus, around one in nine people in the world is suffering from chronic hunger and does not have sufficient nutritionally balanced food for an active and healthy life. The vast majority of these undernourished and chronically hungry people live in developing world (FAO 2015).

While at the global level, there has been an overall reduction in the number of undernourished people between 1990/1992 and 2014/2016 (Fig. 1.1), different rates of progress across the regions have led to change in the distribution of undernourished people in the world. Most of the world's undernourished people are still found in Southern Asia, closely followed by sub-Saharan Africa and Eastern Asia. Asia is a home of nearly two thirds $(63 \%)$ of the total undernourished population (FAO 2015).
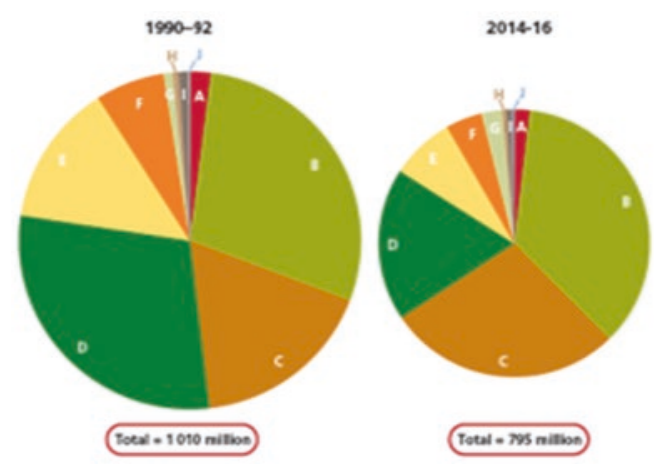

\begin{tabular}{|c|c|c|c|c|}
\hline & \multicolumn{2}{|c|}{$\begin{array}{l}\text { Number } \\
\text { imilions }\end{array}$} & \multicolumn{2}{|c|}{$\begin{array}{c}\text { Regional share } \\
\text { (5) }\end{array}$} \\
\hline & $1990-92$ & $2014-16$ & $1990-92$ & 2014-16 \\
\hline Q Doveloped regions & 20 & 15 & 20 & 18 \\
\hline O Souchers Adia & 291 & 281 & 23.8 & 35.4 \\
\hline OS Subsaharan Atrika & 176 & 220 & 17.4 & 273 \\
\hline O Extern Asia & 285 & 145 & 29.2 & 18.3 \\
\hline OSouth-Eastern Acia & 138 & 61 & 13.6 & 7.6 \\
\hline $\begin{array}{l}0 \text { Latin America } \\
\text { and the Caritcean }\end{array}$ & 66 & 34 & 6.5 & 4.3 \\
\hline Western Asia & 8 & 19 & 0.8 & 24 \\
\hline Northers Africa & 6 & 4 & 0.6 & 0.5 \\
\hline $\begin{array}{l}\text { O Gucaass and } \\
\text { Central Assa }\end{array}$ & 10 & 6 & 0.9 & 0.7 \\
\hline OOceania & 1 & 1 & 0.1 & 0.2 \\
\hline Total & 1011 & 735 & 100 & 100 \\
\hline
\end{tabular}

Note the res
sounce ito

Fig. 1.1 Status of world chronic hunger population (FAO 2015) 


\subsection{Future Outlook Toward 2050}

\subsubsection{Population and Consumption Increase}

The questions are what is the food requirement to meet the needs of growing population and what is the future prospect of the production and challenges to ensure food security for our children and future generations. One of the current UN projections indicates that world population could increase by more than 2 billion people from today's level, reaching around 9.3 billion by 2050 (Fig. 1.2). Incomes and per capita calorie intake will grow even faster. According to FAO's estimate, by 2050, some $52 \%$ of the world's population may live in countries where average calorie intake is more than $3000 \mathrm{kcal} /$ person/day, while the number of people living in countries with an average below $2500 \mathrm{kcal}$ may fall from 2.3 billion to 240 million (FAO 2015).

\subsubsection{World Needs 60\% Food Production Increase by 2050}

To meet rapidly increasing combined food demand from both population growth and per capita food consumption increase, FAO projects that global agricultural production in 2050 would have to be $60 \%$ higher than that of in 2005/2007 if the world is going to satisfy food requirement at that time (FAO 2012a).

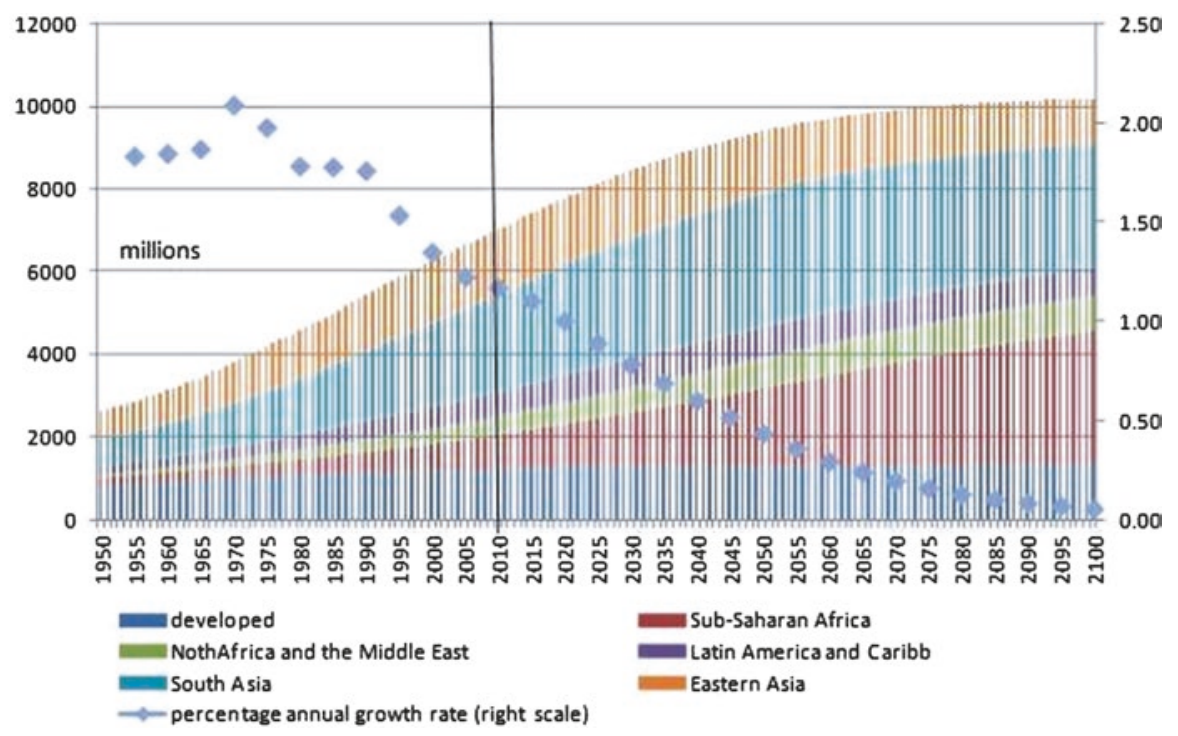

Fig. 1.2 World population trends (Source: UN) 


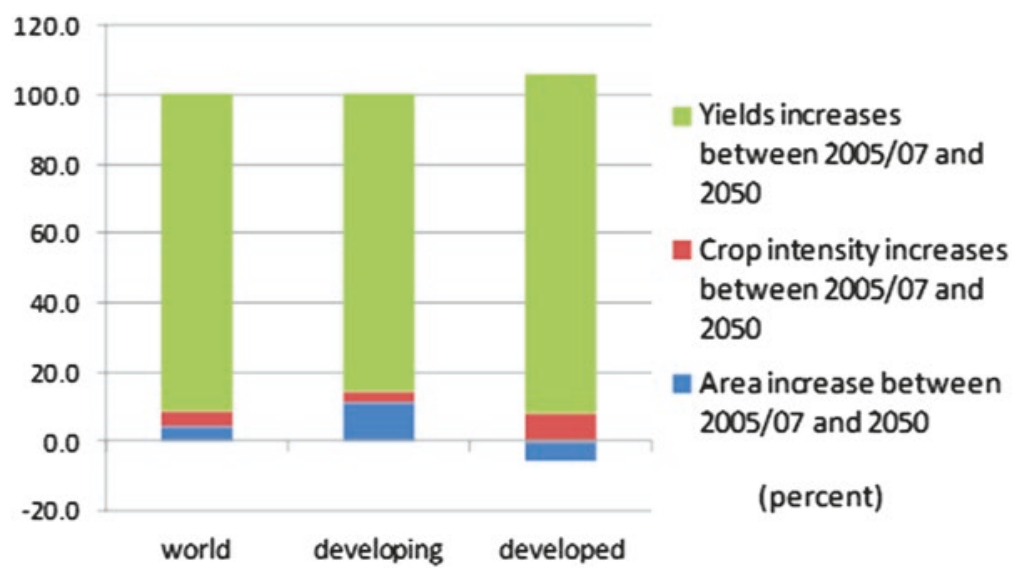

Fig. 1.3 Sources of production growth from 2005/2007 to 2050 (FAO 2012b)

\subsubsection{Agricultural Research Is the Key for Achieving Future Food Security}

According to a FAO study, most of the increase in production (nearly $90 \%$ ) leading up the year 2050 (from 2005/2007 to 2050) is expected to derive from improved yields through agricultural research (Fig. 1.3). Some gains would also come from higher cropping intensity, predominantly in developed countries (FAO 2012b), and about $5 \%$ increase ( 70 million ha) from the expansion of arable land, mainly from developing countries in Africa and Latin America (FAO 2012b).

\subsection{Future Challenges and Uncertainties}

While it might be possible to increase food production by $60 \%$ by 2050 if the above assumptions and prerequisites are met, there would be a number of serious challenges and uncertainties as explained below.

\subsubsection{Stagnation of the Increase of Arable Lands}

Globally, expansion of arable land could be stagnated. Land under crops is projected to increase only by some 70 million ha (about $5 \%$ increase from the level in 2005/2007) by 2050 (Fig. 1.4). As much of the spare land is concentrated in a small number of countries, constraints may be very pronounced in other countries and regions. Where these constraints are coupled with fast population growth and inadequate income opportunities, land scarcity can lead to more poverty and migration. 


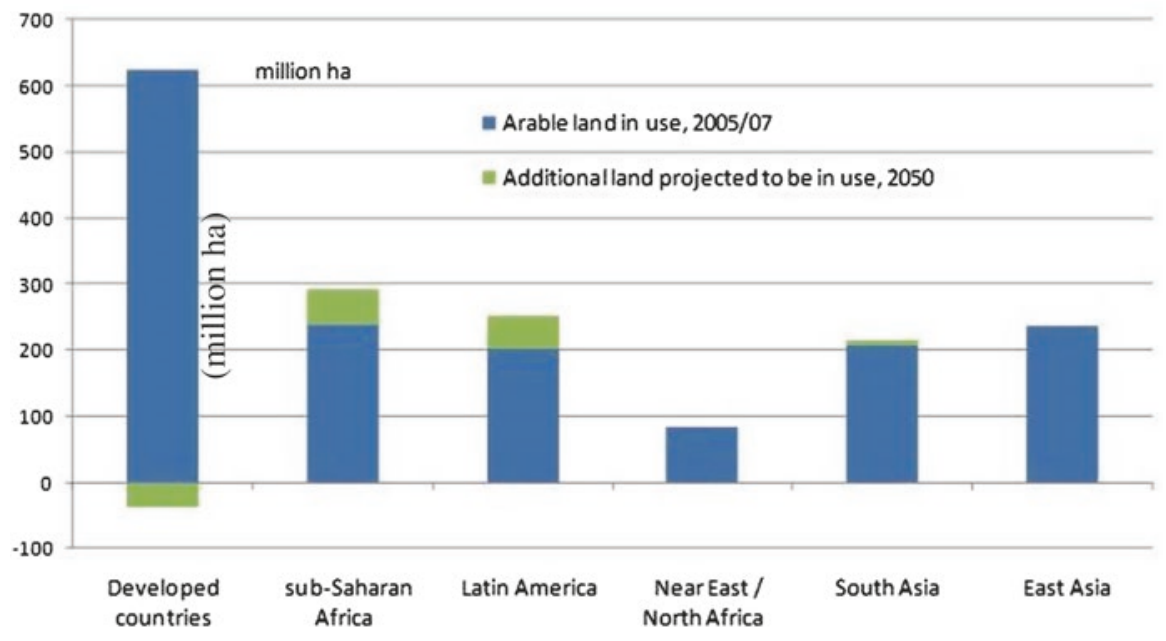

Fig. 1.4 Limited scope for the expansion of arable lands (FAO 2012b)

Thus, local resource scarcities are likely to remain a significant constraint in the quest for achieving food security for all (FAO 2012b).

\subsubsection{Water Scarcity}

Water is another critical resource, and irrigation has played a strong role in contributing to past yield and production growth. The world area under irrigation has doubled since the 1960 s to 300 million ha, but the potential for further expansion is very limited. Water resources are extremely scarce in the Near East and North Africa and in northern China, where they are most needed. A net increase of 20 million ha of irrigated area (only about $7 \%$ increase from the level in 2005/2007) is expected by 2050 (FAO WAT 2030/2050, 2012, Summary). On the other hand, the agriculture sector occupies about $70 \%$ of total water use. If food production is to be increased by $60 \%$, there would be need of a large quantity of additional water for food production in the future, when water scarcity would be taking place at the same time.

\subsubsection{Stagnation of Productivity Growth}

Annual productivity growth rate of main cereals, especially wheat and rice, declined (or expected to decline) sharply in past decade and will decline in future (20052050 ) to $0.8 \%$ (wheat) and $0.6 \%$ (rice) if compared with that of $2.9 \%$ and $1.9 \%$, respectively, during the Green Revolution period and beyond starting in 1961 till 


\section{Growth rate, percent per year}

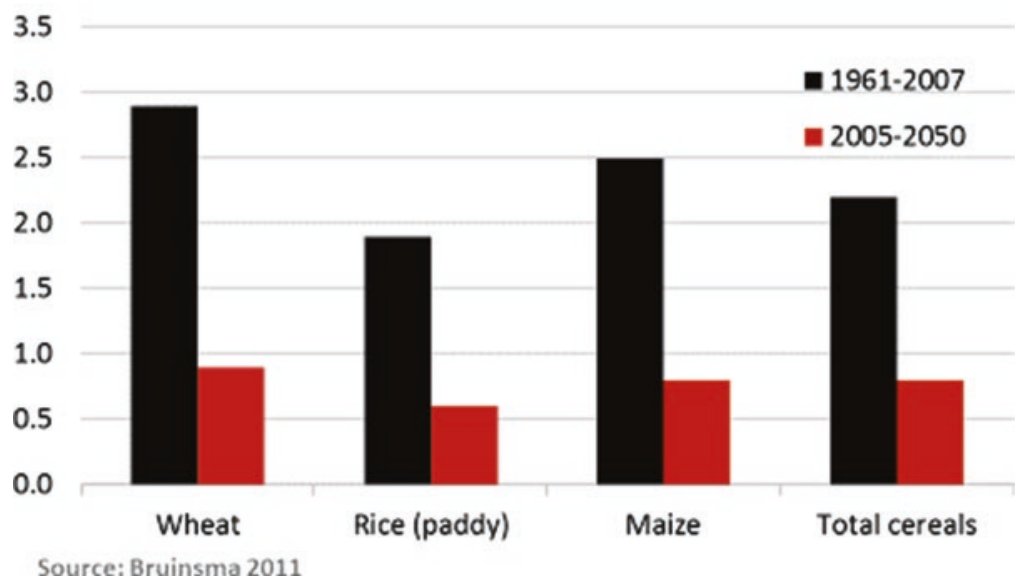

Fig. 1.5 Change in annual productivity growth of major cereals between 1961-2007 and 20052050 (Source: FAO)

2007 (Fig. 1.5). This might be attributed partly to a sharp decline in agricultural investment (especially for agricultural research and development) that recorded the decline in annual growth rate from more than 6\% during 1976-1981 to less than 2\% during 1991-2000 in developing countries (FAO 2012a).

\subsubsection{Uncertainties: Bioenergy and the Impact of Climate Change}

The international price of crude oil has been fluctuating significantly and became very volatile in the recent past. Significant changes in energy prices would potentially divert commodities and land/water to renewable energy production, which would result in increased use of food grains for biofuel production, and higher competition on the use of land and water between food crops and bioenergy crops. Moreover, the impact of climate change is not yet fully understood (FAO 2012b), and there is a great risk that climate change might increase extreme weather events, such as floods and droughts, and might negatively affect food production. Estimated rise of sea water level and surface temperature, as a consequence of global warming, might also result in deduction of agricultural land especially in fertile delta and lowland areas, outbreak of new plant pests and animal diseases, and change in cropping patterns and productivity growth. While actual impacts of climate change to future food production are yet to be known at this stage, there are great uncertainties and high risks associated with climate change on future global food security. 


\subsection{Value of Underutilized Food Crops Toward Promotion of Biodiversity, Food Production, and Food Security}

\subsubsection{Biodiversity and Food Security}

Biodiversity for food and agriculture includes the components of biological diversity that are essential for feeding human populations and improving the quality of life. It includes the variety and variability of ecosystems, animals, plants and microorganisms, at the genetic, species, and ecosystem levels, which are necessary to sustain human life as well as the key functions of ecosystems according to FAO (http://www.fao.org/biodiversity/group/en/).

Such diversity is the result of thousands of years of farmers' and breeders' activities, land and forest utilization, and fisheries and aquaculture activities combined with millions of years of natural selection. Most of the human population lives in areas where food production and nature coexist.

The conservation and sustainable use of biodiversity for food and agriculture play a critical role in the fight against hunger, by ensuring environmental sustainability while increasing food and agriculture production. It is imperative to do so in a sustainable way: harvesting resources without compromising the natural capital, including biodiversity and ecosystem services, and capitalizing on biological processes.

To cope with future challenges and uncertainties in global food security, a large reservoir of genetic and species diversity will need to be maintained and sustainably used. This diversity will further help maintain and rehabilitate productive ecosystems to supply future generations with abundant food and agriculture according to FAO (http://www.fao.org/biodiversity/group/en/).

Despite the importance of biodiversity as outlined above, the declining number of species, upon which food security and economic growth depend, has placed the future supply of food and rural incomes at risk. The shrinking portfolio of species and varieties used in agriculture reduces the ability of farmers to adapt to ecosystem changes, new environments, needs, and opportunities.

About 7000 species of plants have been cultivated for consumption in human history. The great diversity of varieties resulting from human and ecosystem interaction guaranteed food for the survival and development of human populations throughout the world in spite of pests, diseases, climate fluctuations, droughts, and other unexpected environmental events. Presently, only about 30 crops provide $95 \%$ of human food energy needs, four of which (rice, wheat, maize, and potato) are responsible for more than $60 \%$ of our energy intake. Due to the dependency on this relatively small number of crops for global food security, it will be crucial to maintain a high genetic diversity to deal with increasing environmental stress and to provide farmers and researchers with opportunities to breed for crops that can be cultivated under unfavorable conditions, such as drylands, wetlands, swamps, and saline soils, and tolerant to extreme weather conditions according to FAO (http:// www.fao.org/biodiversity/group/en/). 


\subsubsection{Uncertainty in Future Food Security}

As outlined in the above Sects. 1.2 and 1.3, the world population is expected to grow further and would reach around 9.3 billion by the year 2050 with increasing per capita calorie consumption. FAO estimates that the global food production has to be increased by $60 \%$ during the period between 2005/2007 and 2050 to meet the increasing demands, out of which nearly $90 \%$ is expected to come from existing arable land through yield increase as there is a very little potential to expand arable land in the future. This goal has to be achieved under various constraints and uncertainties such as decline of annual productivity growth rate of major staple foods, increasing water scarcity, advancing negative impacts of climate change and natural disasters, and rapidly increasing competition between food crops and bioenergy crops on the use of land and water resources. Consequently, there has been growing global concern of the serious food security challenges and uncertainties in coming decades, which may further impact world peace and stability, if sufficient foods are not produced to satisfy future global needs, especially for poor people in fooddeficit countries. There is an urgent need to advance agricultural research and maximize the effective use of land resources for food production. On the other hand, globalization has created homogeneity of food resources, accompanied by a loss of different culinary traditions and agricultural biodiversity, and created negative consequences for ecosystems, food diversity, and health. Accordingly, FAO has stressed the importance of neglected and underutilized species, which would play a crucial role in the fight against hunger, and called for increased research on underutilized food resources especially those produced on poor and underutilized lands (wetlands, swamps, saline soil, etc.) by the poor. The situation has sparked interests in identifying underutilized alternative crops for food use.

\subsubsection{Value of Underutilized Food Crops and Sago Palm}

Many neglected and underutilized species are adapted to low-input agriculture. The use of these species - whether wild, managed, or cultivated - can have immediate consequences on the food security and well-being of the poor. Dr. Graziano da Silva, the Director-General of FAO, stressed at an international seminar held in Spain in December 2012 that neglected and underutilized species play a crucial role in the fight against hunger and are a key resource for agriculture and rural development. He called for increasing research on underutilized crops for the benefit of smallholder farmers. In addition, many neglected and underutilized species play a role in keeping cultural diversity alive. They occupy important niches, conserving traditional landscape, adapted to the risky and fragile conditions of rural communities (FAO 2012b).

Sago palm (Metroxylon sagu Rottb.) is one of the typical underutilized indigenous food crops in Asia and the Pacific Region, with very little attention and research in the past. It can be grown in underutilized wetlands and peat swamps where other 
food crops cannot be grown economically and produce high yields of starch (150$300 \mathrm{~kg}$ of dry starch per plant). Thus, sago palm has a high potential to contribute to food security as an additional source of staple foods without (or less) competition on the use of arable land with other food crops, as well as for other industrial use including bioplastic and bioethanol production. Sago palm is grown in Indonesia, Papua New Guinea, Malaysia, Thailand, the Philippines, Timor-Leste, Pacific Island countries, etc. Despite playing an important role as a source of traditional foods, and off-farm and nonfarm income generation of poor rural communities, the sago palm population has drastically decreased in the recent past due to the conversion of sagogrowing wetlands and swamps for other purposes including for the expansion of industrial crops such as oil palm and rubber trees.

\subsection{Role of Underutilized Food Resources: Sago Palm and Its Economic, Social, and Environmental Benefit}

Against the background outlined in the earlier sections above, and in view of the fact that it produces high yield of starch and grows in underutilized wetlands and swamps, sago palm was identified as one of the most promising underutilized food resources with a high potential for its contribution to global food security.

\subsubsection{Sago Palm (Metroxylon sagu Rottb.): General Introduction}

Sago palm (Metroxylon sagu Rottb.) is a species of the genus Metroxylon belonging to the Palmae family and is a socioeconomically important crop in Southeast Asia. It grows well in humid tropical lowlands, up to an elevation of $700 \mathrm{~m}$, and is a source of starch and offers considerable potential to contribute to food security where it is grown (Flach 1997).

Sago palm is grown between latitude $10^{\circ}$ north and $10^{\circ}$ south in Southeast Asia and Pacific Island countries (Fig. 1.6).

Indonesia has the largest sago palm-growing areas (both wild and semi-cultivated stands) followed by Papua New Guinea, and limited semi-cultivated stands in Malaysia, Thailand, the Philippines, and Pacific Island countries (Table 1.1).

\subsubsection{Specific Characteristics of Sago Palm}

Sago palm has the following specific characteristics (Flach 1997): 


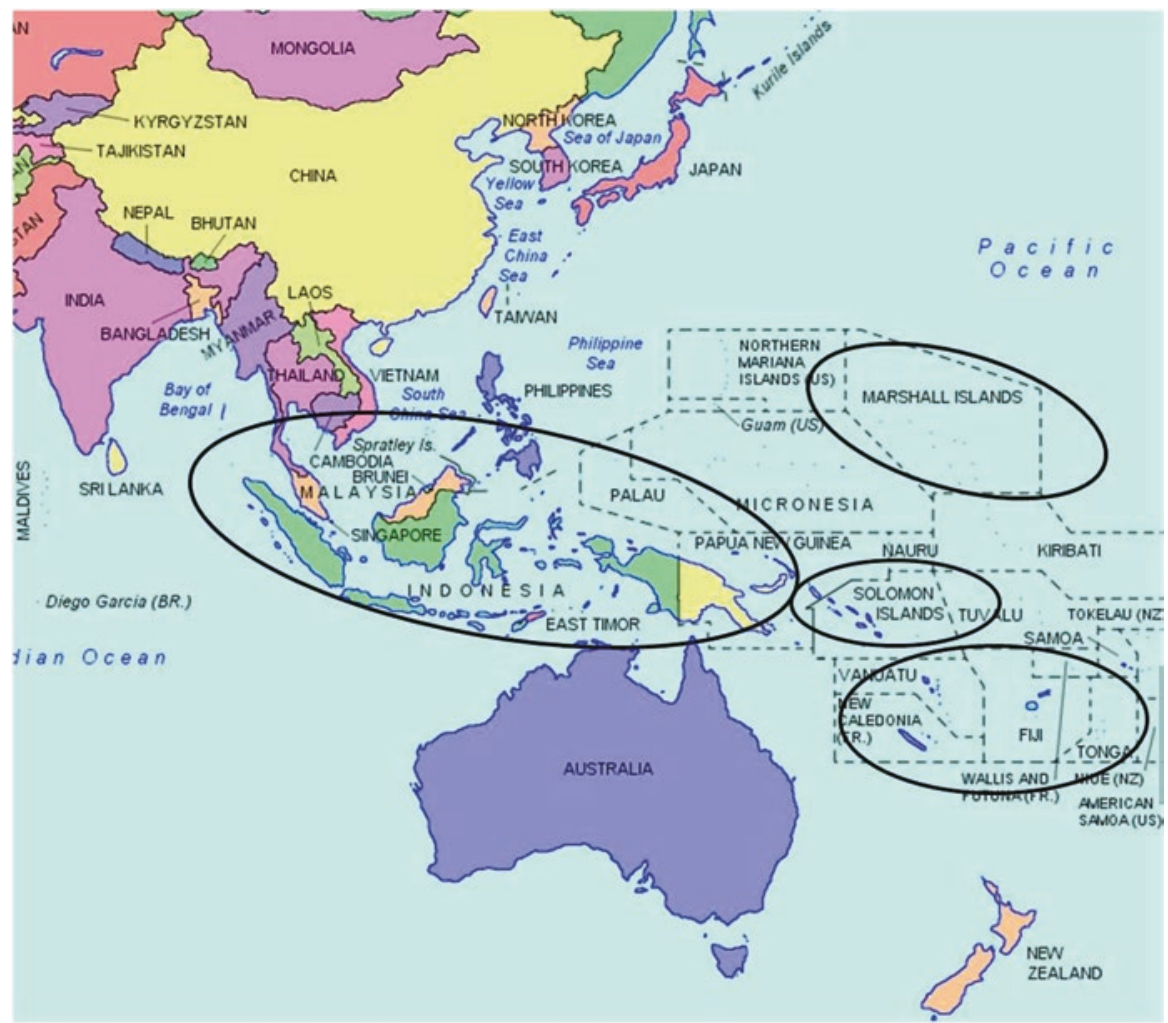

Fig. 1.6 A map of sago palm-growing countries (Modified from google map)

- Grown in fresh water swamps and low-/wetland.

- Found in tropical areas with a warm temperature around $29-32{ }^{\circ} \mathrm{C}$ (minimum $\left.15^{\circ} \mathrm{C}\right)$.

- Found between latitude $10^{\circ}$ north and $10^{\circ}$ south, up to $700 \mathrm{~m}$ above sea level.

- Tolerant of mild saline water but usually borders on nipa palm swamps, which can withstand higher salinity water.

- Takes about 3.5 years before stem (trunk) formation starts.

- Takes 8-12 years to reach maturity stage (before flowering) suitable for harvesting.

- Sago grows about 10-12 m in height with a diameter of trunk at 35-60 cm.

- Fresh weight of trunk 1-2 mt, of which 10-25\% of dried starch (about 100$300 \mathrm{~kg}$ of dried starch from one matured sago palm tree can be obtained).

- Average leaf production is 2 months. Leaves can be harvested when sago palm reaches about 4 years of age for making roofing materials. 
1 Status and Outlook of Global Food Security and the Role of Underutilized Food...

Table 1.1 Distribution of sago stands by country

\begin{tabular}{c|l|l}
\hline & Wild stands & $($ Semi-)cultivated stands \\
\hline Papua New Guinea, total & $1,000,000$ & 20,000 \\
\hline Sepik Province & 500,000 & 5000 \\
\hline Gulf Province & 400,000 & 5000 \\
\hline Other provinces & 100,000 & 10,000 \\
\hline Indonesia, total & $1,250,000$ & 148,000 \\
\hline Irian Jaya, total & $1,200,000$ & 14,000 \\
\hline Bintuni & 300,000 & 2000 \\
\hline Lake Plain & 400,000 & - \\
\hline Southern Irian & 350,000 & 2000 \\
\hline Other districts & 150,000 & 10,000 \\
\hline Moluccas & 50,000 & 10,000 \\
\hline Sulawesi & - & 30,000 \\
\hline Kalimantan & - & 20,000 \\
\hline Sumatra & - & 30,000 \\
\hline Riau Islands & - & 20,000 \\
\hline Mentawai Islands & - & 10,000 \\
\hline Malaysia, total & - & 45,000 \\
\hline Sabah & - & 10,000 \\
\hline Sarawak & - & 30,000 \\
\hline West Malaysia & - & 5000 \\
\hline Thailand & - & 3000 \\
\hline Philippines & - & 3000 \\
\hline Other countries & - & 5000 \\
\hline Total & $2,250,000$ & 224,000 \\
\hline & &
\end{tabular}

Flach (1997)

${ }^{a}$ No wild stands

\subsubsection{Sago Starch and Its Benefits}

The trunk of sago palm has been used to obtain starch as a staple food for human consumption or fed to livestock. According to Flach (1997), at the semi-cultivated sago palm forests in Irian Jaya in Indonesia and Papua New Guinea, the local inhabitants harvest sago palm whenever the starch content per trunk is highest, just before the flowering starts. Their yields usually vary from 150 to $300 \mathrm{~kg}$ of dry starch per harvested trunk (Flach 1997).

Sago starch contains $27 \%$ amylose (the linear polymer) and $73 \%$ amylopectin, the branched polymer (Ito et al. 1979). However, Kawabata et al. (1984) found the amylose content of $21.7 \%$ in sago starch. Flach (1997) estimated that the difference of amylose content might occur according to the age, variety, or growing conditions of sago palm.

In some areas such as Southern Thailand, simple starch extraction methods are used at the farm household level, while a larger industrial-scale extraction is generally found in Indonesia and Malaysia. There are different starch extraction 
methods in different countries. One of the common traditional methods of preparation of sago starch for human consumption is to pour hot water over the wet starch and stir it with a stick or a spoon. The resulting glue-liked mass is eaten with some fish or other associated foods. It is also common to bake sago starch, occasionally mixed with other foods such as ground peanuts (Flach 1997). In Thailand, sago starch is occasionally used as a raw material for making breads, noodles, pasta, etc. (Klanalong 1999). The granular size of sago starch is about $30 \mu \mathrm{m}$ on average, which is similar to that of potato and much larger than all other starches (Griffin 1977). Flach (1997) indicated that in the modern starch industry, starches can be modified to quite an extent. He also stated that sago starch would be competitive with all other starches and, for some purposes, it may even be preferred, provided there is a regular supply of cheap, clean, and noncorroded starch.

A recent study on the substitution of wheat flour with sago starch revealed that wheat flour can be substituted by sago starch up to a level of $40 \%$ in producing cookies that find good consumer acceptance in Southern Thailand. These findings highlighted the potential of sago starch to substitute and mix with wheat flour in other types of local confectionery and food products and eventually increase overall volume and availability of staple food worldwide; hence there might be a good potential for sago palm and its starch to contribute to household and global food security as a wheat flower substitution (Konuma et al. 2012).

In recent years, sago starch is given special attention as a potential source of ethanol production for biofuel due to global concern over climate change and a future energy crisis. It is estimated that whereas other food crops such as maize and cassava compete in the use of land resources for staple food production with that for biofuel production thereby increasing the risk of food insecurity, sago palm can be grown on marginal land or on land where other food crops are unable to grow economically.

\subsubsection{Sago Palm's Contribution to Household Economy and Income Generation}

Sago starch is utilized in some of southern rural villages in Thailand as a raw material to produce food for income generation at the village level. The traditional sweets, cookies, and snacks produced from sago starch are an important extra income of farm families (Konuma 2008).

Sago leaves are widely used to make mats for roofing or partitioning (Flach 1997). Sago roofing mats are strong and last longer than those made from other palms and are an important source of income of sago growers. The useful life of sago leaf roofing mats is about 6-10 years, which is more durable than those made from other palms. Sago rachis is used for producing woven mats and racks for holding shrimps, fish, or vegetables during sun-drying in Thailand. Sago latex, collected from fresh rachis, is clear and very sticky and is used as paper adhesive in Thailand (Konuma 2008). 


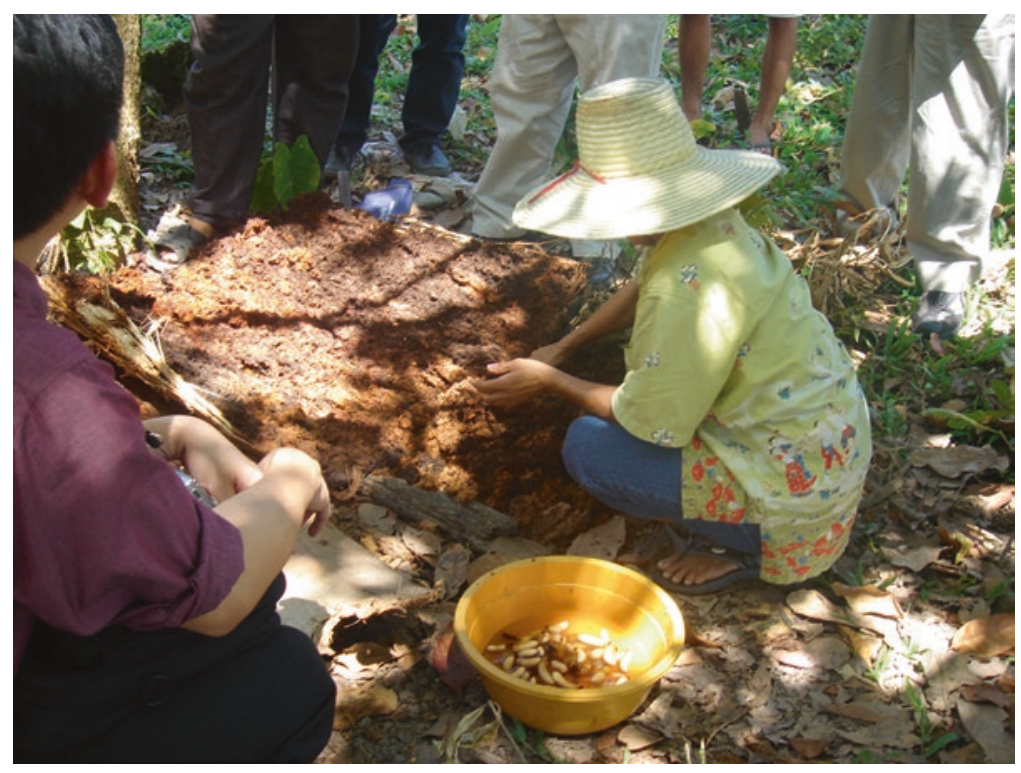

Fig. 1.7 Sago warm farming at Fukkeri Village, Nakhon Si Thammarat Province in Thailand (Photo taken on 23 February 2007 by Hiroyuki Konuma)

The ground pith of sago palm is sometimes used as an animal feed, especially for pigs. When dried, it is also used for horses and chickens (Flach 1997). The lower part of trunk is also used for sago worm farming in Southern Thailand which generates additional income for farmers (Klanalong 1999). Figure 1.7 shows an example of worm farming.

\subsubsection{Sago Palm and Its Social and Environmental Contribution}

In countries like Indonesia, Malaysia, and Thailand, rapid expansion of the oil palm industry and rubber plantations reflects increased world demands and the price hike is another factor which affected the traditional farming systems. As a result, wetlands and peat swamps including sago palm forests have been rapidly disappearing and replaced by industrial crop plantations. The overall situation negatively affected the environment and sustainable ecosystem as well as the traditional social values, culture, and livelihoods of people living in rural communities. A study indicated that sago palm forest was an important local resource of the rural communities in Southern Thailand (Konuma 2008). The villagers have harmonized their traditional lifestyle and community spirit with the sago palm forest for their farming system, economy, and culture. Sago palm trees, with the benefit of their large green leaves existing year-round, would naturally contribute to absorbing carbon dioxide and 
hence contribute to reducing greenhouse gas emissions. Through the review of various research reports, it was found that sago palm played an important role as a symbol for the protection of traditional landscape and ecosystems, biodiversity, and sociocultural heritage in southern part of Thailand.

\section{References}

FAO (2012a) Sustainable diet and bio-diversity. pp 109-115. Accessed on 15 Jul 2014. http:// www.fao.org/docrep/016/i3004e/i3004e.pdf

FAO (2012b) World agriculture towards 2030/2050: the 2012 revision: WAT 2030/50 2012 Summary. pp 1-12, 88-99. Accessed 15 Jul 2014 http://www.fao.org/fileadmin/user_upload/ esag/docs/AT2050_revision_summary.pdf

FAO (2015) State of food insecurity in the world 2015: SOFI 2015. Accessed on 15 Jul 2016. http://www.fao.org/docrep/018/i3434e/i3434e.pdf

Flach M (1997) Sago palm. Promoting the conservation and use of underutilized and neglected crops. IPGRI, No.13. ftp://ftp.cgiar.org/ipgri/Publications/pdf/238.PDF

Griffin GJL (1977) Current development in starch-filled plastics. In: Sago-76: Papers of the 1st international sago symposium: the equatorial swamp as a natural resource. July 1976, Kuching, Sarawak, East Malaysia, pp 230-239

Ito T, Arai Y, Hisajima S (1979) Utilization of sago starch. Japan J Trop Agric 23:48-56

Kawabata A, Sawayama S, Nagashima N, del Rosario RR (1984) Physico-chemical properties of starches from cassava, arrowroot and sago. In: Uritani K, Reyes ED (eds) Tropical root crops: post harvest physiology and processing. Japan Science Society Press, Tokyo, pp 259-271

Klanalong S (1999) Properties and utilization of sago palm in Thailand. The first regional round table meeting on sustainable small scale sago starch extraction and utilization. FAO and KAPI, pp 136-169

Konuma H (2008) Studies on neglected plant resources, sago palm in Thailand. Master's thesis, University of Tsukuba. pp 21-25, 26-39, 40-42

Konuma H, Rolle RS, Boromthanarat S (2012) Adding value to underutilized food resources: substituting wheat flour with sago starch in cookie formulations. J Agric Tech 8:1067-1077

Open Access This chapter is licensed under the terms of the Creative Commons Attribution 4.0 International License (http://creativecommons.org/licenses/by/4.0/), which permits use, sharing, adaptation, distribution and reproduction in any medium or format, as long as you give appropriate credit to the original author(s) and the source, provide a link to the Creative Commons license and indicate if changes were made.

The images or other third party material in this chapter are included in the chapter's Creative Commons license, unless indicated otherwise in a credit line to the material. If material is not included in the chapter's Creative Commons license and your intended use is not permitted by statutory regulation or exceeds the permitted use, you will need to obtain permission directly from the copyright holder.

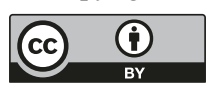




\title{
Chapter 2 \\ Growing Area of Sago Palm and Its Environment
}

\author{
Mochamad Hasjim Bintoro, Muhammad Iqbal Nurulhaq, \\ Agief Julio Pratama, Fendri Ahmad, and Liska Ayulia
}

\begin{abstract}
Sago palms grow well on riverbanks, near lakes, and in wet soil. They can be found at $700 \mathrm{~m}$ elevation in PNG and are well adapted in marginal soils where cash crops cannot grow. Sago palms can grow from low flooded areas to uplands and in soils which are from very acidic to neutral. Sago is one of the most efficient carbohydrate-producing crops. Sago is distributed naturally from Melanesia in the South Pacific in the east $\left(180^{\circ}\right.$ E. Long.) to India in the west $\left(90^{\circ} \mathrm{E}\right.$. Long.) and from Mindanao in the north $\left(10^{\circ} \mathrm{N}\right.$. Lat. $)$ to Java in the south $\left(10^{\circ} \mathrm{S}\right.$. Lat. $)$. Sago populations in the world occupy 2.4 million ha.

Temperature plays a key role in sago palm growth. The lowest temperature at which sago palms will grow is $15^{\circ} \mathrm{C}$. When temperatures are lower than $13{ }^{\circ} \mathrm{C}$ at the seedling stage, sago palms are not able to survive, and the mortality percentage increases. Moreover, fewer leaves are produced at low temperatures. The optimum relative humidity and sunlight intensity for sago palms are $90 \%$ and $900 \mathrm{j} / \mathrm{cm}^{2} /$ day. The optimum rainfall for sago is $2000 \mathrm{~mm}$ per year. In addition, sago can grow when the location has less than two dry months and more than nine wet months.

Sago palms can grow in various types of soils: (1) undeveloped soils, such as sulfaquents (sulfidic soil), hidraquents (waterlogged), tropaquents (tropical climate), fluvaquents (alluvial), and psammaquents (sandy soils), and (2) developed soils, such as tropaquepts, troposaprists of peatlands, tropohemists and sulfihemists (sulfuric soil and low $\mathrm{pH}$ ), and thaptohistic fluvaquents.

Sago palms thrive in swampy conditions where the pneumatophores are not submerged, where mineral nutrition and organic matter are high, and where the standing water is brown and slightly acidic. Such a habitat is suitable for the growth of microorganisms that benefit sago palm growth. Sago palms can also grow in swampy areas near the sea, as they are tolerant of salinity. Sago palms have avoidance tolerance to $\mathrm{Na}^{+}$. Excess $\mathrm{Na}^{+}$is stored in the roots.
\end{abstract}

M.H. Bintoro $(\bowtie) \bullet$ M. Iqbal Nurulhaq • A.J. Pratama • F. Ahmad • L. Ayulia Department of Agronomy and Horticulture, Faculty of Agriculture, Bogor Agricultural

University, Bogor, Indonesia

e-mail: hmh_bintoro@yahoo.com

H. Ehara et al. (eds.), Sago Palm, https://doi.org/10.1007/978-981-10-5269-9_2 
Subsidence will occur after peatlands have been drained, and the process occurs very quickly. Subsidence is approximately $20-50 \mathrm{~cm}$ year ${ }^{-1}$ during the early building of a drainage network. Land clearing for agricultural purposes is usually accompanied by the draining of peatlands. Drainage negatively impacts the soil by decreasing the soil level, which triggers the land's unavailability for agricultural use. Sago palm plantations can be a solution to the degradation of peatlands due to the maintenance of the water level. Sago palms grow optimally in swampy and waterlogged conditions and peatlands. Due to the maintenance of the water level during the sago palm growing period, the degradation of peatlands can be avoided. Sago palm cultivation on peat soil will conserve not only water but also soil, so the environment will be maintained. Sago palms also support peatlands in storing carbon and minimizing greenhouse effects. Moreover, sago palms have the highest $\mathrm{CO}_{2}$ absorption as compared to other major crops.

\subsection{The Origin of Sago Palm}

Sago palm (Metroxylon spp.) is a carbohydrate-producing plant, as are rice, corn, and tuber crops. Sago starch has potential as a food alternative and raw material for agroindustry due to its food resilience. Sago palm is a most productive plant, as compared with other carbohydrate-producing crops. The plant can produce 20-40 mt of dry starch ha ${ }^{-1}$ year $^{-1}$. Sago starch is sold by the farmers in coastal (lowland) areas. However, people outside the sago area assume that sago starch is not important. According to Ruddle (1979), approximately 300,000 people in Melanesia eat sago starch as a staple food, and some one million people consume it as a diet food.

Sago palm was first found and utilized by local people in Southeast Asia. According to Avé (1977) the sago palm is a multifunctional plant: its starch can be used as a staple food, and the pith residue as waste can be used as a medicine, a pesticide, and also as a poison for fish. Haryanto and Pangloli (1992) stated that people in some rural areas in Maluku Province eat sago starch as a staple food.

In Indonesia, sago can be found not only in Maluku but also in the Mentawai Islands in West Sumatra Province, Aceh, Riau Islands, Kalimantan, Sulawesi, Papua (Irian Jaya), West Papua (Irian Jaya Barat), and other provinces (Bintoro et al. 2013). According to Ruddle (1979), in the thirteenth century when Marco Polo went to Sumatra and Maluku, he found that the local people on some islands, i.e., Mentawai, Lingga, and Maluku, ate sago starch.

Sago palm is distributed across the southern part of Thailand, Malaysia, and Brunei and the southern part of the Philippines, Papua New Guinea (PNG), and the Solomon Islands (Ehara 2015). Because so many accessions can be found in those areas, Flach (1997) believes that the sago palm originated in Papua (Irian Jaya) and PNG. 
According to Yamamoto et al. (2005), approximately 15 accessions can be found around Sentani, Jayapura, with the differences in the accessions based on morphological characteristics and their adaptation to environmental conditions (Barahima 2006). Matanubun (2015) reported that there are 17 sago palm varieties and 10 subvarieties around Sentani Lake. Dewi et al. (2016) also found 12 sago varieties in Sayal Village, Saifi District. It is possible that many accessions in Papua and West Papua still have not yet been identified, although 96 varieties can be found in Waropen, Salawati, Wasior, Inanwatan, Onggari, Sentani, Kaureh, and Wandesi in Papua and West Papua (Matanubun et al. 2005). Further exploration of sago palms is needed.

Sago palms grow as a natural forest, especially in peat soil. The water in these areas is very acidic and brown in color. Those conditions are favorable for microorganisms with which sago palms are mutually beneficial (Bintoro et al. 2010). Sago palms grow well on riverbanks, near lakes, and in wet soil. They can be found at $700 \mathrm{~m}$ elevation in PNG and are well adapted in marginal soils where cash crops cannot grow. Notohadiprawiro and Louhenapessy (1992) stated that sago palms can grow from low flooded areas to uplands and in soils which are from very acidic to neutral.

\subsection{Sago Distribution}

Sago is one of the most efficient carbohydrate-producing crops. Sago is distributed from Melanesia in the South Pacific in the east $\left(180^{\circ}\right.$ E. Long.) to India in the west $\left(90^{\circ}\right.$ E. Long.) and from Mindanao in the north $\left(10^{\circ} \mathrm{N}\right.$. Lat.) to Java in the south $\left(10^{\circ} \mathrm{S}\right.$. Lat.) (Johnson 1977). Some of the countries with sago distribution include Indonesia, Malaysia, Papua New Guinea, the Philippines, and Thailand. The extent of sago distribution is different in each country, with Indonesia, Malaysia, and Papua New Guinea having the widest distribution. Metroxylon sagu Rottb., which is spineless, is commonly found in the western part of the archipelago, while the spiny M. rumphii Mart. (= M. sagu Rottb.) is found in the eastern part. The main sago regions in the archipelago are Papua, Maluku, Sulawesi (especially South, Central and Southeast Sulawesi), Kalimantan (especially West Kalimantan), and Sumatra (especially the Riau Islands). In Java, sago is limited to the West Bogor and Banten districts. In regions with less rainfall, such as Nusa Tenggara Barat and Nusa Tenggara Timor, sago trees are hard to find (Djoefrie 1999).

The sago palm is a native plant that has spread across several Indonesian islands, such as Papua, West Papua, Maluku, Kalimantan, Sulawesi, Sumatra, Java, and the Mentawai Islands. The extent and the type of sago cultivation spread across each island are slightly different. There are still natural sago forests as well as semicultivated forests. Most areas of sago palms in Papua and West Papua are sago forests that have not been managed or cultivated, which decreases overall sago productivity. According to Djoefrie (1999), sago palm forests are found in the lands from the coast to $1000 \mathrm{~m}$ elevation, along riverbanks, and around lakes or swampy 
areas. Other islands, such as the Meranti Islands District of Riau Province, have cultivated sago, so the area can be known with certainty. In Indonesia, sago is not distributed among sago plantations but found in the form of patches scattered among islands large and small, which makes it difficult to collect data regarding the extent of the sago distribution. In addition, sago-growing environments, riverbanks, and swampy areas, with sufficient water depth, are difficult for researchers to visit, and the density of sago forests constrains people wishing to go into them.

According to Flach (1997), sago populations in the world occupy 2.4 million ha. But according to Djoefrie et al. (2014), in the Papua area, sago occupies 4.7 million ha, and there are 510,000 ha in West Papua. When these data are combined, the extent of the sago distribution worldwide reaches 6.5 million ha. The sago palm distribution in Indonesia, consisting of $85 \%$ of the sago worldwide, is 5.5 million ha. Of that, as much as 95\% - 5.2 million ha - are in Papua and West Papua (Djoefrie et al. 2014) (Figs. 2.1 and 2.2), with 0.3 million ha spread over several islands in Indonesia. According to the head of the Meranti Islands District, smallholding sago farmers in that district account for 42,130 ha and sago plantations for 21,418 ha.

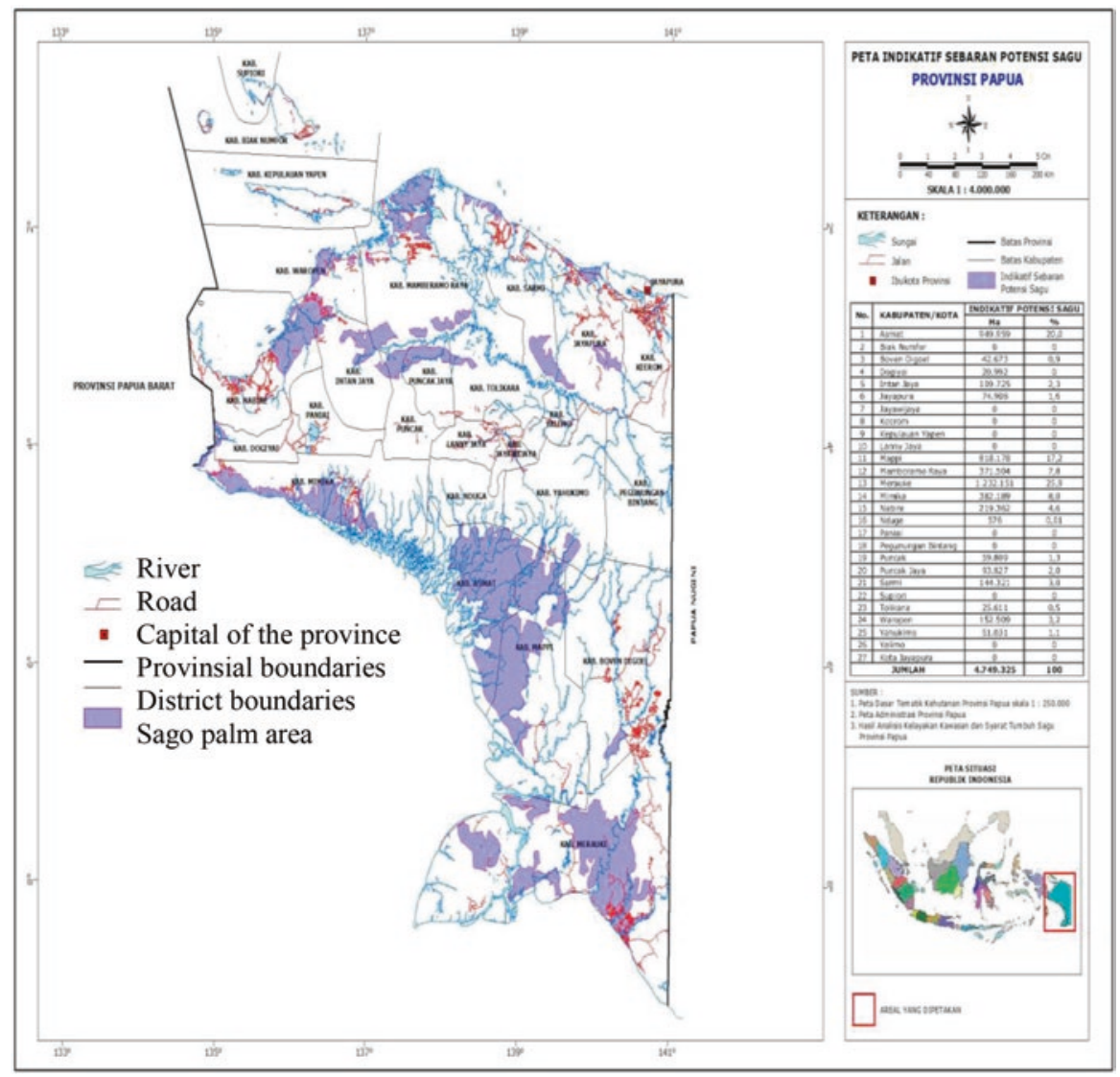

Fig. 2.1 Map of sago palm distribution in Papua 


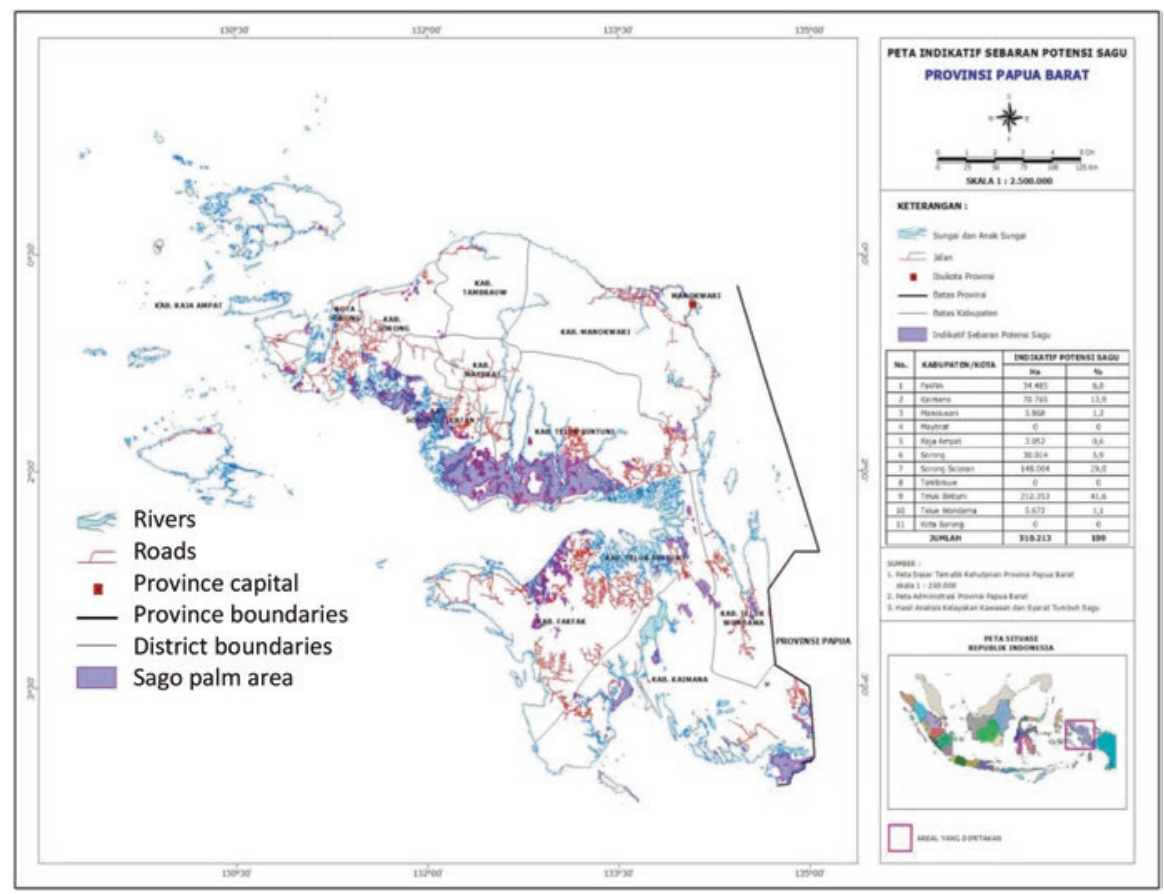

Fig. 2.2 The spread of sago palms in West Papua

The distribution of sago outside Indonesia is very diverse. Sago distribution in Thailand has reached 3000 ha (Flach 1997). According to Konuma, in 2008, as cited in Konuma (2014), sago grows in wetlands, along canals, and forests in southern Thailand. According to Jirasak et al. in 1996, cited in Konuma (2014), sago in Thailand grows on peatlands as sago forests located in the provinces of Narathiwat (50\%), Nakhon Si Thammarat (25\%), Songkhla (7.5\%), Chumporn (5\%), Phatthalung (4\%), and Pattani (2\%), with the remainder in Trat, Surat Thani, Trang, Phang Nga, Krabi, and Saturn. According to the Land Development Department of Thailand, peat swamps cover 64,000 ha and have the potential to become sago habitat, according to Klanarong in 1999, cited by Konuma (2014). According to Flach (1997), sago in Malaysia is in Sabah (10,000 ha), Sarawak (30,000 ha), and West Malaysia (5000 ha). Sago in Malaysia is already grown on plantations. Sago distribution in the Philippines has reached 3000 ha (Flach 1997). Santillan et al. (2012), using Landsat imagery in the province of Agusan del Sur, determined the total sago area to be 597 ha. The distribution of sago in Papua New Guinea is divided into two parts, sago forests (1 million ha) and semi-cultivated areas (20,000 ha) (Flach 1997). In Brunei Darussalam, sago is used as staple food and is second only to rice. Areas of sago production include the districts of Kuala Belait, Tutong, and Temburong (Ruddle 1979). The total area of sago in that district is not known with certainty. 


\subsection{Types of Sago Palms}

Sago palms are highly diverse. Papua has the highest diversity; and Indonesia is the earliest sago area (Abbas et al. 2009, 2010). This diversity is the result of crosspollination of the palm. Initially, there were described only five types of sago (four spiny types and one spineless); however, as observations carried out in the Moluccas Province continued, nine types of sago palms were described (Djoefrie 1999).

Random amplified polymorphism DNA (RAPD) analysis was used to identify the genetic links among sago palms. The results showed that the sago palms that originated in Papua are genetically linked to the sago from Kalimantan and the Sumatra Islands. The sago palm originally from Maluku is genetically correlated to the sago palm from Sulawesi Island, and the sago palm from Java is genetically related to those from other islands (Abbas et al. (2009). There was only one type of sago palm in Papua New Guinea, namely, Metroxylon sagu Rottb. (Kjaer et al. 2014). As they have the same genetic sequences (based on RAPD results), Hisajima in 1995, cited in Konuma (2014), reported that sago from Papua New Guinea spread to Thailand.

Local naming of sago palms is common in Indonesia. According to Djoefrie (1999) and Dewi et al. (2016), local people identify the palms by the presence or absence of spines, leaf color, bark, and bud color. A recent study showed that 12 accessions of sago palms in one district have wide ranging correlations and only 2 of 12 accessions are genetically correlated (Dewi et al. 2016).

Researchers have collected local names for sago varieties in various parts of Indonesia. Widjono et al. (2000) found 60 accessions of sago palms in Papua by the presence or absence of spines, bud color, leaf color, starch color, crown shape, stem diameter and long or short of spines, namely, Ana Apor, Ana Uwabu, Anangga Suanau, Ananggemo, Anaraumar Era, Anatuba Sianggono, Apaigo, Bibewo, Bibutu Mewi, Bosairo, Do Mboh, Edidao, Epesum, Epung Yepha, Fikta, Folio Hongleu, Folio Hongsay, Hanumbo, Hiyakhe, Hopholo Hongleu, Hopholo Hongsay, Igoto, Igoto Ogabarasu, Kambea, Kao, Manno Hongleu, Manno Hongsay, Marido, Merepo, Mongging, Okhu, Osokulu Hongleu, Osokulu Hongsay, Panne, Para Hongleu, Para Hongsay, Puy, Rondo Hongleu, Rondo Hongsay, Ruruna Hongleu, Ruruna Hongsay, Segago, To, Walisa Hongleu, Walisa Hongsay, Wanny Hongleu, Wanny Hongsay, and Wikuarawi. In addition, Dewi et al. (2016) found 12 accessions in Saifi by the shoots color, crown shape, trunk height, number of leaf, existence of spine, starch content, pith and starch color, West Papua-Fablen, Fafion, Failik, Fakattao, Fakreit, Falia, Fanke, Fanomik, Fasai, Fasampe, Fasinan, and Fasongka. According to Matanubun (2015), there are 23 accessions of sago palms in Sentani, Papua (13 with spines), namely, Phara (Phara Habou, Phara Hongsay, Phara Waliha), Mongging, Rondo (Rondo Hongsai, Rondo Honggeleu), Okhu, Pui, Yakhalobe, Ruruna, Ebhesum, Manno (Manno Fiho, Manno Parawakhe/Ohu), Yebha (Yebha Hongsai, Yebha Honggeleu, Ebhung Yebha), Osukhulu, Folo, Phane, Hobholo, Wani, Yakhe, and Hili. According to morphological characteristics, there are three types of sago palms in the Meranti Islands, namely, Sagu Sangka (rarely 
spiny), Sagu Bemban (having a spine), and sago palms with many spines (Novarianto et al. 2016). In Sorong, West Papua, there are five types of sago-Iwabinis, Iwayuluk, Iwarwo, Iwasnan, and Iwamuluk. According to Alfons and Bustaman in 2005, cited by Bintoro et al. (2013), Maluku has some five accessions of sagoDuri Rotan (Metroxylon microcanthum Mart. = M. sagu Rottb.), Ihur (M. sylvestre Mart. = M. sagu Rottb.), Makanaru (M. longispinum Mart. = M. sagu Rottb.), Molat (M. sagu Rottb.), and Tuni (M. rumphii Mart. = M. sagu Rottb.).

The genetic relationships of sago palms have been investigated by researchers. According to RAPD analysis, sago is classified into two main groups (A and B). Group A is divided into two subgroups (A1 and A2). Subgroup A1 consists of nine populations from Johor, eight from Sumatra and surrounding areas, one from Java, and two populations from Southwest Sulawesi. Subgroup A2 consists of three populations from Southwest Sulawesi and two from Mindanao, the Philippines. Group B consists of 12 populations from east Indonesia, 8 from the Seram, and 4 from the Ambon districts. Wakar accessions originated in Papua New Guinea, which is mapped out of the two main groups (Ehara et al. 2003).

\subsection{Ecology of the Sago Palm}

\subsubsection{Latitude and Climate}

The habitat of the sago palm is along rivers, lakes, and swamps. In addition, it adapts to land from sea level to $1200 \mathrm{~m}$ elevation (Schuiling 2009). The most suitable habitat for sago palms is below $400 \mathrm{~m}$ elevation. If sago is planted above $400 \mathrm{~m}$ elevation, it will grow slowly and have low productivity (Djoefrie 1999). Schuiling and Flach (1985) found that sago grown above $600 \mathrm{~m}$ elevation is shorter than $6 \mathrm{~m}$ and has a small trunk diameter.

Temperature plays a key role in sago palm growth. The lowest temperature at which sago palms will grow is $15^{\circ} \mathrm{C}$ (Bintoro et al. 2010). When temperatures are lower than $13{ }^{\circ} \mathrm{C}$ at the seedling stage, sago palms are not able to survive, and the mortality percentage increases. Moreover, fewer leaves are produced at low temperatures. For example, one leaf is produced at 25,20 , and $17^{\circ} \mathrm{C}$, over 20,25 , and 70 days, respectively (Flach et al. 1986; Schuiling 2009); and new leaves stop growing at temperatures below $17^{\circ} \mathrm{C}$ (Schuiling 2009).

The optimum relative humidity and sunlight intensity for sago palms are $90 \%$ and $900 \mathrm{j} / \mathrm{cm}^{2} /$ day (Notohadiprawiro and Louhenapessy 1992; Schuiling 2009; Bintoro et al. 2010). If sago is grown at temperatures below $20{ }^{\circ} \mathrm{C}$ and relative humidity of less than 70\%, starch production will drop by $25 \%$ (Notohadiprawiro and Louhenapessy 1992; Bintoro et al. 2010). Sago palms grown with low light intensity (less than $900 \mathrm{j} / \mathrm{cm}^{2}$ ) or under cloudy and shaded conditions produce less starch (Flach et al. 1986; Bintoro 2008).

The optimum rainfall for sago is $2000 \mathrm{~mm}$ per year (Okazaki and Kimura 2015). According to the Schmidt and Ferguson classification, sago palms are optimally 
grown in types A and B climates with rainfall between 2500 and $3500 \mathrm{~mm}$ and 142-209 days of rainfall per year (Turukay 1986). Moreover, according to the Oldeman (1980) classification, sago in Maluku and Papua grows in climate zones A, B1, B2, C1, C2, D1, D2, and E1. In addition, Notohadiprawiro and Louhenapessy (1992) stated that sago can grow when the location has less than two dry months and more than nine wet months.

In suboptimal conditions, sago palms need a longer time to reach maturity (the rosette phase). Under such conditions, the growth of new leaves is also slow, prolonging the time to maturity and therefore to starch production (Flach et al. 1986).

\subsubsection{Soil}

Sago palms can grow in various types of soils: (1) undeveloped soils, such as sulfaquents (sulfidic soil), hidraquents (waterlogged), tropaquents (tropical climate), fluvaquents (alluvial), and psammaquents (sandy soils), and (2) developed soils, such as tropaquepts, troposaprists of peatlands, tropohemists and sulfihemists (sulfuric soil and low $\mathrm{pH}$ ), and thaptohistic fluvaquents (Notohadiprawiro and Louhenapessy 1992).

Sago palms can grow on peatlands, with high organic matter (C-organic $>18 \%$ ). The depth of organic matter may exceed $50 \mathrm{~cm}$ (Agus and Subiksa 2008). In Malaysia, sago palms grow in peatlands, but they are less productive. Sago palms grown in peat soil have fewer leaves, only 17-19, while the number of leaves of sago palms grown in mineral soil can reach 20-24. The productivity per trunk is also less than of those grown in mineral soil (Flach and Schuiling 1991; Bintoro 2008). In peat soil, the sago palm harvest is more protracted than in mineral soil. In peat soil, sago can be harvested 12.7 years after planting, while in mineral soil, sago palm can be harvested 9.8 years after planting (Kueh et al. 1991). The dry starch content of sago palms grown in peat soil is approximately $88-179 \mathrm{~kg} /$ trunk, while the dry starch content of sago palms grown in mineral soil is approximately 123$189 \mathrm{~kg} / \mathrm{trunk}$ (Sim and Ahmad 1991). The production rate of sago palms grown in peat soil is $25 \%$ less than that of those grown in mineral soil (Kueh 1995). Yamamoto et al. (2003) observed the accumulation rate of sago palms cultivated in different types of soil.

Sago palms can also grow in volcanic, podzolic, grumosol, alluvial, and hydromorphic soil (Djoefrie 1999). According to Haryanto and Pangloli (1992), the growth of sago palms is inhibited in soil with insufficient microorganisms and nutrients. P, K, and Mg in water support sago palm growth. Extended waterlogged conditions inhibit starch formation.

Sago palms thrive in swampy conditions where the pneumatophores are not submerged, where mineral nutrition and organic matter are high, and where the standing water is brown and slightly acidic. Such a habitat is suitable for the growth of microorganisms beneficial to sago palm growth (Bintoro et al. 2010). 
Table 2.1 The influence of the hydrological status of water on the production of sago palm starch

\begin{tabular}{|c|c|c|c|c|}
\hline \multirow[b]{2}{*}{ No. } & \multirow{2}{*}{$\begin{array}{l}\text { Time logged } \\
\text { (months) }\end{array}$} & \multicolumn{2}{|l|}{ Logged } & \multirow{2}{*}{$\begin{array}{l}\text { Production } \\
\text { trunk }^{-1}(\mathrm{~kg})\end{array}$} \\
\hline & & Rainy season & Dry season & \\
\hline 1 & 12 & $+>7 \mathrm{~cm}$ & $+>10 \mathrm{~cm}$ & 94 \\
\hline 2 & $9-12$ & $+>50 \mathrm{~cm}$ & $-<10 \mathrm{~cm}$ & 192 \\
\hline 3 & $9-12$ & $+>50 \mathrm{~cm}$ & $-(10-40) \mathrm{cm}$ & 137 \\
\hline 4 & $9-12$ & $+(10-50) \mathrm{cm}$ & $-(10-40) \mathrm{cm}$ & 216 \\
\hline 5 & $6-9$ & $+>50 \mathrm{~cm}$ & $-(10-40) \mathrm{cm}$ & 348 \\
\hline 6 & $6-9$ & $+(10-50) \mathrm{cm}$ & $-(10-40) \mathrm{cm}$ & 328 \\
\hline 7 & $6-9$ & $+(10-50) \mathrm{cm}$ & $-(50-100) \mathrm{cm}$ & 273 \\
\hline
\end{tabular}

Logged (+) is the mean flooding, logged (-) is the mean beneath the soil surface Source: Notohadiprawiro and Louhenapessy 1992

Sago palms can also grow in swampy areas near the sea, as they are tolerant of salinity. Sago palms have avoidance tolerance to $\mathrm{Na}^{+}$. Excess $\mathrm{Na}^{+}$is stored in the roots. According to Yoneta et al. (2006), high salinity (> $200 \mathrm{mM} \mathrm{NaCl}$ ) inhibits photosynthesis. The ability of sago palms to grow in swampy areas is very important to their economic development.

The hydrological status influences sago palm growth (Table 2.1). The soil water depth is approximately $30-50 \mathrm{~cm}$ beneath the soil surface. According to Djoefrie (1999), the most interesting fact about the sago palm is its ability to grow in areas where other plants cannot be cultivated. Sago palms can grow in waterlogged soil of more than $1 \mathrm{~m}$ depth.

\subsection{Sago Palm's Role in the Environment}

\subsubsection{Soil Subsidence}

Subsidence will take place after peatlands have been drained, and the process occurs very quickly. Subsidence is approximately $20-50 \mathrm{~cm}$ year $^{-1}$ during the early building of a drainage network (Welch and Nor 1989).

Agus and Subiksa (2008) explain that the subsidence process consists of four components:

1. Consolidation: peat consolidates because of the influence of drainage. Decreasing water levels in peat soil will increase the pressure of the peat above the soil surface as compared to the peat below the water surface. Therefore, the peat becomes compacted.

2. Lyses: decreased peat volume above the water soil surface due to the drainage process.

3. Decomposition: decreased peat volume due to the decomposition process of the aerobic condition.

4. Burning: causes a decreased volume of peat. 
Land clearing for agricultural purposes is usually accompanied by the draining of peatlands. Drainage negatively impacts the soil by decreasing the soil level, which triggers the land's unsuitability for agricultural use. The soil level in the peatlands can be reduced by $3 \mathrm{~m}$ in 30 years (Bintoro et al. 2013).

Sago palm plantations can be a solution to the degradation of peatlands due to the maintenance of the water level. Sago palms grow optimally in swampy and waterlogged conditions and peatlands (Bintoro et al. 2013). During the growing period, sago palms need waterlogged conditions, as shown by the green color of the leaves, to produce suckers. Due to the maintenance of the water level during the sago palm growing period, the degradation of peatlands can be avoided.

\subsubsection{Water Conservation}

The conservation of peatlands is important because they are decreasing in area in some parts of Indonesia. In 1952, Pulau Petak Delta had 51,360 ha of peatlands; however, by 1972, peatlands in the same area had been reduced to 26,400 ha and further dwindled to 9600 ha in 1992 (Sarwani and Widjaja-Adhi 1994). Growing sago palms is a solution to overcoming peatland degradation because they do not need soil drainage and they tolerate waterlogging. Sago palms can conserve soil water because the plants require high soil humidity. Areas that are sometimes flooded are suitable for sago palms. Areas for sago palms must conserve high soil humidity; however, if the area will be used for other crops, the water must be drained away to the river or the sea. Sago palm areas have abundant water; humans, cattle, and vegetation/crops need water (Bintoro et al. 2010). Sago palm cultivation on peat soil will conserve not only water but also soil, so the environment will be maintained.

\subsubsection{The Absorption of $\mathrm{CO}_{2}$}

Climate change can be diminished by agricultural practices and the cultivation of sago palms. The ability of sago palms to absorb $\mathrm{CO}_{2}$ is important for maintaining the environment. According to Indonesian Presidential Decree No. 5 in 2006, regarding the national energy obligation to decrease emissions to $17 \%$ in 2025 , steps that can be applied in the face of climate change include the conservation of forests, seas, and agricultural areas, which can decrease $\mathrm{CO}_{2}$ emissions and reduce the greenhouse effect.

Swamps and peatlands are related to global warming. This is because swampy areas can store large amounts of carbon, which can decrease gas emissions in the atmosphere. Open peatlands expose the soil surface to the sun, which triggers the release of $\mathrm{CO}_{2}$ emissions and $\mathrm{CH}_{4}$ to the atmosphere. The increasing amount of $\mathrm{CO}_{2}$ and $\mathrm{CH}_{4}$ can trigger the greenhouse effect, increasing temperatures, and rising sea 
Table 2.2 Capability of $\mathrm{CO}_{2}$ absorption of major crops

\begin{tabular}{l|l|l|l|l|l|l}
\hline & $\begin{array}{l}\text { Average } \\
\text { of harvest } \\
\text { year }^{-1}\end{array}$ & $\begin{array}{l}\text { Average } \\
\text { number of } \\
\text { effective day } \\
\text { cycle }\end{array}$ & $\begin{array}{l}\text { Day } \\
\text { length } \\
\text { (hour) }\end{array}$ & $\begin{array}{l}\text { Photosynthesis } \\
\mathrm{CO}_{2} \mathrm{~m}^{-2} \mathrm{~h}^{-1}(\mathrm{mg})\end{array}$ & $\begin{array}{l}\text { Leaf } \\
\text { coverage } \\
(\mathrm{million} \\
\text { ha) }\end{array}$ & $\begin{array}{l}\mathrm{CO}_{2} \\
\mathrm{Absorption} \\
\mathrm{mt} \mathrm{ha}^{-1} \mathrm{year}^{-1}\end{array}$ \\
\hline Sago & 1 & 365 & 12 & 22 & 3 & 289 \\
\hline Corn & 2.5 & 45 & 13 & 80 & 2 & 216 \\
\hline Rice & 2.5 & 45 & 14 & 30 & 2 & 81 \\
\hline Cassava & 1 & 180 & 15 & 39 & 2 & 168 \\
\hline Sugarcane & 1 & 180 & 16 & 52 & 2 & 225 \\
\hline $\begin{array}{l}\text { Sweet } \\
\text { potato }\end{array}$ & 2 & 80 & 17 & 23 & 3 & 88 \\
\hline
\end{tabular}

Source: (BPPT 2008) cited in (Bintoro et al. 2010)

levels. According to Bintoro et al. (2010), gas emissions of $\mathrm{CO}_{2}$ and $\mathrm{CH}_{4}$ from peatlands vary from $25-200 \mathrm{mgm}^{2-1} \mathrm{~h}^{-1}$, and the rate of the photosynthesis of sago is $22 \mathrm{mg} \mathrm{CO} \mathrm{dm}^{2-1} \mathrm{~h}^{-1}$. According to calculations, sago palms can absorb $240 \mathrm{mt}$ of $\mathrm{CO}^{2} \mathrm{ha}^{-1}$ year $^{-1}$. Sago palms also support peatlands in storing carbon and minimizing greenhouse effects. Sago palms cover 5,259,538 ha in Papua and West Papua provinces and can absorb some 1,262,289,120 mt of $\mathrm{CO}_{2}$ (Bintoro et al. 2010). Moreover, sago palms have the highest $\mathrm{CO}_{2}$ absorption as compared to other major crops (Bintoro et al. 2010), as shown in Table 2.2.

\section{References}

Abbas B, Bintoro MH, Sudarsono et al (2009) Genetic relationship of sago palm (Metroxylon sagu Rottb.) in Indonesia based on RAPD markers. Biodiversitas 10(4):168-174

Abbas B, Renwarin Y, Bintoro MH et al (2010) Genetic relationship of sago palm in Indonesia based on chloroplast DNA (cpDNA) markers. Biodiversitas 11(3):112-117

Agus F, Subiksa IGM (2008) Lahan gambut: potensi untuk pertanian dan aspek lingkungan. balai penelitian tanah dan World Agroforestry Centre (ICRAF). Bogor (in Indonesian)

Avé JB (1977) Sago in insular Southeast Asia: historical aspects and contemporary use. Tan K, (ed) Sago-76 papers of the first international sago symposium. Kuching, July 5-7, 1976, pp 21-30

Barahima (2006) Keragaman genetic tanaman sagu di Indonesia berdasarkan penanda molekuler genom, kloroplas dan genom inti [disertasi]. Bogor (ID): Institut Pertnian, Bogor

Bintoro HMH (2008) Bercocok tanam sagu. IPB Press, Bogor. 71 hal. (in Indonesian)

Bintoro HMH, Purwanto YJ, Amarillis S (2010) Sagu di lahan gambut. IPB Press, Bogor. (in Indonesian)

Bintoro MH, Amarillis S, Dewi RK, Ahyuni D (2013) Sagu mutiara hiaju khatulistiwa yang dilupakan. Digreat Publishing, Bogor. (in Indonesian)

BPPT (2008) Sagu, potensial perkaya keragaman pangan (http://www.bppt.go.id) 13 March 2008

Dewi RK, Bintoro MH, dan Sudradjat (2016) Morphological characteristics and yield potential of sago palm (Metroxylon spp.) accessions in south Sarong District, West Papua. J Agron Indonesia 44(1):91-97. (in Indonesian)

Djoefrie HMHB (1999) Pemberdayaan tanaman sagu sebagai penghasil bahan pangan alternatif dan bahan baku agroindustri yang potensial dalam rangka ketahanan pangan nasional. Orasi 
Ilmiah Guru Besar Tetap Ilmu Tanaman Perkebunan Fakultas Pertanian Institut Pertanian Bogor, Bogor. 69 hal (in Indonesian)

Djoefrie MHB, Herodian S, Ngadiono et al (2014) Sagu untuk kesejahteraan masyarakat Papua: suatu kajian dalam upaya pengembangan sagu sebagai komoditas unggulan di Provinsi Papua dan Papua Barat. Laporan Penelitian. Jakarta, Unit Percepatan Pembangunan Papua dan Papua Barat. $192 \mathrm{hlm}$ (in Indonesian)

Ehara H (2015) Origin, dispersal and distribution. In: The sago palm: the food and environment challenges of the 21 st century. The Society of Sago Palm Studies, Kyoto, Kyoto University Press, pp 1-30

Ehara H, Kosaka S, Shimura N et al (2003) Relationships between geographical distribution and genetic distance of sago palm in Malay Archipelago. Sago Palm 11:8-13

Flach M (1997) Sago palm Metroxylon sagu Rottb. IPGRI, Rome

Flach M, Braber KD, Fredrix MJJ et al (1986) Temperature and relative humidity requirements of young sago palm seedlings. In: Yamada N, Kainuma K (eds) Proceedings of the third international sago symposium. Sago Palm Research Fund, Tokyo, pp 139-143

Flach M, Schuiling DL (1991) Growth and yield of sago palms in relation to their nutritional needs. In: Ng TT, Tie YL, Kueh HS (eds) Proceedings of the fourth international sago symposium, Kuching, Sarawak, Malaysia. Lee Ming Press, Kuching, pp 103-110

Haryanto B, Pangloli P (1992) Potensi dan pemanfaatan sagu. Penerbit Kanisius Jogjakarta (in Indonesisn)

Johnson D (1977) Distribution of sago making in the old world. In: Tan K (ed) Proceedings of the first international sago symposium, Kuching, July 5-7, 1976, pp 65-75

Kjaer A, Barfod AS, Asmussen CB, Seberg O (2014) Investigation of genetic and morphological variation in the sago palm (Metroxylon sagu; Arecaceae) in Papua New Guinea. Ann Bot 94(1):109-117

Konuma H (2014) Studies on the characteristics of sago starch in relation to growth environment of sago palm (Metroxylon sagu Rottb.) and its value addition to wheat flour as a food starch ingredient. Dissertation, University of Tsukuba, Japan

Kueh HS (1995) The effect of soil applied NPK fertilizers on the growth of the sago palm (Metroxylon sagu Rottb.) on undrained deep peat. Acta Hort 389:67-76

Kueh HS, Elone R, Yiu-Liong T et al (1991) The feasibility of plantation production of sago (Metroxylon sagu) on an organic soil in Sarawak. In: Ng TT, Tie YL, Kueh HS (eds) Proceedings of the fourth international sago symposium, Kuching, Sarawak, Malaysia. Lee Ming Press, Kuching, pp 127-136

Matanubun H (2015) Folk taxonomy of sago palm varieties around Sentani Lake, Jayapura, Papua Province, Indonesia. In: Paper presented at the 12th international sago symposium, Tokyo, September 15-16, 2015

Matanubun H, Santoso B, Nauw M et al (2005) Feasibility study of the natural sago forest for the establishment of the commercial sago palm plantation at Kaureh District, Jayapura, Papua Province Indonesia. In: Proceedings of the 8th international sago symposium, August 4-6, 2005. Universitas Negeri Papua, Manokwari, Indonesia

Notohadiprawiro T, Louhenapessy JE (1992) Potensi sagu dalam penganekaragaman bahan pangan pokok ditinjau dari persyaratan lahan. Prosiding Simposium Sagu Nasional. Fakulas Pertanian Universitas Pattimura. Ambon. Hal, pp 99-106 (in Indonesian)

Novarianto H, Tulalo MA, Kumaunang J et al (2016) Seleksi dan pelepasan varietas selatpanjang meranti untuk pengembangan sagu. J Metroxylon Indonesia 1(1):1-9. (in Indonesian)

Okazaki M, Kimura SD (2015) Ecology of the sago palm. In: The sago palm, the food and environmental challenges of the 21st century. The Society of Sago Palm Studies, Kyoto University Press, pp 41-60

Oldeman LR (1980) The agroclimatic maps of Kalimantan, Maluku, Irian Jaya and Bali, West and East Nusa Tenggara. Central Research Institute for Agriculture, Bogor

Ruddle K (1979) The geographical distribution of sago-producing palms. National Museum of Ethnology, pp 572-594 
Santillan JR, Santillan MM, Francisco R (2012) Using remote sensing to map the distribution of sago palms in northeastern Mindanao, Philippines: Results based on Landsat ETM+ image analysis. The 33rd Asian Conference on Remote Sensing. November 26-30, 2012, Pattaya, Thailand

Sarwani M, Widjaja-Adhi IPG (1994) Penyusutan lahan gambut dan gampaknya terhadap produktivitas lahan pertanian di sekitarnya. Kasus Delta Pulau Petak Kalimantan Selatan. Prosiding Seminar Nasional 25 Tahun Pemanfaatan Lahan Gambut dan Pengembangan Kawasan Pasang Surut. December 14-15, 1994, Jakarta (in Indonesian)

Schuiling DL (2009) Growth and development of true sago palm (Metroxylon sagu Rottboll.) with special reference to accumulation of starch in the trunk. Thesis. Wageningen University, Wageningen

Schuiling DL, Flach M (1985) Guidelines for the cultivation of sago palm. Department Tropical Crop Science, Agricultural University, Wageningen

Sim ES, Ahmed MI (1991) Leaf nutrient variations in sago palms. In: Ng TT, Tie YL, Kueh HS (eds) Proceedings of the fourth international sago symposium, Kuching, Sarawak, Malaysia. Lee Ming Press, Kuching, pp 92-102

Turukay B 1986 The role of the sago palm in the development of integrated farm system in Maluku Province of Indonesia. In: Uamada N, Kainuma K (eds) Proc. 3rd int. sago symp. Tokyo, May 20-23, 1985, pp 7-15

Welch DN, Nor MAM (1989) Drainage works on peat in relation to crop cultivation-a review of problems. Malaysian Soc. Soil Sci. National Seminar on Soil Management for Food and Fruit Crop Production, March 1989, Kuala Lumpur, pp 28-29

Widjono A, Mokay Y, Amisnaipa et al (2000) Jenis-jenis sagu beberapa daerah Papua. Pusat Penelitian dan Pengembangan Sosial Ekonomi Pertanian, Bogor, pp 61-64. (in Indonesian)

Yamamoto Y, Yoshida T, Goto Y et al (2003) Differences in growth and starch yield of sago palms (Metroxylon sagu Rottb.) among soil types in Sarawak, Malaysia. Jpn J Trop Agr 47: 250-259

Yamamoto Y, Yoshida T, Miyazaki A et al (2005) Biodiversity and productivity of several sago palm varieties in Indonesia. In: Abstract of the eighth international sago symposium in Jayapura, Indonesia. Japan Society for the Promotion Science

Yoneta R, Okazaki M, Yano Y (2006) Response of sago palm (Metroxylon sagu Rottb.) to $\mathrm{NaCl}$ stress. Sago Palm 14:10-19

Open Access This chapter is licensed under the terms of the Creative Commons Attribution 4.0 International License (http://creativecommons.org/licenses/by/4.0/), which permits use, sharing, adaptation, distribution and reproduction in any medium or format, as long as you give appropriate credit to the original author(s) and the source, provide a link to the Creative Commons license and indicate if changes were made.

The images or other third party material in this chapter are included in the chapter's Creative Commons license, unless indicated otherwise in a credit line to the material. If material is not included in the chapter's Creative Commons license and your intended use is not permitted by statutory regulation or exceeds the permitted use, you will need to obtain permission directly from the copyright holder.

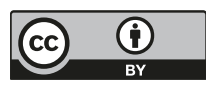




\title{
Chapter 3 \\ Life and Livelihood in Sago-Growing Areas
}

\author{
Yukio Toyoda
}

\begin{abstract}
This chapter describes how people in sago-growing areas are involved with sago, especially in those areas where local people consume sago starch as their staple food, and also describes the cultural and social aspects of sago usage in these areas. Sago is claimed to be one of the oldest crops, and it was the staple foods in large areas of Southeast Asia and Oceania, together with taro and yam, before rice largely replaced these crops. In some areas in Southeast Asia and Oceania, sago is still the staple food, and the sago palm is used not only as a food source but also for various purposes, such as thatching materials. In these areas, sago plays various kinds of social roles as well as being a food. In other areas, such as some places in Malaysia and Indonesia, commercialization of sago starch is practiced, and the starch is processed industrially in factories. Since sago is one of the older crops, it is related to many aspects of people's lives in the sago-growing areas. Having a large number of folk varieties in these areas indicates that sago has a close relationship with people's interests and that it is deeply involved with people's lives. These are shown in mythology, rituals, feasts, and many other human activities.
\end{abstract}

\subsection{Diversity of Sago Usage}

The distribution of sago palm species is shown in Fig. 3.1. Sago grows mostly in the islands of Southeast Asia and also in Melanesia. It includes most of Indonesia, Malaysia, southern Philippines, southern Thailand, Papua New Guinea (PNG), Solomon Islands, Vanuatu, Fiji, and Samoa. It is argued that in Southeast Asia, including islands and mainland areas, taro, yam, and sago formerly were the staple foods before rice largely replaced these crops, and it is claimed that sago is one of the oldest food plants (Spencer 1963).

The way the people use sago varies depending on the area. Using sago as a starch source often refers to the palms being under a system of semi-cultivation, and the

\footnotetext{
Y. Toyoda $(\square)$

College of Tourism, Rikkyo University, Niiza, Saitama, Japan

e-mail: ytoyoda@rikkyo.ac.jp
} 


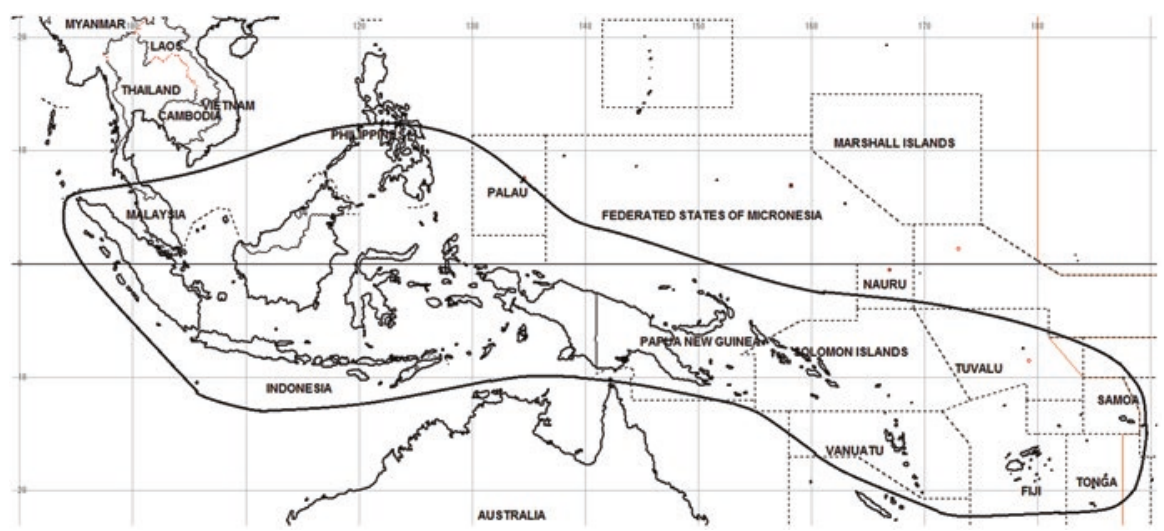

Fig. 3.1 Distribution of Metroxylon spp. in the Asia-Pacific region (Source: Ruddle et al. 1978)

distinction whether the people cultivate sago intentionally or use naturally occurring sago is unclear. The degree of cultivation varies from one area to another.

There are several ways that the local people are involved with sago. First, in some areas sago starch is the staple food for local people. In these areas, the people get starch from sago as a way of subsistence. Second, in some areas, commercialization of sago starch is practiced. Sago is collected, and the starch is processed industrially in factories. Here, the sago starch is exploited as a means of earning cash. Third, in other areas, although they have sago forests or sago palms near their living areas, sago is not used very much. It is only supplementary to other food, only consumed as emergency food, or it is no longer consumed, although it was formerly eaten.

In some areas, sago is the staple food for local people, and these areas include lowlands in Indonesia, Malaysia, and PNG, with some parts of highlands also included. In Indonesia, Papua Province has huge sago forests, more than 1 million ha in total (Ehara 2015), and the people heavily depend on sago as staple food. Also in other areas, such as the Moluccas, northern Sulawesi, and northern Kalimantan, the people utilize sago as a staple food. In Malaysia, Sarawak and Sabah, there are areas where the local people utilize sago as one of their staple foods. Papua New Guinea has a large area where sago is the staple food. Figure 3.2 shows the distribution of land usage of PNG, and it indicates the areas where sago is the staple food. This includes lowland areas in the northern and southern parts of New Guinea Island, and also some areas in smaller islands, including Manus and northern New Ireland. The total area of sago-growing area in PNG is estimated to be around 1 million ha (Power 2002). In some parts of Bougainville, especially in Eivo and Siwai, which are not shown in Fig. 3.2, sago is produced regularly as food (Connell and Hamnett 1978). 


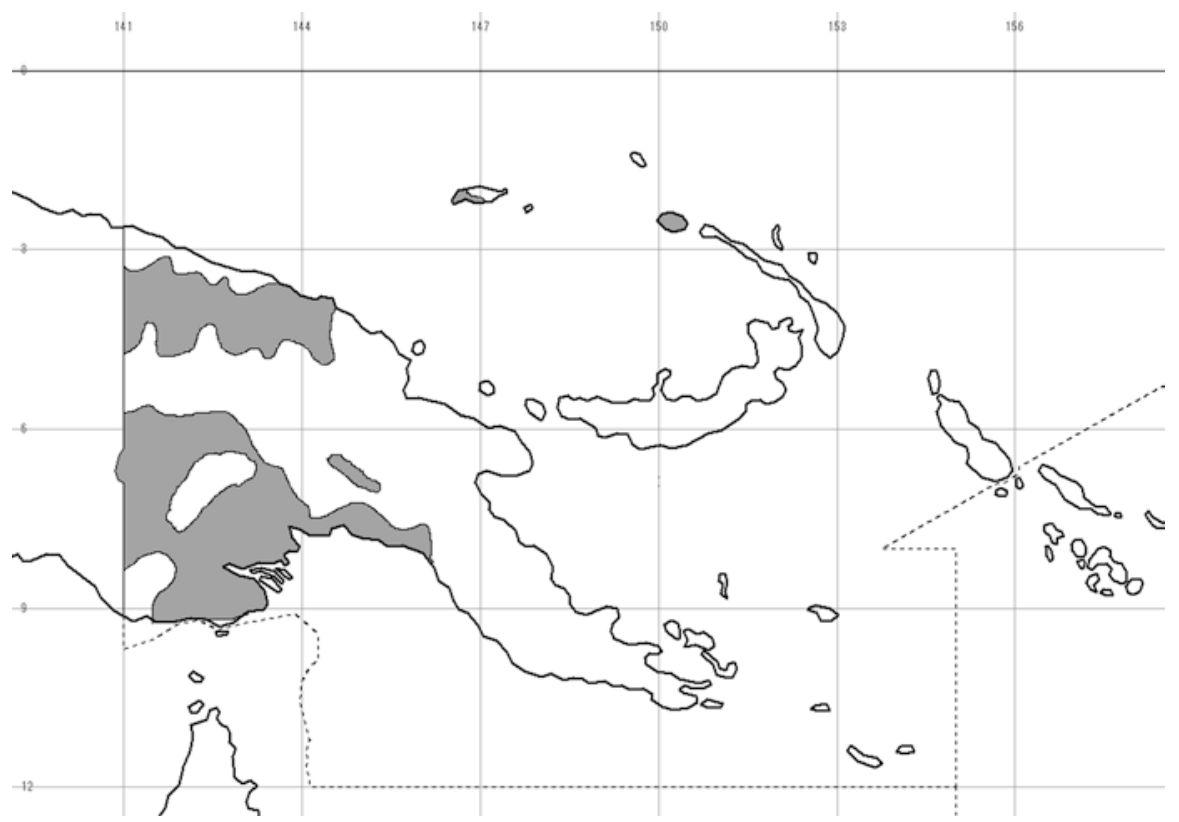

Fig. 3.2 Distribution of the areas where sago is the staple food in Papua New Guinea (Source: Vasey 1982)

As for the commercialization of sago, there are examples only in Malaysia and Indonesia. In Malaysia, there are small-scale sago factories in Sarawak and Sabah. In Indonesia, sago plantations are found in Riau, Sumatra, and Papua Province, as well as small-scale factories (see Chaps. 6, 7, and 8).

In other areas, sago is not used very much. In the current countries of Fiji and Vanuatu, it is believed that sago was once used as a food (Barrau 1959), but at present there is little evidence of its use as food with the exception of Espiritu Santo Island, Vanuatu, and Rotuma Island, Fiji (Connell and Hamnett 1978). In the Solomon Islands, there are some records of its use as a food crop. For example, in the islands of Anuta and Tikopia, sago remains an alternative food to taro, after a cyclone, and in Kwaio and Baegu of northern Malaita, sago was used in times of great scarcity (ibid). There are some areas where it is recorded that the people formerly but no longer consume sago. In many areas where sago grows, sago starch is not eaten, but the palm parts are used for other purposes, such as thatching material. 


\subsection{Sago Use as Food}

When sago is considered as staple food, it has some advantages, compared with the other crops in tropical areas. First, when considered as a food resource, no forward planning is required for getting starch. When the harvest work begins, starch can be consumed after one-half a day or after a day at the most. If sago palms are found just before flowering, starch can be obtained at any time. In the case of root crops, the harvest time depends on the time of planting, and it is possible to adjust the time of harvesting by shifting the time of planting. But in the case of sago, starch is available all the year around, and the flexibility of harvest time in sago is greater than in any of the other crops. In this sense, it can be said that sago has no seasonality. Second, sago palm is constant in that it grows where the other crops cannot grow. Sago palms are able to grow in both mineral and peat soils that have little nutrition, even with high groundwater levels all year around and flooding during the wet season. Also, few diseases and harmful insects damage sago palms, compared with the other crops, such as sweet potatoes, bananas, taro, and cassava (Sasaoka 2006), partly because in the case of insects, the trunk of the sago palm is hard and strong. Third, when extracting starch from sago as one of the land uses, the amount of labor input to obtain calories is less than other crops and shorter than shifting cultivation (Sasaoka 2006; Yamamoto 2015). When a sago palm is felled for starch, 100-800 kg of starch can be taken (in the case of naturally growing palms, it is mostly 100 $200 \mathrm{~kg}$ ), depending on the size and variation of the palm. In this sense, it is efficient for local people to acquire the staple food. Fourth, the starch of sago may be stored for a long time. After making starch, it may be stored for a couple of months in woven bags made of natural fiber, or plastic bags, or ceramic pots (Greenhill 2006) ${ }^{1}$, or even for one-half a year if kept in water in an example from Seram, Indonesia (Sasaoka 2006). In the case of tropical areas, where cereal crops are not available, this characteristic is important, in that sago starch can be stored for the near future.

But on the other hand, sago has some disadvantages as a staple food. First, in sago, the nutritional value, other than carbohydrates, is poor, and the other nutritional requirements, especially protein, must be taken at meals together with sago starch. Second, it takes time to get the first harvest when beginning to grow sago in new locations, since it requires more than 10 years to get starch after the first planting.

There has been discussion as to whether harvesting starch from sago is an easy task for the local people or not. It is said that it requires little managerial work when naturally grown palms are used. But some have argued that it is not easy to manage the sago palm forests for the sake of getting a high quantity of starch, although the man-hours to produce 1 million calories is less than the other crops. It must be acknowledged that it requires collective work for processing starch, since the palms

\footnotetext{
${ }^{1}$ Greenhill (2006) mentioned the possibility of spreading sago disease (sago hemolytic disease: SHD), if the starch is kept for a long period.
} 
are quite large and heavy compared with the other crops (Osozawa 2016). Ellen (2004) also argued that getting sago starch is an adaptive strategy based on complicated technology and refuted the assertion that sago extraction is an intuitively and technically simple solution to food provision for those reluctant to adopt proper agriculture.

As for the starch production potential of sago, once again this subject has been debated. It is reported that the carrying capacity of sago is not very high in PNG (Ohtsuka 1994) and that sago cannot support the human population, especially if population pressures increase significantly. On the contrary, it is argued that sago palm has a very high starch production potential, and higher than the other crops, such as cassava, sweet potatoes, and potatoes. It is acknowledged that making a comparison with other crops in terms of starch production is difficult because it is not easy to find appropriate conditions for sago research to be carried out (Yamamoto 2015).

\subsection{Starch Processing}

Although the method for extracting sago starch is similar throughout the tropics, there is some variation in techniques and implements when examined in detail (Townsend 1974; Ellen 2004). The process of obtaining starch from the palm stems is as follows. First, the people select the appropriate palms for starch harvest, sometimes testing the palms with an axe cut in the trunk to determine that the starch content is adequate. Those testing positive are felled. Felling palms requires hard work, and usually it is done by men. When the palms grow far from home, the trunks are sometimes transported, typically rafted by water, to a processing area near the home. The trunks are quite often cut into log sections, since the entire trunks are too long and heavy to handle. Next, the logs are debarked and the pith chopped out of the trunk interior. Usually wooden pounders are used for this purpose, sometimes with a metal tip. In some areas in Malaysia and Indonesia, this process is done mechanically by using raspers. The next step is to wash the starch from the prepared pith and to settle out the starch. The strainer for filtering is most frequently a fibrous coconut leaf sheath, but recently artificial materials, such as a cloth or nylon netting, are used. For processing, both the hand kneading and trampling method are widely used.

The processing of sago requires collective work, and mostly it is performed by married couples or by consanguineous groups. The gender roles of processing have variations, depending on the area. The general tendency is that the first one-half of processing, including felling the palms and debarking, are performed by men and the latter half by women. In many areas of New Guinea Island, the man is in charge of palm selection, felling palms, debarking, and pith crushing and the woman transporting and storing starch in general. However, the division is different from one area to another, and women perform pith crushing in some locations (Toyoda 2015). 


\subsection{Cooking Practices and Dietary Habits}

The methods of cooking sago also exhibit diversity, such as making sago jelly (also called as sago pudding, sago porridge, or sago dumpling), and also it is eaten baked (as a pancake). Among the Toradja people of Sulawesi, Indonesia, and in the Sepik River area in PNG, wet sago is cooked in bamboo tubes or sandwiched between tree barks. In many areas where sago is consumed as staple food, other foods are eaten with sago, usually in the form of meat, fish, or vegetables, and sometimes with coconut soup (Ruddle et al. 1978).

Table 3.1 shows an example of the dietary habits of the village of Sowom, Arapesh, PNG, where sago is the staple food. Out of 283 meals, 275 included sago; other starches were bananas, root crops, and rice. This shows that the people are heavily dependent on sago as a staple food.

\subsection{Other Usages of Sago}

In sago-growing areas, the palm is used not only as a food source but also for various purposes. Mostly the palms are used for construction materials. For example, the leaves are used as thatching. Thatching with sago leaves is the main usage of sago other than food.

In those locations where sago grows nearby, people utilize every part of sago palm for various purposes. In the case of Nuaulu, Seram, nonfood uses of sago palms are reported in detail by Ellen (2004). Leaves are used to make brushes, baskets, torches, and so on, as well as thatching. Petioles and rachises are used to make fences and toys, as well as for wall construction. In the case of the Melanau people of Sarawak, Malaysia, various kinds of usage of foliage are reported (Goto and Nitta 2015). Dried leaf sheath skins are used to make various kinds of vessels, and the skins of leaf sheath bases are used to make water containers. The vascular bundle at the base of the leaf sheath is made into blowpipe darts. The leaf midribs are used to

Table 3.1 Frequencies of food kinds consumed in Arapesh, Papua New Guinea ${ }^{a}$ (daily basis)

\begin{tabular}{l|l|l}
\hline & No. of days & Percent \\
\hline No. of valid data & 283 & \\
\hline Sago & 275 & 97.2 \\
\hline Bananas & 191 & 67.5 \\
\hline Root crops $^{\text {b }}$ & 84 & 29.7 \\
\hline Rice $^{c}$ & 119 & 42.0 \\
\hline
\end{tabular}

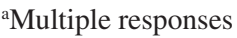

${ }^{\mathrm{b}}$ Root crops include taro, sweet potato, yam, and cassava

'Rice is imported from Australia and sold at shops. Source: Toyoda et al. 2005 
make brooms (ibid.). Dried petioles are also used to make walls and ceilings in many areas (Greenhill 2006; Sasaoka 2006). The bark is sometimes used as flooring materials. Long sections of bark are necessary for flooring, and in this case, the trunks are not cut into sections before crushing the pith. Barks and fronds are also used as fuel, to make fences, and so on.

On the residue of sago pith which is left after processing, certain kinds of mushrooms grow, and they are eaten as supplementary food. Also, when the residue is left for a certain period, larvae of grubs (mostly Rhynchophorus ferrugineus) appear, and the larvae are eaten by local people as a sort of delicacy (Mitsuhashi 2015). Sometimes the residue is left with the intention of collecting these larvae. The residue of sago pith is used as pig feed in some areas (Connell and Hamnett 1978).

\subsection{Social and Cultural Aspects of Sago}

Agricultural crops often play social roles in various societies, and sago is no exception to this point. In sago-growing areas, sago plays various kinds of social roles as well as being a food.

\subsubsection{Folk Classification of Sago}

Sago is considered a single species (Metroxylon sagu Rottb.), but it is classified into several varieties in folk classification in many areas. Ellen (2006) reports that Seram have 11 named folk varieties ${ }^{2}$, and Shimoda and Power (1992) recorded 15 in the lower Sepik River area. Toyoda et al. (2005) report seven among the Arapesh and nine among the Kwanga (Toyoda 2003) in the Sepik River area, both in PNG. The main attributes people use to distinguish folk varieties vary depending on the areas, but mostly they are morphological characteristics, such as spinescence, height, and thickness of trunk, and sometimes characteristics of starch, such as wateriness, solubility, and taste as food (Toyoda 2003; Ellen 2006). The number of folk varieties varies depending on the language group, and it is socially important in that it shows the degree of local peoples' interest in sago and the degree of their dependence on it. The Papua Province of Indonesia has a large number of folk varieties in general, sometimes more than ten. It is reported that there are 35 folk varieties near Sentani Lake of Papua Province (Yamamoto 2015), but it might be possible that these

\footnotetext{
${ }^{2}$ The term folk variety indicates a local category for grouping in each vernacular language. Ellen uses the term landrace for that (Ellen 2006: 269), but the term folk variety has been used in the field of sago studies. It has been used to distinguish local peoples' names from cultivar in the strict agronomic sense, and to indicate the results of folk classification, and to reflect local peoples' recognition. Ethnovariety is a synonym.
} 
varieties include local names in multiple language groups, and the number might be less within a single language group.

\subsubsection{Mythology of Sago}

Although most societies have no myths related to sago, a few have such myths, explaining the origin of sago and the involvement of sago with humans (Ruddle et al. 1978). Among the Toradja in Sulawesi, a series of myths explain the origin of sago. According to these myths, a woman used to provide sago porridge for her husband, but he could not find out where she got this dish. The husband spied on her and noticed that she made the porridge from the white flow from her vagina (others say from the dirt she scraped from her body). When this became known, people killed her. The sago grew out of her corpse. When they chopped into the trunk, blood spurted out, and from these blood spatters sago trees grew anew (Adriani and Kruyt 1951).

The theme of the origin of sago from the corpse of a slain culture hero or heroine can be related to Hainuwele mythologeme, which explains the origin of root crops (Jensen 1939). These myths of the Toradja can be understood as one of them. The Gogodala people, from the middle Fly region of the Western Province, PNG, have a belief that there is a close relationship between humans and sago, and they believe that the first sago palm arose from a man who defecated a seed that grew into a sago palm (Dundon 2002). It can be said that this is also related with the Hainuwele type of myths.

The myths explaining the origin of sago are not found in many areas, and the myths in other areas explain the involvement of sago with humans. In the Sepik River area of PNG, where sago is the staple food, myths related to sago have been reported. Most of these myths say that the local people came to know the ways of washing sago and the customs of cooking it from godlike beings, and then they began to eat sago (Kamimura 2015).

\subsubsection{Sago and Ritual}

Most societies have no rituals for sago, but a few societies have rituals related to sago in that it represents the fertility of crops and humans (Ruddle et al. 1978). Among the Tor people, Papua Province, Indonesia, sago pounding songs are said to have magical efficacy (Oosterwal 1961). The Toradja make small offerings of sago on the way leading to the sago washing place to keep spirits away from their work (Adriani and Kruyt 1951). The Kiwai people of the Fly River, PNG, carry out a lifegiving ceremony, called moguru, to promote human fertility and longevity and to 
enhance the starch production of sago palms. They make life-giving medicine from sago along with a large number of medicinal plants, and they distribute the medicine to each man, who smears it on the trunk of sago palm to encourage the palm to grow large and to yield plenty of starch. They also have a myth suggesting a relationship with the Hainuwele type of myth, in that the dead body of a cultural hero is cut into pieces and buried in the garden (Landtman 1927).

Generally, sago is not related to any kind of taboo. But in Kwoma, Sepik River area of PNG, there is a rule that a man must not eat sago which his wife, or any other woman, has leached, but only that which he himself or another man has leached (Williamson 1979). This is related to the fact that women are considered to be impure, and therefore dangerous, especially when menstruating, in most PNG societies. In Kwoma, sago is considered to be related to women, and it must be purified by leaching by men themselves, before men eat it (ibid.).

\subsection{Sago and Feasts}

As mentioned, one of the advantages of sago as a food resource is that no forward planning is required. Consequently it is useful at times of feasts and famine when ready availability is more important than productivity (Connnell and Hamnett 1978). In sago-growing areas, therefore, it is customary to serve sago to invited guests at special occasions such as weddings. In Arapesh, PNG, sago jellies are offered to visitors from other villages at funerals. At the end of the 3-week mourning period, as an expression of gratitude to the relatives, a lavish feast is held, and sago is the main food on this occasion (Toyoda 2015). In Eivo, Bougainville Island, PNG, sago starch is eaten only at feasts (Connnell and Hamnett 1978).

Sago is treated as goods for giving and receiving gifts. In many places in Melanesia, the groom's family offers some goods (bride price) to the bride's family for matrimony. While pigs are typically presented as the bride price, bags of sago starch are given as a gift at the same time in areas where sago is the staple food (Toyoda 2015).

\subsubsection{Sago and Trade}

As mentioned above, sago starch, unlike almost all the other food crops in tropical area, may be stored for as much as a few months. This has made sago a significant trade item. The Motu people on the southern coast of PNG have traditionally engaged in what is known as Hiri trade with people in the Gulf of Papua area to the 
west to obtain sago. The Motu make unique earthenware pots as their local specialty goods and trade them for sago from the Gulf on a type of sailboat called a lakatoi or lagatoi. As the Motu people cannot obtain sago in their neighborhood, they resorted to this form of trade which involves a 2-3 month-long journey (Toyoda 2015).

\subsection{Conclusion}

Sago is claimed to be one of the oldest crops, and it was the staple food in large areas of Southeast Asia and Oceania together with taro and yam, before rice largely replaced these crops. In some areas in Southeast Asia and Oceania, it is still the staple food, and the sago palm is used not only as a food source but also for various purposes, such as thatching materials. In these areas, sago plays various kinds of social roles as well as being a food. In other areas, such as some places in Malaysia and Indonesia, commercialization of sago starch is practiced, and sago is collected, and the starch is processed industrially in factories.

It has been claimed that getting starch from sago needs little managerial work, and that it is an easy work to get staple food. But recent discussion indicates that it is based on complicated technology and that it needs elaborate management in order to get high-quality products. Whether getting starch from sago is an effective way or not for the local people to get food needs further discussion.

Since sago is one of the oldest crops, it is related to many aspects of livelihood in sago-growing areas. Having a large number of folk varieties in these areas indicates that sago has a close relationship with people's interest and that it is deeply involved with their lives. These are shown in mythology, rituals, feast, and many other human activities.

\section{References}

Adriani N, Kruyt AC (1951) De Bare'e Sprekende Toradjas van Midden Celebes, vol 3. Koninklijke Nederlandse Akademie van Wetenschappen, Amsterdam

Barrau J (1959) The sago palm and other food plants of marsh dwellers in the South Pacific Islands. Econ Bot 13:151-159

Connel J, Hamnett MP (1978) Famine or feast: sago production in Bougainville. J Polyn Soc 87(3):231-242

Dundon A (2002) Mines and monsters: a dialogue on development in Western Province. Austral J Anthr 13(2):139-154

Ehara H (2015) Indonesia and Malaysia. In: The sago palm-the food and environmental challenges of the 21st century. The Society of Sago Palm Studies. Kyoto University Press, Kyoto, pp 23-31 
Ellen RF (2004) Processing Metroxylon sagu Rottboell (Arecaceae) as a technological complex: a case study from south central Seram, Indonesia. Econ Bot 58(4):50-74

Ellen RF (2006) Local knowledge and management of sago palm (Metroxylon sagu Rottboell) diversity in south central Seram, Maluku, Eastern Indonesia. J Ethnobiol 26(2):258-298

Goto Y, Nitta Y (2015) Uses of foliage. In: The sago palm-the food and environmental challenges of the 21st century. The Society of Sago Palm Studies. Kyoto University Press, Kyoto, pp 297-301

Greenhill AR (2006) Food safety and security of sago starch in rural Papua New Guinea. Ph.D. thesis, James Cook University, Australia

Jensen AE (1939) Hainuwele: Volkserzahlungen von der Molukken-Insel Ceram. Vittorio Klosterman, Franfurt-am-Mein

Kamimura T (2015) Mythology surrounding sago palm. In: The sago palm-the food and environmental challenges of the 21st century. The Society of Sago Palm Studies. Kyoto University Press, Kyoto, pp 331-340

Landtman G (1927) The Kiwai Papuans of British New Guinea. Macmillan and Co., London

Mitsuhashi J (2015) Uses of weevils. In: The sago palm-the food and environmental challenges of the 21st century. The Society of Sago Palm Studies. Kyoto University Press, Kyoto, pp 314-319

Ohtsuka R (1994) Subsistence ecology and carrying capacity in two Papua New Guinea population. J Biosoc Sci 26:395-407

Oosterwal G (1961) People of the tor. Royal Van Gorcum, Assen

Osozawa K (2016) Transforming knowledge to action: Sago Techno Park in Tana Luwu. In: Program book of international sago symposium, local initiatives in sago development for food security and human resilience: transforming knowledge to action, held in Makassar, South Sulawesi, July 23, 2016

Power A (2002) Commercialization of sago in Papua New Guinea: PNG-world leader in sago in the 21st century. In: Kainuma K, Okazaki M, Toyoda Y, Cecil JE (eds) New frontiers of sago palm studies: proceedings of the international symposium on sago. Universal Academy Press, Tokyo, pp 159-165

Ruddle K, Johnson D, Townsend PK, Rees JD (1978) Palm sago: a tropical starch from marginal lands, The University of Hawaii Press, Honolulu

Sasaoka M (2006) The meaning of 'sago palm ownership': a monograph on the sago eater in a highland community in Seram, Eastern Indonesia. South East Asian Stud 44(2):105-144. (in Japanese)

Shimoda H, Power AP (1992) Present condition of sago palm forest and its starch productivity in East Sepik province, Papua New Guinea 2. Varieties of sago palm and their distribution. Japan J Trop Agric 36:227-233. (in Japanese)

Spencer JE (1963) The migration of rice from mainland southeast Asia into Indonesia. In: Barrau J (ed) Plants and migration of Pacific peoples. Bishop Museum Press, Honolulu, pp 83-89

Townsend PK (1974) Sago production in a New Guinea economy. Human Ecol 2(3):217-236

Toyoda Y (2003) Rationales for multivariety cultivation in the Sepik region, Papua New Guinea. In: Yoshida S, Hotta M, Into M (eds) Root vegetables and man: root crop farming that supported human survival. Heibonsha, Tokyo, pp 95-111. (in Japanese)

Toyoda Y (2015) Social role of sago palm. In: The sago palm-the food and environmental challenges of the 21st century. The Society of Sago Palm Studies. Kyoto University Press, Kyoto, pp 326-330

Toyoda Y, Todo R, Toyohara H (2005) Sago as food in the Sepik area, Papua New Guinea. Sago Palm 12:1-11 
Vasey D (1982) Subsistence crop system. In: King D, Ranck S (eds) Papua New Guinea atlas: a nation in transition. Papua New Guinea. Robert Brown Assoc, Bathurst, pp 50-51

Williamson MH (1979) Who does what to the sago? Oceania 49:210-220

Yamamoto Y (2015) Productivity comparison with other starch crops. In: The sago palm-the food and environmental challenges of the 21st century. The Society of Sago Palm Studies. Kyoto University Press, Kyoto, pp 230-233

Open Access This chapter is licensed under the terms of the Creative Commons Attribution 4.0 International License (http://creativecommons.org/licenses/by/4.0/), which permits use, sharing, adaptation, distribution and reproduction in any medium or format, as long as you give appropriate credit to the original author(s) and the source, provide a link to the Creative Commons license and indicate if changes were made.

The images or other third party material in this chapter are included in the chapter's Creative Commons license, unless indicated otherwise in a credit line to the material. If material is not included in the chapter's Creative Commons license and your intended use is not permitted by statutory regulation or exceeds the permitted use, you will need to obtain permission directly from the copyright holder. 


\section{Part II \\ Diversity of Sago Resource in Asia and \\ Pacific}




\title{
Chapter 4 \\ Genetic Variation and Agronomic Features of Metroxylon Palms in Asia and Pacific
}

\author{
Hiroshi Ehara
}

\begin{abstract}
Fourteen genera among three subfamilies in the Arecaceae family are known to produce starch in the trunk. The genus Metroxylon is the most productive among them and is classified into section Metroxylon including only one species, $M$. sagu (sago palm: called the true sago palm), distributed in Southeast Asia and Melanesia and section Coelococcus consisting of $M$. amicarum in Micronesia, $M$. salomonense and $M$. vitiense in Melanesia, M. warburgii in Melanesia and Polynesia, and M. paulcoxii in Polynesia. In sago palm, a relationship between the genetic distance and geographical distribution of populations was found as the result of a random amplified polymorphic DNA analysis. A smaller genetic variation of sago palm in the western part than in the eastern part of the Malay Archipelago was also found, which indicated that the more genetically varied populations are distributed in the eastern area and are possibly divided into four broad groups. Metroxylon warburgii has a smaller trunk than sago palm, but the trunk length of $M$. salomonense, $M$. vitiense, and $M$. amicarum is comparable to or longer than that of sago palm. Their leaves are important as building and houseware material, and the hard endosperm of $M$. amicarum and $M$. warburgii seeds is utilized as craftwork material. Preemergent young leaves around the growing point of $M$. vitiense are utilized as a vegetable. Regarding starch yield, palms in Coelococcus are all low in the dry matter and pith starch content as compared with sago palm. For this reason, $M$. salomonense and $M$. amicarum have low yield despite the large size of their trunk. Palms in Coelococcus are mostly regarded as emergency crops and had been utilized when major crops suffered climate damage. Today, roof thatching is the most common use of the leaves, and the domestication of $M$. warburgii is currently under way in Vanuatu and Samoa.
\end{abstract}

The Arecaceae family includes six subfamilies, about 200 genera, and 2600 species. Among three subfamilies (Coryphoideae, Calamoidea, and Arecoideae), 14 genera (Corypha, Phoenix, Borassus, Eugeissona, Metroxylon, Raphia, Mauritia, Caryota,

\footnotetext{
H. Ehara ( $\square)$

Applied Social System Institute of Asia; International Cooperation Center for Agricultural

Education, Nagoya University, Nagoya, Japan

e-mail: ehara@agr.nagoya-u.ac.jp
} 
Wallichia, Roystonea, Butia, Syagrus, and Bactris) produce carbohydrates in the trunk. Considering starch yield, the genus Metroxylon is recognized as the most promising. The genus Metroxylon is distributed from Southeast Asia to Micronesia, Melanesia, and Polynesia. It is divided into two sections: Metroxylon (Eumetroxylon) and Coelococcus (Beccari 1918; Rauwerdink 1986). Metroxylon sagu Rottb. (called the true sago palm: hereafter sago palm) is the only species in the section Metroxylon, although the monophyly of this section remains uncertain. Sago palm extends across Southeast Asia (Thailand, Malaysia, Brunei, Indonesia, Philippines) and northwestern Melanesia (Papua New Guinea and the Solomon Islands). This species has long been used as a food similar to bananas and taro (Barrau 1959) and is one of the oldest crops used by human beings since ancient times (Takamura 1990). The sago-type palms were an important plant food prior to the introduction of rice (around 5000 years ago) in south subtropical China (Yang et al. 2013). Five species are recognized within the section Coelococcus, representing the eastern half of the Metroxylon distributing area (McClatchey 1998; Ehara 2015a). One species is distributed in Micronesia, and the other four species are distributed across Melanesia and Polynesia from the Solomon Islands and Vanuatu to Fiji and Samoa. McClatchey (1998) reported that people on Rotuma in Fiji consume sago (starch obtained from the palm trunk) produced from M. warburgii. Metroxylon warburgii is sometimes called the Vanuatu sago palm. In other areas, Metroxylon palms have been used occasionally. For instance, $M$. amicarum (Caroline ivory nut palm) was used on Moen in Micronesia until the 1940s, and M. warburgii was used on Gaua in Vanuatu until at least the 1950s (Ehara et al. 2003c). On Malekula in Vanuatu, M. warburgii is sometimes used as an emergency food. Indo-Fijian people often harvest $M$. vitiense (Fijian sago palm) to get the preemergent young leaves around the growing point (apical bud together with the very young leaf sheathes and leaves) (Ehara 2015c). The harvested part recognized as palm cabbage is used for cooking similar to bamboo shoot. The leaves of Metroxylon palms are important as building and houseware materials. The hard endosperm of $M$. amicarum and $M$. warburgii seeds is called palm ivory and utilized as craftwork material (Ehara 2015d).

Sago palm and related species grow in swampy, alluvial, and peaty soils where almost no other major crops can grow without drainage or soil improvement (Sato et al. 1979; Jong 1995). Sago palm is a highly important bioresource for not only sustainable agriculture but also rural development in swampy areas of the tropics. Moreover, Metroxylon palms, including sago palm, are recognized as unexploited or underexploited plants (Ehara 2006a) because this species has been harvested mainly from natural forests and/or has been semi-cultivated with very simple maintenance.

Considering the recent social background that a new competition between biofuel production and food production has occurred, and as food demands diversify, an efficient use of carbohydrates from sago palm and related species is currently anticipated, followed by a predicted increase in the development and utilization of land in swampy areas. According to the Department of Agriculture, Sarawak, the amount of sago starch exported from Malaysia was about 44,500 mt in 2010 and 
51,000 $\mathrm{mt}$ in 2011. A private company in Riau, Indonesia, is planning to export around $1000 \mathrm{mt}$ of sago starch annually. Sago palm's presence is actually not high in the international starch market at present. However, considering the estimated sago palm-growing area (distribution) in Southeast Asia and Melanesia (see Chap. 1), sago palm's potential will be extremely high in carbohydrate supply for various industries. The establishment of a concrete system for stable and sustainable production is a pressing demand to enhance the further use of sago palm to strengthen food security for all. This chapter provides a brief review of the genetic variation and agronomic features of Metroxylon palms in Asia and the Pacific.

\subsection{Variation in the Plant Form, Palm Size, and Starch Yield}

Key characters to classification of the genus Metroxylon are shown in Table 4.1. Palms belonging to the Calamoideae subfamily of the Arecaceae, including the genus Metroxylon, produce fruits that are covered with scales. The sago palm produces fruits with 18 rows of longitudinally arranged scales. The other species in the section Coelococcus bear 24-28 rows of scales. Sago palm can be propagated from both seeds and suckers; however, the germination percentage of seeds is very low. The Coelococcus palms are apparently different from sago palm because they do not produce suckers. Instead, the germination percentage of seeds is very high in the section Coelococcus, and those palms depend for their propagation on only the seeds. Regarding distinct characteristics of the inflorescence, only M. amicarum grows lateral inflorescences from leaf axils, while the other five species produce a terminal racemose inflorescence (Fig. 4.1). The lateral inflorescence of M. amicarum is pleonanthic (polycarpic), but the terminal inflorescence of the other species is hapaxanthic (monocarpic). There are variations in the branching system, pattern, and fruit shape. According to Rauwerdink (1986), second-order branches on $M$. salomonense and $M$. warburgii are not pendulous. The second-order branches on the inflorescence of $M$. vitiense are pendulous. Dowe (1989) reported the variation in the second- and third-order branching system of the inflorescence of $M$. salomonense. The different second-order branching patterns are found even on a single first-order branch of M. salomonense (Ehara et al. 2003b). Metroxylon salomonense grows rachillae as third-order branches on a second-order branch; the second-order branch grows erect on the first-order branch. Then, the rachillae are formed on first-order branches as second-order branches in some cases, and these second-order branches (rachillae) are pendulous in such cases. Regarding distinct characteristics of spines on the petiole and rachis, $M$. vitiense forms black spines, and $M$. salomonense has soft and flexible fibrous spines unlike any other species.

Sago palm produces the largest amount of starch depending on its higher dry matter percentage in pith and starch concentration on the basis of pith dry matter among Metroxylon palms (Table 4.2). Metroxylon warburgii has a smaller trunk than sago palm, and the trunk of M. salomonense, M. vitiense, and M. amicarum is 
Table 4.1 Morphological characteristics of the genus Metroxylon

\begin{tabular}{|c|c|c|}
\hline Species & Distribution & Characteristics \\
\hline $\begin{array}{l}\text { M. sagu Rottb. } \\
\text { (Sago palm) }\end{array}$ & $\begin{array}{l}\text { Thailand, Malaysia, } \\
\text { Brunei, the } \\
\text { Philippines, } \\
\text { Indonesia, Papua } \\
\text { New Guinea, and the } \\
\text { Solomon Islands }\end{array}$ & $\begin{array}{l}\text { Clump forming. Spineless or spiny, with varying } \\
\text { spine length and density. Fruit is covered with } 18 \\
\text { rows of vertically arranged scales, } 5 \mathrm{~cm} \text { in diameter }\end{array}$ \\
\hline \multirow{2}{*}{$\begin{array}{l}\text { M. amicarum } \\
\text { (H. Wendl.) Becc. } \\
\text { (Caroline ivory } \\
\text { nut palm) }\end{array}$} & \multirow[t]{2}{*}{$\begin{array}{l}\text { Caroline Islands and } \\
\text { Micronesia }\end{array}$} & $\begin{array}{l}\text { Lateral inflorescence. First-order branches emerge at } \\
\text { leaf axils }\end{array}$ \\
\hline & & $\begin{array}{l}\text { Large globose fruit, } 26-29 \text { rows of scales, } 7-10.5 \mathrm{~cm} \\
\text { in diameter, slightly flat at top, no dent at base }\end{array}$ \\
\hline $\begin{array}{l}\text { M. vitiense } \\
\text { (H. Wendl.) } \\
\text { H. Wendl. ex } \\
\text { Benth. \& Hook. } \\
\text { f. (Fijian sago } \\
\text { palm) }\end{array}$ & Fiji Islands & $\begin{array}{l}\text { Second-order branches on inflorescence droop and } \\
\text { are very short }(18 \mathrm{~cm}) \text {. Spines on petiole and rachis } \\
\text { are black. Globose fruit, } 27-31 \text { rows of scales, } \\
\text { conical with round base and wide top, } 5.5-6.6 \mathrm{~cm} \text { in } \\
\text { length, } 4.5-7 \mathrm{~cm} \text { in diameter }\end{array}$ \\
\hline $\begin{array}{l}\text { M. salomonense } \\
\text { (Warb.) Becc. } \\
\text { (Solomons'sago } \\
\text { palm) }\end{array}$ & $\begin{array}{l}\text { The Solomon } \\
\text { Islands, Northeastern } \\
\text { part of New Guinea } \\
\text { Island, New Britain } \\
\text { Island, and Northern } \\
\text { islands in Vanuatu }\end{array}$ & $\begin{array}{l}\text { Third-order branches (rachillae) on inflorescence } \\
\text { droop and are very long }(20-26 \mathrm{~cm}) \text {, pubescence on } \\
\text { the adaxial side of all pedicel bracts. Spines on } \\
\text { petiole and rachis are soft. Inflorescence shows two } \\
\text { or three orders of branching. Rachillae arising as both } \\
\text { second-order branching on first-order branch of } \\
\text { inflorescence and third-order branching after } \\
\text { second-order branching. Globose fruit, } 27-28 \text { rows of } \\
\text { scales, } 7 \mathrm{~cm} \text { in diameter. Seed diameter: } 4 \mathrm{~cm} \text {; } \\
\text { pericarp thickness, } 5-6 \mathrm{~mm}\end{array}$ \\
\hline $\begin{array}{l}\text { M. warburgii } \\
\text { (Heim) Becc. } \\
\text { (Vanuatu sago } \\
\text { palm) }\end{array}$ & $\begin{array}{l}\text { Vanuatu, Fiji } \\
\text { (Rotuma Is.), Samoa }\end{array}$ & $\begin{array}{l}\text { All branches on inflorescence arising upright. No } \\
\text { pubescence on the adaxial side of all pedicel bracts. } \\
\text { Marked cuticle formation on the abaxial side of } \\
\text { leaflet. Pyriform fruit, } 24-28 \text { rows of scales, } 7-10 \mathrm{~cm} \\
\text { in length, } 4-9 \mathrm{~cm} \text { in diameter }\end{array}$ \\
\hline $\begin{array}{l}\text { M. paulcoxii } \\
\text { McClatchey (M. } \\
\text { upoluense Becc.) }\end{array}$ & Samoa & $\begin{array}{l}\text { Inflorescence shows two to three orders of branching, } \\
\text { rachillae arising nonuniformly (drooping or upright). } \\
\text { Second-order branches arising between the center } \\
\text { and tip of a first-order branch form rachillae, which } \\
\text { droop, and third-order branches arising between the } \\
\text { center and base of a second-order branch form } \\
\text { rachillae, which grow upright (two types of branching } \\
\text { pattern coexist at the central segment). Small fruit } \\
\text { narrowing toward base, length } 3.3 \mathrm{~cm} \text {, diameter } \\
2.5 \mathrm{~cm}, 24 \text { rows of scales }\end{array}$ \\
\hline
\end{tabular}

Sources: Rauwerdink (1986), McClatchey (1998), Ehara et al. (2003b), and Ehara 2015a (some information is from the latest survey by the author) 

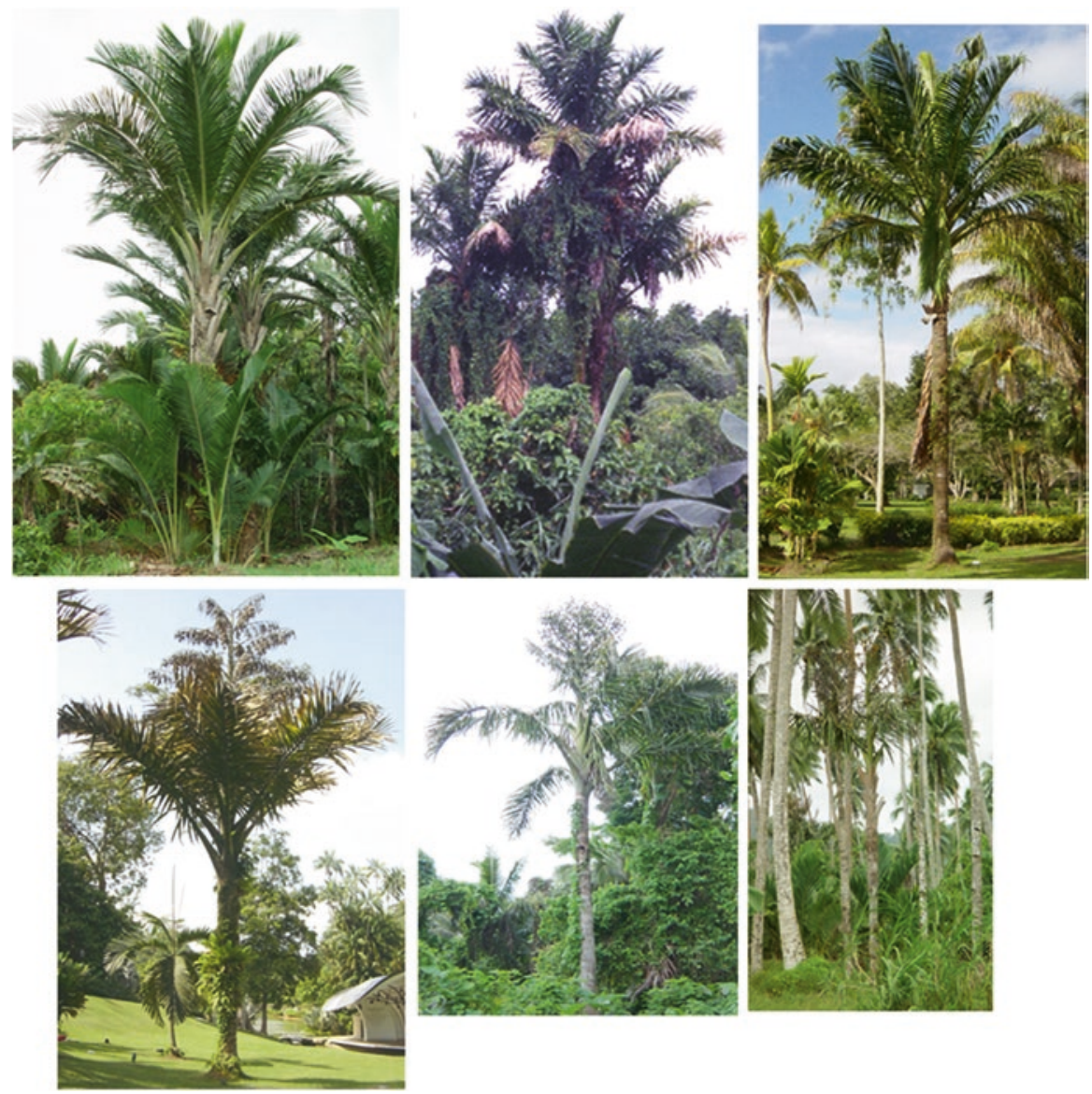

Fig. 4.1 Metroxylon palms (upper left, M. sagu; upper middle, M. amicarum; upper right, $M$. vitiense; lower left, M. salomonense; lower middle, M. warburgii; lower right, M. paulcoxii)

comparable to or longer than that of sago palm. However, M. salomonense, $M$. warburgii, $M$. vitiense, and $M$. amicarum are all low in their dry matter and starch contents of pith in comparison with sago palm. Therefore, the starch yield of $M$. salomonense and M. amicarum is low despite their larger trunk size. Coelococcus palms are mostly regarded as emergency crops as described above. They had been utilized when staple crops suffered environmental damage up to the 1950s or 1960s (Ehara et al. 2003b). Barton (2012) reported that the ethnographic record indicates that several groups of swidden farmers in Sarawak were still utilizing sago $(M$. $s a g u$ ) as their main crop, some used it on a regular basis, while others had shifted more fully toward rice, but were still dependent upon sago, and kept it nearby as insurance against a poor harvest or failure of the rice crop. It has been reported that salt was collected from the ashes of burned leaves in Vanuatu during the 1940s; similar examples were observed in PNG as well (Cabalion 1989). Currently, roof 
Table 4.2 Comparison of yield and yield components of the Metroxylon species

\begin{tabular}{l|l|l|l|l|l|l|l|l}
\hline $\begin{array}{l}\text { Species } \\
\text { (survey } \\
\text { location) }\end{array}$ & $\begin{array}{l}\text { Trunk } \\
\text { length } \\
(\mathrm{m})\end{array}$ & $\begin{array}{l}\text { Trunk } \\
\text { diameter } \\
(\mathrm{cm})\end{array}$ & $\begin{array}{l}\text { Pith } \\
\text { density } \\
\left(\mathrm{g} / \mathrm{m}^{3}\right)\end{array}$ & $\begin{array}{l}\text { Pith dry } \\
\text { matter } \\
\text { content } \\
(\%)\end{array}$ & $\begin{array}{l}\text { Pith dry } \\
\text { matter } \\
\text { weight } \\
(\mathrm{kg})\end{array}$ & $\begin{array}{l}\text { Pith } \\
\text { starch } \\
\text { content } \\
(\%)\end{array}$ & $\begin{array}{l}\text { Pith total } \\
\text { sugar } \\
\text { content } \\
(\%)\end{array}$ & $\begin{array}{l}\text { Starch } \\
\text { yield } \\
(\mathrm{kg} / \\
\mathrm{plant})\end{array}$ \\
\hline $\begin{array}{l}\text { M. sagu } \\
\text { (Indonesia) }\end{array}$ & 8.6 & 45.2 & 0.770 & 41.1 & 413.9 & 77.1 & $4.9^{\mathrm{a}}$ & 309.8 \\
\hline $\begin{array}{l}\text { M. } \\
\text { salomonense } \\
\text { (Vanuatu) }\end{array}$ & 8.5 & 58.0 & 0.850 & 18.5 & 326.0 & 48.9 & 15.3 & 159.4 \\
\hline $\begin{array}{l}\text { M. warburgii } \\
\text { (Vanuatu) }\end{array}$ & 5.5 & 35.0 & 0.902 & 35.7 & 156.5 & 34.8 & 13.5 & 48.6 \\
\hline $\begin{array}{l}\text { M. amicarum } \\
\text { (Micronesia) }\end{array}$ & 10.7 & 44.9 & 0.794 & 16.0 & 179.4 & 38.8 & 10.0 & 71.8 \\
\hline $\begin{array}{l}\text { M. vitiense } \\
\text { (Fiji) }\end{array}$ & 7.6 & 36.7 & 0.894 & 20.8 & 156.1 & 26.7 & 8.4 & 49.4 \\
\hline
\end{tabular}

Sources: Ehara et al. (2003c) and Ehara (2006b)

anly data of pith total sugar content was from PNG (mean value of two folk varieties used for food)

thatching is the most common use of Coelococcus palms, and the domestication of M. warburgii is currently under way in Vanuatu. In Samoa, M. warburgii can be recognized as a cultivated plant, and it is observed throughout Upolu Island.

\subsection{Origin and Distribution of Sago Palm and Related Species}

Sago palm is found in a zone $10^{\circ}$ north and south of the equator at the Malay Peninsula, from southern Thailand to western and eastern Malaysia, Brunei, Indonesia's Sumatra and surroundings, Java, Kalimantan, Sulawesi, the Maluku Islands, Papua and West Papua (formerly Irian Jaya), the central and southern Philippines, Papua New Guinea (PNG), and the Solomon Islands. This species has high environmental adaptability and can grow in lowland swamps, acidic soils, and brackish-water regions where other major crops cannot grow well. Sago palm grows wild near lakes and rivers and is found up to an elevation of about $700 \mathrm{~m}$ above sea level in North Sulawesi and about $1000 \mathrm{~m}$ in PNG. Wild stands of sago palms are found today primarily in swamps and peat moors which are unsuitable even for paddy rice. However, sago palm will show preferable production under upland condition with sufficient water where it in fact grows better than it does under flooded or submerged conditions. These days, sago palm stands are observed in places not suitable for agricultural development, which does not mean that lowland swamps are the most preferable habitat for sago palm (Ehara 2015b). 
Starch yield of sago palm varies greatly depending on both the habitat and the folk variety. Figure 4.2a shows the result of a random amplified polymorphic DNA (RAPD) analysis on a total of 38 population samples collected from 22 sites in the Malay Archipelago and 1 site in Papua New Guinea (PNG) (Ehara et al. 2003a). Among the 38 samples, 16 are spineless and 22 are spiny, including 14 gray or 2 with brown banding on the abaxial side of petiole/rachis, and 3 having reddish pith. The resultant UPGMA dendrogram divides the populations into two main groups. Group A includes subgroup A1 consisting of populations mainly distributed over the western part of the Malay Archipelago and subgroup A2 consisting of three populations from Southeast Sulawesi and two from Mindanao. Group B includes 12 populations collected in the eastern part of the Malay Archipelago: subgroup B1 consisting of 6 populations from Seram and subgroup B2 consisting of 2 from Seram and 4 from Ambon. From this analysis, a relationship between the genetic distance and geographical distribution of sago palms was found. A smaller genetic variation in the western part than in the eastern part of the Malay Archipelago was also found, which indicated that the more genetically varied populations are distributed in the eastern area. According to Vavilov's theory about centers of origin of cultivated plants, the origin of a plant taxon is the place where the highest diversity of that taxon is found. The origin of a plant species can be considered to be the place where the greatest number of varieties and other variants are found within the taxon. Based on the RAPD analysis, the greater genetic variation found in the eastern Malay Archipelago, including the Maluku Islands, supports the traditional hypothesis that the area from the Maluku Islands to New Guinea Island is the center of origin of the sago palm.

On the other hand, the genetic distance between the spineless and spiny populations is not necessarily farther than that between spineless populations or spiny populations in the dendrogram. This result indicated that the presence of spines on the petiole/rachis appears to be unrelated to genetic distance, which supports Rauwerdink's proposition (1986) to recognize the spineless sago palms and the spiny sago palms in the same taxon as $M$. sagu. Furthermore, no definite relationships were also found between the other morphological characteristics such as the banding pattern on petiole/rachis, the color of pith, and the genetic distances of populations. Kjær et al. (2004) have examined the relationships between various characteristics representing morphological features and genetic distances using amplified fragment length polymorphism (AFLP) analysis of sago palm populations growing in Papua New Guinea and reported that no correlations were found between different morphological characteristics and genetic distances. In communities that are highly dependent on sago palm, many folk varieties are recognized based on morphological traits. However, according to the past genetic diversity analyses conducted by Ehara et al. (2003a) and Kjær et al. (2004), the genetic diversity of the sago palm is not very high. Abbas et al. (2010) reported that a simple sequence repeat analysis of chloroplast DNA of plants collected from various locations in Papua Province of Indonesia has found that they are divided into three groups with about $77 \%$ belonging to one group. In any case, it is considered that there is no 


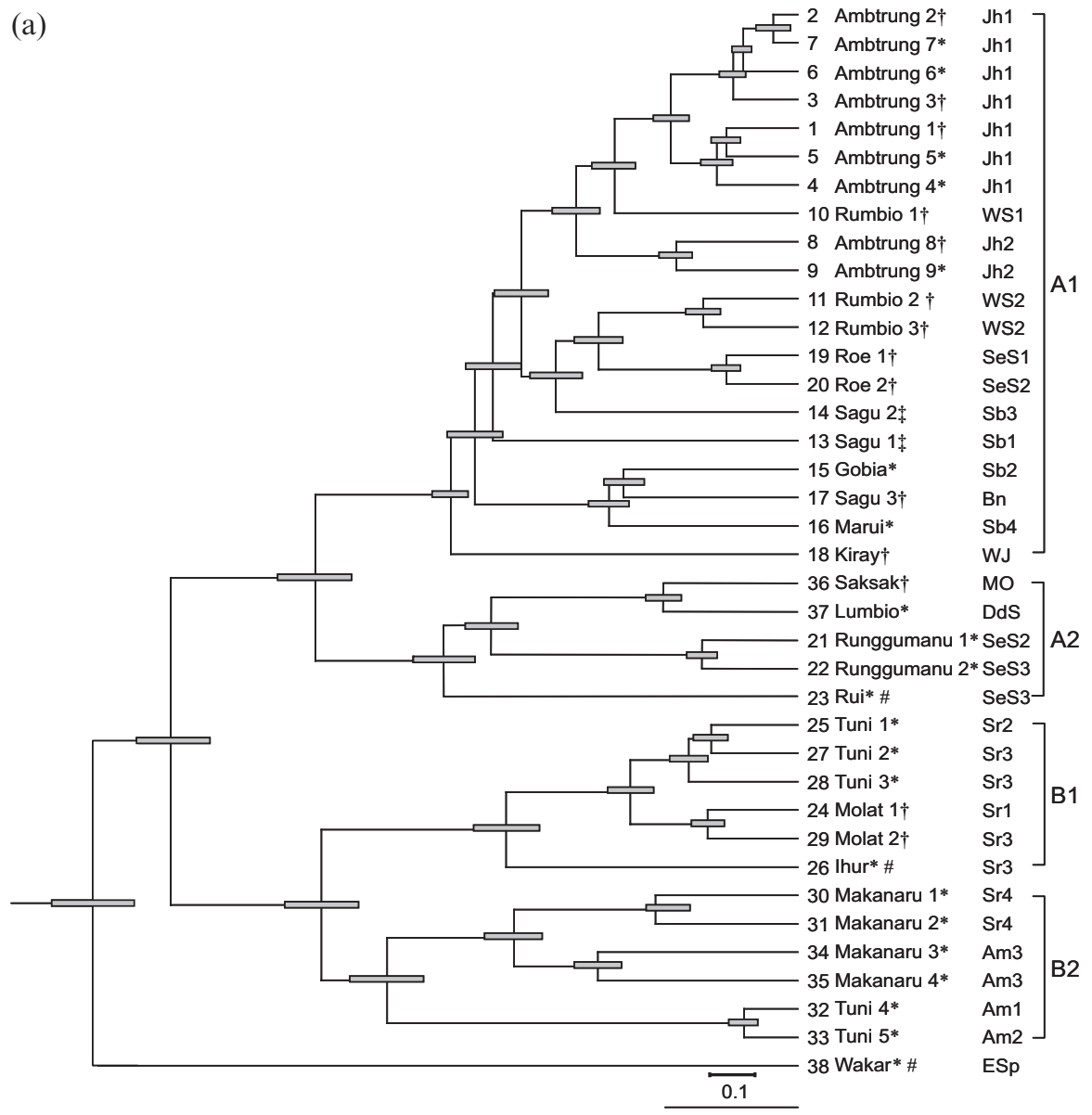

(b)

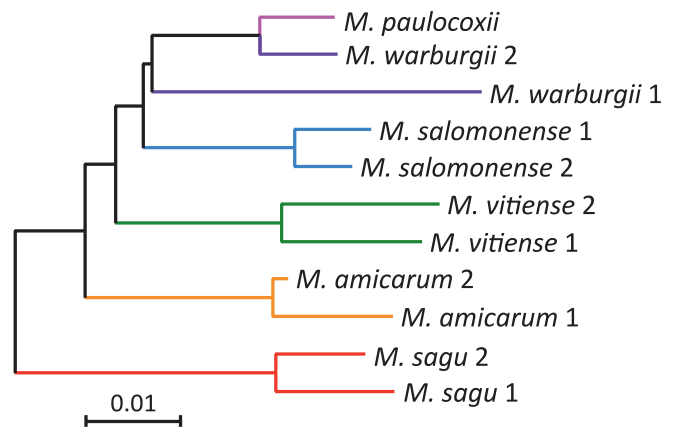

Fig. 4.2 UPGMA dendrogram of sago palm (M. sagu) based on RAPD data (a from Ehara et al. 2003a) and NJ dendrogram of genus Metroxylon based on sequence data of 5S nrDNA (b from Ehara et al. 2017) (* Spiny population, $\uparrow$ dark gray banding population, $\neq$ brown banding population, \# reddish pith population, $\square$ standard error) 
correspondence between morphological characteristics used for the folk classification in local communities and genetic distance.

Regarding the specifications of Metroxylon section Coelococcus, there are reports on the phylogenetics based on the morphological characters (McClatchey 1998, 1999). However, few studies of the molecular phylogenetics on the section Coelococcus exist. Baker et al. (2000) reported molecular phylogenetics of Calamus and related rattan genera based on $5 \mathrm{~S}$ nrDNA spacer sequence data. The phylogenetic analysis based on 5S nrDNA spacer sequence is considered to be available for the genus Metroxylon that belongs to the same tribe (Calameae) with the genus Calamus. Figure $4.2 \mathrm{~b}$ shows the results of the phylogenetic analysis using DNA sequence data from the nontranscribed spacer of 5S nrDNA to investigate phylogenetic relationships among the species of section Coelococcus. Two populations each of M. salomonense, $M$. warburgii, $M$. amicarum, $M$. vitiense, and sago palm (M. sagu grown in Southeast Sulawesi) as the out-group were used in this analysis. In only $M$. paulcoxii, one palm was used because only one individual was found on Upolu in Samoa in 2004. According to the NJ dendrogram from the cladistic analysis, the section Coelococcus was divided into four clades. Metroxylon amicarum grown in Micronesia was genetically distant from the other species in the section Coelococcus. Metroxylon amicarum grown in Micronesia is markedly different from the other species in inflorescence development as described above. Metroxylon salomonense and $M$. vitiense clearly are at or near the purely hapaxanthic definition, and $M$. amicarum is not as clearly near the pleonanthic definition but is close enough to be categorized as pleonanthic, whereas populations of $M$. warburgii and $M$. paulcoxii are intermediate, tending to be closer a hapaxanthic than to a pleonanthic condition (McClatchey 1999).

Metroxylon warburgii formed a clade together with $M$. paulcoxii in this analysis. The other species of the section Coelococcus formed their own clade. M. paulcoxii was reported by McClatchey (1998) as a new species. This species has a reduced floral branching system, which is completely different from the other Metroxylon species including the section Metroxylon (sago palm). Genetic relationship between M. paulcoxii and $M$. warburgii should be studied in detail employing further analysis from the molecular phylogenetic point of view. Besides, the distribution area of $M$. warburgii is very wide from Vanuatu to Vanua Levu Island and Rotuma Island of Fiji and Samoa that is geographically distant from that of sago palm. The clade of $M$. warburgii and $M$. paulcoxii was located at the most distant position from sago palm in this dendrogram. From this analysis, it can be considered that the species in the section Coelococcus were dispersed by two routes: one was to the north for Micronesia, and the other route was to the east for Polynesia through Melanesia. This is in agreement with McClatchey's study (1999) based on phylogenetic analysis using morphological characters. 


\subsection{Resistance Against Abiotic Stresses}

\subsubsection{Salt Stress}

As mentioned above, Metroxylon palms can grow in problem soils. Here, the salt resistance of sago palm and related species is introduced. Figure 4.3a shows the $\mathrm{Na}^{+}$ concentration in different plant parts of sago palm seedlings grown in a hydroponic system after $342 \mathrm{mM} \mathrm{NaCl}$ treatment (corresponding to $2 \% \mathrm{NaCl}$ ) for 1 month (Ehara et al. 2008b). In the leaflets and petioles of the treated plants, the $\mathrm{Na}^{+}$ concentrations were higher at lower leaf positions than at higher leaf positions. The difference in the $\mathrm{Na}^{+}$concentrations in both the leaflets and petiole between the control and treated plants was remarkable at lower leaf positions. The $\mathrm{Na}^{+}$ concentration in the leaflets was less than one-half of that in the petiole. On the other hand, the $\mathrm{Cl}^{-}$concentration increased with the $\mathrm{NaCl}$ treatment in all the parts including the leaflets at nearly all the leaf positions (Ehara et al. 2008b). The pattern of the difference in the $\mathrm{Cl}^{-}$concentration was different from that in the $\mathrm{Na}^{+}$ concentration, especially in the petiole.

Although the $\mathrm{K}^{+}$concentration decreased in the roots during the $\mathrm{NaCl}$ treatment, it did not decrease in the leaflets and petiole. These tendencies were found in the seedlings at more advanced leaf ages as well and under a wide range of $\mathrm{NaCl}$ concentrations in culture solution (Ehara et al. 2006). At some leaf positions, the $\mathrm{K}^{+}$ concentrations were higher in the treated plants than in the control plants (Ehara et al. 2008a, b). The $\mathrm{K}^{+}$concentration in the petiole tended to be higher at higher leaf positions than at lower leaf positions, especially in the treated plants. In some species, plant growth is not affected when the $\mathrm{K}^{+}$concentration is maintained under $\mathrm{NaCl}$ treatment (Yeo and Flowers 1983; Jeschke et al. 1985). The $\mathrm{K}^{+}$concentrations in the top part did not decrease, regardless of the leaf position in the case of sago palm. It appears that $\mathrm{Na}^{+}$absorption clearly did not depress $\mathrm{K}^{+}$absorption and translocation to the leaves in sago palm, and the $\mathrm{K}^{+}$distribution in the top part tended to increase rather than have no effect. Yoneta et al. (2006) also reported that sago palm was able to uptake $\mathrm{K}^{+}$from soil, and $\mathrm{K}^{+}$was accumulated in leaflets through the root systems in response to $\mathrm{NaCl}$ stress. They reported also that proline was under the detection limit in leaflets and roots, and a small amount of glycinebetaine was found in leaflets.

According to Ehara et al. (2008a, b), new leaf emergence was delayed slightly with the $\mathrm{NaCl}$ treatment, although senescence of the lower leaf did not accelerate. In $M$. warburgii and $M$. vitiense also, the $\mathrm{K}^{+}$concentration in the leaflets did not decrease under salt stress conditions (Ehara et al. 2007, 2008a). These results in sago palm and related species strongly support the assumption that salt tolerance is related to the exclusion of $\mathrm{K}^{+}$by $\mathrm{Na}^{+}$absorption in the leaf blade (Yeo and Flowers 1983; Jeschke et al. 1985). Considering these results, $\mathrm{K}^{+}$assumes the role of osmotic adjustment, especially at higher leaf positions in most active leaves. 
a

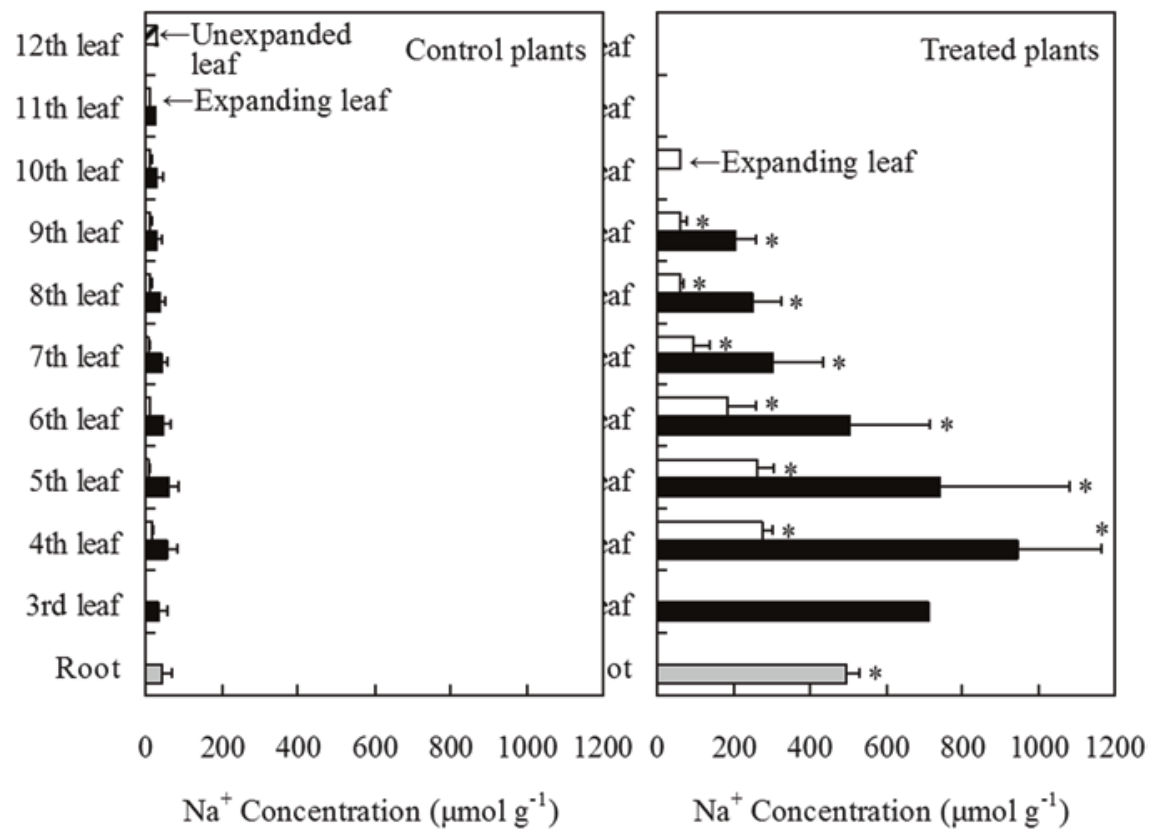

b
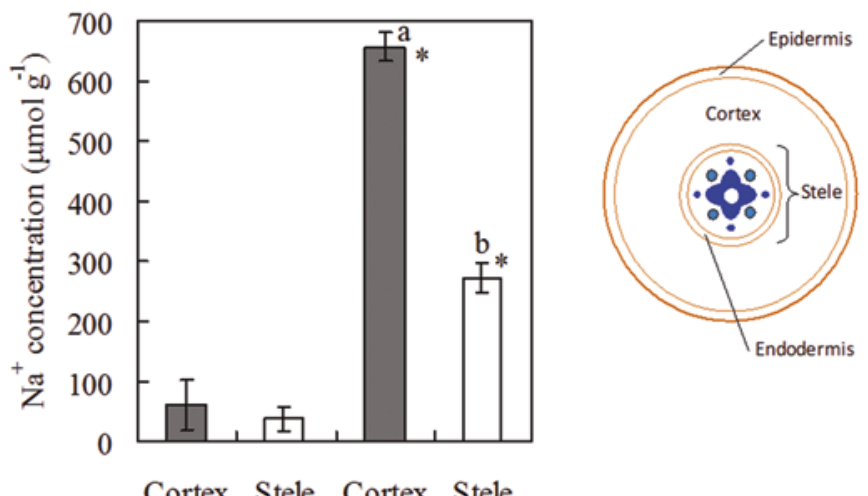

Cortex Stele Cortex Stele

Control Treatment

Fig. 4.3 $\mathrm{Na}^{+}$concentration in roots and leaflets and petiole at different leaf positions (a) and in the cortex and stele of adventitious roots under $\mathrm{NaCl}$ treatment (b) (Source: Ehara et al. 2008a) with schematic of transvers section of root (c). Horizontal and vertical lines indicate the standard deviation $(n=3)$. Asterisks indicate a significant difference in each part between the control and treated plants at a 0.05 probability level, according to the t-test. Different letters indicate significant differences in different parts within the treated plants at a 0.05 probability level, according to the Tukey-Kramer test 
Figure $4.3 \mathrm{~b}$ shows the $\mathrm{Na}^{+}$concentration in different parts in the adventitious roots (Ehara et al. 2008b), and Fig. 4.3c shows a schematic of transverse section of root. The $\mathrm{Na}^{+}$concentration was lower in the stele (central cylinder) than in the cortex. According to the study on Na distribution revealed by X-ray microanalysis from the cortex to the stele in the adventitious roots of the treated plants, much more $\mathrm{Na}$ was detected in the cortex than in the stele (Ehara et al. 2008b). The highest distribution of $\mathrm{Na}$ was found at the inner region of the cortex near the stele. In this region, the endodermis where suberin or lignin (Casparian strip) develops also was observed in sago palm (Prathumyot and Ehara 2010). From only this finding, it is difficult to discuss the information in detail, although it is clear that the region including the endodermis has a mechanism to trap some of the over-influx of $\mathrm{Na}$ into the root. This mechanism will be very important in restricting translocation of $\mathrm{Na}^{+}$from the root to the top parts under salt stress. Sago palm exhibits the mechanism to maintain low $\mathrm{Na}^{+}$concentration in the leaflets by storing $\mathrm{Na}^{+}$in the roots and petioles, especially at lower leaf positions, the mechanism of which can be understood as salt avoidance. However, the photosynthetic rate and transpiration rate decreased by $40 \%$ with $\mathrm{NaCl}$ stress in sago palm seedlings (final 18th leaf age) grown for 4 months in a hydroponic system including $224 \mathrm{mM} \mathrm{NaCl}$ (corresponding to $1.3 \%$ ) (Prathumyot et al. 2011).

\subsubsection{Acid Stress}

Nowadays sago palm populations are often found in swamps and peat soil where soil $\mathrm{pH}$ is low, such as in the Malay Archipelago. Sago palm has been considered to be tolerant of acid soil. From the results of growth analysis of sago palm seedlings

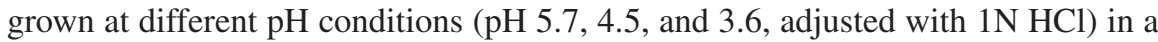
pot filled with vermiculite and culture solution for 4.5 months, it was clear that there were no significant differences in any growth parameters among the three treatments (Anugoolprasert et al. 2012). When sago palm seedlings were planted in a pot filled with vermiculite and culture solution at $\mathrm{pH} 3.6$ (adjusted with $1 \mathrm{~N} \mathrm{H}_{2} \mathrm{SO}_{4}$ ) that included different levels of $\mathrm{AlCl}_{3} \cdot 6 \mathrm{H}_{2} \mathrm{O}$ corresponding to $0,10,20,100$, and $200 \mathrm{ppm} \mathrm{Al}$ (as initial Al concentration before applying to the pots), the weekly increments of plant length, total leaf area, and dry matter weight for 4.5 months were largest in 10 ppm, followed by 0, 20, 100, and 200 ppm Al (Anugoolprasert et al. 2014). The root system under $200 \mathrm{ppm}$ Al was apparently different from that under 0-100 ppm Al, and the branched roots were stunted, brownish, and thick. The root dry weight was also less than the other plots. The change in $\mathrm{P}, \mathrm{N}, \mathrm{K}^{+}, \mathrm{Ca}^{2+}$, and $\mathrm{Mg}^{2+}$ concentrations with the $\mathrm{Al}$ treatments was moderate. The $\mathrm{Al}^{3+}$ concentration tended to be lower in the leaflets at higher leaf position and the stele of the adventitious roots, while it tended to be higher in the cortex of adventitious roots (values ranged from 190 to $950 \mathrm{mg} \mathrm{kg}^{-1} \mathrm{DM}$ in all the plant parts, even at $200 \mathrm{ppm}$ Al). According to Chenery (1948), thousands of plant species are classified as Al 
accumulators ( $\left.\geq 1000 \mathrm{mg} \mathrm{kg}^{-1} \mathrm{DM}\right)$ or Al excluders ( $\left.<1000 \mathrm{mg} \mathrm{kg}^{-1} \mathrm{DM}\right)$. Based on the $\mathrm{Al}$ concentrations in the plant tissues, sago palm is considered to have Al-exclusion ability under acidic conditions. However, the diameter at breast height (DBH) that was one of the most important parameters limiting the pith dry matter yield correlated with soil $\mathrm{pH}$ in the Malay Archipelago (Ehara et al. 2000). Even if sago palm exhibits the mechanism to exclude excess $\mathrm{Al}$ under low $\mathrm{pH}$ condition, the growth and yield will be affected by soil acidity.

Although sago palm can adapt to comparatively severe environments such as saline or acid soils, the growth rate and productivity will be decelerated under salt stress or in acid soil. We should investigate how much sago starch we can expect to produce under saline or acid condition to utilize areas of poor productivity or barren lands with sterile soil. The physiological information described above on the growth of sago palm and its response to abiotic stresses will be valuable for investigating concrete tactics and/or strategies to introduce new plant resources to barren lands with sterile soil and improve the economic activities depending on regional resources in places with low productivity.

\section{References}

Abbas B, Renwarin Y, Bintoro MH et al (2010) Genetic diversity of sago palm in Indonesia based on chloroplast DNA (cpDNA) markers. J Biol Div 11:112-117

Anugoolprasert O, Kinoshita S, Naito H et al (2012) Effect of low pH on the growth, physiological characteristics and nutrient absorption of sago palm in a hydroponic system. Plant Prod Sci $15: 125-131$

Anugoolprasert O, Ehara H, Naito H (2014) Growth response and nutrient concentrations of sago palm under aluminum stress. TIJSAT 19:37-52

Baker JB, Henderson TA, Dransfield J (2000) Molecular phylogenetics of Calamus (Palmae) and related rattan genera based on 5S nrDNA spacer sequence data. Mol Phylogenet Evol 14:218-231

Barrau J (1959) The sago palm and other food plants of marsh dwellers in the South Pacific Islands. Econ Bot 13:151-159

Barton H (2012) The reversed fortunes of sago and rice, Oryza sativa, in the rainforests of Sarawak, Borneo. Quat Int 249:96-104

Beccari O (1918) Asiatic palms-Lepidocaryae. Ann R Bot Gard Calcutta 12:156-195

Cabalion P (1989) Metroxylon, Vanuatu palm. In: Dowe JL (ed) Palms of the south-West Pacific. Palm and Cycad Societies of Australia, Milton, pp 178-180

Chenery EM (1948) Aluminium in the plant world. I. General survey in dicoyledons. Kew Bull 2:173-183

Dowe JL (1989) Palms of the south-West Pacific: their origin, distribution and description. In: Dowe JL (ed) Palms of the South-West Pacific. Palm and Cycad Societies of Australia, Milton

Ehara H (2006a) Diversity of economic plants. In: Morita S, Daimon H, Abe J (eds) Sustainable crop production. Asakura Shoten, Tokyo, pp 25-28

Ehara H (2006b) Geographical distribution and specification of Metroxylon palms. Jpn J Trop Agric 50:229-233

Ehara H (2015a) Taxonomy. In: The sago palm: the food and environmental challenges of the 21st Century. Kyoto University Press, Kyoto and Trans Pacific Press, Melbourne, pp 1-16 
Ehara H (2015b) Geographical origin, dispersal and distribution of true sago palm. In: The sago palm: the food and environmental challenges of the 21st Century. Kyoto University Press, Kyoto and Trans Pacific Press, Melbourne, pp 17-22

Ehara H (2015c) Use of trunk apex. In: The sago palm: the food and environmental challenges of the 21st Century. Kyoto University Press, Kyoto and Trans Pacific Press, Melbourne, pp 302-304

Ehara H (2015d) Use of fruit. In: The sago palm: the food and environmental challenges of the 21st Century. Kyoto University Press, Kyoto and Trans Pacific Press, Melbourne, pp 304-307

Ehara H, Susanto S, Mizota C et al (2000) Sago palm (Metroxylon sagu, Arecaceae) production in the eastern Archipelago of Indonesia: variation in morphological characteristics and pith-dry matter yield. Econ Bot 54:197-206

Ehara H, Kosaka S, Shimura N et al (2003a) Relationship between geographical distribution and genetic distance of sago palms in the Malay Archipelago. Sago Palm 11:8-13

Ehara H, Naito H, Mizota C, Ala P (2003b) Distribution, growth environment and utilization of Metroxylon palms in Vanuatu. Sago Palm 10:64-72

Ehara H, Naito H, Mizota C, Ala P (2003c) Agronomic features of Metroxylon palms growing on Gaua in the Banks Islands, Vanuatu. Sago Palm 11:14-17

Ehara H, Matsui M, Naito N (2006) Avoidance mechanism of salt stress in sago palm (Metroxylon sagu Rottb.) Jpn J Trop Agric 50:36-41

Ehara H, Shibata H, Naito $\mathrm{H}$ et al (2007) $\mathrm{Na}^{+}$and $\mathrm{K}^{+}$concentrations in different plant parts and physiological features of Metroxylon warburgii Becc. Under salt stress. Jpn J Trop Agric 51:160-168

Ehara H, Shibata H, Prathumyoto W et al (2008a) Absorption and distribution of $\mathrm{Na}^{+}, \mathrm{Cl}^{-}$and some other ions and physiological features of sago palm under salt stress. Trop Agric Dev 52:7-16

Ehara H, Shibata H, Prathumyot W et al (2008b) Absorption and distribution of $\mathrm{Na}^{+}$and some ions in seedlings of Metroxylon vitiense H. Wendl. ex Benth. \& Hook. f. Under salt stress. Trop Agric Dev 52:17-26

Ehara H, Yamamoto T, Naito H et al (2017) Phylogenetic study of Metroxylon palms in Southeast Asia and Oceania based on 5S nrDNA spacer sequence data. SAGO PALM (in press)

Jeschke WD, Atkins CA, Pate JS (1985) Ion circulation via phloem and xylem between root and shoot of nodulated white lupin. J. Plant Physiol 117:319-330

Jong FS (1995) Research for the development of sago palm (Metroxylon sagu Rottb.) cultivation in Sarawak, Malaysia. Ph. D. thesis of Agricultural University, Wageningen, The Netherlands

Kjær AS, Barfod AS, Asumussen CB et al (2004) Investigation of genetic and morphological variation in the sago palm (Metroxylon sagu; Arecaceae) in Papua New Guinea. Ann Bot 94:109-117

McClatchey WC (1998) A new species of Metroxylon (Arecaceae) from Western Samoa. Novon 8:252-258

McClatchey WC (1999) Phylogenetic analysis of morphological characteristics of Metroxylon section Coelococcus (Palmae) and resulting implications for studies of other Calamoideae genera. Mem N Y Bot Gard 83:285-306

Prathumyot W, Ehara H (2010) Identification of Casparian strip in roots of Metroxylon sagu, a salt-resistant palm. Trop Agric Dev 54:91-97

Prathumyot W, Okada M, Naito H et al (2011) Physiological response and mineral concentration of sago palm under diurnal changes of $\mathrm{NaCl}$ concentration in culture solution. Trop Agric Dev $55: 11-20$

Rauwerdink JB (1986) An essay on Metroxylon, the sago palm. Principes 30:165-180

Sato T, Yamaguchi T, Takamura T (1979) Cultivation, harvesting and processing of sago palm. Jpn J Trop Agric 23:130-136

Takamura T (1990) Recent research activities and the problems on sago palm. Jpn J Trop Agric 34:51-58. (in Japanese) 
Yang X, Barton HJ, Wan Z et al (2013) Sago-type palms were an important plant food prior to rice in southern subtropical china. PLoS One 8(5):e63148. doi:10.1371/journal.pone.0063148

Yeo AR, Flowers TJ (1983) Varietal differences in the toxicity of sodium ions in rice leaves. Physiol Plant 59:189-195

Yoneta R, Okazaki M, Yano Y (2006) Response of sago palm (Metroxylon sagu Rottb.) to $\mathrm{NaCl}$ stress. Sago Palm 14:10-19

Open Access This chapter is licensed under the terms of the Creative Commons Attribution 4.0 International License (http://creativecommons.org/licenses/by/4.0/), which permits use, sharing, adaptation, distribution and reproduction in any medium or format, as long as you give appropriate credit to the original author(s) and the source, provide a link to the Creative Commons license and indicate if changes were made.

The images or other third party material in this chapter are included in the chapter's Creative Commons license, unless indicated otherwise in a credit line to the material. If material is not included in the chapter's Creative Commons license and your intended use is not permitted by statutory regulation or exceeds the permitted use, you will need to obtain permission directly from the copyright holder. 


\title{
Chapter 5 \\ Sago Palm Genetic Resource Diversity in Indonesia
}

\author{
Barahima Abbas
}

\begin{abstract}
Information of genetic diversity is very important in supporting the implementation of genetic resource conservation and plant breeding. This study aims to determine the genetic diversity of 11 sago palm accessions that have been collected by the Sago Research Consortium (SRC), University of Papua (UNIPA). Methods of research were divided into three steps. Step 1 was DNA extraction by using Geneaid DNA plant Mini Kit. Step 2 was PCR amplification fragments DNA by using KAPA2G Robust HotStart polymerases and performed by using Bio-Rad PCR instrument. Step 3 was purified and sequenced DNA by Macrogen Inc. Seoul, Korea. Data analyses were performed by using a MEGA6.06 software. Morphological characteristics in the rosette stage of 11 sago palm accessions were divided into 4 phenotypes only, and several accessions showed the same phenotypes. Based on atp6-2 gene markers, the 11 sago palm accessions had a different genetic characteristic among the others. Genetic distances among 11 sago palm accessions were in the range among 0.22 and 3.01 with an average 1.21 pairwise distant. Phylogenetic construction showed that the genetic relationship of 11 sago palm accessions was clustered into 6 groups. The accession numbers SP001 and SP002 are in group 1, the accession numbers SP003 and SP011 group 2, the accession numbers SP005 and SP007 group 3, the accession number SP009 group 4, the accession numbers SP008 and SP010 group 5, and the accession numbers SP004 and SP006 group 6. Nucleotide sequence alignments of mitochondrial atp6-2 gene and introns were different from each other in 11 accessions.
\end{abstract}

\subsection{Introduction}

Indonesia has the largest area of sago plantings and sago forests, as well as the richest genetic diversity of the palm. World sago plantations and sago forests were estimated at 2 million ha, with 1 million ha located in Indonesia (Flach 1983). Kertopermono (1996) reported a more extensive area of sago palm in Indonesia

B. Abbas $(\bowtie)$

Faculty of Agriculture, University of Papua, Manokwari, Indonesia

e-mail: b.abbas@unipa.ac.id 
totaling 1,528,917 ha, with 1,406,469 in Papua, 45,540 in Sulawesi, 41,949 in Maluku, 31,872 in Sumatra, 2795 in Kalimantan, and 292 ha in West Java. Sago palms in Indonesia are unevenly distributed, as is their genetic diversity. Flach (1983) estimated the diversity of sago as being higher in Papua than elsewhere in the country.

Plant characters such as morphology, protein, and deoxyribonucleic acid (DNA) can be used as markers to ascertain the diversity of sago palms. Morphology and protein characters are insufficient as indicators to reveal genetic diversity because they are influenced by the environment. DNA markers are not influenced by the environment and therefore are used to establish genetic diversity. Determining the genetic diversity of sago palm populations in Indonesia has focused on diversity based on DNA markers of the nuclear, chloroplast, and mitochondrial genomes. DNA markers used for the analysis are as follows: random amplified polymorphism DNA (RAPD), the expression of specific genes (waxy gene) in the nucleus genome, chloroplast simple sequence repeat (cpSSR) in the chloroplast genome, and the expression of functional genes (gene atp6) in the mitochondrial genome.

\subsection{Genetic Diversity of Sago Palm Based on the Nuclear Genome}

\subsubsection{RAPD Markers}

A total of 100 sago palm samples were collected from 6 locations (Papua, Maluku, Sulawesi, Kalimantan, Java, and Sumatra) and 9 populations (Jayapura, Serui, Manokwari, Sorong, Maluku, Palopo, Pontianak, Bogor, and Selat Panjang) of sago palm centers in several parts of Indonesia.

Polymorphisms of RAPD amplification fragments using 10 RAPD primers and performed with PCR tools resulted in 86 polymorphic fragments and 2-7 genotype numbers per population (Abbas et al. 2009). High numbers of RAPD polymorphisms and genotypes were found in this observation. These results were similar to the genetic diversity of sago palm found in an earlier study by Ehara et al. (2003), which used RAPD markers employing a small number of individual sago palm samples from Indonesia and Malaysia.

Numbers of fragmented DNA bands were amplified from each primer and exhibited a range of 6-12 polymorphic bands per primer; no monomorphic DNA band was observed. The average number of polymorphic DNA bands was calculated to be 9 per primer. Primer P17 resulted in the highest numbers of polymorphic DNA bands produced, 12, whereas primers OPA04 and P06 produced the lowest numbers of polymorphic DNA bands, 6 per primer. The size of DNA bands produced by 10 primer sets had a range of 150-1800 bp (base pairs). Overall primers in this analysis were suitable to study sago palm genetics (Abbas et al. 2009). A previous observation of this involved assaying more than 100 RAPD primers sets. 
Table 5.1 Genetic diversity of sago palm based on 86 polymorphic loci from 10 RAPD loci

\begin{tabular}{l|l|l|l|l|l|l}
\hline Location & Papua & Ambon & Sulawesi & Kalimantan & Java & Sumatra \\
\hline$\sum$ population & 4 & 1 & 1 & 1 & 1 & 1 \\
\hline $\mathrm{R}_{\mathrm{IP}}$ & 16 & 3 & 4 & 18 & 2 & 7 \\
\hline $\mathrm{S}$ & 86 & 29 & 21 & 77 & 16 & 62 \\
\hline $\mathrm{G}$ & 66 & 3 & 4 & 18 & 2 & 7 \\
\hline$\hat{\mathrm{H}} \hat{\mathrm{H}}$ & 1.0000 & 1.0000 & 1.0000 & 1.0000 & 1.0000 & 1.0000 \\
\hline$\pi$ & 0.0026 & 0.2722 & 0.1768 & 0.0185 & 0.5000 & 0.0764 \\
\hline $\mathrm{P}$ & 30.6457 & 19.3333 & 10.8333 & 25.2941 & 16.0000 & 27.9048 \\
\hline$R$ & 98.8372 & 33.7209 & 24.4186 & 89.5349 & 18.6047 & 72.0930 \\
\hline
\end{tabular}

$R_{I P}$ average individual number per population, $S$ polymorphic site number, $G$ genotype numbers, $\hat{H}$ genotype diversity, $V \hat{H}$ variation of genotype diversity, $\pi$ mean pairwise differences, $P$ percentage of polymorphic alleles

The genetic diversity of sago palm populations from six Indonesia locations is presented in Table 5.1. The average number of individuals $\left(\mathrm{R}_{\mathrm{IP}}\right)$ of each population is $2-18$, the number of polymorphic sites ( $\mathrm{S}$ ) is $16-86$, the mean pairwise differences $(\pi)$ is $10.8333-30.6457$, and genotype diversity $(\hat{H})$ equals 1 . Variant diversity of genotype $(\mathrm{VH})$ is $0.0026-0.5000$, and the percentage of polymorphic loci $(\mathrm{P})$ is 18.6047-98.8372. The highest values of $\mathrm{S}, \pi$, and $\mathrm{P}$ are in Papua, meaning that the sago palms there are the most diverse. The $\mathrm{H}$ value of all samples overall in Papua is 1.000 , meaning all samples are different. The highest $\mathrm{VH}$ value is from Java (Table 5.1) because samples from that location were the fewest in number and different from each other.

\subsubsection{Waxy Gene Markers}

A total of a 100 samples of sago palm were collected from Jayapura, Serui, Manokwari, Sorong, Maluku, Palopo, Pontianak, Bogor, and Selat Panjang populations of sago palm in Indonesia. A total of 8 polymorphic alleles and 14 genotypes of $\mathrm{Wx}$ genes were observed in the sago palm genome. Alleles ranging from 100 to 700 bp were detected on agarose gels (Abbas and Ehara 2012). Polymorphism levels detected in sago palm were similar to those found in the wheat (Triticum aestivum L.) genome by Shariflou and Sharp (1999), using a Wx gene (Sun1) primer. Also, Wx gene variations observed in the sago palm genome were similar to those found by Boggini et al. (2001) in the wheat genome. Using single nucleotide genotyping of the Wx gene, high polymorphism in barley was reported by Domon et al. (2004) as well as in rice by Bao et al. (2002) and Tran et al. (2011), using the microsatellite marker for $\mathrm{Wx}$ genes.

The distribution of genotypes of sago palm showed that the populations possessing a specific genotype are found in Serui in Papua and in the population of Palopo in Sulawesi. This indicates that both Papua and Sulawesi are the origin of sago palm variation because of the existence of specific genotypes in their populations; both 
locations are, therefore, considered to be the original sources of sago palm germplasm in Indonesia. Papua exhibited the largest genotype numbers existing in their population based on Wx gene markers; therefore, it is considered to be the center of sago palm genetic diversity in Indonesia.

The genetic diversity of sago palm samples from several areas in Indonesia was calculated. The values of $\mathrm{S}, \mathrm{G}, \hat{\mathrm{H}}, \mathrm{VH}, \pi$, and $\mathrm{P}$, based on 8 alleles and 14 genotypes of Wx gene markers in a total of 100 sago palm samples, all showed variations, except in the samples from Java (Table 5.2). The samples reflect sago palm variations in several of the locations. The Wx gene is one of the genes active in the starch biosynthesis process, especially for synthesizing amylose in plants such as the sago palm, which produce starch. Variations of Wx genes as found in the sago palm genome indicate variations in the quality and quantity of starch produced. Ehara et al. (2005) reported that sago palm stems produced $28-710 \mathrm{~kg}$ of starch; Yamamoto et al. (2005) reported that starch production per trunk varied among varieties. Local people experienced in working with sago palms report that the quality of starch varied in terms of color and the quality of pappeda, a type of porridge made from it.

The quality and the quantity of starch may be affected by the genes that regulate the starch biosynthesis process, among them the Wx gene. Larkin and Park (2003) found that the Wx gene is one of the many genes that play a part in starch synthesis in the endosperm of rice. Furthermore, Wanchana et al. (2003) found two alleles of the Wx gene (Wxa and $\mathrm{Wxb}$ ) that regulated the enhancement of the protein and amylose contents of the starch. The lack of a Wx allele in wheat significantly decreased amylose production (Sharma et al. 2002). Epstein et al. (2002) reported that recombinant inbred lines (RILs) of wheat, which have three Wx genes in their genome, produced better-quality starch in comparison with wheat RILs which do not contain three Wx genes.

Table 5.2 Genetic diversity of the Wx genes based on 8 polymorphic alleles and 14 genotypes

\begin{tabular}{l|l|l|l|l|l|l}
\hline Location & Papua & Ambon & Sulawesi & Kalimantan & Java & Sumatra \\
\hline$\sum$ population & 4 & 1 & 1 & 1 & 1 & 1 \\
\hline $\mathrm{R}_{\mathrm{IP}}$ & 16 & 3 & 4 & 18 & 2 & 7 \\
\hline $\mathrm{S}$ & 7 & 2 & 5 & 5 & 0 & 4 \\
\hline $\mathrm{G}$ & 11 & 3 & 4 & 6 & 1 & 5 \\
\hline$\hat{\mathrm{H}}$ & 0.8163 & 1.0000 & 1.0000 & 0.7190 & 0.0000 & 0.8571 \\
\hline $\mathrm{VH}$ & 0.0285 & 0.2722 & 0.1768 & 0.0933 & 0.0000 & 0.1371 \\
\hline$\pi$ & 1.1543 & 1.3333 & 2.8333 & 1.1569 & 0.0000 & 1.4286 \\
\hline $\mathrm{P}$ & 87.5 & 25.0 & 62.5 & 62.5 & 0.00 & 50.0 \\
\hline
\end{tabular}

$R_{I P}$ average individual number per population, $S$ polymorphic site number, $G$ genotype numbers, $\hat{H}$ genotype diversity, $V \hat{H}$ variation of genotype diversity, $\pi$ mean pairwise differences, $P$ percentage of polymorphic alleles 


\subsection{Genetic Diversity of Sago Palm Based on the Chloroplast Genome}

Polymorphism of cpDNA Primers rpl1671, NTCP21, and NTCP22 resulted in PCR products of 100 samples. No polymorphisms were detected on three of the agarose gels, but SNF analysis using fluorescence primers showed polymorphisms on 97 of the samples. The nucleotide detections clearly appeared in each individual sample. Primer pairs of rpl1671-FAM produced four alleles in the size range 147$406 \mathrm{bp}$, primer pairs of NTCP21-HEX produced five alleles in the size range of $76-406 \mathrm{bp}$, and primer pairs of NTCP22-NED produced two alleles in the range of 75-160 bp. In a previous study, primer pairs of NTCP21 and NTCP22 also detected polymorphism alleles in potato (Bryan et al. 1999).

Haplotype Identification and Composition In the three cpDNA loci (rpl1671, NTCP21, and NTCP22) of sago palm, there were observed 10 haplotypes and 11 alleles in the populations of sago palm (data not shown). Haplotypes H01 and H02 were located in two cpDNA loci, and haplotypes $\mathrm{H} 03-\mathrm{H} 10$ were located in three cpDNA loci. Haplotypes H01, H02, H07, and H09 were found spread into two or more populations (Abbas et al. 2010). Only small individual sago palms were moved from a certain population to others because only four of ten haplotypes were shared in two or more populations, which indicated that only four haplotypes of sago palm were estimated to migrate in many ways. In related studies using cpDNA, markers were also reported in refugial populations of Scots pine (Pinus sylvestris L.) and silver fir (Abies alba Mill.) (Provan et al. 1998; Vendramin et al. 1999).

Haplotype H05 was found only in the population from Palopo, Sulawesi, with a 0.25 frequency, and haplotype H10 was found only in the Jayapura population of Pontianak, Kalimantan, with a 0.06 frequency. Haplotypes H04, H06, and H08 were only found in the Jayapura population with $0.04,0.04$, and 0.12 frequencies, respectively. Haplotype H03 was found only in the Serui population with a 0.04 frequency, so that we found four specific haplotypes in Papua (Abbas et al. 2010). In these observations, we found six specific haplotypes which were distributed in Papua, Sulawesi, and Kalimantan. Specific haplotype phenomena have also found in alyssum flowers (Alyssum spp.) by Mengoni et al. (2003) and in cypress (Cunninghamia spp.) by Hwang et al. (2003). Specific haplotypes within populations indicate that they should be the origin of diversity, but we cannot state that the populations of sago palm are diverse because they also have a haplotype with a shared overall population (H07).

Sago palm populations in Papua (Jayapura and Serui), Sulawesi (Palopo), and Kalimantan (Pontianak) which possess specific haplotypes could be the origin of sago palm diversity. The magnitude of haplotype numbers can be used as one of several indicators to indicate the center of diversity. Vendramin et al. (1999) and Mengoni et al. (2003) reported that high numbers of haplotypes indicated a high level of variation. The presence of a widespread common haplotype indicates a major ancient population (Provan et al. 2001). Papua could be the origin and center 
of sago palm diversity because it has the highest specific haplotypes and the highest numbers of haplotypes, as well as the existence of wild types. Haplotypes described in this study must have existed in the distant past because cpDNA markers exhibit highly conservative sequences (Provan et al. 2001), very low mutation rates which range from $3.2 \times 10^{-5}$ to $7.9 \times 10^{-5}$ (Provan et al. 1999), and no recombinant DNA (Ishikawa et al. 1992; Provan et al. 2001) and are uniparentally inherited (Savolainen et al. 1995; Viard et al. 2001). The highest numbers of haplotypes indicate the highest variation as occurred in populations of Abies alba Mill. (Vendramin et al. 1999). Mengoni et al. (2003) documented that the differentiation of chloroplast haplotypes in a population reflected genetic entity. Other reports were similar to our observation; Flach $(1983,1997)$ documented that Papua had the highest sago palm diversity based on morphological characters and the largest wild stands. Based on the diversity and extensive wild stands, Papua should be considered as the center of diversity (Flach 1997). In Papua, the highest sago palm variety based on morphological characters and environmental adaptability is recognized (Yamamoto et al. 2005).

Genetic Diversity The genetic diversity of sago palm within Indonesia shows that Papua has the highest values of haplotype numbers, polymorphic sites numbers, and percentages of haplotype polymorphisms. Java has the highest mean pairwise differences (Table 5.3). Haplotype diversity values $\left(\mathrm{H}_{\mathrm{E}}\right)$ among individuals were relatively higher than the overall populations. The $\mathrm{H}_{\mathrm{E}}$ value of 1 indicates that no haplotype sharing was found in the sample (single haplotype) or samples were different from the others such as occurred in Java. These features probably occurred because the sample sizes were very limited and the sampling criteria in the population were based on phenotypic differences. In a previous study of sago palm using RAPD markers, a high variance in individuals and a high level of sago palm diversity were observed by Ehara et al. (2003) and were also observed using AFLP by Celiz et al. (2004). In related cases, gene pool variations were also recorded in individual Scots pines (Pinus sylvestris L.) within woodlands (Provan et al. 1998).

Table 5.3 Genetic diversity based on 10 haplotypes and 11 polymorphic alleles

\begin{tabular}{|c|c|c|c|c|c|c|c|}
\hline \multirow[b]{2}{*}{ Location } & \multicolumn{7}{|l|}{ Genetic variability } \\
\hline & No. of populations & $\mathrm{R}_{\mathrm{IP}}$ & $\sum_{\mathrm{H}}$ & S & $\pi$ & $\mathrm{H}_{\mathrm{E}}$ & $\mathrm{P}$ \\
\hline Papua & 4 & 16 & 8 & 9 & 0.9216 & 0.4544 & 81.8182 \\
\hline Maluku & 1 & 3 & 2 & 1 & 0.6667 & 0.6667 & 9.0909 \\
\hline Sulawesi & 1 & 4 & 2 & 1 & 0.5000 & 0.5000 & 18.1818 \\
\hline Kalimantan & 1 & 17 & 3 & 2 & 0.6029 & 0.5221 & 27.2727 \\
\hline Java & 1 & 2 & 2 & 1 & 1.0000 & 1.0000 & 9.0909 \\
\hline Sumatra & 1 & 7 & 2 & 1 & 0.2857 & 0.2857 & 9.0909 \\
\hline
\end{tabular}

$R_{I P}$ average individual number per population, $\sum_{H}$ haplotype number, $S$ polymorphic site number, $H_{E}$ haplotype diversity, $\pi$ mean pairwise differences, $P$ percentage of haplotype polymorphic 


\subsection{Genetic Diversity of Sago Palm Based on the Mitochondrial Genome}

Sago palms used in this study were derived from several regions in Papua with the materials collected by the Sago Research Consortium, University of Papua (SRC, UNIPA). DNA extraction followed the procedures of the Plant Genomic DNA Mini Kit (Geneaid 2012). The design of atp6-2 primer sequences was based on Duminil et al. (2002), and the primers were synthesized by the Genetika Science Company. The primer sequences used for analyses of mitochondrial genetic diversity were forward 5' GCA TCA TTC AAG TAA ATA CA 3' and reverse 5' GTG AAG CTG TCT GGA GGG 3'.

Variation of mtDNA Amplification of mitochondrial DNA (mtDNA) by using a primer pair of mitochondrial atp6-2 genes and their introns from the 11 accessions sago palm was successfully carried out. The sizes of the nucleotide sequences of $\mathrm{mt}$ atp6-2 genes and their introns were detected in the accessions SP001, SP002, and SP003 to SP011 in 829, 825, 772, 651, 855, 640, 680, 690, 629, 728, and $651 \mathrm{bp}$, respectively. The mt atp6-2 gene and their introns from the 11 sago palm accession genomes had high polymorphism with many different nucleotides (Abbas et al. 2015). The phenomenon observed in 11 sago palm accessions resembles those of pine trees which showed a high level of diversity in the mitochondrial genome $(\mathrm{Wu}$ et al. 1998). The high levels of nucleotide diversity of mt atp6-2 genes in the 11 sago palm accessions indicate that they were all different. Touzet and Delph (2009) reported that gynodioecious plants have high nucleotide diversity and form many haplotypes; otherwise hermaphrodite and dioecious species have low nucleotide diversity. Furthermore, Uwai et al. (2006) reported intraspecies variation in the mitochondrial cox3 genes of the seaweed Undaria pinnatifida.

Genetic distances of sago palm accessions were calculated at 0.22-3.01 with an average of 1.21. The 11 sago palm accessions showed a significant difference in the level of genetic distance (data not showed). Phylogenetic construction to demonstrate the genetic relationships of the 11 sago palm accessions showed that the accessions were clustered into six groups. Group 1 consists of accession numbers SP001 and SP002; group 2, SP003 and SP011; group 3, SP005 and SP007; group 4, SP009; group 5, SP008 and SP010; and group 6, SP004 and SP006 (Fig. 5.1). Groups are based on the level of mitochondrial nucleotide polymorphisms of the 11 accessions, in particular genes that encode atp6-2 and their introns. Accessions which have a highly similar genetic value formed the same group in an adjacent phylogenetic branch. Differentiation hypothetically occurred over a long time period because mt markers are maternally inherited and have a low mutation rate. Plant mitochondrial genomes possess a low mutation rate, little compactness, large size, and highly rearranged structure (Darracq et al. 2011). Furthermore, it was reported that the $\mathrm{mt}$ genomes of plants have a mechanism of base excision repair pathway (Boesch et al. 2009) so that the nucleotide structure is very conservative. Phylogenetic construction of the 11 sago palm accessions was relatively inclined to 


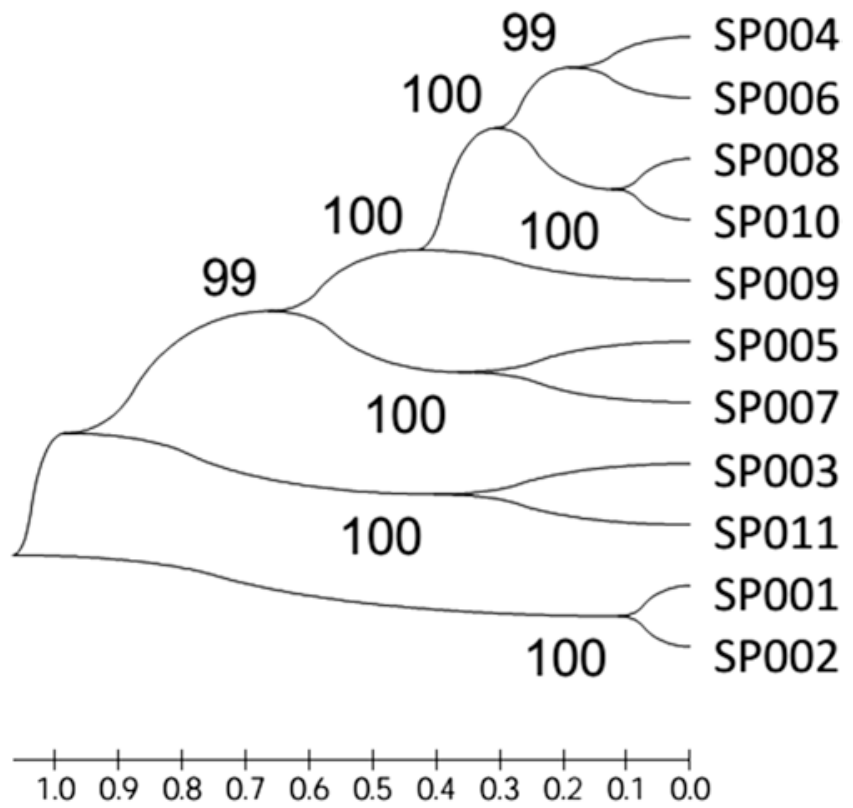

Fig. 5.1 Genetic relationship of sago palm accessions

form many groups because the high level of mt atp6-2 gene polymorphisms. High polymorphisms of the atp6-2 gene in sago palm may be caused by silent segregation. That phenomenon resembles the mitochondrial atp6 genes which occur in bladder campion, Silene vulgaris (Barr et al. 2007). Furthermore, Barr et al. (2007) also reported that the polymorphism levels of certain genes were variable in plant mitochondrial genomes.

\subsection{Conclusions}

Based on the observations, facts, and analytical review of the genetic diversity of sago palm resources in Indonesia, the following conclusions can be made:

1. Molecular markers of sago palm resources in Indonesia show a high variation based on the RAPD polymorphism level and genetic diversity calculations.

2. Wx genes in sago palm are related to starch production variation. Variations of Wx genes in sago palm show a high polymorphism level, with 14 genotypes, high heterozygous value, and high diversity.

3. Sago palm resources in Indonesia are variable based on cpDNA markers, with ten haplotypes found along with high diversity.

4. Based on atp6-2 gene markers, the sago palm accessions showed different genetic characteristics. 
5. Sago palm dispersal in Indonesia was not thwarted by distance and geographic isolation.

6. Vernacular names of sago palms given by local people were not related to genetic characters based on RAPD, Wx genes in the nucleolus genome, cpDNA in the chloroplast genome, and atp6-2 in the mitochondrial genome, neither within a population nor among populations.

7. The center of sago palm diversity in Indonesia is proposed as Papua, while the source of diversity is proposed in addition in Sulawesi and Kalimantan, also based on haplotype distribution of cpDNA markers.

Acknowledgments I am grateful to the management of the MP3EI project with SPPK No. 162/ SP211/LT/DRPM/III/2016 from DRPM Directorate General of Strengthen Research and Development (DGSRD) Indonesia for providing financial support in fiscal year 2016. Thanks also to all who contributed to and reviewed this work.

\section{References}

Abbas B, Ehara H (2012) Assessment genetic variation and relationship of sago palm (Metroxylon sagu Rottb.) in Indonesia based on specific expression gene (Wx genes) markers. African J Plant Sci 6(12):314-320

Abbas B, Bintoro MH, Sudarsono S et al (2009) Genetic relationship of sago palm (Metroxylon sagu Rottb.) in Indonesia based on RAPD markers. J Biol Div 10(4):168-174

Abbas B, Renwarin Y, Bintoro MH et al (2010) Genetic diversity of sago palm in Indonesia based on chloroplast DNA (cpDNA) markers. J Biol Div 11(3):112-117

Abbas B, Listyorini FH, Munarti (2015) Genetic diversity of eleven sago palm accessions fromSRC's germ plasm based on mitochondrial atp6-2 genes and introns. Paper presented at 12th International Sago Symposium, Tokyo

Bao JS, Corke H, Sun M (2002) Microsatellites in starch-synthesizing genes in relation to starch physicochemical properties in waxy rice (Oriza sativa L.) Theor Appl Genet 105:898-905

Barr CM, Keller SR, Ingvarsson PK et al (2007) Variation in mutation rate and polymorphism among mitochondrial gene of Silene vulgaris. Mol Biol Evol 24(8):1783-1791

Boesch P, Ibrahim N, Paulus F et al (2009) Plant mitochondria possess a short-patch base excision DNA repair pathway. Nucleic Acids Res 37(17):5690-5700

Boggini G, Cttaneo M, Paganoni P, Vaccino P (2001) Genetic variation for waxy proteins and starch properties in Italian wheat germplasm. Euphytica 119:111-114

Bryan GJ, McNicol J, Ramsay G et al (1999) Polymorphic simple sequence repeat markers in chloroplast genomes of solanaceous plants. Theor Appl Genet 99:859-867

Celiz LL, Toyota K, Okazaki M, Power A (2004) Genetic characteristic of sago palm (Metroxylon sagu) cultivars using AFLP (amplified fragment length polymorphism) markers. Proceeding of Japanese Society Sago Palm, pp 61-65

Darracq A, Varre JS, Drouard LM et al (2011) Structural and content diversity of mitochondrial genome in beet: a comparative genomic analysis. Genom Biol Evol 3:723-736

Domon E, Yanagisawa T, Saito A, Takeda K (2004) Single nucleotide polymorphism genotyping of the barley Waxy gene by polymerase chain reaction with confronting two-pair primers. Plant Breed 123(3):225-228

Duminil J, Pomonge MH, Petit RJ (2002) A set of 35 consensus primer pairs amplifying genes and introns of plant mitochondrial DNA. Mol Ecol Notes 2:428-430 
Ehara H, Kosaka S, Shimura N et al (2003) Relationship between geographical distribution and genetic distance of sago palm in Malay Archipelago. Sago Palm 11:8-13

Ehara H, Naito H, Mizota C (2005) Environment factors limiting sago production and genetic variation in Metroxylon sagu Rottb. Eighth International Sago Symposium in Jayapura, Indonesia. Japan Society for the Promotion Science, pp 93-104

Epstein J, Morris CF, Huber KC (2002) Instrumental texture of white salted noodles prepared from recombinant inbred lines of wheat differing in the three granule bound starch synthase (waxy) genes. J Cereal Sci 35(1):51-63

Flach M (1983) The sago palm: domestication, exploitation, and product. FAO Plant Production and Protection, Rome

Flach M (1997) Sago palm Metroxylon sagu Rottb. Promoting the conservation and use of underutilized and neglected crops. IPGRI, Rome

Geneaid (2012) Genomic DNA mini kit (plant) protocol. http://www.geneaid.com/sites/default/ files/GP9.pdf (Acces July 3, 2013)

Hwang SY, Lin TP, Ma CS et al (2003) Postglacial population growth of Cunninghamia konishii (Cupressaceae) inferred from phylogeographical and mismatch analysis of chloroplast DNA variation. Mol Ecol 12:2689-2695

Ishikawa S, Kato S, Imakawa S et al (1992) Organelle DNA polymorphism in apple cultivars and rootstocks. Theor Appl Genet:963-967

Kertopermono AP (1996) Inventory and evaluation of sago palm (Metroxylon sp.) distribution. Sixth International Sago Symposium. Pekan Baru 9-12 Dec 1996, pp 59-68

Larkin PD, Park WD (2003) Association of waxy gene single nucleotide polymorphisms with starch characteristics in rice (Oriza sativa L.) Mol Breed 12(4):335-339

Mengoni A, Gonelli C, Brocchini C et al (2003) Chloroplast genetic diversity and biogeography in the serpentine endemic Ni-hyperaccumulator Alyssum bertolonii. New Phytol 157:349-356

Provan J, Soranzo N, Wilson NJ et al (1998) Gene-pool variation in Caledonian and European Scots pine (Pinus sylvestris L.) revealed by chloroplast simple-sequence repeats. Proc Biol Sci 265(1407):1697-1705

Provan J, Soranzo N, Wilson NJ et al (1999) A low mutation rate for chloroplast microsatellites. Genetics 153:943-947

Provan J, Powel W, Hollingsworth M (2001) Chloroplast microsatellites: new tools for studies in plant ecology and evolution. Trends Ecol Evol 16(3):142-147

Savolainen V, Corbaz R, Moncousin C et al (1995) Chloroplast DNA variation and parentage analysis in 55 apples. Theor Appl Genet 90:1138-1141

Shariflou MR, Sharp PJ (1999) A polymorphic microsatellite in the $3^{\prime}$ end waxy genes of wheat, Triticum aestivum. Plant Breed 118:275-277

Sharma R, Sison MJ, Rathjen AJ, Jenner CF (2002) The null allele at the waxy locus in durum wheat affect pasta cooking quality. J Cereal Sci 35(3):287-297

Touzet P, Delph LF (2009) The effect of breeding system on polymorphism in mitochondrial genes of sine. Genetics 181:631-664

Tran NA, Daygon VD, Resurreccion AP et al (2011) A single nucleotide polymorphism in the waxy gene explains a significant component of gel consistency. Theor Appl Genet 123:519-525

Uwai S, Yotsukura N, Serisawa Y et al (2006) Intraspecific genetic diversity of Undaria pinnatifida in Japan, based on the mitochondrial cox3 gene and the ITS1 of nrDNA. Hydrobiology 553:345-356

Vendramin GG, Degen B, Petit RJ (1999) High level of variation at Abies alba chloroplast microsatellite loci in Europe. Mol Ecol 8:1117-1126

Viard F, Kassaby YAE, Ritland K (2001) Diversity and genetic structure in populations of Pseudotsuga menziesii (Pinaceae) at chloroplast microsatellite loci. Genome 44:336-344

Wanchana S, Toojinda T, Tragoonrung S, Vanavichit A (2003) Duplicated coding sequence in the waxy allele of tropical glutinous rice (Oryza sativa L.) Plant Sci 16(6):1193-1199 
Wu J, Krutovskii KV, Strauss SH (1998) Abundant mitochondrial genome diversity, population differentiation, and convergent evolution in pines. Genetics 159:1605-1614

Yamamoto Y, Yoshida T, Miyazaki A et al (2005) Biodiversity and productivity of several sago palm varieties in Indonesia. Eighth International Sago Symposium in Jayapura, Indonesia. Japan Society for the Promotion Science, pp 35-40

Open Access This chapter is licensed under the terms of the Creative Commons Attribution 4.0 International License (http://creativecommons.org/licenses/by/4.0/), which permits use, sharing, adaptation, distribution and reproduction in any medium or format, as long as you give appropriate credit to the original author(s) and the source, provide a link to the Creative Commons license and indicate if changes were made.

The images or other third party material in this chapter are included in the chapter's Creative Commons license, unless indicated otherwise in a credit line to the material. If material is not included in the chapter's Creative Commons license and your intended use is not permitted by statutory regulation or exceeds the permitted use, you will need to obtain permission directly from the copyright holder. 


\section{Part III Sago Industry Contributes for Food Security and Rural Development in Core Producing Countries}




\title{
Chapter 6 \\ An Overview of Sago Industry Development, 1980s-2015
}

\author{
F.S. Jong
}

\begin{abstract}
The major world commercial sago producers are Malaysia and Indonesia. In Malaysia, sago was mainly produced in family-owned small factories $(<100 \mathrm{mt} /$ month) before the 1980s. There were over 40 such sago factories along the Mukah and Dalat Rivers. Modernized sago-processing factories (500-1000 mt/month) mushroomed in the 1980s, largely replacing the small factories by late 1980 to early 1990. Processing technologies in these larger factories were mostly adopted from cassava processing with innovations to tackle the structural differences between sago and cassava. Malaysian's annual sago export is around 47,000 mt. Sago palms were mostly cultivated in a semi-wild state by smallholders. This is still the mainstream cultivation practice by most smallholders today. A large-scale sago plantation was initiated in the mid-1980s, but the outcome was disappointing.

In Indonesia, the hub of commercial sago production is at Selat Panjang. About $80,000-90,000 \mathrm{mt}$ of dried sago is produced annually. Processing is mostly done in the 50-60 small factories with capacity ranging from 50 to $200 \mathrm{mt} / \mathrm{month}$. In 2010 , a $3000 \mathrm{mt} / \mathrm{month}$ modern sago factory was built at Selat Panjang and is in operation. In the late 1980s, medium-sized factories were also established in Halmahera (Maluku) and Arandai (West Papua) but were subsequently closed down. A new sago factory (3000 mt/month) is currently under establishment at West Papua.

At Selat Panjang, sago palms are mainly cultivated in a semi-wild manner in smallholdings, similar to those practiced in Malaysia. A 12,000 ha sago plantation employing improved agronomic/management practices was initiated in 1996. It is still in production though not all the palms are in optimal growth conditions. Development of natural sago forest at West Papua initiated at around 2010. Harvesting of existing mature palms followed by systematic rehabilitation was planned and is ongoing.

Marketing of sago starch was mainly confined to meet domestic demands in Malaysia and Indonesia. The sago starch is mainly used in food industries like vermicelli and glass noodles.
\end{abstract}

F.S. Jong $(\bowtie)$

Formerly, P.T. Lestari Sago Papua, Jakarta, Indonesia

e-mail: fsjong06@gmail.com 
In this paper, more detailed reports are given with specific reference to technological innovation in cultivation and processing. Potentials and challenges in plantation development, processing, and marketing are also discussed.

\subsection{Sago Production in Malaysia}

\subsubsection{Transition Between Traditional and Modernized Processing}

The Mukah and Dalat regions of Sarawak are the major sago production areas in Malaysia. Before the 1980s, most of the sago produced was from traditional small mills, and the starch was dried in the sun. Many such mills processed a few palms per day with a yield of less than $1 \mathrm{mt}$ dry starch per day. In the mid-1980s, there were over 40 such sago factories along the Mukah and Dalat Rivers, together with a few relatively modernized mills that produced refined sago starch. Crude wet starch produced by some of the traditional mills was sent to these larger mills for refining.

By the late 1980s, there were about ten such modernized sago-processing factories each with production capacities of about 500-1000 mt dry sago per month. Most modern and traditional factories did not own sago palm plantation to support their raw material needs and had to outsource from smallholders. With the increase in the number of modernized factories, competition for sago logs in the limited pool became intense. Many small mills were outcompeted by the more efficient modern mills and had to shut down. By the early 1990s, nearly all the traditional mills were closed, and many of the modern mills were unable to get sufficient quantities of raw materials for full operation.

To encourage sago palm cultivation, the Department of Agriculture introduced a sago subsidy scheme to smallholders, but they were hardly able to meet the demand for raw material supplies. As of 2015, there are still about ten modern sago factories in operation in Sarawak, producing a total of about 47,000 mt/month of refined sago. At Batu Pahat in Peninsular Malaysia, there were about seven factories (producing a few hundred mt/month) in the mid-1980s. Some of these factories purchased wet starch from Riau for refining. With the opening up of the Batu Pahat area for oil palm and other developments, as well as the cost increase to import crude sago, only three factories remained in 2012, and probably only one is still in production, producing about $100-200 \mathrm{mt} / \mathrm{month}$ of refined sago.

Sago starch-processing technologies in the larger factories in Malaysia were mostly adopted from cassava processing, with modifications to accommodate the structural differences between sago and cassava starch. In the last 30 years, continuous improvements have been made and innovative equipment fabricated by individual factories or by local engineering workshops. The following are some examples: 


\subsubsection{Debarking Sago Logs}

Sago starch is stored in the pith tissue of the sago palm trunk (stem). The trunk has a length ranging from 5 to $18 \mathrm{~m}$ and a diameter of about $25-70 \mathrm{~cm}$. The starch-rich pith is enclosed in an outer layer of bark, and this highly lignified bark is normally removed before sago can be extracted from the soft pith. The sago trunk is normally cut into sections about $0.9-1.2 \mathrm{~m}$ long and the bark removed manually or mechanically. In traditional processing, bark removal is done manually by an axe or heavy knife (Fig. 6.1). A skilled worker can debark 100 sections per day, but the average is about 50. In the 1980s, mechanized debarking was developed. The trunk section, together with the bark, is split lengthwise into a few pieces. The pith side of the split trunk is placed downward on a rotary nail-studded rasper to remove the pith, leaving the hard outer bark. At around the same time, a pith chopper and scraper was also developed. In this procedure, the split trunk is placed on a conveyor with the pith side upward and carried to a set of mechanically operated choppers to cut the pith into small pieces. The depth of chopping action is adjusted so that only the pith is chopped while avoiding cutting through the hard bark. The chopped pith is then scraped out by a rotary scraper thereby removing the pith from the bark. This technique was used at Arandai, West Papua, Indonesia, but discarded after being found inefficient.

The pith scrapper was replaced by the screw mill (Fig. 6.2a), whereby the split trunk is fed with the bark sideway onto rotary screw-like blades to cut and scrape the pith in a continuous motion. In all the above debarking operations, the capacity was small. More energy has to be used in subsequent hammer milling of the large amount of pith removed by scraper and screw mill. In the 2000s, veneer peeling machines used in the timber and plywood industries were tested to peel off the hard bark but met with little success as the soft pith made log gripping difficult. Slipping occurred if insufficient pressure is applied, and breakage happened when too much pressure is applied at the ends. Peeling machines were not adopted in any of the Sarawak sago factories.

A bark scrapper (Fig. 6.2b) for timber logs was also tested in 2000. In view of the much harder outer bark and shorter length of sago log sections, various modifications to the scraper were made. The entire sago log section was successfully debarked without the need for splitting (Fig. 6.2c). Despite the bulkiness and high power consumption of the modified bark scrapper, it was successfully adopted and
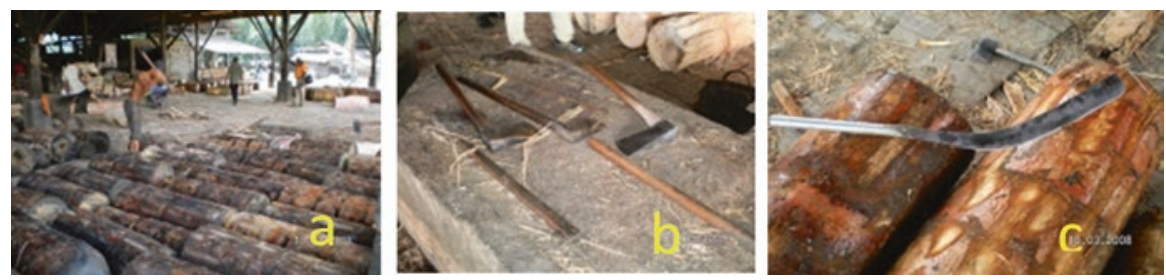

Fig. 6.1 (a) Manual sago trunk debarking. (b) Using an axe. (c) Using a knife 

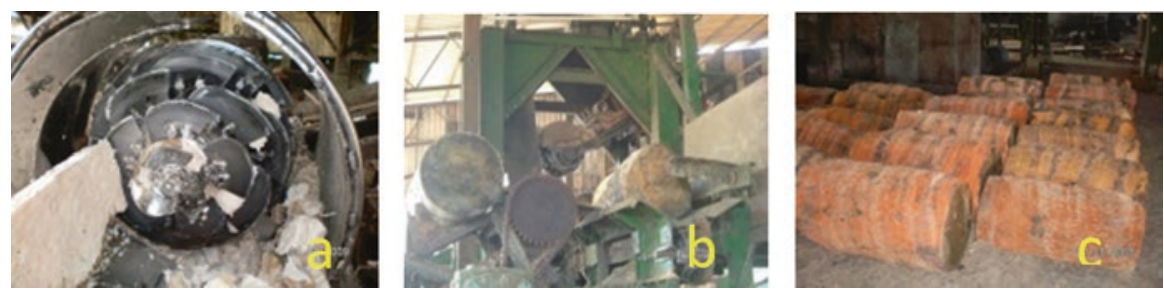

Fig. 6.2 (a) Screw mill. (b) Bark scrapper. (c) Debarked section

is now in use in most of the sizable sago factories in Sarawak. A skilled operator can debark about 60-70 m per hour of trunk sections with this machine. Innovation continues, and in late 2000, a light-weight ring debarker operated by a hydraulic jack was fabricated by a local engineering workshop. A set of ring knives with different diameters to debark sago logs of different diameters was constructed to move on a rail. With the end of trunk section aligned to the desired ring knife, the sago log section is then pushed by a hydraulic jack against the ring knife so that the bark is cut and separated from the pith. A second-generation ring debarker was fabricated in 2013 with different ring knives fixed on a rotating wheel instead of a sliding rail. The ring debarker has a capacity similar to a bark scraper but is much less bulky and much more energy efficient. A hydraulically operated free-size ring debarker is currently being fabricated and under trial. It is aimed at simplifying and replacing the set of five rings with a single expandable ring to remove bark from sago logs of different diameters.

\subsubsection{Pith Milling}

Pith milling using steel nails manually fixed to a wooden drumlike rasper powered by a motor to rotate at high speed was common in the 1980s. Pieces of split sago pith are pressed against a rotary rasper to pulverize the pith and release the starch granules. Gradually, larger raspers were made to increase the rasping capacity but were limited by the use of a wooden drum for nail studding. When modernized mills employing the cassava-processing technology were adopted, a saw-blade rasper typically used for milling tapioca was tested but quickly rejected. Unlike tapioca, sago pith needs to be chipped before feeding it into the saw-blade rasper. The much higher content of fiber together with its hardness and structure/shape made sawblade rasping inefficient. Among the drawbacks reported were fast wear and tear of saw blades as well as frequent sieve clogging. Steel drums with a quick-fit nailstudded case were then introduced and further modified to rasp the entire pith section without the need to split the pith into batons. Powered by a 60-75 KW motor, this is the most common sago pith milling equipment in Sarawak. Such a rasper is normally paired with the debarker to handle 60-70 $\mathrm{m}$ of sago log sections per hour. Pith rasping by a nail rasper offers the advantage of producing fine pith for 
subsequent starch extraction. With a well-designed rasper, subsequent hammer milling may be circumvented to save machinery investment and energy costs. Even if a hammer mill is desired to improve extraction efficiency, less energy will be required to pulverize the fine rather than the coarse sago pith.

\subsubsection{Starch Extraction}

After pith pulverizing, the starch must be separated from undesired debris like fiber and cell masses. In traditional practice, coarse debris is commonly removed by sieving and finer debris separated by starch sedimentation. Starch granules are heavier and normally sink faster than debris. Before modern factories were established, rotary wooden-framed barrel sieves were used (Fig. 6.3a). These are cheap and efficient and require reduced power to run and experience little wear and tear (low speed rotation). One drawback is its bulkiness which requires a larger space for installation. When modernized sago factories were first established, using cassava extraction technology, various problems were encountered with the extractors (Fig. 6.3b) used for separating starch from fibers. Sago palms have somewhat more fiber than tapioca. Furthermore, the hardness, structure, and water-absorbing capability of sago fiber are different from those of tapioca fiber.

Adopting cassava-processing technology for sago processing without modification resulted in greatly decreased efficiency/capacity. However, problems were not uncommon because extractors were often clogged, overloaded, vibrated severely, and tore the sieves in the extractor. Sieve damage in the extractor often resulted in malfunctioning of subsequent refining equipment such as nozzle clogging in the disc separators. Fungal growth at the back screen can occur if it is not cleaned regularly and lead to fungal spore contamination of the starch. To improve extraction capacity, and reduce starch loss, more extractors (compared with cassava processing) were installed but increased the equipment investment and energy consumption. Today, extractors are being phased out, except in some factories where they are used in combination with other starch extraction equipment.
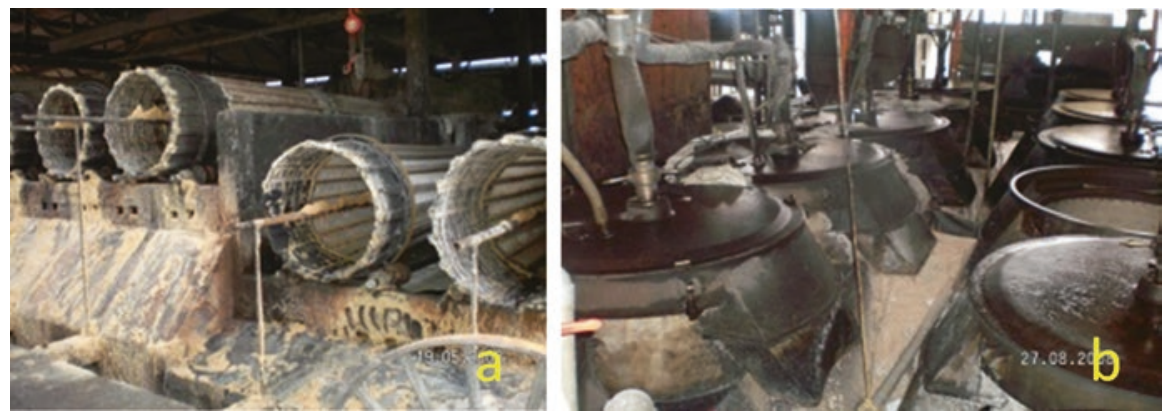

Fig. 6.3 (a) Rotary barrel sieves. (b) Vertical extractors 
Some sago factories chose sieve bends instead of extractors. According to one factory operator, significant starch is also lost in discharged fiber owing to sieve clogging. The sieve bend requires regular backwash to remove clogging by the long spindle-shaped sago fibers. As compared with corn starch processing, relatively more sieve bends (repeated steps) are required to reduce starch loss. A few sago factories in Sarawak are currently using sieve bends to separate sago starch from fiber. Extractors or sieve bends are expensive equipment and consume high energy. A local engineering workshop developed the rotary sieves about 2010; improved stainless rotary sieves were fabricated to partially or totally replace extractors or sieve bends. This is now used in a few sago factories replacing or in combination with extractors.

\subsubsection{Separation of Starch and Fiber in Submerged Condition: A New Concept to Be Explored}

In the abovementioned equipment used for starch and fiber separation, the starch separation by forced filtration occurs when fiber containing starch milk is sprayed onto a sieve under pressure (sieve bend). In an extractor, aqueous fiber/starch mixture is fed to a fast-rotating sieve (extractor) so that the smaller starch granules are pushed out by centrifugal force. In a rotary barrel sieve, water is sprayed onto the pulverized pith on the sieve screen to wash out the starch granules. The above separation techniques often resulted in starch being trapped and lost in the discarded fiber, especially in the absence of adequate water or when sieves are clogged. In the course of laboratory experiments to filter sago starch, it was noted that starch filtration is easier and more efficient when the sieve is placed in water (as compared with washing down the starch with sieves placed above the water). Further tests were carried out in 2012 by partially submerging a wooden rotary sieve so that the starch granules are separated from fiber in water (by gravity and moving water). Promising results prompted the fabrication of a commercial-size stainless sieve for more comprehensive trials in 2014, and preliminary results indicated that:

(a) Starch separation is more efficient than the current commercially used rotary sieves of the same size. Relatively clean fiber is discharged in a single step.

(b) There is a significant saving in consumption of processing water because continuous spraying onto the macerated pith is not necessary. Also, water can be partially recycled to further reduce both water consumption and effluent treatment volume.

(c) The rotary sieve, partially submerged, is powered by a $2 \mathrm{KW}$ motor, and thus power consumption is greatly reduced as compared with extractors.

(d) Minimal fiber clogging occurs as clogged fibers are automatically removed by backwashing when the drum screen rotates in water. 
With further R\&D, submerged starch-fiber separation may contribute significantly to the advancement of sago starch processing, with the potential of replacing existing rotary sieves, extractors, and sieve bends. It may also be applicable to other starch-processing industries.

\subsubsection{Starch Slurry Concentration, Refining, and Drying}

After starch extraction, the steps of refining, concentration of starch slurry, starch dewatering, and drying are almost identical to cassava processing. Disc separators are mostly used in starch refining and concentration, some in combination with decanters or hydro-cyclones to produce better-quality starch. Few issues were reported with these processing steps, and so they are not discussed further.

\subsection{Sago Production in Indonesia}

In Indonesia, the hub of commercial sago production is Selat Panjang, Riau Island. About 7000-8000 $\mathrm{mt}$ of dried sago is produced monthly. Processing is mostly done in the 50-60 small factories with capacities ranging from 50 to $200 \mathrm{mt} / \mathrm{month}$ (Jong 2000a). Sago-processing technology varies from the very traditional sago pith chopping using metal-capped wooden implement in Eastern Indonesia to modernized processing technology in large factories in Riau. Debarking is very much manually done using a heavy-duty knife. The screw mill, described earlier, is becoming popular in several factories in Selat Panjang. When the screw mill is used, the resulting pith is fed into a hammer mill for further pulverizing. In factories not using a screw mill, debarked pith batons are rasped using nail-studded wooden drum raspers. No hammer milling is carried out. Usually, a considerable amount of starch is lost because of coarse rasping which is relatively inefficient in breaking down the pith tissue. In the small factories, starch extraction is almost totally carried out using wood-framed rotary barrel sieves. Normally this is a one-step operation, two sieves in parallel for removing coarse fibers and one or two sieves for removing fine fibers (Fig. 6.3a). Starch is recovered by sedimentation in concrete tanks (Fig. 6.4a). Normally in a factory, several concrete sedimentation tanks are built, and filtered starch slurry is channeled into these tanks. Heavier starch granules sink to the bottom, and most of the lighter fibrous wastes are discharged in the overflow.

When all the tanks are filled (a few days to a week), the water is drained out. The starch cake can either be dug out manually or pumped to another tank after water is added to make concentrated slurry. The starch cake or slurry is then refined, again using sedimentation, in wooden or concrete troughs with slurry flow controlled manually by a skilled operator. The refined crude starch that settles in the trough is dug out, crushed into finer particle sizes, and mostly sun-dried. Some factories use a centrifuge de-watering device to remove water from refined crude slurry before 

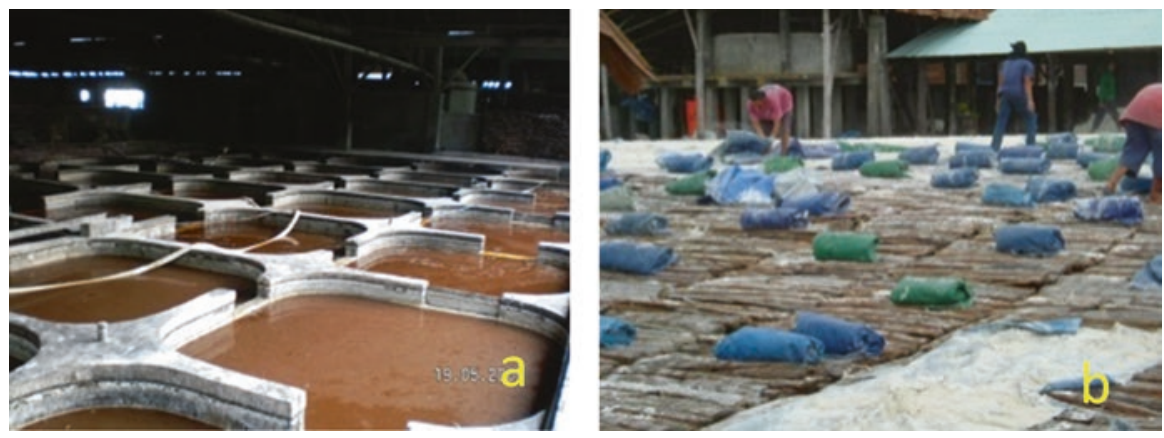

Fig. 6.4 (a) Sedimentation tanks. (b) Sun-drying sago starch

sun-drying. Crushed starch is spread out on a rainproof sheet measuring about $3 \mathrm{~m}$ $\times 3 \mathrm{~m}$. When rain is approaching, the starch is gathered at the center, and the sides of the sheet are folded over the starch to keep off the rainwater (Fig. 6.4b).

In 2010, a $3000 \mathrm{mt} /$ month modern sago factory was built at Selat Panjang and is currently in operation. In the late 1980s, medium-sized factories were also established in Halmahera (Maluku) and Arandai (West Papua) but were subsequently closed. A new sago factory $(3000 \mathrm{mt} / \mathrm{month})$ is currently being built in West Papua.

\subsection{Sago Palm Cultivation in Malaysia and Indonesia}

In Malaysia, sago palms are mostly cultivated in a semi-wild state by smallholders with varying plant densities. This is still the mainstream cultivation practice by most smallholders today. The total sago-growing area is difficult to estimate but is roughly $30,000-40,000$ ha, with less than 20,000 ha in sustainable production. Owing mainly to non-intensive cultivation, the average starch yield is low, about $2 \mathrm{mt} / \mathrm{ha} /$ year as estimated from the export figures. The first large-scale sago plantion (7700 ha) in Malaysia was initiated in the mid-1980s at Mukah. Palms were planted rather semi-intensively on raw deep peat. The plantation was expanded to over 21,000 ha (Hassan 2002) at two nearby locations in the following two decades or so. Despite great effort to improve sago palm cultivation in the mid-2000s, the growth of most palms is suboptimal, and starch yield is generally low.

In Indonesia, sago palms are mainly cultivated in a semi-wild manner in smallholdings, similar to the practices in Malaysia. The planting density also varies greatly but on average is about 30 palms/ha (Jong 2000a). Yields also vary with some good gardens achieving about $10 \mathrm{mt} / \mathrm{ha} / \mathrm{y}$ in some intensive sago farms (Yamamoto et al. 2008). At Selat Panjang, a 12,000 ha sago plantation (Fig. 6.5) employing improved agronomic and management practices, somewhat similar to oil palm cultivations, was initiated in 1996 on rather mature deep peat (Jong 2000b). In this plantation, sago palms were cultivated in 50-ha blocks surrounded by canals. 


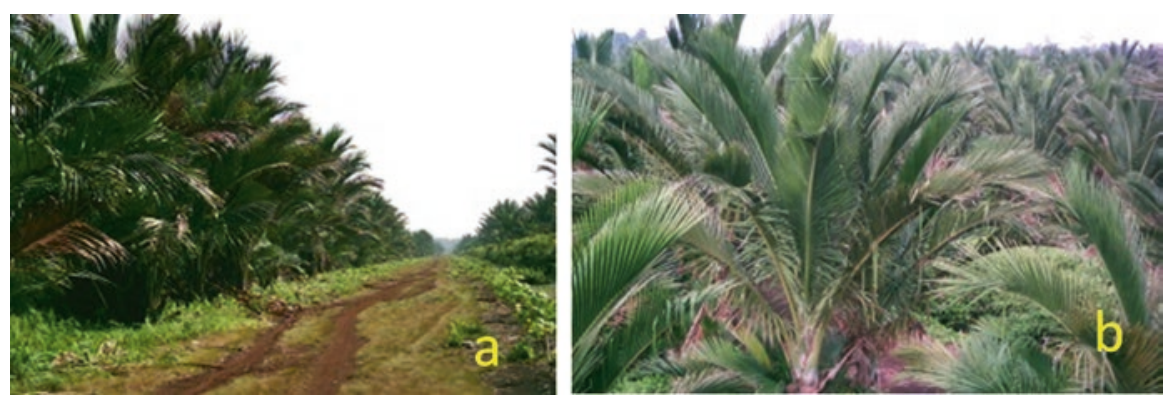

Fig. 6.5 (a) A commercial sago plantation at Selat Panjang, Riau, showing road made from canal dugout. (b) Nearly mature palms

The canals are used to transport farm inputs and harvested sago logs and for fire prevention/fighting, as well as for water table control. To facilitate management and reduce travel time, a base camp was built for every 1000 ha and a 10-man worker's quarter constructed for each 200 ha within the plantation. Excavated material from digging the canals was compacted to form roads for light vehicles and motorcycles to expedite supervisory work. Started in 1996, some palms reached maturity (flowering) in 9-10 years, but most palms matured in about 11 years in this plantation. It is still in production although not all the palms are in optimal growth conditions.

\subsection{Natural Sago Forest Development}

There are reportedly about 2 million ha of naturally occurring sago forests on New Guinea Island, consisting of Papua New Guinea in the east and the Indonesian West Papua (formerly Irian Jaya) and Papua on the west (Flach 1983). In the late 2000s, licenses were granted by local government to a few companies to develop some of the natural sago forests in Irian Jaya (West Papua). Until today, field development was observed in a private company. Prior to finalizing a development plan, aerial and ground surveys were carried out to determine the sago palm distribution, palm density, variety, morphology, as well as their starch content (Jong 2011 unpublished). Based on the aerial surveys around Timika and South Sorong, high density or nearly pure sago stands (Fig. 6.6a) were rather limited, occurring only in isolated patches. Most of the sago palms were mixed with other indigenous tree species with variable sago palm densities (Fig. 6.6b). The diameter of sago palms varied from 25 to $60 \mathrm{~cm}$, normally with thick bark and a small trunk diameter at the lower trunk portion to a height of about 3-4 m, under heavily shaded conditions. The palms are tall, with trunk lengths (excluding leaves) ranging from 10 to $18 \mathrm{~m}$. The starch content also varied greatly from a few percent to about $17 \%$ (dry starch: fresh trunk); the average around $10-11 \%$. Higher starch contents were found in inhabited and more open areas leading to the conclusion that low starch content was mainly 

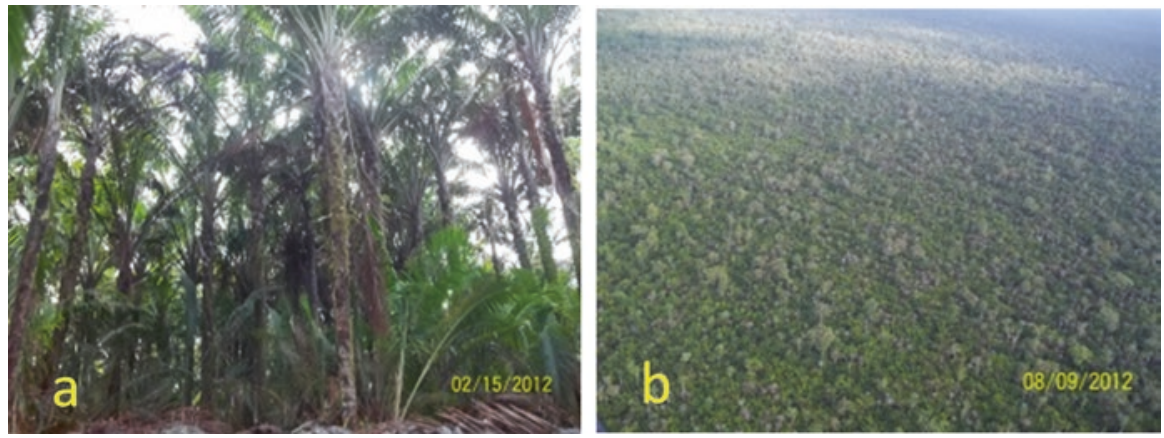

Fig. 6.6 (a) A natural sago forest at West Papua: pure sago stands. (b) Aerial photo showing sago palms (shorter) mixed with other tree species

attributed to the environment (overcrowding and shading by sago palms and other trees) (data is not shown).

The varieties of sago palms found in different regions varied greatly. Over 18 varieties were reported at Sentani, Papua (Widjono et al. 2000), and over 10 on Salawati Island (Schuiling et al. 1992). Around South Sorong and Bintuni, West Papua, nearly all the naturally occurring wild sago palms are apparently of the same variety (Jong, pers. obs). Harvesting of existing mature palms followed by systematic rehabilitation is planned, and this project is ongoing by a company.

\subsection{Sago Marketing}

In Malaysia, about 42,000-50,000 mt of refined sago were produced annually from 2004 to 2013. Sago is mainly sold to West Malaysia and added (at 20-30\%) to rice flour in the production of flat rice noodle and rice vermicelli. Despite the higher prices, as compared with cassava or corn starch, sago is preferred as it is reported by some users to have superior properties over corn or cassava starches to create rice noodles and vermicelli less brittle to handle and chewier in texture. In Indonesia, a total of about 100,000 mt/year is produced in Riau and nearby areas and sent to Cirebon, West Java (unpublished company data), for further processing or redistribution to other regions of Indonesia. Sago produces clear starch when cooked, and this property is ideal for the production of glass noodle (so-hun). A private company survey in 2009 found that over $90 \%$ of the sago produced in Indonesia is used for the production of glass noodles. Marketing of sago starch is mainly confined to meeting domestic demands in Malaysia and Indonesia. Apart from domestic consumption, Malaysia also exports some sago starch to Japan, reportedly for use in coating noodles. Commercial production of sago in other countries like Papua New Guinea, Thailand, and the Philippines is relatively small and mainly for local markets. 


\subsection{Potential and Challenges in Future Development}

\subsubsection{Potential of Sago Palms}

Sago palm is a high energy-yielding crop, and estimated yields of $25 \mathrm{mt} / \mathrm{ha} /$ year of dry starch have been reported (Flach 1983). An intensively cultivated sago farm, harvesting over 100 mature palms per ha (about 20-30 mt dry starch), is achievable in a particular year, but palm yield will decrease in subsequent harvests, dragging the average yield down significantly over a longer period. Recent studies by Yamamoto et al. (2008) indicated that a sustainable dry starch yield of $10 \mathrm{mt} / \mathrm{ha} /$ year is achievable on a relatively good farm.

Other advantages of sago palm cultivation are:

(a) It has a perpetual economic life owing to its sucker (offshoots) regeneration capability. The offshoots produced by sago palms have very strong growth vigor. In sago-growing areas in Sarawak, most sago gardens have been passed down for generations with minimal maintenance or replanting and are still in sustainable production.

(b) Sago palms can tolerate flood conditions very well. Aerial roots are produced under continuously inundated conditions enabling them to outcompete most other plants in swamp lands.

(c) They are very adaptable to a wide range of soil $\mathrm{pH}$. Sago palms are found growing from acidic to limestone areas.

The major disadvantage of cultivating sago palms is the long juvenile phase of about 10 years. Because of this, financial institutions are unwilling to support sago plantation projects.

\subsubsection{Sago Starch Potentials}

Starch is in demand as a commodity for both food and industrial applications. As such, sago starch should be able to gain a share in the huge world starch market. Sago has unique properties that render it ideal in specific applications (Hamanishi et al. 1999). Among these properties are large starch granules, clear gel, high swelling power, non-gluten, and slow in releasing sugar. Currently, its gel clarity property is utilized in the glass noodle and vermicelli industries, and other properties have yet to be commercially exploited. On the other hand, sago starch can be used as a multipurpose raw material for both food and nonfood applications such as in the fermentation industry. Because of its high yield and other advantages over most other crops, sago could be competitively produced for such applications. 


\subsubsection{Market Challenges}

Sago starch is relatively unknown to the international starch markets owing to its limited production for domestic demands in major producing countries like Malaysia and Indonesia. Currently selling at about USD 700/mt FOB Sarawak, refined sago is, respectively, about 35 and $20 \%$ more expensive than cassava and corn starches. As such, corn or cassava starch buyers are not willing to consider sago for their existing uses. Because of its unique properties, refined sago starch could be used in more specific applications. However, potential new buyers that require such starch properties are unfamiliar with sago and need to be educated and convinced through further R\&D before being considered together with other factors like cost advantages, quantity and constancy of supply, as well as suitability/modification of the existing setup if sago were to be used. Thus, before refined sago can be readily marketed internationally, more R\&D on its properties and applications, followed by aggressive product promotions, need to be looked into. A more plausible way is to market sago as a raw material for fermentation and modified starch industries. Crude sago without refining could be produced more competitively than refined sago especially in areas where the sago palms are plentiful and cheap, e.g., from the million hectares of natural sago forests in Papua New Guinea and West Papua. A commercial processing line to produce sago without added water would be ideal to produce sago at a competitive price for the fermentation as well as health-food industries. In such a process, proteins, minerals, sugar, polyphenols, and other nutrients will be retained. There will be no effluent, and all by-products will be utilized in the process (e.g., bark for fuel, fiber for feed and biofuel).

\subsubsection{Development Challenges}

Large-scale commercial cultivation of sago palms is limited mainly because of its long growth period of about 10 years before being ready for harvest. In fertile soil and with good care, some sago palms in mine tailing areas at Timika (Papua, Indonesia) reached maturity (flowering initiation) about 8 years from planting. On poor soil, such as deep peat in Sarawak, palms may take 15 years or longer to reach maturity (Tie et al. 1987). In Riau where a large-scale sago plantation was established on semi-decomposed deep peat, about $30 \%$ of the palms attained harvesting stage in about 11 years (Jong, unpublished). The long juvenile phase of sago palm is extremely unfavorable for project financing from commercial banks, and thus large-scale sago plantations are very rare. In the 2 million ha of natural sago forests, young sago palms are continuously generated either from offshoots or from seeds to 
replenish the older palms. The palms are in various stages of growth, from seedlings to overgrown/dead palms. In a census done in 2009-2012, there were on average 32 mature and harvestable palms per ha. The highest category is actually represented by overmatured palms, about 50/ha (Jong, unpublished). In a dense sago forest (>70\% sago palms) at South Sorong, an estimated $5 \mathrm{mt}$ of dry starch per ha can be harvested immediately by cutting mature palms. It appears to be quite a simple task to harvest the mature palms and rehabilitate the younger follower palms into sustainable sago plantations because no waiting time and planting costs are involved. However, in reality, as personally experienced in 2010-2012, there are several challenges to the harvesting and developing of these natural sago forests into sustainable plantations:

(a) Geographical remoteness: this makes mobilization and logistical costs very high for personnel, equipment, farm inputs, as well as transporting finished products.

(b) Lack of technical expertise: sago cultivation, rehabilitation, and processing are new to most investors, and there is limited expertise in this field.

(c) High infrastructure development costs: sago forests are normally located in swampy areas, and costly infrastructure has to be developed to facilitate harvesting and mobilization operations.

(d) Sago palm ownership and compensation: this is a rather complicated matter. All the land and sago palms belong to the local communities (by virtue of native customary rights), and negotiation has to be made with regard to royalty and other fees for any development. It is also a time-consuming process involving multiple meetings with local communities and governmental authorities.

(e) Social and security issues: this may be one of the biggest challenges of all. Issues may frequently arise from unforeseen land ownership disputes among family members, clans or tribes, absentee owners, or unexpected requests by local people. Misunderstandings or miscommunications between investors and local people may result in temporary protests or blockage of operations.

Despite the above challenges, it is not impossible to solve them. With time and innovative approaches, as experienced in the development of other projects, sago forests are expected to be sustainably developed to supply an alternative source of starch to benefit local people and consumers. 


\subsection{Conclusion}

Commercial development of the sago industry is slow. Despite the great potential of sago palms, and contributions from 11 international sago symposia to create awareness and promote sago in the last 40 years, little realization has been achieved in cultivation, production, and marketing. Since the First International Sago Symposium in 1976, improved sago processing did gain momentum in the mid1980s in Sarawak and the late 2000s in Indonesia. More efficient sago-processing equipment was developed and adopted by sago factory owners or local workshops. However, all these were at a relatively small scale, and total commercial sago productions today remain relatively unchanged. Apart from the two sago plantations mentioned, there have been no new and large-scale developments. Established on deep peat soils, palm growth in both of the two plantations are not in optimal condition owing mostly to the poor soil conditions. Cultivation of sago palms should be avoided on deep peat unless they are for noncommercial purposes. Commercialscale development of natural sago forests in West Papua began in 2010, and its progress has yet to be followed. Only a success story will convince other investors to participate. The abovementioned challenges in cultivation, shortage in expertise, sago forest development, processing, and marketing need to be critically addressed in order to improve, promote, and attract investors to expedite the development of the sago industries.

\section{References}

Flach M (1983) The sago palm, FAO Plant Production and Protection Paper 47. FAO, Rome

Hamanishi T, Hatta T, Jong FS et al (1999) Physiochemical properties of starches obtained from various parts of sago palm trunks at different growth stages. J Appl Glocosci 46(1):39-48

Hassan AH (2002) Agronomic practice in cultivating the sago palm, Metroxylon sagu Rottb.: the Sarawak experience. In: Kainuma K, Okazaki M, Toyoda Y, Cecil JE (eds) New frontiers of sago palm studies: proceedings of the international symposium on sago. Universal Academy Press, Tokyo, pp 3-7

Jong FS (2000a) Sago production in Tebing Tinggi Sub-district, Riau, Indonesia. Sago Palm 9(1):9-15

Jong FS (2000b) Commercial sago palm plantation on deep peat: the NTFP's approach. Sago Palm $9(1): 16-20$

Schuiling DL, Jong FS, Flach M (1992) Exploitation and natural variability of the sago palm (M. sagu Rottb.). Report of a Sarawak and all Indonesian study tour, Jan-Feb 1992. Wageningen Agricultural University $82 \mathrm{pp}$

Tie YL, Jaman HjO, Kueh HS (1987) Performance of sago (Metroxylon sagu) on deep peat. In: Proceedings of 24th research officer's conference. Department of Agriculture, Sarawak, pp 105-118

Widjono A, Mokay Y, Aminsnaipa H et al (2000) Jenis jenis sagu berapadareah Papua. Sustainable Agriculture project P2SUT/SADP (in Indonesian) 
Yamamoto Y, Omori K, Yoshida T et al (2008). The annual production of sago (Metroxylon sagu Rottb.) starch per hectare. In: Toyoda Y, Okazaki M, Quevedo M, Bacosmo J (eds) Sago: its potential in food and industry. Proceedings of 9th international sago symposium. TUAT Press, Tokyo, pp 95-101

Open Access This chapter is licensed under the terms of the Creative Commons Attribution 4.0 International License (http://creativecommons.org/licenses/by/4.0/), which permits use, sharing, adaptation, distribution and reproduction in any medium or format, as long as you give appropriate credit to the original author(s) and the source, provide a link to the Creative Commons license and indicate if changes were made.

The images or other third party material in this chapter are included in the chapter's Creative Commons license, unless indicated otherwise in a credit line to the material. If material is not included in the chapter's Creative Commons license and your intended use is not permitted by statutory regulation or exceeds the permitted use, you will need to obtain permission directly from the copyright holder.

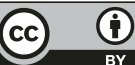




\title{
Chapter 7 \\ Suitability of Peat Swamp Areas for Commercial Production of Sago Palms: The Sarawak Experience
}

\author{
Roland Yong Chiew Ming, Yusup Sobeng, Fariza Zaini, and Noraini Busri
}

\begin{abstract}
Realizing the potentials of sago as a new commodity to contribute to the Sarawak economy, the government initiated the development of sago plantations to address the shortage of raw materials in order to support the sago industry in its starch export and downstream activities. Initially the development of sago plantations was on peat, based on findings that sago can tolerate wet conditions including peat swamps. Furthermore Sarawak has the largest peat soil area in Malaysia of about 1.5 million hectares. For over the period of 15 years, it was observed that only $4 \%$ show good growth performance and these palms are mainly on shallow peat areas $(<1.5 \mathrm{~m})$, while those on very deep peat areas $(>2.5 \mathrm{~m})$ showed poor growth performance at the trunking phase as characterized by small crowns, low leaf count, stunted growth, and low succession suckers.

The Crop Research and Application Unit (CRAUN) conducted detailed studies of sago growth performance on peat to find solutions to the problems mentioned above. The study covers land preparation, prospection and selection of quality planting material, nursery management, nutritional and soil studies, cultural practices, and weed and pest control.

Based on the agronomic and cultural practices done by CRAUN for the past 10 years, it was observed that the performance of sago on peat areas $(>2.5 \mathrm{~m})$ for the first 4 years did show good growth and were on par with those palms grown on mineral soil. However, upon reaching trunking phase (4 years onward), the growth performance began to deteriorate, exhibiting distinct elemental deficiency symptoms, low leaf count, tapering trunk, and low yield.

Cost comparison on the development of sago on alluvial and peat shows a significant difference between the two soil types whereby the latter incurred high development cost and low revenue and thus contributed to the low internal rate of return (IRR). Therefore it is not economic and feasible to cultivate sago on peat. Recommendations for any new sago expansion program should focus on mineral or shallow peat soil.
\end{abstract}

R. Yong Chiew Ming $(\bowtie) \bullet Y$. Sobeng $\bullet$ F. Zaini $\bullet$ N. Busri

CRAUN Research Sdn. Bhd, Jalan Sultan Tengah, Kuching, Sarawak, Malaysia

e-mail: rldyong@yahoo.com

(C) The Author(s) 2018

H. Ehara et al. (eds.), Sago Palm, https://doi.org/10.1007/978-981-10-5269-9_7 


\subsection{Introduction}

Sago has been among the key agriculture trading commodities of Sarawak since the 1880s. Initially, sago was grown in Sarawak primarily as a smallholder crop for starch production, mainly for local food industries. Presently, although Sarawak is not the world's largest producer, it is the sole world exporter of sago starch. The export volume recorded in 2013 was 48,000 mt valued at MYR 71 million, while in 2014, it was 46,900 $\mathrm{mt}$ valued at MYR 81 million. The major export destinations are Peninsular Malaysia (60\%) and Japan (30\%), as reported by the Statistics Department, Malaysia. Nevertheless, the sago starch export volume has not increased for the past 10 years due to the low and unreliable supply of sago logs. In 1988, the State Government decided to establish sago plantations located in Mukah Division with an area of 19,063 ha, mainly in a peat area. The decision was made based on the outcome of a feasibility study. The study area comprised mainly of peat soils of the Anderson 3 series (>2 m peat depth) and observations on farmers' fields. The study recommended sago cultivation on swampy peat land with minimal water management and maintenance.

Thirteen years after plantation establishment, there were no harvestable sago palms except those planted on shallow peat areas $(<1.5 \mathrm{~m})$ which represented approximately $4 \%$ of the total plantation area. Generally, the sago palms planted on deep peat exhibited stunted growth and remained in a suppressed vegetative stage after year 5. In those palms that did have trunks, they were tapered, and the leaves had brownish necrotic leaflets. In spite of practicing an intensive and adequate fertilizer application program, none of the sago palms planted in deep peat areas of the plantation showed good growth performance.

In view of these circumstances, the Crop Research and Application Unit (CRAUN) conducted its first detailed experiment on deep peat in 2003 at the Sebakong Sago Plantation (SSP) in Mukah, Sarawak, and followed up with a subsequent experiment at the Sungai Talau Research Station (STRS) in Dalat Sarawak in 2007. The experiments covered land preparation, water management, fertilizer application, and soil studies.

\subsection{Materials and Method}

\subsubsection{Plot Establishment}

The study was conducted in Sebakong Sago Plantation and Sungai Talau Research Station with peat depth of more than $5 \mathrm{~m}$. An experimental plot was also established on mineral soil at Sungai Talau Research Station as a control plot. Besides that, observation was also made on the smallholder areas in Senau, Dalat, and in Kampung Tellian and Kampung Sesok, Mukah (Fig. 7.1). The plot preparation was in accordance with the standard practices for oil palm land clearing and water management 


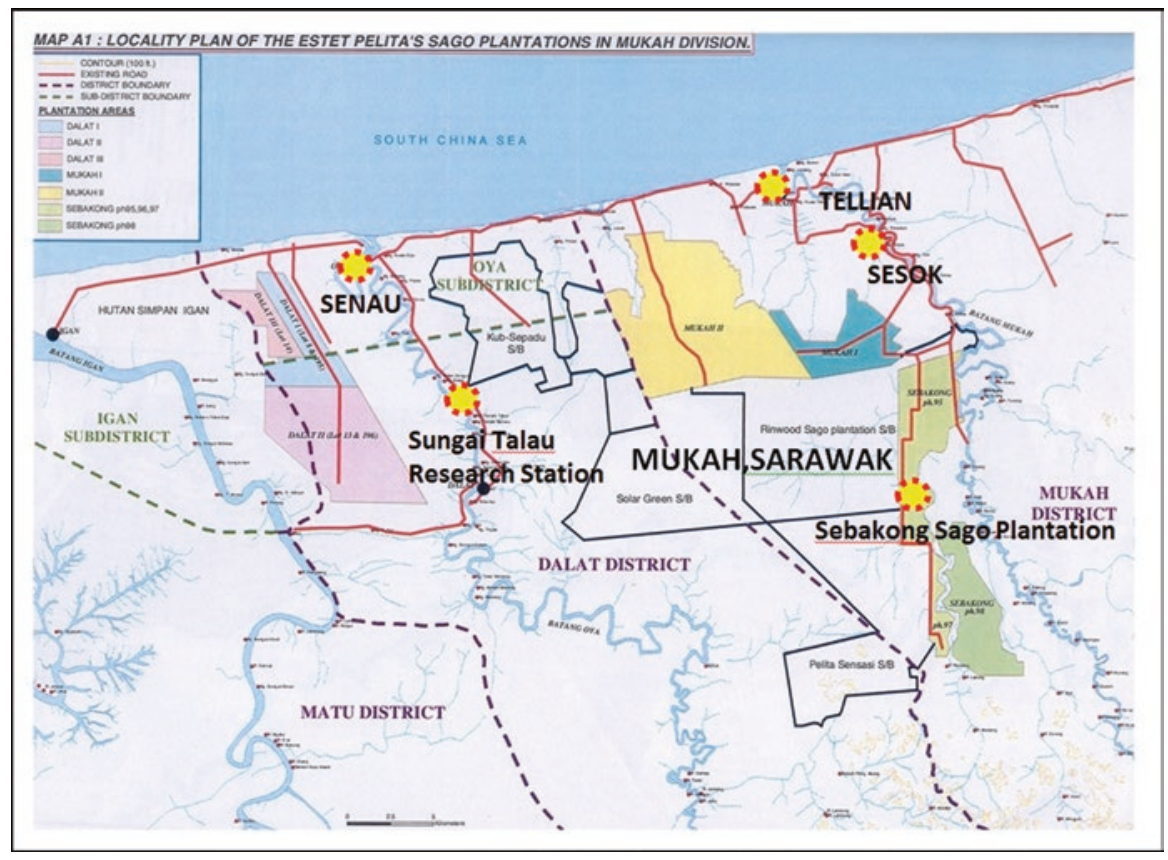

Fig. 7.1 Location of study area

on peat (Tayeb 2005) except that water table was maintained at $20-40 \mathrm{~cm}$, as compared to $50-75 \mathrm{~cm}$ for oil palm.

\subsubsection{Planting Material and Field Planting}

Selected suckers were nursed in polybags. Those with a minimum of three developed leaves and well-developed root systems were selected for field planting (Fig. 7.2). The planting density was 100 palms per hectare. The water table was maintained at $20 \mathrm{~cm}$. Lime was applied 7 days prior to planting to increase the $\mathrm{pH}$, and $200 \mathrm{~g}$ of rock phosphate fertilizer was applied during planting (Fig. 7.3).

\subsubsection{Cultural Practices and Maintenance}

Chemical weeding was done after land clearing and crop establishment to prevent regeneration of residual weeds and stop the growth of new weeds in the recently cleared areas. Planting rows were slashed followed by herbicide spraying to prevent weed competition with sago palm growth. Contact herbicide was used for the first 
Fig. 7.2 Standard polybag planting material

Fig. 7.3 Rock phosphate applied to promote root development
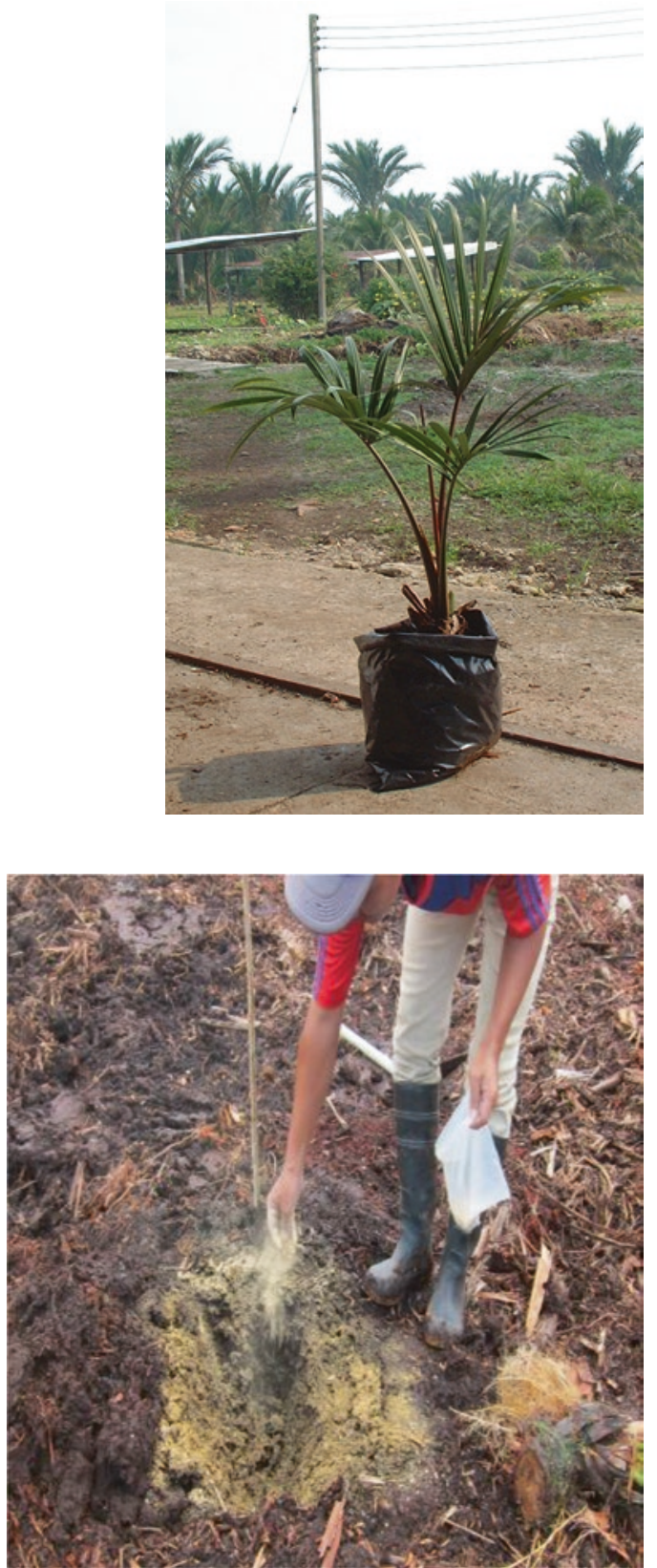

2 years after planting to reduce the risk of damage to the palms in the event of spray drift. Circular weeding was done three times per year before each fertilizer application. Weeding prevents shading out of the suckers and the choking action of creepers that can cause plant death before the crop can be well established (Yusup et al. 2007). 
Cluster maintenance is necessary to minimize the competition between mother palm and the suckers for nutrients, sunlight, and space (Peter et al. 2012). Sucker pruning is done in year 4 (Fig. 7.4). In year 4, two successional suckers are retained, followed by one successional sucker for each 18 months in the following years. This ensures sustainably harvestable palms. Dead leaves are pruned and stacked between rows to suppress weeds and to recycle the nutrients and biomass to the soil (Fig. 7.5).

Fig. 7.4 Cluster

maintenance to clear weeds
Fig. 7.5 Pruned cluster to promote trunking and damaged or dead leaves
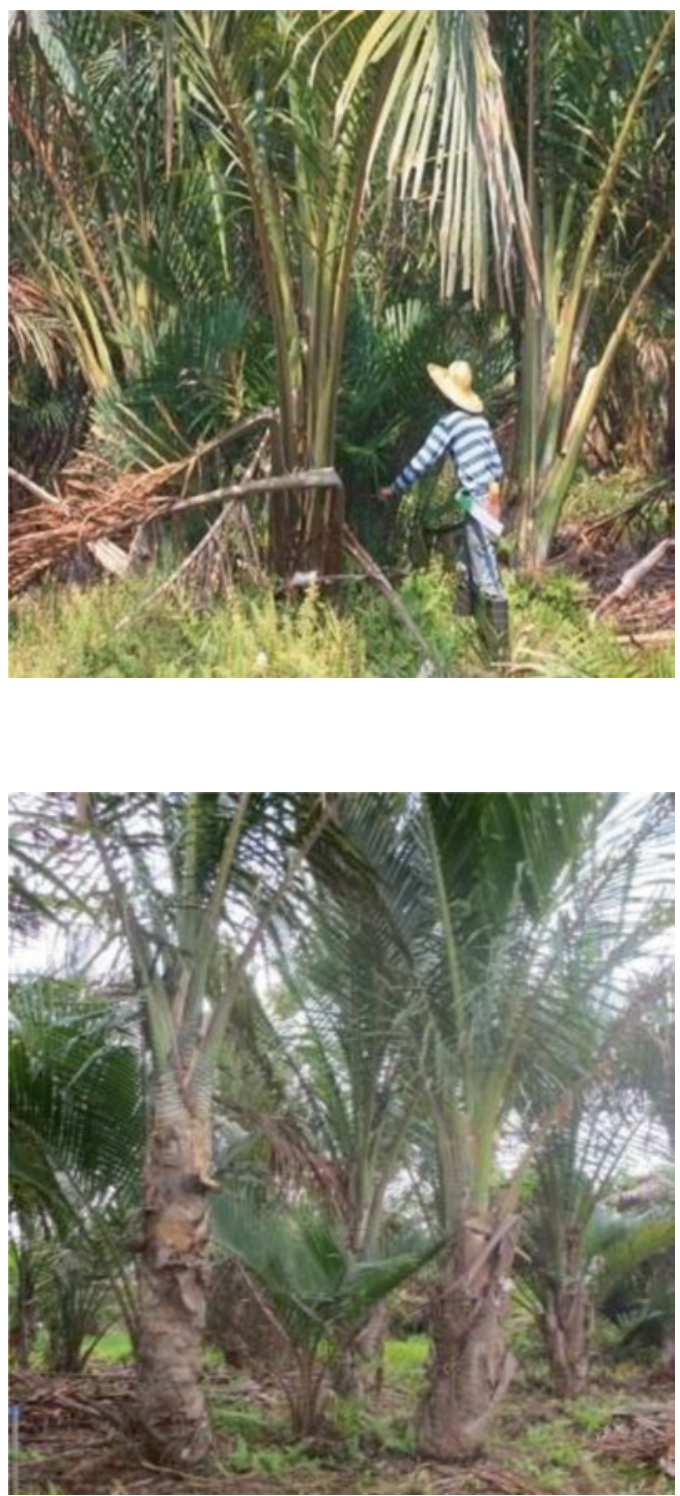
Fertilizer placement Studies using P-32

Active Root zones for 4 yrs old sago palm

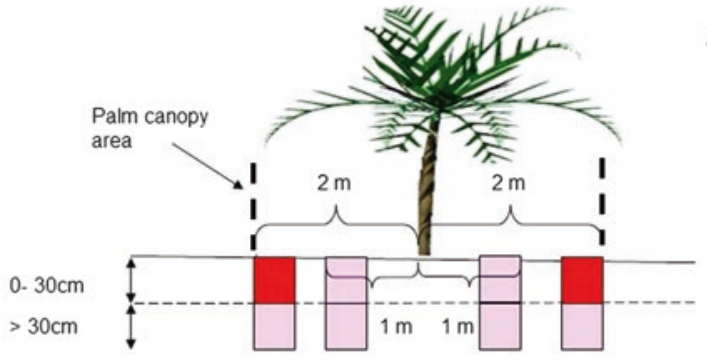

\section{Active Root Zone Area}

$0-30 \mathrm{~cm}$ depth

Most active root zone (high

density feeder roots)

$\square>30 \mathrm{~cm}$ depth

Less active root zone area (low density feeder roots)

\section{Active Root zone for 2yrs old sago palm}

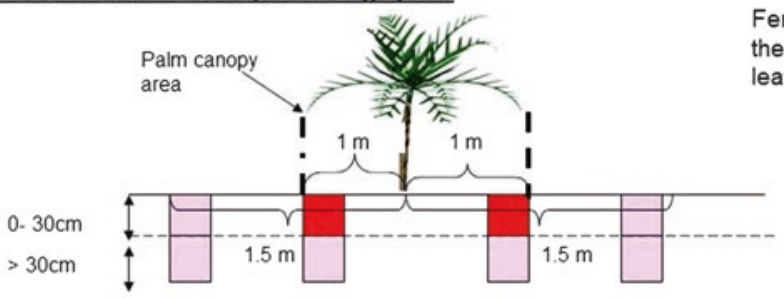

\section{Placement}

Fertilizer to be applied within the palm base to the edge of leaf canopy

Fig. 7.6 Fertilizer placement study using the P-32 isotopic method

\subsubsection{Fertilizer Application}

Fertilizer was applied around the palm base out to the edge of the leaf canopy and at the soil surface, based on the P-32 isotope dilution technique (Roland et al. 2012), as shown in Fig. 7.6.

\subsubsection{Fertilizer Trials}

Peat is a marginal soil lacking most of the important major and trace elements, namely, $\mathrm{N}, \mathrm{P}, \mathrm{K}, \mathrm{Cu}, \mathrm{Zn}$, and $\mathrm{B}$. A sago fertilizer program was initiated and formulated based on previous reports (Jong and Flach 1995) and foliar analysis (Tayeb 2005) for trials in peat areas.

The fertilizer formulated for sago is shown in Table 7.1a and 7.1b.

\subsubsection{Palm Growth Assessment Parameters}

Under optimal ecological conditions, the average number of leaves formed per year is 24 for both the rosette stage and bole formation (trunking) stage (Flach 1977). Parameters to be observed and measured for growth performance on peat are given in Table 7.2. 
Table 7.1a Fertilizer formulated for trials in the plantation (SSP)

PELITA plantation: *total amount (kg) per cluster for sago prior to first harvest (12 years)

\begin{tabular}{l|l|l|l|l|l}
\hline $\mathrm{N}$ & $\mathrm{P}$ & $\mathrm{K}$ & $\mathrm{Cu}$ & $\mathrm{B}$ & $\mathrm{Zn}$ \\
\hline 5.81 & 1.94 & 7.49 & 0.50 & 0.48 & 0.02 \\
\hline
\end{tabular}

Design: Randomized Completely Block Design $(R C B D)$ with four replications

${ }^{*}$ The total amount is apportioned according to age/stage of palm

Table 7.1b Fertilizer formulated for trials in Research Station (STRS)

\begin{tabular}{l|l|l|l|l|l|l}
\hline \multicolumn{7}{l}{ CRAUN station: *total amount (kg) per cluster before the first harvest (12 years) } \\
\hline Factorial NPK & $\mathrm{N}$ & $\mathrm{P}$ & $\mathrm{K}$ & $\mathrm{Cu}$ & $\mathrm{B}$ & $\mathrm{Zn}$ \\
\hline Level 1 & 11.6 & 3.9 & 15.0 & 0.50 & 0.48 & 0.02 \\
\hline Level 2 & 23.2 & 7.8 & 30.0 & & & \\
\hline Level 3 & 34.9 & 11.6 & 45.0 & & & \\
\hline
\end{tabular}

Design: $3 \times 3 \times 3$ factorial arranged in RCBD with three replications. Treatment: three levels of $\mathrm{N}$, $\mathrm{P}$, and $\mathrm{K}$

${ }^{*}$ The total amount is apportioned according to age/stage of palm

Table 7.2 Parameters for assessing growth performance of sago

\begin{tabular}{l|l|l|l}
\hline Number of leaves and trunking initiation year \\
\hline \multirow{2}{*}{ Status (growth performance) } & \multirow{2}{*}{ Palm stages } & $\begin{array}{l}\text { Total number of } \\
\text { leaves }\end{array}$ & $\begin{array}{l}\text { Initiation of } \\
\text { trunking year }\end{array}$ \\
\hline Good & Rosette & $>15$ & - \\
\hline Poor & & $\leq 15$ & - \\
\hline Good & \multirow{2}{*}{ Trunking } & $\geq 14$ & $<5$ years \\
\hline Poor & & $<14$ & $>5$ years \\
\hline
\end{tabular}

CRAUN (2010)

\subsubsection{Starch Yield Determination}

Starch yield determination was done for all sago palm that had reached a harvestable stage (pelawei manit). The targeted harvestable period is less than 10 years with starch yield of more than $150 \mathrm{~kg}$ per palm.

\subsubsection{Soil Studies}

The objective of this study was to determine the edaphic factors that affect sago growth on peat. The study included:

- Soil profiling for physical characterization

- Chemical analysis

- Root incursion through the soil profile 
Excavation of a soil pit was done as shown in Figs.7.7 and 7.8. Soil samples were collected from different depth horizon for nutritional analysis. The level of decomposition was determined by using the Von Post Scale which ranges from H1 (least humified) to H10 (most humified) and further grouped into three main peat types using US Department of Agriculture terminology, based mainly on their fiber content, as shown in Table 7.3 (USDA 1993).

Fig. 7.7 Excavation of soil pit (SSP, Mukah)

Fig. 7.8 An excavated soil pit (SSP, Mukah)
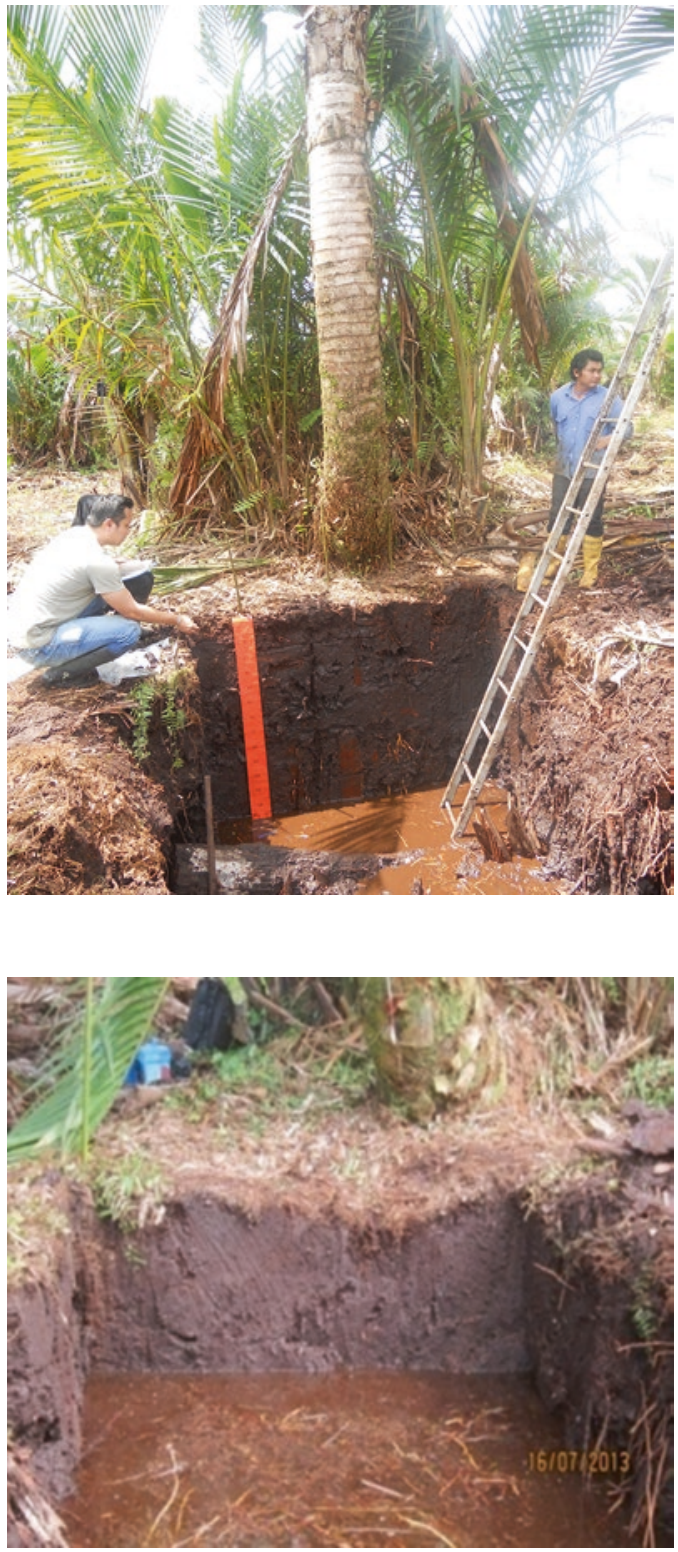
Table 7.3 An equivalent of USDA and Von Post Scale for peat humification

\begin{tabular}{l|l|l}
\hline Classification & Fiber content & Von Post class \\
\hline Fibric & $>66 \%$ & H1-H3 \\
\hline Hemic & $33-66 \%$ & H4-H6 \\
\hline Sapric & $<66 \%$ & H7-H10 \\
\hline
\end{tabular}

\subsubsection{Statistical Data Analysis}

The growth measurements and nutrient data were subjected to ANOVA using the general linear model (GLM) procedure of the Statistical Analysis Systems (SAS ${ }^{\mathrm{TM}}$ ). The least significant difference (LSD) test at $p<0.05$ was employed for the mean.

\subsection{Results and Discussions}

\subsubsection{Fertilizer Study}

Growth measurement data were taken both at the vegetative stage (1-4 years) and trunking stage ( $>5$ years) of growth. Figures 7.9 and 7.10 show the number of palm leaves under different soil types over 12 years of growth.

At the vegetative stage, the growth performance at all three locations showed good results, the number of leaves produced per palm was more than 14 (Fig. 7.9), and the highest leaf count was observed in year 2 . There were no apparent symptoms of leaf nutrient deficiency observed as the foliar analysis showed that the levels of major elements $\mathrm{N}, \mathrm{P}$, and $\mathrm{K}$ were sufficient but were not for $\mathrm{Mg}$ and trace elements for palms planted on deep peat (Tables 7.4 and 7.5).

After year 5, palm growth on deep peat started to weaken. Average number of leaves per palm dropped to less than 14 (Fig. 7.10) due to necrosis that led to rapid leaf senescence. Foliar analysis indicated that the palms were experiencing deficiencies in the major elements, $\mathrm{K}$ and $\mathrm{Mg}$ (Fig. 7.11). In addition, trace elements Mn, B, and $\mathrm{Cu}$ were also found to be deficient. These were indicated by the symptoms of retarded young spear, crinkled leaflets, and chlorotic leaves at the tips of the young leaf, respectively, as shown in Fig. 7.12. Trace elements are required in small quantities for critical enzymatic biochemical reaction to metabolize sugar and starch. Therefore, any shortfall in the availability of those elements will result in the above symptoms. Although remedial effort was done in year 5 of growth by increasing the level of insufficient major and trace elements mentioned above, there is no significant improvement on the crop growth in subsequent years. For example, K leaf nutrient concentration for sago grown on deep peat was found to be only $0.41 \%$, whereas the critical value for $\mathrm{K}$ for good growth is $0.73-0.89 \%$. When an additional $1.12 \mathrm{~kg} / \mathrm{palm}$ of $\mathrm{K}$ was added, the leaf nutrient concentration only increased to 


\section{Number of leaves at rosette stage}

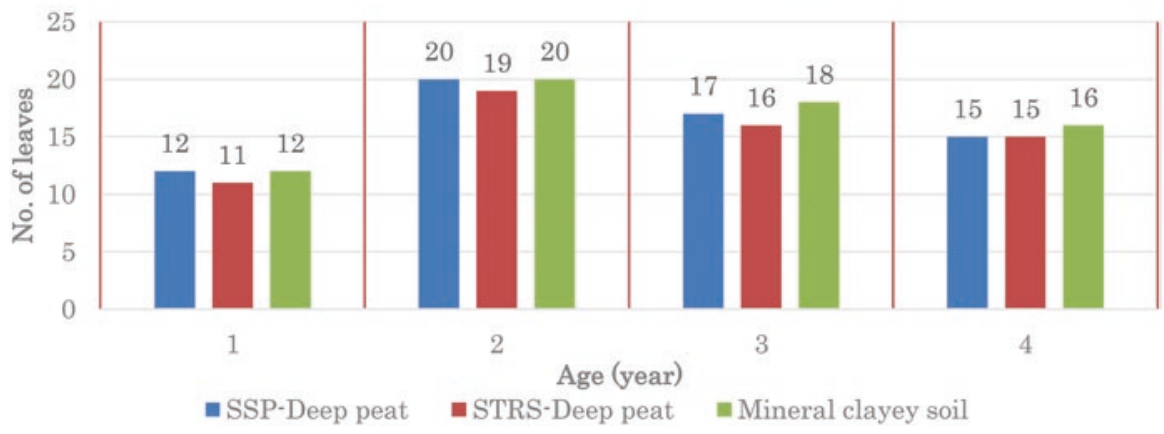

Fig. 7.9 Average number of leaves per palm at vegetative stage (1-4 years) on deep peat and mineral clayey soil

\section{Number of leaves at Trunking stage}

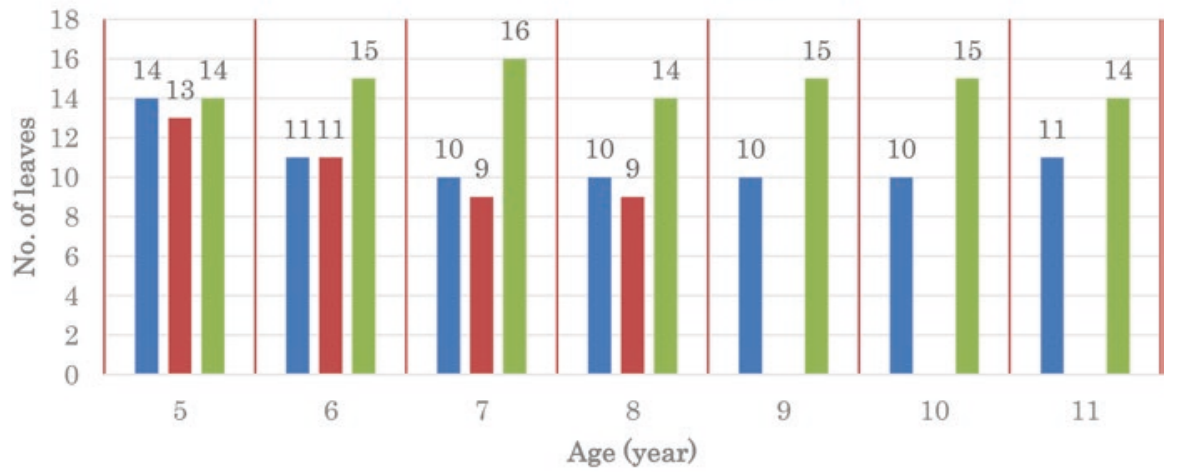

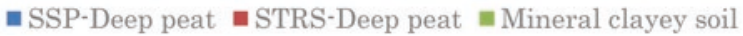

Fig. 7.10 Average number of leaves per palm at trunking stage ( $>5$ years) on deep peat and mineral clayey soil. *Leaf census at SSP-deep peat and mineral clayey soil from 5 to 11 years and STRS-deep peat from 5 to 8 years old

Table 7.4 Nutrient concentration in sago palm leaves at vegetative stages on deep peat at SSP

\begin{tabular}{|c|c|c|c|c|c|c|c|c|c|c|}
\hline \multirow[b]{2}{*}{ Palm age } & \multicolumn{5}{|l|}{$\%$} & \multicolumn{5}{|l|}{ ppm } \\
\hline & $\mathrm{N}$ & $\mathrm{P}$ & K & $\mathrm{Ca}$ & $\mathrm{Mg}$ & $\mathrm{Mn}$ & $\mathrm{Fe}$ & $\mathrm{Zn}$ & B & $\mathrm{Cu}$ \\
\hline 2 & 2.28 & 0.13 & 0.82 & 0.19 & 0.07 & 63.38 & 39.38 & 31.50 & 5.25 & 3.63 \\
\hline $\begin{array}{l}\text { a Rosette } \\
\text { stage }\end{array}$ & $\begin{array}{l}1.34- \\
1.65\end{array}$ & $\begin{array}{l}0.10- \\
0.11\end{array}$ & $\begin{array}{l}0.52- \\
0.62\end{array}$ & $\begin{array}{l}0.21- \\
0.26\end{array}$ & $\begin{array}{l}0.09- \\
0.11\end{array}$ & $\begin{array}{l}83.60- \\
249.00\end{array}$ & $\begin{array}{l}48.00 \\
79.00\end{array}$ & $\begin{array}{l}16.00- \\
21.00\end{array}$ & $\begin{array}{l}5.00- \\
9.00\end{array}$ & $\begin{array}{l}3.00- \\
8.00\end{array}$ \\
\hline 4 & 1.71 & 0.09 & 0.56 & 0.24 & 0.07 & 60.13 & 72.38 & 20.75 & 1.00 & 3.50 \\
\hline $\begin{array}{l}\text { aTrunk } \\
\text { initiation } \\
\text { stage }\end{array}$ & $\begin{array}{l}1.27- \\
1.56\end{array}$ & $\begin{array}{l}0.09- \\
0.11\end{array}$ & $\begin{array}{l}0.56- \\
0.70\end{array}$ & $\begin{array}{l}0.23- \\
0.28\end{array}$ & $\begin{array}{l}0.10- \\
0.12\end{array}$ & $\begin{array}{l}126.00- \\
248.00\end{array}$ & $\begin{array}{l}44.40- \\
57.50\end{array}$ & $\begin{array}{l}13.00- \\
19.00\end{array}$ & $\begin{array}{l}6.00- \\
11.00\end{array}$ & $\begin{array}{l}3.00- \\
11.00\end{array}$ \\
\hline
\end{tabular}

avalue of critical nutrient range of sago palm growth 
7 Suitability of Peat Swamp Areas for Commercial Production of Sago Palms...

Table 7.5 Nutrient concentration in sago palm leaves at vegetative stages on deep peat at STRS

\begin{tabular}{|c|c|c|c|c|c|c|c|c|c|c|}
\hline \multirow[b]{2}{*}{ Palm age } & \multicolumn{5}{|l|}{$\%$} & \multicolumn{5}{|l|}{ ppm } \\
\hline & $\mathrm{N}$ & $\mathrm{P}$ & K & $\mathrm{Ca}$ & $\mathrm{Mg}$ & $\mathrm{Mn}$ & $\mathrm{Fe}$ & $\mathrm{Zn}$ & B & $\mathrm{Cu}$ \\
\hline 2 & 2.05 & 0.13 & 0.72 & 0.21 & 0.09 & 202.33 & 59.00 & 14.67 & 3.67 & 2.33 \\
\hline $\begin{array}{l}\text { aRosette } \\
\text { stage }\end{array}$ & $\begin{array}{l}1.34- \\
1.65\end{array}$ & $\begin{array}{l}0.10- \\
0.11\end{array}$ & $\begin{array}{l}0.52 \\
0.62\end{array}$ & $\begin{array}{l}0.21- \\
0.26\end{array}$ & $\begin{array}{l}0.09- \\
0.11\end{array}$ & $\begin{array}{l}83.60- \\
249.00\end{array}$ & $\begin{array}{l}48.00- \\
79.00\end{array}$ & $\begin{array}{l}16.00- \\
21.00\end{array}$ & $\begin{array}{l}5.00- \\
9.00\end{array}$ & $\begin{array}{l}3.00- \\
8.00\end{array}$ \\
\hline 4 & 2.05 & 0.15 & 0.82 & 0.28 & 0.08 & 186.33 & 42.00 & 18.67 & 9.67 & 4.00 \\
\hline $\begin{array}{l}\text { aTrunk } \\
\text { initiation } \\
\text { stage }\end{array}$ & $\begin{array}{l}1.27- \\
1.56\end{array}$ & $\begin{array}{l}0.09- \\
0.11\end{array}$ & $\begin{array}{l}0.56- \\
0.70\end{array}$ & $\begin{array}{l}0.23- \\
0.28\end{array}$ & $\begin{array}{l}0.10- \\
0.12\end{array}$ & $\begin{array}{l}126.00- \\
248.00\end{array}$ & $\begin{array}{l}44.40- \\
57.50\end{array}$ & $\begin{array}{l}13.00- \\
19.00\end{array}$ & $\begin{array}{l}6.00- \\
11.00\end{array}$ & $\begin{array}{l}3.00- \\
11.00\end{array}$ \\
\hline
\end{tabular}

${ }^{a}$ Value of critical nutrient range for sago palm growth

Fig.7.11 K deficiency with symptoms of necrotic leaflets and early senescence (SSP, Mukah)

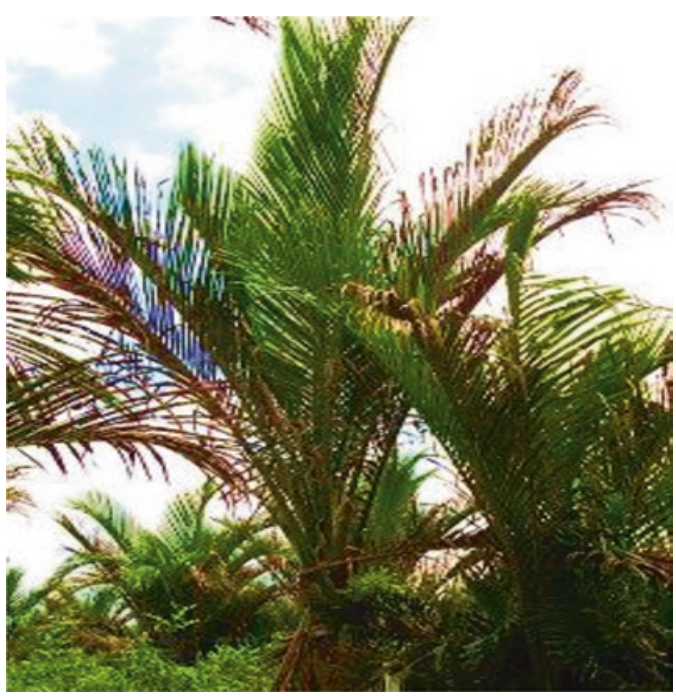

Fig. 7.12 $\mathrm{Cu}$ deficiency with symptom of leaf tip chlorosis (SSP, Mukah)

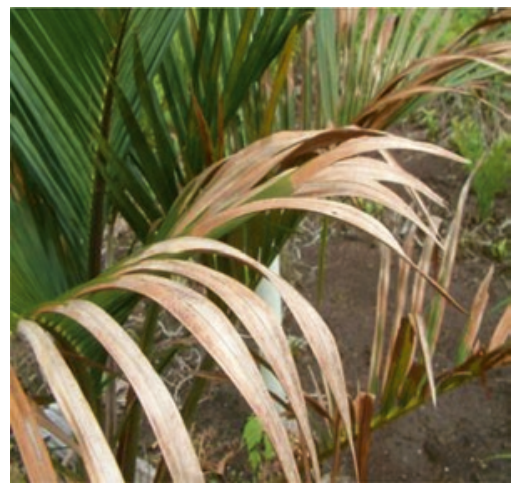


Table 7.6 Nutrient concentration in sago palm leaves at 6 years after planting on deep peat at SSP

\begin{tabular}{|c|c|c|c|c|c|c|c|c|c|c|}
\hline \multirow[b]{2}{*}{ Palm age } & \multicolumn{5}{|l|}{$\%$} & \multicolumn{5}{|l|}{ ppm } \\
\hline & $\mathrm{N}$ & $\mathrm{P}$ & $\mathrm{K}$ & $\mathrm{Ca}$ & $\mathrm{Mg}$ & $\mathrm{Mn}$ & $\mathrm{Fe}$ & $\mathrm{Zn}$ & B & $\mathrm{Cu}$ \\
\hline 6 & 1.65 & 0.09 & 0.44 & 0.23 & 0.08 & 44.92 & 35.21 & 15.08 & 3.88 & 2.71 \\
\hline $\begin{array}{l}{ }^{a} \text { Trunking } \\
\text { stage }\end{array}$ & $\begin{array}{l}1.34- \\
1.65\end{array}$ & $\begin{array}{l}0.10- \\
0.11\end{array}$ & $\begin{array}{l}0.52- \\
0.62\end{array}$ & $\begin{array}{l}0.21- \\
0.26\end{array}$ & $\begin{array}{l}0.09- \\
0.11\end{array}$ & $\begin{array}{l}83.60- \\
249.00\end{array}$ & $\begin{array}{l}48.00- \\
79.00\end{array}$ & $\begin{array}{l}16.00- \\
21.00\end{array}$ & $\begin{array}{l}5.00- \\
9.00\end{array}$ & $\begin{array}{l}3.00- \\
8.00\end{array}$ \\
\hline
\end{tabular}

${ }^{a}$ Value of critical nutrient range for sago palm growth

Table 7.7 Nutrient concentration in sago palm leaves at 6 years after planting on deep peat at STRS

\begin{tabular}{|c|c|c|c|c|c|c|c|c|c|c|}
\hline \multirow[b]{2}{*}{ Palm age } & \multicolumn{5}{|l|}{$\%$} & \multicolumn{5}{|l|}{ ppm } \\
\hline & $\mathrm{N}$ & $\mathrm{P}$ & K & $\mathrm{Ca}$ & $\mathrm{Mg}$ & $\mathrm{Mn}$ & $\mathrm{Fe}$ & $\mathrm{Zn}$ & B & $\mathrm{Cu}$ \\
\hline 6 & 2.06 & 0. & 6 & 0.28 & 0.10 & .67 & 39.67 & 19.00 & 8.67 & 4.00 \\
\hline $\begin{array}{l}{ }^{a} \text { Trunking } \\
\text { stage }\end{array}$ & $\begin{array}{l}1.34- \\
1.65\end{array}$ & $\begin{array}{l}0.10- \\
0.11\end{array}$ & $\begin{array}{l}0.52- \\
0.62\end{array}$ & $\begin{array}{l}0.21- \\
0.26\end{array}$ & $\begin{array}{l}0.09- \\
0.11\end{array}$ & $\begin{array}{l}83.60- \\
249.00\end{array}$ & $\begin{array}{l}48.00- \\
79.00\end{array}$ & $\begin{array}{l}16.00- \\
21.00\end{array}$ & $\begin{array}{l}5.00- \\
9.00\end{array}$ & $\begin{array}{l}3.00- \\
8.00\end{array}$ \\
\hline
\end{tabular}

${ }^{a}$ Value of critical nutrient range for sago palm growth

Table 7.8 Starch yield and growth parameter of sago palm on deep peat and mineral clayey soil at harvestable stage (pelawei manit)

\begin{tabular}{|c|c|c|c|c|c|}
\hline \multirow[b]{2}{*}{ Soil type } & \multicolumn{2}{|c|}{ Starch yield } & \multirow[b]{2}{*}{$\begin{array}{l}\text { Trunk length } \\
\text { (m) }\end{array}$} & \multirow[b]{2}{*}{$\begin{array}{l}\text { Average diameter } \\
(\mathrm{cm})\end{array}$} & \multirow[b]{2}{*}{$\begin{array}{l}\text { No. o } \\
\text { leaves }\end{array}$} \\
\hline & $\begin{array}{l}(\mathrm{Kg} / \\
\text { trunk })\end{array}$ & $(\mathrm{Kg} / \mathrm{m})$ & & & \\
\hline SSP-deep peat & 18.6 & 3.4 & 5.4 & 43.8 & 12 \\
\hline $\begin{array}{l}\text { Mineral clayey } \\
\text { soil }\end{array}$ & 156.7 & 16.5 & 9.5 & 56 & 18 \\
\hline
\end{tabular}

$0.44 \%$ which is still below the critical $\mathrm{K}$ value. All the deficient element results are provided in Tables 7.6 and 7.7.

A total of $80 \%$ of palms on peat were trunking, but only $36 \%$ reached a harvestable stage at year 11. Moreover, the harvestable palms recorded very low starch yield of less than $20 \mathrm{~kg} / \mathrm{palm}$ (Table 7.8). Furthermore, the growth of successional palms was also very slow. Based on the current growth, the second-generation harvesting can only be expected after 4-5 years from the first harvest (mother palm).

Whereas those palms planted on mineral clayey soil showed good growth for both mother and successional palms, the palms started reaching harvestable stage in year $9(9 \%)$ and were $100 \%$ harvestable palms by year 11 . The starch yield was also higher, more than $150 \mathrm{~kg} / \mathrm{palm}$.

Sago palm growth performance on deep peat and mineral clayey soil is shown in Fig. 7.13. 


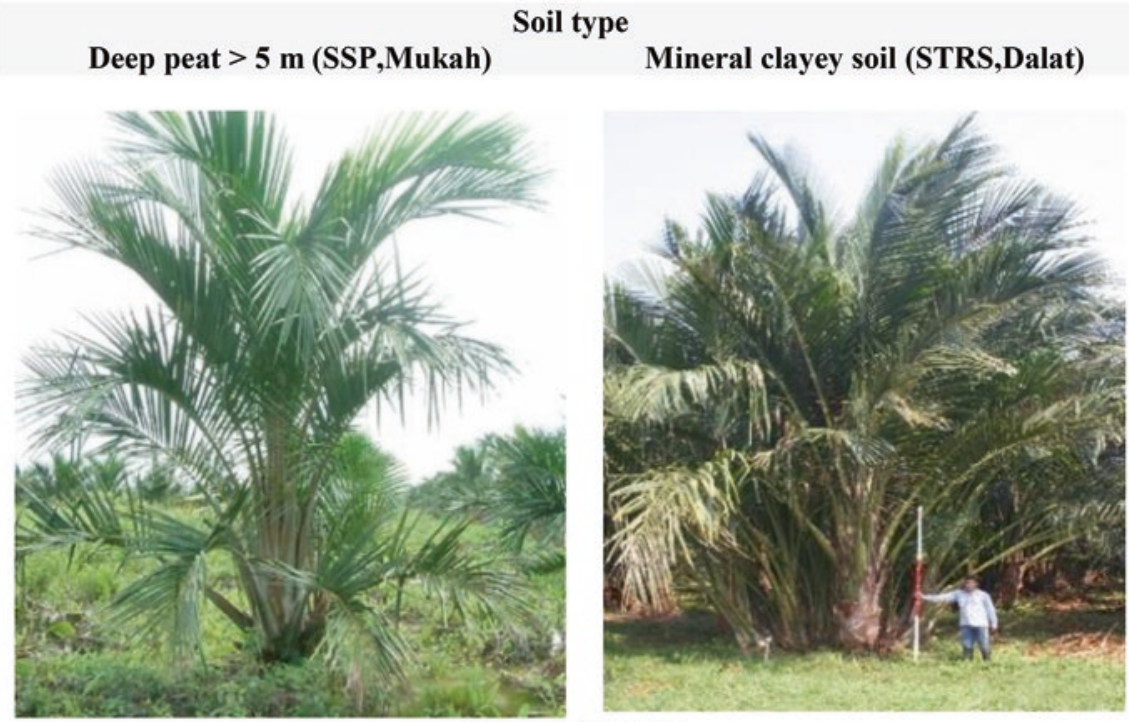

At 4 years of age
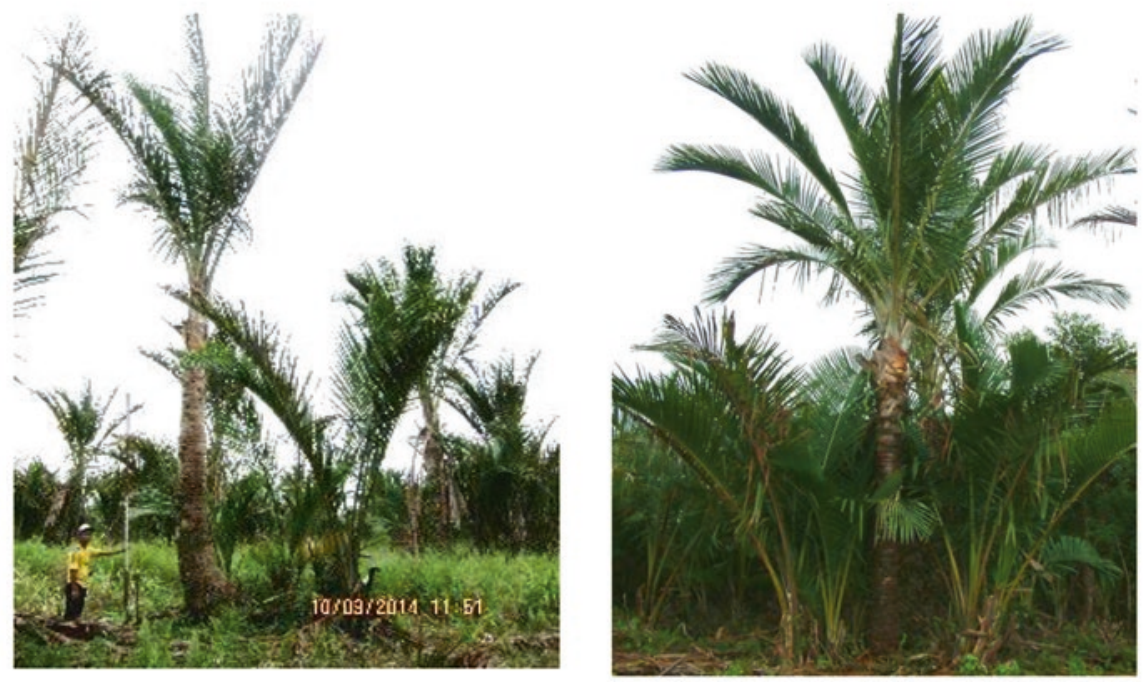

At 8 years of age

Fig. 7.13 Sago growth performance on deep peat (SSP) and mineral clayey soil (STRS) 


\subsubsection{Soil Study}

\subsubsection{Physical Properties}

In deep peat at Sebakong Sago Plantation, the top horizon, 0-20 cm, is generally highly decomposed (sapric) having a humification value of $\mathrm{H} 8$. The second horizon, which is more than $20 \mathrm{~cm}$ deep, is moderately decomposed (hemic) with a humification value of $\mathrm{H} 4$. The color change from very dark brown to dark brown, from the top horizon to second horizon, is due to the changes in the organic matter decomposition process.

The bulk density in deep peat was less than $0.15 \mathrm{~g} / \mathrm{cm}^{3}$, while in mineral soil, the bulk density is more than $1 \mathrm{~g} / \mathrm{cm}^{3}$. This was due to more than $70 \%$ of the deep peat content of undecomposed woody materials with preserved tree trunks and large roots (Fig. 7.14) compared to a low percentage of undecomposed woody materials in the mineral soil (Fig. 7.15). The undecomposed materials of deep peat areas needed a longer time to decay, and this contributed to the vacant zone where there was no growth media for sago palms. In addition, due to poor soil physical properties, root development and distribution are limited. The roots confined and limited themselves at the $50 \mathrm{~cm}$ from the soil surface which produced poor anchorage leading to poor trunking. In mineral clayey soil, the palms have better anchorage due to the underlying solid foundation that contributes to early trunking.

Fig. 7.14 Deep peat profile (SSP, Mukah)

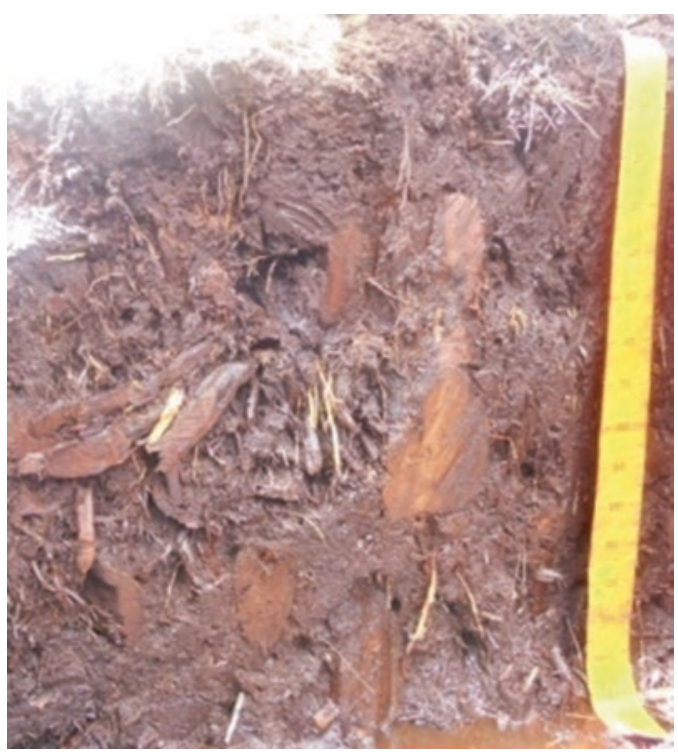


Fig. 7.15 Mineral clayey soil profile (STRS, Dalat)

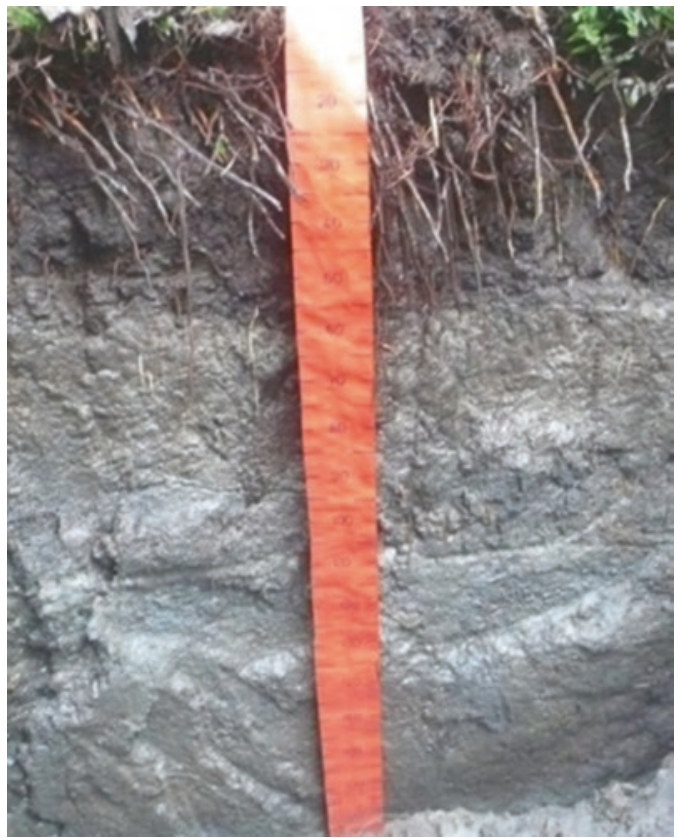

\subsubsection{Chemical Properties}

Peat soils have very low mineral content, with organic matter content reaching more than $90 \%$, and are also very acidic with a $\mathrm{pH}$ range of 3.0-4.0. Low $\mathrm{pH}$ limits the availability of major nutrients to the palms (Table 7.9). Besides this, excessive rainfall results in key nutrients, such as $\mathrm{K}, \mathrm{Mg}$, and $\mathrm{Ca}$, being washed out (leached) from the soil.

The cation exchange capacity (CEC) determines the amount of nutrients the soil can hold and that is readily available to the palms. The CEC in deep peat is very high $>70 \mathrm{meq} / 100 \mathrm{~g}$ or $70 \%$ meq which should indicate a high amount of readily available nutrients, but the high CEC is not due to the presence of cations $\mathrm{K}, \mathrm{Ca}$, or $\mathrm{Mg}$ but because of the presence of exchangeable hydrogen cations $\left(\mathrm{H}^{+}\right)$as shown by the low base saturation. Hydrogen ions are generated from organic acids during organic decay. As the soil surface is saturated with $\mathrm{H}^{+}$ions, this makes the soil unable to retain and hold other cations that will lead to nutrient leach out. In mineral soil, the CEC content is lower than in peat, but the base saturation is relatively high $(65 \%)$ compared to peat soil $(15 \%)$ which leads to nutrients in the soil being readily available to the palms. A relatively high base saturation of CEC (70-80\%) should be maintained for most cropping systems, since the base saturation determines in large measure the availability of bases for plant uptake and strongly influences soil $\mathrm{pH}$ as well (Steven 2000). 
Table 7.9 Base saturation and acidity in SSP (Deep peat) and STRS (Mineral Soil)

\begin{tabular}{|c|c|c|c|c|c|c|c|c|c|}
\hline \multirow[b]{2}{*}{ Location } & \multirow[b]{2}{*}{ Horizon } & \multirow{2}{*}{$\begin{array}{l}\text { CEC } \\
\text { (meq } \\
\%)\end{array}$} & \multicolumn{4}{|c|}{ Basic cations (meq \%) } & \multirow{2}{*}{$\begin{array}{l}\text { Base } \\
\text { saturation } \\
(\%)\end{array}$} & \multirow{2}{*}{\begin{tabular}{|l|}
$\begin{array}{l}\text { Acidic } \\
\text { cation } \\
\text { (meq \%) }\end{array}$ \\
Exch. Al \\
\end{tabular}} & \multirow[b]{2}{*}{$\begin{array}{l}\text { Acidity } \\
(\%)\end{array}$} \\
\hline & & & $\begin{array}{l}\text { Exch. } \\
\mathrm{K}\end{array}$ & $\begin{array}{l}\text { Exch. } \\
\mathrm{Ca}\end{array}$ & $\begin{array}{l}\text { Exch. } \\
\text { Mg }\end{array}$ & Total & & & \\
\hline \multirow[t]{2}{*}{ SSP1 } & $\mathrm{O}_{\mathrm{a}}$ & 84.8 & 0.29 & 12.4 & 3.39 & 16.08 & 18.96 & 0.20 & 81.04 \\
\hline & $\mathrm{O}_{\mathrm{e}}$ & 83.5 & 0.09 & 2.15 & 2.61 & 4.85 & 5.81 & 0.80 & 94.19 \\
\hline \multirow[t]{2}{*}{ SSP2 } & $\mathrm{O}_{\mathrm{a}}$ & 80.8 & 0.26 & 6.28 & 3.28 & 9.82 & 12.15 & 0.80 & 87.85 \\
\hline & $\mathrm{O}_{\mathrm{e}}$ & 82.3 & 0.14 & 1.96 & 2.79 & 4.89 & 5.94 & 1.59 & 94.06 \\
\hline \multirow[t]{3}{*}{ SSP3 } & $\mathrm{O}_{\mathrm{a}}$ & 82.7 & 0.41 & 8.47 & 3.00 & 11.88 & 14.37 & 0.20 & 85.63 \\
\hline & $\mathrm{O}_{\mathrm{a}}$ & 77.7 & 0.10 & 1.96 & 1.72 & 3.78 & 4.86 & 1.20 & 95.14 \\
\hline & $\mathrm{O}_{\mathrm{e}}$ & 79.7 & 0.08 & 1.58 & 1.85 & 3.51 & 4.40 & 2.39 & 95.60 \\
\hline \multirow[t]{4}{*}{ STRS1 } & $\mathrm{O}_{\mathrm{e}}$ & 38 & 0.17 & 1.13 & 1.92 & 3.22 & 8.47 & 8.99 & 91.53 \\
\hline & $\mathrm{O}_{\mathrm{a}}$ & 30.6 & 0.10 & 0.69 & 2.87 & 3.66 & 11.96 & 7.09 & 88.04 \\
\hline & A & 7.47 & 0.12 & 0.73 & 4.03 & 4.88 & 65.33 & 2.60 & 34.67 \\
\hline & $\mathrm{E}$ & 23.3 & 0.28 & 8.23 & 12.6 & 21.11 & 90.60 & 5.45 & 9.40 \\
\hline \multirow[t]{4}{*}{ STRS2 } & $\mathrm{O}_{\mathrm{a}}$ & 20.7 & 0.08 & 0.98 & 1.02 & 2.08 & 10.05 & 4.27 & 89.95 \\
\hline & OA & 4.97 & 0.05 & 0.37 & 0.25 & 0.67 & 13.48 & 4.27 & 86.52 \\
\hline & A & 2.07 & 0.07 & 0.46 & 1.04 & 1.57 & 75.85 & 3.75 & 24.15 \\
\hline & $\mathrm{E}$ & 6.65 & 0.14 & 1.37 & 3.70 & 5.21 & 78.35 & 3.94 & 21.65 \\
\hline
\end{tabular}

The carbon-to-nitrogen ratio $(\mathrm{C}: \mathrm{N})$ in deep peat determines the humification rate of the organic materials. The $\mathrm{C}: \mathrm{N}$ ratio on deep peat was more than 29:1 and coupled with the low $\mathrm{pH}$ resulted in low mineralization. The rate of peat deposition exceeds the rate of decomposition as most of the humification process is by anaerobic decay and the rate of metabolism is much less than the aerobic process. Most of the organic residues in these areas have a high $\mathrm{C}: \mathrm{N}$ ratio, and this requires the microbes to find additional nitrogen for the decomposition process and creates a nitrogen deficit for the palms. For example, deep peat areas mostly covered with ferns, with a high C:N ratio of 43, and tree stumps, with $\mathrm{C}: \mathrm{N}$ ratio of 560, require a long time to decay. The total $\mathrm{P}$ content of tropical peat is generally low. According to Zhang and Zhao (1997), phosphorus exists in soils in organic and inorganic form. In soils, P may exist in many different forms such as solution P, active P, and fixed P (Busman 2009).

In peat the $\mathrm{P}$ will react with humic compound to form complex formations that are easily diluted in soil solution and eventually leach out (Kim 1993). As the soil contains no clay minerals, it does not have the ability to retain the soluble phosphate being leached out. In mineral soil, high amounts of total phosphorus were due to the fixation by iron $(\mathrm{Fe})$ to form strengite $\left(\mathrm{FePO}_{4} \cdot 2 \mathrm{H}_{2} \mathrm{O}\right)$ ( $\mathrm{Kim} \mathrm{1993).}$

Potassium is generally very low in peat soil as the available $\mathrm{K}$ which was always present in the soil solution is strongly mobile and prone to leaching. The total $\mathrm{K}$ in mineral clayey was higher than deep peat due to the fixation by the negatively charged clay crystals.

The levels of trace elements in peat were very low. Total $\mathrm{Cu}, \mathrm{Zn}, \mathrm{Mn}$, and $\mathrm{Bo}$ in particular were extremely low, averaging less than $20 \mathrm{ppm}$ or $20 \mu \mathrm{g} / \mathrm{g}$ as it is taken out of the solution by forming complex formation with humid compounds. 
Table 7.10 Economic implications of sago grown on different soil types

\begin{tabular}{l|l|l|l}
\hline Soil type & Peat $>2.5 \mathrm{~m}$ & Peat $<2.5 \mathrm{~m}$ & Mineral clayey soil \\
\hline Maturity (years) & $>11$ & 10 & 9 \\
\hline Yield (tons/ha) & $<2$ & 9 & $>15$ \\
\hline Development cost (MYR/ha) & 30,800 & 26,800 & 23,600 \\
\hline Payback period (years) & - & 14 & 11 \\
\hline Sago starch production cost (MYR) & 3520 & 1020 & 700 \\
\hline Internal rate of return (IRR) & - & $13.1 \%$ & $23.4 \%$ \\
\hline
\end{tabular}

\subsubsection{Economic Evaluation}

From an economic prospective of sago development on peat and mineral soil, a comparison cost analysis was carried out. A highly significant difference was found in terms of return on investment as shown in Table 7.10

Despite providing the crop with appropriate agronomic and cultural practices, sago palms planted on peat did not respond to give better growth. It took 11 years to reach the first harvestable stage, and only $36 \%$ of the palms had starch yield of less than $20 \mathrm{~kg} /$ palm. Furthermore, the cost of development and maintenance was high which led to no return on investment.

Therefore, economically, cultivation of commercial sago plantation on peat soil seems unviable. However, on shallow peat $(<2.5 \mathrm{~m})$, it can yield about $90 \mathrm{~kg}$ per palm with $81 \%$ harvestable palms and giving a marginal internal rate of return (IRR) of $13.1 \%$, while on mineral soil, it could yield more than $150 \mathrm{~kg}$ per palm giving an IRR of $23.4 \%$.

\subsection{Conclusion and Recommendation}

All study plots for both peat and mineral soil showed good vegetative growth in the first 4 years. However, the growth started to decline on peat areas after year 5, while on the mineral soil, it continues to grow well. The leaf number started to decline. Only $36 \%$ reached harvestable stage at year 11 when grown on peat, whereas those palms planted on mineral clayey soil reached $100 \%$ harvestable stage by year 11 . In fact the first harvest of $9 \%$ of the palms in mineral clayey soil can be done at year 9 . The harvestable palms in peat areas had a low starch yield of less than $20 \mathrm{~kg} / \mathrm{palm}$, while the harvestable palms on mineral soil had a starch yield of more than $150 \mathrm{~kg} / \mathrm{palm}$.

Thus, the studies showed that the number of harvestable palm and starch yield on peat area after 12 years of planting is lower than that of mineral clayey soil. Therefore, planting sago on peat is not feasible. Based on the economic evaluation, sago on peat with the yield of less than $20 \mathrm{~kg}$ per palm does not give any return on investment. To be viable, the harvestable age must be less than 10 years with the yield of $150 \mathrm{~kg}$ per palm which will give an IRR of $23 \%$ (as compared to $21 \%$ for oil palm). This IRR of $23 \%$ can be achieved if palms are planted on mineral soil. 
Last but not least, the cost of development and maintenance on peat is comparatively higher and tends to affect the environment adversely if not managed properly.

Acknowledgments We acknowledge the Government of Sarawak; Land Custody and Development Authority (LCDA); Pelita Mukah Sebakong Sago Plantation (PMSSP); Malaysia Nuclear Agency; Dr. Mohd. Tayeb Dolmat, former MPOB agronomist; and the staff of CRAUN at Sungai Talau Research Station for their support and success of this project.

\section{References}

Busman L (2009) The nature of phosphorus in soils. University of Minnesota, St Paul

CRAUN (2010) Monitoring and evaluation on sago growth performance in the plantations. CRAUN Research Sdn. Bhd, Sarawak

Flach M (1977) Sago palm (Metroxylon sagu Rottb.) promoting the conservation and use of underutilized and neglected crops. 13. Institute of Plant Genetics and Crop Plant Research, Rome

Jong FS (1995) Research for the development of sago palm (Metroxylon sagu Rottb.) cultivation in Sarawak, Malaysia. PhD thesis, Wageningen Agricultural University, Netherlands

Kim HT (1993) Principles of soil chemistry, 2nd edn. Marcel Dekker Inc., New York

Peter SH, Noraini B, Yusup S (2012) Effect of selective sucker pruning of sago (Metroxylon sagu) four years field performance. 2nd Asean Sago Symposium proceeding, UNIMAS Sarawak Malaysia

Roland YCM, Noraini B, Ahamad SM, Khairuddin AR (2012) Fertilizer placement study using P isotopic tracer technique on sago palms. In: 2nd Asean Sago symposium proceeding, UNIMAS Sarawak Malaysia

Steven CH (2000) Soil fertility basics. Soil science extension. North Carolina State University, Raleigh

Tayeb MD (2005) Technologies for planting oil palm on peat. Malaysian Palm Oil Board, Kuala Lumpur

USDA (1993) Soil survey manual. Soil Survey Division, USDA, Washington, DC

Yusup S, Edwin LCL, Noraini B, Ahmad Zaki H (2007) Manual for planting and maintenance of sago plantation on peat. CRAUN Research Sdn. Bhd, Sarawak

Zhang J, Zhao B (1997) Phosphorus dynamics: from soil to plant. American Society of Plant Biologists, Rockville

Open Access This chapter is licensed under the terms of the Creative Commons Attribution 4.0 International License (http://creativecommons.org/licenses/by/4.0/), which permits use, sharing, adaptation, distribution and reproduction in any medium or format, as long as you give appropriate credit to the original author(s) and the source, provide a link to the Creative Commons license and indicate if changes were made.

The images or other third party material in this chapter are included in the chapter's Creative Commons license, unless indicated otherwise in a credit line to the material. If material is not included in the chapter's Creative Commons license and your intended use is not permitted by statutory regulation or exceeds the permitted use, you will need to obtain permission directly from the copyright holder. 


\title{
Chapter 8 \\ Feasibility of Small-Scale Sago Industries in the Maluku Islands, Indonesia
}

\author{
Wardis Girsang
}

\begin{abstract}
The sago industry has a pivotal role to exploit underutilized sago starch in the sago forest but is little known in terms of the feasibility of existing sagoprocessing industries, particularly in small islands. This paper outlines the feasibility and possible future development of existing sago industries in Maluku, Indonesia. Data were collected from field observations, in-depth interviews, and focus group discussions from nine small-scale sago industries in Ambon and Seram Islands. Existing sago industries were found financially feasible in the short term but may be unsustainable over the longer term. Modern sago industries are 25 times higher in investment and operational costs but 15 times higher in production, up to 4 times higher in labor absorption, and 5 times higher in profit than that of semi-modern industry technology. However, modern sago industries are difficult to sustain because of the high price of raw material, uncertain market demand, fragile institutional development, and uncertain sago forest sustainability in the islands because the cutting of sago trees occurs about 15 times faster than that of conventional technology industry. This suggests that sustainable sago industries for food security in Maluku need adaptive technology to improve added value and to reduce operational costs and be small scale but intensive and efficient.
\end{abstract}

\subsection{Introduction}

Food security and population growth are a challenge to human development in the world, particularly in developing countries like Indonesia. The world population is projected to increase from seven billion in 2010 to nine billion in 2050 suggesting that food production needs to increase some $70 \%$ over that period to fulfill projected food demand (National Food Security Board 2011). However, due to the impact of climate change on agriculture and fisheries, food production will probably decrease. As part of the developing world, Indonesia's population reached 250 million in 2016 and is increasing steadily; therefore, future food availability will be at risk,

\footnotetext{
W. Girsang $(\triangle)$

Faculty of Agriculture, University of Pattimura, Ambon, Indonesia

e-mail: girsangwardis@faperta.unpatti.ac.id; girsangwardis@yahoo.com
} 
particularly in small islands like the Malukus. Small islands are vulnerable to food insecurity because they are relatively isolated, are less developed and have limited accessibility and connectivity within and between islands. In this case, staple food in small islands should be based on local food products; however, staple food has changed considerably from sago, maize, and tubers to rice as the national staple food. This situation will endanger local staple food and create dependency on imported rice and vulnerability of food security (Fig. 8.1).

Rice production in the Malukus is only 70,000 mt/year, satisfying around $40 \%$ of total rice demand. To avoid consumption dependency on imported rice, therefore, local food crops, particularly sago starch, have the potential to be considered as an alternative strategy to sustain food security in small islands. In Indonesia, around 2 million ha of sago palms exist which could theoretically produce 60 million $\mathrm{mt}$ of sago starch or twice the national rice production. Unlike rice, sago palms have special characteristics: (1) they are environmentally friendly trees which conserve water; (2) they are more resistant to climate change impacts, pests, and diseases (Amien 2011); (3) they grow well in marginal lands (Louhenapessy 1992); (4) they are self-regenerating trees which grow naturally in clusters along the rivers and on level areas (Ellen 2006); and (5) they can also contribute to bioethanol and sugar production as well as to reduce global warming (Ishizaki 1997; Bujang 2010).

Because food security is a crucial issue in small islands, therefore the great potential of sago forests in the Malukus should prioritize for food security, and the government should implement a policy to protect them. In fact, the potential of sago is underutilized, while current government policy follows national food policy that is to expand new paddy rice areas by up to 6000 ha in the next 6 years. As a consequence, sago forests will probably be cleared and replaced by rice cultivation. In addition, the rapid pace of sago tree cutting by sago starch industries may exceed natural regeneration and cultivation. To some extent, sago forests are unsustainable in some areas and unutilized in others. Therefore, the feasibility of small-scale sago industries in small islands needs to be assessed.

\subsection{Methodology}

Sago forest can be found in several regions of the Malukus, including the islands of Seram, Ambon-Lease, Buru, Kei, and Aru, and a limited area in the Tanimbar Islands. Research for this study was carried out in Seram and Ambon islands. These two islands were selected because sago industries are found there and they have relatively good accessibility to Ambon, the capital of Maluku Province.

Nine sago industries were studied: seven in Ambon and two in Seram. The sago industries in Ambon consist of five wet sago starch producers and two sago food producers. One wet sago starch producer uses traditional technology, which is called nani (a traditional handmade tool that is made from small bamboo which is added with iron ring at the top and designed into L-shape to extract pith from the body of sago tree), and three producers use semi-modern technology, while the fifth 


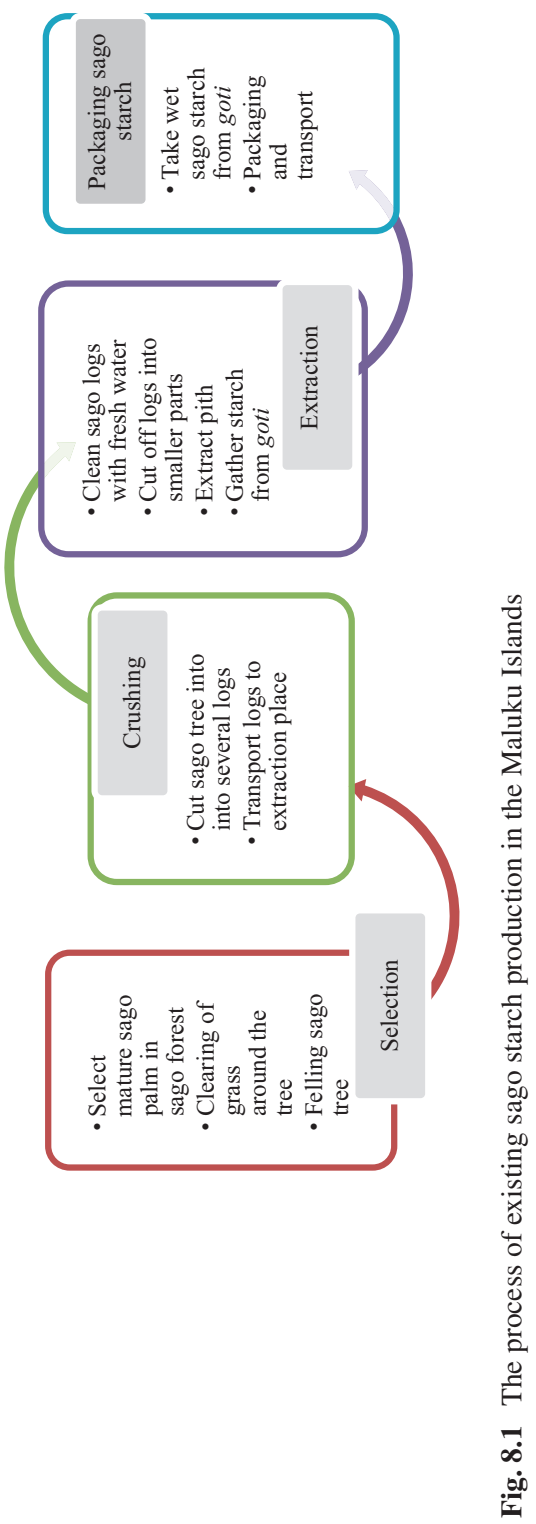


employs modern technology. Traditional technology is mobile, using simple tools, without machines and wage labor; semi-modern technology is mobile, using sago processing machines and sharing wage labor. Modern technology is immobile, using large machines and wage labor. The two sago food producers make baked sago (local name sago lempeng) using semi-modern technology and sago noodle (SN) employing modern sago food processing technology. Meanwhile, the two examples of modern sago industries in Seram use modern sago-processing technology, exporting wet sago starch to Java islands.

To collect primary and secondary data, a questionnaire was designed and applied by well-trained research assistants in the field. Field observations, focus group discussions, and in-depth interviews were developed as mixed methods to collect data from individuals and sago group members. Small-scale businesses and home industries were the unit of analysis for the sago industry in order to assess the feasibility of small-scale sago industries (Ibrahim 1985).

\subsection{Results and Discussions}

\subsubsection{The Potential of Sago Palm}

The area of sago palm in the world is estimated at 2,474,000 ha (Flach 1984); it is assumed that sago palm productivity could be improved up to $30 \mathrm{mt} / \mathrm{ha}$ (Bujang 2010); therefore, sago palms have the potential to produce 74.2 million mt of starch. As sago starch consumption is approximately $180 \mathrm{~kg} / \mathrm{capita} /$ year (Yamamoto 2011), sago palm is theoretically able to feed some 412.3 million people per year in the world. This indicates that sago is a solution to the problem of food insecurity. Haryanto and Pangloli (1992) estimated that the sago palm area in Indonesia was approximately 851,260 ha, whereas Flach estimated around 1.25 million ha with about 154,000 ha classified as semi-cultivated (Flach 1983 in Bintoro et al. 2013). Other studies set the sago palm area in Indonesia at around 1,127,630 ha with 90\% found in Papua Province (Jong and Widjoyo 2007). In the Malukus, Alfons and Bustaman (2005) estimated around 31,360 ha, Provincial Central Bureau of Statistics noted around 52,000 ha (CBS 2012), whereas Flach (1997) and Bintoro (2011) estimated around 60,000 ha. Based on the previous sago area data evaluation in different areas and times (Alfons and Bustaman 2005; BPPS Maluku 2009; Bintoro 2011; CBS 2012), it can be argued that the total area of sago in the Malukus is probably about 64,205 ha which could potentially produce around $500,800 \mathrm{mt}$ of dry sago starch (Table 8.1).

Based on a nutrition security perspective, the potential of sago starch in Maluku could be around $1593 \mathrm{kcal}$ per capita/day or $145 \%$ of total need of 1100 calorie per capita/day for the 1.8 million people living in the Malukus. Due to sago land conversion, up to $30 \%$ of the total area is now in rice fields, oil palms, resettlement villages, government infrastructures, and other agricultural crops; the actual productive 


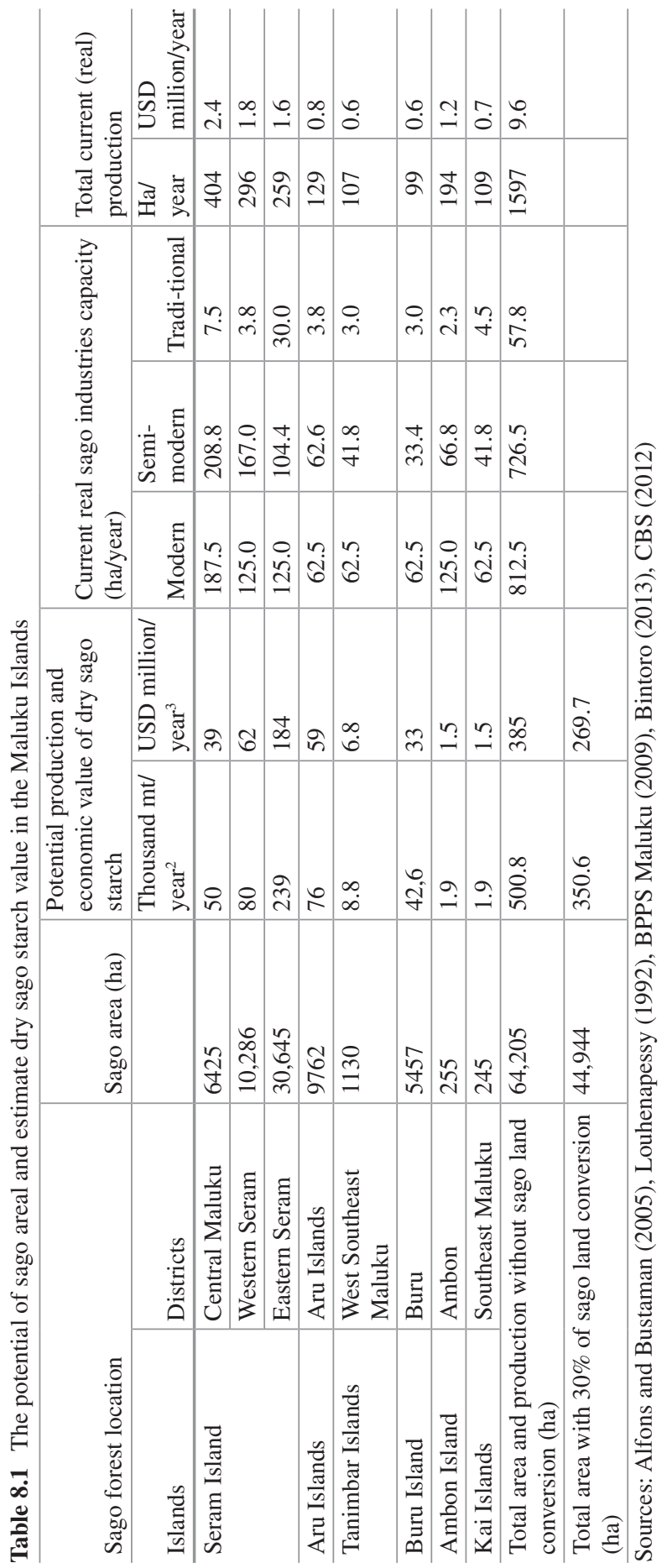


sago area is estimated to have decreased considerably to around 44,944 ha, potentially producing 350,559 mt/year with an economic value of around USD 269.7 million per year.

It is estimated that the actual sago forest exploitation is around 1597 ha or $4 \%$ of total sago forests. This implies that the remaining $96 \%$ of sago area is underutilized with a theoretical economic loss of around USD 260.1 million/year. To achieve maximum sustainable yield of the sago forests in the Malukus, sago farmers need to harvest a maximum of about 8989 ha/year to produce around 70,112 mt of dry sago starch. This means that there needs to be land protection, revitalization, zonation, and consolidation of the existing sago forest areas and the creation of infrastructural systems to increase sago value chain and to reduce transportation and the other operational costs within and between sago forests.

\subsubsection{Feasibility Small-Scale Sago Industries}

\subsubsection{Production Technology}

Previously, most sago studies in the Malukus were focused on upstream subsystems including soil types, wild stand management practices, total area, types of sago palms, and sago cultivation (Louhenapessy 1992; BPPS 2009). Very little research on sago industries was done in line with well-designed sago production and promotional development that involved cultural, environmental, and educational values (Papilaya 2009) within the downstream subsystems. Optimizing the use of sago palm can be accomplished through developing knowledge and harvest technology, sago processing, and product development to increase added value and competitiveness of local food products (Girsang and Papilaya 2009). Generally, existing sago palm harvesting and starch processing are divided into four steps: (1) determining the stage of the sago palm maturity for felling, (2) cutting the trunk and collecting the pith, (3) extracting sago starch, and (4) packaging and storage. Rumalatu (1992) identified three criteria as to local knowledge for the selection of high starch sago trees. First, maputi is the best time to harvest tuni sago (Metroxylon rumphii) which is indicated by yellow leaf stalks, smaller young leaves, and decline in thorn development. Tuni sago is one of the five sago types with local names in Maluku: ihur, duri rotan, makanaru, and molat. Second, maputi masa is indicated by the white and yellow color of leaf stalks and flowers beginning to develop; this is the best time to harvest ihur sago. Third, siri buah stage is signaled by fully developed flowers.

Traditional technology enables sago farmers to cut one sago tree every 2 weeks, using an ax without cutting into the smaller sago stems and then using nani (a traditional handmade technology tool that is made from small bamboo including iron ring at the top of the bamboo which is designed like L-shape to extract sago pith from the body of sago tree) and sahane (a traditional tool that is made from sago branch/frond to extract sago starch from pith and a fine nylon net to filter sago starch that flows to the sago starch storage). This technology was in use by farmers 
before the 1980s and then was replaced by semi-modern industry. Semi-modern technology uses chainsaws to fell sago palms and cut them into 1-m-long sections. A grater machine is employed to process the sago pith, and a receptacle called a goti, made from thick plastic material, collects the sago starch. This is a place for wet sago starch storage. Semi-modern technology was first adopted by sago farmers in the 1980s and increased considerably in the 1990s. Different from the previous technology, modern technology has a direct, automatic, and integrated process of extracting sago, with water pumped from a well to the sago extractors, and then the sago starch flows directly through a pipe into a large sago starch storage tank (goti) made from permanent materials.

The sago production capacity of traditional technology is estimated around $6 \mathrm{mt} /$ year or 30 sago trees/year, whereas semi-modern and modern technology can produce up to $45 \mathrm{mt}$ and $480 \mathrm{mt} / \mathrm{year}$, respectively, equivalent to cutting 167 and 2500 trees/year, respectively. In this case, the rapidity of cutting sago palms for semi-modern technology is almost 5.6 times faster than the conventional, while the speed of modern technology was around 15 times faster than that of semi-modern technology. The production capacity of semi-modern technology is 7.5 times higher than traditional, while modern technology is almost 11 times greater than semimodern technology production capacity. Even though traditional technology is known as time-consuming, people perceive that the quality of sago starch from traditional technology is finer, more delicious and batali (purer in sago starch), and most suited to local taste and culture. Probably this suggests that different technology prototypes will produce different qualities of sago starch.

Table 8.2 compares average investment cost data based on the technology level. For modern technology, the cost is 17 times higher than that of semi-modern technology, whereas the investment costs of the sago noodle industry is almost 46 times higher than that of semi-modern sago (lempeng sago) technology. Due to the high investment costs, the number of modern sago-processing industries is less than ten, with capital sourced from personal and family savings, financial institutions, and government aid.

\subsubsection{Investment and Production Costs}

Of the total, the operational costs for semi-modern technology are $40 \%$, mainly for labor for cutting trees, extracting, packaging, and transportation. The labor wage is the same as the minimum provincial wage, around USD 300/month. The next cost is $25 \%$ for rental of chainsaws and grater machines, $20 \%$ for raw material, and the remaining $15 \%$ for fuel/gasoline. Because sago processing companies have no sago palm forest, they have to buy every single sago tree from its owner. The prices of sago palms vary from IDR 100,000 (USD 7.6) up to IDR 150,000 (USD 11.5) per tree. To some extent, sago palm owners prefer a share of the sago starch produced, a practice called maаnu, a shared harvesting systems. In this case, the owner of the sago palm will get one-third while the other two-thirds going to the sago starch processor. 


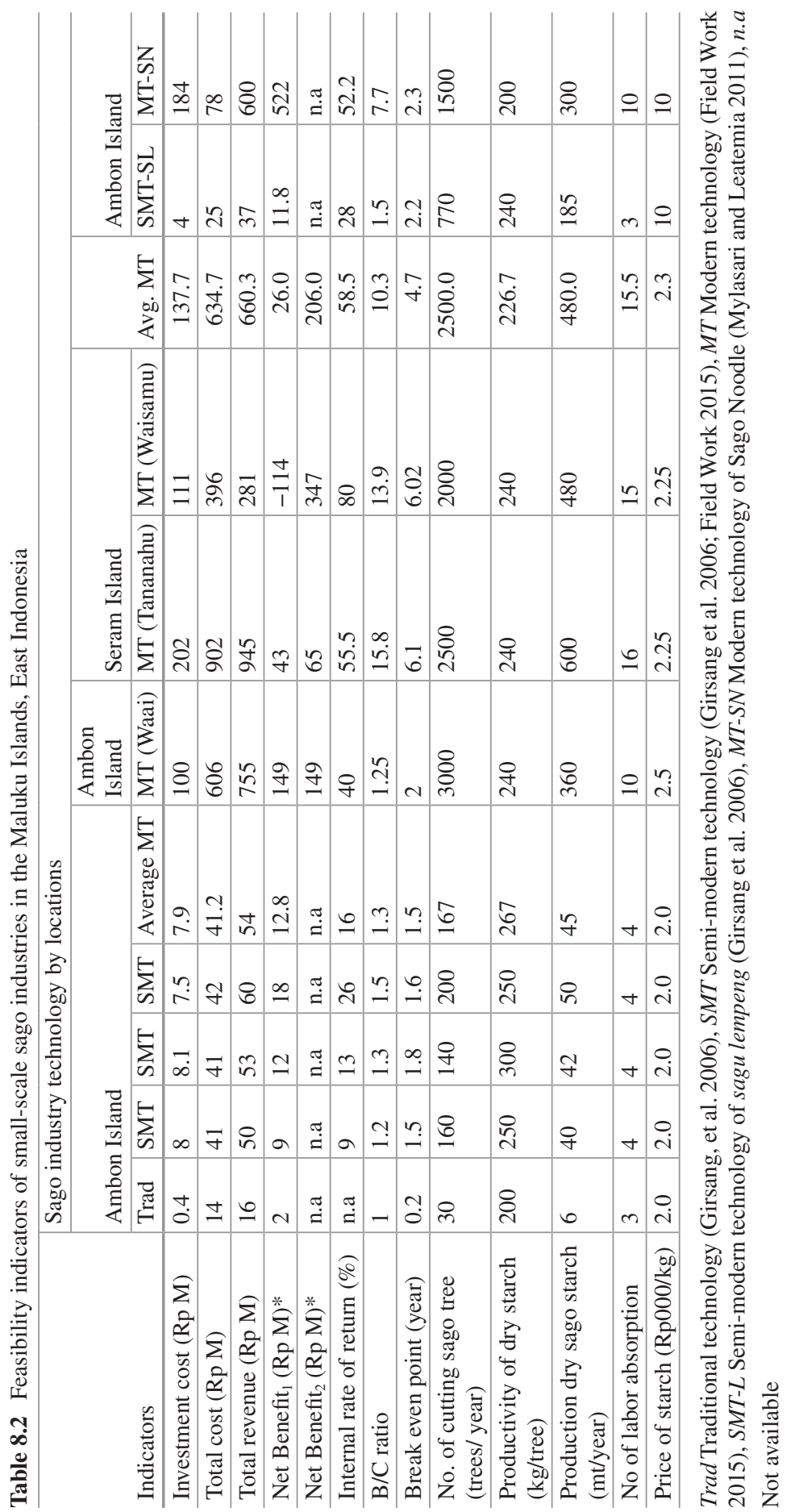




\subsubsection{Profitability of Small-Scale Sago Industries}

The main objective of sago industries is profitability. The annual net benefit of traditional and semi-modern technology is IDR 2 million and IDR 12.7 million, respectively, while the average net benefit of modern technology is IDR 26 and IDR 206 million in the first and second year of production, respectively. Traditional technology is subsistence oriented, for household consumption, whereas semi-modern and modern technologies are fully market oriented. Thus the benefit of the modern industry is almost eight times higher than that of semi-modern technology. In addition, the annual net benefit of sago lempeng (SL) and sago noodle (SN) industry is estimated at IDR 11.8 million and IDR 522 million, respectively. This means that the SN benefit is almost 44 times higher than semi-modern SL technology; however, the SN industry was unsustainable and failed due to compatibility and institutional constraints. In terms of compatibility, sago noodle industry failed to sustain because of ignored social preparation, human capital building capacity, and absenteeism of professional facilitators. In terms of institutional constraints, the sago noodle industry failed to sustain because sago farmer association, as the owner of the sago noodle industry, was unable to manage labor, private, and government intervention as well as to maintain and stabilize the price of sago starch.

Based on profitability indicators, all technology prototypes are feasible, particularly semi-modern and modern technologies. The highest total costs, revenue, and benefit of sago industries are found in the modern technology at Tananahu, followed by the modern sago industry in Waai and Waisamu villages. The amount of operational costs is determined by the distance and transportation cost to and from extraction site to sago forest, the price of raw material, and labor cost. To some extent, modern sago industries in Waisamu village operated at a loss in the first year (negative IDR 114 million) to pay for labor and high credit interest payment cost, but they achieved positive benefit in the second year (Table 8.2).

\subsubsection{Discussion}

The problem of food security in small islands is that the abundant local food resources like sago and the other local foods are abandoned by local people and replaced by imported rice (Girsang 2014). The area of rice fields in the Malukus is estimated at 22,470 ha (CBS 2014) with annual production around 73,028 $\mathrm{mt}$ or $45 \%$ of total annual rice demand of $161,213 \mathrm{mt}$ in 2015. As a result, the Malukus import $88,185 \mathrm{mt}$ of rice annually or $55 \%$ of total provincial rice consumption. Because the rice crop is vulnerable to pests and diseases as well as climate change impact, dependency on imported rice will create food insecurity over the long term in the islands. Thus sago forests need to be revitalized because they are environmentally friendly and suitable in small islands and sago starch is still the source of energy for $70 \%$ of people who live in remote rural areas on Seram Island, the largest of the Maluku Islands (Sasaoka and Loumonier 2011). 
Based on investment criteria, all types of sago industries were identified as financially feasible in the short term; however, these sago industries are challenged by financial, market, and institutional sustainability in the middle and longer term. Based on historical background, there are several reasons why sago industries failed to survive: (1) they are time-consuming and hard work; (2) they have high operational costs, especially labor, poor infrastructure and transportation, and high fuel and raw material costs (Louhenapessy 1992); (3) they have poor social preparation, ineffectiveness of farmer group institutions, and a low sago starch price (Mylasari and Leatemia 2011); and (4) there are uncertain sago land tenure status, failure to address sociocultural issues, and lack of the participation of local people.

Because of geographical landscape conditions, sago palm areas are spread over several regions, and each area is relatively small, growing naturally as sago forests on small islands. Therefore, it is inevitable that the rapidity of sago tree cutting by sago industries will exceed the natural regrowth of sago palm in an exploited area. As a consequence, the owner of a sago forest may decide to increase the price of sago trees. At this stage, the sago industry is vulnerable and hard to sustain because sago producers need more investment for equipment and operational cost to expand into the other sago forest land.

Therefore, to create a sustainable sago forest and sago industry, there needs to be a balance between sago supply and demand by creating sago clustering and rehabilitation zonation (Louhenapessy 2006; Girsang et al. 2010). Sago palm trees grow in clusters and each cluster consists of three to five trees with different age intervals of between 4 and 5 years. Each sago cluster is capable of self-regeneration; therefore, sago forests are sustainable because they do not need replanting and can be harvested regularly.

Due to poor infrastructure and accessibility to sago forests, existing sago industries need to be managed carefully to avoid an imbalance between the rate of cutting and the rate of regrowth. Other limiting factors are continuous supply of raw material, hilly topographical conditions, widely dispersed sago forest locations, and limited transport access within and between villages and islands. In addition, the land tenure status of sago forest needs to be made clear, otherwise sago land tenure and uncertain boundaries can be a source of social conflict. Basically, sago land tenure status can be categorized into three types, namely, (1) tanah negeri (village land), (2) tanah dati (family land), and (3) tanah pusaka (private land). This suggests that sago industrial development will need the certainty borders and status of sago forest land tenure to sustain sago production and to avoid social conflict.

\subsection{Conclusion}

The sago forest area in Maluku Province is estimated at 64,205 ha; however, the extent has probably been reduced to 44,944 ha because of sago land conversion into rice paddy, resettlement villages, offices, plantations, roads, and agriculture crops. It is concluded that existing traditional, semi-modern, and modern sago industries are financially feasible but vulnerably sustainable even though the whole sago 
exploitation rate in Malukus is estimated currently at only around 1597 ha/year or $3.6 \%$ of total sago forest area, and the remaining of $96.4 \%$ of sago forest area is unutilized with a theoretical annual economic loss around USD 260 million.

Traditional sago technology is being abandoned because it is time-consuming while semi-modern and modern sago industries are employed only in sago forest areas that have access to district or provincial capitals. This causes uneven exploitation of sago forests in the area and an unsustainable raw material supply because the rate of cutting will be faster than the rate of natural regrowth of sago trees. At the same time, sago industries are reluctant to operate in other inaccessible sago areas with poor infrastructure to avoid high operational costs, considering the low price of wet sago starch and limited demand for dry sago flour.

The other reasons for unsustainable sago industries are lack of financial capital and social preparation, failure to address cultural values, and lack of participation and facilitation of sago farmers and local people. As a result, most of sago forest areas are not utilized and are neglected. The central government probably prefers to promote replacement of sago forest areas with enlarged new rice fields to support the national rice production target; however, local governments should take affirmative action for food security and dignity based on sago and other local food resources, including revitalizing and promoting sustainable and feasible sago industries based on a sustainable landscape of sago forest areas on small islands.

Finally, sago forest is a natural resource endowment in the Malukus; therefore, the advancement of the sago forests and industries goes beyond food security. Sago forests need to be developed under a zero waste sago industry model that will produce healthy food, sugar, and biofuel (Ishizaki 1997; Bujang 2010) and create stable agroforestry systems (Stanton 1993) that are more resistant to climate change impacts. Moreover, the role of sago forests will bridge, bond, and link the forests, agriculture and fisheries, mangrove and coral reefs to support sustainable integrated community-based resource management landscapes in small islands. This goes beyond Provincial Government Regulations number 110/2011 that focus on sustainable sago forest exploitation and central government regulations in line with accelerating local food consumption diversification (Indonesia 2009). To achieve sustainable sago forests and industries as well as to protect the environment of small islands, the government needs to boost rural infrastructural development in each sago area, including incentives and law enforcement, human capital and capacity building, social and political stability, communications, tax holidays, and financial institutional support.

\section{References}

Alfons JB, Bustaman S (2005) Prospect and direction of sago development in Maluku. The Agricultural Research and Dissemination Agency, Ambon. [In Indonesian]

Amien I (2011) Coping with climate change. Paper presentation at: the future of global food security and safety: issues and justification. IPB International Convention Center, 27 October 2011, Bogor 
Bintoro MH (2011) Progress of sago research in Indonesia. In: Siregar ZI et al. (eds) The 10th international Sago Symposium "Sago for food security, bio-energy and industry: from research to market", IPB international convention center-The Indonesian Sago Palm Society, Bogor

Bintoro MH, Amarilis S, Kemala Dewi R, Ahyuni D (2013) The forgotten equator-green pearl sago. IPB Press, Bogor

BPPS (2009) Mapping and potential stockpile of Sago Palm in Tutuk Tolu-Eastern Seram, Western Seram, Saparua-Central Seram, and Namrole-Southern Buru islands. Research Report. Cooperation Project Research of Maluku Province Agricultural Agency Office and Maluku Sago Research and Development Board, Ambon. Maluku. (in Indonesian)

Bujang K (2010) Production and processing of sago: a food and fuel alternative. Paper presented at International seminar on sago and spices for food security, Swissbel Hotel, Ambon, 28-29 July, 2010

CBS (2012) Maluku in figures. Statistical Centre Board and Maluku Regional Development Planning Agency, Ambon, Maluku

CBS (2014) Central Board of Statistics, Maluku Province in figures. Cooperation-Provincial Statistic Center Agency and Regional Development Plan Board, Ambon. http://maluku.bps. go.id

Ellen R (2006) Local knowledge and management of sago palm (Metroxylon sagu Rottboell) diversity in South Central Seram, Maluku, Eastern Indonesia. J Ethnobiol 26(2):258-298

Field Work (2015) Notes on field observation of Sago industries in Western and Central Seram island, Ambon. Maluku (In Indonesian)

Flach M (1984, January 16-21) Agronomy of sago based on cropping system: a preliminary approach. In: Proceedings of the The FAO/BPPT expert consultation on the development of sago palm and palm product. Jakarta

Flach M (1997) Sago palm. Metroxylon sagu Rottb. Promoting the conservation and use of underutilized and neglected crops, Pub. No. 3. Institute of Plant Genetics and Crop Plant Research, International Plant Genetic Resources Institute, Rome

Girsang W (2006) Feasibility study of sago, bamboo and cajuput oil: start-up small scale business. Final Report for United Nations Industrial Development Organization (UNIDO), Maluku, Ambon

Girsang W (2014) Socio-economic factors that have influenced the decline of sago consumption in small islands: a case in rural Maluku, Indonesia. S Pac Stud 34(2):99-116

Girsang W, Papilaya EC (2009) Improvement of sago competitiveness for food security in Maluku. In: Lilis N (ed) Proceeding: investing in food quality, safety and nutrition. Southeast Asian Food Science and Technology (SEAFAST) Centre, Bogor Agricultural University, Bogor

Girsang W, Rumalatu FJ, Louhenapessy JE et al (2010) Sago in Maluku: policies, potential, processing and social economic. Paper presented at The International seminar on spices and sago for food security to support Sail Banda Programs, 28 July 2010, Swissbel Hotel, Ambon

Haryanto B, Pangloli P (1992) The potential and use of sago. Kanisius, Jakarta. [In Indonesian]

Ibrahim (1985) Introduction to the project evaluation. Gramedia, Jakarta. [In Indonesian]

Indonesia (2009) President of Republic of Indonesia Regulation No. 22 Year 2009 on the Acceleration of food consumption diversification based on local resources [In Indonesian]

Ishizaki A (1997) Concluding remarks for the 6th International Sago Symposium. Riau Indonesia. Sago Commun 8(2):22-24

Jong FS, Widjoyo A (2007) Sago: the big potential of agriculture in Indonesia. Sci Tech Food 2(1):59-65. (In Indonesian)

Louhenapessy JE (1992) Sago in Maluku: its potential, land condition and its problem. National Symposium of Sago, Faculty of Agriculture, University of Pattimura [In Indonesian]

Louhenapessy JE (2006) Potential and management of sago in Maluku Proceedings, sago workshop, revitalization of agriculture in Maluku, Ambon 29-31 May 2006. Faculty of Agriculture University of Pattimura Press, Ambon [In Indonesia]

Mylasari R, Leatemia E (2011) Feasibility study of sago noodle project in Tulehu village, Central Maluku. Unpublished research report. Research Institution University of Pattimura, Ambon [In Indonesian] 
National Food Security Board (2011) Reality and expectation of food diversification. Paper presented in International seminar on the future of global food security and safety: issues and justification. IPB Convention Centre, Bogor, Indonesia

Papilaya EC (2009) Sago for the country people education. IPB Press, Bogor. [In Indonesian]

Rumalatu FJ (1992) Sago in Maluku: past, present and future prospect. J Cakalele, vol 3. The University of Hawai'i at Manoa. pp 64-67

Sasaoka M, Laumonier Y (2011) The influence of 'sago-based vegeculture' on forest landscapes in central Seram, eastern Indonesia. Paper presentation at The 10th International Sago Symposium, 29-30 October 2011. IPB International Convention Center, Bogor

Stanton WR (1993) Perspectives on, and future prospects for, the sago palm. Sago Palm 1:2-7

Yamamoto Y (2011) Starch productivity of sago palm and related factors. In: Proceeding of the 10th international sago symposium Bogor, Indonesia, pp 10-15

Open Access This chapter is licensed under the terms of the Creative Commons Attribution 4.0 International License (http://creativecommons.org/licenses/by/4.0/), which permits use, sharing, adaptation, distribution and reproduction in any medium or format, as long as you give appropriate credit to the original author(s) and the source, provide a link to the Creative Commons license and indicate if changes were made.

The images or other third party material in this chapter are included in the chapter's Creative Commons license, unless indicated otherwise in a credit line to the material. If material is not included in the chapter's Creative Commons license and your intended use is not permitted by statutory regulation or exceeds the permitted use, you will need to obtain permission directly from the copyright holder.

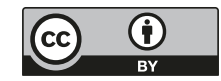




\title{
Chapter 9 \\ Addressing Food Insecurity in Papua New \\ Guinea Through Food Safety and Sago Cropping
}

\author{
Aisak G. Pue, Mary T. Fletcher, Barry Blaney, Andrew R. Greenhill, \\ Jeffery M. Warner, Atagazli Latifa, and Jack C. Ng
}

\begin{abstract}
Papua New Guinea (PNG) is known to have a large resource base of sago with over 1 million ha, as well as a high number of germplasm types of the Metroxylon species. The country's food security status is very low and is primarily dependent on subsistence fresh garden produce as practiced by $85 \%$ of the population who are rural dwellers. Postharvest losses can be as high as $40 \%$ with little to no postharvest technology nor processing of foods done. Sago provides well for food security and sustains life in rural communities during disasters such as droughts, floods, and cyclones. The dilemma of sago being an underutilized crop in PNG is exacerbated by the introduction of new food crops, cash crops, and limited accessibility to cash to purchase other foods. Over the last 50 years, sago consump-
\end{abstract}

The original version of this chapter was revised.

An erratum to this chapter can be found at https://doi.org/10.1007/978-981-10-5269-9_25

A.G. Pue $(\square)$

Papua New Guinea University of Natural Resources and Environment,

PMB Kokopo, Papua New Guinea

e-mail: apue@unre.ac.pg; aipue@ hotmail.com

M.T. Fletcher • B. Blaney

Queensland Alliance for Agriculture and Food Innovation, University of Queensland,

Coopers Plains, QLD, Australia

e-mail: mfletcher@uq.edu.au; bblaney@dpi.qld.gov.au

A.R. Greenhill

Monash University, Melbourne, VIC, Australia

e-mail: andrew.greenhill@federation.edu.au

J.M. Warner • A. Latifa

Department of Microbiology and Immunology, School Vet and Biomed Science, James Cook

University, Townsville, QLD, Australia

e-mail: jwarner@jcu.edu.au

J.C. Ng

National Research Centre for Environmental Toxicology, University of Queensland,

Coopers Plains, QLD, Australia

e-mail: jng@uq.edu.au

H. Ehara et al. (eds.), Sago Palm, https://doi.org/10.1007/978-981-10-5269-9_9 
tion has diminished as one of the major traditional food staples, from $16 \%$ to less than $10 \%$. Neglect of sago is further due to food safety concerns about traditionally processed sago, in particular, the risk from sago hemolytic disease (SHD). For over 30 years, SHD has been a food safety issue since it was first reported in 1973. Investigations on SHD highlight the serious need to improve on the hygiene and sanitation of the traditional postharvest processing and storage methods of sago starch in PNG. A set of hazard analysis and critical control point (HACCP) protocols has been developed for traditional processing of sago as a food safety measure to improve food safety for food security. While commercial cultivation is nonexistent, there is increased planting of the larger hapaxanthic, non-soboliferous sago species, Metroxylon salomonense Becc., in some nontraditional sago-consuming areas as a low-cost raw material source for roof thatching and other building materials. It is however a wasted opportunity for food security in these areas as the starch from the palm is not utilized. Current work in these areas promotes sago as a potential food source that can be harvested or processed into flour. This is to improve the food security status in areas of high population density, like island communities where land is scarce.

\subsection{Background}

The island of New Guinea, shared between Papua New Guinea (PNG) and Indonesia, has the largest combined sago resources, with well over 2 million ha or $88 \%$ of global sago stocks (Schuiling 1995). The island is also regarded as the center of sago diversity. Genetic studies by Kjari et al. (2004) reveal that only one species of Metroxylon sagu exists but with many cultivars (Boonsermsuk et al. 1999; Kjari et al. 2004).

The inhabitants of New Guinea island, as in other sago-producing countries of the Western Pacific and Southeast Asia (McClatchey et al. 2004, 2006), rely chiefly on sago for their livelihood needs. Sago leaves are used for roof thatching, the leaf midribs are bundled into a broom, and the bark of the trunk is used as a building material for floors, walls, or fences. The seeds of the flowering palm are used as ornaments or other decorations, while the roots are used as a source of medicine (Flach 1980; Gemo 1999).

Unlike other foods, sago has a very high food security level both as a live commodity and as processed starch that can be conveniently used. Sago starch has many uses as food and as material feedstock for industrial applications (Abd-Aziz 2002). In PNG sago starch is mostly eaten in the rural coastal regions where it is cultivated or exists in the wild. Sago is also indigenous to several inland lowland communities of the highlands region of PNG. In the Karimui District of the Simbu Province, the Purari River, and Fly River tributaries, such as lakes Murray, Kutubu, and Kopiago in the Southern Highlands Province, sago is a staple food (Sopade 1999). Food security of sago in PNG is, however, hampered by food safety issues, in particular the incidence of the rare sago hemolytic disease (SHD) reported in three provinces in the past, as shown by blue stars in the map (Fig. 9.1). 


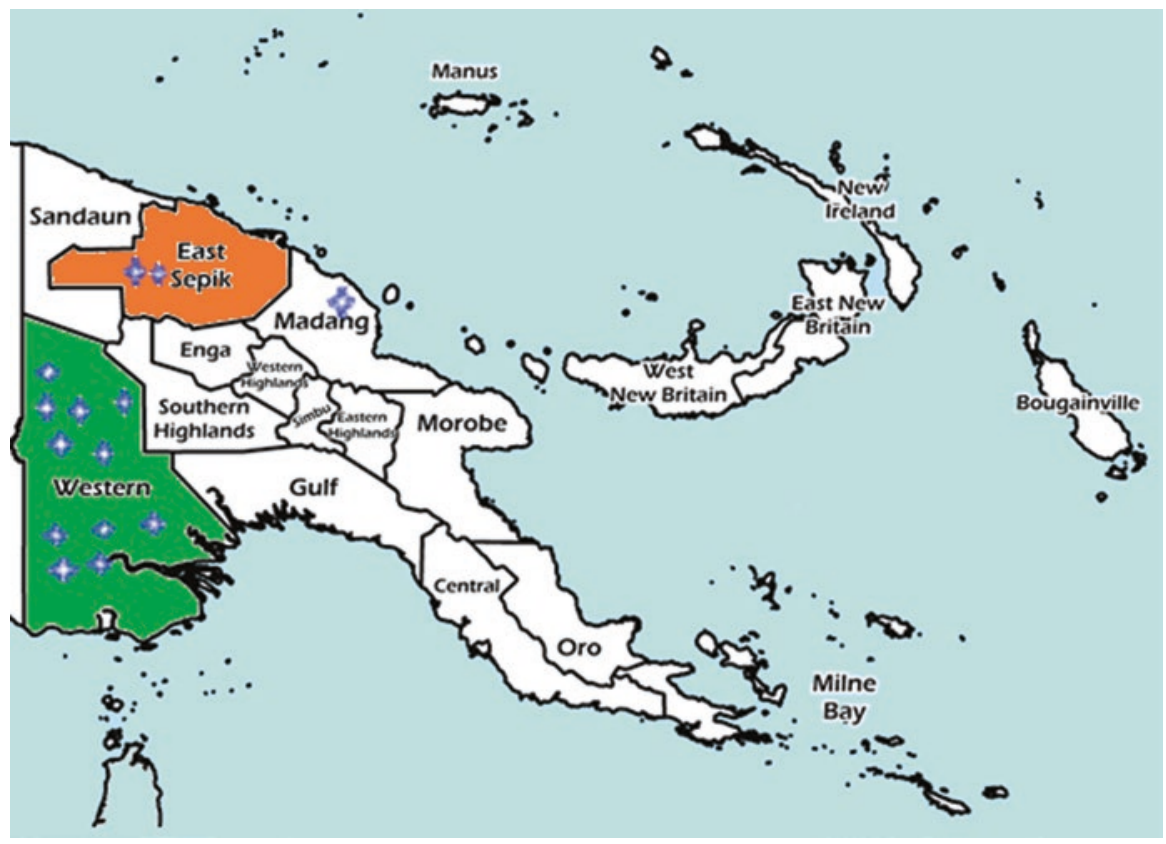

Fig. 9.1 Map of Papua New Guinea provinces, with East Sepik (orange) and Western Province (green) highlighted. Blue stars represent sago hemolytic disease outbreaks over the past 30 years. There were 2 in East Sepik, 1 in Madang, and 12 in the Western Province

\subsection{Significance of Sago to Papua New Guinea}

The PNG government recognizes sago as a major staple (Table 9.1), for almost 30\% of its seven million people (Bourke 2001). Sago making is the mainstay of low and wetland communities of PNG and plays a significant cultural role as a commodity of trade or being used in barter exchanges for other foods or goods, as in bride price ceremonies and for many other special occasions (Temu and Saweri 2001).

Virtually all sago starch in PNG is produced on a subsistence level in the villages with only the surplus being sold. The need for cash and encouragement by the authorities for economic development has caused villagers to produce more sago for marketing. Better transportation in the form of motorized canoes has greatly facilitated marketing of sago and improved the welfare of sago-producing communities, some of which are the poorest in PNG (Morauta 1982; Temu 2006).

There is no record of sago being exported from PNG into markets such as the 60 million mt market of Southeast Asia (Wang et al. 1996). There are small exports to the PNG communities overseas (e.g., Australia and New Zealand), but this is negligible compared to the total annual production.

Many rural communities are food insecure and rely solely on sago during periods of disasters like cyclones, floods, or droughts. The starch can be eaten for extended 
Table 9.1 Consumption patterns of Sago in Papua New Guinea

\begin{tabular}{|c|c|c|c|c|c|}
\hline \multirow[b]{3}{*}{ Province } & $\begin{array}{l}\text { Sago as a } \\
\text { dominant } \\
\text { staple }\end{array}$ & $\begin{array}{l}\text { Sago as a } \\
\text { subdominant } \\
\text { staple }\end{array}$ & \multirow[b]{3}{*}{$\begin{array}{l}\text { Total } \\
\text { population }\end{array}$} & \multirow{3}{*}{$\begin{array}{l}\text { Population } \\
\text { depending on } \\
\text { sago as a } \\
\text { dominant } \\
\text { staple }(\%)\end{array}$} & \multirow{3}{*}{$\begin{array}{l}\text { Population } \\
\text { depending on } \\
\text { sago as dominan } \\
\text { or subdominant } \\
\text { staple }(\%)\end{array}$} \\
\hline & $\begin{array}{l}\text { Population } \\
\text { depending on } \\
\text { sago as a } \\
\text { dominant } \\
\text { staple }(\%)\end{array}$ & $\begin{array}{l}\text { Population } \\
\text { depending on } \\
\text { sago as dominant } \\
\text { or subdominant } \\
\text { staple }(\%)\end{array}$ & & & \\
\hline & $\begin{array}{l}\text { aPopulation } \\
\text { Est. }\end{array}$ & bPopulation Est. & & & \\
\hline Western & 101,853 & 8865 & 141,230 & 72.1 & 78.4 \\
\hline Gulf & 41,828 & - & 65,002 & 64.3 & 64.3 \\
\hline Central & - & - & 148,230 & 0.0 & 0.0 \\
\hline Milne Bay & - & 17,546 & 182,324 & 0.0 & 9.6 \\
\hline Oro & 3310 & - & 88,695 & 3.7 & 3.7 \\
\hline $\begin{array}{l}\text { Southern } \\
\text { Highlands }\end{array}$ & 8355 & 8844 & 415,877 & 2.0 & 4.1 \\
\hline Enga & - & - & 340,480 & 0.0 & 0.0 \\
\hline $\begin{array}{l}\text { Western } \\
\text { Highlands }\end{array}$ & - & - & 364,335 & 0.0 & 0.0 \\
\hline Simbu & 626 & - & 180,575 & 0.3 & 0.3 \\
\hline $\begin{array}{l}\text { Eastern } \\
\text { Highlands }\end{array}$ & - & - & 282,523 & 0.0 & 0.0 \\
\hline Morobe & 2149 & - & 330,550 & 0.7 & 0.7 \\
\hline Madang & 23,418 & 1456 & 250,425 & 9.4 & 10.0 \\
\hline East Sepik & 106,291 & 79,359 & 255,752 & 41.6 & 72.6 \\
\hline Sandaun & 124,312 & 8065 & 157,189 & 79.1 & 84.2 \\
\hline Manus & 22,294 & - & 31,865 & 70.0 & 70.0 \\
\hline $\begin{array}{l}\text { New } \\
\text { Ireland }\end{array}$ & 16,938 & 1604 & 96,361 & 17.6 & 19.3 \\
\hline $\begin{array}{l}\text { East New } \\
\text { Britain }\end{array}$ & - & - & 195,689 & 0.0 & 0.0 \\
\hline $\begin{array}{l}\text { West New } \\
\text { Britain }\end{array}$ & - & - & 160,176 & 0.0 & 0.0 \\
\hline $\begin{array}{l}\text { North } \\
\text { Solomon }\end{array}$ & - & - & 144,978 & 0.0 & 0.0 \\
\hline Total & 451,374 & 125,739 & $3,832,256$ & 11.8 & 15.1 \\
\hline
\end{tabular}

Data Source:

$N B$ : Three additional provinces, namely, the National Capital District, Jiwaka, and Hela have been formed since this information was first published

${ }^{a}$ Bourke and Harwood 2009, Agricultural Systems of Papua New Guinea

${ }^{b}$ National Statistics Office, Port Moresby 
periods over many months so long as it is kept stored in a good condition (Bosro et al. 1999).

\subsubsection{Sago Consumption Patterns in Papua New Guinea}

Sago starch is a very convenient food staple available in the local communities in PNG, prepared and consumed daily at all meals and as a snack in various ways just like rice is in Asian countries. Sago consumption in PNG as shown in Table 9.1 varies by province, but the major consuming provinces are Western Province, East Sepik, Sandaun, and Manus, with $70-80 \%$ of the population consuming sago (Bourke and Harwood 2009). Some provinces are indicated as non-sago consuming, but sago is sold in supermarkets and other distribution channels indicating that consumption of sago exists.

Consumption of sago in PNG is very low and in reality has diminished over the past 50 years from $16 \%$ to $10 \%$ of the total annual food consumption. Declining sago consumption may also be overshadowed by alternative convenient staples like rice that is becoming a major food staple in urban centers (Bourke and Harwood 2009).

The total annual production of sago in PNG is estimated to be around 100,000 mt (Gibson 2001); however, considering the total hectarage of sago to be 1 million, there is scope for a greater amount of sago to be produced. If on average there are 20 sago stands per ha giving a minimal yield of $50 \mathrm{~kg}$ per stand, then a reasonable estimate of $1 \mathrm{mt}$ per ha is possible. This should amount to an estimate of 1 million $\mathrm{mt}$ of sago starch reserve in PNG. The potential for $50 \%$ of this, or $500,000 \mathrm{mt}$, as a conservative estimate to be harvested annually in reality would be a significant contribution to national food security as well as to the global market.

\subsubsection{Sago Cropping Provides Food Security in Papua New Guinea}

Sago is produced and consumed throughout the year and is the most secure food source for communities in rural PNG. Sago starch is obtained mainly from the palm family Arecaceae of only one species Metroxylon sagu, with two main cultivars identified as the spiny and the non-spiny. Sago palms are perennial and nonseasonal with a long maturity stage of 2 years as indicated by the inflorescence protruding from its head after which the palm dies. At this fell ripen stage, sago starch yield is at its maximum (Schuiling 1995).

Although there is some cultivation of selected sago stands by villagers, commercial farming is unheard of in PNG (Power 1999). During food shortages, mature or even immature sago palms are readily harvested and processed. New sago is pro- 
duced when old stocks reach low levels or when stands mature and have to be harvested. Sago making is often a communal activity with the extended family helping and sharing harvested sago using a payback system. This enables sago logs to be shared among a number of households, conserving other sago stands to be processed at a later time when needed (Wamala 1999).

Sago generates much interest in the world as an adaptable climate changeresilient crop, mitigating global warming through carbon $\left(\mathrm{CO}_{2}\right)$ sequestration while surviving in hostile swampy non-arable environments unsuitable for agriculture (Schuiling 1995). Sago palm forest carbon dynamics estimates a carbon sink capacity of $8.3 \mathrm{mt}$ per ha annually as convertible carbohydrate (Inubushi et al. 1998). The East Sepik and Gulf regions of PNG are home to 1 million ha of sago palms, close to $41 \%$ of the global total, behind Indonesia which has $47 \%$ of the total global palms (Flach 1980; Schuiling 1995).

\subsubsection{Potential for Sago Addressing Food Insecurity in Papua New Guinea}

It is imperative that PNG revisits its policy on sago as a potential indigenous food source. PNG's agricultural production growth rate of $1 \%$ lags behind a high population growth rate of $3 \%$ resulting in a deficiency in food supply that is being serviced through importing rice and cereal (Bourke et al. 2001; Bourke and Harwood 2009).

The starch density per hectare compared to other starchy crops is very high and dependent on the cultivar and size of logs but also on the processing method, such as degree of milling and extraction efficiency (Sopade 1999). The amount of starch produced per palm per ha can vary between 3.5 to as high as $6 \mathrm{mt}$ per ha or $65-100 \mathrm{~kg}$ per palm. It has been considered as a potential food source for an increasing world population (Haska 1995). It, however, takes 7-10 years for sago palms to mature before they can be harvested. Sago is propagated mostly by suckers rather than by seed. Sizable clusters per grove may allow for palms to mature at regular intervals of around 42 palms per ha per annum (Tie and Lim 1991).

Palms from germinated seeds normally take longer to mature, 10 years, and are less suitable as a regular food crop. The larger hapaxanthic, non-soboliferous sago species Metroxylon salomonense Becc., or dry land sago, is mostly planted for use as a source of low-cost roof thatching and building material (Paijmans 1980). However, efforts are being made to make use of this wasted opportunity to process the pith into starch. Current work in these areas promotes the palm as an alternate food crop contributing toward food security in high population density areas, where land is scarce as it is in island communities. 


\subsection{Traditional Processing of Sago Starch in Papua New Guinea}

Sago processing in villages by traditional methods is shown in Fig. 9.2 and is similar throughout the country, as it has been for generations. Traditional methods of sago production and storage in PNG have been reviewed elsewhere by Greenhill (2006). Extraction yields of traditionally processed sago are still very poor due to their crudeness (Sopade 1999).

Sago processing can take more than 1 day to complete depending on workload, number of people involved, and location in relation to a water source and the village. The main stages of traditional sago making are shown below. Figure 9.2a-c shows milling of the pith and then washing the milled pith into a trough fixed at a sloping angle to the ground, as shown in Fig. 9.2d. The starchy liquid runs through filters at the top end of the trough into a collecting vat. The suspension is allowed to settle out, and the starch is collected in the vat for a few hours before the clear water is decanted off (Fig. 9.2e). The wet sago starch cake (Fig. 9.2f) is then removed and taken in baskets, bags, or other containers to the village to be stored by various methods, such as by wrapping with leaves and storing in pots, in plastic bags, or under water in containers.

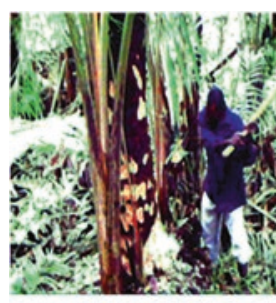

a. Harvesting of selected mature palm

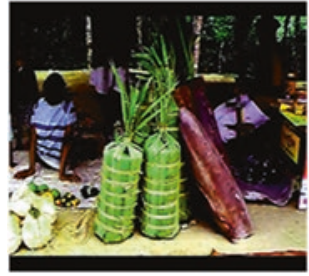

f. Package, storage and end-use

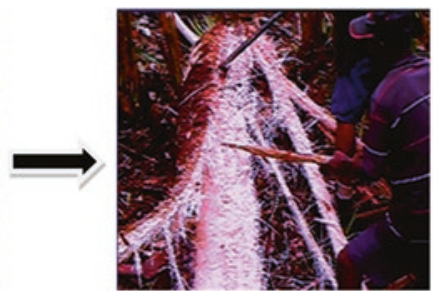

b. Cleaning trunk and debarking of trunk

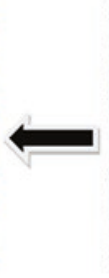$$
\text { e. }
$$

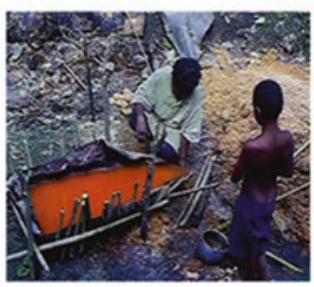

e. Decanting of water and collecting sago starch

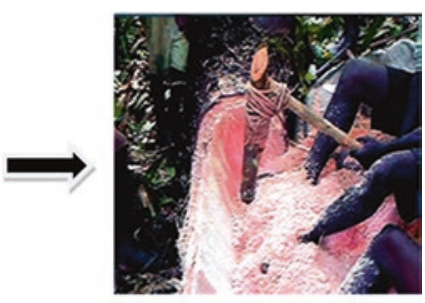

c. Pounding of fibrous pith

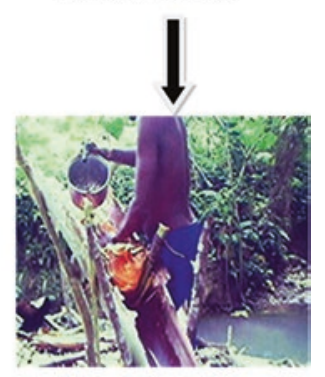

d. Extraction of milled pith

Fig. 9.2 Major stages of traditional processing of sago practiced in Papua New Guinea. (a) harvesting of selected mature palm, (b) cleaning trunk and debarking of trunk, (c) pounding of fibrous pith, (d) extraction of milled pith, (e) decanting of water and collecting sago starch, (f) package, storage and end-use 


\subsubsection{Traditional Methods of Storing Sago}

Sago starch storage practices vary with communities from dry storage of wrapped or covered sago to wet storage with sago suspended in water held in carved wooden canoes, containers, or wrapped and suspended in water holes for extended periods (Greenhill 2006; Pue 2013).

\subsubsection{Dry Storage of Sago}

Sago can be stored for long periods if properly dried, as in some island communities in PNG such as in Manus and New Ireland provinces, or packaged in moistureproof containers as is done for the export market in Malaysia and other Asian countries (Pue 2013).

In the Western Province of PNG, sago is wrapped and placed into large woven rattan cane baskets for storage over extended periods. The moist improperly dried sago stored this way has been found to support the growth and proliferation of fungi (Greenhill et al. 2007a). In a similar practice, fresh sago is usually wrapped in sago, banana, or other leaves and stored for extended periods in the Maprik area of East Sepik Province (Greenhill 2006). There are variations to dry storage, such as the burning of freshly wrapped sago to produce a skin around the sago that is peeled off before the dry sago is properly wrapped and stored.

\subsubsection{Wet Storage of Sago}

The Sepik River people of East Sepik Province, however, do not store sago in a dry form, the way the Maprik and Western Province people do. Sago starch is submerged in water in wooden dugout canoes or containers. The water in the containers is changed regularly to remove the stench and keep the sago fresh. No cases of SHD have been reported in this major sago-producing area, and the water-storage method has been recommended as a safe way to store sago, according to Greenhill (2006), due to its food safety, keeping quality of sago (Greenhill 2006; Pue 2013).

\subsection{Food Safety of Sago in Papua New Guinea}

A food staple can be a vehicle for diseases, in particular, if it is a major staple eaten daily like sago. Its exposure during processing to various sources of contaminants is widely expected. As is typical of subsistence communities which have a less diverse food staple base, accessing other foods during food shortages is a major problem. As a consequence, old sago is sometimes eaten in such dire situations (Bosro et al. 1999; Greenhill 2006). 
The commercialization of sago for domestic consumption or export is impeded by poor food safety quality and health standards (Power 1999). Reduced consumer confidence in food safety means diminished economic returns to producers, with potential cascading effects on the usability of sago as food. Because sago is mostly produced for subsistence purposes, it is not subjected to monitoring under the PNG health and sanitation regulations like other processed foods. The risk to the consuming population from sago exposed to food- and waterborne diseases is too high to ignore and is a major concern to the PNG government. A set of hazard analysis and critical control point (HACCP) protocols, outlined in Fig. 9.4, have been developed from recent sago investigations (Greenhill 2006; Pue 2013).

\subsubsection{Nutrition, Health, and Welfare Status of Sago Communities}

Sago is regarded a poor man's food, lacking in most nutrients and having a low caloric value of $3750 \mathrm{kcal} / \mathrm{kg}$, as it is entirely starch. A diet composed of sago and other foods is always recommended to complement nutrient deficiencies and achieve high caloric values. This is not always possible for most of these communities which depend on wetlands that for long periods are under water (Mueller et al. 2001). Most of these communities are impoverished with little or no alternative food sources and are economically disadvantaged (Mueller et al. 2001). This restricts the diet solely to sago as a daily food source for prolonged periods of days to weeks, with little or no access to mixed diets of game, fish, or other bush foods. The poor nutritional status of these communities may be a prevalent factor contributing to poor general health and vulnerability to diseases (Gibson 2001; Muller et al. 2002).

\subsubsection{Public Health Concerns on Traditional Production and Storage of Sago}

Sago stored for longer than 4 weeks in porous containers, such as those woven from rattan, palm, or other leaves and bark, were mostly found to contain molds. Common filamentous fungi normally associated with mycotoxin production were present in more than $50 \%$ of sago samples analyzed in an investigation by Greenhill et al. (2008).

Foodborne illnesses may be unavoidable for foods produced in an environment that is host to contaminants and their agents. The safety of sago is compromised by the quality imparted by the poor hygienic practices and storage conditions employed. The socioeconomic impact of SHD outbreaks is unknown, but the burden in cost to the public health service is probably less notable than more common diseases in PNG like malaria, HIV-AIDS, and TB, among others (Pue 2013). 


\subsubsection{The Prevalence of Fungi in Sago and Its Implication on Food Safety}

Fungi have long been suspected of having some role in SHD with the etiological agent being a contaminant introduced as metabolic products of fungi onto sago (Taufa 1974; Donovan et al. 1977; Stace et al. n.d.). Sago starch in the pith is known to be sterile but as soon as it is exposed, during processing, becomes contaminated with microorganisms from unsanitary milling implements (Greenhill et al. 2007b, 2010). Investigations by Greenhill (2006) and Pue (2013) have identified two potential contamination points as (i) preharvest infection of the palm (Fig. 9.3a) and (ii) postharvest infection (Fig. 9.3b) during processing, through handling and from utensils such as the palm leaf sheeting on which the sago pith is placed.

\section{Preharvest Infection}

It has been observed that pathologically-infected palms (Fig. 9.3a) can be a source of fungal contamination. Despite removing the large portions of the rotten trunk, infection was seen to have spread throughout the whole palm as evidenced by black spots of fungi in the pith (Pue 2013). Sago produced from infected palms are bound to contain fungi let alone microorganisms that would lead to food spoilage if not food poisoning.

Sometimes there can be delays in the sago pith pounding and washing steps where a trunk is left unattended and exposed over many days. In some of the local communities visited, delayed processing of sago existed so as to extend the food supply. Food security took precedence over food safety through intermittent processing of felled logs done over a number of days (even weeks) by which time some logs would already have fungal growth (Pue 2013). In such cases the visible appear-
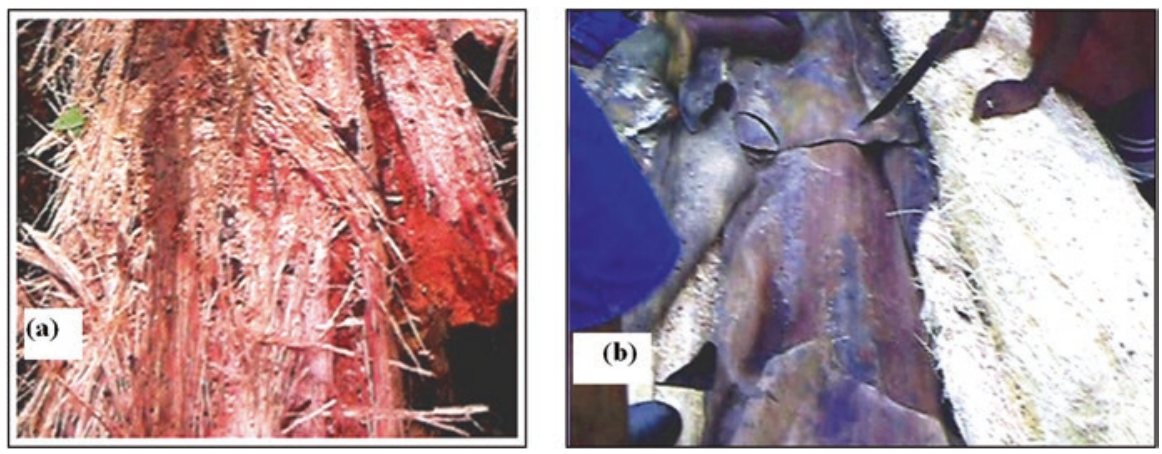

Fig. 9.3 Evidence of preharvest infection of palm and sago making utensils. (a) Reddish rotten base of over matured sago palm, (b) blue moldy spadix sheets showing fungal growth ready to be used to place the milled sago 
ance of the sago pith or milled sago showed inherent biochemical changes from exposure and microbial growth.

\section{Postharvest Infection}

The milled pith of the harvested palm is exposed to contamination from human handling and unsanitized equipment like implements left unwashed from the last sago making, apart from general poor hygiene practices. For example, in Fig. 9.3b, the old palm spadix being placed for the milled pith to be pounded on has bluish mold growth. This spadix may have been used in previous sago making activities (Pue 2013).

Water from natural streams and rivers used in sago processing is also a major contamination source, if it is from an environment that is heavily used by humans, animals, and other users (Greenhill et al. 2010). High levels of microbial contamination, in particular, E.coli, were found in surveys in the waters and sago from around Lae and different parts of PNG (Omoloso and Bomaigi 1996). The risks from waterborne diseases are evident by fecal contamination, and generally high microbial loads in traditionally processed sago are a public health concern for most communities in PNG (Omoloso 1999; Greenhill et al. 2007b).

\subsubsection{Sago Hemolytic Disease in Papua New Guinea}

There are no known reports of SHD occurring in other Southeast Asian-Pacific countries, where sago starch is also produced and consumed. SHD is the acute intravascular hemolysis of red blood cells arising from the consumption of moldy sago. The symptoms of SHD are usually manifested 12-20 h after a meal and commonly include a rapid onset of fever with vomiting, severe diarrhea, jaundice, reddish brown urine, lethargy, and mental confusion. It has been estimated that 2 out of every 10,000 people are affected annually by SHD in PNG. Outbreaks of SHD in PNG are sporadic but are sometimes fatal if severe and untreated, with mortality rates of reported outbreaks estimated as high as 25\% (Greenhill 2006) and a health concern.

\subsubsection{Reported Outbreaks of Sago Hemolytic Disease in Papua New Guinea}

Information on SHD outbreaks in PNG is scarce and not readily available. SHD episodes as marked on the map in Fig. 9.1 show three provinces: East Sepik reporting 2, Madang 1, and the Western Province with 12, the most cases including recent outbreaks. These reports are from case notifications at medical centers over the past 30 years (Greenhill 2006). 
The two initial outbreaks reported at the Maprik hospital, East Sepik Province, in 1973 and 1974, also drew attention to previous outbreaks locally known to medical workers but not documented, suggesting that SHD was underreported (Taufa 1974). There is credible information from local sago-producing communities that sago over 5 weeks old would be unfit for consumption; however, it is eaten during times of food shortage (Donovan et al. 1977; Stace et al. n.d.).

\section{Hemolytic Fungi Isolated from Sago}

Research studies into SHD in the past have all suspected fungi as the causative agent. In 1977, an investigation by Donovan et al. (1977) on two early episodes in the Western Province found various species of bacteria but strongly implicated fungi. In the study by Greenhill (2006), 21 fungal strains isolated from sago and cultivated as pure cultures on wheat tested positive for common mycotoxins. Considerable amounts of citrinin were produced by 14 of the isolates and small amounts of sterigmatocystin (Greenhill et al. 2008). Seven fungal isolates from four genera Penicillium, Aspergillus, Trichoderma, and Fusarium including one from an implicated sago showed varying degrees of hemolytic activity on human erythrocytes as shown in Table 9.2.

\subsection{The Way Forward for a Safer Sago Product in Papua New Guinea}

It is of major economic concern that sago contaminated with SHD reduces the quantity of available low-cost food as well as negatively impacting demand for sago. Sago is now listed under the PNG National Agriculture Quarantine Inspection

Table 9.2 Hemolytic activity of fungi isolated from sago

\begin{tabular}{l|l|l}
\hline Organism & Hemolytic activity (crude extract) & Comments \\
\hline Yeast & & 8 isolates 6 unidentified \\
\hline Geotrichum candidum link & $>50 \%$ over $24 \mathrm{~h}$ & Weak hemolysis \\
\hline Candida tropicalis & $>50 \%$ over $24 \mathrm{~h}$ & Weak hemolysis \\
\hline Fungi & & 7 isolates \\
\hline Aspergillus flavipes & Hemolytic & \\
\hline Fusarium semitectum & $>40 \%$ in $2 \mathrm{~h}$ & $2-100 \%$ hemolysis in $6 \mathrm{~h}$ \\
\hline Penicillium citrinum $(3$ isolates) & Highly hemolytic & \\
\hline Penicillium brevicompactum & $40 \%$ after $8 \mathrm{~h}$ & \\
\hline Trichoderma virens & $>80$ in $30 \mathrm{~min}$ & Control \\
\hline Trichoderma reeisei & $>80$ in $2 \mathrm{~h}$ &
\end{tabular}

Source: Greenhill et al. (2009)

Except for few known hemolytic toxins of fungi like that of Aspergillus fumigatus (Kamaguchi et al. 1979; Yokota et al. 1984), mycotoxins are not known to be hemolytic as confirmed by tests (Greenhill 2006) 


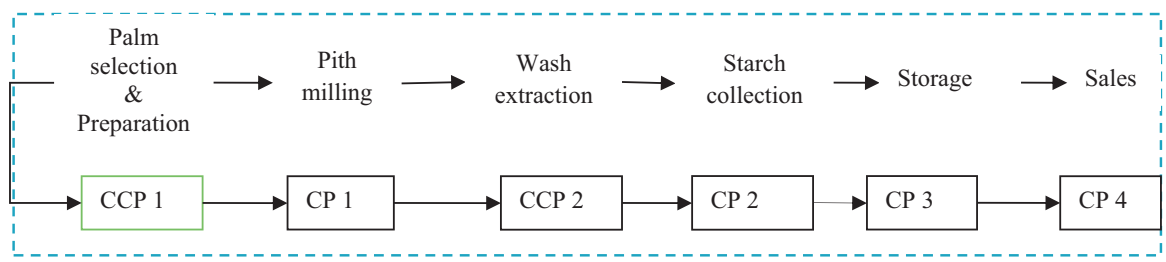

Fig. 9.4 HACCP protocols for safe sago making where $\mathrm{CCP}$ is a critical control point and $\mathrm{CP}$ is a control point

Authority www.NAQIA.gov.pg as requiring testing for food safety. The application of good manufacturing practices (GMP) guided by HACCP protocols (Fig. 9.4) achieved through research findings will pave the way for safer sago products of economic importance becoming available.

Two critical control points identified for careful monitoring in traditional sago making processes are the preharvest stage $\mathrm{CCP} 1$, when selecting the palm, and the postharvest stage $\mathrm{CCP} 2$. It is further recommended that the milling of the pith takes place in the shortest time possible to prevent microbial growth. The use of clean implements and clean water to extract the sago is highly important in producing a safe food.

In conclusion, sago is an underutilized indigenous crop that is well adapted to PNG conditions, having great potential in addressing the food insecurity status of the country. Food security through sago in PNG would be pursued on two fronts as discussed in this chapter through:

1. Commercial cropping of suitably selected cultivars

2. Regulated processing guided by good manufacturing practices addressing food safety issues using the recommended HACCP procedures

\section{References}

Abd-Aziz S (2002) Sago starch and its utilisation. J Biosci Bioeng 94:526-529

Boonsermsuk S, Jong F, Anai T et al (1999) Classification of sago palm (Metroxylon sagu Rottb.) cultivars by randomly amplified polymorphic DNA analyses. SABRAO J Breed Genet $31: 109-117$

Bosro J, Sau M, Kasindu P (1999) Sago and food security: community concerns, questions and suggestions. In: Sopade P (ed) Sago starch and food security in PNG: first national sago conference. Unitech Press, Lae, pp 70-75

Bourke RM, Harwood T (eds) (2009) Food and agriculture in Papua New Guinea. ANU, Canberra

Bourke RM, Allen MG, Salisbury JG (2001) An overview of food security. In: Bourke RM, Allen MG, Salisbury JG (eds) Food security for Papua New Guinea. Proceedings of the Papua New Guinea food and nutrition 2000 conference, PNG University of Technology, Lae, PNG, 26-30 June 2000. Australian Centre for International Agricultural Research (ACIAR), Canberra, pp 5-14

Donovan KO, Shaw DE, Amato D (1977) Sago hemolysis - clinical features and microbiological studies. Papua New Guinea Med J 20:167-174 
Flach M (1980) Sago palms from equatorial swamps; a competitive source of tropical starch. In: Stanton WR, Flach M (eds) Sago: the equatorial swamp as a natural resource, proceedings of the second international sago symposium Kuala Lumpur. Martinus Nijhoff Publishers, The Hague, pp 110-127

Gemo O (1999) Sago for thought. In: Sopade PA (ed) First national sago conference- sago starch and food security in Papua New Guinea. Unitech Press, Lae, pp 121-125

Gibson J (2001) The nutritional status of PNG's population. In: Bourke RM, Allen MG, Salisbury JG (eds) Food security for Papua New Guinea, Food security for Papua New Guinea. Proceedings of the Papua New Guinea food and nutrition 2000 conference, PNG University of Technology, Lae, PNG, 26-30 June 2000. Australian Centre for International Agricultural Research (ACIAR), Canberra, pp 407-413

Greenhill A (2006) Food safety and security of sago starch in Papua New Guinea. PhD, James Cook University

Greenhill AR, Shipton WA, Blaney BJ, Warner JM (2007a) Fungal colonization of sago starch in Papua New Guinea. Int J Food Microbiol 119:284-290

Greenhill AR, Shipton WA, Omoloso AD et al (2007b) Bacterial contamination of sago starch in Papua New Guinea. J Food Prot 70:2868-2872

Greenhill AR, Blaney BJ, Shipton WA et al (2008) Mycotoxins and toxigenic fungi in sago starch from Papua New Guinea. Lett Appl Microb 47:342-347

Greenhill AR, Shipton WA, Blaney BJ et al (2010) Spontaneous fermentation of traditional sago starch in Papua New Guinea. Food Microbiol 26:136-141

Haska N (1995) Study of productivity and starch yield of sago palm in West Java. Acta Hort 389:217-222

Inubushi K, Hadi A, Okazaki M, Yonebayashi K (1998) Effect of converting wetland forest into sago palms on methane gas flux and organic carbon dynamics in tropical peat soil. Hydrol Process 12:2073-2080

Kamaguchi A, Yokota K, Sakaguchi O (1979) Investigation of the hemolytic site of asp-hemolysin. Japan J Med Sci Biol 32:118-121

Kjari A, Barfod AS, Asmussen CB, Seberg O (2004) Investigation of genetic and morphological variation in the sago palm (Metroxylon sagu; Arecaceae) in Papua New Guinea. Ann Bot (London) 94:109-117

McClatchey W, Manner HI, Elevitch CR (2004) Metroxylon amicarum, M. paulcoxii, M. sagu, M. salmonense, M. vitiense, and M. warburgii (sago palm). Permanent Agricultural Resources, Honolulu

McClatchey W, Manner HI, Craig RE (2006) Metroxylon amicarum, M. paulcoxii, M. sagu, M. salomonense, M. vitiense, and M. warburgii (sago palm) Arecaceae (palm family). Species Profiles for Pacific Island Agroforestry www.traditionaltree.org

Morauta L (1982) Sago for food in a changing economy. PNG Institute of Applied Social and Economic Research, Discussion Paper 44:39-76

Mueller I, Vounatsou P, Smith T, Allen B (2001) Subsistence agriculture and child growth in Papua New Guinea. Ecol Food Nutr 40:367-395

Muller I, Betuela I, Hide R (2002) Regional patterns of birthweights in Papua New Guinea in relation to diet, environment and socio-economic factors. Ann Hum Biol 29:74-88

Omoloso AD (1999) Microbial profile of sago starch from different area of Papua New Guinea. In: Sopade P (ed) Proceedings of the first national sago conference. Unitech Press, Lae, pp 85-90

Omoloso AD, Bomaigi A (1996) Microbiological suitability of drinking water from settlements in and around Lae. Proceedings of the 9th annual congress of PNG Institute of Chemistry. PNG University of Technology, Lae, pp 82-87

Paijmans K (1980) Ecological notes on sago in New Guinea. In: Stanton WR, Flach M (eds) Sago. The equatorial swamp as a natural resource. Proceedings of the second international sago symposium. Martinus Nijhoff Pub, The Hague, pp 9-12

Power AP (1999) The sago industry for Papua New Guinea: the time is now. In: Sopade PA (ed) Sago starch and food security in Papua New Guinea. The proceedings of the first national sago conference 15-16 November, vol 1999. Unitech Press, Lae, pp 1-13 
Pue AG (2013) Studies on haemolytic compounds from fungi of sago and their role in sago haemolytic disease in Papua New Guinea. PhD, University of Queensland

Schuiling DL (1995) The variability of the sago palm and the need and possibilities for its conservation. Acta Hort 389:41-62

Sopade PA (1999) Sago starch in Papua New Guinea: making the most of it. In: Sopade PA (ed) First national sago conference. Unitech Press, Lae, pp 22-25

Stace J, Pitt JL, Conway PL, Adams RF (n.d.) Sago haemolysis, a mycotoxicosis in Papua New Guinea, unpublished

Taufa T (1974) Sago haemolytic disease. Papua New Guinea Med J 17:227-228

Temu P (2006) Food security in PNG. Post Courier, Port Moresby 23 Oct 2006

Temu PI, Saweri W (2001) Nutrition in transition. In: Bourke RM, Allen MG, Salisbury JG (eds) Food security for Papua New Guinea. Proceedings of the Papua New Guinea food and nutrition 2000 conference. PNG University of Technology, Lae, PNG, 26-30 June 2000. Australian Centre for International Agricultural Research (ACIAR), Canberra, pp 395-406

Tie Y-L, Lim E-TK (1991) The current status and future prospects of harvestable sago palms in Sarawak. In: Ng TT, Tie YL, Kueh HS (eds) Towards greater advancement of the sago industry in the '90s: proceedings of the fourth international sago symposium. Kuching, Sarawak, pp 11-16

Wamala M (1999) Distribution of sago as staple food in southern region (Western, Gulf, Central, Milne Bay, and Oro Provinces). In: Sopade P (ed) Sago starch and food security in PNG: first national sago conference. Unitech Press, Lae, pp 56-69

Wang WJ, Powell AD, Oates CG (1996) Sago starch as a biomass source: raw sago starch hydrolysis by commercial enzymes. Bioresour Technol 55:55-61

Yokota K, Kamaguchi A, Sakaguchi O (1984) Studies on the toxin of Aspergillus fumigatus. XVIII. Photooxidation of Asp-hemolysin in the presence of various dyes and its relation to the site of hemolytic activity. Microbiol Immunol 28:385-391

Open Access This chapter is licensed under the terms of the Creative Commons Attribution 4.0 International License (http://creativecommons.org/licenses/by/4.0/), which permits use, sharing, adaptation, distribution and reproduction in any medium or format, as long as you give appropriate credit to the original author(s) and the source, provide a link to the Creative Commons license and indicate if changes were made.

The images or other third party material in this chapter are included in the chapter's Creative Commons license, unless indicated otherwise in a credit line to the material. If material is not included in the chapter's Creative Commons license and your intended use is not permitted by statutory regulation or exceeds the permitted use, you will need to obtain permission directly from the copyright holder. 


\title{
Chapter 10 \\ Conservation and Sustainable Utilization of the Fiji Sago Palm Metroxylon vitiense
}

\author{
Dick Watling
}

\begin{abstract}
The Fiji sago palm is an endemic palm with a restricted and declining population, whose long-term survival is threatened by habitat loss and unsustainable harvesting for thatch and heart of palm. NatureFiji-MareqetiViti, a Fijian conservation organization, initiated a campaign in 2007 to highlight its endangered status and to stimulate the introduction of conservation management measures. After widespread consultation with the landowners of the remaining sago stands, users, government and administrative agencies, and other stakeholders, a 2010 2015 Species Recovery Plan was endorsed by the government and became the foundation for implementation activities. The plan is currently being reviewed with a view to the preparation of a successor. This paper reviews the successes and failures of the past 5 years of implementation. Despite some notable successes, given the seriousness of the decline of the Fiji sago palm, the achievements can be viewed as mixed, while overall progress has been an insufficient response in the circumstances. In part, this is probably because the project is not owned or mainstreamed by the government (which has not contributed funding); the administrative energy still remains with NatureFiji-MareqetiViti which has difficulties in resourcing a program with the necessary continuity.
\end{abstract}

\subsection{Introduction}

The Fiji sago palm Metroxylon vitiense is endemic to Fiji where it has been recorded from the islands of Viti Levu, Vanua Levu, and Ovalau. Pollen analysis in sediment cores from a variety of swamp sites on Viti Levu and Vanua Levu confirms that the species was once much more widely distributed than at present (Hope et al. 2009). Today it has a remnant distribution and is declining on Viti Levu. Only one population is known from Vanua Levu and this may be introduced (Watling 2005). The remaining natural stands are found in lowland freshwater swamp sites, although the

\footnotetext{
D. Watling $(\bowtie)$

NatureFiji-MareqetiViti, Suva, Fiji

e-mail: watling@naturefiji.org
} 
Upper Navua River Conservation Area stand is an exception being in a mixed lowland forest setting.

Another species of sago, Metroxylon warburgii, is found on the northern Fijian island of Rotuma and has been introduced to a few places on Viti Levu and Vanua Levu.

The Fiji sago palm never produces suckers, and the only confirmed growing period to flowering is 24 years for two palms (Watling pers. obs.) which may be the longest growth interval for any species of sago.

Concern at the decline of the Fiji sago palm was first raised in Fiji's first State of the Environment Report in 1992 (Watling and Chape 1992). Unlike Fiji's other native palms, it was not listed in Fiji's Endangered and Protected Species Act 2002, and it was not until research was conducted in 2006-2007 which confirmed that it is seriously threatened (Rounds 2007). Thereafter, NatureFiji-MareqetiViti (NFMV), a local conservation organization, instigated a campaign to highlight its endangered status and to stimulate the introduction of conservation management measures.

Because of its restricted distribution, aspects of its biology, and threats from habitat destruction and harvesting, the Fiji sago palm has been classified as endangered under IUCN Red List criteria; it may in fact be critically endangered. However, there has been no rush to have it officially categorized by IUCN until such time as conservation measures workable in the Fijian context are successful. Initially, NFMV conducted wide-ranging field surveys and consultation with landowners, harvesters, and users (for thatch and heart of palm) which enabled the production of a Species Recovery Plan for the Fiji sago palm. This plan has been endorsed by the Fiji Government and has been the basis of ongoing conservation and sustainable utilization efforts.

\subsection{Population Status of the Fiji Sago Palm}

Fifteen single-species stands of Fiji sago palm (of 1 ha or more) are known with a combined original area of approximately 450 ha. All but one of the significant sites are within the provinces of Namosi and Serua in southern Viti Levu (Fig. 10.1). Only one of these, at Nukusere, Namosi ( 15 ha), is considered safe because of its inaccessibility. Culanuku ( 10 ha) has been restored by the local community with NFMV assistance and with continued community support will survive. Another approximately 450 ha of sago is mixed with native forest and mahogany plantation on the banks of the Navua River in the vicinity of Upper Navua gorge, much of which are within the Upper Navua Conservation Area (Fiji's first and sole Ramsar Site). This population is receiving active conservation attention from Rivers Fiji Ltd., a rafting tourism company operating in the Navua Gorge.

The others need a range of management interventions from cessation of harvesting to intensive weed removal and drainage reversal for them to survive (NFMV 2010; Morrison et al. 2012). 

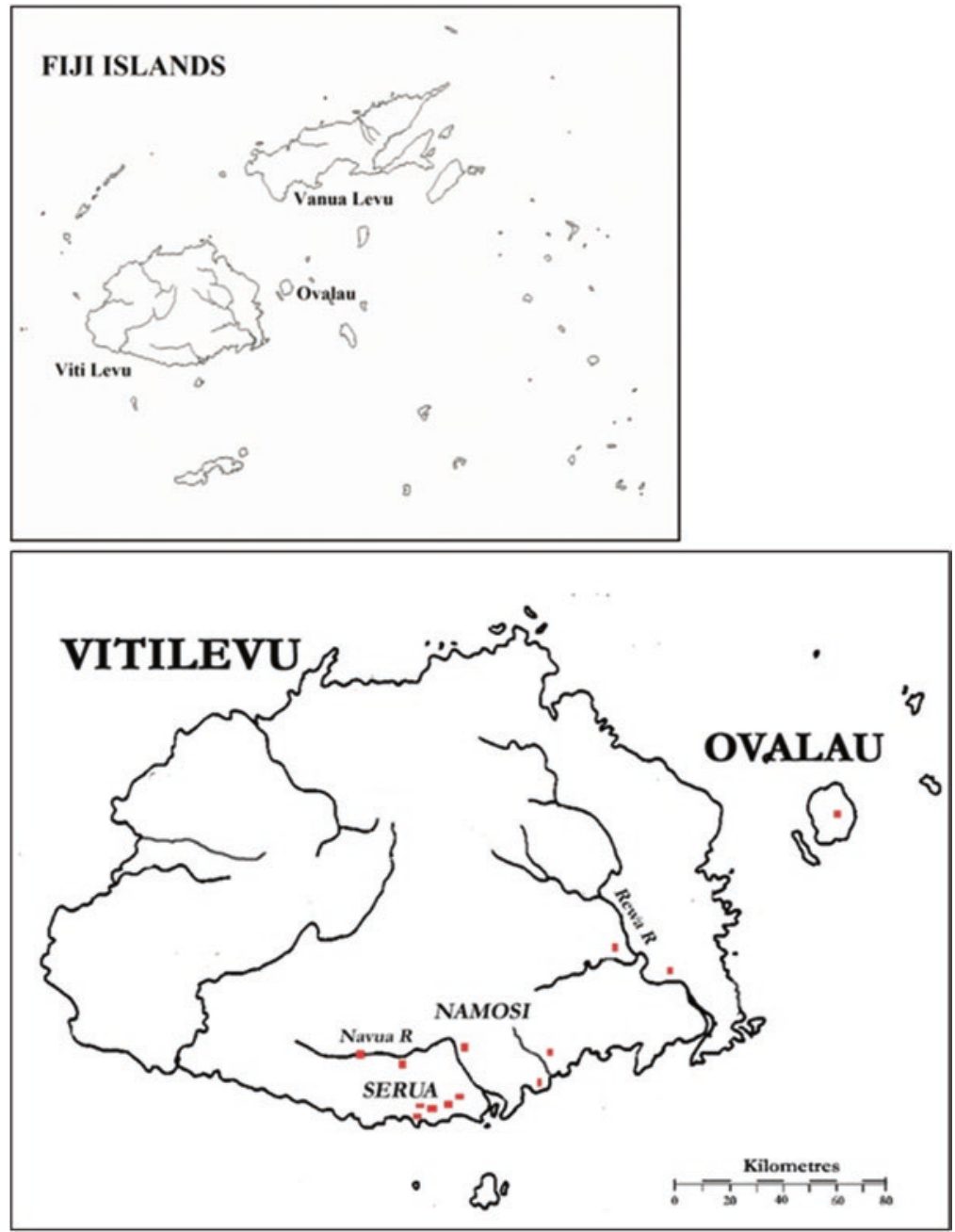

Fig. 10.1 Fiji Islands (upper) and location of remaining Fiji sago palm stands on Viti Levu and Ovalau

\subsection{Cultural Use of the Fiji Sago Palm}

In 1860-1861, Berthold Seemann in his travels through Serua and Namosi provinces probably collected and subsequently described the Fiji sago palm Metroxylon vitiense. He made no mention of Fijians using sago for any purpose; however, he was clearly impressed by the abundance of sago palms which he described as: “... fine groves, several miles in extant were seen by us on various branches and deltas of the Navua River" (Seemann 1862). 
The various species of Metroxylon have important cultural values wherever they occur in the Pacific islands and SE Asia. The two primary uses are for the production of edible starch from the stem and durable leaf thatch. Of all the Pacific islands where Metroxylon are found, Fijians appear to have made least use of sago palms. Except in Rotuma where $M$. warburgii occurs, there is no record of Fijians ever eating sago, even as a famine food. The Rotuman language has at least 25 words which relate to the cultural use of their sago (McClatchey and Cox 1992), while the Fijian language has none; even the original Fijian name for the sago palm is uncertain. The absence of any linguistic association with sago palm or its use has led to linguists wondering if it is not an introduced species (P. Geraghty pers. comm), something it clearly is not.

Although some Fijian communities used sago extensively as thatching material during the twentieth century, it is quite likely that its use as such was learned from Solomon islanders in Fiji, as indeed the people of Deuba explicitly told the anthropologist Geddes during his stay at Deuba village, from 1942 to 1943. Geddes relates that "... the use of the leaf itself is comparatively recent, having been learnt from indentured Solomon islanders..." (Geddes 2000). Currently, sago palm is rarely if ever used for thatching materials for Fijian houses, because it is very labor intensive and because of the increased use of corrugated iron as a roofing material.

Unlike the use of sago species in Vanuatu, Rotuma, Samoa, and Solomons ( $M$. warburgii, M. paulcoxii, and $M$. salomonense) which remains an integral part of the traditional agricultural system, this is not the case with $M$. vitiense in Fiji. The rural communities of Vanuatu, Rotuma, Samoa, and Solomons habitually practice traditional agriculture, and, where used for leaf thatch, there is good practical knowledge of its sustainable use for this purpose. What use is made of sago in Fiji is from wildgrown-natural stands of Fiji sago palm with only quasi-cultural sustainable use practices.

The lack of a cultural connection to sago in Fiji has significant repercussions for its conservation management.

\subsection{Causes of Decline and Current Threats}

The causes of decline and current threats of the Fiji sago palm are described in detail elsewhere (NFMV 2012; Morrison et al. 2012); they are summarized here:

1. Biology. Fiji sago palm does not produce suckers and reproduces only through a single fruiting before it dies. It may also have the longest period of growth - germinating seed to mature fruit of 25 years or more. Such a life history renders it vulnerable to catastrophic events - cyclones, new pests, new human uses, etc. Vulnerability increases as the stand size decreases.

2. Drainage for agriculture and land use needs. Ongoing, presumably since the first arrival of humans to Fiji, but recently subject to increased agricultural land needs, as well as residential subdivisions in key sago habitats, such as Pacific Harbour (Fig. 10.2). 


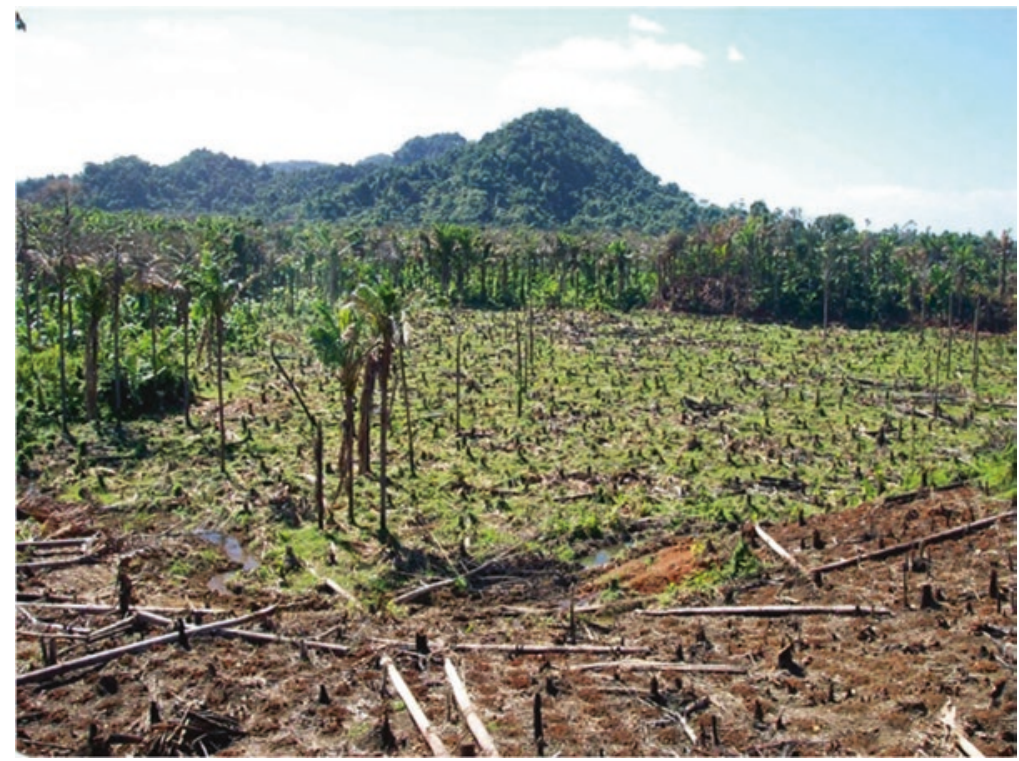

Fig. 10.2 Dakunikoro, the world's largest stand of Fiji sago palm: drained and subdivided for agriculture (Photo: NFMV)

3. Harvesting for thatch. Historically insignificant, there was a sudden and dramatic increase in the demand for sago palm thatch from the tourism industry to provide a traditional bure hut look (Fig. 10.3), 2000-2010. Originally, Fijians may have developed or adopted sustainable thatch harvesting techniques, but the attraction of major cash income for sago palm shingles from the tourist industry resulted in large areas of sago palm being felled using chain saws so that leaves could be easily removed.

4. Palm heart trade. In 2008 , at least 200 palms were felled per week to cater to palm heart consumers. This number would increase up to 250 trees during special religious or cultural events rendered important for Indo-Fijians (NFMV 2008a; Fig. 10.4).

5. Invasive weeds. Excessive leaf removal and/or felling for thatching (and the palm heart trade) opens up the canopy of Fiji sago palm stands and introduces a serious threat of weed invasion by the exotic vines Merremia peltata, Mikania micrantha, and other creepers which can smother young palms and even kill adults before they fruit. Regenerating palms are attractive to wandering cattle and susceptible to grazing causing death. 


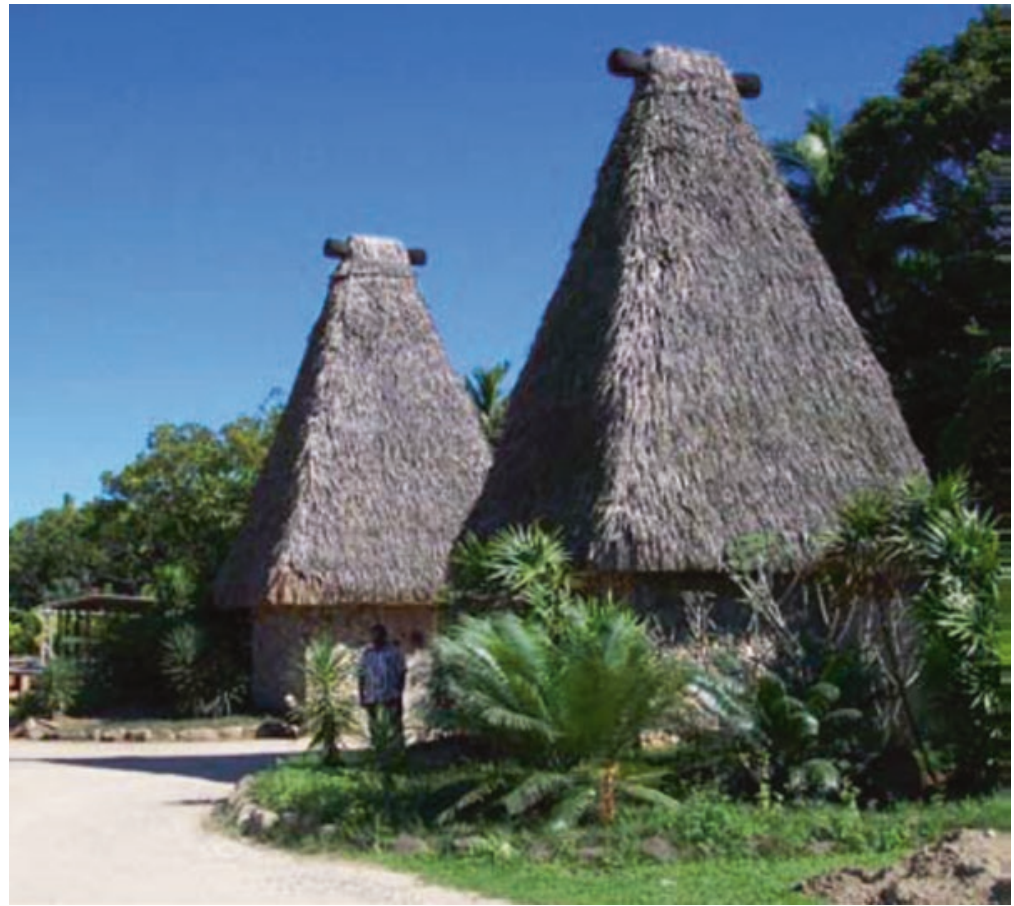

Fig. 10.3 Use of Fiji sago palm thatch in the tourism industry (Photo: NFMV)

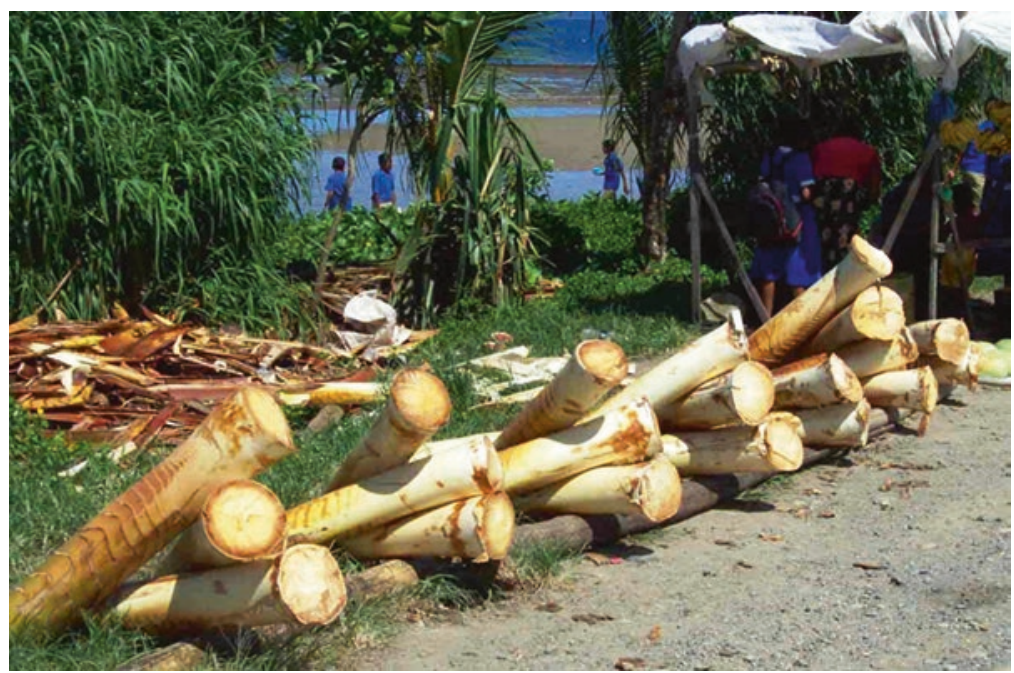

Fig. 10.4 Fiji sago palm heart for sale - 2010 (Photo: NFMV) 


\subsection{Conservation Management of the Fiji Sago Palm}

Soon after its establishment in 2007, NFMV selected the Fiji sago palm as one of its flagship conservation campaigns identifying it as an unknown national priority completely overlooked by government and the big international conservation NGOs (BINGOs). NFMV saw the need, which is even more pressing today, for local priorities to be identified and championed in the face of a lack of government expertise and resources and well-funded campaigns for species of international interest which form the core of the BINGO agenda in small countries. Since the start, NFMV has provided all the energy to advance management initiatives, generated almost all the funding, and developed or co-opted the necessary expertise.

Initially, NFMV undertook wide-ranging field surveys and consultation with landowners, harvesters, users (thatch and heart of palm), and government, and the National Trust of Fiji set up a multi-agency Sago Palm Recovery Plan Committee which had representatives from all major stakeholders. Through this committee, The Fiji Sago Palm Species Recovery Plan (2010-2015) was drawn up and endorsed by the government's Department of Environment in June 2010 (NFMV 2010).

The most challenging issue which emerged, as knowledge of the Fiji sago palm, its status, and utilization was gained, revolved around the fundamental conservation approach which the recovery plan should adopt. Should there be a push for international listing as an endangered or critically endangered species, inclusion on Fiji's Endangered and Protected Species Act, a ban on commercial use, strict protection, and priority identification of sago-protected areas? Alternatively, were the conditions in Fiji less conducive to a top-down legislative/administrative approach and more conducive to a controlled stimulation of the market for thatch using sustainable harvesting methods, such that the landowners would become interested in maintaining the sago stands for their own commercial benefit? Landowners in Fiji are extremely powerful in respect of the resources on their land, and NFMV with the Sago Palm Recovery Plan Committee opted for the latter approach in the Recovery Plan.

The management recommendations in the recovery plan are categorized into five main groups as summarized below.

1. Public Awareness/Working with Communities

The priorities here were to work with the following stakeholders:

- Landowning communities - to assist them to understand the commercial elements of the sago palm thatch industry, to take control out of the hands of middlemen, to set up an association of sago palm landowners, and to develop and have accepted sustainable harvesting guidelines (NFMV 2008b) and sago restoration guidelines.

- Provincial authorities - ensuring that the provincial authorities understand the potential rural economy gains from a sustainably harvested sago thatch industry as well as the alternative: its inevitable demise and the loss of cash benefitting an underdeveloped rural economy calculated at USD 1.5 million in 2009. 
- Freehold landowners - some of the remaining Fiji sago palm stands are on freehold land (land which is owned by individuals or corporate bodies). Initiatives were envisaged to introduce protection and restoration and additional planting of stands.

\section{Fiji Sago Palm Users}

- Thatch users: the tourism industry - to instigate a change in behavior in the use of sago palm thatch by tourism users, through direct contact, presentations, and distribution of quality awareness material. Promotion of the opportunity to engage in a meaningful green and socially beneficial industry through the use of only sustainably harvested thatch.

- Thatch users: architects - as an in vogue artifact of pseudo-cultural reference used in tourism projects, ensure that the architects are fully aware of what they are promoting and to cooperate in educating clients on the sustainability issues relating to the use of palm thatch.

- Palm heart users - the sago palm heart trade was identified as a serious contributor to the decline of accessible sago palm populations. The phasing out of the trade was identified in the Recovery Plan, but the mechanism remained to be agreed upon. An alternative palm heart source from a species which could be harvested sustainably was to be sought (Fig. 10.5).

3. Conservation Actions

- Prioritizing populations - given the great variation in the status of the remaining sago palm stands, there was a need to prioritize management actions based on an in-depth and up-to-date survey of the remaining stands.

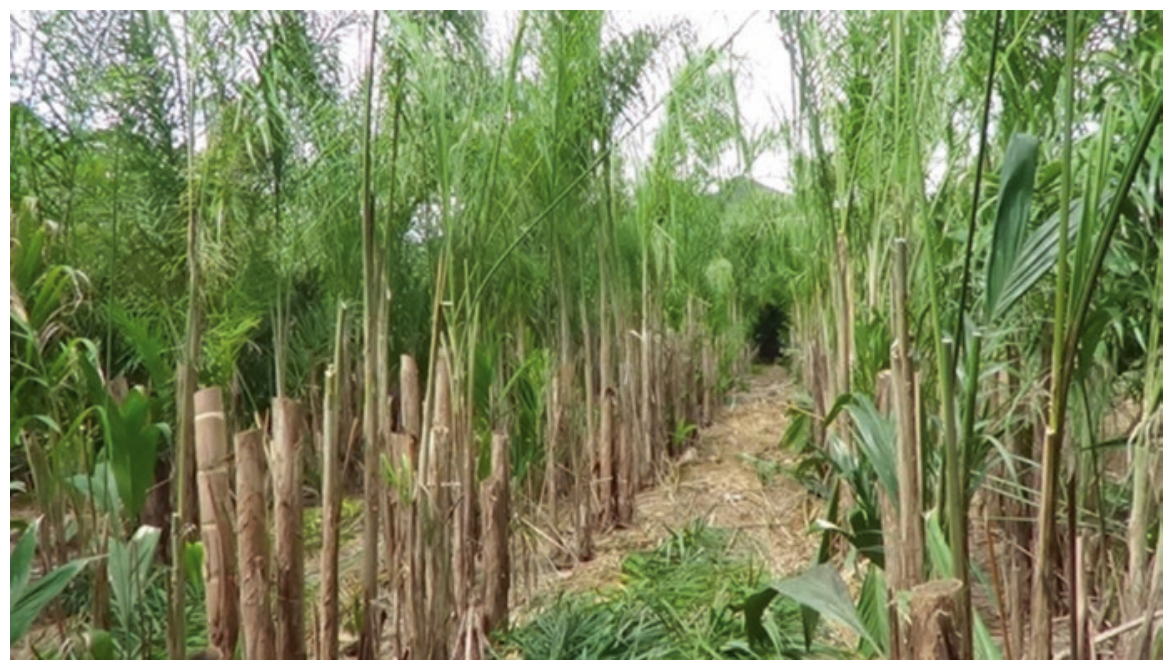

Fig. 10.5 Fiji sago heart of palm substitute - peach palm (Bactris gasipaes) after the third successive annual stem harvest -5 years after planting (Photo: NFMV) 
- Additional sites - surveys are still required for reported but unvisited sites and enquiries to locate any unregistered sites.

- Threat analyses - more in-depth discussion with sago palm landowners, especially the larger stands with a view to understanding current threats and the conservation management approaches most suitable and/or favorable with the landowners, for the particular sites.

- Ex situ populations - given the precarious nature of the majority of the existing sago stands, naturalized ex situ stands are an important conservation strategy and should be used to maintain the genetic diversity of the species (Fig. 10.6).

- Development of guidelines - guidelines required for sustainable harvesting, restoration of degraded Fiji sago palm stands, and the establishment of ex situ stands.

4. Update Threatened Status Listing of Fiji Sago Palm

The priorities here were:

- To include the Fiji sago palm in Fiji's Endangered and Protected Species Act

- Have it recognized as a non-timber forest product under the Forestry Decree 1992

- To liaise with IUCN in respect of the IUCN Red List.

5. Research

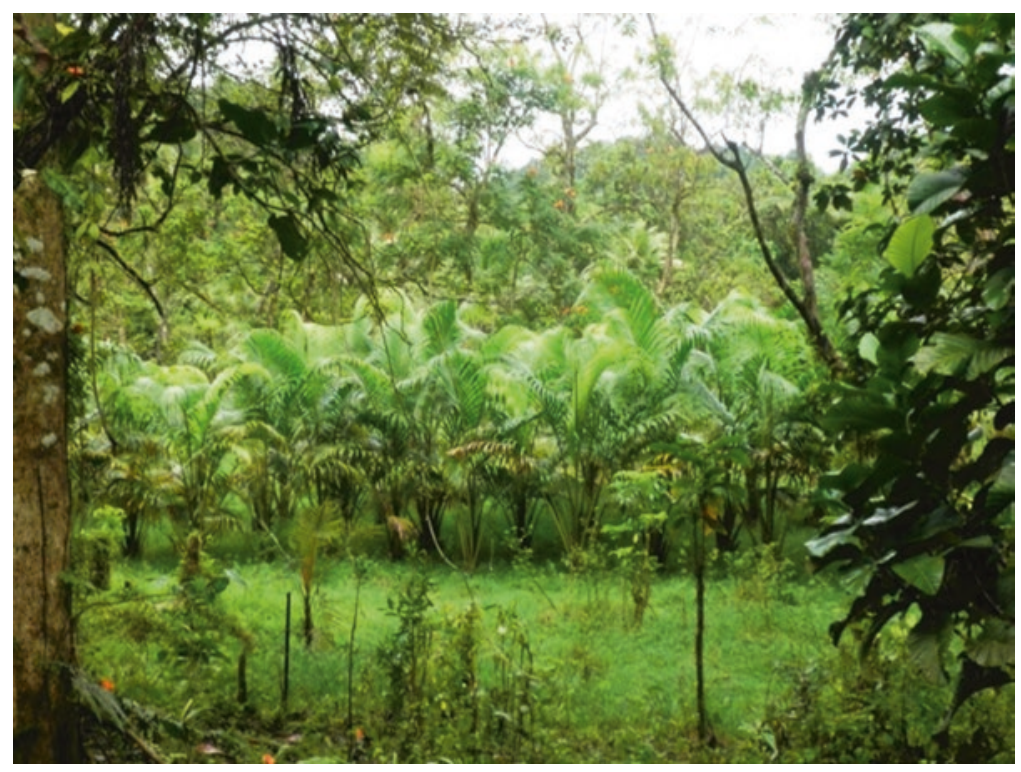

Fig. 10.6 Ex situ planting of Fiji Sago Palm in the Garrick Forest Reserve, Navua planted by NatureFiji-MareqetiViti members 
- Genetic variation - the Fiji sago palm is currently fragmented into at least 15 stands, with only one stand each on Vanua Levu and Ovalau. Maintaining diversity within the species is clearly important for its survival.

- Invasive species - small stands of Fiji sago palm are susceptible to invasion by a variety of aggressive alien species. The vines Merremia peltata and Mikania micrantha are particularly aggressive, while the naturalized pond apple Annona glabra can be a serious threat. How to deal with these requires restoration work experience trialing different techniques.

- Ecosystem value - given the former abundance of the Fiji sago palm especially in coastal areas behind the mangrove and its tolerance of saline inundation, it may have potential in developing climate change adaptation measures. Currently we do not fully understand the role that the palm plays in its ecosystem at natural levels of abundance and ecosystem composition (predators, dispersal, pollinators, etc.). Given its former abundance, this role may be substantial. A detailed study of its synecology was identified as being important including the variation in the current natural populations.

\subsection{Conservation Management: Achievements and Lessons Learned from the First 5 Years}

The first 5-year Fiji Sago Palm Species Recovery Plan (2010-2015 NFMV 2010) is currently being reviewed with the intention of producing another 5-year plan building on the achievements and lessons learned. Currently NFMV is seeking the resources to initiate a comprehensive review with all stakeholders.

Table 10.1 provides a summary of outcomes of the recovery plan during its 5-year implementation period.

Notable achievements include:

- Increased awareness and control of thatch harvesting by the majority of landowners. Sustainable harvesting guidelines are now widely, but not universally, agreed with and adopted.

- Active involvement by provincial offices.

- Fiji Sago Palm Species Recovery Plan agreed upon by all stakeholders and endorsed by the Department of Environment.

- Forestry department implementing requirements of the Forests Decree 1992 and Endangered and Protected Species Act.

- Introduction of peach palm (Bactris gasipaes) as a sustainable alternative for sago palm heart trade with first seedlings provided to Ministry of Agriculture for bulking up and distribution.

- Successful restoration of 10 ha Culanuku sago palm stand (Fig. 10.7).

- Successful ex situ planting in the Garrick Forest Park. 


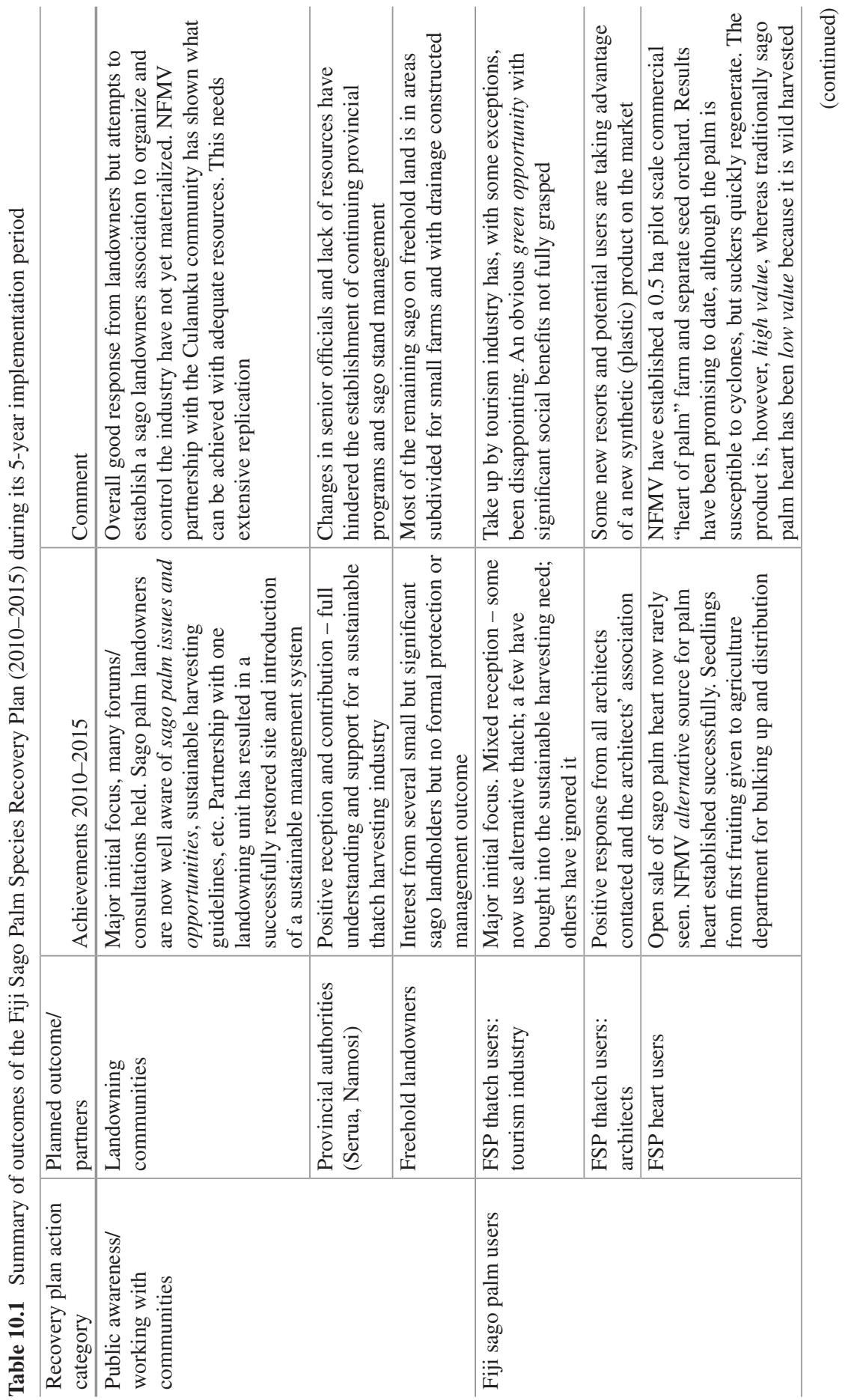




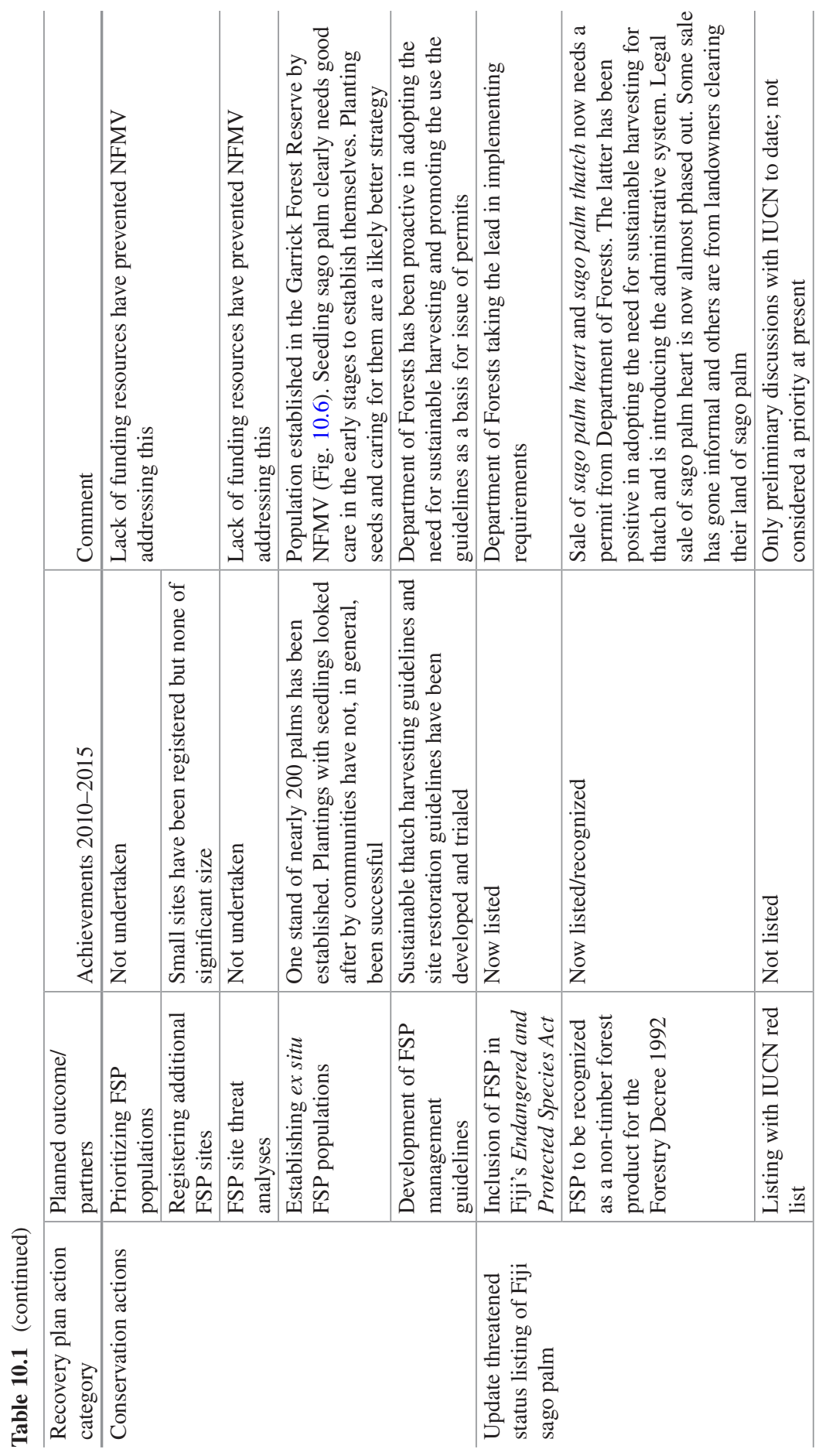




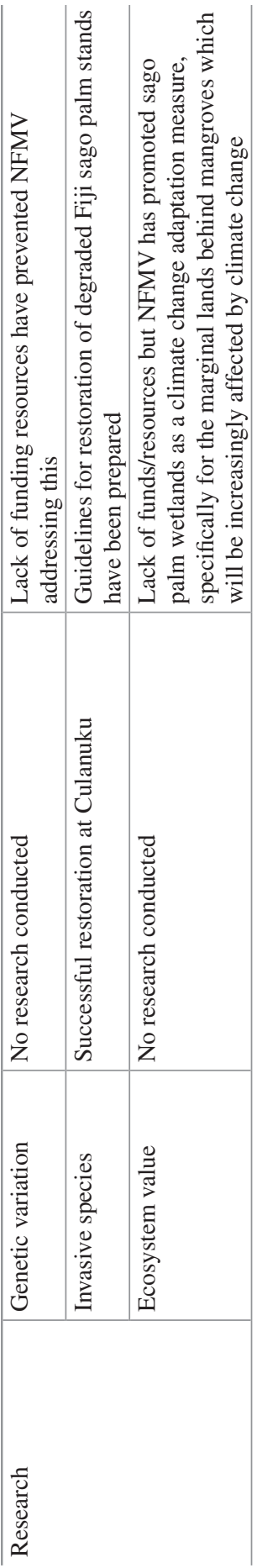




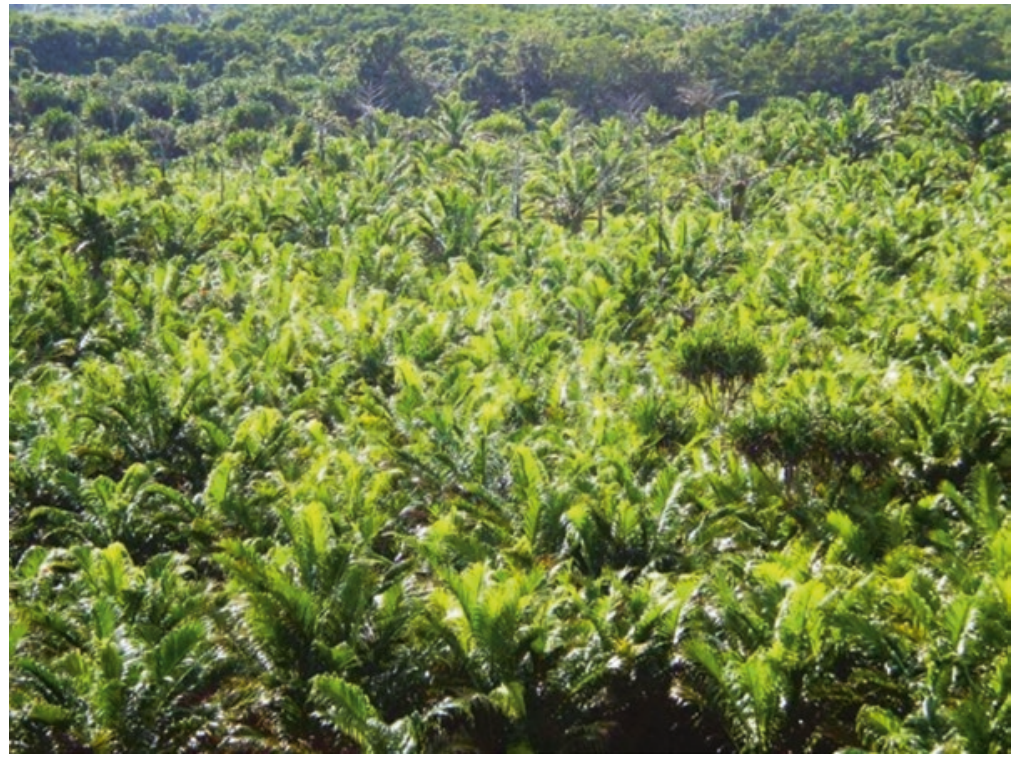

Fig. 10.7 The Culanuku community Fiji Sago Palm stand which has been sucessfully restored with the removal of invasive creepers and replanting

In conclusion, despite some notable successes, given the seriousness of the decline of the Fiji sago palm, the achievements can been viewed as mixed, while overall progress has been an insufficient response in the circumstances. In part, this is probably because the project is not owned or mainstreamed by government (which has not contributed funding); the administrative energy still remains with NFMV which has difficulties in resourcing a program with the necessary continuity.

\section{References}

Geddes WR (2000) Deuba: a study of a Fijian village. Institute of Pacific Studies, University of the South Pacific, Suva

Hope G, Stevenson J, Southern W (2009) Vegetation histories from the Fijian Islands: alternative records of human impact. In: Clark G, Anderson A (eds) The early prehistory of Fiji. ANUE Press, Canberra, pp 63-86

McClatchey WC, Cox PA (1992) Use of sago palm Metroxylon warburgii in the Polynesian Island, Rotuma. Econ Bot 46:305-309

Morrison C, Rounds I, Watling D (2012) Conservation and management of the endangered Fiji sago palm, Metroxylon vitiense, in Fiji. Environ Manag. doi:10.1007/s00267-012-9836-3

NFMV (2008a) A report on the edible palm heart trade of the Fiji sago palm Metroxylon vitiense. Unpublished report, NatureFiji-MareqetiViti, Suva

NFMV (2008b) Guidelines for the sustainable harvesting of the Fiji sago palm. Unpublished report, NatureFiji- MareqetiViti, Suva 
NFMV (2010) Soga: Fiji sago palm Metroxylon vitiense recovery plan 2010-2015. Unpublished report (2010/06), NatureFiji- MareqetiViti, Suva

NFMV (2012) Fiji sago palm Metroxylon vitiense restoration guidelines. Unpublished report (2012/06), NatureFiji-MareqetiViti, Suva

Rounds I (2007) Conservation, management and ethnobotany of sago (Metroxylon vitiense) in South East Viti Levu, Fiji Islands. MSc. Thesis, University of the South Pacific, Fiji

Seemann B (1862) Viti: an account of a government mission to Vitian or Fijian Islands in the years 1860-61. Colonial History Series No. 85 Cambridge. (Reprinted 1973)

Watling D (2005) Palms of the Fiji Islands. Environmental Consultants Fiji Ltd, Suva

Watling D, Chape SA (1992) Fiji: National State of the Environment Report. IUCN Consultants Government of Fiji, Suva

Open Access This chapter is licensed under the terms of the Creative Commons Attribution 4.0 International License (http://creativecommons.org/licenses/by/4.0/), which permits use, sharing, adaptation, distribution and reproduction in any medium or format, as long as you give appropriate credit to the original author(s) and the source, provide a link to the Creative Commons license and indicate if changes were made.

The images or other third party material in this chapter are included in the chapter's Creative Commons license, unless indicated otherwise in a credit line to the material. If material is not included in the chapter's Creative Commons license and your intended use is not permitted by statutory regulation or exceeds the permitted use, you will need to obtain permission directly from the copyright holder. 


\section{Part IV Agricultural Botany of Sago Palm}




\title{
Chapter 11 \\ Dry Matter Production as a Basis of Starch Production in Sago Palm
}

\author{
Yoshinori Yamamoto
}

\begin{abstract}
The differences of starch productivity of sago palms among folk varieties (hereafter, varieties) are discussed from the viewpoint of dry matter production which has been rarely reported in sago palm, to provide basic knowledge to establish the cultivation methods of sago palm and to select varieties for new introduction and breeding of new varieties. The research was performed in Kendari, Southeast Sulawesi, Indonesia, to clarify the dry matter production and the factors related to it in the sago palm varieties with different starch yields. The results revealed that the varietal differences of starch yield of sago palm varieties, Molat (425 kg dry starch/ palm) and Rotan (142 kg in dry starch/palm), are mainly based on the biomass difference and not on the difference of matter distribution ratios to the harvesting part (trunk/pith). The biomass production in sago palm is closely related to the leaf area per plant, mainly determined by the leaf area per leaf compared to the number of leaves per plant. The leaflet width contributed most to the leaf area per leaf. I concluded that the leaf area in sago palm was the key factor to determine the starch yield and varietal differences of leaflet width should be paid attention to as an important character to determine the leaf area.
\end{abstract}

\subsection{Introduction}

Sago palm is a clustering (soboliferous), perennial plant which accumulates large quantities of starch in the stem (trunk). This characteristic of sago palm gives it tolerance to various climatic conditions. It can grow in marginal land such as deep peat soil, high water table areas, etc. Besides the increase of production of major world starch crops, it is very important to evaluate and develop new starch crops to effectively meet the growing demand from the predicted population increase in this century. New starch sources can reduce hunger in the world and, moreover, help deal with the crop production problems brought about by climate change due to global warming.

Y. Yamamoto $(\square)$

Formerly, Faculty of Agriculture, Kochi University, Nankoku-shi, Kochi, Japan

e-mail: yamayosi@kochi-u.ac.jp 
The starch productivity of sago palm is affected by environmental conditions, cultivation and management methods, processing practices and harvesting stage, as well as variety (i.e., folk variety) (Yamamoto 2011). The amount of starch accumulated in the trunk varies greatly among regions and/or varieties (Yamamoto 2006, 2011). To precisely understand the regional and/or varietal differences of starch productivity among sago palms, it essentially needs to be researched from the viewpoint of dry matter production. However, limited research on dry matter production in sago palm has been done so far (Yatsugi 1977; Flach and Schuiling 1991; Kaneko et al. 1996; Yamamoto et al. 2014, 2016).

Starch yield of sago palm was analyzed according to biomass produced, biomass ratio of harvesting portion (pith), and the starch percentage in pith. Therefore, to calculate the starch yield, starch yield $($ dry starch $)=$ biomass $($ dry weight $) \times$ pith dry weight/biomass (dry weight) $\times$ starch dry weight/pith dry weight. That is, the starch yield is determined by biomass, biomass distribution ratio to pith, and starch content in pith. As for biomass production, it is mainly determined by leaf area, photosynthetic rate, and growth duration.

This chapter discussed the dry matter production and the factors related to it in sago palm to clarify the differences in starch productivities in sago palm varieties.

\subsection{Biomass Production and Related Factors in Sago Palm}

The main data described in this chapter were collected in Kendari, Southeast Sulawesi, Indonesia, from 1998 to 2000. In Kendari, measurements were made of the changes in total sugar and starch in the pith of three major varieties, with general and local names: Molat (Roe), Tuni (Runggunmanu), and Rotan (Rui), along with palm ages (Yamamoto et al. 2010). Based on the starch yield results, Molat and Rotan were chosen as the highest and lowest yielding varieties to compare the changes of each organ or part biomass weight of the shoot (aboveground part) and leaf area and leaf area-related characters. Thirteen Molat palms, 1-7 years after trunk formation (ATF), and nine Rotan palms, 1-7 years ATF, of different ages were sampled to determine their biomass and leaf area (Yamamoto et al. 2014, 2016).

\subsubsection{Leaf Area}

The sago palm leaf is pinnate and compound, consisting of rachis, petiole, and many leaflets attached to the rachis. The size of each leaf part increases from the lower to the higher node until the trunk formation stage. The size of each part almost reaches a maximum value at about the trunk formation stage, and the size remains the same until flower bud formation stage. However, the size gradually decreases acropetally after the flower bud formation stage (Yamamoto 1998). Nakamura et al. (2009) developed a method to analyze the leaf area of sago palm based on studies of leaf and leaflet characters (Nakamura et al. 2004, 2005). 
Leaf area per plant was compared between Molat and Rotan. The result showed a great difference in leaf area per plant between the two from the early stage after trunk formation. The leaf area of Molat increased linearly, but that of Rotan did not show a clear increase after trunk formation. Table 11.1 shows the leaf and leaflet characters (average values after trunk formation to harvesting) in both varieties. All of the values in the measured characters of leaf and leaflets were higher in Molat than in Rotan except specific leaf area (SLA), and the leaf areas per plant on the average after trunk formation and at harvesting stage were 2.0 and 2.9 times higher in Molat $\left(269.5\right.$ and $\left.439.0 \mathrm{~m}^{2}\right)$ than in Rotan $\left(139.1\right.$ and $\left.150.0 \mathrm{~m}^{2}\right)$, respectively. The difference in leaf area per plant was mainly caused by the difference in leaf area per leaf (Molat 17.5, Rotan $11.1 \mathrm{~m}^{2}$ ) compared with that in the number of leaves per plant (Molat 15.0, Rotan 12.5). The differences of leaf area per leaf by the regions and/or varieties were reported by Flach and Schuiling (1991). As for the leaflet characters which related to the leaf area per leaf, the difference in leaflet width (Molat 11.6, Rotan $8.7 \mathrm{~cm}$ ) was the greatest, and it showed the closest relationship with the leaf area per leaf. Yamamoto (2016) reported the same relationships among the characters related to leaf and leaflet areas in the sago palm varieties around Lake Sentani near Jayapura, Papua, Indonesia.

\subsubsection{Photosynthesis}

Sago palm is classified as $\mathrm{C}_{3}$ plant based on its leaflet anatomy (Nitta et al. 2005) and characteristics of photosynthesis (Uchida et al. 1990). Although the research on photosynthesis of sago palm is minimal, Flach (1977) and Uchida et al. (1990) reported that the maximum photosynthetic rate is $13-15 \mathrm{mg} \mathrm{CO}_{2} / \mathrm{dm}^{2} / \mathrm{h}$ and $8-12 \mathrm{mg}$ $\mathrm{CO}_{2} / \mathrm{dm}^{2} / \mathrm{h}$, respectively, by using young seedlings grown in pots. Moreover, Uchida et al. (1990) clarified that a sago palm leaf attained a maximum photosynthetic rate after 37-45 days of unfolding of the leaf and more than $50 \%$ of the maximum photosynthetic rate was maintained for 70 days after the unfolding of the leaf. This implies the lateness of sago palm leaf to attain the maximum photosynthetic rate and to retard the photosynthetic rate compared to an annual plant (Uchida et al. 1990). Sago palm leaf shows the shade leaf characteristics because of the low light saturation point $\left(5.3 \mu \mathrm{mol} / \mathrm{m}^{2} / \mathrm{s}\right)$ (Uchida et al. 1990).

On the other hand, the photosynthetic rate of sago palm leaf after trunk formation growing in the field is higher than that of seedlings grown in pots, ranging from 25 to $27 \mathrm{mg} \mathrm{CO} / \mathrm{dm}^{2} / \mathrm{h}$ (Miyazaki et al. 2007). The photosynthetic rate differences between seedling and plant after trunk formation might be brought about by the differences in leaflet thickness, chlorophyll content, stomata density, etc. (Miyazaki et al. 2007). Leaf thickness and chlorophyll content (SPAD value) increase from sucker transplanting or emergence to trunk formation stage (Yamamoto et al. 2006). Uchida et al. (1990) reported that the photosynthetic rate of sago palm seedling is strongly affected by the stomata density. Omori et al. (2000) clarified that the differences in stomatal density based on the position in leaflets and leaves changed with palm age, that is, it ranged from ca. $50 / \mathrm{mm}^{2}$ on the adaxial side and ca. $400 / \mathrm{mm}^{2}$ on 


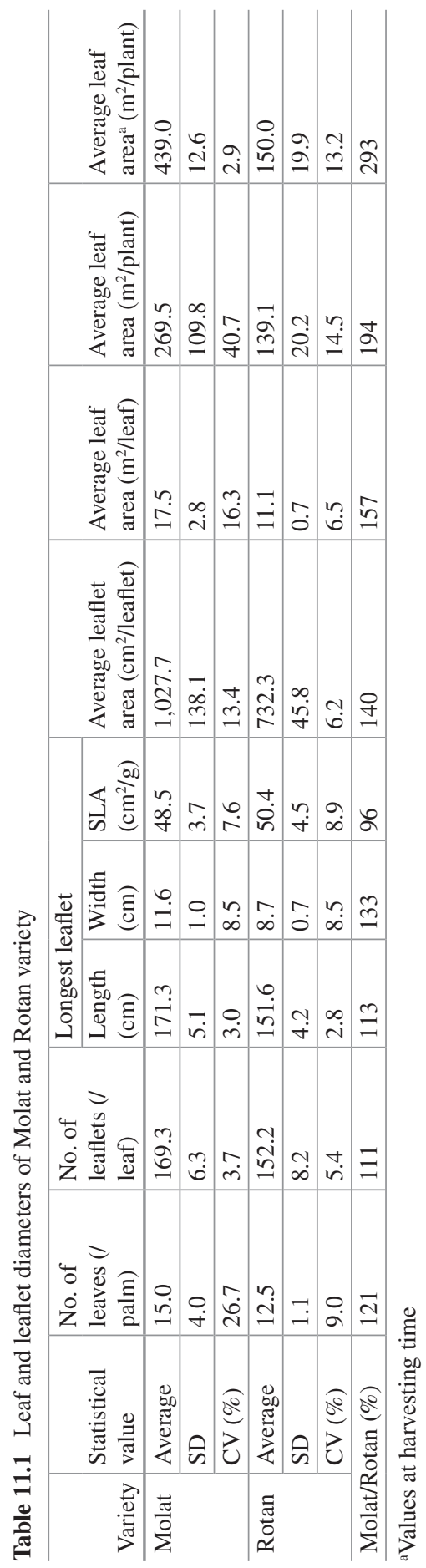


the abaxial side in the seedling stage to ca. $120 / \mathrm{mm}^{2}$ and ca. $1000 / \mathrm{mm}^{2}$ after trunk formation stage, respectively.

Miyazaki et al. (2007) reported the differences of photosynthetic rate of sago palm varieties growing in Bogor, Kendari, and Jayapura (around Lake Sentani), but the differences were small. According to Miyazaki et al. (2007) and the reports of the small differences in stomatal density by Omori et al. (1999), along with the study of mineral element contents in leaflets (Yoshida et al. 2000), there may be a small difference in photosynthetic rates between the Molat and Rotan varieties.

\subsubsection{Growth Duration}

The growth duration from sucker planting or emergence to flowering stage, that is, harvesting stage, varies greatly among varieties (Yamamoto 2011). The range of growth duration is from about 10 to 25 years (Yamamoto 1998, 2011). Moreover, the growth duration is affected by the soil types and soil nutrient conditions where the sago palms grow (Yamamoto 1998). The biomass of sago palm at harvesting stage is greatly influenced by the growth duration. Biomass production of early maturing varieties is lower than that of the late maturity varieties. Yamamoto (2011) reported that the difference in starch productivity was assumed to relate closely to the years to flowering, as reflected from the positive high correlation between the numbers of leaf scars and living leaves and the dry pith weight or starch yield.

The growth duration from trunk formation to harvesting was a little longer in Molat (7 years ATF) than in Rotan (5.5-7 years ATF); however, it was not very different (Table 11.2).

\subsubsection{Biomass}

The shoot fresh and dry weights ranged from 600 to $3053 \mathrm{~kg}$ in Molat and from 479 to $1123 \mathrm{~kg}$ in Rotan for the fresh weight and from 104 to $1028 \mathrm{~kg}$ in Molat and from 86 to $425 \mathrm{~kg}$ in Rotan for the dry weight (Table 11.2) and increased exponentially with years ATF. The annual weight gains ATF were $357.8 \mathrm{~kg} / \mathrm{year}$ in Molat and $92.5 \mathrm{~kg} /$ year in Rotan for the fresh weight and $144.3 \mathrm{~kg} / \mathrm{year}$ in Molat and $46.5 \mathrm{~kg} /$ year in Rotan for the dry weight, with 3.9 and 3.1 times higher values in Molat than in Rotan, respectively. The average shoot fresh and dry weights at the harvesting stage (three palms at 7 years ATF for Molat and three palms at 5.5-7 years ATF for Rotan) were 2781 and $986 \mathrm{~kg}$ for Molat and 1000 and $359 \mathrm{~kg}$ for Rotan.

The leaf dry weight of Molat ranged from 76 to $291 \mathrm{~kg}$ and increased exponentially with years ATF, while that of Rotan ranged from 62 to $107 \mathrm{~kg}$; a significant change with years ATF was not observed (Table 11.2). The trunk dry weight in both varieties ranged from 29 to $746 \mathrm{~kg}$ in Molat and from 25 to $336 \mathrm{~kg}$ in Rotan and increased exponentially with years ATF. The average trunk dry weight at harvesting stage in Molat (721 kg) was 2.7 times higher than that in Rotan (267 kg) (Table 11.2). 
Table 11.2 Changes in dry weight of each part of shoot of sago palm varieties after trunk formation in Kendari, Southeast Sulawesi, Indonesia

\begin{tabular}{|c|c|c|c|c|c|c|c|c|c|}
\hline \multirow[b]{2}{*}{ Variety } & \multirow[b]{2}{*}{$\begin{array}{l}\text { Years } \\
\text { ATF }^{a}\end{array}$} & \multicolumn{4}{|c|}{ Leaf (kg/palm) } & \multicolumn{3}{|c|}{ Trunk (kg/palm) } & \multirow[b]{2}{*}{$\begin{array}{l}\text { Shoot }(\mathrm{kg} / \\
\text { palm) }\end{array}$} \\
\hline & & Leaflet & Rachis & $\begin{array}{l}\mathrm{P}+ \\
\mathrm{LS}^{\mathrm{b}}\end{array}$ & Total & Bark & Pith & Total & \\
\hline \multirow[t]{14}{*}{ Molat } & 1 & 23.8 & 22.0 & 30.2 & 76.0 & 10.6 & 17.9 & 28.5 & 104.4 \\
\hline & 1 & 34.7 & 28.9 & 41.4 & 104.9 & 11.6 & 22.9 & 34.4 & 139.4 \\
\hline & 1 & 28.8 & 22.5 & 32.2 & 83.5 & 13.0 & 18.1 & 31.1 & 114.6 \\
\hline & 2 & 52.5 & 38.2 & 46.9 & 137.5 & 31.0 & 41.7 & 72.6 & 210.1 \\
\hline & 3.5 & 47.2 & 37.3 & 50.1 & 134.6 & 34.5 & 64.2 & 98.7 & 233.3 \\
\hline & 3.5 & 43.6 & 32.5 & 39.9 & 115.9 & 36.3 & 63.3 & 99.6 & 215.5 \\
\hline & 4 & 46.8 & 40.1 & 46.9 & 133.8 & 36.8 & 62.4 & 99.2 & 233.0 \\
\hline & 4 & 58.1 & 41.3 & 52.3 & 151.7 & 63.9 & 66.2 & 130.1 & 281.9 \\
\hline & 5 & 42.8 & 30.9 & 41.6 & 115.4 & 69.3 & 211.5 & 280.8 & 396.2 \\
\hline & 5.5 & 94.9 & 71.0 & 101.8 & 267.7 & 122.2 & 328.0 & 450.2 & 717.9 \\
\hline & 7 & 106.6 & 76.7 & 107.4 & 290.7 & 153.2 & 584.2 & 737.4 & 1028.1 \\
\hline & 7 & 101.8 & 69.0 & 90.8 & 261.6 & 123.1 & 558.2 & 681.2 & 942.8 \\
\hline & 7 & 97.4 & 57.7 & 84.8 & 239.9 & 145.7 & 600.0 & 745.6 & 985.5 \\
\hline & Aveg. & 101.9 & 67.8 & 94.3 & 264.1 & 140.6 & 580.8 & 721.4 & 985.5 \\
\hline \multirow[t]{10}{*}{ Rotan } & 1 & 22.6 & 14.6 & 24.6 & 61.8 & 6.7 & 17.9 & 24.6 & 86.4 \\
\hline & 1 & 31.7 & 19.6 & 29.5 & 80.8 & 13.6 & 23.1 & 36.7 & 117.6 \\
\hline & 1 & 26.4 & 16.1 & 29.0 & 71.5 & 14.0 & 18.6 & 32.6 & 104.1 \\
\hline & 3.5 & 21.7 & 15.3 & 20.9 & 57.9 & 25.8 & 44.7 & 70.6 & 128.5 \\
\hline & 3.5 & 34.3 & 24.0 & 33.0 & 91.3 & 37.4 & 82.5 & 119.9 & 211.2 \\
\hline & 4 & 22.1 & 16.5 & 23.2 & 61.7 & 27.8 & 44.7 & 72.5 & 134.2 \\
\hline & 5.5 & 30.1 & 21.4 & 27.4 & 78.9 & 43.1 & 151.9 & 195.0 & 273.9 \\
\hline & 6.5 & 40.3 & 29.2 & 37.7 & 107.2 & 55.9 & 215.7 & 271.6 & 378.8 \\
\hline & 7 & 32.4 & 26.0 & 30.8 & 89.2 & 65.3 & 270.3 & 335.5 & 424.7 \\
\hline & Avg. & 34.2 & 25.5 & 32.0 & 91.7 & 54.8 & 212.6 & 267.4 & 359.1 \\
\hline
\end{tabular}

a'Years after trunk formation

bPetiole + leaf sheath. The palms shown in gray color are at harvesting stage

Source: Yamamoto et al. (2016)

All the leaf components, leaflet, rachis, and petiole + leaf sheath, in Molat increased exponentially in dry weight with years ATF (Table 11.2). On the other hand, in Rotan, although that of rachis increased linearly, few changes were observed in the dry weights of leaflet and petiole + leaf sheath with years ATF. Among the leaf components, the dry weight of leaflet, rachis, and petiole + leaf sheath ranged from 24 to 107, 22 to 77, and 30 to $107 \mathrm{~kg}$ in Molat, respectively, and 22 to 40, 15 to 29 , and 21 to $38 \mathrm{~kg}$ in Rotan, respectively, showing the higher dry weight in the order of petiole + leaf sheath $\fallingdotseq$ leaflet $>$ rachis in both varieties.

Exponential increases of the bark and pith dry weights with years ATF in Molat and Rotan were observed. The dry weights of bark and pith ranged from 11 to $153 \mathrm{~kg}$ and from 18 to $600 \mathrm{~kg}$ in Molat, respectively, and from 7 to $65 \mathrm{~kg}$ and 18 to $270 \mathrm{~kg}$ in Rotan, respectively, while showing a marked varietal difference after 
4 years of trunk formation. The average bark and pith dry weight values at the harvesting stage in Molat (141 and $581 \mathrm{~kg}$ ) were 2.6 and 2.7 times higher than that in Rotan (55 and $213 \mathrm{~kg}$ ), respectively (Table 11.2).

\subsection{Dry Matter Distribution Ratio to Each Part of Sago Palm}

Table 11.3 shows the dry weight ratio of each organ or part to the shoot weight of varieties Molat and Rotan based on the values in Table 11.2. In contrast to the dry weight differences of each organ or part between the two varieties, there were no

Table 11.3 Changes in dry weight percentage of each part of shoot of sago palm varieties after trunk formation in Kendari, Southeast Sulawesi, Indonesia

\begin{tabular}{|c|c|c|c|c|c|c|c|c|c|}
\hline \multirow[b]{2}{*}{ Variety } & \multirow{2}{*}{$\begin{array}{l}\text { Years } \\
\text { ATFF }^{a}\end{array}$} & \multicolumn{4}{|c|}{ Leaf $(\%)$} & \multicolumn{3}{|c|}{ Trunk (\%) } & \multirow[b]{2}{*}{ Shoot $(\%)$} \\
\hline & & Leaflet & Rachis & $\mathrm{P}+\mathrm{LS}^{\mathrm{b}}$ & Total & Bark & Pith & Total & \\
\hline \multirow[t]{14}{*}{ Molat } & 1 & 22.8 & 21.0 & 28.9 & 72.7 & 10.1 & 17.1 & 27.3 & 100.0 \\
\hline & 1 & 24.9 & 20.7 & 29.7 & 75.3 & 8.3 & 16.4 & 24.7 & 100.0 \\
\hline & 1 & 25.1 & 19.6 & 28.1 & 72.9 & 11.3 & 15.8 & 27.1 & 100.0 \\
\hline & 2 & 25.0 & 18.2 & 22.3 & 65.4 & 14.7 & 19.8 & 34.6 & 100.0 \\
\hline & 3.5 & 20.2 & 16.0 & 21.5 & 57.7 & 14.8 & 27.5 & 42.3 & 100.0 \\
\hline & 3.5 & 20.2 & 15.1 & 18.5 & 53.8 & 16.9 & 29.4 & 46.2 & 100.0 \\
\hline & 4 & 20.1 & 17.2 & 20.1 & 57.4 & 15.8 & 26.8 & 42.6 & 100.0 \\
\hline & 4 & 20.6 & 14.7 & 18.6 & 53.8 & 22.7 & 23.5 & 46.2 & 100.0 \\
\hline & 5 & 10.8 & 7.8 & 10.5 & 29.1 & 17.5 & 53.4 & 70.9 & 100.0 \\
\hline & 5.5 & 13.2 & 9.9 & 14.2 & 37.3 & 17.0 & 45.7 & 62.7 & 100.0 \\
\hline & 7 & 10.4 & 7.5 & 10.4 & 28.3 & 14.9 & 56.8 & 71.7 & 100.0 \\
\hline & 7 & 10.8 & 7.3 & 9.6 & 27.7 & 13.1 & 59.2 & 72.3 & 100.0 \\
\hline & 7 & 9.9 & 5.9 & 8.6 & 24.3 & 14.8 & 60.9 & 75.7 & 100.0 \\
\hline & Avg. & 10.3 & 6.9 & 9.6 & 26.8 & 14.2 & 59.0 & 73.2 & 100.0 \\
\hline \multirow[t]{10}{*}{ Rotan } & 1 & 26.2 & 16.9 & 28.5 & 71.5 & 7.8 & 20.7 & 28.5 & 100.0 \\
\hline & 1 & 27.0 & 16.7 & 25.1 & 68.7 & 11.6 & 19.6 & 31.3 & 100.0 \\
\hline & 1 & 25.3 & 15.5 & 27.8 & 68.7 & 13.5 & 17.9 & 31.3 & 100.0 \\
\hline & 3.5 & 16.9 & 11.9 & 16.3 & 45.1 & 20.1 & 34.8 & 54.9 & 100.0 \\
\hline & 3.5 & 16.2 & 11.4 & 15.6 & 43.2 & 17.7 & 39.1 & 56.8 & 100.0 \\
\hline & 4 & 16.4 & 12.3 & 17.3 & 46.0 & 20.7 & 33.3 & 54.0 & 100.0 \\
\hline & 5.5 & 11.0 & 7.8 & 10.0 & 28.8 & 15.7 & 55.5 & 71.2 & 100.0 \\
\hline & 6.5 & 10.6 & 7.7 & 10.0 & 28.3 & 14.8 & 56.9 & 71.7 & 100.0 \\
\hline & 7 & 7.4 & 6.0 & 7.0 & 20.4 & 14.9 & 61.8 & 76.8 & 100.0 \\
\hline & Avg. & 9.7 & 7.2 & 9.0 & 25.8 & 15.1 & 58.1 & 73.2 & 100.0 \\
\hline
\end{tabular}

${ }^{a}$ Years after trunk formation

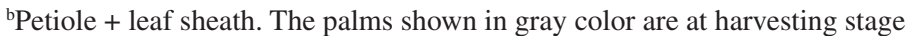

Source: Yamamoto et al. (2016) 
clear varietal differences in the changes of dry weight ratio of each organ or part to the shoot weight. The leaf and trunk weight ratio conversely changed showing 70-75 and $30-25 \%$ at trunk formation stage and 25-30 and 75-70\% at harvesting stage, respectively. The dry weight ratios were almost the same at 3-4 years after trunk formation; thereafter, the trunk ratio increased with years ATF, compared to the leaf ratio. These ratios at harvesting stage are similar to the results from sago palms growing in Sarawak, Malaysia (Flach and Schuiling 1991; Kaneko et al. 1996).

Moreover, the dry weight ratio of each part of leaf to the shoot dry weight decreased with years ATF. Petiole + leaf sheath dry weight decreased more rapidly than in the other two parts, due to the gradual shortening of the length with palm age (Yamamoto et al. 2014).

The dry weight ratio of bark in the trunk to the shoot dry weight in both varieties ranged from 10 to $20 \%$ and did not differ with palm age. On the other hand, the ratio of pith of both varieties ranged from $15-20 \%$ to $55-60 \%$ and increased with years ATF. The pith dry weight ratio at harvesting stage was about $60 \%$ in both varieties. This value is a little higher than that in sago palms grown in Sarawak, Malaysia (Kaneko et al. 1996). Moreover, the pith dry weight ratios to the trunk dry weights at the harvesting stage in both varieties were about $80 \%$. These results compared closely with those reported by Yatsugi (1977).

\subsection{Starch Content (Percentage) in Pith of Sago Palm}

Samples were collected from the sago palm varieties Molat, Tuni, and Rotan of various ages, each growing in research gardens. The age range of Molat palms was 1-10 years ATF, 1-8 years ATF for Tuni, and 1-7 years ATF for Rotan. Samples were collected from 18 Molat palms, 17 Tuni palms, and 14 Rotan palms. Of those, five Molat, four Tuni, and five Rotan palms were at the harvesting stage, which is characterized by flower bud formation and flowering (Yamamoto et al. 2010). Total sugar and starch content in the pith were analyzed following the method of Murayama et al. (1955).

The starch percentage (dry weight basis) in the pith in Rotan increased from 1 to 3 or 4 years ATF and in Molat and Tuni from 3 to 7 or 8 years ATF. The final starch percentage (at harvesting stage) was almost the same in the three varieties (60-70\%; dry starch weight/dry pith weight $\times 100$ ). The starch percentage in the pith of each variety showed a positive and negative significant correlation with the dry matter percentage and the total sugar percentage, respectively (Yamamoto 1998, 2006; Yamamoto et al. 2010).

\subsection{Starch Yield and Its Related Factors of Sago Palm}

The starch yields of three major varieties at harvesting stage were higher, in descending order, of Molat (425 kg/palm) > Tuni $(305 \mathrm{~kg} / \mathrm{palm})>$ Rotan $(142 \mathrm{~kg} / \mathrm{palm})$ (Yamamoto et al. 2010). The starch yields of Molat and Tuni were 3.0 and 2.1 times higher than that 
Table 11.4 Starch yield and dry matter production characters related to the yield

\begin{tabular}{l|l|l|l|l|l|l|l}
\hline Variety & $\begin{array}{l}\text { Shoot wt. } \\
(\mathrm{kg} / \text { palm })(\mathrm{a})\end{array}$ & $\begin{array}{l}\text { Trunk }^{\mathrm{a}} \text { wt. } \\
(\mathrm{kg} / \mathrm{palm})(\mathrm{b})\end{array}$ & $\begin{array}{l}\text { b/a } \\
(\%)\end{array}$ & $\begin{array}{l}\text { Trunk }^{\mathrm{a}} \text { pith } \\
\text { wt. }(\mathrm{kg})(\mathrm{c})\end{array}$ & $\begin{array}{l}\text { c/a } \\
(\%)\end{array}$ & $\begin{array}{l}\text { Starch } \\
(\%)^{\mathrm{b}}\end{array}$ & $\begin{array}{l}\text { Starch yield } \\
(\mathrm{kg} / \mathrm{palm})^{\mathrm{c}}\end{array}$ \\
\hline Molat & $985.5 \pm 42.7$ & $670.4 \pm 36.2$ & 68.0 & $543.6 \pm 26.3$ & 55.2 & $68.4 \pm 4.5$ & $371.8 \pm 18.0$ \\
\hline Rotan & $363.2 \pm 82.7$ & $230.0 \pm 46.7$ & 63.3 & $185.1 \pm 41.4$ & 51.0 & $69.0 \pm 2.4$ & $127.7 \pm 28.5$ \\
\hline
\end{tabular}

${ }^{a}$ Lower trunk portion from the node of lowest living leaf, which part is actually harvested for starch extraction in sago palm-growing areas

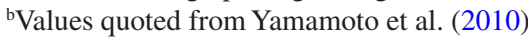

${ }^{\mathrm{c}}$ Calculated from the pith dry weight and the average starch percentage

of Rotan. Table 11.4 shows the starch yield and dry matter production characters related to the yield of both varieties. The results showed that the difference in starch yield between Molat and Rotan was based on the differences in the shoot, trunk, and pith biomasses and not on the ratios of harvested part and starch percentage in the pith.

\subsection{Conclusion}

Shoot biomass (aboveground part) of sago palm increased exponentially after trunk formation, and those at harvesting stage (flower bud formation-flowering stages) showed a greater difference between the varieties Molat and Rotan. The shoot biomass was mainly determined by the leaf area per plant, and it was primarily determined by the leaf area per leaf compared to the number of leaves. The differences in leaf area per leaf between the two varieties were closely related to the width of leaflet compared to the number of leaflet and leaflet length.

The dry weight ratio of each organ or part of sago palm shoot after trunk formation was not very different between the two varieties. The dry weight ratios of leaf and trunk to the shoot weight decreased and increased with aging, respectively, and the pith ratio of harvesting trunk was about $60 \%$.

The starch yields of Molat were three times greater than that of Rotan, and the yield differences were mainly based on the differences in shoot biomass.

The results presented above reveal that varietal differences in dry matter production based on leaf area provide useful information to establish the best methods of cultivation of sago palm and the leaf and leaflet traits may be useful as a selection trait to breed new high-yielding varieties. 


\section{References}

Flach M (1977) Yield potential of the sago palm and its realization. In: Tan K (ed) Sago '76: papers of the 1st international sago symposium: the equatorial swamp as a natural resource. University of Malaya, Kuala Lumpur, pp 157-177

Flach M, Schuiling DL (1991) Growth and yield of sago palms in relation to their nutritional needs. In: Ng TT, Tie YL, Kueh HS (eds) Towards greater advancement of the sago industry in the '90s: proceedings of the 4th international sago symposium. Kuching, Sarawak, pp 103-110

Kaneko T, Okazaki M, Kasai N et al (1996) Growth and biomass of sago palm (Metroxylon sagu) on shallow peat soils of Dalat District, Sarawak. Sago Palm 4:21-24

Miyazaki A, Yamamoto Y, Omori K et al (2007) Leaf photosynthetic rate in sago palms (Metroxylon sagu Rottb.) grown under field conditions in Indonesia. Japan J Trop Agric 51:54-58

Murayama N, Yoshino M, Oshima M et al (1955) Studies on the accumulation process of carbohydrates associated with growth of rice plant. Bull Nat Inst Agric Sci Japan Series B 4:123-166. (in Japanese)

Nakamura S, Nitta Y, Goto Y (2004) Leaf characteristics and shape of sago palm (Metroxylon sagu Rottb.) for developing a method of estimating leaf area. Plant Prod Sci 7:198-203

Nakamura S, Nitta Y, Watanabe M, Goto Y (2005) Analysis of leaflet shape and area for improvement of leaf area estimation method for sago palm (Metroxylon sagu Rottb.) Plant Prod Sci $8: 27-31$

Nakamura S, Nitta Y, Watanabe M, Goto Y (2009) A method for estimating sago palm (Metroxylon sagu Rottb.) leaf area after trunk formation. Plant Prod Sci 12:58-62

Nitta Y, Matsuda T, Miura R et al (2005) Anatomical leaf structure related to photosynthetic and conductive activities of sago palm. In: Karafir YP, Jong FS, Fere VE (eds) Sago palm development and utilization: proceedings of the 8th international sago symposium. Universitas Negeri Papua Press, Manokwari, pp 105-112

Omori K, Yamamoto Y, Nitta Y et al (1999) Differences of stomatal density by palm ages and varieties in sago palm (Metroxylon sagu Rottb.). In: Proceeding of the 8th conference of the society of sago palm studies, pp 10-15 (in Japanese)

Omori K, Yamamoto Y, Nitta Y et al (2000) Stomatal density of sago palm (Metroxylon sagu Rottb.) with special reference to positional differences in leaflets and leaves, and change by palm age. Sago Palm 8:2-8

Uchida N, Kobayashi S, Yasuda T, Yamaguchi T (1990) Photosynthetic characteristics of sago palm, Metroxylon rumphii Martius. Japan J Trop Agric 34:176-180

Yamamoto Y (1998) Sago palm. Tropical agriculture series, tropical crop manual No. 25, Association for International Cooperation of Agriculture and Forestry, Tokyo (in Japanese)

Yamamoto Y (2006) Starch productivity of sago palm (Metroxylon sagu Rottb.) in Indonesia and Malaysia. Japan J Trop Agric 50:234-237. (in Japanese)

Yamamoto Y (2011) Starch productivity of sago palm and the related factors. In: Siregar IS, Sudaryanto T, Ehara $\mathrm{H}$ et al (eds) Sago for food security, bio-energy, and industry, from research to market: Proceeding of the 10th international sago symposium, Bogor, pp 9-15

Yamamoto Y (2016) Matter production as a basis of starch production in sago palm (Metroxylon sagu Rottb.). In: Ehara H, Toyoda Y, Mishima T et al (eds) Proceeding of the 12th international sago symposium, Tokyo, pp 1-5

Yamamoto Y, Katayama K, Yoshida T et al (2006) Changes of leaf characters with ages in two sago palm varieties grown near Jayapura, Papua state, Indonesia. In: Proceedings of the 15 th conference of the society of sago palm studies, pp 1-4 (in Japanese)

Yamamoto Y, Rembon FS, Omori K et al (2010) Growth characteristics and starch productivity of three varieties of sago palm (Metroxylon sagu Rottb.) in Southeast Sulawesi, Indonesia. Trop Agric Devel 54:1-8

Yamamoto Y, Omori K, Nitta Y et al (2014) Changes of leaf characters in sago palm (Metroxylon sagu Rottb.) after trunk formation. Trop Agric Devel 58:43-50 
Yamamoto Y, Omori K, Nitta T et al (2016) Dry matter production and distribution after trunk formation in sago palm (Metroxylon sagu Rottb.) Trop Agric Devel 60:71-80

Yatsugi T (1977) Sago starch. In: Nakamura M, Suzuki S (eds) Starch science handbook. Asakura Shoten, Tokyo, pp 404-410. (in Japanese)

Yoshida T, Omori K, Yamamoto Y et al (2000) Mineral contents in leaf and pith of three varieties grown in Kendari, Southeast Sulawesi, Indonesia. In: Proceeding of the 9th conference of the society of sago palm studies, pp 23-30 (in Japanese)

Open Access This chapter is licensed under the terms of the Creative Commons Attribution 4.0 International License (http://creativecommons.org/licenses/by/4.0/), which permits use, sharing, adaptation, distribution and reproduction in any medium or format, as long as you give appropriate credit to the original author(s) and the source, provide a link to the Creative Commons license and indicate if changes were made.

The images or other third party material in this chapter are included in the chapter's Creative Commons license, unless indicated otherwise in a credit line to the material. If material is not included in the chapter's Creative Commons license and your intended use is not permitted by statutory regulation or exceeds the permitted use, you will need to obtain permission directly from the copyright holder. 


\title{
Chapter 12 \\ Morphogenesis of Sago Palm
}

\author{
Satoshi Nakamura
}

\begin{abstract}
Suckers are normally used for sago palm propagation. The stem of a transplanted sucker elongates in a horizontal direction on the ground, producing leaves in the first 4-5 years after transplanting (the rosette stage). During the rosette stage, transplanted suckers produce large numbers of daughter suckers which develop from lateral buds. The lateral bud of sago palm (sucker bud) differentiates on the opposite side of the axil. In the suckers for transplantation, detailed observation of the differentiation position and the development of the sucker bud showed that the sucker bud differentiates inside near the connate part of the leaf petiole. This is also the part that is gradually split as new leaves emerge and the stem enlarges. In the lower leaf position from rbL 6, which is the sixth leaf from the youngest leaf primordium, there were only one sucker bud and two sucker buds on leaf positions of $30.1 \%$ and $68.1 \%$, respectively. Sago palm has reduplicate leaves; however, little has been reported on the leaf formation process of sago palm. The youngest visible leaf, a spear leaf, contains a number of folded leaflets and these open as the plant grows. Observation of the cross section of a spear leaf after trunk formation and the unemerged young leaves during rosette stage showed that the midribs of leaflet are on the adaxial side, and the edges of leaflet are on the abaxial side. When splitting occurs along the abaxial ribs, leaflets that are $\Lambda$-shaped in section form. These suggest that splitting would occur along the abaxial ribs in sago palm. An approximately 8-year observation of the stem length in the creeping part of transplanted suckers revealed that the creeping part length increased exponentially from transplantation to around 4 years, thereafter, and gradually increased slowly. As a result of growth analysis for creeping elongation of the sucker stem, the maximum elongation rate was estimated as $0.38 \mathrm{~m}$ per year at YAT 3.8.
\end{abstract}

S. Nakamura $(\square)$

School of Food Industrial Science, Miyagi University, Sendai, Japan

e-mail: nakamurs@myu.ac.id 


\subsection{Introduction}

Sago palm (Metroxylon sagu Rottb.), which accumulates a large amount of starch in its trunk, is a hapaxanthic palm which dies after flowering. Generally, the suckers emerging from the base of stem are used for propagation. The stem of transplanted sucker elongates in a horizontal direction on the ground, producing leaves in the first 4-5 years after transplanting. During this period, called the rosette stage, the size of the leaves and stem increases gradually (Fig. 12.1a-c). After the rosette stage, the stem elongates from a horizontal direction to the vertical direction, swelling up at the bottom part with leaves attached (trunk formation), and the trunk (stem) then elongates vertically (Fig. 12.1d, e). The trunk is harvested during the time from just before flower initiation to flowering because the amount of starch accumulated in the trunk decreases thereafter due to the development of the inflorescence and fruit. Although the period for harvest differs by cultivated regions, varieties, and rate of growth, sago palm takes over 10 years from transplantation to the first harvestable trunk. In recent years, sago palm has received much attention as a starch crop for use not only as food but also an industrial raw material; however, the morphogenesis of sago palm is still incompletely understood. This chapter describes recent research on the suckers, leaves, and stem in the morphogenesis of sago palm.

\subsection{Suckers}

Suckers are normally used for sago palm propagation (Sato et al. 1979). The suckers, cut from mature stems which are creeping horizontally, are grown as seedlings for about 6 months in a nursery and then transplanted into the field. During the rosette stage, transplanted suckers produce large numbers of daughter suckers which develop from lateral buds (Fig. 12.1b). In sago palm cultivation, thinning of daughter suckers in the clump is performed (sucker control) to regulate the density of the suckers. If all of daughter suckers grow well, the clump would become rampant with growth, and the suckers would have a negative influence on each other, resulting in reduction of starch productivity. Nabeya et al. (2013) reported that a farmer in Sarawak, Malaysia, not only has regulated the sucker density in the clump by pruning leaves of daughter suckers to suppress their growth but also has made observations of clumps consisting of suckers at different growing stages, the direction of the creeping growth, and the position of the trunk at harvest time. Yanagidate et al. (2009) suggested that proper cultivation techniques to maintain a suitable trunk density of different trunk lengths (ages) by appropriate sucker thinning should be established to achieve stable annual starch production per unit area, based on investigations in Southeast Sulawesi Province, Indonesia. 

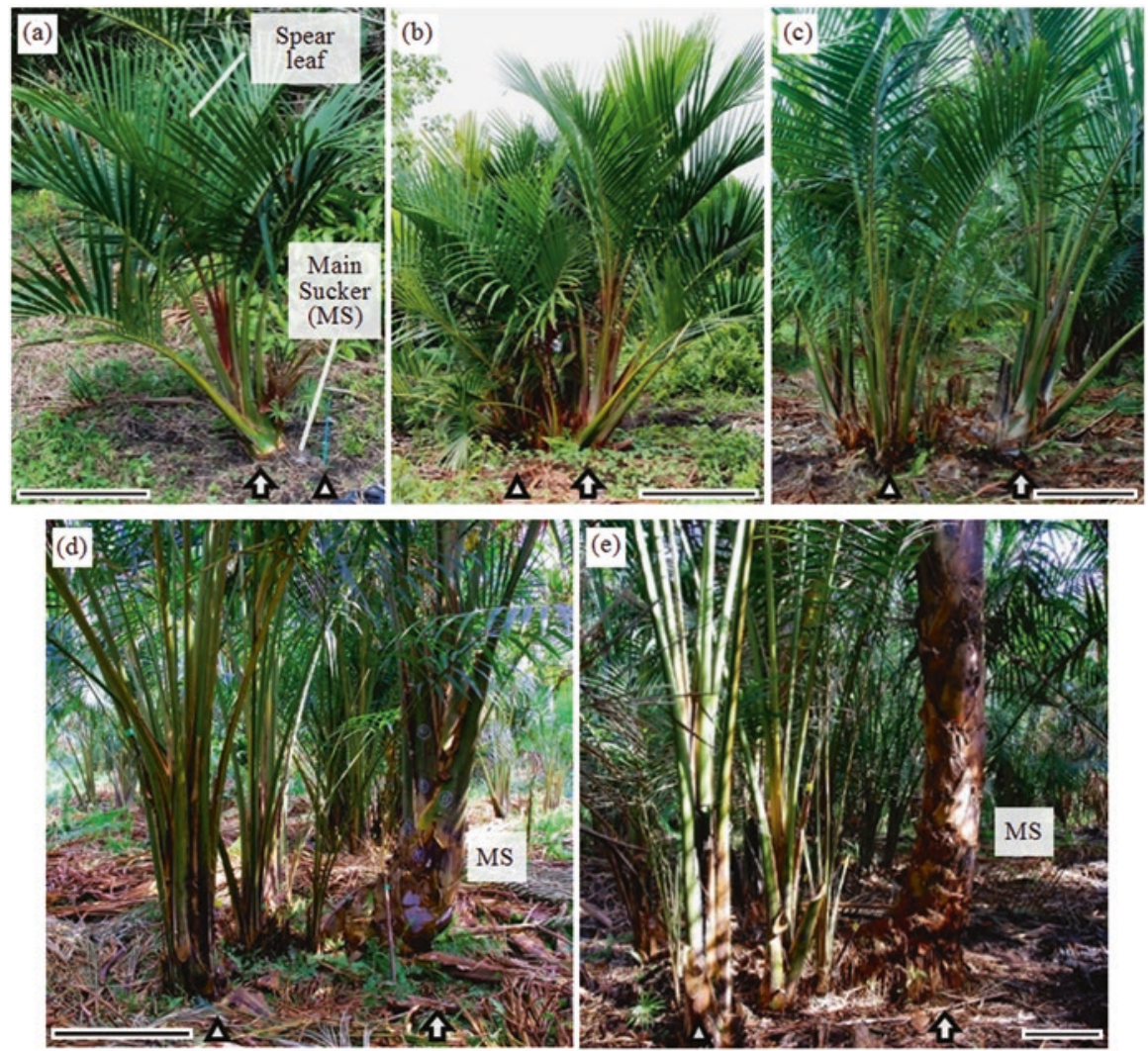

Fig. 12.1 A sago palm without spines. (a) 1 year after transplantation (YAT 1), (b) YAT 2.9, (c) YAT 4.8, (d) YAT 5.8, and (e) YAT 7.8 in Sarawak, Malaysia. The triangle shows the transplanting position. The arrow indicates the position of the estimated growth point. The stem length in the creeping part was defined as the horizontal distance from the growth point judged by the appearance to the transplanting position. Bar $=50 \mathrm{~cm}(\mathbf{a}, \mathbf{e}), 1 \mathrm{~m}(\mathbf{b}-\mathbf{d})$ (From Nabeya et al. 2015d)

\subsubsection{Differentiation of Lateral Sucker Buds}

Although utilization and management of suckers are very important in sustainable sago palm cultivation, there are only a few reports about the presence and development of lateral buds from suckers. Goto et al. (1998) described how the lateral bud of sago palm (sucker bud) differentiates on the opposite side of the axil, unlike many plants. Fisher and Dransfield (1979) reported that the lateral bud of rattan palms Daemonorops spp. and Korthalsia rigida differentiated on the opposite side to the axil and named it a leaf-opposed bud.

Nabeya et al. (2015b) reported in detail the differentiation position and the development of the lateral bud of the sago palm sucker for transplantation. In sago palm, since the lower part of the petiole (leaf sheath) wraps around the stem, the part of 

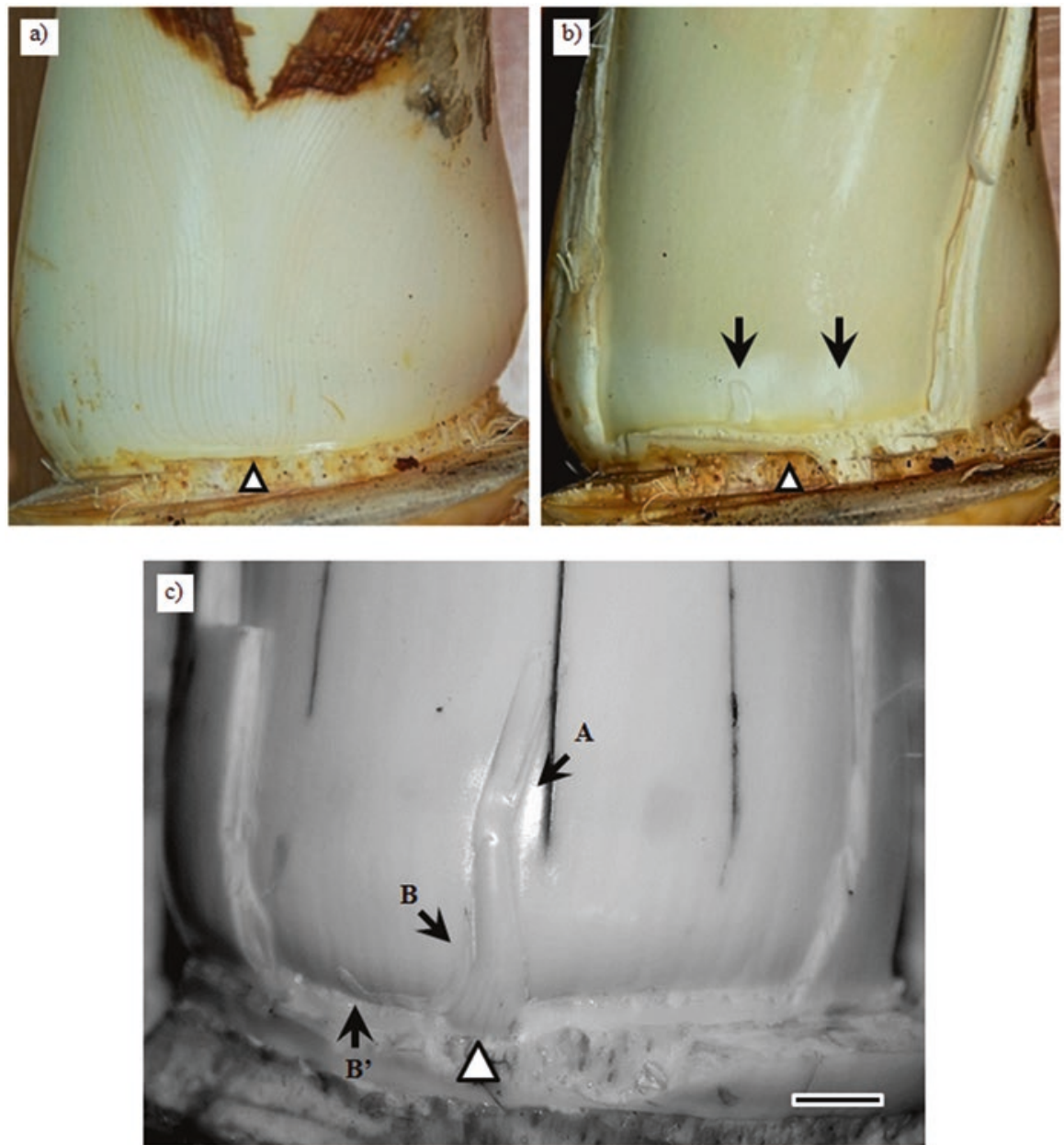

Fig. 12.2 Connate part of both edge of the leaf petiole. (a) The connate part of the leaf petiole. (b) Sucker removed connate part of the leaf petiole presented in (a). The triangle denotes the reference point. Two sucker buds differentiated inside of the connate part of the leaf petiole and near the reference point. (c) A sucker bud greatly developed. Sucker bud $(A)$ differentiated at the reference point and developed greatly. Sucker bud $(B)$ differentiated at the position $\mathrm{B}^{\prime}$ and elongated narrowly. The triangle denotes the reference point. Bar $=10 \mathrm{~mm}$ (From Nabeya et al. 2015b)

the petiole attaching to the stem appears to be a node-like ring after removal of the petiole (Fig. 12.2a). At the connate part of the leaf petiole, following the vascular bundle along both edges of the petiole to the base, the two bundles fuse into one near the base. The sucker bud differentiates near the reference point which is inside the connate part of the leaf petiole (Fig. 12.2b). This is also the part that is gradually split as new leaves emerge and the stem enlarges. To investigate the differentiation of the sucker bud, the youngest leaf primordium, in which the tip of the hoodlike 
leaf was beyond the tip of growth point, was assumed to be rbL 1 (relative basipetally Leaf 1) and sequentially rbL 2, rbL 3, and so on (Nabeya et al. 2015b). Sucker buds which differentiated inside of $\operatorname{rbL} n$, outside of $\operatorname{rbL~} n$ - 1 , were regarded as $\mathrm{rbS}$ $n$. As a result of investigations, the sign of differentiation of $\operatorname{rbS} 1$ and $\operatorname{rbS} 2$ was not visible, but the swelling of tissue of $\mathrm{rbS} 3$ and $\mathrm{rbS} 4$ was visible in $13.6 \%$ and $77.3 \%$ of investigated suckers, respectively. The initiation of sucker bud of rbS 5 was visible in all of the investigated suckers; the sucker bud was visible in almost all of leaf position after rbL 5. In the lower leaf positions from rbL 6, only one sucker bud differentiated in a leaf position $30.1 \%$, and there were two sucker buds and three sucker buds on leaf positions of $68.1 \%$ and $1.8 \%$, respectively. In Plectocomia elongata, the instance of multiple vegetative buds differentiated in a leaf position was reported by Fisher and Dransfield (1979). In P. elongata, vegetative buds appear, one to ten, as small swellings in a node, and become multiple branches. By contrast, in sago palm, a small swelling occurred and then differentiated into two sucker buds (Nabeya et al. 2015b). An instance of both sucker buds developing and appearing from a leaf position has not yet been observed in our investigations.

\subsubsection{Development of Sucker Buds}

It is not clear as to when and how sucker buds develop after differentiation and emerge from the leaf sheath. Nabeya et al. (2015b) reported that both the length and width of sucker buds from rbS 6 to rbS 13 increased exponentially in suckers for transplantation. In the lower leaf position from rbS 11, some sucker buds, greatly developed in length and width, were observed (Fig. 12.2c). The large sucker buds were about $7.0 \%$ of all sucker buds from rbS 11 to rbS 13, and the length and the width near the base were $28.7 \pm 10.8$ and $5.5 \pm 2.0 \mathrm{~mm}$ on average, respectively. Some sucker buds that only increased in length but not in width were also observed from $\mathrm{rbS} 11$ to rbS 13. Most of these sucker buds elongated in a meandering fashion like the one (B) shown in Fig. 12.2c.

A number of suckers emerge from the stem when it is elongating in a horizontal direction; however, few suckers emerge from the trunk, elongating in a vertical direction. Differentiation and development of sucker buds may be related to gravitational direction. Further studies are required to clarify the development and emergence of sucker buds.

\subsection{Leaf}

The leaf, which is the distinguishing character of the palm, has three components: a sheathing base (a leaf sheath), a petiole, and a blade (Dransfield et al. 2008; Tomlinson 1990). Palm leaf blades are fundamentally of two types: pinnate or palmate (Dransfield et al. 2008). The sago palm has large compound pinnate leaves 
which have many leaflets attached to an elongated rachis. The leaflets range in shape from linear lanceolate to narrow lanceolate. The leaf sheath is the extended base of the petiole, which wraps around the trunk and fuses on both ends (Fig. 12.2a). This fused state is observable from the leaf primordium stage, but no morphological boundaries between the petiole and leaf sheath are found on the adaxial or abaxial sides of the petiole (Goto and Nakamura 2004). The leaf sheath has two types: bearing spines on the abaxial surface of the petiole and spineless. The leaf sheath remains attached to the stem (trunk) after the leaf dies (Fig. 12.1c-e).

The youngest visible leaf, which has a pointed stick, forms and emerges along a groove running longitudinally in the petiole of the previous leaf and is called a spear leaf (Fig. 12.1a) (Jones 1995; Tomlinson 1990). A spear leaf contains a number of folded leaflets and these open as the plant grows. When a spear leaf opens, a cordlike tissue connects the tips of leaflets as if to trace the outline of the leaf and then falls away, or breaks up, leaving individual leaflets fully independent (Goto and Nakamura 2004). Sago palm reportedly has a phyllotaxis of 4/13 and a divergence angle of $110.77^{\circ}$ (Jong 1991). Sago palm has a dextrorse or a sinistrorse phyllotaxis, depending on the plant.

\subsubsection{Leaf Characteristics in the Rosette Stage}

Sago palm leaf size increases as the plant grows during the rosette stage (Fig. 12.1). Figure 12.3 exemplifies a sago palm 3.3 years after transplantation and leaf characteristics in the rosette stage (Nakamura et al. 2009). This plant has 16 leaves including a spear leaf and one dead leaf. The spear leaf provides a convenient marker for growth research. The position of the spear leaf, the emerging youngest leaf, is labeled as ebL 1, and the leaves thereafter are labeled basipetally as ebL 2, ebL3, and so on (Fig. 12.3a). Concerning the position of unemerged leaf, the leaf position immediately above (inside) ebL 1 is $\mathrm{uL} 1$, and the positions further up (inside) are labeled acropetally uL 2, uL3, and so on. The leaf length ranged from 2.96 (ebL16) $\mathrm{m}$ to $5.37 \mathrm{~m}$ (ebL3) (Fig. 12.3b). The leaf length of ebL 2 was shorter than that of ebL3 because the petiole of ebL 2 was elongating and did not reach its final length. The number of leaflets per leaf ranged from 62 (ebL16) to 86 (ebL2). In regard to unexpanded leaves, the leaf blade of $\mathrm{uL} 2$ started to elongate rapidly (Fig. 12.3c) and would reach its final length by the time the position of the leaf becomes ebL2. Although the leaf petiole of ebL 1 could not be measured due to the invisible position at which the lowest leaflet attached, the petiole of ebL 1 would start to elongate rapidly and reach its final length by the leaf position of ebL 3 . These results suggested that emergence of a spear leaf (ebL 1) should be attributed to the elongation of the leaf blade and petiole during the rosette stage. After trunk formation, the leaf blade elongated to its final length during the period, from the leaf position of uL 3 to that of ebL 1 , and the leaf petiole elongates rapidly at the position of ebL 1 (Nakamura et al. 2015). 


\subsubsection{Development of Leaflets}

The Arecaceae family includes palms with induplicate leaves such as in the date palm and with reduplicate leaves such as in the coconut palm. In leaves with induplicate segmentation, the leaflets are $\mathrm{V}$-shaped in transverse section with the singlefold abaxial; in leaves with reduplicate segmentation, they are $\Lambda$-shaped with the single-fold adaxial (Tomlinson 1990). Sago palm has reduplicate leaves (Goto and Nakamura 2004); however, little has been reported on the leaf formation process of sago palm.

Figure 12.4 represents the cross section of the lower part of a spear leaf after trunk formation and unemerged young leaves of the sago palm shown in Fig. 12.3. The midribs of leaflet are on the adaxial side and the edges of leaflet are on the abaxial side (Fig. 12.4a, b). When splitting occurs along the abaxial ribs, leaflets that are $\Lambda$-shaped in section form. These suggest that splitting would occur along the abaxial ribs in sago palm. A number of pleats with alternating ridges and furrows are observed in $\mathrm{uL} 2$ to $\mathrm{uL} 4$ (Fig. $12.4 \mathrm{c}, \mathrm{d}$ ). The midrib of leaflet might be

a )

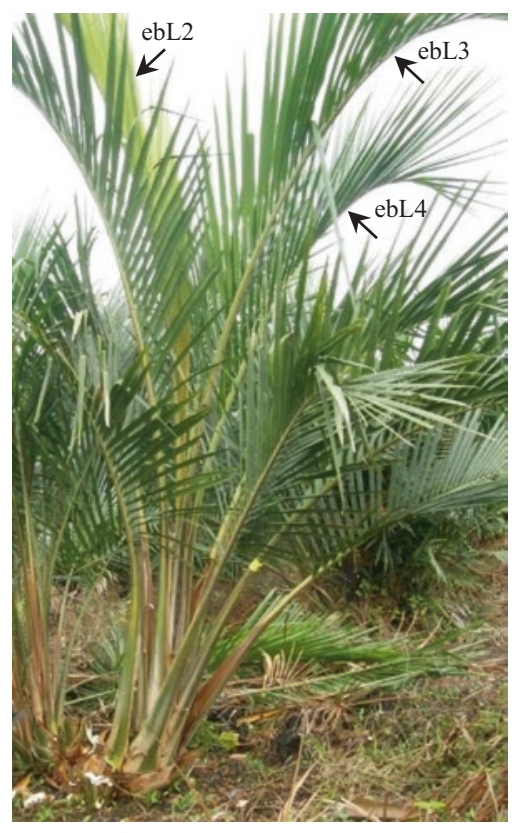

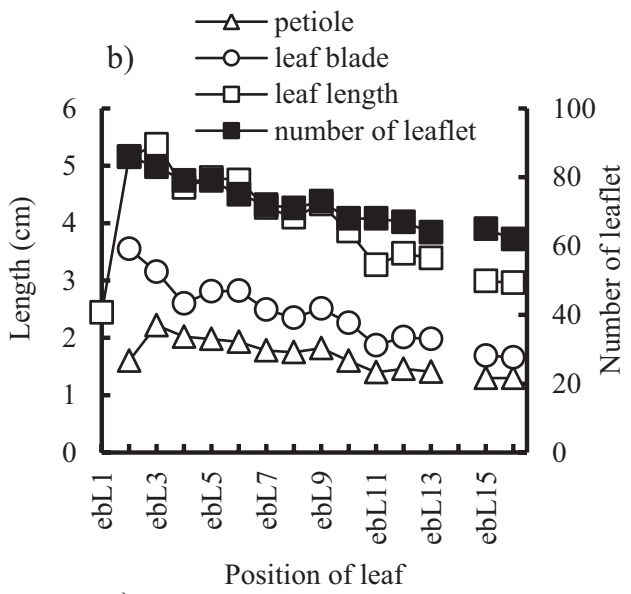

c)

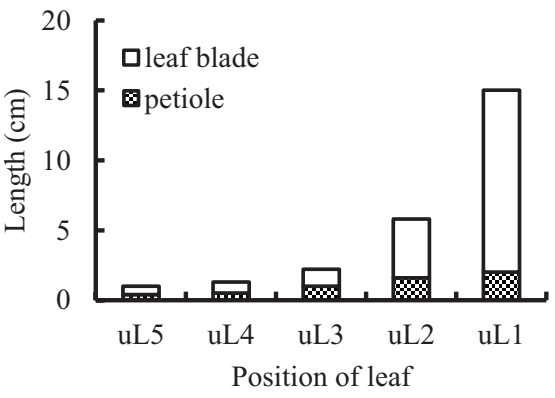

Fig. 12.3 (a) A sago palm with no spines 3.3 years after transplantation, (b) characteristics of expanded leaves, and (c) unexpanded leaves (From Nakamura et al. 2009) 

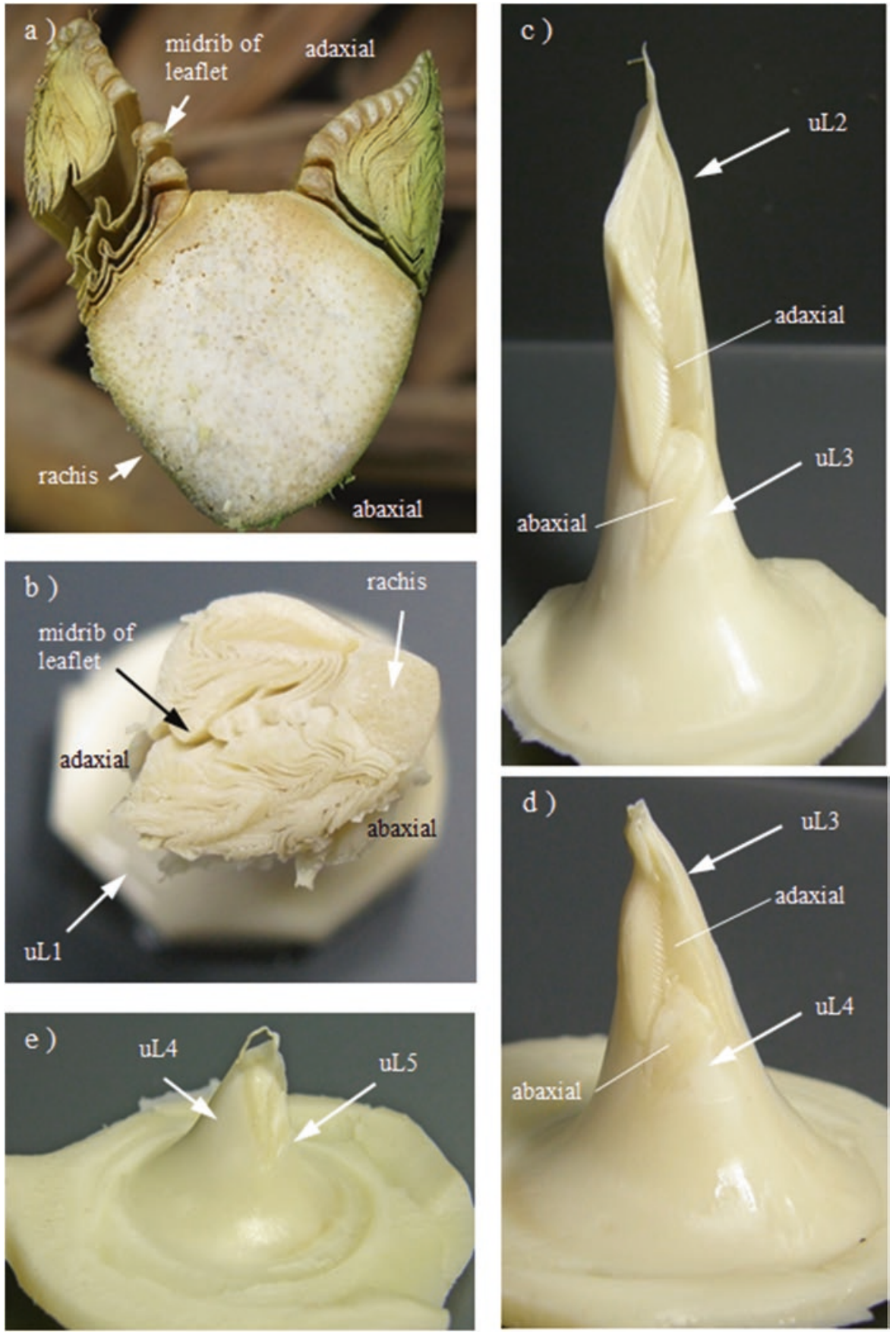

Fig. 12.4 Cross section of the lower part of a spear leaf of plant after trunk formation (a) uL1, (b) young leaves from uL2 to uL5, and (c-e) of the sago palm at rosette stage (shown in Fig. 12.3a) 
formed in the ridges on the adaxial side. Among the palms with pinnate compound leaves, Dengler et al. (1982) reported on the morphogenetic process in the early stage of leaflet formation in Chrysalidocarpus lutescens (=Dypsis lutescens). A similar morphogenetic process is expected to occur in sago palm. Further studies are needed for confirmation.

\subsubsection{The Number of Unemerged Leaves}

An understanding of the number of unemerged leaves is useful for growth analysis of sago palm. Flach and Schuiling (1989) reported that the number of unemerged leaves was 24 , which was the same as the number of green leaves in the crown, in the early stage of trunk formation. Nakamura et al. (2015) reported that the number of unemerged leaves of a tree with 15 emerged leaves 4 years after trunk formation was 18 and that of a tree with 17 emerged leaves 8 years after trunk formation was 19. Nabeya et al. (2015a) found that there was a close relationship between the diameter of the attached part of a spear leaf and the number of unemerged leaves of suckers of proper size for transplantation. This result suggests that the number of unemerged leaves inside a spear leaf increases with an increase of the diameter of the attached part of a spear leaf. The diameter of the attached part of a spear leaf may be an indicator of the unemerged leaves; however, further studies are needed on the details of leaf formation.

\subsection{Stem}

\subsubsection{Stem Formation During the Rosette Stage}

The stem of a transplanted sucker creeps in a straight line on the ground. The creeping direction remains the same later when the sucker is transplanted. According to observations of the longitudinal section of stem, morphological characteristics such as nodes are not recognized clearly (Nabeya et al. 2015d). Representing the nodal planes, which were estimated as the positions of attached leaves, the nodal planes coincided with an angle of about $40^{\circ}$ to the ground (Nabeya et al. 2015d). In other words, during the rosette stage, sago palm stems are formed by the horizontal line of thin disciform internodes with an angle of about $40^{\circ}$ to the ground. 


\subsubsection{Creeping Elongation of Sucker Stems}

It is important to know the creeping elongation rate of the stem and the distance from the transplanted position or the attached position to the mother stem to the trunk stand position in order to manage the density of a trunk stand properly. A few studies have focused on this. According to an approximately 8-year observation of the stem length in the creeping part of transplanted suckers by Nabeya et al. (2015c), the creeping part length increased exponentially from transplantation to around 4 years thereafter, and gradually increased slowly, suggesting that the growth curve was sigmoidal. The length from the transplanted position to the trunk stand position ranged from 1.62 to $2.05 \mathrm{~m}$ (avg. $1.81 \mathrm{~m}$ ) 7.8 years after transplantation (YAT 7.8) (Fig. 12.1). As a result of growth analysis for creeping elongation of the sucker stem, the maximum elongation rate was estimated as $0.38 \mathrm{~m}$ per year at YAT 3.8.

Nabeya et al. (2015c) also observed the growth of the derivative suckers such as primary suckers from the main sucker and secondary suckers from the primary suckers, finding that the creeping part length from the attached position to main stem to the trunk stand position was about $1.7 \mathrm{~m}$ away in the primary suckers which formed trunks. However, the elongation rate of the primary suckers which were in the rosette stage ranged from 0.11 to 0.14 m per year, and the increasing rate of leaf numbers of them was slower than the main suckers. As the main sucker forms a trunk and elongates vertically, the position of the crown is higher, implying that the amount of sunlight that the derivative suckers receives decreases. The low elongation rate and the low increasing rate of leaf numbers of these suckers could be attributed to the low sunlight due to crown shading of main suckers which formed a trunk. Further studies on the growth of not only main suckers but also derivative suckers are needed to establish the sustainable cultivation of sago palm with high starch productivity.

\section{References}

Dengler NG, Dengler RE, Kaplan DR (1982) The mechanism of plication inception in palm leaves: histogenetic observations on the pinnate leaf of Chrysalidocarpus lutescens. Can J Bot 60:2976-2998

Dransfield J, Uhl NW, Asmussen CB et al (2008) The structure of palms. Genera palmarum: the evolution and classification of palms. Kew Publishing, Kew, pp 1-39

Fisher JB, Dransfield J (1979) Development of axillary and leaf-opposed buds in rattan palms. Ann Bot 44:57-66

Flach M, Schuiling DL (1989) Revival of an ancient starch crop: a review of the agronomy of the sago palm. Agrofor Syst 7:259-281

Goto Y, Nakamura S (2004) Forms of sago palm leaf. Sago Palm 12:24-27

Goto Y, Nitta Y, Kakuda K et al (1998) Differentiation and growth of suckers in sago palms (Metroxylon sagu Rottb.) Jpn J Crop Sci 67(Extra issue 1):212-213. (in Japanese)

Jones DL (1995) Palms throughout the world. Smithsonian Institution Press, Washington, DC 
Jong FS (1991) A preliminary study on the phyllotaxy of sago palms in Sarawak. In: Ng TT, Tie YL, Kueh HS et al (eds) Towards greater advancement of the sago industry in the '90s: proceedings of the 4th international sago symposium. Lee Ming Press, Kuching, pp 69-73

Nabeya K, Nakamura S, Akama M et al (2013) Analysis of effects of the sucker-control in the sago palm (Metroxylon sagu Rottb.) cultivation. In: Proceedings of 2nd ASEAN sago symposium, pp 50-52

Nabeya K, Nakamura S, Fujii A, Goto Y (2015a) The number of unemerged leaves in young sucker of sago palm. In: Proceedings of 8th Asian crop science association conference, pp 116-117

Nabeya K, Nakamura S, Goto Y (2015b) The position and the development of differentiated lateral bud in sago palm (Metroxylon sagu Rottb.) Plant Prod Sci 18(4):435-442

Nabeya K, Nakamura S, Goto Y (2015c) Growth of derivative suckers compared with main stem in sago palm. In: Proceedings of the 12th international sago symposium. (in press)

Nabeya K, Nakamura S, Nakamura T, Fujii A, Watanabe M, Nakajima T, Nitta Y, Goto Y (2015d) Growth behavior of sago palm (Metroxylon sagu Rottb.) from transplantation to trunk formation. Plant Prod Sci 18(2):209-217

Nakamura S, Nitta Y, Watanabe M, Goto Y (2009) Stem formation of sago palm (Metroxylon sagu Rottb.) before trunk formation. In: Proceedings of the 18th conference of the Society of Sago Palm Studies, pp 43-46 (in Japanese)

Nakamura S, Watanabe M, Goto Y (2015) Leaf formation and development. In: Sago palm: the food and environmental changes of the 21st century. Kyoto University Press and Trans Pacific Press, pp 104-109

Sato T, Yamauchi T, Takamura T (1979) Cultivation, harvesting and processing of sago palm. Jpn J Trop Agr 23:130-136. (in Japanese)

Tomlinson PB (1990) The structural biology of palms. Clarendon Press, New York

Yanagitate I, Rembon FS, Yoshida T et al (2009) Studies on trunk density and prediction of starch productivity of sago palm (Metroxylon sagu Rottb.): a case study of a cultivated sago palm garden near Kendari, Southeast Sulawesi Province, Indonesia. Sago Palm 17:1-8

Open Access This chapter is licensed under the terms of the Creative Commons Attribution 4.0 International License (http://creativecommons.org/licenses/by/4.0/), which permits use, sharing, adaptation, distribution and reproduction in any medium or format, as long as you give appropriate credit to the original author(s) and the source, provide a link to the Creative Commons license and indicate if changes were made.

The images or other third party material in this chapter are included in the chapter's Creative Commons license, unless indicated otherwise in a credit line to the material. If material is not included in the chapter's Creative Commons license and your intended use is not permitted by statutory regulation or exceeds the permitted use, you will need to obtain permission directly from the copyright holder. 


\title{
Chapter 13 \\ Morphological and Anatomical \\ Characteristics of Sago Palm Starch
}

\author{
Yoji Nitta
}

\begin{abstract}
Amyloplasts, in which starch granules accumulate, are formed near the apical portion of sago palm stems. Amyloplast separation and division occur abundantly and specifically in the apical portion and in the basal stem during the middle and even in the late growth stage. Because of those separations and divisions, amyloplast sizes differ greatly among varieties and stem portions within a plant. The numbers of amyloplasts in the cross-sectional area of the parenchyma tissue also differ among cultivars. Generally, a stem parenchyma cell has 10-30 amyloplasts. Most amyloplasts are egg-like structures with a smooth surface. Still, the sago palm starch grain size is situated in the middle of grain sizes of 54 examined plant species. Furthermore, intercellular spaces are large in sago palm stem tissue, accounting for nearly $40-50 \%$ of their total space. This specific feature is a causal factor supporting the starch yield. These results suggest that the separation and division, amyloplast shape, amyloplast size diversity, and large intercellular spaces are specific to sago palm stems. Moreover, intercellular spaces are large in stem tissue, which might be a factor strongly affecting the starch yield.
\end{abstract}

\subsection{Introduction}

In higher plants, starch accumulation features are widely diverse among species, cultivars, and varieties, as are storage organs such as seeds, grains, roots, and stems. In the case of sago palm, great amounts of starch are accumulated in parenchyma cells in the stem (trunk). Within the stem, starch accumulates in cell organelles, called amyloplasts, in the center of ground parenchyma.

Many crops produce and accumulate starches. However, starch storage organs differ among crops: (A) grains are used by rice, wheat, corn (maize), barley, and other cereal crops; (B) tubers are used by potato, Jerusalem artichokes, and arrowroot; (C) tuberous root are used by sweet potato, cassava, dahlia, and snake gourd plants; and (D) other organs are used by lotus and banana plants.

Y. Nitta $(\square)$

The College of Agriculture, Ibaraki University, Ami, Ibaraki, Japan

e-mail: youji.nitta.cs@vc.ibaraki.ac.jp 
Regarding starch accumulation in an amyloplast, if starch grains accumulate there, they are called simple starch grains such as sago palm stems, potato tubers, and yam tubers. If multiple starch grains accumulate in an amyloplast, the starch accumulation is called compound starch grains such as rice grains, taro tubers, and sweet potato tuberous roots.

For cereal crops, accumulation features of stored substances such as starches, proteins, and lipids have been investigated intensively, suggesting that starch accumulation features are widely diverse among species, cultivars, and varieties as well as growing area, culturing methods, and environmental conditions. Starch accumulation features of sago palm stem are also diverse.

As described in this paper, morphological and anatomical characteristics of starch accumulation features in sago palm stem are explained using a specific method and procedures with electron microscopy.

\subsection{Research Methodology}

Observation using scanning electron microscopy requires specific procedures because plant tissues, cells, and starches in parenchyma cells have an artifact structure during material preparation for observations and require charged viewing during observation. General preparation procedures for observation by scanning electron microscopy include the following: dissection of stem portions of small volumes ( $5 \mathrm{~mm}$ length $\times 5 \mathrm{~mm}$ width $\times 2 \mathrm{~mm}$ thickness $)$ is preferred for materials. They are subjected to rapid freezing using slush nitrogen $\left(-210{ }^{\circ} \mathrm{C}\right)$ followed by vacuum freeze-drying $\left(-60^{\circ} \mathrm{C}, 10^{-3} \mathrm{~Pa}\right)$ (Matsuda 2003). Subsequently, the revealed cross-sections were coated by $\mathrm{OsO}_{4}$ and/or platinum. In our laboratory, we use a scanning electron microscope (JSM6360A; JEOL, Japan). Cell and/or tissue crosssectional areas are also measured using a personal computer with specific software (WinROOF; Mitani Corp., Japan).

This paper presents a summary of observation results obtained using several materials as follows.

(A) Varieties Rotan, Tuni, and Molat were collected in Kendari, Southeast Sulawesi, Indonesia, in August 1999.

(B) Plants of 2 years after trunk formation (YATF) were collected in Mukah, Sarawak, Malaysia, in July 2001.

(C) Varieties were Wani (17-18 years YATF), Ruruna (20 YATF), Folo (20 YATF), Yepha Hongleu (18 YATF), Pane (20 YATF), Osukul (17-18 YATF), Para Hongleu (17-18 YATF), Rondo (12 YATF), Manno, Para Waliha, Yepha Hongleu, Rondo, Ruruna, and Para Hongleu. They were collected in the neighboring region of Lake Sentani, Papua Province, Indonesia.

(D) Sucker. Collected from a four YATF plants in Mukah, Sarawak, Malaysia, in July 2008. 
(E) Stem. Collected at the Municipal Agriculture Training Center in Burauen, Leyte Province, Philippines, in July 2007.

Furthermore, potato tubers, Chinese yam tubers, wheat grains, edible canna tubers, rice grains, sweet potato tuberous roots, and eddoe tuberous roots were used derived from our laboratory collection.

\subsection{Morphological and Anatomical Features of Sago Palm Stems and Starch}

\subsubsection{Internal Structure of Sago Palm Stem}

In sago palm, starch is accumulated in parenchyma cells in the stem.

Monocotyledonous plants, like the sago palm, have no interfascicular cambium for secondary thickening and growth. Sago palm stem thickening depends solely on its primary growth and moreover has great ability and activity for thickening and growth from their apical portion to the base.

The sago palm stem encloses large intercellular spaces (Fig. 13.1) (Nakayama et al. 2007; Warashina et al. 2007). The percentage of intercellular spaces in the cross-sectional area of stem parenchyma is as great as 40-50\%. Scanning electron microscope observation revealed that intercellular spaces are formed by surrounding six to eight parenchyma cells in the apical part of the stem (Fig. 13.1). A honeycomb structure produced by surrounding parenchyma cells was also observed, indicating the physical strengthening of the stem structure.
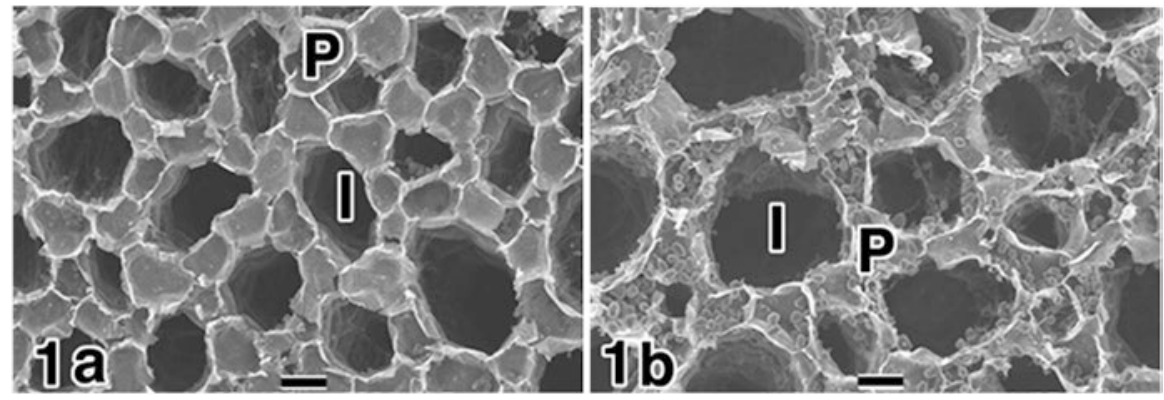

Fig. 13.1 Scanning electron micrographs of parenchyma and intercellular spaces of sago palm stem: (a) apical meristem portion, (b) middle position of stem, $P$ parenchyma, $I$ intercellular space, Bar: $10 \mu \mathrm{m}$ (Source: Nakayama et al. 2007) 


\subsubsection{Starch Accumulation Structure in Sago Palm Stem}

In higher plants, starch granules accumulate in amyloplasts. Jong (1995) measured the long axes of amyloplasts in parenchyma cells of sago palm stem from after the trunk formation stage to the full trunk growth stage and the fruit ripening stage and reported that amyloplasts are longer at later stages of development. According to Ogita et al. (1996), amyloplasts within the stem parenchyma aged 3, 5, 8, and 13 years showed differences with increased age. They found that the major axis of the amyloplast was 5-20 $\mu \mathrm{m}$ in 3-year-old palms, $20-30 \mu \mathrm{m}$ in 5-year-old palms, and greater than $30 \mu \mathrm{m}$ in 8 -year-old palms or 13-year-old palms. Kawasaki (1999) and Kawakami (1975) reported that when sago palm amyloplasts are compared with simple starch grains (simple starch grain type as described above) in other plants, they are larger than those in wheat (secondary starch granules, 2-8 $\mu \mathrm{m}$ diameter; primary starch granules, 20-40 $\mu \mathrm{m}$ diameter) or yam (about $20 \mu \mathrm{m}$ diameter) but smaller than those in potato $(10-90 \mu \mathrm{m}$ diameter) or edible canna (40-100 $\mu \mathrm{m}$ diameter) (Table 13.1). In comparison with amyloplasts containing compound starch granules (compound starch grain type as described above), they are larger than those in rice (2.0-8.0 $\mu \mathrm{m}$ diameter), sweet potato (8.0-36.0 $\mu \mathrm{m}$ diameter), or taro $(0.13-0.42 \mu \mathrm{m}$ diameter). Jane et al. (1994) also reported from comparison of 54 crop species that sago palm amyloplasts are regarded as medium-sized among simple starch grain crop species.

Table 13.1 Characteristics of starches of several crops

\begin{tabular}{|c|c|c|c|c|}
\hline Crop and organ & $\begin{array}{l}\text { Feature of starch } \\
\text { accumulation }\end{array}$ & $\begin{array}{l}\text { Amyloplast major } \\
\text { axis }(\mu \mathrm{m})\end{array}$ & $\begin{array}{l}\text { Starch major } \\
\text { axis }(\mu \mathrm{m})\end{array}$ & $\begin{array}{l}\text { No. of starch in an } \\
\text { amyloplast }\end{array}$ \\
\hline Sago palm stem & Simple & Same as starch & $30-50$ & 1 \\
\hline Potato tuber & Simple & Same as starch & $10-90$ & 1 \\
\hline $\begin{array}{l}\text { Chinese yam } \\
\text { tuber }\end{array}$ & Simple & Same as starch & 20 & 1 \\
\hline Wheat grain & Simple & Same as starch & $2-8,20-40$ & 1 \\
\hline $\begin{array}{l}\text { Edible canna } \\
\text { tuber }\end{array}$ & Simple & Same as starch & $40-100$ & 1 \\
\hline Rice grain & Compound & $10-15$ & $2-8$ & Several to 100 \\
\hline $\begin{array}{l}\text { Sweet potato } \\
\text { tuberous root }\end{array}$ & Compound & $10-50$ & $8-36$ & Several to 20 \\
\hline $\begin{array}{l}\text { Eddoe tuberous } \\
\text { root }\end{array}$ & Compound & $10-20$ & $0.13-0.42$ & $100-4000$ \\
\hline
\end{tabular}

Source: Nitta et al (2010) 


\subsubsection{Amyloplast Proliferation}

Starch production of simple starch grain crops depends on the number and size of amyloplasts that contain starch. Proliferation of amyloplasts differs greatly among crops. In sago palm stems, the proliferation feature of amyloplasts is more specific than in other crops.

Nitta (2014) reported amyloplast proliferation of sago palm stems as follows (Fig. 13.2): a plastid, which is a precursor of an amyloplast, is formed near the apical portion. After commencement of starch accumulation, a plastid becomes an amyloplast. Amyloplasts are cell organelles after starch accumulation within a plastid.

Amyloplasts in the early growth stage are mostly oval-shaped or spindle-shaped with a smooth, round surface. Many amyloplasts develop a protuberance in one part of the oval or spindle body at the middle stage of growth. In addition, a part of the oval or spindle has separated or is about to separate in many amyloplasts. The planes of separation are very flat and smooth.

Some amyloplasts separate in more than one place. No protuberance exists on the amyloplast surface after separation or immediately before separation in many cases.

In short, amyloplast proliferation of sago palm stems proceeds in the following manner (Fig. 13.2):

Fig. 13.2 Pattern of separation/division of sago palm amyloplast: (a) a protuberance is formed near the surface; (b) the basal portion of protuberance extends; (c, d), separation or division occurs in the middle portion of the major axis (c) or a little toward the protuberance from it (d); $S$ stroma; $\boldsymbol{\Delta}$ protuberance (Source: Nitta 2014)
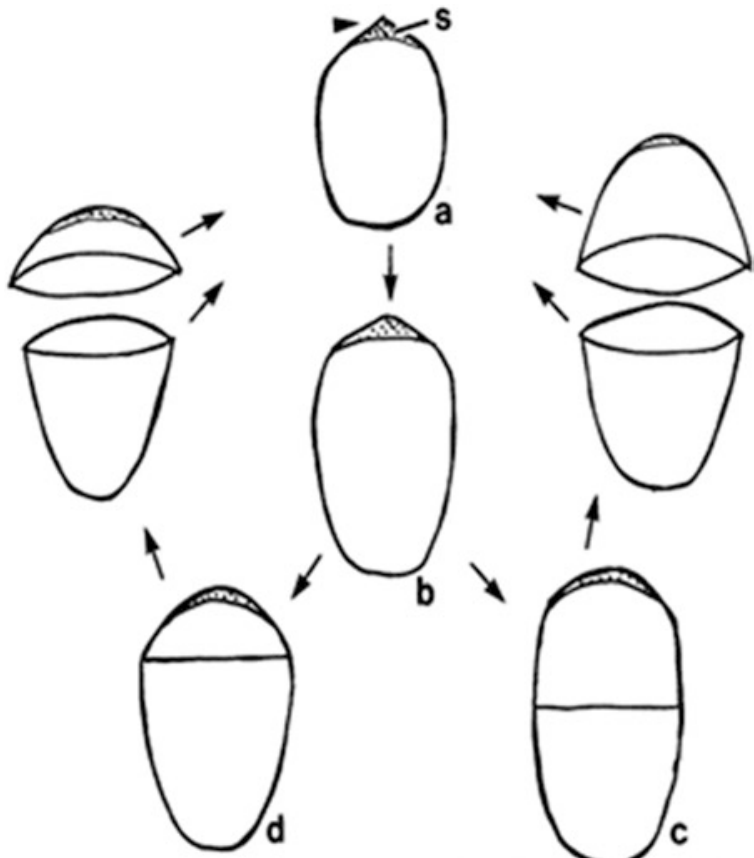
1. Plastid accumulates starch (i.e., plastid becomes an amyloplast).

2. A protuberance forms on the amyloplast surface.

3. The base of the protuberance develops, and the protuberance grows out while the curvature of the oval or the spindle on the protuberance side becomes flatter.

4. Separation or division occurs at the middle point along the major axis or on the protuberance side of the midpoint in the developed amyloplast.

These proliferation features, separation and division, occur in amyloplasts at or after the middle growth stage and in large amyloplasts at the early growth stage. In the protuberance, a stroma is apparently localized inside.

\subsubsection{Amyloplast Size and Number Among Varieties}

Mizuma et al. (2007) reported that the size and number of amyloplasts vary according to the position within the stem or by variety. Experiments using six sago palm varieties growing on the shores of Lake Sentani near Jayapura, Papua Province, Indonesia, close to the place of origin of sago palms, reveal that the major axis in all varieties is longer in amyloplasts in the middle and lower positions of the stem than in the upper positions. These results demonstrate that separation and division occur frequently in the middle and the lower positions of the stem. The major axis is short at the lower stem in Rondo and Para, suggesting that separation and division occur with high frequency on the basal side of the middle stem. The minor axis is also longer in the middle and lower positions than in the upper position in all varieties.

The numbers of amyloplasts in the cross-sectional area of the parenchyma tissue also differ among cultivars. Our experiments have found the most numerous amyloplasts in Rondo $\left(262.4 \mathrm{~mm}^{-2}\right)$ and the fewest in Para Wiliha $\left(184.4 \mathrm{~mm}^{-2}\right)$.

Starch accumulation features of potato tuber, Chinese yam tubers, wheat grains, and edible canna tubers are those of simple starch grain, while those of rice grains, sweet potato tuberous roots, and eddoe tuberous roots are those of compound starch grain. The starch major axis is longer in simple starch grains than in compound starch grains (Fig. 13.3).

However, considerable differences among varieties were observed in terms of the amyloplast size (Nitta et al. 2005, 2006, 2007). The major axis was longest in Pala Hongleu $(38.7 \mu \mathrm{m})$ and shortest in Para Wiliha $(27.7 \mu \mathrm{m})$.

In all varieties, the number of amyloplasts per unit cross-sectional area in the stem parenchyma is larger in the upper position than in the middle or basal position. Rondo and Yepha Hongleu, however, had more numerous amyloplasts in the lower position of the stem than in the middle, suggesting that separation and division occur frequently in these stem positions. 

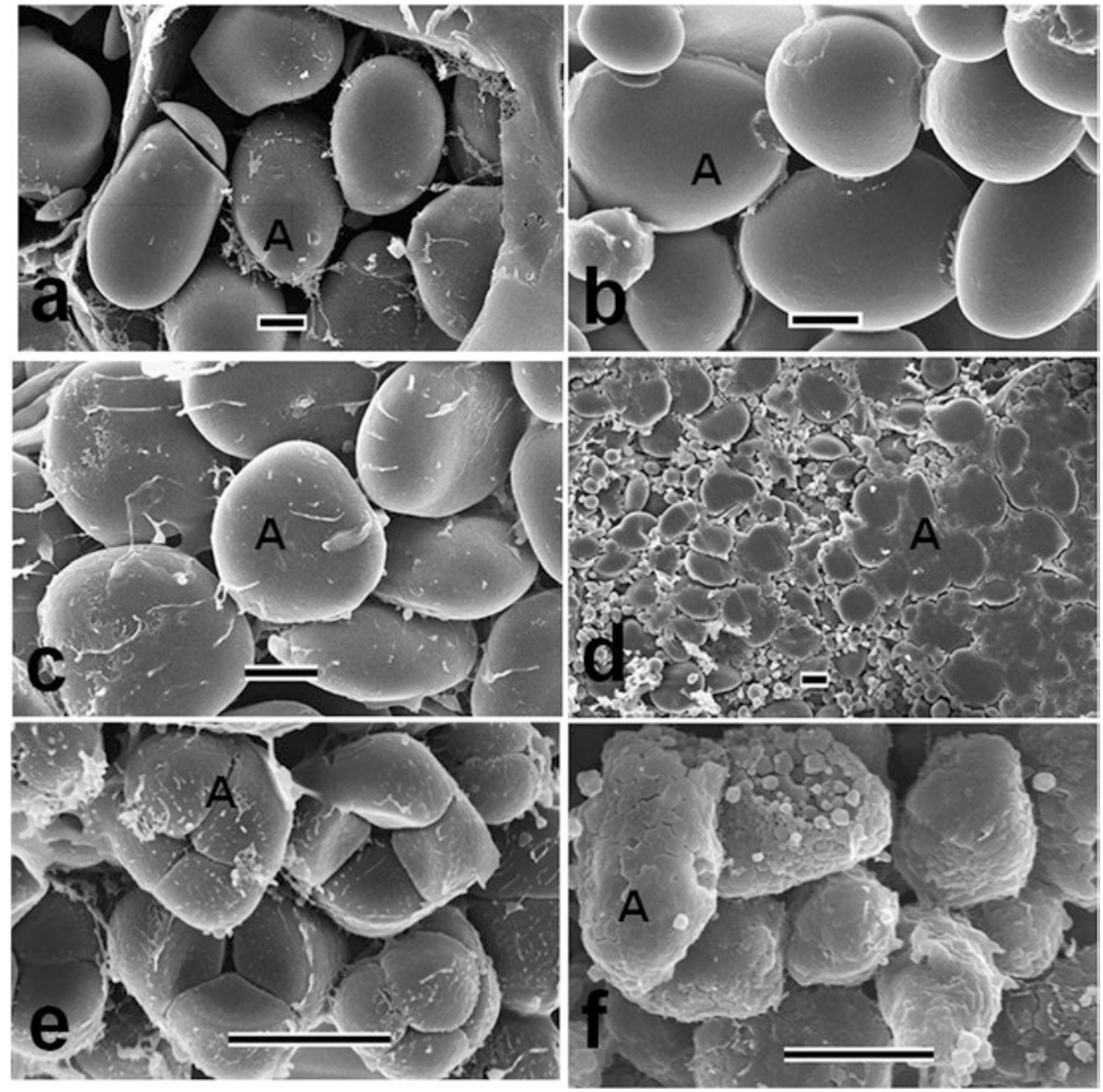

Fig. 13.3 Starch accumulation and amyloplast structures of several crops: (a) sago palm stem parenchyma; (b) potato tuber; (c) Chinese yam tuber; (d) wheat grain; (e) sweet potato tuberous root; (f) eddoe tuberous root; Bars, $10 \mu \mathrm{m} ; A$ amyloplasts. Amyloplasts include starch granules

\subsubsection{Sucker Structure and Starch Accumulation}

In sago palm-growing areas such as Indonesia and Malaysia, transplanting is conducted using suckers for maintaining and propagating sago stubs. Suckers are formed in the basal portion of the mother stem accompanied by several emerging leaves. When the stem base diameter reaches about $10 \mathrm{~cm}$, the sucker can be detached from the mother stem and transplanted into the field after brief nursery cultivation. Therefore, adequate management based on morphological and physiological characters is needed for rapid growth after transplantation.

In sago palm suckers, the cross-sectional area of parenchyma cells is larger in the lower stem portion. Intercellular spaces are formed even in the apical portion of the stem, followed by their enlargement in the lower stem portion. These features are almost identical to those of the main stem, as described above. 
Plastid accumulates starch to become an amyloplast, followed by amyloplast enlargement. Amyloplasts, which are round and smooth, are formed in the apical meristem portion of the stem.

The occurrence of separation and division of amyloplasts is not often observed. Major and minor axes of amyloplasts are smaller in the upper stem portion. Arai et al. (2009) reported that suckers show not only early growth of parenchyma cells and tissues but also more rapid starch accumulation in amyloplasts than in the mother stem (Warashina et al. 2009) at the same distance from the apical meristem portion.

As described above, amyloplasts are formed in the apical meristem portion of sago suckers. They are round and smooth, with few occurrences of separation and division. These features differ from those of the mother stem.

\subsubsection{Gelatinized Feature of Sago Palm Starch}

One sago palm starch cooking method is heating in water. By heating in water, starches included in the sago palm swell and gelatinize. Gelatinized starch and nongelatinized starch of commercialized sago palm starch after heating to $60{ }^{\circ} \mathrm{C}$ in water were assessed using scanning microscopic observation and comparison to starches of other species.

In gelatinized portions of sago palm starch, small holes of several micrometers in diameter are observed. Gelatinized starches are integrated into neighboring tissues. Holes of several micrometers in diameter and a thick skeleton structure are apparently causal factors of stickiness. Small pits (within several micrometers) were observed on the gelatinized starch surface.

Boiled sago palm starch, which is sold in city markets, revealed two distinct portions: a portion showing advanced gelatinization and a portion showing no advancement with remaining starch granules.

Stem materials of the Rondo cultivar are well known to be eaten after boiling in water in Indonesia. Scanning electron microscopic observations reveal that structures of vascular bundles, cells, and other tissues were not changed after boiling. However, boiling has advanced gelatinization not only within cells but also at the tissue level, including surrounding cells.

\section{References}

Arai Y, Nitta Y, Warashina S et al (2009) Internal structure and starch accumulation within the stem of sago sucker. In: Abstracts of the 227th meeting of the Crop Science Society of Japan. University of Tsukuba, Tsukuba, 27-28, March 2009

Jane J, Kasemsuwan T, Leas S et al (1994) Anthology of starch granule morphology by scanning electron microscopy. Starch 46:121-129

Jong FS (1995) Research of the development of sago palm (Metroxylon sagu Rottb.) cultivation in Sarawak, Malaysia. Ph. D. thesis, Agricultural University, Wageningen, The Netherlands

Kawakami I (1975) Starch morphology. Ishiyaku Publishers, Tokyo, pp 1-288 
Kawasaki M (1999) Histological and cytological studies on synthesis and accumulation of storage substances in vegetative organs of tuberous crops. Ph. D. thesis, Tokyo University of Agriculture and Technology, Tokyo, pp 1-247

Matsuda T (2003) Morphological analysis on accumulation and mobilization of reserve substances in crops. In: Abstracts of the 215th meeting of the Crop Science Society of Japan. Chiba University, Chiba, 4-5, April 2003

Mizuma S, Nitta Y, Matsuda T et al (2007) Starch accumulation of sago palm grown around Lake Sentani, near Jayapura of the Papua province, Indonesia. In: Abstracts of the 223th meeting of the Crop Science Society of Japan. Ibaraki University, Ibaraki, 29-30 March 2007

Nakayama T, Nitta Y, Matsuda T (2007) Structure and function of intercellular spaces of sago palm (Metroxylon sagu Rottb.). In: Abstracts of the 223th meeting of the Crop Science Society of Japan. Ibaraki University, Ibaraki, 29-30 March 2007

Nitta Y (2014) Starch granule formation in parenchyma. In: The Society of Sago Palm Studies (ed) The sago palm the food and environmental challenges of the 21st century. Kyoto University Press, Kyoto, pp 210-216

Nitta Y, Warashina S, Matsuda T et al (2005) Varietal differences in amyloplast accumulation of sago palms grown around Lake Sentani near Jayapura, Indonesia electron microscopic study. In: The abstracts of the 14th conference of the Society of Sago Palm Studies. Tokyo University of Agriculture, Setagaya, Tokyo, 25 June 2005

Nitta Y, Mizuma S, Matsuda T et al (2006) Varietal differences of starch accumulation of sago palm grown around Lake Sentani, near Jayapura of the Papua province, Indonesia - electron microscopic study-. In: The abstracts of the 15th conference of the Society of Sago Palm Studies. Tohoku University, Sendai 24 June 2006

Nitta Y, Matsuda T, Mizuma S et al (2007) Diversity of starch accumulation in sago palm stem. In: Abstracts of the 9th international sago symposium - enhancing the potential of sago for food and industrial uses-. Sabin Resort Hotel, Ormoc, Philippines, 19-21 July 2007

Nitta Y, Asagi N, Homma T et al (2010) Morphological characters of sago palm starch. In: Abstracts of the 19th Conference of the Society of Sago Palm Studies. Ibaraki University, Ami, 19 June 2010

Ogita S, Kubo T, Takeuchi M et al (1996) Accumulations and distribution of starch in sago palm (Metroxylon sagu) stems. Sago Palm 4:1-5

Warashina S, Nitta Y, Matsuda T et al (2007) Formation of intercellular spaces and their function of sago palm stem. In: Abstracts of the 9th international sago symposium - enhancing the potential of sago for food and industrial uses-. Sabin Resort Hotel, Ormoc, Philippines, 19-21 July 2007

Warashina S, Nitta Y, Arai Y et al (2009) Morphological relations between thickening growth and structure of ground parenchyma tissue and/or starch accumulation of sago palm stem. In: Abstracts of the 227th meeting of the Crop Science Society of Japan. University of Tsukuba, Tsukuba, 27-28 March 2009

Open Access This chapter is licensed under the terms of the Creative Commons Attribution 4.0 International License (http://creativecommons.org/licenses/by/4.0/), which permits use, sharing, adaptation, distribution and reproduction in any medium or format, as long as you give appropriate credit to the original author(s) and the source, provide a link to the Creative Commons license and indicate if changes were made.

The images or other third party material in this chapter are included in the chapter's Creative Commons license, unless indicated otherwise in a credit line to the material. If material is not included in the chapter's Creative Commons license and your intended use is not permitted by statutory regulation or exceeds the permitted use, you will need to obtain permission directly from the copyright holder.

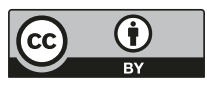


Part V

Growth Environment 


\title{
Chapter 14 Soil Environment in Sago Palm Forest
}

\author{
Masanori Okazaki and Yuka Sasaki
}

\begin{abstract}
Soils (acid sulfate soils, peat soils, gley soils, and others) distributed under sago forest and their productivity of sago palm are described in this chapter. Sago palm in tropical lowland areas is growing with the formation of the communities behind the mangrove forest. The main sources of water for sago palm are rivers, which are present in the eutrophic environment and more or less affected by sea tides. Sago palm equipped with the mechanism to eliminate salt effect or regulate salt uptake in several ways can grow in brackish water. Acid sulfate soils are derived from sulfate ion $\left(\mathrm{SO}_{4}{ }^{2-}\right)$ in seawater. Sulfate ion is reduced to form sulfide compounds by sulfate-reducing bacteria in soils (potential acid sulfate soils). Sulfide compounds are oxidized to sulfate ion and hydrogen ion is produced by sulfur- and iron-oxidizing bacteria in soils (actual acid sulfate soils). The sago starch yield is observed to be extremely high near the coast and lower in the inland places (soil pH 3.3-3.8). The tropical woody thick peat soils called Histosols in the tropical rainforest climate of Southeast Asian islands are formed to transport small amount of sediments by the shorter rivers compared to large rivers of continents. The constituent components in water flowing into tropical peat soils ensure the normal growth of sago palm. In Sarawak no effect of nitrogen (N) application on leaf production of sago palm was found, which was explained by the findings of endophytes' activities on the nitrogen fixation. The sago palm growth in Inceptisols of the Philippines and Indonesia at the different stages was larger than those in Histosols of Malaysia from the long-term growth study.
\end{abstract}

\author{
M. Okazaki (ه) \\ Japan Soil Research Institute Inc., Nishitokyo, Tokyo, Japan \\ e-mail: japansoilco_okazaki@mbr.nifty.com \\ Y. Sasaki \\ Faculty of Agriculture, Yamagata University, Tsuruoka, Yamagata, Japan
}




\subsection{Natural Habitat of Sago Palm in Tropical Lowland Areas}

Natural lowland forest in tropical areas consists of mangrove, tropical lowland, and tropical peatland forests, in that order moving inland from the sea (Okazaki et al. 2008) (Fig. 14.1). Although distributed in both tropical and subtropical lowland areas affected by seawater, the dominant distribution of mangrove forest is present in tropical brackish water areas. Brackish water is defined as a mixture of sea- and freshwater with a salt concentration of $0.2-30$ parts per thousand $(\% o)$, equivalent to $1 / 100-1$ of the salt concentration of seawater, because seawater generally contains 33-34\%o. Nipa and sago palm are present behind mangrove forest and form a large plant community. Both tropical lowland forest and tropical peatland forest are found in brackish water areas, each with a different freshwater source. Tropical lowland plants grow under relatively eutrophic nutrient conditions, while tropical peatland plants are under poor nutrient conditions and affected by rainfall and flowing groundwater with high reduction and oxidation (redox) potential (Table 14.1).

Sago palm (Metroxylon sagu Rottb.) is part of the formation of vegetation communities behind the mangrove forest (Yamada 1986) (Table 14.1). In the very poorly drained to swampy conditions of Papua New Guinea, sago palms and pandans (Pandanus) are found in the understory (Bleeker 1983). The main source of water for sago palm is the rivers, which are present in the eutrophic environment and more or less affected by sea tides (Tie and Lim 1977).

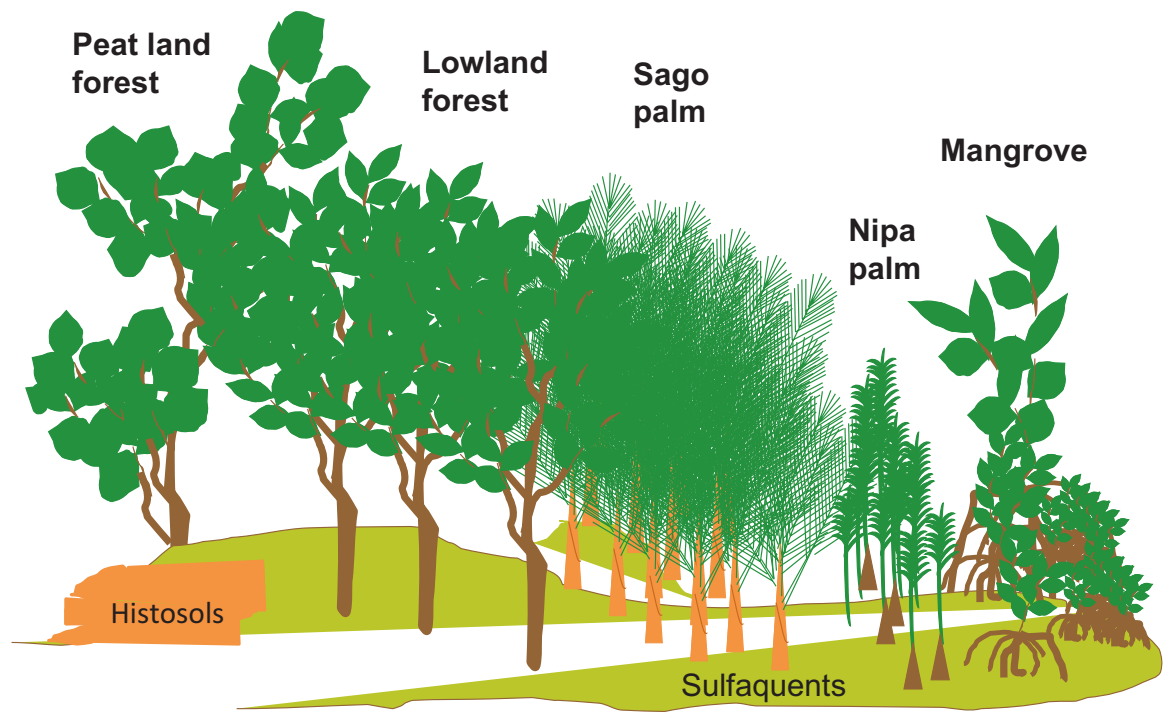

Fig. 14.1 Distribution of tropical lowland forest along the sea (Okazaki et al. 2008, partly modified) 
Table 14.1 Typical tropical plant communities (Yamada 1986)

\begin{tabular}{|c|c|c|c|}
\hline & & Tropical lowland forest & \\
\hline & Mangrove & $\begin{array}{l}\text { Fresh water lowland } \\
\text { forest }\end{array}$ & $\begin{array}{l}\text { Brackish water lowland } \\
\text { forest }\end{array}$ \\
\hline Niche & Sea shore & Back marsh & $\begin{array}{l}\text { Deeper portion of back } \\
\text { marsh }\end{array}$ \\
\hline Water & Sea to brackish water & Brackish to fresh water & Rain water \\
\hline Soil & Muddy & Clayey & Peaty \\
\hline Environment & Tidal area & Flooding area & $\begin{array}{l}\text { Acidic stagnant/running } \\
\text { water }\end{array}$ \\
\hline Nutrient & Eutrophic & Eutrophic to Oligotrophic & Oligotrophic \\
\hline Distribution & Band structure & Uncertained & Concentric circle \\
\hline \multirow[t]{5}{*}{ Species } & Rhizophora & Alstonia & Shorea albida \\
\hline & Avicennia & Campnosperma & Dactylocladus \\
\hline & Bruguiera & Palaquium & Gonystylus \\
\hline & Acrostichum & Metroxylon & Pandanus \\
\hline & Nypa & Oncosperma & Salacca \\
\hline
\end{tabular}

Halophytic plants equipped with mechanisms to eliminate salt effect or regulate salt uptake in several ways can grow in brackish water. Flach et al. (1977) found that sago palm was not inhibited in a Hoagland solution of about 6-7 millisiemens $(\mathrm{mS})$ per $\mathrm{cm}$ electrical conductivity, which corresponds to $1 / 7-1 / 8$ of electrical conductivity of seawater. However, the growth rate of sago palm slowed when this range of electrical conductivity was exceeded. Many terrestrial plants suffer from a salt concentration of $0.1 \%$, and significant growth suppression is found when it exceeds $0.3 \%$ (around $60 \mathrm{mmol} \mathrm{L}^{-1}$ ) (Matoh 2002). Salt stress is divided into two types: the inhibition of water absorption due to osmotic pressure generated by salt (osmotic stress) and the excess damage caused by the specific physiological effects of the salt-constituting ions (ionic stress). Generally ionic stress is regarded as the primary factor of salinity stress. As sago palm is highly tolerant of salinity stress, it is likely to be equipped with several kinds of mechanisms. By the treatment of $0-0.2 \%$ sodium chloride solution, sago palm absorbed sodium ions from the root and translocated them to the petiole and the leaflets. However, sago palm seedlings retained sodium ions in the roots and transferred them to the lower leaves gradually (Ehara et al. 2006). Yoneta et al. $(2004,2006)$ determined that sago palm seedlings grew best at a salt concentration of around $10 \mathrm{mmol} \mathrm{L}^{-1}$ (1/60 of sea salt concentration), while sago palm growth was inhibited in water or in a salt concentration range of 50-200 mmol L ${ }^{-1}$ (Fig. 14.2). Ehara et al. (2008) cultured Metroxylon sagu Rottb. and $M$. vitiense for 1 month hydroponically; thereafter a $2 \%$ sodium chloride solution was used for the culture for another month. Results showed that the transpiration rate of all sago palms declined with the treatments and that the potassium content in sago palm increased with increasing sodium content in the petiole. Yoneta et al. (2006) deduced that sago palm primarily maintained a high osmotic pressure 


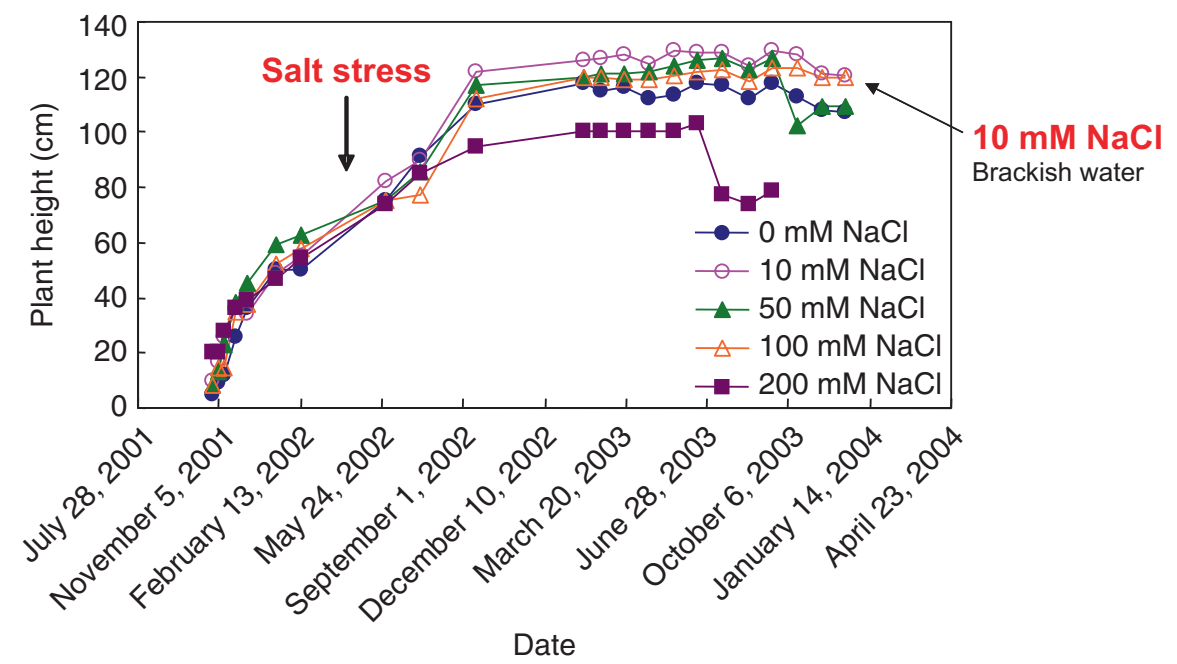

Fig. 14.2 Changes in the height of sago palms under different $\mathrm{NaCl}$ concentrations (Yoneta et al. 2006)

Table 14.2 Soils related to sago palm growing areas (common name, US Soil Taxonomy)

\begin{tabular}{l|l}
\hline Peat soils: & Tropofibrists, Tropohemists, Troposaprists \\
\hline Acid sulfate soils: & Sulfaquents, Sulfaquepts, Sulfic Tropaquents \\
\cline { 2 - 2 } & $\begin{array}{l}\text { Sulfic Humaquents, Sulfic Haplaquepts, Sultfic } \\
\text { Haplaquents }\end{array}$ \\
\hline Gley soils: & Hydraquents, Fluvaquents, Tropofluvents \\
\hline Other soil types: & Oxisols, Entisols, Inceptisols \\
\hline
\end{tabular}

in the cytoplasm using potassium ions as the osmotic pressure regulator (compatible solute). They concluded that small amounts of other compatible solutes such as proline and glycine betaine were produced. In addition, Ehara et al. $(2003,2006)$ showed that sago palm roots excluded sodium ions using the barriers to inhibit sodium ion absorption.

\subsection{Soils Distributed Under Sago Palm Forest}

In this chapter, soil names (common and US Soil Taxonomy names) distributed beneath sago palm forests are shown in Table 14.2. 


\subsection{Acid Sulfate Soils (Typic Sulfaquents, Sulfic Hydraquents, Sulfic Tropaquents, Typic Sulfihemists, etc.)}

The pedogenic process of acid sulfate soils requires a source of sulfate $\left(\mathrm{SO}_{4}{ }^{2-}\right.$ : $2650 \mathrm{mg} / \mathrm{L}$ ) derived from seawater and brackish water to supply organic matter as an energy source for heterotrophic bacteria (Desulfovibrio and Desulfotomaculum), resulting in the formation of $\mathrm{S}^{2-}$ and $\mathrm{S}^{0}$ (Kyuma 1986). The reaction of $\mathrm{Fe}^{2+}$ and $\mathrm{S}^{2-}$ gives ferrous sulfide (FeS). Ferrous sulfide reacts $\mathrm{S}^{0}$ to form $\mathrm{FeS}_{2}$ (pyrite) (Figs. 14.3 and 14.4). $\mathrm{Fe}^{2+}$ and $\mathrm{S}^{2-}$ in $\mathrm{FeS}_{2}$ are oxidized to $\mathrm{Fe}^{3+}$ mediated by Thiobacillus ferrooxidans and Ferrobacillus ferrooxidans and $\mathrm{SO}_{4}{ }^{2-}$ mediated by thiobacilli groups (Fig. 14.5), respectively. Jarosite $\left(\mathrm{KFe}_{3}\left(\mathrm{SO}_{4}\right)_{2}(\mathrm{OH})_{6}\right.$ and goethite $(\alpha-\mathrm{FeOOH})$ are produced which are pale yellow (2.5 Y 6/8-2.5 Y 8/8) and yellow brown (Fig. 14.6). Clayey yellow brown sediments in acid sulfate soils are called cat clay, which derives from the Dutch term katteklei.

In the 1840s, sago palm cultivated in Sarawak was grown quite successfully in some parts of the island (Borneo), and the raw sago exported in large quantities from the west coast to Singapore (Fukui 1980; cited from Low 1848). Metroxylon sagu is still the main food of several Papua groups in New Guinea; the inhabitants of most of the islands in the Moluccas; the southeast arm of Sulawesi; the Banggai and Sula archipelagoes east of Sulawesi; the Mentawai Islands west of Sumatra; the Melanau people in Sarawak; the east coast of Sumatra (Bengkalis); in the Riau, Karimun, and Lingga archipelagoes; and in some coastal regions in west Kalimantan (Avé 1977). The proper growing areas for sago palm are tana nabo (peat soils con-

Fig. 14.3 Pyrite in acid sulfate soils

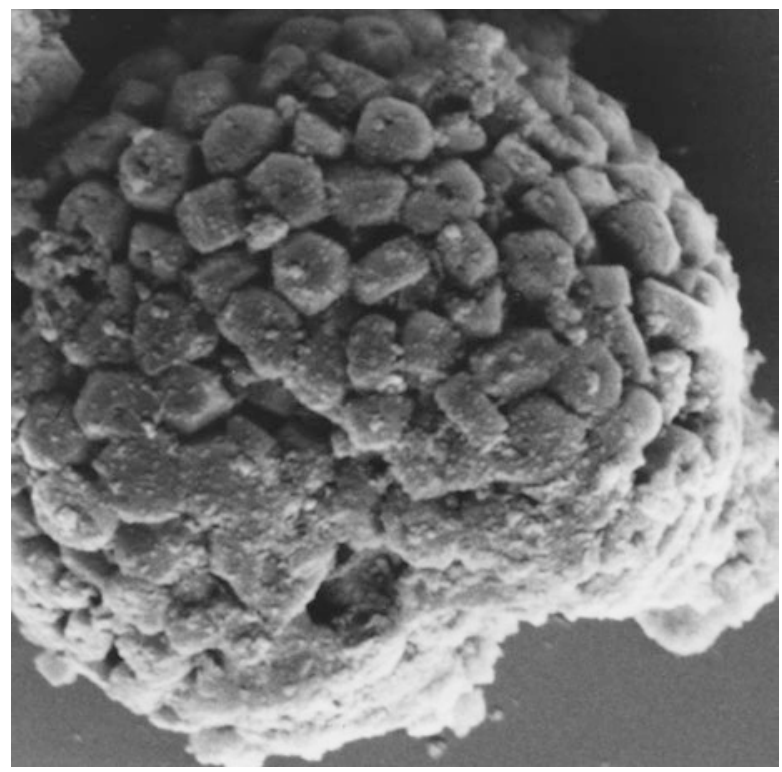




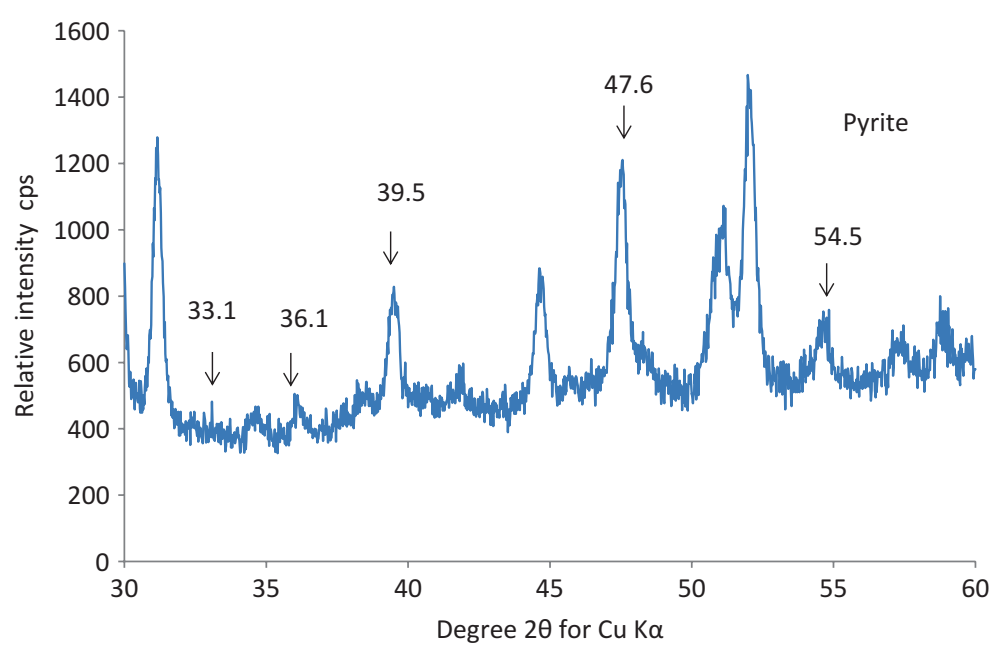

Fig. 14.4 X-ray diffraction pattern of HF-treated acid sulfate soil

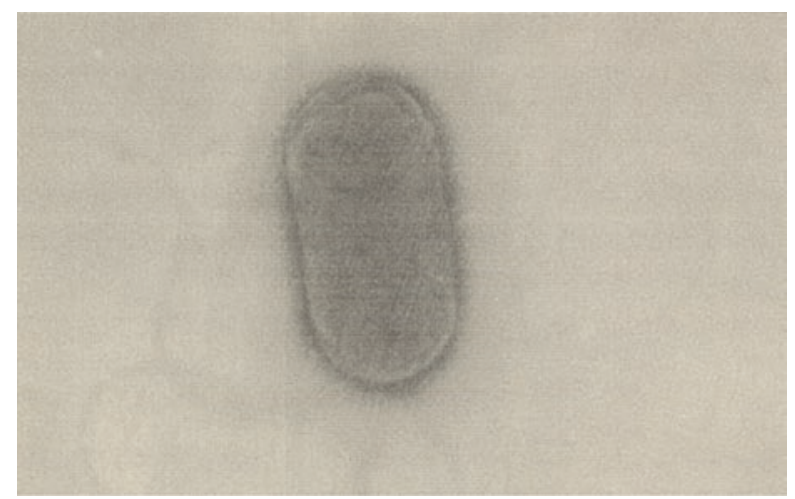

Fig. 14.5 Thiobacillus in acid sulfate soils

taining alluvial sand and clay) and tana pala on the interfluves produced by rivers in their meandering in Sarawak (Morris 1953). The peat soils (tana guun) away from the river, however, give rise to fast growth of sago palm, but they are poor in sago starch content. The sago palm-growing areas, however, are often composed of alluvial soils and peat soils (Sato et al. 1979). Flach (1983) revealed that sago palm grew best in mineral soils which should be high in organic matter as opposed to peat soils and that clay soils were usually found in the natural habitat of sago palm.

The soils under sago forest in South Sulawesi, Indonesia, (Tables 14.3 and 14.4) are located in transition areas between the natural river bank and black marsh (Takaya 1983; Okazaki 1995). Soils that are already strongly acidic are called actual acid sulfate soils (Table 14.3), and those which become acidic after oxidation are called potential acid sulfate soils (Table 14.4). 


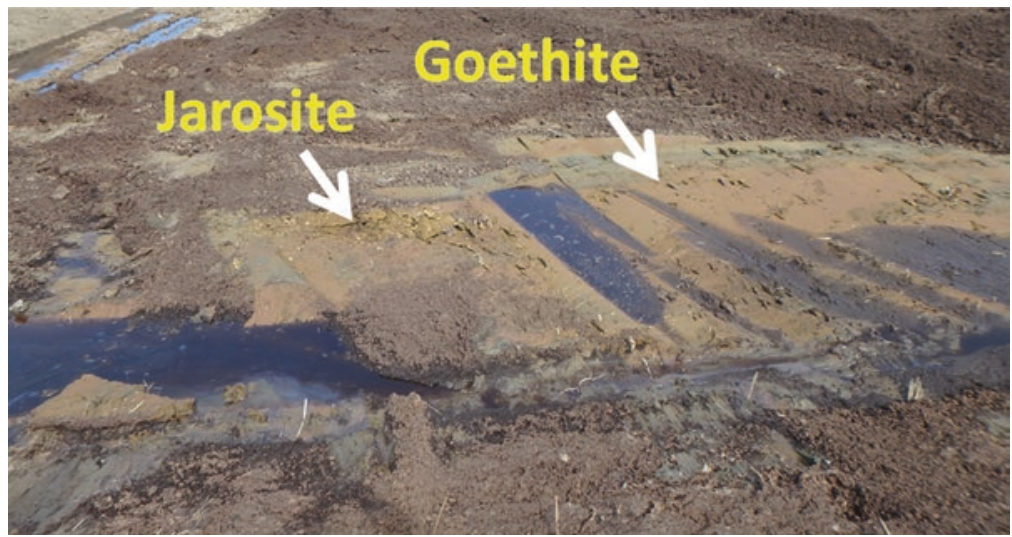

Fig. 14.6 Jarosite and goethite in acid sulfate soils

Table 14.3 Soil profile in Desa Takkalala, Kabupaten Luwu, South Sulawesi, Indonesia (Takaya 1983, partly modified)

Profile A (Center of sago forest)

3-0 cm, L, litter horizon, sago and other leaves

0-82 cm, B, light gray color in matrix, coarse texture, bright brown (7.5 YR 5/6 to 5/8) to brown (7.5 YR 4/3 to 4/6) of tube type mottles with diffusing outside, 2-3 cm structure in diameter, present gley mottles, many fresh and old sago roots (5-7 $\mathrm{mm}$ in diameter) in the structure, yellow (fresh roots) and black (old roots) color roots surrounded by blue gray (reduced) color parts

Table 14.4 Soil profile in Tobimeita, Kendari, South Sulawesi, Indonesia (Okazaki 1995)

Profile B (Sago forest, potential acid sulfate soil)

0-7 cm, A, surface horizon, very yellowish brown (10 YR 5/5), moist, coarse sand, structureless, few medium and fine weed roots, $\mathrm{pH} 7.8, \mathrm{EC} 0.30 \mathrm{mS} / \mathrm{cm}$, clear smooth boundary to

7-35 cm, B1, grayish olive (5Y 5/2), moist, coarse sand, structureless, few organic debris with original shape and decomposed shape, $\mathrm{pH} 6.5, \mathrm{EC} 0.32 \mathrm{mS} / \mathrm{cm}$, clear smooth boundary to $35-70 \mathrm{~cm}, \mathrm{~B} 2$, brownish black (2.5 YR 3/2) in matrix and black (2.5 Y 2/1), wet, silty clay, structureless, common medium and fine sago roots, very sticky, plastic, pH 6.8, EC $0.32 \mathrm{mS} / \mathrm{cm}$, gradual wavy boundary to

70- cm, dark grayish yellow (2.5 YR 5/2), wet, silty clay, structureless, sticky, pH 6.7, EC $0.35 \mathrm{mS} / \mathrm{cm}$

Jalil and Bahari (1991) compared the starch yield of sago palm growing in plantations $0.5,0.7$, and $3.0 \mathrm{~km}$ from the seashore (soil $\mathrm{pH}: 3.3-3.8$ in acid sulfate soils) and found that the starch yield was extremely high near the coast and lower in the inland plantations. In Thailand, Nozaki et al. (2004) compared the sago starch content and starch synthetic enzyme activity of sago palms growing in acid sulfate soils and Oxisols and found that the sago growth in acid sulfate soils was lower than that in Oxisols. 


\subsection{Peat Soils (Histosols)}

In continental Southeast Asia under the tropical monsoon climate, rivers have complicated systems, while Southeast Asian islands under the tropical rainforest climate have shorter rivers than on the continents, which transport a small amount of sediments, resulting in the formation of peat soils called Histosols (Fibrists, Hemists, and Saprists) (Fig. 14.7). Trees, shrubs, and grasses that love water can thrive in the areas of high water table and tidal action. Dead plants are broken down usually by decomposers. However, the decomposition processes are inhibited in the areas of high groundwater. Plant residues accumulate to produce peat soils (Histosols), in which plant biomass production exceeds plant decomposition, regardless of temperature (Fig. 14.7).

Histosols are formed in the tropics in areas with high temperature and vigorous woody plant materials and are called woody peats (Okazaki 1998). Tropical peat soil is known to form a dome-shaped surface at the final stage of its development (Scott 1985) (Fig. 14.8). Tropical peat soils derived from woody materials in Southeast Asia exhibit strong to weak acidity and lack nutrient elements (Tie and Lim 1991; Yamaguchi et al. 1994). The constituent components in water flowing into tropical peat soils ensure the normal growth of sago palm (Yamaguchi et al. 1998). Sato et al. (1979) reported that the thicker the peat deposit in soil, the slower the sago palm grows and that the sago palm grew better in soil with a thinner peat layer and an underlying argillaceous deposit. In Sarawak $62 \%$ of sago palms are grown on Histosols, those with more than $150 \mathrm{~cm}$ of surface peats (Tie and Lim 1991). Kueh $(1979,1980,1981,1982,1983)$ performed a cultivation study of sago palm in undrained tropical peat soils at Stapok in Sarawak and found a depression or no effect of nitrogen (ammonium sulfate) application on leaf production and no effect by $\mathrm{P}_{2} \mathrm{O}_{5}$ and $\mathrm{K}_{2} \mathrm{O}$, as their results, since 1976. Jaman (1983) found that NPK fertilizer application had no significant positive effect on the rate of leaf production of sago palm in the first year at Sungai Talau Peat Research Station. Jaman (1983, 1984, 1985) carried out experiments of fertilizer application, pruning, weeding,

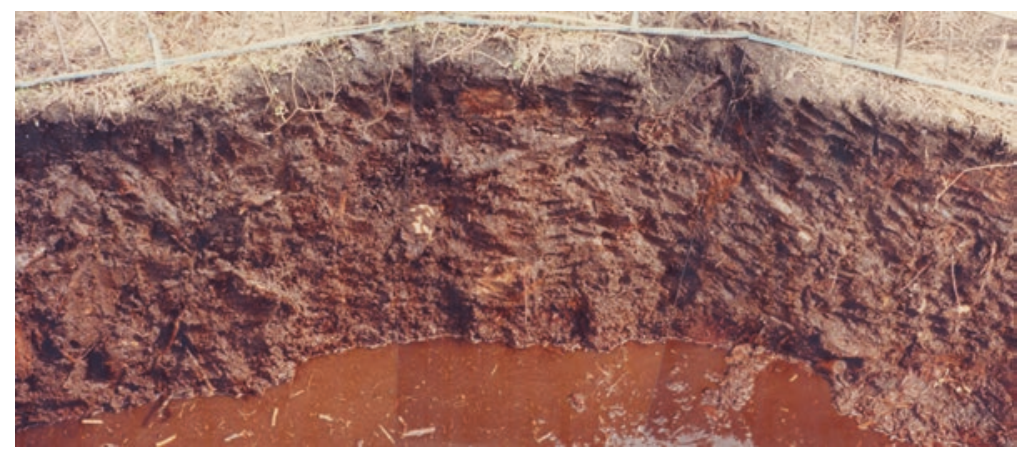

Fig. 14.7 Soil profile of tropical peat in Sarawak 


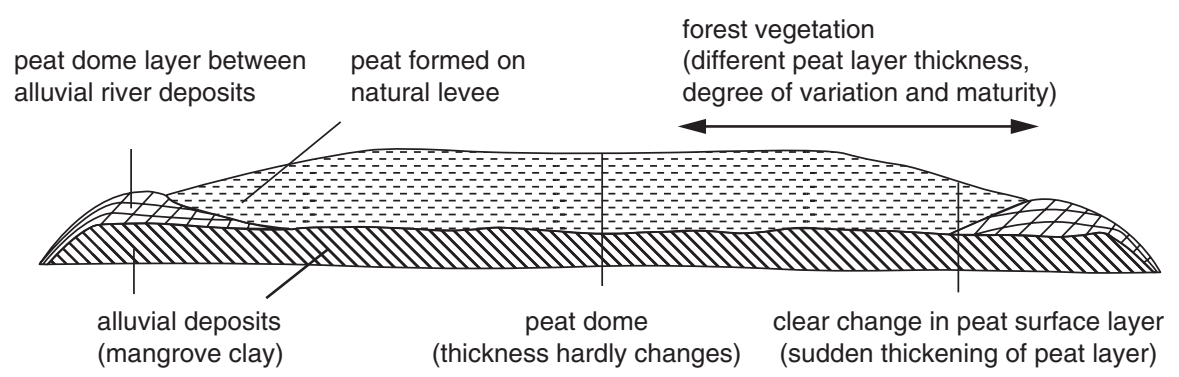

Fig. 14.8 Interrelations between landform units in tropical peat swamps wedged between 2 rivers (Scott (1985), cited from Anderson (1961))

seed germination, spacing, and intercropping related to girth, trunk height, and leaf production and reported that none of the NPK fertilizer application, pruning, weeding, seed germination, spacing, and intercropping had any significant positive effect on the annual leaf production rate of sago palms. Although in the 11th year of growth, trunk height in peat soil under minimal drainage at Stapok Station seemed to be increased by $\mathrm{N}$ application (Kueh 1987), there was no significant effect of $\mathrm{N}$ application on trunk height in the 13th year of growth (Kueh 1989, 1990, 1995). Kakuda et al. (2000) compared the nitrogen supply in peat and mineral soils. The amount of ammonium nitrogen released from peat soils through mineralization on the 50th day of incubation (100 days in case of transform at $25^{\circ} \mathrm{C}$ ) was approximately $5.8 \mathrm{mg} / \mathrm{kg}$ in Tebing Tinggi, Indonesia, and $4.7 \mathrm{mg} / \mathrm{kg}$ in Mukah, Sarawak. It is a property of peat soils that mineralization and nitrogen supply occur more readily as compared with mineral soils. The application of seven times the usual amount of $\mathrm{N}, \mathrm{P}, \mathrm{K}, \mathrm{Ca}, \mathrm{Mg}, \mathrm{Cu}, \mathrm{Zn}, \mathrm{Fe}$, and $\mathrm{B}$ provided a significant difference of petiole and sucker dry weight (Kakuda et al. 2005). However, no difference was found in other growth factors of sago palm.

The lack of any effect of nitrogen $(\mathrm{N})$ application on sago palm growth is explained by the findings of the endophytes' activities on the $\mathrm{N}$ fixation (Shrestha et al. 2006, 2007). When sago palm easily becomes able to absorb $\mathrm{N}$ from soils, it does not require the $\mathrm{N}$ support by the endophytes. Accordingly it is concluded that the endophytes play an important role in sago palm growth without $\mathrm{N}$ application.

Beginning in 1986, Jaman and Jong (1986), Jong and Jaman (1987), Jong (1989, 1990), and Shoon et al. (1995) performed sago spacing (4.5, 7.5, 10.5, and $13.5 \mathrm{~m})$ trials in peat soils in Sarawak and concluded that sago palm should be cultivated in a rectangular pattern of $12 \times 8 \mathrm{~m}$ to facilitate maintenance work and farm management and suggested around 100 points per hectare. Traditional sago palm cultivation is carried out under minimal management, little sucker control, and no fertilization.

Groundwater level and subsidence related to drainage inhibit sago palm growth and yield of starch. Takaya (1983) and Shimoda and Power (1990) described that sago starch yield declined remarkably or even to zero in permanently submerged land. Flach et al. (1977) found in a sago seedling culture study that the rate of leaf 
emergence slowed under waterlogged conditions. Hashimoto et al. (2006) also reported that both the number of leaves and the diameter at breast height of sago palms growing in tropical peat soils with an average water table of 57-68 cm were smaller than those in the areas with a lower water table. Kakuda et al. (2015) revealed that sago palms grew better at $50 \mathrm{~cm}$ than at $90 \mathrm{~cm}$ of groundwater level. The groundwater level around the sago palm root zone is important for growth.

Sugawara (1979) proposed a 10,000 ha sago plantation on areas of tropical peat soils, which strongly required land reclamation and drainage for common tropical crop cultivation and its potential economic effect on Southeast Asian countries. Studies of the relationship between sago (Metroxylon sagu and M. rumphii) starch quality and soil types (shallow peat soils and mineral soils) in Sarawak were started by Lim and Loi (1987). However, thus far no results have been reported.

\subsection{Other Entisols and Inceptisols}

Soils eroded by rivers form sediments at the seashore at various rates. The soils along the Sepik River of Papua New Guinea are heavy clays high in organic matter and only flooded seasonally by the Sepik (Holmes and Newcombe 1980). Periodic flooding with water high in mineral elements should provide all of the nutrients required for optimum sago palm growth. Furthermore, Shimoda and Power (1990) reported that the soils of swampy areas in the Sepik River consisted of Hydraquents, Fluvaquents, and in part Histosols, which are poorly drained soils. Shimoda (2000) found the peat horizon at about $1 \mathrm{~m}$ depth in a Hydraquent profile. The formation of peat horizons and alluvial materials sedimentation has produced the sago-growing areas in the islands of Southeast Asia.

In Panay, Leyte, Cebu, and Mindanao, Philippines, the habitats of sago palm are predominantly located in Entisols and Inceptisols with periodic flooding and continuous water flow, from 0 to $700 \mathrm{~m}$ above sea level (Okazaki and Toyota 2003, 2004). The sago palms in Entisols and Inceptisols grow relatively well, compared to their growth on Histosols mainly utilized for leaf roofing materials in the Philippines, although local people know well how to extract starch in the mature sago palms.

\subsection{Comparison of Sago Palm Growth Between on Inceptisols and Histosols}

At the same growing stage, a comparison of sago palm has shown that the starch yield per trunk of the sago palm planted in deep peat soils is only $23 \%$ of those planted in mineral soils (Jong and Flach 1995). Okazaki (2012) reported in a longterm growth study that the trunk weights of sago palm growing in Inceptisols of the Philippines and Indonesia at the different stages were larger than those in Histosols 


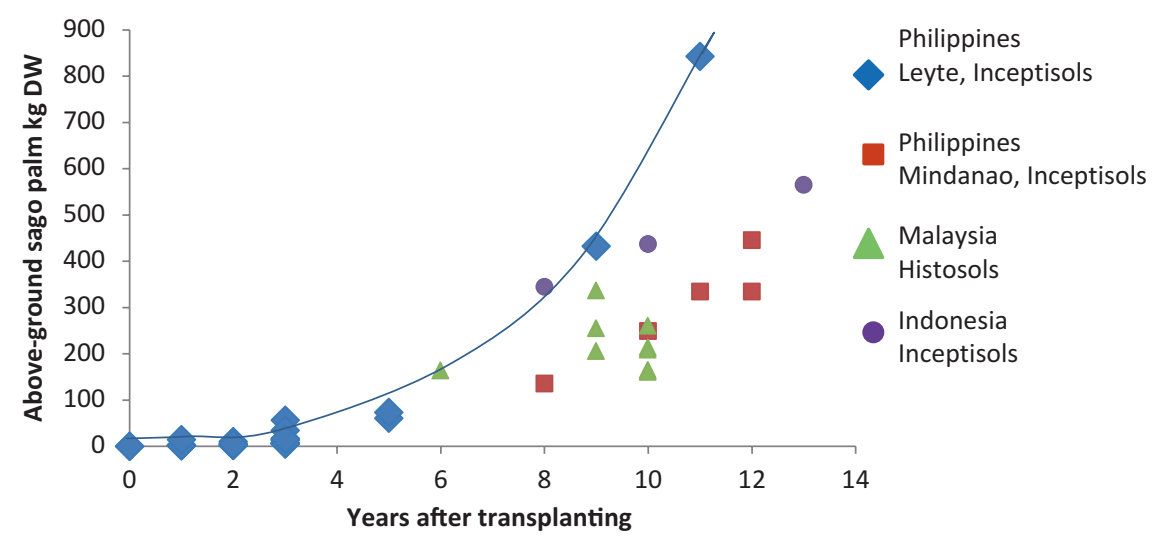

Fig. 14.9 Difference on biomass (above-ground) of sago palm growing in Inceptisols and Histosols (Okazaki 2012)

of Malaysia (Fig. 14.9). It is concluded that the sago palm growth and starch yield depend on the physicochemical soil characteristics.

\section{References}

Anderson JAR (1961) The ecology and forest types of the peat swamp forests of Sarawak and Brunei in relation to their silviculture. Ph.D. thesis, University of Edinburgh

Avé JB (1977) Sago in insular Southeast Asia: historical aspects and contemporary use. In: Tan K (ed) Sago-76: papers of the first international sago symposium. University of Malaya, Kuala Lumpur, pp 21-30

Bleeker P (1983) Soils of Papua New Guinea. The Commonwealth Scientific and Industrial Research Organization, Australia, Australian National University Press, Canbera, London, Miami

Ehara H, Matsui M, Naito H (2003) Absorption and translocation of $\mathrm{Na}^{+}$in sago palm under $\mathrm{NaCl}$ treatments. Sago Palm 11:35-36. (in Japanese)

Ehara H, Matsui M, Naito H (2006) Avoidance mechanism of salt stress in sago palm (Metroxylon sagu Rottb.) Jpn J Trop Agric 50:36-41. (in Japanese)

Ehara H, Shibuya H, Prathumyot W et al (2008) Absorption and distribution of $\mathrm{Na}^{+}, \mathrm{Cl}^{-}$and some other ions and physiological characteristics of sago palm under salt stress. Trop Agric Dev $52: 7-16$

Flach M (1977) Yield potential of the sago palm and its realization. In: Tan K (ed) Sago "76: Papers of the 1st International Sago Symposium. University of Malaysia, Kuala Lumpur, pp 157-177

Flach M (1983) The sago palm. FAO Plant production and Protection Paper 47. p 1-85

Flach M, Cnoops FJG, van Roekel-Jansen GC (1977) Tolerance to salinity and flooding of young sago palm seedlings. In: Tan K (ed) Sago-76: papers of the first international sago symposium. University of Malaya, Kuala Lumpur, pp 190-195

Fukui H (1980) Use and nonuse of the lowland of Sarawak. Southeast Asian Stud 17:708-740. (in Japanese)

Hashimoto K, Sasaki Y, Kakuda K et al (2006) Relationship of sago palm and groundwater in tropical peat soil. In: Proceedings of the 15th conference of the Society of Sago Palm Studies. pp 25-26 (in Japanese) 
Holmes EB, Newcombe K (1980) Potential and proposed development of sago (Metroxylon spp.) as a source of power alcohol in Papua New Guinea. In: Stanton WR, Flach M (eds) Sago the equatorial swamp as a natural resource. Proceedings of 2 nd international sago symposium. Martinus Nijhoff Pub, The Hague, pp 164-174

Jalil M, Hj N, Bahari J (1991) The performance of sago palms on river alluvial clay soils of Peninsular Malaysia. In: Ng TT, Tie YL, Kueh HS (eds) Towards greater advancement of sago industry in the '90s: proceedings of the 4th international sago symposium. Lee Ming Press, Kuching, pp 114-121

Jaman O (1983) Fertilizer response in drained peat at Sungai Talau Station. Annual report of Department of Agriculture of Sarawak, pp 87-88

Jaman O (1984) Fertilizer response in drained peat at Sungai Talau Station. Annual report of Department of Agriculture of Sarawak, pp 97-101

Jaman O (1985) Fertilizer response in drained peat at Sungai Talau Station. Annual report of Department of Agriculture of Sarawak, pp 105-110

Jaman HJO, Jong FS (1986) Sago palm spacing trial. Annual report of Department of Agriculture of Sarawak, pp 75-76

Jong FS (1989) Sago palm spacing trial. Annual report of Department of Agriculture of Sarawak, p 90

Jong FS (1990) Sago palm spacing trial. Annual report of Department of Agriculture of Sarawak, pp 70-71

Jong FS, Flach M (1995) The sustainability of sago palm (Metroxylon sagu) cultivation on deep peat in Sarawak. Sago Palm 3:13-20

Jong FS, Jaman HJO (1987) Sago palm spacing trial. Annual report of Department of Agriculture of Sarawak, p 84

Kakuda K, Ando H, Yoshida T et al (2000) Soil characteristics in sago palm grown area; factors associated with fate of inorganic nitrogen in soil. Sago Palm 8:9-16. (in Japanese)

Kakuda K, Watanabe A, Ando H, Jong FS (2005) Effects of fertilizer application on the root and aboveground biomass of sago palm (Metroxylon sagu Rottb.) cultivated in peat soil. Jpn Tropical Agric. 49: 264-269

Kakuda K, Sasaki Y, Jong FS (2015) Post-planting management. In: The sago palm. Society of Sago Palm Studies. Kyoto University Press, Kyoto, pp 178-186

Kueh HS (1979) Sago NPK fertilizer experiment. Annual report of Department of Agriculture of Sarawak, pp 157-158

Kueh HS (1980) Sago NPK fertilizer experiment. Annual report of Department of Agriculture of Sarawak, pp 167-168

Kueh HS (1981) Sago NPK fertilizer experiment. Annual report of Department of Agriculture of Sarawak, pp 169-170

Kueh HS (1982) Sago NPK fertilizer experiment. Annual report of Department of Agriculture of Sarawak, pp 168-170

Kueh HS (1983) Fertilizer response in undrained deep peat at Stapok Station. Annual report of Department of Agriculture of Sarawak, pp 85-86

Kueh HS (1987) Fertilizer response of sago in deep peat under minimal drainage conditions at Stapok Station. Annual report of Department of Agriculture of Sarawak, p 81

Kueh HS (1989) Fertilizer response of sago in deep peat under minimal drainage conditions at Stapok Station. Annual report of Department of Agriculture of Sarawak, pp 86-87

Kueh HS (1990) Fertilizer response of sago in deep peat under minimal drainage conditions at Stapok Station. Annual report of Department of Agriculture of Sarawak, pp 68-69

Kueh HS (1995) The effects of soil applied NPK fertilizers on the growth of the sago palm (Metroxylon sagu Rottb.) on undrained deep peat. Acta Hortic 389:67-76

Kyuma K (1986) Soils in lowlands of Southeast Asia, in wet lands in Southeast Asia, Japan International Research Center for Agricultural Sciences, Association of Agriculture and Fisheries Statistics, Tokyo. pp 41-103 (in Japanese) 
Lim ET, Loi KS (1987) Starch quality and soil types. Annual report, Sarawak Branch, Department of Agriculture, Sarawak for the year 1987. pp 82-85

Low H (1848) Sarawak: its inhabitants and productions, New impression (1968) Frank Cass, London

Matoh T (2002) Salt stress. In: Encyclopedia of plant nutrition and fertilizer. Asakura Shoten, Tokyo, pp 319-321

Morris HS (1953) Report on a Melanau sago producing community in Sarawak. Her Majesty's Stationary Office for The Colonial Office, Kuala Lumpur. pp 1-184

Nozaki K, Nuyim T, Shinano T et al (2004) Starch properties of the sago palm (Metroxylon sagu Rottb.) in different soils. Plant Foods Hum Nutr 59:85-92

Okazaki M (1995) Sago plantation for sustainable agriculture in tropical lowland areas. In: Sago study. Tokyo University of Agriculture and Technology, pp 117-145

Okazaki M (1998) Sago study. Tokyo University of Agriculture and Technology, pp 1-34

Okazaki M (2012) Sago in Leyte - breaking resistance of sago palm leaflets. Tokyo University of Agriculture and Technology, pp 1-56

Okazaki M, Toyota K (2003) Sago study in Cebu and Leyte. Tokyo University of Agriculture and Technology, pp 1-66

Okazaki M, Toyota K (2004) Sago study in Panay and Leyte. Tokyo University of Agriculture and Technology, pp 1-62

Okazaki M, Igura M, Tsujimoto M (2008) Technology development for utilization of natural resources inventory: sago palm. In: The 28th annual conference international association for impact assessment, May 4-10, 2008, Perth, p 24

Sato T, Tamaguchi T, Takamura T (1979) Cultivation, harvesting and processing of sago palm. Jpn J Trop Agric 23:136-141. (in Japanese)

Scott IM (1985) The soil of Central Sarawak Lowlands, East Malaysia. Soil Survey Division Research Branch, Department of Agriculture, Sarawak

Shimoda H (2000) Ecological studies on sago palm forest and its starch productivity in PNG. Jpn J Trop Agric 44:321-324. (in Japanese)

Shimoda H, Power AP (1990) Actual condition of sago palm forest and its starch productivity in east Sepik Province, Papua New Guinea, 1. Outline of survey area and natural environmental conditions of sago palm forest. Jpn J Trop Agric 34:292-301. (in Japanese)

Shoon J, Siong K, Osman JHJ (1995) Effects of plant spacing on the growth and development of sago palm (Metroxylon spp.) on undrained deep peat. Acta Hortic 389:77-89

Shrestha AK, Toyota K, Nakano Y et al (2006) Nitrogen fixing activity in different parts of sago palm (Metroxylon sagu) and characterization of aerobic nitrogen fixing bacteria colonizing sago palm. Sago Palm 14:20-32

Shrestha AK, Toyota K, Okazaki M et al (2007) Enhancement of nitrogen-fixing activity of microbial interaction with non-nitrogen fixers. Microbes Environ 22:59-70

Sugawara M (1979) Economic evaluation of agricultural development projects in tropical swampy lands. Jpn J Trop Agric 23:21-27. (in Japanese)

Takaya Y (1983) Sago production in south Sulawesi. Jpn J SE Asian Stud 21:235-260. (in Japanese)

Tie YL, Lim CP (1977) Lowland peat soils for sago-growing in Sarawak. In: Tan K (ed) Sago76: papers of the first international sago symposium. University of Malaya, Kuala Lumpur, pp 187-189

Tie YL, Lim ETK (1991) The current status and future prospects of harvestable sago palms in Sarawak. In: Ng TT, Tie YL, Kueh HS (eds) Towards greater advancement of the sago industry in the '90s: proceedings of the 14th international sago symposium. Lee Ming Press, Kuching, pp 11-16

Yamada I (1986) Plant communities in lowlands of Southeast Asia, in wet lands in Southeast Asia Japan International Research Center for Agricultural Sciences, Association of Agriculture and Fisheries Statistics, Tokyo. pp 104-196 (in Japanese) 
Yamaguchi C, Okazaki M, Kaneko T (1994) Sago palm growing on tropical peat soil in Sarawak, with special reference to copper and zinc. Sago Palm 2:21-30

Yamaguchi C, Okazaki M, Hassan AH (1998) The behavior of various elements in tropical swamp forest and sago plantation. Jpn J For Environ 40:33-42

Yoneta R, Okazaki M, Yano Y, Power AP (2004) Possibility of osmotic pressure regulation using $\mathrm{K}+$ in sago palm (Metroxylon sagu). In: Proceedings of the 13th conference of the society of sago palm studies. pp 17-22 (in Japanese)

Yoneta R, Okazaki M, Yano Y (2006) Response of sago palm (Metroxylon sagu Rottb.) to $\mathrm{NaCl}$ stress. Sago Palm 14:10-19

Open Access This chapter is licensed under the terms of the Creative Commons Attribution 4.0 International License (http://creativecommons.org/licenses/by/4.0/), which permits use, sharing, adaptation, distribution and reproduction in any medium or format, as long as you give appropriate credit to the original author(s) and the source, provide a link to the Creative Commons license and indicate if changes were made.

The images or other third party material in this chapter are included in the chapter's Creative Commons license, unless indicated otherwise in a credit line to the material. If material is not included in the chapter's Creative Commons license and your intended use is not permitted by statutory regulation or exceeds the permitted use, you will need to obtain permission directly from the copyright holder. 


\title{
Chapter 15 \\ Microbial Interactions and Activities Affecting Sago Palm Growth
}

\author{
Koki Toyota
}

\begin{abstract}
Microbes are ubiquitous soil inhabitants. Both aboveground and belowground parts of plants are associated with diverse and abundant microbes. Such microbes have positive and negative impacts on the plant productivity. Biological nitrogen fixation (BNF) is such a beneficial interaction. To reveal BNF by freeliving bacteria in sago palm, different parts (root, rachis, petiole, leaflet, bark, pith, and extracted starch) were collected in the Philippines, and their nitrogen-fixing ability was measured. Almost all the samples showed positive nitrogen fixation. Then, nitrogen-fixing bacteria (NFB) were isolated, belonging to different genera, such as Klebsiella sp., Pantoea sp., Burkholderia sp., Stenotrophomonas sp., and Bacillus sp. All the isolates preferred simple carbon compounds, like glucose, sucrose, and mannitol, as their substrates for nitrogen fixation, while they showed very low activity in starch, pectin, and hemicellulose media. When NFB were cocultured in such a medium with the polymer-degrading bacteria, nitrogen-fixing ability was markedly increased. Stimulatory effects were observed in Rennie medium by co-inoculation of NFB and indigenous bacterial consortia isolated from sago palm samples. These results indicate that complex microbial interactions may increase in situ nitrogen fixation and contribute to nitrogen nutrition in sago palm. This chapter also introduces characteristics of nitrogen-fixing bacteria and amounts of BNF in palm trees in recent studies.
\end{abstract}

\subsection{Microbial Activities Relating to Plant Growth}

Microbes exist everywhere, especially in soil. A classic report in Russia revealed that bacteria are a ubiquitous soil inhabitant, and total bacterial numbers are stable across quite diverse soil environments, from dry and desert steppe through meadow steppe, from forest meadow to taiga, and from 1200 to $3600 \mathrm{~m}$ above sea level (Mishustin and Mirsoeva 1968). By contrast, they found that specific groups of bacteria favor certain habitats and show large fluctuations depending on time and

K. Toyota $(\bowtie)$

Tokyo University of Agriculture and Technology, Koganei, Tokyo, Japan

e-mail: kokit@cc.tuat.ac.jp 
location. For example, spore-forming bacteria, enumerated as heat-tolerant ones, showed large fluctuations in their numbers, ranging from 0.01 to $1.2 \times 10^{6} \mathrm{~g}^{-1}$ soil (more than 100 times difference) depending on the sampling sites, but the differences in total bacterial numbers were only less than five times. Recent studies demonstrate that soil contains as many as $10^{10}-10^{11}$ bacteria, $6000-50,000$ bacterial species, and up to $200 \mathrm{~m}$ of fungal hyphae per $1 \mathrm{~g}$ and the soil microbes play key roles in ecosystems (van der Heijden et al. 2008).

In addition to soil, plants harbor a diverse and an abundant microbial community and support their activities as the key primary producers in most terrestrial ecosystems. In particular, the rhizosphere, defined as the soil environment influenced by the presence and activities of plant roots, has a huge impact on soil microbes. Plant roots release organic matter called rhizodeposition or root exudate, and the amount of rhizodeposition represents ca. $11 \%$ of carbon fixed by the plant and $27 \%$ of carbon allocated to roots (Dennis et al. 2010). Rhizodeposition supports the microbial activities in the rhizosphere. A wide range of organisms, i.e., different kinds of bacteria, fungi, protozoa, and nematodes, show higher populations in the rhizosphere than in the non-rhizosphere, which is not affected by plant roots. The rhizosphere consists of endorhizosphere (root tissue area), rhizoplane (root surface), and exorhizosphere (rhizosphere soil: soil directly surrounding the root). According to a report summarizing the results of 22 different plants, the numbers of aerobic bacteria were on average 9.9 times (2.6-24.2) higher in rhizosphere soil than in non-rhizosphere soil (Lochhead and Rouatt 1955), and microbial densities are markedly higher in the rhizoplane than in the endorhizosphere. An example showed that the numbers of total bacteria, Gram-negative bacteria, and fungi were 100-1000 times higher in the rhizoplane than in the endorhizosphere (Fig. 15.1). Rhizosphere soil and the rhizoplane are microbial hot spots, and many microbes colonize even the endorhizosphere.

In addition to belowground, the aboveground parts of plants also support a variety of bacteria, yeasts, and fungi. According to Lindow and Brandl (2003), bacteria are by far the most numerous colonists of leaves, ranging from $10^{6}$ to $10^{7}$ cells cm $\mathrm{cm}^{-2}$ (up to $10^{8}$ cells $\mathrm{g}^{-1}$ ). The aerial habitat colonized by these microbes is termed the phyllosphere, and the inhabitants are called epiphytes. The number of epiphytes is affected by surrounding environments. For example, Enya et al. (2007) compared the number of leaf-associated bacteria between field-grown and greenhouse-grown tomato leaves and found that the former harbored 100 times higher densities and the population densities increased with age. Since sago palm grows under field conditions, its leaves and stems are colonized by many microbes.

Microbes affect plant productivity through different mechanisms. First, a typical one is direct effects on plants via plant-associated organisms that form mutualistic or pathogenic relationships with plants. Another is indirect effects via the action of free-living microbes that alter rates of nutrient supply and the partitioning of resources (van der Heijden et al. 2008). Plant productivity is enhanced by different microbial actions, while there are a number of microbial threats to crop production (Table 15.1).

Nitrogen-fixing bacteria contribute to plant productivity to the largest extent, as described below. Arbuscular mycorrhizal (AM) fungi enhance plant productivity, especially in grasslands (van der Heijden et al. 1998). These two symbiotic micro- 


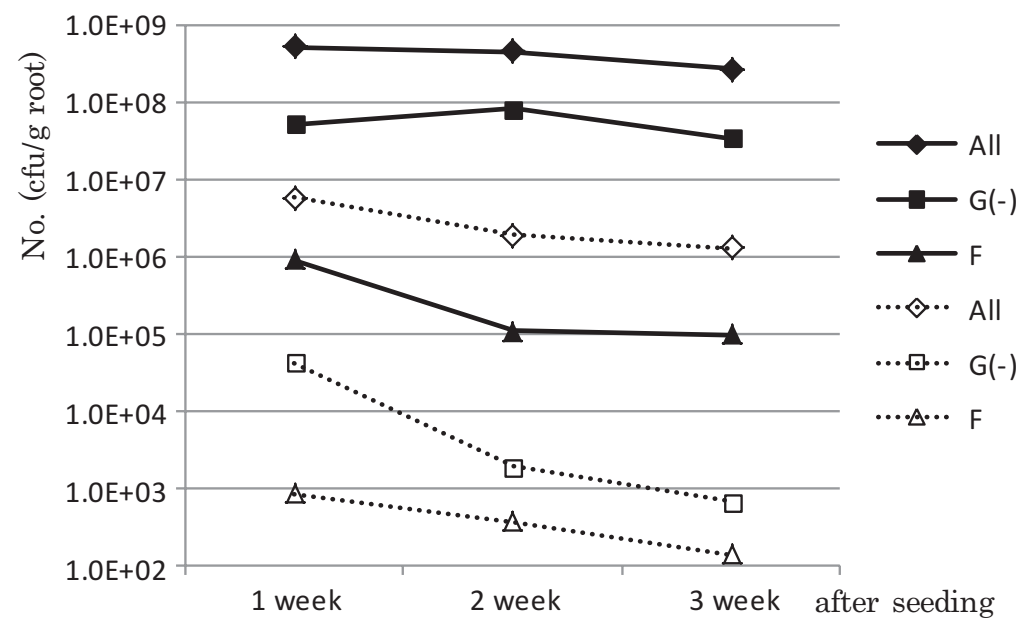

Fig. 15.1 The number of microorganisms in the rhizoplane and endorhizosphere of radish grown in soil. Solid lines, rhizoplane; dotted line, endorhizosphere. All: total culturable bacteria, $G(-)$ Gram-negative bacteria, $F$ fungi (Toyota et al. unpublished data)

Table 15.1 Influence of soil microbes on various ecosystem processes (From van der Heijden et al. 2008)

\begin{tabular}{|c|c|c|}
\hline Ecosystem process & Microbes involved & $\begin{array}{l}\text { Estimated microbial contribution } \\
\text { to ecosystem process }\end{array}$ \\
\hline \multirow[t]{2}{*}{ Plant productivity } & $\begin{array}{l}\text { Nitrogen-fixing bacteria, } \\
\text { mycorrhizal fungi }\end{array}$ & $0-50 \%$ \\
\hline & Microbial pathogens & $-50-0 \%$ \\
\hline Decomposition & Bacteria, fungi & Up to $100 \%$ \\
\hline Plant acquisition $\mathrm{N}$ fixation & $\begin{array}{l}\text { Rhizobia, actinomycetes, } \\
\text { free-living bacteria }\end{array}$ & 0-20\% (sometimes higher) \\
\hline Soil uptake & Mycorrhizal fungi & $0-80 \%$ \\
\hline Nitrogen loss denitrification & $\begin{array}{l}\text { Denitrifying bacteria and } \\
\text { some fungi }\end{array}$ & Up to $60 \%$ \\
\hline $\begin{array}{l}\text { Enhanced leaching because } \\
\text { of nitrification }\end{array}$ & Nitrifying bacteria, archaea & $? ?$ \\
\hline Phosphorus cycle & \multirow{2}{*}{$\begin{array}{l}\text { Mycorrhizal fungi, } \\
\text { P-solubilizing bacteria }\end{array}$} & \multirow[t]{2}{*}{$0-90 \%$} \\
\hline $\begin{array}{l}\text { Plant phosphorus } \\
\text { acquisition }\end{array}$ & & \\
\hline $\begin{array}{l}\text { Phosphorus loss because of } \\
\text { leaching }\end{array}$ & & $? ?$ \\
\hline
\end{tabular}

organisms have the greatest impact on plant productivity, but such symbiotic interactions have not been reported in sago palm.

Nutrient supply is an important function of soil microbes. Usually, plants do not use organic forms of $\mathrm{N}$, the dominant form in soil, but use inorganic $\mathrm{N}$, which is mineralized by the actions of soil microbes and animals. Even in agricultural crops 


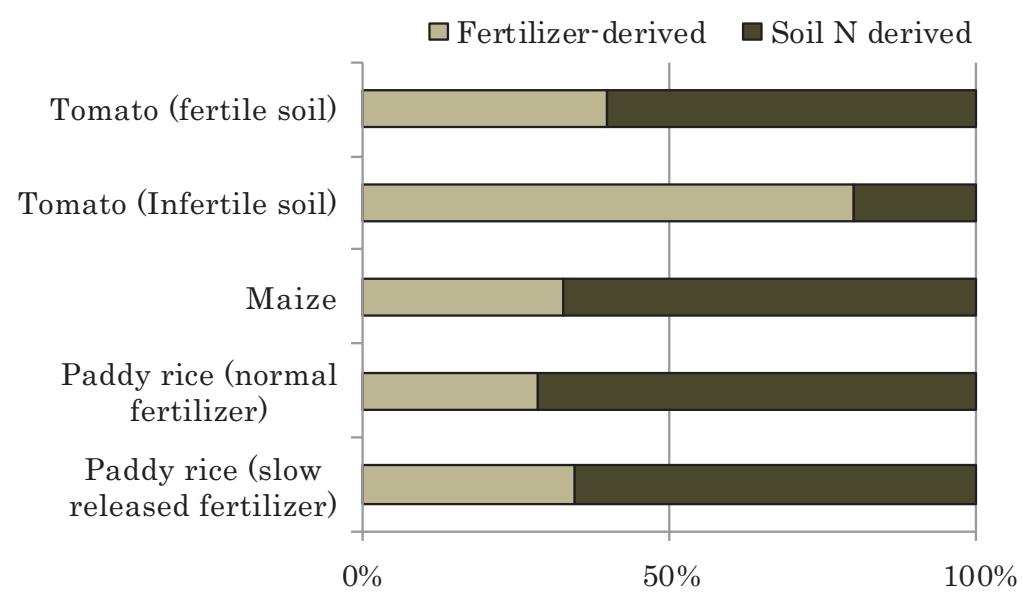

Fig. 15.2 Origin of N uptake by crops (Drawn from Fujiwara et al. 1996, paddy rice; Brady and Weil 2008, maize; Kato 2004, tomato)

where fertilization is always done, crops absorb more $\mathrm{N}$ from the soil organic matter fraction than from applied fertilizer (Fig. 15.2). Since sago palm is often cultivated under non-fertilized conditions, the most important mechanism for its $\mathrm{N}$ acquisition is the mineralization of soil organic matter by soil microbes and animals. Indeed, a pot experiment conducted in a glasshouse showed that sago palm growth evaluated by its plant height did not appear to be affected by urea fertilization (Lina et al. 2010), suggesting the importance of the nutrient-supplying capacity of soil.

Direct yield losses caused by pathogens, insects, and weeds are estimated to range from 20 to $40 \%$ of global agricultural productivity (Savary et al. 2012). In the natural environment, there are many airborne and soilborne plant pathogens, including fungi, bacteria, viruses, and nematodes. On the other hand, many studies have reported biological control of plant pathogens by epiphytes and rhizosphere microbes.

In sago palm, infestation with the bagworm larvae (Pteroma pendula) was found in the Philippines, but its damage to plant productivity was not estimated (Okazaki et al. 2012). As far as the author knows, there is no study reporting damage to sago palm caused by pathogens.

\subsection{Importance of Biological N Fixation}

Biologically fixed $\mathrm{N}$ is a free and renewable resource that plays a key role in sustainable agriculture. Biological $\mathrm{N}$ fixation (BNF) is seen to a varying degree in the soil environment including various parts of plants grown in soil. The potential for $\mathrm{N}$ fixation exists in any environment capable of supporting the growth of $\mathrm{N}$-fixing bacteria (NFB). The global terrestrial amount of BNF is estimated between 100 and 290 million mt per year (Cleveland et al. 1999), 40-48 million mt per year of which 
is fixed by agricultural crops in fields (Jensen and Nielsen 2003), corresponding to nearly one-half of global fertilizer usage. Symbiotic BNF in leguminous plants is famous, and $\mathrm{N}$-fixing bacterial symbionts of legumes can contribute up to $20 \%$ of all plant $\mathrm{N}$ that is annually acquired by vegetation (Cleveland et al. 1999), and its amount reaches as high as $300 \mathrm{~kg} \mathrm{~N} / \mathrm{ha} / \mathrm{crop}$. In addition to symbiotic relations, $\mathrm{BNF}$ through the activities of free-living $\mathrm{N}$ fixers is often seen in non-leguminous plants, e.g., sugarcane (Urquiaga et al. 1992), rice (Shrestha and Ladha 1996), and sago palm (Shrestha et al. 2006). Free-living $\mathrm{N}$-fixing bacteria, which are ubiquitous in terrestrial ecosystems, can also contribute significantly to the $\mathrm{N}$ budget of some systems. Cleveland et al. (1999) reported free-living N-fixing bacteria fix relatively small amounts of $\mathrm{N}(<3 \mathrm{~kg} \mathrm{~N} / \mathrm{ha} / \mathrm{year})$, but there are studies reporting larger contributions, such as 3.3-7.8 kg N/ha/year in tropical forest ecosystems (Reed et al. 2011) and $150 \mathrm{~kg} \mathrm{~N} / \mathrm{ha} / \mathrm{crop}$ in sugarcane (Dobereiner 1997). In oil palm plantations, legume covers are sometimes used under tree crops for the purpose of weed suppression, soil erosion control, and biological control of insect pests (Agamuthu and Broughton 1985). In addition to these, symbiotic BNF is expected; a report found $0.3-34.2 \mathrm{~kg} \mathrm{~N} / \mathrm{ha}$ fixed by legume covers (Pipai 2014).

\subsection{Taxonomy of N-Fixing Bacteria in Palm Trees}

Many free-living $\mathrm{N}$-fixing bacteria have been reported in different crops (Table 15.2). In sago palm, Shrestha et al. (2006) reported that different genera of N-fixing bacteria, such as Klebsiella pneumoniae, K. oxytoca, Pantoea agglomerans, Enterobacter cloacae, Burkholderia sp., Stenotrophomonas maltophilia, and Bacillus megaterium, were isolated from the root, rachis, petiole, leaflet, bark, and pith collected from sago palms in the Philippines. Enterobacter sp., Klebsiella sp., and Pantoea sp. were isolated from extracted starch (Shrestha et al. 2007). Shipton et al. (2010) also focused on starch extracted from sago palm trees and isolated Enterobacter oryzae, Klebsiella oxytoca, and Cronobacter (former Enterobacter) turicensis as N fixers. They also isolated Pectobacterium (former Erwinia) cypripedii from the rhizosphere of sago palm. Few studies have been done on N-fixing bacteria colonizing palm trees. Except for the studies by Shrestha et al. (2006) and Shipton et al. (2010), Reis et al. (2000) reported that oil palm was colonized by Azospirillum brasilense, A. amazonense, and Herbaspirillum seropedicae, and Tang et al. (2010) reported that A. amazonense was isolated from the root of sago palm and that Burkholderia vietnamiensis and B. kururiensis from the root of nipa palm. The genus Azospirillum is a Gram-negative free-living $\mathrm{N}$-fixing rhizosphere bacterium, and A. amazonense was first isolated from roots and rhizosphere soil of Gramineae, in the Amazon region, Brazil (Steenhoudt and Vanderleyden 2000). Burkholderia vietnamiensis was the only known $\mathrm{N}$-fixing species of this bacterial genus and was first isolated from the rhizospheres of rice, maize, and coffee plants (Santos et al. 2001). Since then, several species have been isolated from the endophytic environment of a wide range of taxonomically unrelated plants such as maize, sorghum, sugarcane, 
Table 15.2 Lists of free-living N-fixing bacteria isolated from different plants

\begin{tabular}{|c|c|}
\hline Plants & Isolated bacteria \\
\hline $\begin{array}{l}\text { Sugarcane } \\
\text { (Saccharum spp.) }\end{array}$ & $\begin{array}{l}\text { Azospirillum sp., Azospirillum brasilense, Azospirillum lipoferum, } \\
\text { Azospirillum amazonense, Azotobacter } \mathrm{sp} ., \text { Beijerinckia indica, Beijerinckia } \\
\text { fluminensis, Burkholderia brasiliensis, Burkholderia tropicalis, Derxia sp., } \\
\text { Enterobacteriaceae, Gluconacetobacter diazotrophicus, Gluconacetobacter } \\
\text { azotocaptans, Herbaspirillum seropedicae, Klebsiella sp., Paenibacillus } \\
\text { azotofixans, Pantoea sp., Vibrio sp. }\end{array}$ \\
\hline Maize (Zea mays) & $\begin{array}{l}\text { A. lipoferum, Azotobacter vinelandii, Bacillus circulans, Burkholderia sp., } \\
\text { B. vietnamiensis, Enterobacter sp., Enterobacter cloacae, Klebsiella } \\
\text { terrigena, P. azotofixans }\end{array}$ \\
\hline $\begin{array}{l}\text { Rice }(\text { Oryza } \\
\text { sativa })\end{array}$ & $\begin{array}{l}\text { A. lipoferum, Azospirillum irakense, Azotobacter } \mathrm{sp} ., \text { B. brasiliensis, } \\
\text { Clostridium sp., E. cloacae, H. seropedicae, K. oxytoca, K. pneumoniae, } \\
\text { Pantoea agglomerans, P. azotofixans, Pseudomonas } \mathrm{sp} .\end{array}$ \\
\hline $\begin{array}{l}\text { Wheat (Triticum } \\
\text { spp.) }\end{array}$ & $\begin{array}{l}\text { A. lipoferum, Azotobacter sp., Bacillus sp., E. cloacae, Klebsiella oxytoca, } \\
\text { Klebsiella pneumoniae, P. agglomerans }\end{array}$ \\
\hline $\begin{array}{l}\text { Bahia grass } \\
\text { (Paspalum } \\
\text { notatum) }\end{array}$ & Acetobacter paspali, Acetobacter halopareferans, $P$. agglomerans \\
\hline $\begin{array}{l}\text { Banana (Musa } \\
\text { spp.) }\end{array}$ & $\begin{array}{l}\text { K. pneumoniae, E. cloacae, } \text { H. seropedicae, Herbaspirillum } \\
\text { rubrisubulbicans }\end{array}$ \\
\hline Cereals & $\begin{array}{l}\text { H. seropedicae, A. lipoferum, A. amazonense, A. irakense, A. brasilense, } B . \\
\text { brasilense }\end{array}$ \\
\hline Coffee & Gluconacetobacter johannae, G. azotocaptans \\
\hline Dune grass & B. tropicalis, P. agglomerans, Stenotrophomonas maltophilia \\
\hline Forage grasses & H. seropedicae, A. brasilense, A. lipoferum, B. brasiliensis \\
\hline $\begin{array}{l}\text { Kallar grass } \\
\text { (Leptochloa fusca) }\end{array}$ & A. halopareferans, Azoarcus sp., E. cloacae, P. agglomerans \\
\hline Mangrove & Azotobacter chroococcum, A. vinelandii, A. beijerinckii \\
\hline Miscanthus spp. & A. doebereinerae, A. lipoferum, $H$. frisingense \\
\hline Oak & B. megaterium, Pseudomonas putida, P. fluorescence, Xanthomonas oryzae \\
\hline $\begin{array}{l}\text { Oil palm (Elaeis } \\
\text { spp.) }\end{array}$ & A. brasilense, A. amazonense, $H$. seropedicae \\
\hline Pine (Pinus spp.) & Bacillus sp., Burkholderia gladioli, Burkholderia glathei \\
\hline $\begin{array}{l}\text { Pineapple (Ananas } \\
\text { comosus) }\end{array}$ & Acetobacter diazotophicus, $H$. rubrisubulbicans \\
\hline $\begin{array}{l}\text { Sago palm } \\
\text { (Metroxylon sagu) }\end{array}$ & B. megaterium, K. pneumoniae, $K$. oxytoca, E. cloacae, $P$ agglomerans \\
\hline Spartina & $\begin{array}{l}\text { A. brasilense, A. lipoferum, A. vinelandii, Azotobacter chroococcum, } G \text {. } \\
\text { diazotrophicus, Herbaspirillum frisingense, H. seropedicae, } P \text {. stutzeri }\end{array}$ \\
\hline $\begin{array}{l}\text { Sweet potato } \\
\text { (Ipomoea batatas) }\end{array}$ & Acetobacter diazotrophicus, $P$. agglomerans \\
\hline
\end{tabular}


pineapple, and coffee, and currently nine diazotrophic plant-associated Burkholderia, including B. kururiensis, have been validly described (Wong-Villarreal and Caballero-Mellado 2010). These studies conclude that palm trees harbor $\mathrm{N}$ fixers such as facultative anaerobic enteric bacteria, Burkholderia and Azospirillum, which have been also isolated from major crops, such as rice and maize.

\subsection{Enhancement of N-Fixing Ability by Microbial Interactions}

BNF requires many factors; the most important element among them is a carbon substrate. In symbiotic BNF, abundant substrate is provided through photosynthesis by the host plant, while in free-living BNF, a crucial issue is how to obtain enough substrate for the energy source. For that reason, many free-living $\mathrm{N}$-fixing bacteria are associated with plants. In general, NFB utilizes exclusively simple carbon sources like glucose and sucrose (Haahtela et al. 1983). In contrast, the major carbohydrates in plants are complex carbon sources like cellulose, hemicellulose, and pectin (Lack and Evans 2001). Thus the effects of microbial interactions between NFB and indigenous bacteria, both of which were isolated from sago palm, on BNF were investigated. All NFB isolated from sago palm preferred simple sugars, like glucose, sucrose, and lactate, as their substrate for $\mathrm{N}$ fixation and showed extremely low levels of N-fixing activity in starch, hemicellulose, and pectin-containing media (Fig. 15.3) (Shrestha et al. 2007). N-fixing activity by NFB was markedly enhanced by the consortium of starch-degrading Bacillus sp. strain B1 in a starch medium, although the NFB showed negligible N-fixing activity when inoculated singly (Fig. 15.4). The consortium of hemicellulose-degrading Agrobacterium sp. strain

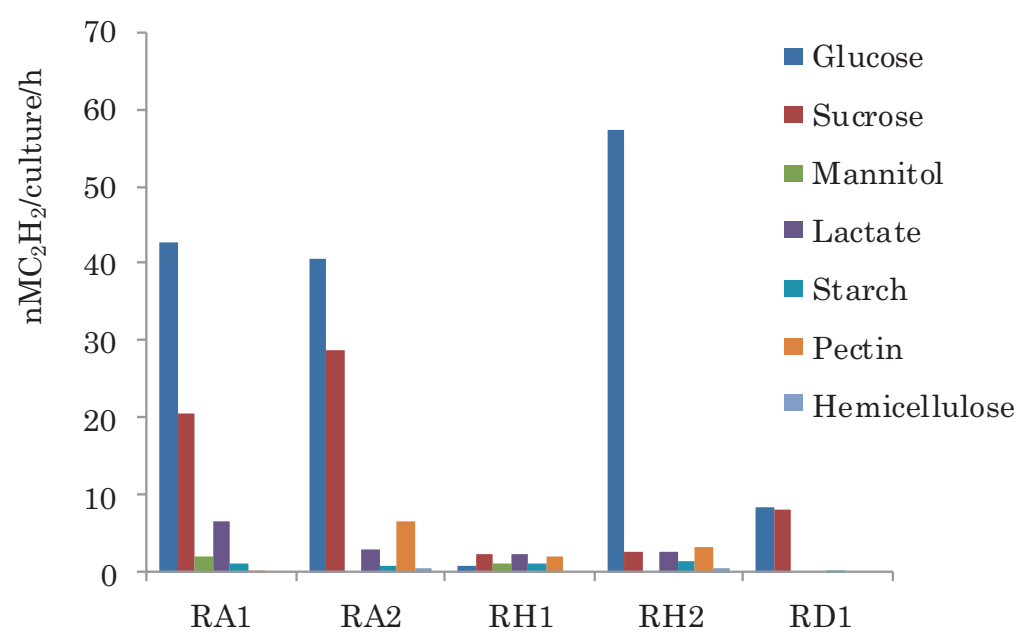

Fig. 15.3 Nitrogen-fixing activity of nitrogen-fixing bacteria in different carbon substrates. Glu glucose, Suc sucrose, Lac lactate, Pec pectin (Shrestha et al. 2007) 

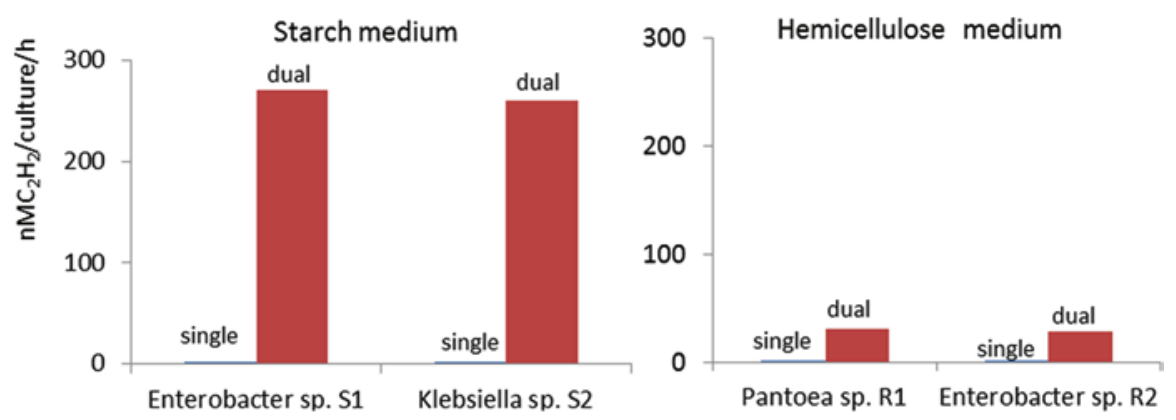

Fig. 15.4 Effect of co-inoculation of nitrogen-fixing bacteria (S1, S2, R1, and R2) and polymerdegrading bacteria on the nitrogen-fixing activity in polymer media (Shrestha et al. 2007)

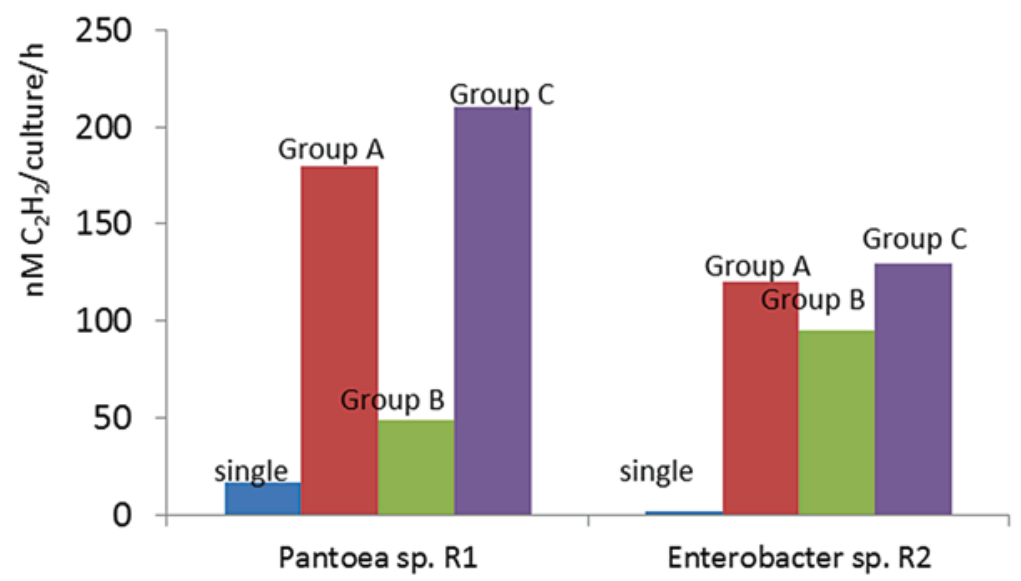

Fig. 15.5 Effects of co-inoculation of randomly isolated strains (each group consisted of ten strains) on nitrogen-fixing ability of nitrogen-fixing bacteria (R1 and R2) (Shrestha et al. 2007)

HMC1 or Flexibacter sp. strain HMC2 and NFB also showed enhanced N-fixing activity in a hemicellulose medium. Such stimulation was not observed in a pectin medium. These results suggest that $\mathrm{N}$-fixing bacteria may actively fix $\mathrm{N}$ in collaboration with degraders of starch and hemicellulose, the major carbohydrates in sago palm plant bodies.

The second important parameter in BNF is an oxygen level which affects nitrogenase activity directly (Robson and Postgate 1980). Coculture of NFB and indigenous bacteria, isolated from sago palm using nutrient agar medium, in a nitrogen-free Rennie medium containing simple organic compounds showed significantly higher $\mathrm{N}$-fixing activity than single inoculations of NFB did in almost all combinations (Fig. 15.5), suggesting that co-inoculated bacteria consumed $\mathrm{O}_{2}$ and made conditions with deficient $\mathrm{O}_{2}$. Indeed, we confirmed that a reduced oxygen status itself enhanced the N-fixing activity of NFB (Fig. 15.6) (Shrestha et al. 2007). 


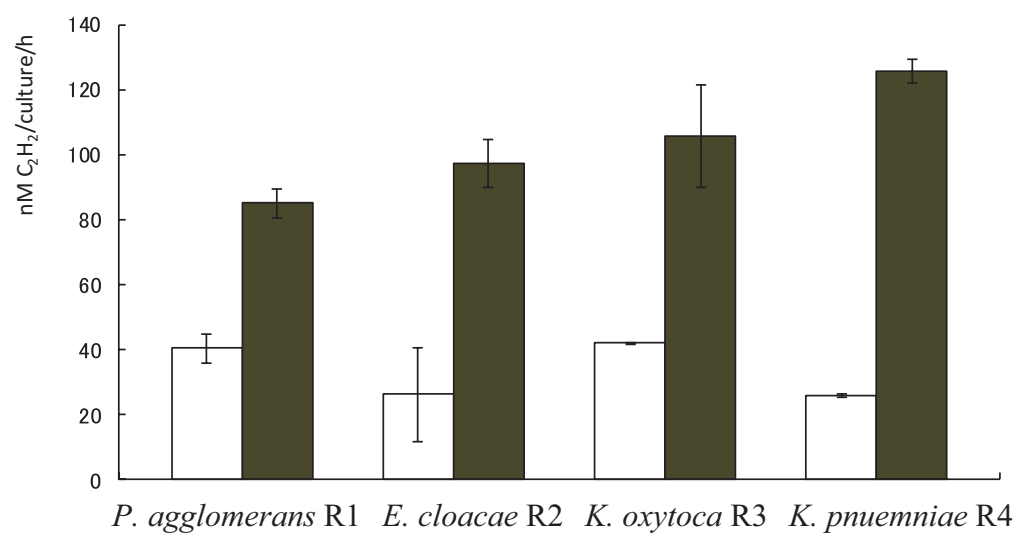

Fig. 15.6 Effect of ambient (white bar) and reduced $\mathrm{O}_{2}$ (gray bar) conditions on the nitrogenfixing activity of selected nitrogen fixers (R1, R2, R3, and R4) (Shrestha et al. 2007)

These results may indicate that beneficial microbial interactions occur in sago palm to enhance $\mathrm{N}$-fixing activity through collaborative utilizations of starch, hemicellulose, and their degradation products.

\subsection{Estimate of Amounts of N Fixation in Palms}

Shrestha et al. $(2006,2007)$ quantified N-fixing activity in different parts of sago palm, such as stem, leaf, root, bark, and starch, and isolated a wide range of $\mathrm{N}$-fixing bacteria. Although the estimation of fixed $\mathrm{N}$ based on the acetylene-reducing activity contains some uncertainties, the amount of fixed $\mathrm{N}$ in a mature sago palm stand was estimated at $210 \mathrm{~kg} \mathrm{~N} / \mathrm{ha} / \mathrm{y}$ from calculation based on $\mathrm{N}$-fixing activity in root (221 nM C ${ }_{2} \mathrm{H}_{4} / \mathrm{g} /$ day), pith (213 $\mathrm{nM} \mathrm{C}_{2} \mathrm{H}_{4} / \mathrm{g} /$ day), and leaf sheath (35.4 nM C ${ }_{2} \mathrm{H}_{4} / \mathrm{g} /$ day) and their mean weights per palm $(68,721$, and $97 \mathrm{~kg}$ in root, pith, and leaf sheath, respectively) with a sago palm density in a mature forest of 923 sago palms/ ha (Toyota 2015).

Yonebayashi et al. (2014) estimated the amount of $\mathrm{N}$ fixation in sago palm using a tracer experiment. They measured $\delta 15 \mathrm{~N}$ values of the youngest leaves of sago palms at different stages of growth and found that $\delta 15 \mathrm{~N}$ values were lower with age, indicating higher $\mathrm{N}$ fixation with maturing. The contribution of biologically fixed $\mathrm{N}$ to total $\mathrm{N}$ of sago palm leaves was less than $10 \%$ at the beginning of growth stage (3 years), but it increased with age and reached more than $90 \%$ at the later stage (13 years).

Amounts of $\mathrm{N}$ fixation have been estimated in other palms. De Carvalho et al. (2008) reported that $13-76 \%$ of total $\mathrm{N}$ in oil palm depended on biological $\mathrm{N}$ fixation in a 1-year growth experiment using $\mathrm{N}$ poor quartz sand and subsoil. Zakry et al. (2012) found that the contribution of biological $\mathrm{N}$ fixation to total $\mathrm{N}$ uptake by oil palm was different depending on the plant parts in oil palm $(75 \%$ in leaflet, $13 \%$ in stem, and $13 \%$ in root) and was $63 \%$ on the whole plant basis. These results reveal that BNF functions as a biofertilizer and is essential in establishing sustainable crop production. 


\section{References}

Agamuthu P, Broughton WJ (1985) Nutrient cycling within the developing oil palm-legume ecosystem. Agric Ecosyst Environ 13:111-123

Brady NC, Weil RR (2008) The nature and properties of soils, 14th edn. Pearson Education Inc, Upper Saddle River, p 573

Cleveland CC, Townsend AR, Schimel DS et al (1999) Global patterns of terrestrial biological nitrogen $\left(\mathrm{N}_{2}\right)$ fixation in natural ecosystems. Glob Biogeochem Cycles 13:623-645

de Carvalho ALV, Alves BJR, Baldani VLD, Reis VM (2008) Application of (15)N natural abundance technique for evaluating biological nitrogen fixation in oil palm ecotypes at nursery stage in pot experiments and at mature plantation sites. Plant Soil 302:71-78

Dennis PG, Miller AJ, Hirsch PR (2010) Are root exudates more important than other sources of rhizodeposits in structuring rhizosphere bacterial communities? FEMS Microbiol Lett 72:313-327

Dobereiner J (1997) Biological nitrogen fixation in the tropics: social and economic contributions. Soil Biol Biochem 29:771-774

Enya J, Shinohara H, Yoshida S et al (2007) Culturable leaf-associated bacteria on tomato plants and their potential as biological control agents. Microb Ecol 53:524-536

Fujiwara S, Anzai T, Kato T (1996) Methods and applications of soil diagnosis. Rural Culture Association Japan, Tokyo, p 141. (in Japanese)

Haahtela KT, Kari K, Sundman V (1983) Nitrogenase activity of root associated, cold climate Azospirillum, Enterobacter, Klebsiella and Pseudomonas species during growth on various sources and at various partial pressures of oxygen. Appl Environ Microbiol 45:563-570

Jensen ES, Hauggaard-Nielsen H (2003) How can increased use of biological N2 fixation in agricultural benefit the environment? Plant Soil 252:177-186

Kato (2004) Encyclopedia of vegetables and horticulture 22 hydroponics. Rural Culture Association Japan, Tokyo, p 429. (in Japanese)

Lack AJ, Evans DE (2001) The plant cell wall. In: Hames BD (ed) Instant notes: plant biology. BIOS Scientific Publishers Limited, Milton Park, pp 6-7

Lina SB, Okazaki M, Kimura SD et al (2010) Nitrogen uptake and growth response of sago palm (Metroxylon sagu Rottb.) to two types of urea fertilizer application. Sago Palm 18:73-83

Lindow SE, Brandl MT (2003) Microbiology of the phyllosphere. Appl Environ Microbiol 69:1875-1883

Lochhead AG, Rouatt JW (1955) The "rhizosphere effect" on the nutritional groups of soil bacteria. Soil Sci Soc Am J 19:48-49

Mishustin EN, Mirsoeva VA (1968) Spore forming bacteria in the soils of USSR. In: Gray TRG, Parkinson D (eds) The ecology of soil bacteria. University Press, Liverpool, pp 458-473

Okazaki M, Kimura SD, Suzette LB et al (2012) Pteroma pendula infestation of sago palm (Metroxylon sagu Rottb.) in Leyte, Philippines. Sago Palm 20:69-75

Pipai R (2014) Biological nitrogen fixation by cover legumes under oil palm plantations in Papua New Guinea. Master of Agricultural Science thesis, The University of Adelaide

Reed SC, Cleveland CC, Townsend AR (2011) Functional ecology of free-living nitrogen fixation: a contemporary perspective. Annu Rev Ecol Evol Syst 42:489-512

Reis VM, Baldani JI, Baldani VLD, Dobereiner J (2000) Biological dinitrogen fixation in Gramineae and palm trees. Crit Rev Plant Sci 19:227-247

Robson RL, Postgate JR (1980) Oxygen and hydrogen in biological nitrogen fixation. Annu Rev Microbiol 34:183-207

Santos PEDL, Bustillos-Cristales R, Caballero-Mellado J (2001) Burkholderia, a genus rich in plant-associated nitrogen fixers with wide environmental and geographic distribution. Appl Environ Microbiol 67:2790-2798

Savary S, Ficke A, Aubertot JN, Hollier C (2012) Crop losses due to diseases and their implications for global food production losses and food security. Food Sec 4:519-537 
Shipton WA, Baker A, Blaney BJ et al (2010) Nitrogen fixation associated with sago (Metroxylon sagu) and some implications. Lett Appl Microbiol 52:56-61

Shrestha RK, Ladha JK (1996) Genotypic variation in promotion of rice nitrogen fixation as determined by nitrogen ${ }^{15} \mathrm{~N}$ dilution. Am J Soil Sci 60:1815-1821

Shrestha A, Toyota K, Nakano Y et al (2006) Nitrogen fixing activity in different parts of sago palm (Metroxylon sagu) and characterization of aerobic nitrogen fixing bacteria colonizing sago palm. Sago Palm 14:20-32

Shrestha A, Toyota K, Okazaki M et al (2007) Enhancement of nitrogen-fixing activity of Enterobacteriaceae strains isolated from sago palm (Metroxylon sagu) by microbial interaction with non-nitrogen fixers. Microbes Environ 22:59-70

Steenhoudt O, Vanderleyden J (2000) Azospirillum, a free-living nitrogen-fixing bacterium closely associated with grasses: genetic, biochemical and ecological aspects. FEMS Microbiol Rev 24:487-506

Tang SY, Hara S, Melling L et al (2010) Burkholderia vietnamiensis isolated from root tissues of nipa palm (Nypa fruticans) in Sarawak, Malaysia, proved to be its major endophytic nitrogenfixing bacterium. Biosci Biotechnol Biochem 74:1972-1975

Toyota K (2015) Nitrogen fixing bacteria. In: Society of Sago Palm Studies (ed) The sago palm: the food and environmental challenges of the 21 st century. Kyoto University Press, Kyoto, pp 150-155

Urquiaga S, Cruz KHS, Boddey RM (1992) Contribution of nitrogen-fixation to sugar cane: nitrogen-15 and nitrogen-balance estimates. Soil Sci Soc Am 56:105-114

van der Heijden MGA, Klironomos JN, Ursic M et al (1998) Mycorrhizal fungal diversity determines plant biodiversity, ecosystem variability and productivity. Nature 396:69-72

van der Heijden MGA, Bardgett RD, van Straalen NM (2008) The unseen majority: soil microbes as drivers of plant diversity and productivity in terrestrial ecosystems. Ecol Lett 11:296-310

Wong-Villarreal A, Caballero-Mellado J (2010) Rapid identification of nitrogen-fixing and legumenodulating Burkholderia species based on PCR 16S rRNA species-specific oligonucleotides. Syst Appl Microbiol 33:35-43

Yonebayashi K, Katsumi N, Nishi T, Okazaki M (2014) Activation of nitrogen-fixing endophytes is associated with the tuber growth of sweet potato. Mass Spectrom 3:A0032

Zakry FAA, Shamsuddin ZH, Rahim KA et al (2012) Inoculation of Bacillus sphaericus UPMB10 to young oil palm and measurement of its uptake of fixed nitrogen using the ${ }^{15} \mathrm{~N}$ isotope dilution technique. Microbes Environ 27:257-262

Open Access This chapter is licensed under the terms of the Creative Commons Attribution 4.0 International License (http://creativecommons.org/licenses/by/4.0/), which permits use, sharing, adaptation, distribution and reproduction in any medium or format, as long as you give appropriate credit to the original author(s) and the source, provide a link to the Creative Commons license and indicate if changes were made.

The images or other third party material in this chapter are included in the chapter's Creative Commons license, unless indicated otherwise in a credit line to the material. If material is not included in the chapter's Creative Commons license and your intended use is not permitted by statutory regulation or exceeds the permitted use, you will need to obtain permission directly from the copyright holder. 


\section{Part VI \\ Starch Production and Utilization}




\title{
Chapter 16 \\ Sago Starch: Transformation of Extraction and Consumption Processes in Traditional Indonesian Societies
}

\author{
Yoshihiko Nishimura
}

\begin{abstract}
New Guinea Island (NGI) is the origin of sago palm. Sago became a food plant not only in NGI but was also dispersed to Asian areas for use as a staple food. In the current study, the transformation of extraction technology and the trends in sago consumption were surveyed in the area of sago origin and the other areas subsequently adopted sago palm in Indonesia. The original starch extraction method was to pulverize the sago pith with an ax and wash the pieces of pith by hand, which was practiced in NGI. Then this technology of starch extraction was transferred to western Indonesia through the process described below.

Pith pulverization: Original form of pith crushing by ax (chopping with an ax while sitting and a long ax while standing) transferred to west part of Indonesia and Malaysia, followed by further development in grater forms and adaptation to rasper machine use.

Washing pieces of crushed pith: Original form of washing by hand was transferred to the west for further modification of crushing the pith by foot with highpressure water (pumping and gravity) form. This form of washing by water flow is a transformation from a horizontal to a vertical direction.

Sago starch is used for various foods from papeda (dough type with soup) as a staple food to confectionery products (lempeng, baked crackers, cookies, or jellies), noodles, and dry powder (a substitute for other starches).

An important aspect of sago production system depends on farmers' needs, whether they sell it or utilize it themselves. The next important issue is to increase production for the commercial market. In this step, group production system is adapted in the process. This group work is performed by farmers which is the target for specialized business. In addition, mechanization has been introduced, like using a rasper for grating and a pump for washing the pith. These transformations indicate how to develop an efficient economic output. Sago is changing from the concept of staple food to other starch food uses and starch goods use, as the social economy and cash-based economy are developed in the rural Indonesian society.
\end{abstract}

\footnotetext{
Y. Nishimura $(\square)$

Formerly, Nagoya University, Nagoya, Japan

e-mail: nishimuratomobe@gmail.com
} 


\subsection{Introduction}

The sago palm, which originated in New Guinea Island, has created the sago culture that is the means of livelihood for local people where the palm occurs. The traditional dietary food culture of sago has developed under the conditions of different traditions of consumption and extraction of the starch. It is considered that the socioeconomic conditions determine the regional forms of sago extraction and use. Thus the changes in extraction technology have modified the forms of using sago. This subject was investigated in Indonesia where sago palm grows widely, extending from east to west. The factors relating to the various forms are also considered in this chapter.

The prototype of the starch extraction method is found in New Guinea and uses a hand ax type of pulverization of the palm pith and the hand-washing method for extraction of starch from crushed pith. Furthermore, the pulverization method was transformed through the following process modifications: hand ax or hatchet (sitting type), broadax (standing type), grater type (rasping model), and rasper (mechanization pulverization). Moreover, the starch extraction method, which washes pulverized pith, was also transformed as follows: the hand-washing type, the footwashing type, and the pump-use type (providing high pressure) (Nishimura 2015).

As for utilization, sago starch shifted from ugari as the staple food to various food uses. It is supposed that development from a staple food moved with the flow of confectionery (baked crackers, cookies) to noodles and to flour (substitution of other starch flour) (Hirao 2015). At present, sago starch as well as other starches can produce sugar and the materials for plastics through changing the starch character. The nature of these changes is related to the socioeconomics of production and consumption areas.

This paper clarifies the following points in consideration of the two factors of a geographical flow and time flow regarding the extraction method of sago starch. These are the change of method by geographical factors, change of consumption patterns of starch, and, in addition, the relationship between methods of change and the regional economy.

This study is based on results obtained from sago palm investigations in Indonesia conducted from 1992 to 2014. Moreover, some results of investigation from Mindanao, the Philippines, and Papua New Guinea are also included. The study concludes by incorporating results of the investigations in the field and interviews with people in the study areas.

\subsection{Changes in Sago Starch Extraction}

The extraction technique of sago starch is an important task for sago-producing farmers; there are traditional extraction methods and technologies in each local area. It is recognized that there are regional differences even if the technology appears to be simple (Nishimura and Laufa 2002). This study examines the 
technologies or methods of sago starch extraction in Indonesia, a country extending for over $5000 \mathrm{~km}$ from east to west. As a result, the investigation found that there was a difference of the methods in New Guinea, which was the place of origin of a sago palm, and the western regions of Indonesia, to which sago spread. The difference of these methods has taken the form of technology transfer from the original area and a series of improvements in technology in each area.

The study analyzed in detail elements of the technology of four types: the New Guinea type, the Malay type, the intermediate type, and the mixed type as classified by Nishimura (2008b, 2012). From this analysis, enhanced investigations have been carried out, with the results shown in Table 16.1.

In New Guinea, a prototype of the extraction method (New Guinea type) was developed, and there are two forms for the pulverization of sago pith, sitting and standing. The tools used for this work of chopping are a sitting form using a hand ax (chopping ax/hatchet) and a standing form using a common ax (broadax). With the Malay type, which is a more developed type, the sitting form uses a hand ax as a basic form, and a grater form has also been developed. Moreover, the mechanization using raspers is progressing. The intermediate type is a sitting form using a hand ax. Moreover, in Mindanao, Philippines, there is a standing form involving a broadax considered as a mixed type (Nishimura 2008a).

The method of washing the mashed sago pith and extraction of starch exhibits regional differences like pulverization. The New Guinea type is a method in which water is poured in from the side by hand. More elaborate equipment may be made in some cases. In this case, the water flow is from the side (horizontal). Moreover, the Malay type is a starch extracting process which places the mashed pith into a basket where it is washed by foot action under pouring water. The water flow is vertical in this case. The intermediate type is the same as the Malay type which places the mashed pith into a basket and washing it by foot action under a vertical water flow. On the other hand, the method in Mindanao, Philippines, is the technology called the mixed type, and the flow of water is vertical although the mashed pith is washed by hand. Moreover, the mixed type which washes mashed pith by hand by

Table 16.1 Grouping of the regional methods of sago starch extraction

\begin{tabular}{l|l|l|l|l}
\hline \multirow{2}{*}{ Extraction form } & \multicolumn{2}{|l|}{ Sago palm with chopping } & \multicolumn{2}{l}{ Starch extraction by water } \\
\cline { 2 - 5 } & Pulverization & Chopping tools & Washing by & Water flow \\
\hline Original form (New Guinea type) & Sitting & Hatchet & Hand & Horizontal flow \\
\cline { 2 - 3 } & Standing & Broadax & & Horizontal flow \\
\hline Intermediate form (K) & Sitting & Hatchet & Feet & Vertical flow \\
\hline Intermediate form (B) & & & Hand & Vertical flow \\
\hline Developed form (Malay type) & Standing & Grater & Feet & Vertical flow \\
\cline { 2 - 5 } & Standing & Rasper & Feet & Vertical flow \\
\hline Mixed form & Standing & Broadax & Hand & Vertical flow \\
\hline
\end{tabular}

Note:

Type/form: New Guinea T.; Intermediate F.; Malay T.; Mixed F.

Observed region: South Sorong; (K) Kendari, (B) Bogor; Riau; Mindanao 
vertical water flow is seen as a peculiarity in Bogor, Java Island. In the case of comparison of these methods, origin/prototype and developed type, the pith pulverization went from a hand ax to a broadax and then a grater. Moreover, the method of starch extraction by washing in water has evolved from horizontal washing by hand (rubbing) to vertical washing by foot (crushing). Then, a mechanical motorized rasper came into use.

The local processing of sago palm is demonstrated using photographs (Fig. 16.1): the technical change of the pith-crushing work and washing (starch extraction) of the crushed pith, as currently performed in each area. In the case of diffusion of sago technology spreading from Papua Province, Indonesia, and New Guinea Island, the place of origin of sago palm, to the west, technology of the pulverization was transmitted from the east to the west changing to hand ax (sitting form), broadax (standing form), grater form (rasping model), and rasper (mechanization pulverization). Moreover, the method of washing crushed pith by water (starch extraction) changes, moving east to west similarly, going from hand to foot, and finally to the pump-use form. With the addition of a time factor, mechanization becomes technical development.

\subsection{Changes in the Form of Starch Utilization}

Sago palm is an important crop, and the entire plant can be used by native Indonesians. The starch which is extracted serves as the staple food of people in the villages. It is clear that the areas of Indonesia which are located closer to New Guinea Island have a stronger dependence on sago as their staple food. In Kendari, Southeast Sulawesi, and South Sorong, West Papua province, a comparison was made between the staple food and other food. The results are shown in Table 16.2.

In the West Papua province, South Sorong district, and Metamani subdistrict, the staple food is sago, and it is eaten as papeda (porridge). There is also in their diet fish, shellfish, and wild animal meat, such as wild boar, deer, etc., obtained by hunting, as side dishes. On the other hand, in the Kendari district in Southeast Sulawesi, the staple food is rice and sago. Although rice as the staple food was grown as upland rice a long time ago, paddy rice is now cultivated. When indigenous people harvest rice, they eat it in the dry season; during the rainy season, they extract starch from the sago palm. Thus these two plants together provide their staple food. Side dishes in the diet are fish, shellfish, and wild animal meat, similar to West Papua. Cultivation of rice in Indonesia did not take place in the eastern part bordering Sulawesi (Takaya 1990). However, it can be seen that the movement of rice consumption as a staple food spread from the western to eastern regions where the main food is sago. Therefore, traditionally people in the eastern region most commonly consume sago starch as the staple food. Moreover, a unique use of sago starch is processed as noodles. Production of these noodles is mainly carried out in Semarang, Central Java. Since many Chinese immigrants have lived in Java since ancient times, production of the noodles as Chinese food was accomplished. However, sago starch is not produced in Semarang, and the sago starch used to make noodles is mainly brought from the Riau Province (commercialization). Moreover, confections are made as 
16 Sago Starch: Transformation of Extraction and Consumption Processes...

1. Pulverizing pith with sitting form

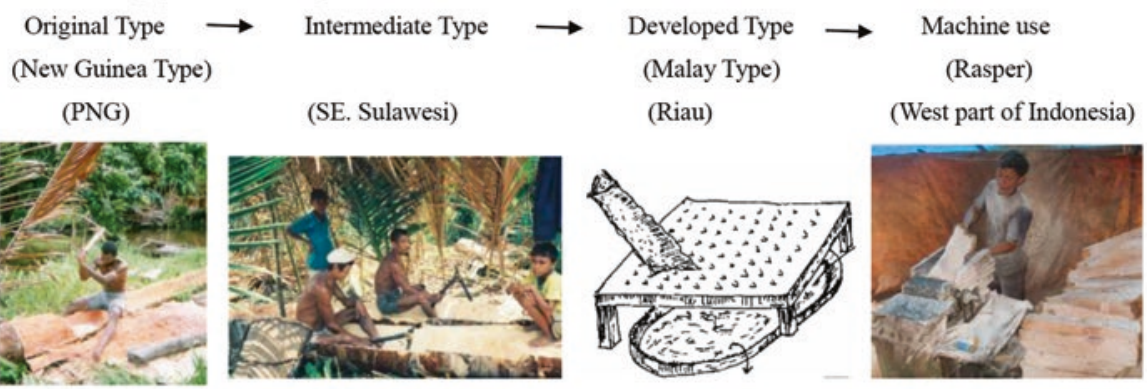

2. Pulverizing pith with standing form
Original Type
$\rightarrow$ Mixed Type
$\rightarrow \quad$ Developed Type
$\rightarrow \quad$ Machine use
(New Guinea Type)
(S. Sorong)
(Mindanao)
(Malay Type)
(Rasper)
(Riau)
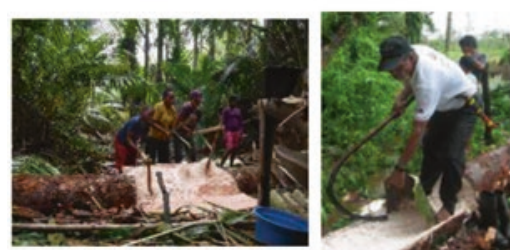

3. Starch extraction by washing (hand-rubbing from and horizontal water flow)

Original Type $\longrightarrow$ Original Type $\rightarrow$ Original Type (improved) $\rightarrow$

Machine use

(New Guinea Type)

(PNG)

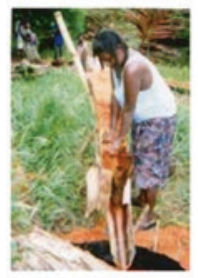

(S. Sorong)

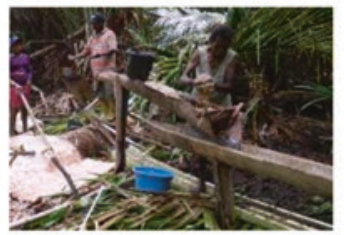

(Sub. Sorong city)

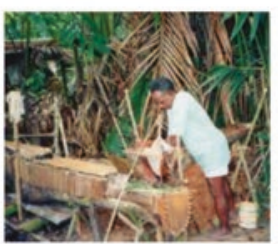

(Pump)

(Bogor)

\section{Starch extraction by washing (foot-paddling form and vertical water flow)}

Developed Type (Malay Type) $\longrightarrow$ Machine Use (pump)

(SE. Sulawesi)

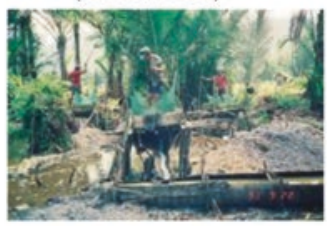

(SE. Sulawesi)

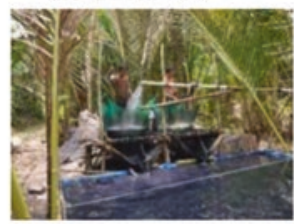

5. Mixed Type

(hand-rubbing form but vertical water flow)

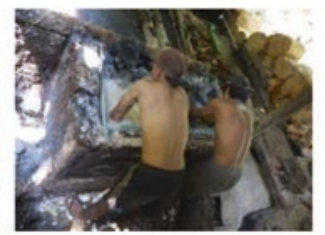

Fig. 16.1 The diffusion and transformation of the methods of sago starch extraction 
Table 16.2 Food situation in sago villages

\begin{tabular}{l|l|l|l|l}
\hline \multirow{2}{*}{ Main food } & \multicolumn{2}{|l|}{ Kiaea village $^{\mathrm{a}}$} & \multicolumn{2}{l}{ Saga village $^{\mathrm{b}}$} \\
& Rice & $99.4 \%$ & Sago & $100 \%$ \\
\cline { 2 - 5 } & Sago & $52.6 \%$ & Rice & A little \\
\cline { 2 - 5 } & Corn & $42.1 \%$ & Banana & Sometimes \\
\cline { 2 - 5 } & Cassava & $2.9 \%$ & & \\
\hline \multirow{5}{*}{ Side dish } & Fish & & Fish & \\
\cline { 2 - 5 } & Shrimp & & Shrimp, Shellfish & \\
\cline { 2 - 5 } & Meat & & Wild animal meat & \\
\cline { 2 - 5 } & Vegetable & & Vegetable & \\
\hline
\end{tabular}

${ }^{a}$ Kiaea village in Southeast Sulawesi province; observation was done in 1992 (Nishimura 1995)

${ }^{b}$ Saga village in West Papua province, located in a wild sago forest. Observation was done in 2012

additional food. One form is lempeng (pancake), which is generally dried food, and can also be considered a preserved food. As well, cookies, shrimp crackers, sago pearls, etc. are made (Hirao 2015). Although confections are made and eaten by the farmers themselves, in many cases they are sold. Moreover, there are some people who make confections, especially in the towns. These forms change depending on regions, and in order to carry out sales, producers need to prepare a product suitable to meet the needs of local consumers.

According to the results of this study, the form of consumption of sago starch is classified into staple food, confections, starch flour, and biomaterial. Traditional farmers in sago palm areas consume sago starch as the staple food and as a confection. Depending on the developing rural economy, the use of sago is diversified and increasingly used as a confection and commercial starch. If the multiple use of this staple food progresses, it will shift from the use of sago starch to uses other than as a staple food. Looking at the usage of the sago starch regionally, diversification of the staple food is moving from east to west. That is, there is one staple food of sago in the provinces of Papua and Maluku to the east, but moving west to Sulawesi and the central islands, there are two staple food areas of rice and sago starch. Also, sago starch goes more to the development of confections and a commercial use to make noodles, such as in Java. Furthermore, in the Malay region on the western side of Kalimantan Province, it has shifted more to commercial starch use. This trend shows a change from east to west, similar to the change in sago starch extraction techniques. Therefore, the form of consumption of sago starch relates to the level of economic development of an area and to social change.

As for sago starch as a staple food, it is eaten in two forms, added to dishes such as soup or porridge, or as a dry food as a bread or biscuit. It is also consumed in the form of noodles made of sago starch. In confectionary form it is consumed as a specialty in Indonesia as crackers, cookies, or jelly. In traditional villages, the confectionery form is generally dry and consumed as a cracker. In addition, in a village on Mindanao Island, Philippines, the confectionery is made of sago starch fried in oil or steamed (Nishimura 2008a). Therefore, sago starch is important as a staple food in eastern Indonesia and consumed as a side dish or confectionery in the western part of the country. It is believed that this tendency is especially influenced by 
the Java culture which eats sweets (diversification of a meal). Furthermore, in the western Malay area, as commercialization progresses toward industrial uses such as starch flour, food use in the rural area of sago starch is being reduced.

\subsection{Technical Flow and Economic Positioning}

It is believed that sago starch extraction technology spread to the western region of Indonesia from New Guinea, the place of sago origin. Extraction technology has improved into an appropriate form in each place over the process of this diffusion. The improved technological conditions are based on the development situation of sago villages. The production systems of sago starch differ in villages where sago is only a staple subsistence food and villages where sago is produced for sale. The rural socioeconomic situation becomes one of the factors for different forms of the production system. The economy of Java is the most developed in Indonesia. However, the economy is still underdeveloped elsewhere, especially in the eastern Indonesia islands. The economy and the social conditions of the study areas are shown in Table 16.3. Therefore, the socioeconomic conditions are still low for the areas of the eastern island region near the origin center of sago.

It is possible to consider how the starch extraction method currently found in each region has been changed from the prototype of New Guinea. The changing technology in an area, considering the form of the process from east to west, is shown in Table 16.4.

For the change of extraction technology, it is clear that the pulverization method of New Guinea of using an ax became a grater-type technology in and to the west of Sulawesi. In this development process, the use of mechanical raspers began. Similarly, also in the extraction technology, it changes from the hand-rubbing method which is the prototype to the more efficient foot-mashing method on Sulawesi Island in the western region. Also, pumping water under high pressure was introduced to this method, giving an improved and more efficient technology. However, the method of hand rubbing in Bogor is carried out by flushing water by gravity. This situation indicates that technology has developed toward the west from the east. This phenomenon is related to the social development situation of sago societies; economic conditions, especially, are a key factor in the development. That

Table 16.3 GDP and literacy rate in main islands in Indonesia

\begin{tabular}{l|l|l}
\hline Area (islands) & $\begin{array}{l}\text { GDP('000Rp)/ } \\
\text { capita }\end{array}$ & Literacy rate (\%) \\
\hline Sumatra & 2447 & 92.8 \\
\hline Java & 2275 & 86.5 \\
\hline Kalimantan & 3774 & 89.2 \\
\hline Sulawesi & 1289 & 86.8 \\
\hline Others & 1377 & 77.9 \\
\hline
\end{tabular}

Source: Statistic Indonesia (BPS), Financial Statistics (BPS) by OECF (1998) 
Table 16.4 Flow of the methods of sago starch extraction in Indonesia

\begin{tabular}{|c|c|c|c|c|}
\hline \multirow{2}{*}{ Developed steps } & \multirow{2}{*}{ Relevant island } & \multirow{2}{*}{$\begin{array}{c}\text { spread } \\
\text { flow }\end{array}$} & \multicolumn{2}{|c|}{ Technology and tools } \\
\hline & & & Palm pith pulverization tools & Sago extraction with wash by rubbing \\
\hline Original Type & New Guinea & east & hatchet type $\leftrightarrow$ broadax type & by hands (horizontal water flow) \\
\hline$\downarrow$ & & region & & \\
\hline Intermediate Type & Sulawesi & 1 & hatchet type & by feet (vertical water flow) \\
\hline \multicolumn{5}{|l|}{$\downarrow$} \\
\hline Developed Type & Sumatra, Sulawesi & & grater & by feet (vertical water flow) \\
\hline$\downarrow$ & & $\downarrow$ & & \\
\hline \multirow[t]{4}{*}{ Machine Use Type } & Sumatra & west & rasper & by feet with pumped up water \\
\hline & Java & region & & (vertical water flow) \\
\hline & & & & by hands with gravity pressure water \\
\hline & & & & (holizontal water flow) \\
\hline
\end{tabular}

is, the sago starch which is used only as a staple food is diversified for use in confectionery. The factor influencing the change in sago utilization is related to the background of the needs of consumers and markets. It is apparent that the greater diffusion of sago palms going toward the western regions, where there is a strong economy, the more diversification of sago utilization and extraction technology takes place. Therefore, the transformation in extraction and consumption process of sago starch depends on the development situation of the society and the economy in the regions.

\subsection{Conclusion}

Sago starch extraction methods, pith pulverization and washing mashed pith by rubbing, changed their forms and diffused from place to place, spreading from the eastern regions. The changing factor of the method relates to the social economy and trade situation of the areas. The changes influence improvements toward practices that are more efficient and economical. In an area where the social economy and cashbased economy are developed, sago utilization shifts from staple food use to starch goods use. Commercialization of sago is determined by the result of comparison with the price of rice for staple food and other starch use for confectionery products.

Therefore, sago starch changes into a side dish of confectionery from a staple food, in areas of more developed economies. And sago has become the alternative (complementary) staple food of rice. Societies where sago became the staple food in the area do not have a developed economy, but sago becomes the alternative staple food in those more developed areas which have rice. It has already progressed as a food material for confectionery in the area in which it is no longer the staple food. Moreover, noodles are produced as a unique form of consumption and are considered to have been influenced by Chinese food culture. And it has changed in terms of the consumption needs from a subsistence food to a market product. The utilization and production forms of sago can be seen under the following circumstances:

1. Staple food for subsistence - family work (New Guinea)

2. Supplement of the staple food - family/specialization work (Sulawesi) 
3. As a commercial product-formation of special production groups (east of Sulawesi)

4. Commercialization/industrialization (Sumatra, Sarawak, Malay Peninsula)

The development circumstances of sago palm use in Indonesia have progressed from east to west. In order to shift development into commercialization from the stage of subsistence use of sago starch, the degree of socioeconomic development, consumption needs, and transportation development are indispensable factors. Moreover, it is simultaneously necessary to consider the time factor of the development standard of each area. Therefore, time flow (for the axis of regional development) becomes an important factor as well as regional factors for studying a technical change of the diffusion of the method. Therefore, it is necessary to take into consideration not only the changes in technology but also the time factor (development axis of the region) as well as the socioeconomic condition of a region for the full development of sago starch production.

\section{References}

Hirao K (2015) Use as food, starch properties and use. The sago palm. The Society of Sago Palm Studies, Kyoto Univ Press, pp 264-272

Nishimura Y (1995) Agriculture in the villages of Southeast Sulawesi, Indonesia - part 1. the intervillage variations in food production and consumption. Sago Palm 3:55-61

Nishimura Y (2008a) Present sago palm situation in Mindanao, Philippines. In: Proceedings of the 17th conference of the society of sago palm studies. Mie, Japan, pp 31-36 (in Japanese)

Nishimura Y (2008b) Different methods of sago starch extraction depending on different areas, Trop Agr Develop Sym Presentation

Nishimura Y (2012) Changing and diversification of sago palm utilization. In: Food and farming being nurtured by biodiversity. Commons Co. Ltd., Tokyo. pp 133-148 (in Japanese)

Nishimura Y (2015) Traditional extraction methods, starch extraction and production. In: The sago palm. The Society of Sago Palm studies, Kyoto Univ Press, pp 235-242

Nishimura Y, Laufa TM (2002) A comparative study on technology adaption for sago starch extraction in Pacific and Asian local regions. Sago Palm 10(1):7-17

OECF (1998) Present situation and problems of regional gap in Indonesia. OECF research paper no. 23 (in Japanese)

Takaya Y (1990) How is rice considered? NHK Books, p 226 (in Japanese)

Open Access This chapter is licensed under the terms of the Creative Commons Attribution 4.0 International License (http://creativecommons.org/licenses/by/4.0/), which permits use, sharing, adaptation, distribution and reproduction in any medium or format, as long as you give appropriate credit to the original author(s) and the source, provide a link to the Creative Commons license and indicate if changes were made.

The images or other third party material in this chapter are included in the chapter's Creative Commons license, unless indicated otherwise in a credit line to the material. If material is not included in the chapter's Creative Commons license and your intended use is not permitted by statutory regulation or exceeds the permitted use, you will need to obtain permission directly from the copyright holder. 


\title{
Chapter 17 \\ Improvement of Sago Processing Machinery
}

Darma

\begin{abstract}
The traditional method of sago starch extraction is a time- and laborintensive process. The most laborious stage is pith disintegration which is done by using a hammer-like tool called a pounder followed by washing and screening the starch. However, the use of mechanical processing equipment is saving time and energy. Consequently, sago starch production increased, both in quantity and quality. With regard to the mechanical processing, it is necessary to provide mechanical equipment which is suitable and easy to use by ordinary farmers. This paper provides an overview of improvement of small-scale sago processing machinery in order to improve the performance. It consists of two separate operation units, namely, the cylinder-type sago rasping machine and the stirrer blade-type sago starch extractor. The performance of the improved sago rasping machine is characterized by (a) rasping capacity $730-1009 \mathrm{~kg} / \mathrm{h}$, (b) starch percentage $47.2 \%$, and (c) starch loss in sago pith waste of only $4 \%$. Meanwhile, the performance of improved sago extraction machine is (a) extraction capacity $1007 \mathrm{~kg}$ of rasped pith per hour, (b) starch percentage was $24 \%$, and (c) starch loss in waste is $2.1 \%$. The machines are intended for small-scale (household) processing of sago and are suitable for adoption in most sago-producing areas, such as those in Papua and Papua New Guinea.
\end{abstract}

\subsection{Introduction}

Indonesia has the largest potential of sago in the world, but the sago starch production and utilization are very small compared with its potential. According to Samad (2002), the utilization of sago palm resources in Indonesia is only about $0.1 \%$ of its total potential. Matanubun and Maturbongs (2006) stated that utilization of sago resources in West Papua, which has over 95\% of Indonesia's sago palms, represents less than $5 \%$ of its existing potential. Up to the present time, farmers in this region cut sago palms and process starch mainly for subsistence use and to sell starch locally, but they exploit only a very small amount compared with its potential. Consequently, a large number of mature sago palm go unharvested and are lost

Darma $(\square)$

Faculty of Agricultural Technology, University of Papua, Manokwari, Indonesia

e-mail: darmabond@gmail.com 
every year. Meanwhile the current demand for sago starch, both for local and global markets, continues to increase. There has been no significant increase in sago starch production in West Papua. Unlike in Sarawak, Malaysia, even though the sago potential is small, it was the world's largest exporter of sago starch with total exports of 44,700 mt in 2007 (Karim et al. 2008; Singhal et al. 2008; Bujang 2011). The sago industry in Malaysia (State of Sarawak) is well established and has become one of the important industries contributing to export revenue (Karim et al. 2008).

Traditional methods of sago starch extraction are now being used in most parts of West Papua, but mainly for subsistence. It is well known that the traditional method of sago starch processing is a time-consuming and labor-intensive process. Consequently, sago starch production is very low, both in quantity and quality. Farmers in the area continue to use traditional systems to process sago starch because they lack mechanical equipment. The industrial technology of processing starch and its derivatives from potato, cassava, maize, rice, and wheat is well developed. However, this is not the case with sago starch technology. There are only a few simple technologies besides the traditional method.

The principles and methods of sago starch processing or sago starch extraction are almost the same for both traditional and mechanical production, differing only in the equipment which is used and the scale of operation (Rajyalakshmi 2004; Kamal et al. 2007; Karim et al. 2008). The purpose of the extraction is to separate starch from the cellulosic cell walls of the trunk. This procedure is as follows: (1) palms are selected and felled; (2) clearing, debarking, and splitting the logs; (3) disintegration or breaking down the pith of the log; (4) starch extraction/separation; (5) starch sedimentation and dewatering; and (6) starch drying and packaging. The traditional method of sago starch extraction is not only ineffective and inefficient but also produces starch of low quality. In contrast, mechanical processing of sago palm pith, besides being much more effective and efficient, produces starch having higher quality and is more hygienic (Karim et al. 2008; Singhal et al. 2008). Therefore, farmers should change from the traditional method to the mechanical one in order to increase sago starch production. With regard to the mechanical processing, it is necessary to provide equipment that is suitable and easy to use by typical farmers. Mechanical processing of sago will transform the traditional agricultural system into a developed and commercial agriculture and result in an increase of farm income.

Mechanization in agriculture plays an important role because of its contribution in improving efficiency and productivity of agricultural resources. The application of technology in the form of appropriate machinery and equipment (appropriate technology) to the farmers in developing countries, such as Indonesia, is suitable to be applied. The characteristics of the technology should be simple, low in cost, small in scale, and labor-intensive. In addition, a region should have developed for it mechanical equipment suited to local conditions; consequently its application should not encounter any constraints. The application of mechanical equipment in some areas should pay attention to the various sociocultural aspects of the local community; otherwise mechanization will be unsuccessful. For instance, Sembiring et al. (1998) stated that the failure of agricultural mechanization in Sri Lanka was 
due to the application of imported agricultural machinery directly, unlike the Japanese who make modifications according to local conditions and then produce their own for use by their farmers. The sago processing equipment/machines to be improved and discussed in this paper are intended for small-scale (household) processing of sago starch because it was considered suitable for application in most sago-producing areas such as in Papua and Papua New Guinea. The mechanization consists of two separate operational units, cylinder-type sago rasper and a stirrer blade-type sago starch extractor.

\subsection{Sago Processing}

The main edible food product obtained from sago palm is starch, which is stored in large quantities in its trunk as a prelude to flowering. The objective of sago processing is to extract starch from the sago logs. Sago palm is reported to be one of the cheapest and most readily available sources of food starch, with the highest productivity per land area among other starch crops (Bintoro 2011). There are several ways to extract the starch from the sago pith, but the principles and methods are similar. Traditionally, the starch extraction is performed manually by individual farmers or at domestic-scale sago processing plants. In contrast, modern processing is fully mechanized, has a relatively short processing time, and is more hygienic, as compared to traditional processing (Karim et al. 2008; Singhal et al. 2008). Principally, manual or traditional starch extraction is similar to the modern one, differing only in the scale of operation and the equipment used. In general, ready-to-harvest palms are selected and felled. The bark-like layer is stripped from the trunk, and it is cut into sections or floated whole to a central processing facility. There, it is, if necessary, cut into sections and reduced to battens and rasped either manually or mechanically to pulverize the pith and loosen starch particles within the fiber. The starch is removed from the fiber by kneading by hand or trampling by foot using water or by a spray of water. Starch-laden water or starch in suspension runs into a settling container, where the starch is precipitated out and the water overflows. The starch is then removed and dried.

\subsubsection{Traditional Method of Sago Processing}

In most of the main sago areas throughout Southeast Asia and New Guinea, starch is extracted using the traditional method. This method is still commonly used in Papua New Guinea (Greenhill 2006), West Papua (Darma and Istalaksana 2011; Darma and Sarunggallo 2010, Darma and Kito 2014a, b), the Molucca Islands (Rumalutur 1992; Girsang 2014), and Seram (Ellen 2004). The traditional method is very labor-intensive and time-consuming, usually involving the cooperation of a small group of people or a family. 
Traditional sago starch processing involves cutting the trunk with an ax, and then the bark is either stripped back or split into two sections to expose the pith of the palm. In some locations, chainsaws are now used for cutting the trunk. The pith is disintegrated or pulverized using a pounder, an adze-like tool. Close human contact with pulverized/chopped pith is common during this stage of the process. The pulverized pith is then collected and carried manually to the extraction site. Starch is extracted from the pulverized pith by pouring water over it and kneading it in a trough made of the large sheath base of the sago leaves. The mixture of pulverized pith and water is then forced or pressed through a filter made of fine cloth. The suspended starch passing through the filter is collected into a larger trough, also made of sheath base of the sago leaf, where the starch separates out through sedimentation. It is then ready for packing into a container, also made of sago leaves sheaths.

The traditional method of extraction of sago starch can be classified into two levels: domestic and small-scale processing plant levels (Karim et al. 2008). The domestic level is practiced by individual farmers, where sago palms are felled and processed in the garden, without the need to transport the heavy trunks. After felling the trunk with an ax, it is split lengthwise. The pith is pulverized by means of a chopper or pounder. The pulverized mixture of fiber and pith is placed at the wide end of a leaf sheath of the sago palm, where a sieve is positioned at its lowest end. Water is added to the mixture and then the mixture is kneaded by hand. The fibers are trapped by the sieve, while the water carrying the starch granules in suspension passes through the sieve and collects in an old dugout canoe or any suitable container. The starch settles on the bottom, while the excess water flows over the sides. After kneading, the fibrous remnants are discarded, and the wet starch is removed from the canoe/container (Ruddle et al. 1978; Flach 1983, 1997).

In a small-scale processing plant, sago trunks are cut into shorter lengths of $1-1.2 \mathrm{~m}$ and tied into rafts and transported by flotation to the plant via rivers or manmade canals. Rasping is done using a board with nails in it. Some processors use engine-powered rasps with which the pith is dug out of the split trunk and then rasped. The rasped pith is trampled by foot on a platform. In some operations, a rotating mesh washer made of metal, wood, or screen washers is used to separate the starch and coarse fiber. The starch slurry is channeled to a small settling pond made of boards. Finally, wet starch is mostly dried in the sun (Ruddle et al. 1978; Cecil et al. 1982; Karim et al. 2008). Some small cottage mills produce only lamentak (wet processed sago starch) or second-grade-quality flour, which is sun-dried and unsieved wet sago starch.

\subsubsection{Mechanical Method of Sago Processing}

Malaysia, Indonesia, and Papua New Guinea are the main world producers where sago is a commercial palm for the production of starch and/or conversion to animal feed or to ethanol. Indonesia has the largest forest stands of wild sago palms, in which some factories have been established in Halmahera Island and in West Papua 
Province to process sago starch and by-products. However, at present, Malaysia is the world's largest sago starch exporter. The most extensive sago-growing areas in Malaysia are outside the Peninsula, in Sarawak, which is the leading exporter of sago starch, annually exporting about 25,000-40,000 $\mathrm{mt}$ of sago products to Peninsular Malaysia, Japan, Taiwan, Singapore, and other countries (Bujang and Ahmad 2000; Singhal et al. 2008).

Currently, there are eight sago factories operating in Sarawak, seven of them in the Mukah-Dalat areas and one in the Igan-Sibu area (Manan et al. 2001). Modern methods of extraction involve some modifications from that of the small processing plant. New technologies for extracting starch are being adopted by the large-scale factories. These factories are fully mechanized; that level of technology is mostly found in Sarawak (Karim et al. 2008; Bujang 2011).

The commercial process is either partially (semi-mechanized) or fully mechanized, involving a sequence as presented in Fig. 17.1. Palm logs are rafted to the mill or factory and stored in the river to reduce deterioration. In the mill yard, the bark-like layer is stripped from each log with an ax or bush knife, and the logs are split into six to eight battens which are then rasped by a diesel-powered, homemade rasping wheel which rotates at high speed. The wheel is mounted on a platform to permit the rasped pith to drop into one end of a cylindrical washing reel that rotates on a central shaft. A perforated water pipe sprays water into the body of the reel and flushes the rasped pith as it is passed along the inside by perpendicular splines arranged in a spiral pattern along the central shaft of the reel. This loosens starch grains from the stem fiber and washes them out in suspension. Waste fibers drop from the lower end of the washing cylinder. Starch-laden water then flows through

Fig. 17.1 Flow diagram of modern sago starch processing

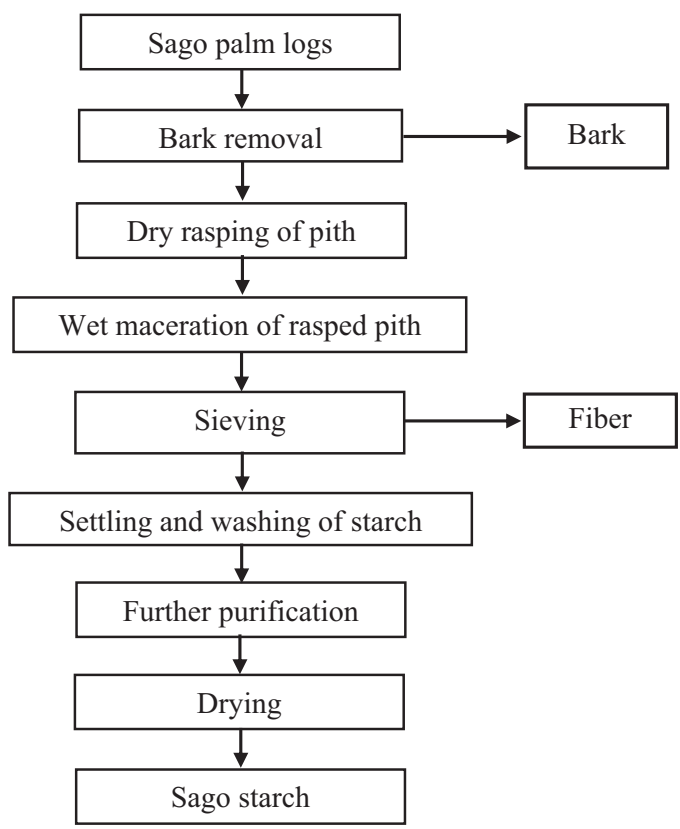


the coarse wire screen that encases the reel and is led off by a conduit through a coarse sieve which removes most of the fiber prior to sedimentation in cement tanks or wooden troughs. The starch may be separated using cyclone separators and dried on a rotary vacuum drum drier, followed by hot-air drying. When dry, it is known as chong hoon. The mill extracts wet starch mechanically and produces three grades of dry starch, from low to high, known as chong hoon, thai hoon, and siong hoon. To produce thai hoon, the middle grade, it is sieved after drying. Crude dry starch can be rewashed, dried again, and then sieved to produce the highest grade of starch, siong hoon (Singhal et al. 2008).

In some factories, the 30 -cm-long log sections from the storage pond are first split lengthwise into about eight segments. These segments are fed into slicers that cut the pith from the bark. In certain other factories, the bark is first removed from sections of the logs. Each of the debarked sections, about $80-100 \mathrm{~cm}$ long, is fed into the mechanical rasper (with chrome nails mounted on one face of a disc or a drum). This rasps the pith into finer pieces, which are fed into the hammer mill via a conveyor belt. The resulting starch slurry is passed through a series of centrifugal sieves to separate the coarse fibers. Further purification is achieved by separation in a nozzle separator through sieve bends. A series of cyclone separators have also been used to obtain very pure starch. Dewatering of starch is carried out using a rotary vacuum drum dryer followed by hot-air drying (Singhal et al. 2008; Manan 2011).

\subsection{Small-Scale Sago Processing Machine Improvement}

\subsubsection{Cylinder-Type Sago Rasping Machine Improvement}

Rasping is the most frequently useful method to disintegrate or to break down the cellular structure of sago pith for mechanical processing. Sago palms produce starch inside pith cells. In the sago starch processing under traditional or mechanical methods, washing is the only method that is used to extract or to separate out the starch. Unless a cell is ruptured in some way, the starch cannot be washed. Therefore, the efficiency of subsequent processes (starch extraction) depends on the proportion of the starch cells that are ruptured. The amount of starch obtained depends on how fine the level of rasping is and the efficiency of starch washed out from the rasped pulp. The more finely the pith is rasped, the more starch can be extracted in the subsequent rinsing process. In other words, in order to free as much starch as possible, the pith must be disintegrated as fine as possible. However, the rinsing process becomes more complicated in separating the starch from the pith residue (hampas) (Colon and Annokke 1984; Cecil 1992).

A small increase in starch yield (perhaps 3-5\%) can be obtained with secondary rasping, but this is not practical in small operations. Further rasping gives little fur- 
ther increase in yield and makes separation of the starch and fiber very difficult. In addition, in large factories, hammer mills are used (Cecil 1992).

As previously mentioned, rasping is aimed at disintegrating or breaking down the cellular structure of the pith. There are other terms commonly used synonymously with pith disintegration such as pith macerating (Greenhill 2006) and pith pulverizing (Ellen 2004). Meanwhile, rasping is synonymous with grating. By doing so, the starch granules which exist in the cells are freed or loosened and thus suspended in the water during the extraction process.

Rasping is the third step in sago starch processing after the trunk is felled and debarked. Once the bark is removed, the pith is split into pieces up to $10 \mathrm{~cm}$ square called batons or billets. The pieces are fed onto the rasper end-on direction, the correct direction for optimal rasping (Cecil 1992). Whatever type of rasper is used, it is important not to press the pith too forcefully onto the rasping surface, as this will seriously reduce the efficiency of the rasper. In extreme cases, it could overload the motor or the engine. Furthermore, forcing material onto the rasper will result in coarser repos (rasped pith), fewer cells will be ruptured, and as a result more starch will be lost in the sago pith waste.

There are two types of raspers commonly used in sago starch processing: cylindrical and disc raspers. The functional component of a cylindrical rasper is a rotating cylinder/drum with an abrasive surface, while the disc rasper is a rotating disc with an abrasive surface. Because of its high rotational speed in the rasping process, it can cause a very nasty wound; thus for safety the raspers must be enclosed so that operator cannot be injured. The pith should be fed through an opening that should be the entire width of the rasper, but it should be made difficult for anyone to injure a hand or foot, either accidentally or in trying to push the pith into the cylinder or disc. Lumps of unrasped pith will always find their way through gaps between the rotating cylinder/disc and the housing. It is therefore important that these gaps should be kept as narrow as possible.

There are some different types of rasping surfaces for both cylindrical and disc raspers. The simplest form is made from a sheet of metal perforated with nails, which has been wrapped around a wooden cylinder or fastened on a wooden disc. It is very easy to make, and nothing more than a nail and sheet of tin plate is needed for a new rasping surface, but they are inefficient. They only process a small quantity per hour and do not last very long.

Another type of rasper that is widely used and can be made locally is the nail rasper. There are various designs. Nails are held in a wooden or metal cylinder. The more nails there are, the better the rasper will work, but it is impractical to set them closer than $5 \mathrm{~mm}$ apart (Cecil 1992). The nails must be embedded in the cylinder so that they do not fly out under the considerable centrifugal force that is produced by the high-speed rotation. This type of rasper, even one with a wooden cylinder, will last a long time if it is properly made. As the nails get worn down, the wood also wears down, often at about the same rate. Every effort should be made to use the full width of the cylinder so that wear is even along its entire length.

A better nail rasper is a modification of a design widely used in larger factories. Two curved plates are made from 4-mm steel plate, each covering half the circum- 
ference of a steel or wooden cylinder $25 \mathrm{~cm}$ in diameter and $30 \mathrm{~cm}$ in length. Holes just large enough for the shafts of 15 -mm-long nails (preferably masonry nails) are drilled in the plates on a slightly skewed square pattern; thus the nails which protrude through the plate do not exactly follow one another as the cylinder rotates. The nails are put in from the inner side and cannot go through the plate because their heads are too large to pass through the holes in the plate. The curved plates are bolted to the outside of the cylinder, which holds the nails securely in place. This rasper can be driven at $1500 \mathrm{rpm}$ (Cecil 1992).

The best type of rasper is the Jahn rasper, but these are too expensive for smallscale operation. It consists of a rotating cylinder on which replaceable serrated flat blades, similar to saw blades, are mounted. The individual blades are made of steel about $1 \mathrm{~mm}$ thick and are available in different lengths such as 10,20 , and $30 \mathrm{~cm}$. They are about $2 \mathrm{~cm}$ wide with teeth along each long side. The saw teeth may be 2-3 $\mathrm{mm}$ deep with the tips $1.5-2.5 \mathrm{~mm}$ apart. The blades are mounted in the plane of the axis of the cylinder. The length of the blade is parallel to the axis, and the length of the working part of the cylinder is thus the same as the length of the blades. The blades are separated by wooden or metal blocks so that they are parallel and about $10 \mathrm{~mm}$ apart. The blocks are cut so that the teeth protrude from the surface of the blocks by $2-3 \mathrm{~mm}$. The blocks have to be narrower on the inside (nearer the center of the drum) than on the outside. A 30-cm-diameter cylinder having a circumference of about $100 \mathrm{~cm}$ will need between 70 and 100 blades, depending on the thickness of the wooden blocks. End plates with strong lips are necessary to hold the locks and saw blades against the strong centrifugal forces that occur in the highspeed rotating cylinder.

When the cylinder rotates, the saw teeth are dragged sideways through any material held against them. A 30-cm-diameter cylinder can be driven at $1500 \mathrm{rpm}$, and a 50-cm-diameter cylinder can be driven at $1200 \mathrm{rpm}$ (Cecil 1992). Modern imported rasping machines can be driven considerably faster, depending on the manufacturer's specifications. The manufacturers claim that the high speed makes them substantially more efficient, but maximum efficiency is accompanied by problems in starch separation.

In addition to the various sago rasping machines (sago rasper/grater) mentioned, another cylinder-type sago rasping machine, recently used widely for small-scale operations in West Papua Province, Indonesia, is similar to the nail rasper (Fig. 17.2). The processing system of this rasper is a hard wooden cylinder $15 \mathrm{~cm}$ in diameter and $20 \mathrm{~cm}$ in length. The teeth are made of stainless steel rods $4 \mathrm{~mm}$ in diameter and $2 \mathrm{~cm}$ in height. This rasping machine is driven by a gasoline engine, $5.5 \mathrm{hp}$ (4.103 kW) at $3000 \mathrm{rpm}$ (Darma and Reniana 2009; Darma and Worabai 2010). The performance of the rasper is (a) rasping capacity $500-700 \mathrm{~kg} / \mathrm{h}$, (b) starch percentage $46 \%$, and (c) starch loss in waste/hampas $4.6 \%$.

The most recently improved sago rasping machine is similar to the previous one, differing only in the power source and the characteristics of the cylinder. Unlike the previous prototype, the improved one is driven by a more powerful 6.5-hp gasoline 

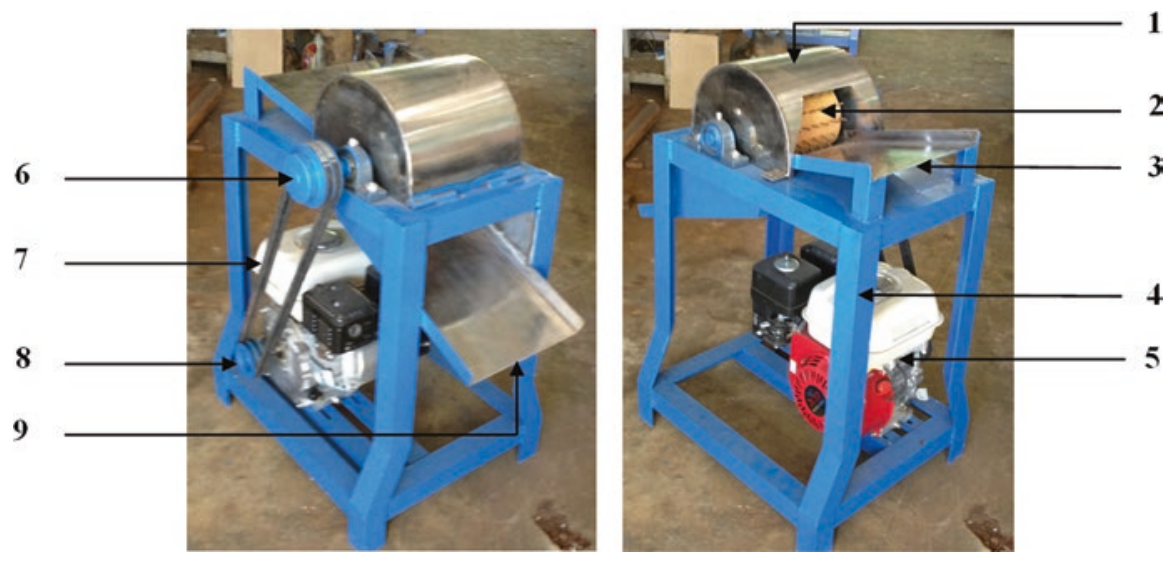

Fig. 17.2 Overall structure of cylinder-type sago rasping machine. (1) Cylinder cover, (2) rasping cylinder, (3) input hopper, (4) main frame, (5) gasoline engine, (6) cylinder pulley/driven, (7) V-belt, (8) engine pulley/driver, (9) output hopper

engine. Meanwhile, the cylinder is made of stainless steel covered with pointed teeth.

The rasper consists of four main components: (a) a rotating rasping cylinder covered with pointed teeth on its circumference surface enclosed in a housing made of plat 2-mm-thick stainless steel plate. The size of the cylinder is $16.8 \mathrm{~cm}$ in diameter and $22 \mathrm{~cm}$ in length. (b) A four-stroke gasoline engine (6.5 hp, maximum shaft rotation $3600 \mathrm{rpm}$ ) as power driver. (c) Power is transmitted by a pulley and V-belt. (d) The main frame is made of $5 \times 0.5-\mathrm{cm}$ equal angle steel bar. In addition, it is equipped with a cylinder cover and feeding component both made of plat steel, $2 \mathrm{~mm}$ in thickness. The overall structure of the improved sago rasper is shown in Fig. 17.3.

The performance of the rasper is (a) rasping capacity 730-1009 kg/h, (b) starch percentage $47.2 \%$, and (c) starch loss in waste/hampas $4 \%$.

\subsubsection{Stirrer Rotary Blade Sago Starch Extraction Machine Improvement}

To free the sago starch, pith must be disintegrated or pulverized, mostly using a rasper. It is well known that the more completely the pith is disintegrated, the higher the yield of starch. On the other hand, at a high degree of disintegration, fiber also is disintegrated to an appreciable extent which gives rise to trouble in subsequent fiber-starch separation (starch extraction) (Colon and Annokke 1984; Cecil 1992). After rasping, starch and fiber are in a free state and are able to be separated in the extraction process. 

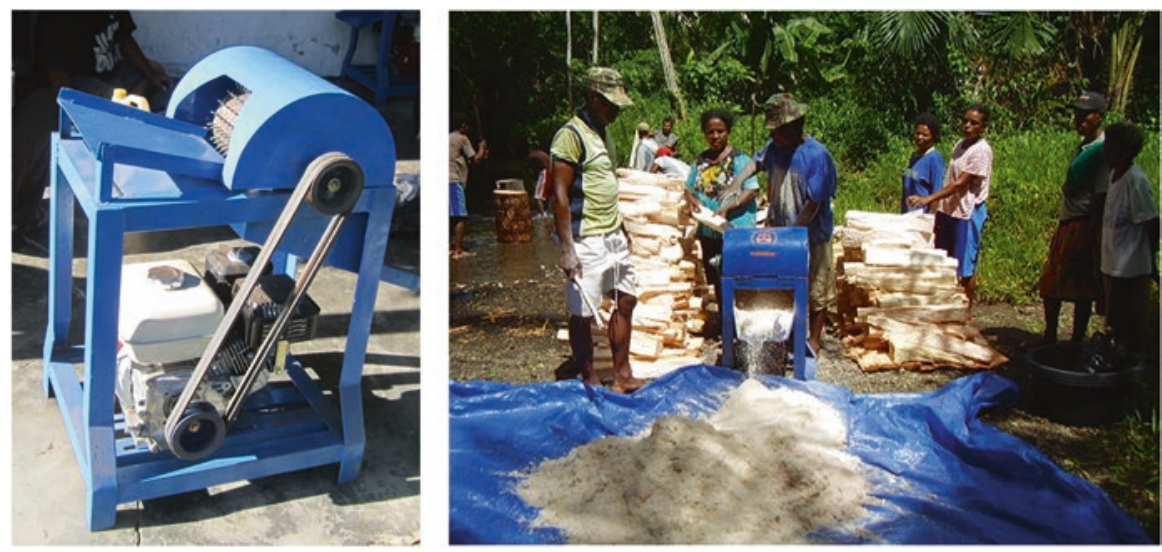

Fig. 17.3 Overall structure of improved cylinder-type sago rasping machine

The objective of the extraction process is to remove the maximum amount possible of fiber from the starch and to obtain the maximum amount of starch. The efficiency of the extraction depends on how carefully the operation is managed.

Up to the present time, the only way to separate starch from the fiber (starch extraction) is by using water. The freed starch which is contained in the rasped pith (repos) is washed out using an abundant amount of water. The principles of starch extraction are to suspend or to dissolve the rasped pith in water and then stir it vigorously to release the starch. The suspended starch or starch slurry is then separated from the fiber using a screen.

Screening is the main operation in starch separation. Its purpose is to separate starch from fiber and other constituents. The fractions are separated by size by washing the rasped pith on a screen or a series of screens. Screening is often done in two stages, a coarse screening operation to remove most of the fiber and to thoroughly wash the starch out of it and a fine screening operation to separate the fine fiber from the starch. Soluble materials such as sugars, some of the protein, and many of the other constituents are dissolved and pass through the screen along with the fine insoluble materials (starch granules and fine fiber) (Cecil 1992).

An effective screening operation should wash as much starch as possible through the screen using as little water as possible. A screen with large apertures will have a high capacity, but it will allow the passage of too much oversized material. On the other hand, a screen with small apertures will give a better result, but its capacity will be less. The use of a screen with apertures of mixed sizes gives the worst result. In this case, the largest apertures will largely determine the quality of what passes through, but the smaller apertures may contribute to the capacity of the screen. It is best if all apertures are the same size. Fine cloth is commonly used as screening material in the traditional method of starch extraction, and sometimes it is made from the fibrous leaf sheath of either the coconut or sago palm.

Another important physical aspect of a screen is the total open area of the holes. Both solids and liquids can only pass between the strands; thus the more bulky the 
strands are, the less open area there can be for the product to pass through. Natural fibers are relatively short, and in order to make a long strong thread, they have to be twisted together in a bundle. This makes the strands comparatively bulky, and there are always loose hairs that restrict the passage of particles through nearby apertures. Synthetics can be made in strong single strands which are fine and smooth and cause the least possible restriction to the passage of starch and water. It is also much easier to keep synthetic cloth clean than it is natural fibers. The screens work best if the cloth is tight. Synthetic cloth expands when it is wet; thus before putting it on the screen frames, the cloth should be soaked in water.

The choice of screening technology to be used in a starch processing plant depends on a number of factors, including availability of water and labor and settling tanks. At the present time, there are two suitable designs for the screening operation: a rotating screen and a flat vibrating (shaking) screen. A rotating screen is much more expensive and more difficult to install, but it is much easier to operate once installed. In a small-scale operation, a coarse mesh flat screen is recommended (Cecil 1992).

In addition to the rotating and shaking screens, Darma and Gani (2010), Darma and Kito (2014b) developed a new type of sago starch separation called a stirrer rotary blade sago starch extractor. It consists of a cylinder with a screen at the bottom of the cylinder. To release the starch granules from the fiber, the pulp is stirred vigorously using a stirrer blade. Unlike the rotating screening in which the screen is rotated as it operates, the screen of this extractor is neither rotating nor shaking. It is mounted and fixed at the bottom of the cylinder.

In principle, this extractor is similar to the traditional one, but instead of using either hands or feet to knead or trample the pulp, it is kneaded mechanically using a stirrer. After pith disintegration, which aims to break down the cellular structure and rupture the cell walls, the fiber and starch existing in the repos have not yet been separated. The function of this extractor is to separate starch from fiber (pith waste). In doing so, the rasped pith (disintegrated pith) and water are fed into the extraction cylinder and then stirred vigorously. The separation of the starch granules from the fiber can thus far only be achieved by a water-washing process. The starch separation mechanism is a combination of kneading and screening. First, rasped pith (repos) is suspended in water and then stirred vigorously to release the starch. The suspended starch or starch slurry is separated from the fiber using a screen. Starch in suspension that passes through the screen then flows into the settling tank through a pipe.

Overall, this sago starch extractor consists of several main components which are integrated into a single operating system (Fig. 17.4). The extractor has the following features:

1. Extraction cylinder, made of 2-mm-thick steel. The cylinder is $74 \mathrm{~cm}$ in diameter and $120 \mathrm{~cm}$ in height $\left(\right.$ volume $\left.=0544 \mathrm{~m}^{3}\right)$. The lower end of the cylinder has a conical shape to prevent starch sedimentation in the bottom of cylinder. 

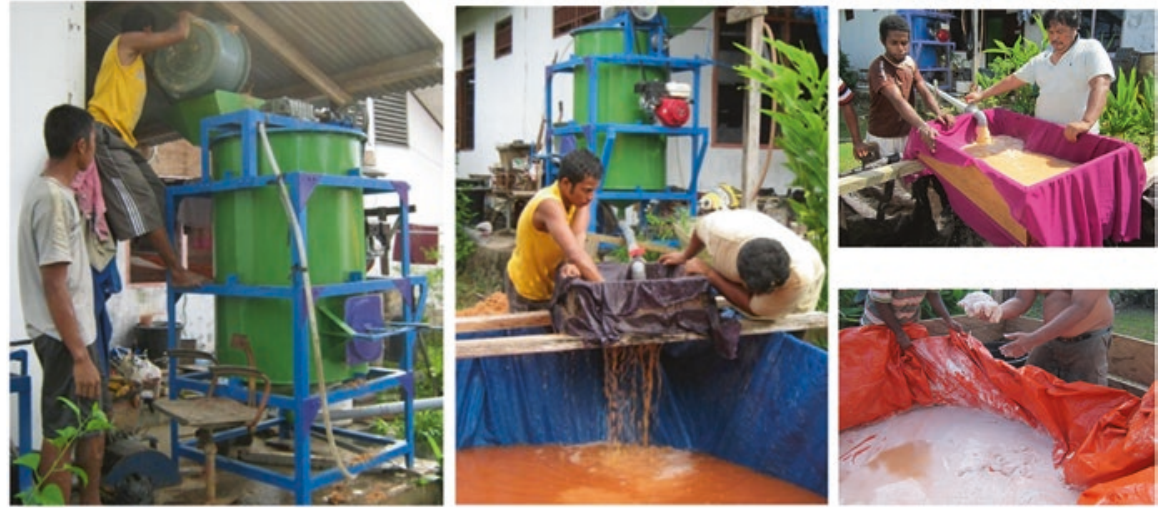

Fig. 17.4 Overall structure of stirrer rotary blade sago starch extraction machine

2. A screen, made of perforated stainless steel sheet with a hole size of $1.5 \mathrm{~mm}$ in diameter. The screen diameter is slightly smaller than the extraction cylinder into which it is placed.

3. Stationary blades are made of 5-mm-thick L-shape $50 \times 50$-mm steel bar. These are mounted vertically on the inner surface of cylinder.

4. The stirrer rotary blades are suspended in water and function to free starch granules from the fiber.

5. The power transmission system consists of a V-belt, pulley, and reduction gear box (WPX 80, ratio 10:1).

6. The power source is a 6.5 -hp gasoline engine.

7. The frame is made of $5 \times 0.5-\mathrm{cm}$ equal angle steel bar. In addition, it is equipped with a pipe ( $5 \mathrm{~cm}$ in diameter) to carry the starch suspension from the extraction cylinder to the sedimentation tank. The end of the pipe is fitted with a stop tap (valve) to control starch suspension flow. Moreover, because some fine fiber also passes through the screen along with the starch, further screening is necessary to remove the fine fiber. For these purposes, a second screen made of fine cloth is used, and it is placed at the end of flowing pipe. Starch suspension from the extraction cylinder is passed through this second screen before flowing into the sedimentation tank.

The performance of the extractor is (a) extraction capacity $185-211 \mathrm{~kg}$ of rasped pith per hour, (b) starch percentage 28-32\%, and (c) starch loss in waste $2.75-4.56 \%$.

Recently, a new variant of the extractor was introduced by Darma and Kito (2014b). Overall, its components and construction are similar to the previous one, except for the screening system used. Unlike with the previous prototype in which the screen was mounted and fixed at the bottom of cylinder, an open-ended cylinder with a circular cross section is employed. 

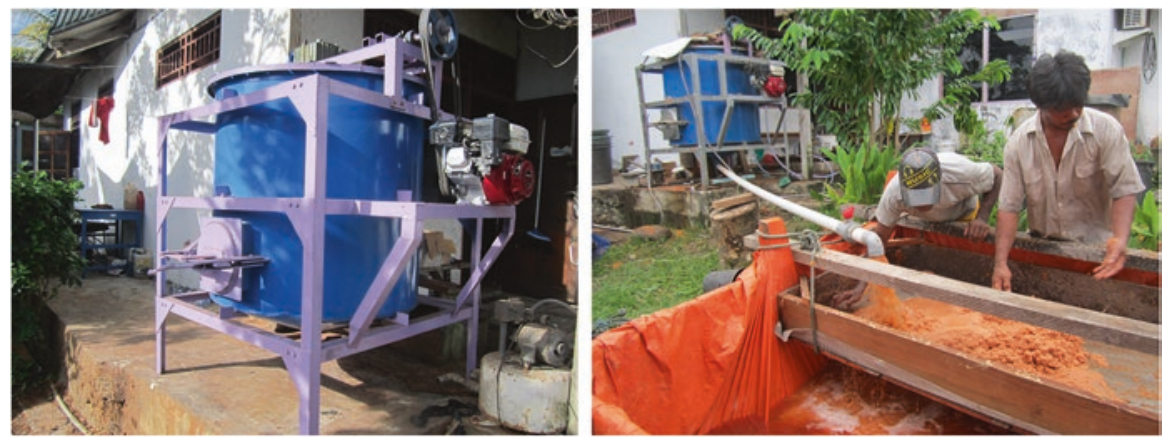

Fig. 17.5 Overall structure of improved stirrer rotary blade sago starch extraction machine

Similar to the previous prototype, this sago starch extractor consists of seven main components which are integrated into a single operational system (Fig. 17.5). They are:

1. Extraction cylinder, made of 2-mm-thick steel. The cylinder is $103 \mathrm{~cm}$ in diameter and $100 \mathrm{~cm}$ in height $\left(\right.$ volume $\left.=0785 \mathrm{~m}^{3}\right)$. The lower end of the cylinder has a conical shape to prevent starch sedimentation in the bottom of cylinder.

2. A screen, made of perforated stainless steel sheet with a hole size of $0.7 \mathrm{~mm}$ in diameter. The screen diameter is slightly smaller $(92 \mathrm{~cm}$ in diameter) than the extraction cylinder, and it is placed inside the extraction cylinder.

3. Stationary blades are made of 5-mm-thick L-shape $50 \times 50-\mathrm{mm}$ steel bar. They are mounted vertically on the inner surface of screen.

4. Stirrer rotary blades function to free starch granule from fiber and are suspended in water.

5. The power transmission system consists of a V-belt, pulley, and reduction gear box (WPX 80, ratio 10:1).

6. The power source is a 6.5 -hp gasoline engine.

7. The frame is made of $5 \times 0.5-\mathrm{cm}$ equal angle steel bar. In addition, it is equipped with a pipe $(5 \mathrm{~cm}$ in diameter) to carry the starch suspension from the extraction cylinder to the sedimentation tank. The end of the pipe is equipped with a stop tap (valve) to control starch suspension flow. In addition, because some fine fibers also pass through the screen along with starch and water, further screening is necessary to remove the fine fiber. For this purpose, a second stage screen, of 100 mesh stainless steel strainers, is used, and it is placed at the end of flowing pipe.

The performance of this extractor is much higher compared to the previous prototype, i.e., (a) extraction capacity $1007 \mathrm{~kg}$ of rasped pith per hour, (b) starch percentage $24 \%$, and (c) starch loss in waste $2.1 \%$. 


\subsection{Conclusion}

The improved sago processing machinery which consists of two separate operational units, namely, the cylinder-type sago rasping machine and the stirrer bladetype sago starch extraction machine, working properly gives high performance. The performance of the improved sago rasping machine is (a) rasping capacity 730 $1009 \mathrm{~kg}$ per hour, (b) starch percentage $47.2 \%$, and (c) starch loss in waste $4 \%$. Meanwhile, the performance of improved sago extraction machine is (a) extraction capacity $1007 \mathrm{~kg}$ of rasped pith per hour, (b) starch percentage 24\%, and (c) starch loss in waste $2.1 \%$. The machines are intended for small-scale (household) processing of sago and are suitable for adoption in most sago-producing areas, such as those in Papua and Papua New Guinea.

\section{References}

Bintoro MH (2011) Progress of sago research in Indonesia. In: Proc 10th int sago symposium: sago for food security, bio-energy, and industry from research to market. Bogor, p 16-34

Bujang KB (2011) Potential of sago for commercial production of sugars. In: Proc 10th int sago symposium: sago for food security, bio-energy, and industry from research to market. Bogor, p 36-41. Oct. 29-31

Bujang KB, Ahmad FB (2000) Country report of Malaysia: production and utilization of sago starch in Malaysia. In: Proceedings of the international sago seminar. IPB, Bogor, p 1-8

Cecil JE (1992) Small-, medium-and large-scale starch processing, vol 98. FAO Agric Serv Bull, Rome

Cecil JE, Lau G, Heng H, Ku CK (1982) The sago starch industry; a technical profile, based on a preliminary study made in Sarawak. Tropical Product Institute, London

Colon FJ, Annokke GJ (1984) Survey of some processing route of sago. In: Proc. the expert consultation of the sago palm and palm products. Jakarta. January 16-21

Darma R (2009) Prototype of cylinder type sago rasper powered by $5.5 \mathrm{hp}$ gasoline engine. Agrotek J 1(6):49-56

Darma WT (2010) Variant-1 of cylinder type sago rasper powered by $5.5 \mathrm{hp}$ gasoline engine. Agrotek J 2(3):82-90

Darma IP, Gani A (2010) Prototype of stirrer rotary blades type sago starch extractor. Agritech J 30(4):204-211

Darma, Istalaksana P (2011) Traditional processing of sago in Papua Province. In: Proceedings 10th international sago symposium: sago for food security, bioenergy, and industry from research to market. Bogor, p 115-116. 29-31 October

Darma WX, Kito K (2014a) Development of cylinder type sago rasper for improving rasping performance. Int Agric Eng J 23(3):31-40

Darma WX, Kito K (2014b) Development of sago starch extractor with stirrer rotary blade for improving extraction performance. Int Agric Eng J 6(5):2472-2481

Darma IP, Sarunggallo ZL (2010) Starch content and production potency of natural sago palm (Metroxylon sagu Rottb). Agrotek J 2(2):7-14

Ellen R (2004) Processing Metroxylon sagu Rottboel (Arecaceae) as a technological complex: a case study from South Central Seram, Indonesia. Econ Bot 58(4):601-625

Flach M (1983) The sago palm, domestication and product. FAO, Rome

Flach M (1997) Sago palm. Metroxylon sagu Rottb. International Plant Genetic Resources Institute, Rome 
Girsang W (2014) Socio-economic factors that have influenced the decline of sago consumption in rural Maluku, Indonesia. S Pac Stud 34(2):99-116

Greenhill AR (2006) Food safety and security of sago starch in Rural Papua New Guinea. James Cook University, Townsville

Kamal SMM, Mahmud SN, Hussain SA, Ahmadun FR (2007) Improvement on sago flour processing. Int Eng Tech 4(1):8-14

Karim AA, Tie PL, Manan DMA, Zaidul ISM (2008) Starch from the sago (Metroxylon sagu) palm tree-properties, prospect, and challenges as a new industries source for food and other uses. Comp Rev Food Sci Food Safe 7(3):215-228

Manan DMA (2011) Optimization of sago starch extraction using drum rasper in Proc. 10th int sago symposium: sago for food security, bio-energy, and industry from research to market. Bogor, p 93-95

Manan DMA, Islam MN, Noor BM (2001) Enzymatic extraction of native starch from sago (Metroxylon sagu) waste residue. Starch 53(12):639-643

Matanubun H, Maturbongs L (2006) Sago palm potential, biodiversity and socio-cultural consideration for industrial sago development in Papua, Indonesia. In: Proc. 8th Int. sago symposium: sago palm development and utilization. Jayapura, p 41-54

Rajyalakshmi P (2004) Caryota palm sago, a potential yet underutilized natural resource for modern starch industry. Nat Prod Rad 3(3):144-149

Ruddle K, Johnson D, Townsend PK, Rees JD (1978) Palm sago a tropical starch from marginal lands. University Press of Hawaii, Honolulu

Rumalatu FJ (1992) Sago in Maluku: past, present, and future prospects. Cakalele 3:63-68

Samad MY (2002) Application of semi mechanical technology to improve production of small scale sago industry. Indon J Sci Tech 4(5):11-17

Sembiring EN, Radite PAS, Suastawa IN (1998) Development of agricultural mechanization in supporting self-sufficient of food. Agric Eng J 12(3):1-6

Singhal RS, Kennedy JF, Gopalakrishnan SM et al (2008) Industrial production-processing, and utilization of sago palm-derived products. Sci Direct Carbohydr Polym 72:1-20

Open Access This chapter is licensed under the terms of the Creative Commons Attribution 4.0 International License (http://creativecommons.org/licenses/by/4.0/), which permits use, sharing, adaptation, distribution and reproduction in any medium or format, as long as you give appropriate credit to the original author(s) and the source, provide a link to the Creative Commons license and indicate if changes were made.

The images or other third party material in this chapter are included in the chapter's Creative Commons license, unless indicated otherwise in a credit line to the material. If material is not included in the chapter's Creative Commons license and your intended use is not permitted by statutory regulation or exceeds the permitted use, you will need to obtain permission directly from the copyright holder. 


\title{
Chapter 18 \\ The Structure and Characteristics of Sago Starch
}

\author{
Masanori Okazaki
}

\begin{abstract}
The crystalline structure of sago starch related to the gelatinization characteristics is reported in this chapter, although the sago starch synthesis at the molecular biological level is still under discussion. Sago starch granules are oval with a temple bell-like shape, a mean diameter of $37.59 \mu \mathrm{m}$, and exhibit a Maltese cross, indicating the presence of some common internal ordering. Sago starch from its X-ray diffraction pattern shows a peak at around $5.6,17,18$, and $23^{\circ}(2 \theta$ for $\mathrm{Cu}$ $\mathrm{K} \alpha$ ), which corresponds to $1.58,0.521,0.492$, and $0.386 \mathrm{~nm}$, respectively. Sago starch is classified as a C type (a mixture of A type and B type as an accessary), containing slightly higher content of B type in the basal portion of sago palm trunk. Low viscosity of sago starch amylopectin is explained by the presence of smaller molecule with a slightly higher number of long chains than the high-viscosity amylopectin. The gelatinization temperature and enthalpy of sago starch determined by a differential scanning calorimeter (DSC) are 69.4-70.1 ${ }^{\circ} \mathrm{C}$ and $15.1-16.6 \mathrm{~J} \mathrm{~g}^{-1}$, depending on the moisture content, degree of a crystallinity within the granule, granule size, and the amylose to amylopectin ratio. The observation of granular birefringence (Maltese cross) under polarized light is one of the useful tools to determine the gelatinization behavior of sago starch.
\end{abstract}

\subsection{Starch Synthesis}

Starch production is the most important agricultural activity for peace in the world. Plants can produce glucose and its dehydrated and condensed substances as starch by photosynthesis from carbon dioxide, temporarily accumulating starch in leaves, twigs, and buds, which serve as energy stores (Fig. 18.1). Toward the end of the growing season, starch is transformed into sucrose prior to translocation. This means that sucrose is the starting substance of storage starch synthesis. From sucrose in the cell, glucose-1-phosphate, glucose-6-phosphate, and adenosine

M. Okazaki ( $\square)$

Japan Soil Research Institute Inc., Nishitokyo, Tokyo, Japan

e-mail: japansoilco_okazaki@mbr.nifty.com 


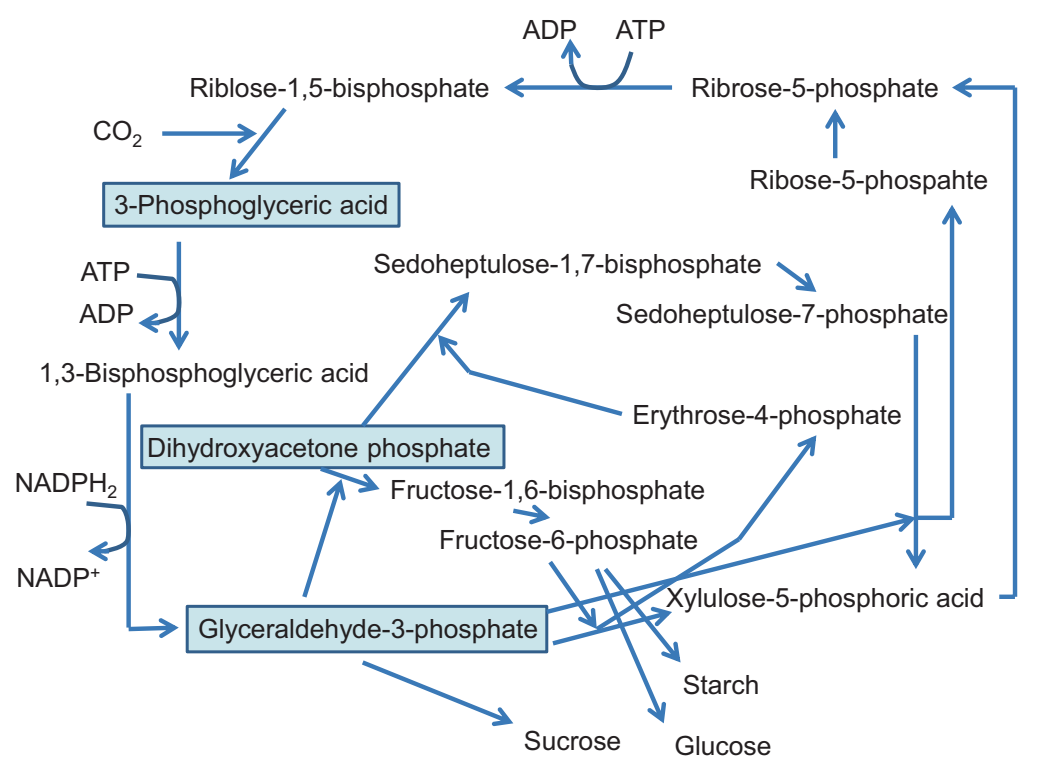

Fig. 18.1 Starch production by photosynthesis (Akazawa 1965, partly modified)

diphosphate glucose (ADPG) are synthesized, and, finally, ADPG is produced from glucose-1-phosphate and glucose-6-phosphate. The glucose residue of ADPG is dehydrated and condensed by granule-bound starch synthase (GBSS) and soluble starch synthase (SSS) to make amylose and amylopectin chains. GBSS relates to the production of amylose which exhibits a low amount of branching. Meanwhile, the long chains of $\alpha-1,4$ glucans are partly cut by branching enzymes, and thereafter $\alpha-1,6$ glucans are produced by the dehydration reaction of $\mathrm{OH}$ at $\mathrm{C} 1$ and $\mathrm{OH}$ at $\mathrm{C} 6$. Large amounts of non-reductive edges in the chains of starch are able to become elongated edges by SSS, and new side chains of non-reductive are formed by branching enzymes. Over-numbers of binding part of $\alpha-1,6$ binding are cut down by cutting enzymes, resulting in side chains being reduced to form amylopectin. When GBSS is lost, only the waxy type of starch containing no amylose will be formed. On the other hand, when the activity of SSS becomes lower, high amylose starch will be formed. At the same time and/or after the elongation of amylose and amylopectin chains occur, polymorphs are formed during high dimension of structure formation. Although this phenomenon in starch science is one of the important issues, scientific light has not completely elucidated it until now (Fig. 18.2).

No information on sago starch synthesis in relation to starch synthase is available at the present time. 


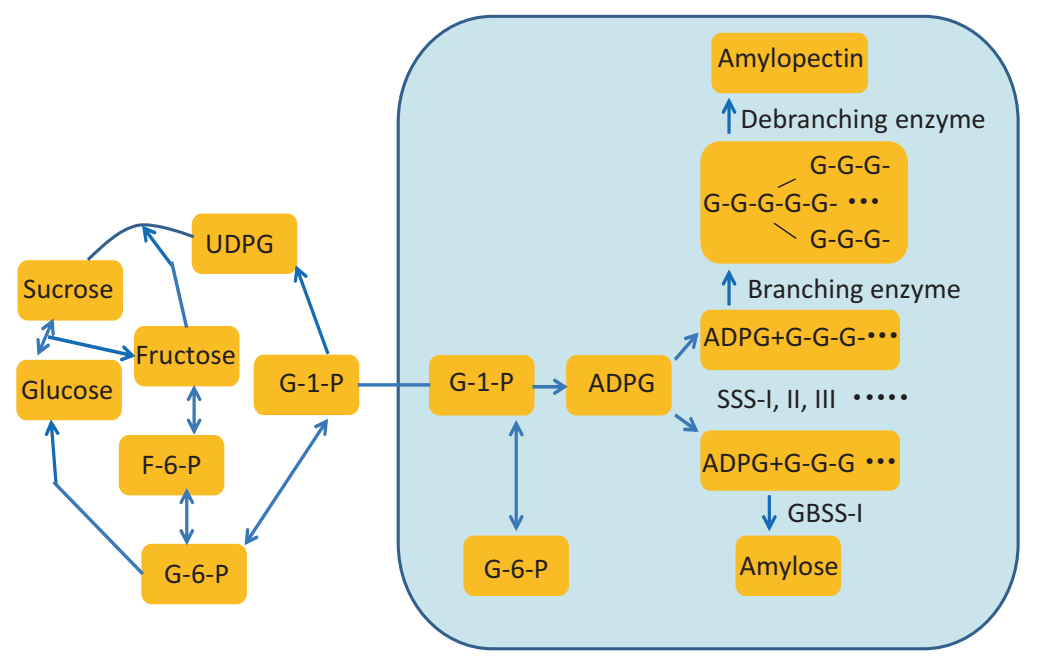

Fig. 18.2 Starch production in storage organs (F-6- $P$ fructose-6-phospahte, $G-1-P$ glucose-6phosphate, $A D P G$ adenosine diphosphate glucose, GBSS granule-bound starch synthase, SSS soluble starch synthase)

\subsection{Starch Conformation}

Starch contains polymer chains of glucose units with a high degree of regularity, crystalline clusters of double helices (Kainuma and French 1971, 1972), which consist of two glucans: amylopectin and amylose. Amylopectin is the major component in most starches. It is the extensively branched structure and is composed of short chains of $\alpha$-(1,4)-linked D-glucosyl units that are interconnected through $\alpha-(1,6)$ linkages (Vamadevan and Bertoft 2015). Amylose is a minor component and is essentially longer linear chains than amylopectin.

The X-ray diffraction technique is popular for the analysis of the crystalline structure of starch and has developed rapidly. Until the 1970s, it was not known that amylose has a crystalline structure and exhibited a monoclinic and hexagonal structure with a double helix (Wu and Sarko 1978a, b; Imberty and Perez 1988, Imberty et al. 1988). However, it is still unclear if the helical structure is right- or lefthandled. One unit (a total of 12 glucose residues consisting of 6 glucose residues making a double helix forming 1 unit) of A-type starch, monoclinic structure, holds eight water molecules (Fig. 18.3). Meanwhile, one unit of B-type starch, hexagonal structure, holds 36 water molecules in the cavities of the structure. In addition, C-type starch also was proposed to be a mixture of A and B type (Hizukuri and Nikuni 1957). However, C type always consists of A and B type.

The synthetic processes and mechanisms of starch by synthetic enzymes in amyloplast have been elucidated. However, the working processes of A-, B-, and C-type starch are not yet clear. Synthesized ADPG forms $\alpha-1,4$ glucoside bonding by dehydration shrinkage with $\mathrm{OH}$ group of non-reductive edges of glucose, and the 
Fig. 18.3 Crystalline structure of A-type and B-type amylose (Imberty et al. 1991, partly modified)

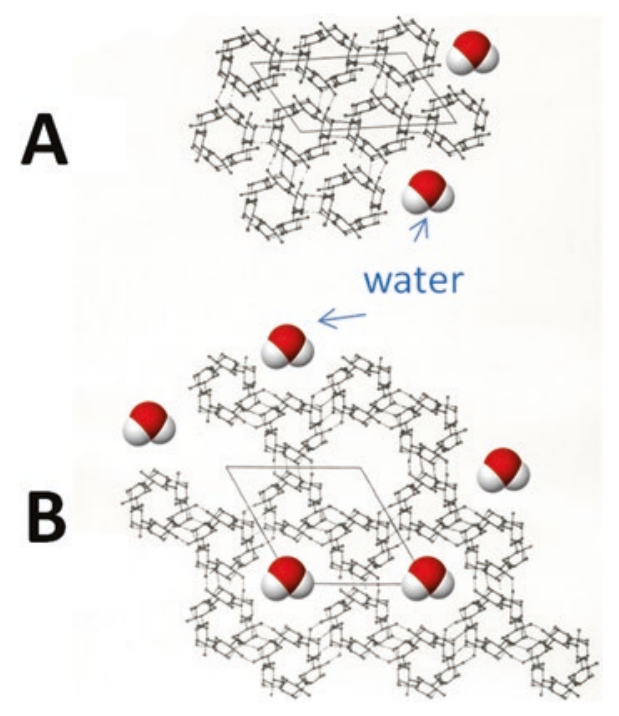

elongation of glucose gradually occurs to make maltose and/or maltotriose. The basic unit of six glucoses, consisting of A-type starch, is maltose. Three units of maltose form a basic unit of amylose and amylopectin, in the case of A type. On the other hand, two units of maltotriose form a basic unit of amylose and amylopectin for B type. Two basic units are closely hydrated to each other, allowing hydrogen bonding to produce a double helix. Double-helical units can precipitate from the soluble state of starch to high molecular starch in amyloplast.

The fragments of low molecular starch form the double helix structure, associated with the formation of stable three-dimensional structures at a low energy level. The conformation analysis has been developed in protein science and elucidated the structure of the domains. When amyloplast is present at a high temperature and a low moisture content, the restriction of free movement in the solution of amyloplast and the limitation of water molecules result in the formation of A-type starch, monoclinic crystalline structure, which is found in aboveground starch accumulation organs. Meanwhile when amyloplast is at a low temperature and high moisture content, the double helix can easily move and hold water molecules resulting in the formation of hexagonal crystalline structure in belowground starch accumulation organs.

The C-type starch structure derived from both A type and B type consists of exsolution-like materials formed by GBSS and SSS under a given temperature and concentration. Most sago starch is C-type starch, so-called $\mathrm{C}_{\mathrm{A}}$ type, including B-type starch as accessary. 


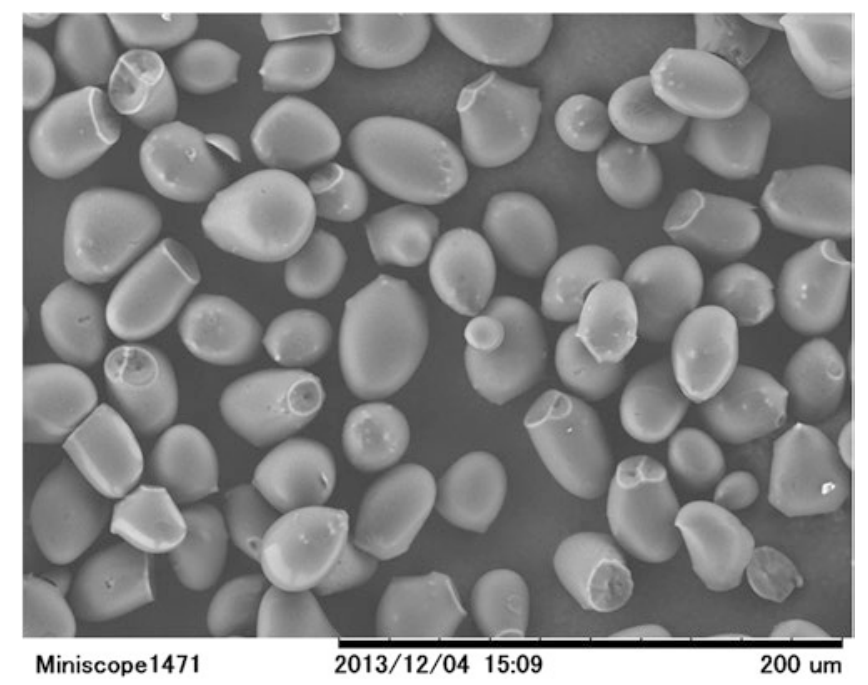

Fig. 18.4 Scanning electron microscope image of sago starch granules from Leyte, Philippines

Fig. 18.5 Particle size distribution of sago starch from Leyte, Philippines (Nishiyama et al. 2015)

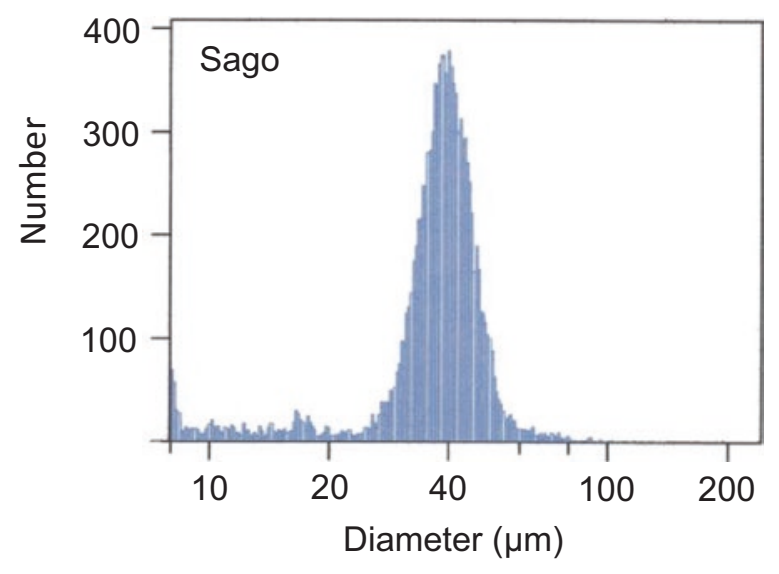

\subsection{Sago Starch Structure}

\subsubsection{Crystalline Structure of Sago Starch}

Sago starch granules are oval with a temple bell-like oval shape (Fig. 18.4). Scanning electron microscopy provided a clear shape and size of native sago starch granules from Leyte, Philippines, which varied from 8 to $240 \mu \mathrm{m}$ in diameter with the mean value of $37.59 \mu \mathrm{m}$ (Fig. 18.5), which is relatively larger than that found by Kobayashi (1993), suggesting that the stroma developed the septum-like structure in an amyloplast and finally produced the temple bell-like shape. 
A

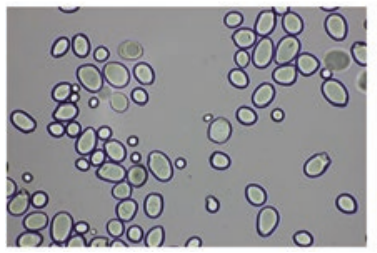

B

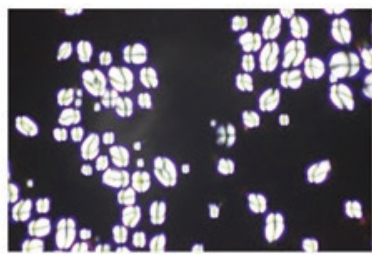

$\mathrm{C}$

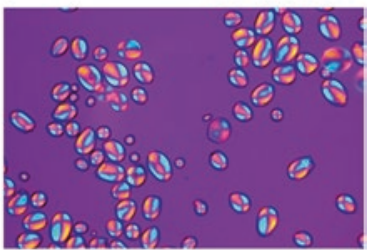

Fig. 18.6 Light and polarized light microscope images of sago starch (Nishiyama et al. 2015)

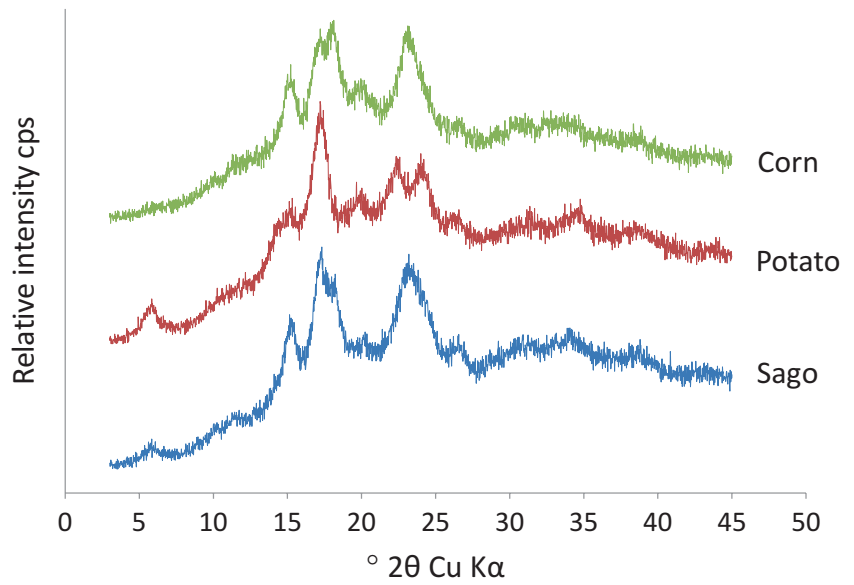

Fig. 18.7 XRD pattern of sago starch from Leyte, Philippines (Nishiyama et al. 2015) (Corn, Kosakai Pharmaceutical Co.; potato, Miyazawa Pharmaceoutical Co.; sago, collected from Leyte, Philippines)

The observation of sago starch granules under a polarized light microscope is effective to see their crystalline properties (Nishiyama et al. 2015) (Fig. 18.6). Sago starch granules exhibit a distinctive Maltese cross (Fig. 18.6 B, C), which indicates the presence of some common internal ordering.

The X-ray diffraction (XRD) pattern of starch granules of corn, potato, and sago at the nanoscopic level shows that starch consists of thin lamellar domains (Nishiyama et al. 2015) (Fig. 18.7). Takahashi et al. (1981), Kawabata et al. (1984), and Yatsugi (1986) used XRD to analyze the structure of sago starch and to compare the starch of corn, potato, mung bean, cassava, and arrowroot. Yatsugi (1986) reported four sago starches did not show differences in their XRD patterns, although it clearly indicated the difference in the first and fourth ring among them.

The XRD pattern of sago starch collected from various portions of the trunk at different growth stages (9-14.5 years after transplanting) and the relative crystallinity of sago starch, corrected by the internal standard of $\mathrm{CaF}_{2}$, ranging from 22 to $40^{\circ}$, were reported by Hamanishi et al. (1999, 2000). Ahmad et al. (1999a), Okazaki et al. (2008) (Fig. 18.8), and Yaacob et al. (2011) also found that sago starch showed 


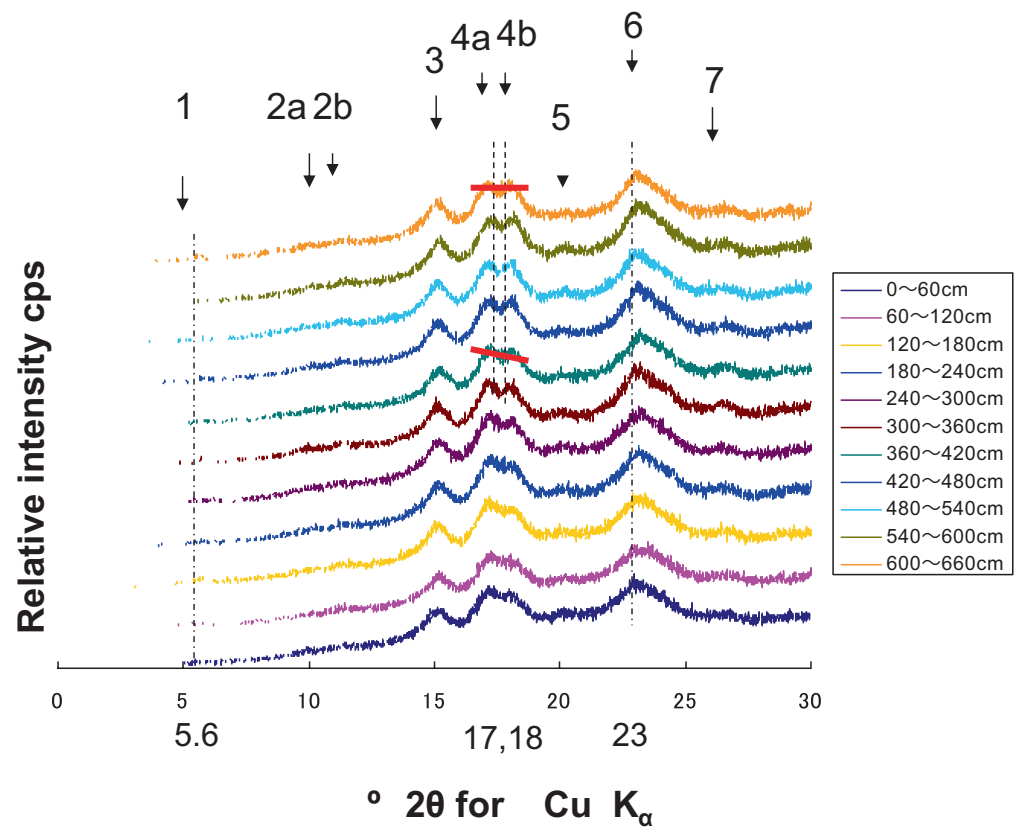

Fig. 18.8 XRD patterns of sago starch from Leyte, Philippines (Okazaki et al. 2008). Sago starches were extracted from the lower trunk $(0-80 \mathrm{~cm})$ to the apical $(600-660 \mathrm{~cm})$ portion. The numbers $1,2 \mathrm{a}, 2 \mathrm{~b}, 3,4 \mathrm{a}, 4 \mathrm{~b}, 5,6$, and 7 show the peaks

a peak at around $5^{\circ}$ of X-ray diffraction. The X-ray diffraction pattern of sago starch indicates the peaks at around 5.6, 17, 18, and $23^{\circ}$, which corresponds to 1.58 , $0.521,0.492$, and $0.386 \mathrm{~nm}$, which are classified as a $\mathrm{C}_{\mathrm{A}}$ type of starch (Cai et al. 2014), a mixture of A type and B type of starch. Sago starch is classified as C type, containing A type mainly and B type as an accessary. Srichuwong et al. (2005) found that sago starch extracted from 14 local varieties of sago palm in Vanuatu was of the $\mathrm{C}$ or $\mathrm{C}_{\mathrm{A}}$ type.

$\mathrm{XRD}$ is a useful tool to determine the crystalline degree of sago starch and to evaluate its thermodynamics. The crystalline index of sago starch was 609, calculated by the equation (1), which shows the similar crystalline index to the result obtained by Katsumi et al. (2014) (Fig. 18.9).

Recently, Polnaya et al. (2013) also revealed that native sago starch from Indonesia was characterized by a weak diffraction peak at $2 \theta=5.67^{\circ}$ and broad peaks at $2 \theta=15.30^{\circ}, 17.12^{\circ}, 18.08^{\circ}$, and $23.46^{\circ}$, which indicated the $\mathrm{C}$ type. In addition, Uthumporn et al. (2014) showed that the XRD patterns of sago starch at different growth stages from Malaysia were $\mathrm{C}$ type. However, the XRD analysis of sago starch was not sufficient to provide an understanding of the flexibility of sago starch structure during wet and dry processes. 
Fig. 18.9 X-ray

diffraction after waveform separation (Katsumi et al. 2014) (Amylopectin, MP Biomedicals Inc.; amylose, Sigma-Aldrich Inc.; corn, Kosakai Pharmaceutical Co.; potato, Miyazawa Pharmaceutical Co.; sago, collected from Leyte, Philippines. Crystalline index $=$ peak height ${ }_{3 \mathrm{~b}} /$ $\mathrm{FWHM}_{3 \mathrm{~b}}+$ peak height ${ }_{4 \mathrm{a}} /$ $\mathrm{FWHM}_{4 \mathrm{a}}$ (1) FWHM: full width at half maximum)

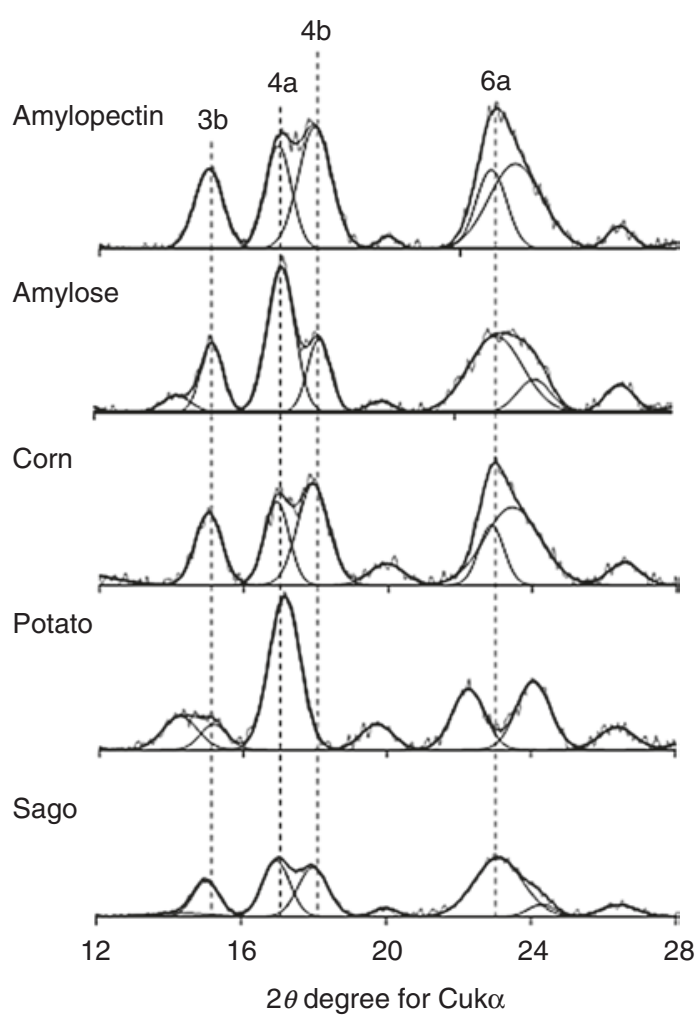

Okazaki et al. (2014) found that the scarcity of change in sago starch structure (from non-spiny and spiny palms) was due to heating up to $60^{\circ} \mathrm{C}$ in the case of low moisture content according to X-ray diffraction. However, over $60{ }^{\circ} \mathrm{C}$ the dehydration caused structural changes in sago starch.

\subsubsection{Amylopectin and Amylose in Sago Starch}

Amylopectin is made up of chains of $\alpha-(1,4)$-linked D-glucosyl units that are interconnected through $\alpha-(1,6)$-linkages, containing $10^{7}-10^{8}$ of molecular weight (degree of polymerization: 12,000-40,000) (Hizukuri 2003). On the other hand, amylose is mainly composed of a liner structure of glucose units linked by $\alpha-(1,4)$ bonds with $10^{5}-10^{6}$ of molecular weight (degree of polymerization: 600-36,000) (Hizukuri 2003), entangled with amylopectin. These components represent approximately 98-99\% of the dry weight of starch (Tester et al. 2004). Amylose itself comprises $15-35 \%$ of the starch by weight. High percentages of amylose give starch less stickiness and a low gelatinization temperature. 
Takeda et al. (1989) reported that the low viscosity of sago starch amylopectin is explained by the presence of a smaller molecule with a slightly higher number of long chains than the high-viscosity amylopectin. The amylopectin chain distribution of sago starch is composed of four fractions with the different chain lengths of Fraction I $(22.9 \pm 0.8 \%)$, Intermediate Fraction $(3.9 \pm 0.4 \%)$, Fraction II $(17.2 \pm 0.4 \%)$, and Fraction III $(56.0 \pm 1.4 \%)$ (Ishii et al. 1990). Takahashi and Hirao (1994) reported that Fraction III of sago amylopectin was 52.3\%, intermediate in value between sweet potato and mung bean amylopectin. Furthermore, Srichuwong et al. (2005) reported that the mean chain length of amylopectin taken from 14 varieties of sago starch from Fiji, Samoa, and Vanuatu was $41.0 \%$ for the degree of polymerization (DP) of $6-12,53.8 \%$ for DP $13-24$, and $5.2 \%$ for DP 25-30.

\subsubsection{Gelatinization Characteristics of Sago Starch}

Starch gelatinization is the disruption of molecular order within the starch granule manifested in irreversible changes in properties such as granular swelling, native crystallite melting, loss of birefringence, and starch solubilization (Maaruf et al. 2001). Starch undergoes a glass transition in the amorphous components prior to the gelatinization when the starch granule is heated in the presence of water (Vamadevan and Bertoft 2015).

The behavior of sago starch gelatinization was observed by a light microscope, a polarized light microscope equipped with a micro-heater, X-ray diffraction, and Brabender amylograph. The highest viscosity of $8 \%$ sago starch suspension was determined with a Brabender amylograph to be 830 B.U. around $92.5^{\circ} \mathrm{C}$ (Takahashi et al. 1981). Arai et al. (1981) revealed that the viscosity of $8 \%$ sago starch suspension was lower than that of $8 \%$ sweet potato, corn, cassava, wheat, and $4 \%$ potato suspension. In addition Kawabata et al. (1984) reported that $6 \%$ sago starch suspension showed the lowest viscosity at $135 \mathrm{~B}$. U. with a small breakdown, compared to cassava, arrowroot, and potato. Yasugi (1986) compared the amylograms of four kinds of 5\% sago starch suspension to corn and cassava starch suspension and concluded that good quality sago starch had low viscosity. The viscosity of six sago starches from Papua New Guinea was determined at $30-70{ }^{\circ} \mathrm{C}$ with a rotational viscometer and was inversely related to the handling temperature and showed different temperature sensitivity (Sopade and Kiaka 2001). Takeda et al. (1989) found that amylose and amylopectin from sago starches with low and high viscosity on amylography differed in molecular structure. The maximum viscosity of sago starch with high and low viscosity was 735 and 280 B. U., respectively. They concluded that amylose controlled the pasting by the interaction with other materials such as lipid and/or intermolecular hydrogen bonds between other amylose and amylopectin. 

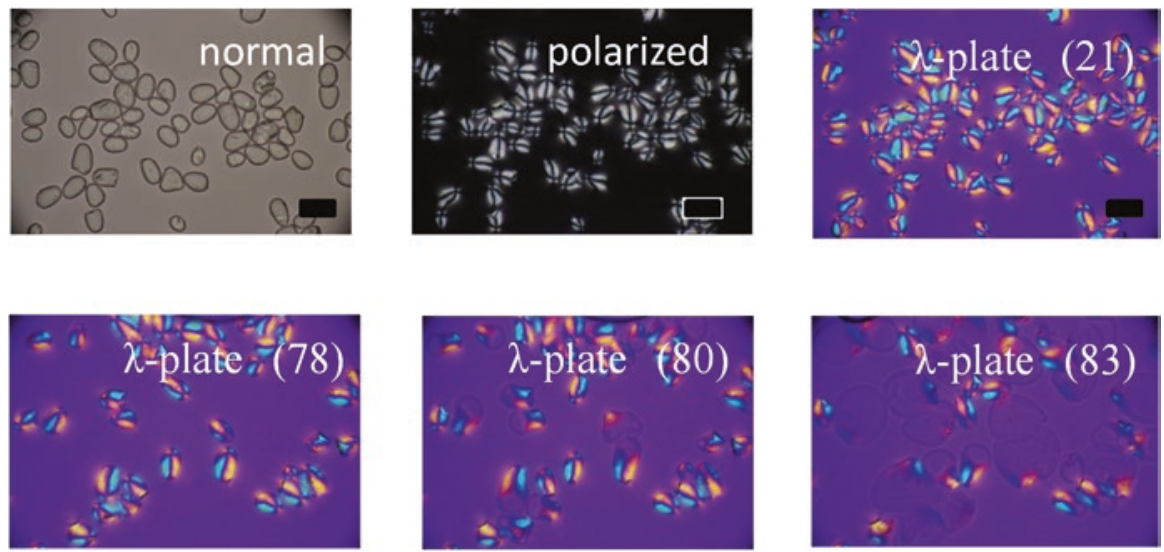

Fig. 18.10 Micrographs of sago starch from Papua New Guinea under normal and polarized light in conjunction with a $\lambda$-plate during gelatinization (Okazaki et al. 2016) (Bar is $50 \mu \mathrm{m}$. The numbers in parentheses represent the temperature during gelatinization)

The gelatinization temperature and enthalpy of starch determined by a differential scanning calorimeter (DSC) depends on the moisture content and degree of crystallinity within the granule and also on granule size and the amylose to amylopectin ratio (Ahmad et al. 1999b). Ahmad et al. (1999b) showed that the gelatinization peak temperature and enthalpy varied from $69.4-70.1{ }^{\circ} \mathrm{C}$ and from $15.1-16.7 \mathrm{~J}$ $\mathrm{g}^{-1}$, respectively, among 11 sago starches. The gelatinization peak temperature of sago starch was higher than those of corn, cassava, potato, and pea. Furthermore, Ahmad and Williams (1999a, b) Ahmad et al. (1999a, b)and Maaruf et al. (1999, 2001) reported that the presence of salts and sugars affected the gelatinization properties of sago starch. Intrinsic viscosity decreased with increasing temperature, but the critical concentration remained fairly constant over the range of temperatures (Nurul et al. 2001). Siau et al. (2004) attempted to make cationic sago starch using 3-chloro-2-hydroxypropyltrimethylammonium chloride $\left(0.01-0.10 \mathrm{~mol} \mathrm{~L}^{-1}\right)$ and sodium hydroxide $\left(0.03-0.86 \mathrm{~mol} \mathrm{~L}^{-1}\right)$ and found that the gelatinization enthalpy of cationic sago starch was lower, compared with native sago starch. The enthalpy of a transition is explained as corresponding to the amount of crystal order (or double helical structure) in the starch suspension (Mohamed et al. 2008). The structural transformation of sago starch modified by osmotic pressure and heat moisture was observed by DSC (Pukkahuta and Varavinit 2007). The gelatinization peak temperature of sago starch increased linearly with increasing osmotic pressure and heat moisture.

The behavior of sago starch granules accompanied by gelatinization was shown by observing granular birefringence (Maltese cross) under polarized light (Okazaki et al. 2016) (Fig. 18.10). The blue and yellow color areas, indicating radial alignments, represent the regions of crystallinity of sago starch. The loss of color on heating indicated the disappearance of radial alignment of crystallinity. The disruption 
of crystallinity occurred on the proximate surface of the eccentric hilum and was propagated from the proximate surface to the distal surface of the eccentric hilum. The initial, middle, and end gelatinization temperatures determined at a hot stage were 78.0, 80.0, and $83.0^{\circ} \mathrm{C}$ for sago starch from Papua New Guinea.

\section{References}

Ahmad FA, Williams PA (1999a) Effect of salts on the gelatinization and rheological properties of sago starch. J Agric Food Chem 47:3359-3366

Ahmad FA, Williams PA (1999b) Effect of sugars on the thermal and rheological properties of sago starch. Biopolymers 50:401-412

Ahmad FA, Che Man YB, Asbi BA et al (1999a) Differential scanning calorimetry: gelatinisation of sago starch in the presence of sucrose and sodium chloride. J Sci Food Agric 79:2001-2009

Ahmad FA, Williams PA, Doublier J-L et al (1999b) Physico-chemical characterisation of sago starch. Carbohydr Polym 38:361-370

Akazawa T (1965) Biosynthesis of starch. Kagaku to seibutsu (Chem Biol) 3:282-291. (in Japanese)

Arai Y, Kaneko T, Ito T (1981) Rheological and chemical properties of sago starch. Japan J Trop Agric 25:41-46. (in Japanese)

Cai CH, Cai JW, Man JM et al (2014) Allomorph distribution and granule structure of lotus rhizome C-type starch during gelatinization. Food Chem 142:408-415

Hamanishi T, Hatta T, Jong FS et al (1999) Physicochemical properties of starches obtained from various parts of sago palm trunks at different growth stages. J Appl Glycosci 46:39-48. (in Japanese)

Hamanishi T, Hatta T, Jong FS et al (2000) The relative crystallinity, structure and gelatinization properties of sago starch at different growth stages. J Appl Glycosci 47:335-341

Hizukuri S (2003) Molecular structure of starch. In: Fuwa E, Komaki T, Hizukuri S, Kainuma K (eds) Encyclopedia of starch science. Asakura Shoten, Tokyo, pp 11-38. (in Japanese)

Hizukuri S, Nikuni J (1957) X-ray diffractometric studies on starches. Part II. Structure of "C"-crystallite. J Agric Chem 31:525-527. (in Japanese)

Imberty A, Perez S (1988) A revisit to the three-dimensional structure of B-type starch. Biopolymers 27:1205-1221

Imberty A, Buleon A, Tran V et al (1991) Recent advances in knowledge of starch structure. Starch/Stärke 43:375-384

Imberty A, Chanzy H, Perez SA et al (1988) The double-helical nature of the crystalline part of A-starch. J Mol Biol 201:365-378

Ishii Y, Nagashima N, Kawabata A et al (1990) A study of chain length distribution in amylopectins from tropical starches. Starch Sci (Denpun Kagaku) 37:251-257. (in Japanese)

Kainuma K, French D (1971) Nageli amylodextrin and its relationship to starch granule structure. I. Preparation and properties of amylodextrins from various starch types. Biopolymers 10:1673-1680

Kainuma K, French D (1972) Nageli amylodextrin and its relationship to starch granule structure. II. Role of water in crystallization of B-starch. Biopolymers 11:2241-2250

Katsumi N, Okazaki M, Yonebayashi K (2014) New proposal for "crystalline index" of starch. Sago Palm 22:25-30

Kawabata A, Sawayama S, Nagashima N (1984) Some physic-chemical properties of starches from cassava, arrowroot and sago. J Japan Soc Starch Sci 31:224-232 
Kobayashi S (1993) Utilizing characteristics of sago palm. Sago Palm 1:25-32. (in Japanese)

Maaruf BA, Ghani YB, Che Man YB et al (1999) A differential scanning calorimetric (DSC) study on the effects of annealing and sugar-emulsifiers on gelatinization of sago starch (Metroxylon sagu). J Food Process Preserv 23:443-462

Maaruf AG, Che Man YB, Asbi BA et al (2001) Effect of water content on the gelatinization temperature of sago starch. Carbohydr Polym 46:331-337

Mohamed A, Jamilah B, Abbas KA et al (2008) A review on physicochemical and thermorheological properties of sago starch. Amer J Agric Biolog Sci 3:639-646

Nishiyama S, Okazaki M, Katsumi N et al (2015) Surface charge on sago starch granules. Sago Palm 23:77-83

Nurul IMD, Abdul MDM, Azemi BMN (2001) Effect of temperature and starch concentration on the intrinsic viscosity and critical concentration of sago starch (Metroxylon sagu). Starch/ Stärke 53:90-94

Okazaki M, Igura M, Kimura SD et al (2008) Development of the structure of sago starch. In: Toyoda Y, Okazaki M, Quevedo M, Bacusmo J (eds) Sago: its potential in food and industry. TUAT Press, Tokyo, pp 127-135

Okazaki M, Katsumi N, Nishiyama S et al (2014) Thermal denaturation properties of non-spiny and spiny sago palm starches under low moisture content. Sago Palm 22:31-37

Okazaki M, Katsumi N, Nishiyama S et al (2016) Polymorph and crystallinity disruption of sago starch during gelatinization. Sago Palm 24:20-25

Polnaya FJ, Haryadi MDW et al (2013) Effects of phosphorylation and cross-linking on the pasting properties and molecular structure of sago starch. Int Food Res J 20:1609-1615

Pukkahuta C, Varavinit S (2007) Structure transformation of sago starch by heat-moisture and osmotic-pressure treatment. Starch/Stärke 59:624-631

Siau CL, Karim AA, Norziah MH et al (2004) Effects of cationization on DSC thermal profiles, pasting and emulsifying properties of sago starch. J Sci Food Agric 84:1722-1730

Sopade PA, Kiaka K (2001) Rheology and microstructure of sago starch from Papua New Guinea. J Food Eng 50:47-57

Srichuwong S, Sunarti TC, Mishima T et al (2005) Starches from different botanical sources I: contribution of amylopectin fine structure to thermal properties and enzyme digestibility. Carbohydr Polym 60:529-538

Takahashi S, Hirao K (1994) Studies on the physical and the chemical properties of sago starch, and its performance when used in the preparation of Japanese sweets. Bul Fac Home Econ, Kyoritsu Women's Univ 40:59-64. (in Japanese)

Takahashi S, Kitahara H, Kainuma K (1981) Properties and cooking quality of starches. Part I, chemical and physical properties of starches from mung bean and sago. J Japan Soc Starch Sci 28:151-159. (in Japanese)

Takeda Y, Takeda C, Suzuki A (1989) Structures and properties of sago starches with low and high viscosities on amylography. J Food Sci 54:177-182

Tester RF, Karkalas J, Qi X (2004) Starch - composition, fine structure and architecture. J Cereal Sci 39:151-165

Uthumporn U, Wahidah N, Karim AA (2014) Physicochemical properties of starch from sago (Metroxylon sagu) palm grown in mineral soil at different growth stages. Global Conf on Polymer Compos Mater (PCM 2014):1-11. doi:10.1088/1757-899X/62/1/012026

Vamadevan V, Bertoft E (2015) Structure-function relationships of starch components. Starch/ Stärke 67:55-68

Wu H-CH, Sarko A (1978a) The double-helical molecular structure of crystalline B-amylose. Carbohydr Res 61:7-25

Wu H-CH, Sarko A (1978b) The double-helical molecular structure of crystalline A-amylose. Carbohydr Res 61:27-40 
Yaacob B, Mohd CIMA, Kamaruddin H et al (2011) Optimization of reaction conditions for carboxymethylated sago starch. Iran Polym J 20:1-14

Yatsugi T (1986) Problems of sago starch manufacturing. In: Yamada N, Kainuma K (eds) Proceedings of $3^{\text {rd }}$ international sago symposium. Sago Palm Research Fund, Tokyo, pp 201-207

Open Access This chapter is licensed under the terms of the Creative Commons Attribution 4.0 International License (http://creativecommons.org/licenses/by/4.0/), which permits use, sharing, adaptation, distribution and reproduction in any medium or format, as long as you give appropriate credit to the original author(s) and the source, provide a link to the Creative Commons license and indicate if changes were made.

The images or other third party material in this chapter are included in the chapter's Creative Commons license, unless indicated otherwise in a credit line to the material. If material is not included in the chapter's Creative Commons license and your intended use is not permitted by statutory regulation or exceeds the permitted use, you will need to obtain permission directly from the copyright holder. 


\title{
Chapter 19 \\ Recovery of Starch from Sago Pith Waste and Waste Water Treatment
}

\author{
Budi Santoso
}

\begin{abstract}
The objective of this study was to investigate sago starch recovery from sago pith waste (SPW) using wet milling and its physical properties. For comparative purposes, the same parameters were evaluated for untreated sago starch. As a result of the super mass colloider mill (SMCM), a 21\% dry basis of sago starch can be recovered from SPW. Scanning electron microscopy showed that the granule morphology was not changed. X-ray diffraction showed that relative crystallinity and diffractogram patterns between SMCM sago starch and untreated sago starch were similar. Particle size distribution analysis demonstrated that untreated and SMCM sago starch were relatively narrow and uniform size distribution and the particle size distribution index were not different. The results indicate that wet milling of SPW using a SMCM can increase sago starch yield and the physical properties of SMCM sago starch were similar to untreated sago starch.
\end{abstract}

\subsection{Introduction}

At present, food security is a serious issue in the world because the population rate continues to increase. According to the US Census Bureau (2014), the world population was around 6.1 billion in 2000 and increased by about $13 \%$ (to 6.9 billion) in 2010. It is projected that the population of the world, with an average growth rate of about $0.8 \%$, will increase in billions to 8.3 by 2030, 8.9 by 2040, and 9.4 by 2050 . This indicates that by 2050 the world needs to produce $50 \%$ more food than it does now to feed around 9 billion people.

In the world, there are various plant sources of starch, such as rice, wheat, corn, potato, sweet potato, cassava, barley, and sago. Among carbohydrate polymers, starch is currently enjoying increased attention owing to its usefulness in different food products. Starch contributes greatly to the textural properties of many foods and is widely used in food and industrial applications as a thickener, colloidal stabilizer, gelling agent, bulking agent, and water retention agent (Singh et al. 2007).

\footnotetext{
B. Santoso $(\square)$

Faculty of Agricultural Technology, Papua University, Manokwari, West Papua, Indonesia

e-mail: budsandida@yahoo.com
} 
Industries use starch to give products certain properties, such as consistency and mouthfeel in food products or sizing of textiles. While some products require very specific kinds of starch, for most starch uses, there is a high degree of substitutability between one starch and another (Fuglie 2004). The utilization of starch sources depends on the functional properties of starches including thickening behavior and the ability to form a gel or paste. The textural properties of gelatinized and retrograded starches are important for their potential use in food systems and depend on the molecular component and structure of the starch (Adawiyah et al. 2013).

Recently, attention to sago starch as a new food and a food security crop has increased, especially due to the anticipated growth in human population and potential future environmental disasters (Yamamoto 2011). Sago starch has not only foodstuff potential but also can be used as a bio-resource, such as ethanol (Ishizaki 1998). Compared to other starches, sago starch has low cost of production and high yield. Also, sago produces a higher amount of starch, around 15-20 mt of air-dried starch per hectare (Flach 1997). The sago yield could be about 3-4 times higher than those of rice, corn, or wheat and about 17 times higher than that of cassava (Ishizaki 1998; Singhal et al. 2008).

The sago palm is an underutilized potential food source which grows well in the tropical rainforest. Sago palm is adapted to the tropical areas with an average temperature of $25{ }^{\circ} \mathrm{C}$ and approximate relative humidity of $70 \%$; an extremely hardy plant, it thrives in swampy, acidic peat and saline soils where other crops cannot survive (Flach and Schuilling 1989; Flach 1997). The three leading countries in terms of approximate areas of sago palms are Indonesia with 1,284,000, Papua New Guinea 1,020,000, and Malaysia 45,000 ha (Flach 1997). Agronomically, sago palm is a potentially important indigenous crop of Southeast Asia and Oceania which has remained relatively underexploited (Flach 1983). It is estimated that about 60 million $\mathrm{mt}$ of starch, extracted from sago palms, are produced per annum in Southeast Asia alone (Wang et al. 1996).

\subsection{Problems of Sago Starch Extraction}

Sago starch accumulates in the trunk of the sago palm until the flowering stage, with maximum starch content occurring just before the onset of palm flowers; the palm slowly dies thereafter. The plant reaches commercial maturity at 9-12 years of age. At the mature stage, it possesses a large trunk and may reach a height of 6-25 $\mathrm{m}$ and a diameter of $40 \mathrm{~cm}$ (Flach 1997). Sago starch can be extracted by maceration of the pith of a sago trunk. Extracting starch from the sago trunk, according to Nishimura et al. (2010), involves tree felling, cutting the trunk into log sections, log splitting, pith crushing, starch filtering, starch extraction, drying, and packaging. However, the method of extraction in different locations is quite diverse depending on starch use, local resource use, and economic factors among different ethnic groups.

The sago starch extraction process can be divided into two methods: traditional and modern. The principles of sago extraction for both methods are similar; the 
differences are only in the scale of operation (Karim et al. 2008) and the processing tools that are used (Greenhill 2006). The traditional method is further divided into two levels, the domestic level and the small-scale processing plant level. The smallscale level of sago starch extraction uses electrical power on some processors. Santoso et al. (2015) found that the actual starch content in the pith is about 65\% with fiber making up the remaining $35 \%$. The mechanical process currently employed to extract sago starch is inefficient and often fails to dislodge residual starch embedded in the fibrous portion of the trunks (Karim et al. 2008). Several studies have found that sago starch can be extracted using commercial methods, only up to 55-70\% (dry weight basis) of the true sago starch content. The remaining starch is still trapped within the parenchyma cells or fibers in the sago pith waste (Mohd et al. 2001; Awg-Adeni et al. 2013; Lai et al. 2013).

Sago pith waste still contains a lot of starch. According to Abd-Aziz (2002), the composition of sago pith waste on a dry weight basis contains $65.7 \%$ starch, $14.8 \%$ crude fiber, $1 \%$ crude protein, $4.1 \%$ ash, and $59.1 \%$ moisture. Linggang et al. (2012) reported that sago pith waste contains $58 \%$ starch, $23 \%$ cellulose, $9.2 \%$ hemicellulose, and 4\% lignin on a dry basis. Awg-Adeni et al. (2013) state that on a dry basis, the proportions of sago pith waste consist of 30-45\% starch, 5-7\% ash, $1 \%$ protein, and $4.6-4.7 \%$ fiber. Several studies have been done on utilizing sago pith waste as a substrate for the production of enzymes and adsorbents (Singhal et al. 2008), glucose syrup (Asben et al. 2011; Linggang et al. 2012), fructose syrup (Mishima et al. 2011), bioethanol (Awg-Adeni et al. 2011; Peristiwati et al. 2011), and biobutanol (Linggang et al. 2011; Awg-Adeni et al. 2013).

\subsection{Recovery of Starch from Sago Pith Waste}

According to Cecil (1992) and Mohd et al. (2001), the starch in sago pith waste is trapped within the parenchyma cells or fibers. To liberate the starch, it is necessary to break down the sago pith waste. There are two ways to recover starch from sago pith waste, enzymatically and physically. Recovering starch from sago pith waste using enzymes was introduced by Mohd et al. (2001). The residual native starch was extracted from sago pith residue using two types of commercial cell wall-degrading enzymes, Pectinex Ultra SP-L and Ultrazyme 100G. The results showed that the type of enzyme produced different effects to release starch from pith waste. The highest starch yield was achieved using Pectinex; after $1 \mathrm{~h}$ reaction time it yielded $42.3 \%$, dry weight basis, and then declined. By comparison, the Ultrazyme had a high yield at $2 \mathrm{~h}$ reaction time of $28.4 \%$. The physical appearance of the starch granules showed that more larger granules were extracted using Pectinex, while the distributional pattern of starch granules was more uniform with the Ultrazyme treatment during the 30 min-incubation period (Mohd et al. 2001).

Physically, recovery of starch from pith waste with further grating (secondary grating), by using a hammer mill, gives a small increase in yield of only around $3-5 \%$ and then makes separation of the sago starch from fibers difficult (Cecil 
1992). This method is not efficient for small and medium sago factories. Another way to recover starch from sago pith waste is through the use of a super mass colloider mill (Santoso et al. 2015). A micro powder mill is a dry milling method commonly used for milling cereals and grains, but also can be used to physically separate the starch from sago pith waste. This method is practical because industrial operation of a micro powder mill is easy. The yields of sago starch can be increased to around $17 \%$ (dry weight basis) when the milling process is performed at a medium narrow level of disc clearance; this was easier as compared with a narrow level of disc clearance. Based on scanning electron microscopy (SEM) micrographs (Fig. 19.1), the granule surfaces in native sago starch are smooth and oval, without any pores and fissures, and with diameters in the range 20-60 $\mu \mathrm{m}$ (Cecil 1992; Ahmad et al. 1999). The granular surface of starch from sago pith waste has slightly rough granules. When the starch is observed under polarized light (Fig. 19.2), the
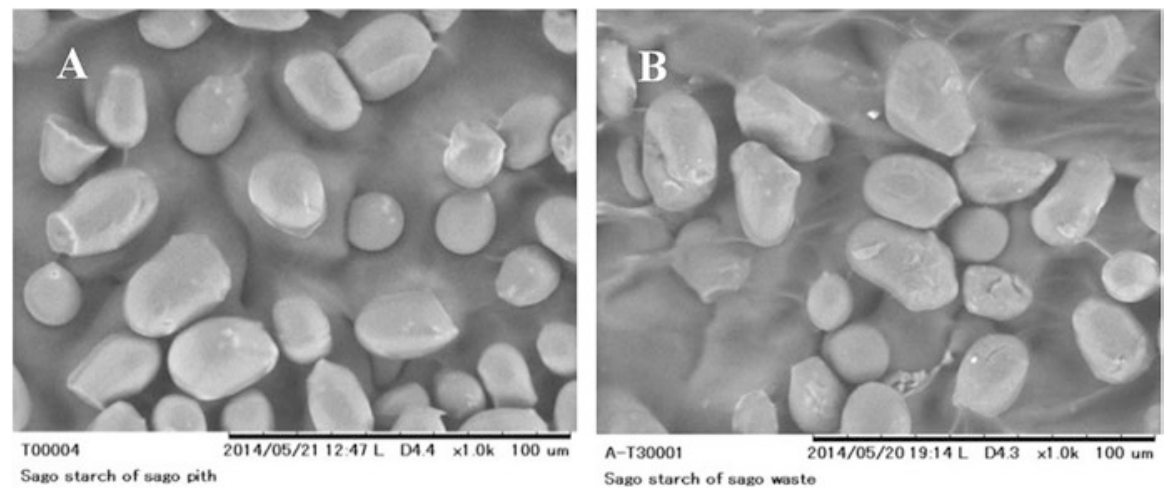

Fig. 19.1 Scanning electron microscopy images of sago starch, (a) native sago starch and (b) micro-powder-milled sago starch (magnification is 1000x)
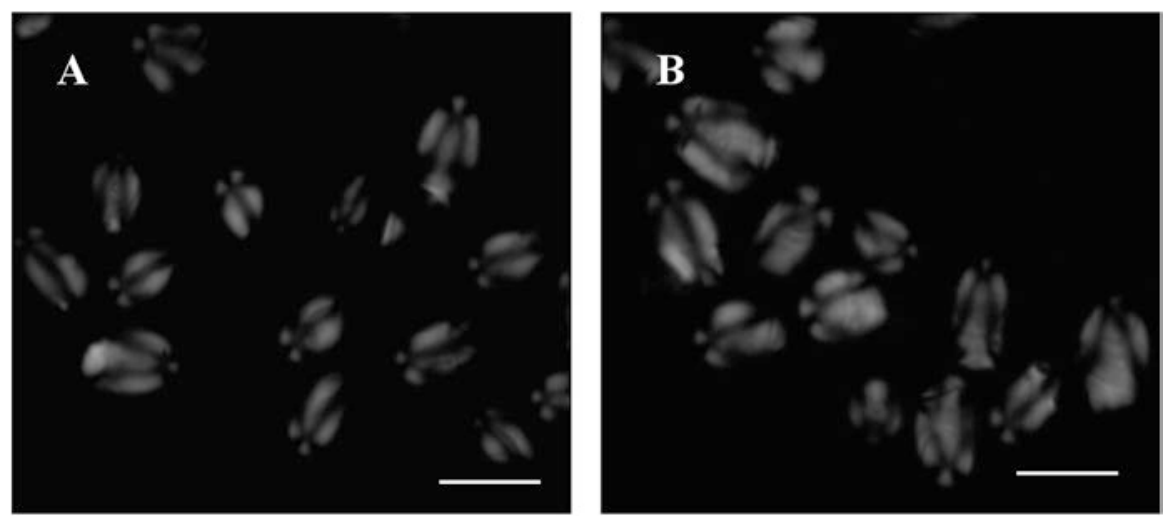

Fig. 19.2 Microscopy photographs with polarized light for (a) native sago starch and (b) micropowder-milled sago starch (magnification is $40 \times$ and bar indicates $50 \mu \mathrm{m}$ ) 
birefringence of micro-powder-milled sago starch is unchanged compared to native sago starch, with strong patterns at the granule centers; the typical Maltese crosses are uniform, with two crossed lines and a dark line at the center. According to Stahl et al. (2007), the birefringent and Maltese cross pattern can be observed on all of the native starch granules under polarized light.

The XRD pattern and the relative crystallinities of native sago starch and micropowder-milled sago starch are presented in Fig. 19.3 and Table 19.1. Native sago starch has a C-type diffraction pattern. The $\mathrm{C}$ type is a mixture of both $\mathrm{A}$ and $\mathrm{B}$ type. A-type pattern is associated mainly with cereal starches and has main peaks at $\sim 15$, 17, 18, and $23^{\circ}$ (Huijbrechts et al. 2008; O'Brien and Wang 2008; Hu et al. 2014). B-type pattern is usually obtained from tuber starches and shows main peaks at 5.6, 15, 17, 22, and 24 (O'Brien and Wang 2008; Alvani et al. 2011). The C type formed when both A- and B-polymorphic arrangement coexist and are characterized by diffraction peaks at $2 \theta$ values of around $5^{\circ}$ and strong peaks at around $\sim 15$, 17,18 , and $23^{\circ}$ (Karim et al. 2008; Wang et al. 2008). Although the relative crystallinities of micro-powder-milled sago starch are slightly decreased (Table 19.1), the XRD pattern (Fig. 19.3) shows no difference between these two starches.

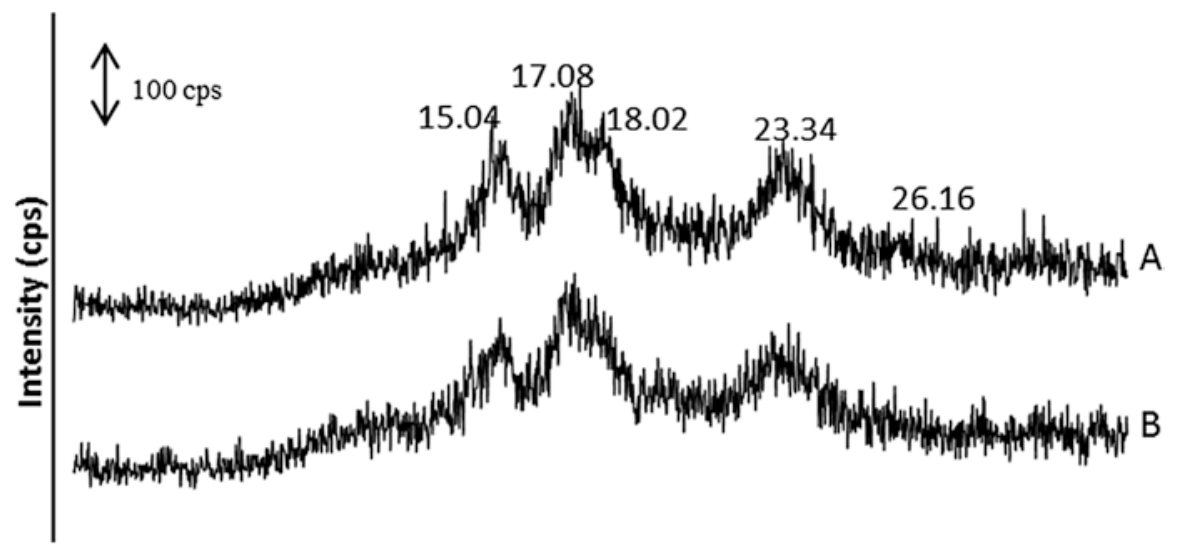

Fig. 19.3 X-ray diffraction patterns of (a) native sago starch and (b) micro-powder-milled sago starch

Table 19.1 Relative crystallinities and gelatinization properties of sago $\mathrm{starch}^{\mathrm{a}}$

\begin{tabular}{l|l|l|l|l|c|l}
\hline & \multirow{6}{|c|}{ Gelatinization properties } \\
\cline { 3 - 7 } Treatment & $\mathrm{RC}(\%)$ & $T_{\mathrm{o}}\left({ }^{\circ} \mathrm{C}\right)$ & $T_{\mathrm{p}}\left({ }^{\circ} \mathrm{C}\right)$ & $T_{\mathrm{c}}\left({ }^{\circ} \mathrm{C}\right)$ & Range $\left(T_{\mathrm{c}}-T_{\mathrm{o}}\right)\left({ }^{\circ} \mathrm{C}\right)$ & $\Delta H(\mathrm{~J} / \mathrm{g})$ \\
\hline A & $30.5 \pm 1.8$ & $56.3 \pm 0.3$ & $66.9 \pm 0.0$ & $75.9 \pm 0.1$ & $19.6 \pm 0.1$ & $15.4 \pm 0.5$ \\
\hline B & $22.1 \pm 1.1$ & $56.3 \pm 0.3$ & $66.3 \pm 0.1$ & $74.6 \pm 0.0$ & $18.3 \pm 0.3$ & $11.9 \pm 0.6$ \\
\hline
\end{tabular}

$R C$ relative crystallinity, $T_{\mathrm{o}}$ onset temperature, $T_{\mathrm{p}}$ peak temperature, $T_{\mathrm{c}}$ conclusion temperature, $\Delta H$ enthalpy

A native sago starch, B micro-powder-milled sago starch

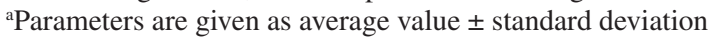



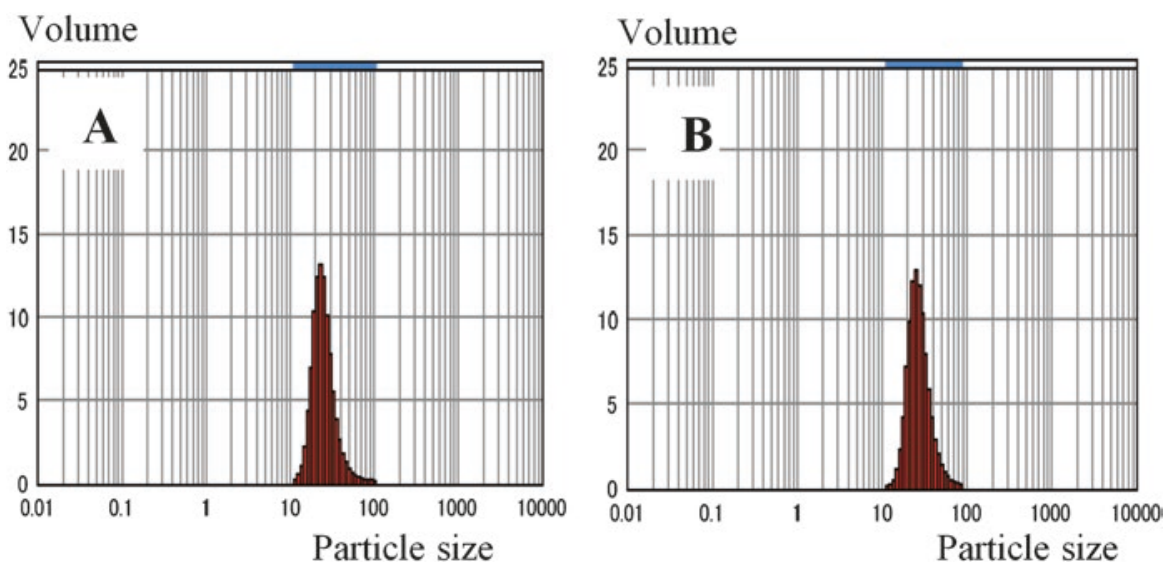

Fig. 19.4 Particle size distribution of (a) native sago starch and (b) micro-powder-milled sago starch

Table 19.2 Size distributions of sago $\operatorname{starch}^{\mathrm{a}}$

\begin{tabular}{l|l|l|l|l}
\hline \multirow{2}{*}{ Treatment } & \multicolumn{4}{l}{ Particle size } \\
\cline { 2 - 5 } & $D_{(v, 0.1)}(\mu \mathrm{m})$ & $D_{(v, 0.5)}(\mu \mathrm{m})$ & $D_{(v, 0.9)}(\mu \mathrm{m})$ & Span $^{\mathrm{b}}$ \\
\hline A & $17.3 \pm 0.1$ & $23.8 \pm 0.1$ & $36.4 \pm 0.2$ & $0.8 \pm 0.0$ \\
\hline B & $18.9 \pm 0.0$ & $26.1 \pm 0.1$ & $40.1 \pm 0.6$ & $0.8 \pm 0.0$
\end{tabular}

A native sago starch, B micro-powder-milled sago starch

aParameters are given as average value \pm standard deviation

${ }^{\mathrm{b}}$ Span: size dispersion index

Table 19.1 shows the gelatinization temperatures for native and micro-powdermilled sago starch. The onset temperature $\left(T_{\mathrm{o}}\right)$, peak temperature $\left(T_{\mathrm{p}}\right)$, and conclusion temperature $\left(T_{\mathrm{c}}\right)$ did not differ much for all treatments. The enthalpy of gelatinization $(\Delta H)$ slightly decreased from $15.4 \mathrm{~J} / \mathrm{g}$ for native sago starch to $11.9 \mathrm{~J} / \mathrm{g}$ for micro-powder-milled sago starch. This suggests that the physical force of micro powder milling is not disrupting the crystalline structure.

Graphic representation of particle size distribution of the native and micropowder-milled sago starch is shown in Fig. 19.4, and the mean diameters and spans are summarized in Table 19.2. The average sizes of the granules of micro-powdermilled sago starch were slightly higher than that of native sago starch; the span reflects the width of the starch granules. The span of native sago starch did not differ from micro-powder-milled sago starch. 


\subsection{Waste Water Treatment}

The type of waste from a sago starch factory is not only pith waste but also effluent waste. The effluent has the potential to cause water pollution in the surrounding environment due to containing a large amount of organic material. Furthermore, Singhal et al. (2008) stated that a high biomass concentration of $2.5 \mathrm{~g} / \mathrm{L}$ with a pigment content of about $1.1 \mathrm{mg}$ carotenoid per $\mathrm{g}$ cell mass was achieved after $96 \mathrm{~h}$ of growth in anaerobic-light culture system together with a $77 \%$ reduction in the COD (chemical oxygen demand) of the sago effluent.

Meanwhile, according to Mishima (2015), the sago factory effluent contains finely milled fibers, inextricable starch, and polyphenols and is discolored and prone to putrefaction. Existing treatment methods such as the use of sedimentation ponds have had detrimental effects on neighboring areas, such as a foul odor. More positive waste water treatment operations are hoped for. On the flip side, waste water contains abundant carbohydrates. The application of this material as a biomass resource might lead to new products instead of waste treatment.

\subsection{Conclusion}

Loss of starch in the sago starch extraction process is very high because the extraction methods cannot recover all of starch embedded in the fibrous portion of the trunks. This is a problem in sago starch production process for producers of sago palms. The average of sago starch recovery from sago pith waste using enzymes was $35.35 \%$ on a dry weight basis (28.4-42.3\%). Whereas sago starch yield can be increased to around $17 \%$ (dry weight basis) when sago pith waste is passed through a micro powder mill. According to Mohd et al. (2001), in Malaysia the total annual of starch disposed of as sago pith waste is estimated at 20,000 $\mathrm{mt}$. Therefore, both enzymes and a micro powder mill recovery can increase sago starch production by around 3400-7070 mt annually. This yield is very valuable and calls attention to the sago palm as a new food and a food security crop in the world. The sago factory effluent contains a large amount of organic material, such as carbohydrates that can be used as a biomass resource.

\section{References}

Abd-Aziz S (2002) Sago starch and its utilization. J Biosci Bioeng 94(6):526-529

Adawiyah DR, Tomoko S, Kaoru K (2013) Characterization of arenga starch in comparison with sago starch. Carbohydr Polym 92:2306-2313

Ahmad FB, Peter AW, Jean-Louis D et al (1999) Physico-chemical characterization of sago starch. Carbohydr Polym 38:361-370

Alvani K, Xin Q, Richard FT, Colin ES (2011) Physico-chemical properties of potato starches. Food Chem 125:958-965 
Asben A, Tun TI, Khaswar S et al (2011) Study of sago hampas' cellulose conversion to glucose in batch fermentation. In: Proceedings of the 10th international sago symposium, Bogor, Indonesia, pp 83-84

Awg-Adeni DS, Abd-Aziz S, Bujang KB, Hassan MA (2011) Ethanol fermentation from waste starch of sago processing industry by commercial baker's yeast. Proceedings of the 10th international sago symposium, Bogor, pp 78-81

Awg-Adeni DS, Bujang KB, Hassan MA, Abd-Aziz S (2013) Recovery of glucose from residual starch of sago hampas for bioethanol production. Research article. Hindawi publishing corporation. Biomed Res Int 2013:1-8

Cecil JE (1992) Small, medium, and large-scale starch processing. In: Agricultural service bulletin 98, Food and Agriculture Organization, Rome

Flach M (1983) The sago palm. Plant production and protection paper 47. Food and Agriculture Organization, Rome

Flach M (1997) Sago palm. In: Promoting the conservation and use of underutilized and neglected crops, report No.13, Institute of plant genetics and crop plant research, Gatersleben/ International plant genetic resources institute, Rome, p 1-61

Flach M, Schuilling DL (1989) Revival of an ancient starch crop: a review of the agronomy of the sago palm. Agrofor Syst 7:259-281

Fuglie KO (2004) Challenging Bennet's law: the new economics of starchy staples in Asia. Food Policy 29:187-202

Greenhill AR (2006) Food safety and security of sago starch in rural Papua New Guinea. Dissertation, School of Veterinary and Biomedical Science. James Cook University, Townsville, Australia

Hu X, Hongyan L, Benxi W et al (2014) Hydrolysis process of normal rice starch by 1-butanolhydrochloric. Food Hydrocoll 41:27-32

Huijbrechts AML, Desse M, Budtova T et al (2008) Physicochemical properties etherified maize starches. Carbohydr Polym 74:170-184

Ishizaki A (1998) Concluding remarks. In: Jose C, Rasyad A (eds) Proceedings of the 6th international sago symposium. Pekanbaru, Riau

Karim AA, Tie APL, Manan DMA, Zaidul ISM (2008) Starch from the sgo (Metroxylon sagu) palm tree-properties, prospects, and challenges as a new industrial source for food and other uses. Compr Rev Food Sci Food Saf 7(3):215-228

Lai JC, Wan AWAR, Wen YT (2013) Characterisation of sago pith waste and its composites. Ind Crop Prod 45:319-326

Linggang S, Abd-Aziz S, Phang LY, Wasoh H (2011) Sago pith residue as an alternative cheap substrate for bio-butanol production. Proceedings of the 10th international sago symposium, Bogor, pp 75-77

Linggang S, Phang LY, Wasoh MH, Abd-Aziz S (2012) Sago pith residue as an alternative cheap substrate for fermentable sugars production. Appl Biochem Biotechnol 167:122-131

Mishima T (2015) Extraction methods and production processes in starch factories. In: The sago palm. The food and environmental challenges of the 21st century. The Society of the Sago Palm Studies. Kyoto University Press and Trans Pacific Press, pp 242-246

Mishima T, Koutatsu S, Hitoshi N et al (2011) Glucose made from sago residue. Proceedings of the 10th international sago symposium, Bogor, pp 72-74

Mohd AMD, Islam MN, Noor BM (2001) Enzymic extraction of native starch from sago (Metroxylon sagu) waste residue. Starch 53:639-643

Nishimura Y, Takashi M, Hiroshi E (2010) Starch extraction and production. In: The sago palm, the food and environmental challenges of the 21st century. The Society of Sago Palm Studies. Kyoto University Press, Japan, pp 235-242

O'Brien S, Wang Y-J (2008) Susceptibility of annealed starches to hydrolysis by $\alpha$-amylase and glucoamylase. Carbohydr Polym 72(2008):597-607

Peristiwati P, Sayuti JN, Safitri R et al (2011) Bio-ethanol production from sago pith flour hydrolyte by yeasts and Zymomonas mobilis. Proceedings of the 10th international sago symposium, Bogor, Indonesia, p 82 
Santoso B, Koutatsu S, Hitoshi N et al (2015) Effects of micro powder milling on physicochemical properties of sago starch. J Appl Glycosci 62:73-80

Singh N, Nakaura Y, Inouchi N, Nishinari K (2007) Fine structure, thermal and viscoelastic properties of starches separated from Indica rice cultivars. Starch 60:349-357

Singhal RS, Kennedy JF, Gopalakrishnan SM et al (2008) Industrial production, processing, and utilization of sago palm-derived products. Carbohydr Polym 72:1-20

Stahl JA, Lobato LP, Bochi VC et al (2007) Physicochemical properties of pinhão (Araucaria angustifolia, Bert, O. Ktze) starch phosphates. LWT Food Sci Technol 40:1206-1214

United States Census Bureau (2014) International data base. http://www.census.gov/population/ international/data/worldpop/table_population.php. Downloaded on February 10, 2015

Wang WJ, Powell AD, Oates CG (1996) Sago starch as a biomass source: raw sago starch hydrolysis by commercial enzymes. Bioresour Technol 55:55-61

Wang S, Yu J, Yu J (2008) Conformation and location of amorphous and semi-crystalline regions in C-type starch granules revealed by SEM, NMR and XRD. Food Chem 110:39-46

Yamamoto Y (2011) Starch productivity of sago palm and the related factors. Proceedings of the 10th international sago symposium, Bogor, Indonesia, pp 9-15

Open Access This chapter is licensed under the terms of the Creative Commons Attribution 4.0 International License (http://creativecommons.org/licenses/by/4.0/), which permits use, sharing, adaptation, distribution and reproduction in any medium or format, as long as you give appropriate credit to the original author(s) and the source, provide a link to the Creative Commons license and indicate if changes were made.

The images or other third party material in this chapter are included in the chapter's Creative Commons license, unless indicated otherwise in a credit line to the material. If material is not included in the chapter's Creative Commons license and your intended use is not permitted by statutory regulation or exceeds the permitted use, you will need to obtain permission directly from the copyright holder. 


\title{
Chapter 20 \\ Acid Modification of Sago Hampas for Industrial Purposes
}

\author{
Titi Candra Sunarti, Vioni Derosya, and Indah Yuliasih
}

\begin{abstract}
Sago pith and sago hampas mainly consist of starch and fiber. In this research, acid modification of starch and fiber was conducted by high-temperature (autoclaving) and microwave-assisted treatments and slow or mild acid hydrolysis. Autoclaving and microwave-assisted treatments influenced the gelatinization and solubilization of starch granules to produce depolymerized starch and changed the fiber structure to become more amorphous forms. Heating in dilute acid produced high soluble total sugars with high dextrose equivalent, but the process also released hydroxymethylfurfural as undesired by-products. Slow or mild acid hydrolysis attacked the amorphous regions of starch and fiber. It did not change the starch and fiber crystallinity pattern but increased the degree of crystallinity. Acid modification techniques for sago starch and its fiber can be used for producing certain products such as starch sugar, fermentable sugars, and filler for biofoam production.
\end{abstract}

\subsection{Introduction}

Sago palm is considered an ideal crop for a starch-based sweetener and feedstock, since in Indonesia there is negligible competition between food and ethanol fuel and land resources are underutilized. Sago starch has been used for a long time, especially in Southeast Asia in the food industry for the production of sago pearl, vermicelli, bread, cake, biscuits, and many other traditional foods (Ahmad and Williams 1999). Sago palm (Metroxylon sp.) is a species from which starch-rich flour can be extracted from the pith of the trunk. The pith consists mainly of starch, which has to be separated from cellulosic materials by several stages of processing. Fujii et al. (1985) reported that the composition of dried sago pith was mainly starch (81.51$84.72 \%)$ and fiber (3.20-4.20\%).

Sago starch is one of the least expensive starches but has low quality. Yatsugi (1985) has identified several problems associated with sago starch and manufacture, including whiteness, viscosity, starch particles, and starch content in starch pro-

T.C. Sunarti $(\varangle) \bullet$ V. Derosya $\bullet$ I. Yuliasih

Department of Agroindustrial Technology, Faculty of Agricultural Technology and

Engineering, Bogor Agricultural University, Bogor, Indonesia

e-mail: titi-cs@ipb.ac.id

H. Ehara et al. (eds.), Sago Palm, https://doi.org/10.1007/978-981-10-5269-9_20 
Table 20.1 Characteristics of acid and enzymatic hydrolysis products*

\begin{tabular}{|c|c|c|c|}
\hline \multirow[b]{2}{*}{ Characteristics $* *$} & \multicolumn{3}{|l|}{ Sago samples } \\
\hline & Sago pith flour & Sago starch & Sago hampas \\
\hline \multicolumn{4}{|l|}{ Chemical components } \\
\hline Ash $(\%)$ & 1.18 & 0.12 & 7.59 \\
\hline Crude lipid (\%) & 1.35 & 1.82 & 2.04 \\
\hline Crude protein $(\%)$ & 0.49 & 0.19 & 0.86 \\
\hline Crude fiber $(\%)$ & 3.34 & 0.19 & 15.34 \\
\hline Starch $(\%)$ & 86.00 & 97.83 & 55.33 \\
\hline \multicolumn{4}{|l|}{ Acid hydrolysis product } \\
\hline Total dry matter $(\%)$ & $56.13^{c}$ & $53.80^{\mathrm{b}}$ & $51.44^{\mathrm{a}}$ \\
\hline Yield $(\%)$ & $52.56^{\mathrm{b}}$ & $63.04^{\mathrm{c}}$ & $32.67^{\mathrm{a}}$ \\
\hline Degree of polymerization & $2.97^{\mathrm{b}}$ & $2.88^{\mathrm{b}}$ & $2.45^{\mathrm{a}}$ \\
\hline Dextrose equivalent & $33.70^{\mathrm{a}}$ & $34.12^{\mathrm{b}}$ & $41.58^{\mathrm{b}}$ \\
\hline \multicolumn{4}{|l|}{ Enzymatic hydrolysis product } \\
\hline Total dry matter $(\%)$ & $57.74^{\mathrm{a}}$ & $60.67^{\mathrm{b}}$ & $69.81^{\mathrm{c}}$ \\
\hline Yield (\%) & $62.12^{\mathrm{b}}$ & $70.63^{c}$ & $33.76^{\mathrm{a}}$ \\
\hline Degree of polymerization & $1.35^{\mathrm{a}}$ & $1.40^{\mathrm{c}}$ & $1.38^{\mathrm{b}}$ \\
\hline Dextrose equivalent & $72.69^{b}$ & $71.52^{\mathrm{a}}$ & $73.88^{\mathrm{c}}$ \\
\hline
\end{tabular}

*Means within a row related to particular parameter with the same superscript letter are not significantly different as $\alpha=0.05$ confidence level; **measured as dry weight basis

duced by rural factories in the tropics. The color of the starch, which turns brown in the process of separation, is one of the factors responsible for low quality. When sago palm pith is chopped up and grated into a powder, colored substances are formed and tightly bound to the starch granules.

There are two methods for sago starch extraction from fresh sago pith, wet and dry. The dry process is conducted without water. In this method, fresh sago pith is shredded, oven-dried, ground, and sieved to produce fine starch particles. But as raw material for nonfood industry, the dry process can produce large and coarse particles passing through the 35 mesh sieve (Table 20.1); this is called sago pith flour. While from the wet method, the main product is sago starch, and its residue (sago hampas) is generated from the processing. Sago hampas is the fibrous by-product from crushing and sieving during the wet extraction process. In our research, samples of sago hampas were oven-dried, ground, and sieved to produce fine flour.

Table 20.1 shows that starch is the main component in all sago samples. Sago pith flour, as a part of the dry extraction production, contains a high amount of starch $(86 \%)$, while, as a by-product from the inefficient wet extraction process, sago hampas contains approximately 55\% starch and $15 \%$ fiber on a dry weight basis. Composition of this sago hampas was similar to that reported by Lingga et al. (2012) which showed 58\% starch, compared to Awg-Adeni et al. (2013) who reported a lower starch content (30-45\%) and higher fiber content (30-35\%).

Previously we have reported that crude fiber was the second most common component in pith (Sunarti et al. 2011). Hampas also contains high amounts of cellulose (11\%), hemicellulose (7.6\%), and lignin (12\%) (Utami et al. 2014); Abd-Aziz 
(2002) reported similar results. With significant amounts of starch and fiber remaining in the hampas, it may be used for hydrolysis to make starch syrup, an alternative cheap substrate for fermentable sugar production (Lingga et al. 2012), a source for biohydrogen production (Jenol et al. 2014), and a composite material for biofoam production (Lai et al. 2013; Utami et al. 2014; Rao and Kumar 2015).

\subsection{Acid-Catalyzed Hydrolysis}

For industrial use, raw sago pith must be fresh and be processed quickly. With the passage of time, the separation yields less of a white product. Some importing countries are dissatisfied because each lot of starch received is variable in quality and in addition most are of inferior quality. Therefore, industrial application of the sago starch is limited. One way to overcome this inferior quality is to utilize the sago starch for glucose syrup production, which is not dependent on the properties of native starch.

Acid hydrolysis of starch to produce sugars has long been a commercial practice. Sago pith flour and hampas which contain mostly starch and lignocellulosic materials are good sources of glucose syrup and substrate for fermentation, either by enzymatic or acid hydrolysis (Table 20.1). In the acid process, a slurry containing about $30 \%(\mathrm{w} / \mathrm{v})$ of starch or flour solid is suspended and acidified to a $\mathrm{pH}$ of about 2.0 by using diluted hydrochloric acid. The suspended starch or flour is then autoclaved at $121{ }^{\circ} \mathrm{C}$ for $1 \mathrm{~h}$ and neutralized by a $1 \mathrm{~N} \mathrm{NaOH}$ solution. Although acid hydrolysis is a rather (but not completely) random process (BeMiller 1967), the hydrolysis produces syrup with a dextrose equivalent (DE) value range of 34-42, a lower value as compared to enzymatic (liquefaction and saccharification) hydrolysis (DE 71-74). Hebeda (1987) predicted that the carbohydrate profiles of the syrup in the 36-43 DE range consisted of 14-19\% $\mathrm{DP}_{1}$ (monosaccharides, dextrose), 11-14\% $\mathrm{DP}_{2}$ (disaccharides, primary maltose), $10-12 \% \mathrm{DP}_{3}$ (trisaccharides, primary maltotriose), and 55-65\% $\mathrm{DP}_{4+}$ (oligosaccharides, maltotetraose, and higher saccharides). Lorenz and Johnson (1972) reported that at $120{ }^{\circ} \mathrm{C}$, autoclaving treatment completely gelatinized the starch, as expected, but did not completely hydrolyze it.

Sweetness is an important and easily identifiable characteristic of glucose. When compared to sucrose, the relative sweetness value of 30-42 DE acid-converted syrup is between 30-35 and 45-50 (Pancoast and Junk 1980). Furthermore, the starch-derived sweetener also provides a highly fermentable substrate suitable as intermediate substrate for many industrial applications such as for making ethanol, lactic acid, and kojic acid (Shinghal et al. 2008).

Starch is hydrolyzed by acid to produce D-glucose, but other products are formed such as oligosaccharides and products of decomposition and dehydration of D-glucose, such as 5-hydroxymethylfurfural, levulinic acid, formic acid starchderived products, and colored products. Lorenz and Johnson (1972) reported that in neutral $\mathrm{pH}$ hydrolysis, color change was very slight as the temperature of hydrolysis increased from 120 to $135{ }^{\circ} \mathrm{C}$; the greatest color change was from 150 to $180{ }^{\circ} \mathrm{C}$. Several reactions can also cause color development in starch because the 
material contains reducing sugars via the nonenzymatic browning reaction between sugars and primary or secondary amines (Maillard reaction). Color development in the absence of nitrogenous compounds with the application of heat or acid is the result of caramelization (BeMiller and Whistler 2009).

\subsection{Effect of Microwave-Assisted Hydrolysis in Dilute Acid}

Conventional acid hydrolysis of starch is usually conducted under high-pressure and high-temperature treatment for several hours. Excessive heating of starchderived products will result in partial caramelization and development of undesirable flavors. Pentose as a fiber-derived product will be converted to furfural, while hexose produces hydroxymethylfurfural (HMF), both giving a brown color solution. Furfural is more toxic than HMF. More browning compounds make the solution have less clarity.

The heating process using a microwave represents a different mechanism from that of using a conventional convection or conduction heating process. A microwave uses electromagnetic waves between $300 \mathrm{MHz}$ (wavelength $1 \mathrm{~m}$ ) and $300 \mathrm{GHz}$ (wavelength $1 \mathrm{~mm}$ ). Microwave heating is usually called dielectric heating since in the microwave electric field, dipole molecules such as water or other dielectric materials rotate vigorously to orient in the field (Gabriel et al. 1998). Microwave energy can penetrate into materials, so that it directly and uniformly heats the materials. Microwave heating avoids degradation of product strength and surface properties caused by excessive and long conventional heating.

Previously, Matsumoto et al. (2011) and Khan et al. (1979) reported that microwave treatment can be an alternative method for starch hydrolysis in water; Warrand and Janssen (2007) and Yu et al. (1996) stated that starch in acid hydrolysis can produce oligosaccharide. Some researchers also reported the microwave-assisted hydrolysis can be applied to the mixture of starch and fiber from industrial waste such as cassava pulp (Hermiati et al. 2011) and waste from the corn starch industry (Yoshida et al. 2010). A study carried out by Palav and Seetharaman (2006) showed that gelatinization of starch during microwave heating did not produce the same phenomenon as using conduction heating. This can be observed in the loss of birefringent properties and in the swelling of the starch granules. Luo et al. (2006) conducted a study to investigate changes in crystallinity, swelling power and solubility, gelatinization parameters, retrogradation characteristics, and pasting properties of corn starches at $30 \%$ moisture after being subjected to microwave heating at $1 \mathrm{~W} / \mathrm{g}$ microwave energy for $20 \mathrm{~min}$. Microwave heating could convert starch directly to glucose in a relatively short time. Compared with conventional heating, the reaction rate of starch hydrolysis to glucose was accelerated 100 times under microwave irradiation (Kunlan et al. 2001).

Treatment or degradation of starch using microwave heating can use water or dilute acid, such as hydrochloric or sulfuric acid, as media. Kunlan et al. (2001) reported that the addition of inorganic salts containing $\mathrm{Cl}$ and $\mathrm{SO}_{4}$ ions could 


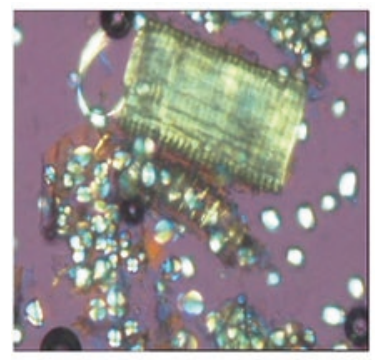

(a)

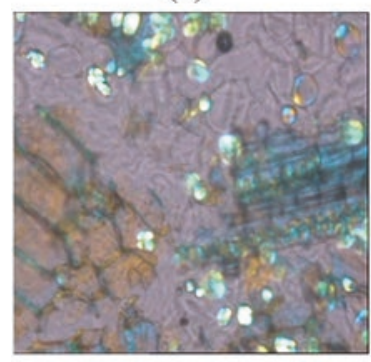

(d)

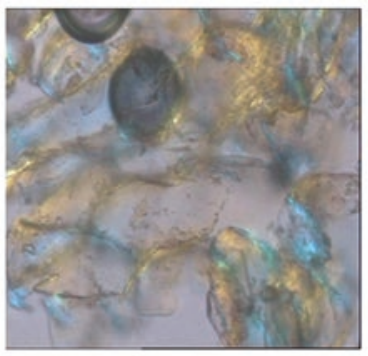

(b)

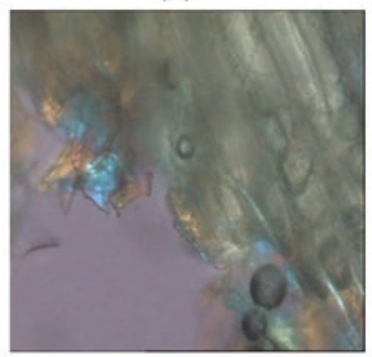

(e)

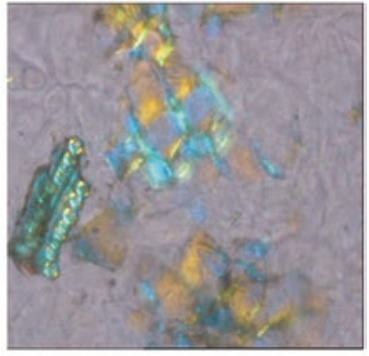

(c)

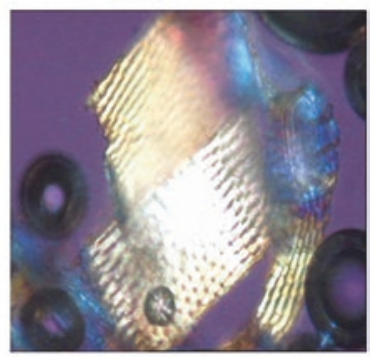

(f)

Fig. 20.1 Microscopic structures of (a) native sago pith, (b) microwave heating of $8 \%$ of sago pith in dilute acid, (c) $8 \%$ of sago pith in water, (d) $10 \%$ of sago pith in water, (e) fiber residue from microwave treatment, (f) autoclaving treatment after enzymatic saccharification. Magnification 200X (Sunarti et al. 2012)

enhance the hydrolysis of starch. However, the $\mathrm{Cl}$ ion gave better results. Yu et al. (1996) stated that $10 \%$ starch suspension in $0.5 \mathrm{M} \mathrm{HCl}$ could be completely converted to glucose in only $5 \mathrm{~min}$ without the formation of colored by-products, but if heated using the conventional method, it was not completely hydrolyzed. Figure 20.1 shows the effects of microwave treatment on the microscopic structure of sago pith, which contained starch and fiber, in water (c) and dilute acid (b) compared to native sago pith (a). Microwave-assisted heating in dilute acid (Fig. 20.1b) directly converted the starch and fiber in sago pith into depolymerized products and gave more simple sugars compared to the autoclaving treatment. Microwave heating of sago pith in water mainly caused gelatinized of the starch, as long as water remained in the slurry. Insufficient water produced partial or incomplete gelatinized starch as described from a higher concentration of sago pith (10\%) (Fig. 20.1d) compared to $8 \%$ of suspended solids (Fig. 20.1c).

Microwave heating also affects the lignocellulosic materials. The effects of microwave heating on major chemical components of lignocellulosic biomass (lignin, cellulose, and hemicellulose) have been reported by Tsubaki et al. (2009), who stated that the required heating temperature for degradation of either lignin or cellulose corresponded with the glass transition ( $\mathrm{Tg}$ ) of the components. Some disruptions in fiber were detected after microwave treatment in water (Fig. 20.1e) compared to autoclave treatment (Fig. 20.1f). 
Table 20.2 Characteristics of microwave-assisted hydrolysis of sago pith in dilute acid

\begin{tabular}{|c|c|c|c|c|}
\hline Treatment & $\begin{array}{l}\text { Total soluble } \\
\text { sugar }(g / l)\end{array}$ & $\mathrm{DE}$ & $\begin{array}{l}\text { Clarity }^{\mathrm{a}} \text { At } \lambda_{660 \mathrm{~nm}} \\
\text { (OD) }\end{array}$ & $\operatorname{HMF}(\mathrm{g} / \mathrm{l})$ \\
\hline \multicolumn{5}{|c|}{ Autoclaving $\left(121^{\circ} \mathrm{C}, 15 \mathrm{~min}\right)$} \\
\hline $\mathrm{HCl} 0.2 \mathrm{M}$ & 294 & 45 & 1.12 & 0.16 \\
\hline $\mathrm{HCl} 0.3 \mathrm{M}$ & 299 & 50 & 1.26 & 0.24 \\
\hline \multicolumn{5}{|l|}{ Microwave } \\
\hline \multicolumn{5}{|l|}{ - $\mathrm{HCl} 0.2 \mathrm{M}$} \\
\hline PL 50\%, $1 \mathrm{~min}$ & 32 & 40 & 0.81 & 0.0069 \\
\hline PL 50\%, 2 min & 40 & 39 & 0.63 & 0.0072 \\
\hline PL 50\%, 3 min & 66 & 45 & $(0.09)$ & 0.0074 \\
\hline PL 70\%, $1 \mathrm{~min}$ & 201 & 81 & 0.78 & 0.0089 \\
\hline PL $70 \%, 2$ min & 261 & 69 & 0.37 & 0.0091 \\
\hline PL 70\%, 3 min & 282 & 84 & $(0.09)$ & 0.0094 \\
\hline \multicolumn{5}{|l|}{$-\mathrm{HCl} 0.3 \mathrm{M}$} \\
\hline PL $50 \%, 1 \mathrm{~min}$ & 27 & 50 & 1.09 & 0.0075 \\
\hline PL $50 \%, 2$ min & 41 & 40 & 0.86 & 0.0079 \\
\hline PL $50 \%, 3 \mathrm{~min}$ & 69 & 45 & $(0.07)$ & 0.0082 \\
\hline PL $70 \%, 1 \mathrm{~min}$ & 266 & 57 & 0.05 & 0.0095 \\
\hline PL $70 \%, 2$ min & 272 & 71 & 0.25 & 0.0097 \\
\hline PL 70\%, 3 min & 285 & 90 & $(0.10)$ & 0.0100 \\
\hline
\end{tabular}

Source: Sunarti et al. 2011

${ }^{a}$ Data in parenthesis express negative values

There are some distinct characteristics of $10 \%$ sago pith slurry in dilute acid when poured into a glass jar with a lid and then heated in a microwave oven with varied power levels (50-70\% of maximum output 1000 watts) for 1-3 min heating duration (Table 20.2). Interaction between heating level and its duration influenced the hydrolysis yield (Sunarti et al. 2012). Bej et al. (2008) also stated that acid hydrolysis of starch follows the first-order reaction. Time-dependent conversion was observed with variation of temperature, $\mathrm{pH}$, and initial starch concentration. Similar results have been reported by Khan et al. (1979) who found that liquefying and coloring were the most obvious visible changes during starch hydrolysis. With extended heating times, temperature, and pressure, total acidity increased causing darker hydrolyzates. Starch sugar syrups of high dextrose equivalent can be produced within a short time by using microwave energy.

Heating in dilute acid produced high soluble total sugars with high dextrose equivalent; the process also released HMF as an undesired by-product, and a high amount of salt was produced from neutralization of acid. Long exposure to microwave heating increased the formation of brown coloring as detected in low syrup clarity. Compared to autoclaving treatment, microwave heating treatment produced less furfural compound. Autoclaving for a longer heating time (15 min) influenced the formation of furfural and HMF compounds, as $0.24 \mathrm{~g} / \mathrm{l}$ compared to the highest HMF content from microwave treatment $(0.01 \mathrm{~g} / \mathrm{l})$. As substrate for ethanol production, the presence of HMF and furfural negatively influenced productivity. Nigam 
(2001) found that a furfural concentration of more than $1.5 \mathrm{~g} / \mathrm{l}$ inhibits the yeast (Pichia stipites) growth and influences ethanol production. Furfural and HMF show different inhibitory effects to yeast growth in bioethanol production (Sunarti et al. 2011). Modig et al. (2002) reported that $1 \mathrm{~g} / \mathrm{l}$ of furfural can inhibit the microbial enzymes for ethanol production, such as alcohol dehydrogenase, aldehyde dehydrogenase, and pyruvate dehydrogenase, while $2 \mathrm{~g} / \mathrm{l}$ of HMF shows the same effects.

\subsection{Slow Acid Hydrolysis}

For many years, slow and mild acid hydrolyses have been applied to starch by industries to improve its solubility. This process involves suspending starch in an aqueous solution of hydrochloric or sulfuric acid at certain temperatures, since in the presence of strong acid and heat, the glycosidic bonds between the monosaccharides in the starch polymer are cleaved (Yiu et al. 2008) and produce glucose and oligosaccharides. Prolonged mild acid hydrolysis can be performed to produce lintnerized starches. Odeku et al. (2009) stated that acid modification has been proven to change the physicochemical properties of starch without destroying its granular structure, yielding starch with increased solubility and gel strength but decreased viscosity. The extent of hydrolysis depends on starch consistency, acidity of the medium, hydrolysis temperature, and duration of hydrolysis. The effects of acid hydrolysis of various starches, such as corn, potato, and rice, have been studied previously (Wang and Wang 2001; Wang et al. 2003; Thirathumthavorn and Charoenrein 2005). Moreover, acid treatment in alcohol, especially for sago starch, has been conducted by Yiu et al. (2008), and their study showed that sago starch can be modified through hydrolysis and alcoholysis to give various limit dextrins with high solubility.

Acid treatment also can be applied to fiber-rich starch such as sago hampas. Ning et al. (1991) reported that acid modification of fiber at high temperature $\left(90^{\circ} \mathrm{C}\right)$ can produce oligosaccharides and changes in its crystallinity. It has been shown that sulfuric or trifluoroacetic acid has been used to hydrolyze the hemicellulose in fiber (Englyst and Cumming 1984). In the present research, sago hampas was modified by the acid-methanol treatment according to the Chung and Lai (2006) methods. Sago hampas flour was acid-treated with a low concentration of hydrochloric acid in methanol (4 $\mathrm{ml}$ of $\mathrm{HCl}$ concentrated in 1 liter of methanol) solution at room temperature $\left(30{ }^{\circ} \mathrm{C}\right)$ for $0,60,120,180$, and $240 \mathrm{~h}$.

Modification of sago hampas by acid in methanol cleaved the amorphous site of fiber and starch. The sago hampas was immerged in acid in methanol solution and produced a dark filtrate color. The dark color of sago pith flour comes from an oxidative reaction of phenolic compounds. This acid condition causes solubilization of phenolic compound and dissolves some reducing sugars and produces 91-94\% yield of acid modified sago hampas as described on Table 20.3. This made the acid modified sago hampas's color or performance brighter compared to that before the treatment. Lignins are amorphous and noncarbohydrate compounds containing phe- 
Table 20.3 Starch and fiber characteristics of native and acid modified sago hampas*

\begin{tabular}{l|l|l|l|l|l|l|l}
\hline & $\begin{array}{l}\text { Total } \\
\text { soluble } \\
\text { solid in } \\
\text { filtrate } \\
(\mathrm{ppm})\end{array}$ & $\begin{array}{l}\text { Yield } \\
(\%)\end{array}$ & $\begin{array}{l}\text { Starch } \\
(\%)\end{array}$ & $\begin{array}{l}\text { Lignin } \\
(\%)\end{array}$ & $\begin{array}{l}\text { Cellulose } \\
(\%)\end{array}$ & $\begin{array}{l}\text { Hemicellulose } \\
(\%)\end{array}$ & $\begin{array}{l}\text { Crystallinity } \\
(\%)\end{array}$ \\
\hline $\begin{array}{l}\text { Treatment } \\
\text { hydrolysis } \\
\text { hampas }\end{array}$ & & 100 & 49.94 & 4.97 & 15.10 & 5.33 & \\
\hline $0 \mathrm{~h}$ & 0.39 & 93.81 & $48.07^{\mathrm{a}}$ & $4.32^{\mathrm{a}}$ & $15.31^{\mathrm{b}}$ & $5.87^{\mathrm{a}}$ & 57.33 \\
\hline $60 \mathrm{~h}$ & 51.70 & 93.67 & $42.94^{\mathrm{b}}$ & $4.70^{\mathrm{a}}$ & $14.00^{\mathrm{ab}}$ & $4.98^{\mathrm{a}}$ & 64.37 \\
\hline $120 \mathrm{~h}$ & 72.21 & 91.62 & $40.02^{\mathrm{c}}$ & $4.83^{\mathrm{a}}$ & $11.37^{\mathrm{a}}$ & $4.58^{\mathrm{a}}$ & 62.68 \\
\hline $180 \mathrm{~h}$ & 79.62 & 91.48 & $25.72^{\mathrm{d}}$ & $5.71^{\mathrm{a}}$ & $13.04^{\mathrm{ab}}$ & $5.04^{\mathrm{a}}$ & 52.22 \\
\hline $240 \mathrm{~h}$ & 87.73 & 91.35 & $19.38^{\mathrm{e}}$ & $3.11^{\mathrm{a}}$ & $14.20^{\mathrm{ab}}$ & $5.91^{\mathrm{a}}$ & 58.55 \\
\hline
\end{tabular}

Source: Sunarti et al. 2015

"Means within a column related to particular parameter with the same superscript letter are not significantly different as $\alpha=0.05$ confidence level

nolic substances which were diluted in acid solution. This condition also causes small changes in fiber composition (lignin, hemicellulose, and cellulose) but has significant effects on changes in molecular weight and composition of starch.

Sathaporn et al. (2005) reported that some branched points in amylopectin were hydrolyzed and remained crystalline parts of starch. Soluble carbohydrate produced from acid hydrolysis can be glucose, maltose or malto-oligosaccharides as products from starch hydrolysis, and soluble hemicellulose or its derived products. It was detected that a small amount of soluble carbohydrate (not more than $90 \mathrm{ppm}$ ) (Table 20.3) was produced from acid hydrolysis.

Previously, we reported that the crystalline type of starch and fiber were not markedly changed after acid modification (Sunarti et al. 2016). Higher diffraction intensities were clearly obtained after acid treatment. An increase in starch and fiber crystallinity is attributed to preferential hydrolysis of the amorphous domains by acid (Gerard et al. 2002). Ahmad and Williams (1999) and Pukkahuta and Varavinit (2007) found that sago hampas has a crystallinity type between cereal (A-type) and tuber (B-type). The profiles also expressed the mixture of starch and fiber crystalline fractions. Typical diffraction angle for starch can be detected on $2 \Theta 15.1,17.2$, 17.8, and 23.4 ${ }^{\circ}$; Lai et al. (2013) also reported diffraction angle of $22.5^{\circ}$ for fiber.

Changes of molecular structures are also expressed on surface morphology of starch granules and fiber structures. Compared to native sago hampas, internal fissures in starch granules appeared after 180 and $240 \mathrm{~h}$. The fiber also degraded into small parts and became transparent which showed the increment of amorphous fraction of fiber (Sunarti et al. 2016). Some data in Table 20.3 also proved that the destruction of fiber and starch took place after acid modification.

Hampas, sago pith residue, a solid waste of sago wet extraction industry, is a potential source for use as fiber reinforcement on starch-based foam production due to its composition that contains starch and fiber which are necessary for producing biofoam. Utami et al. (2014) also reported that partial acid hydrolysis of sago ham- 
pas modified the structural and physico-mechanical properties of the resulting foam. Compared to styrofoam, biofoam produced from acid modified sago hampas has better mechanical properties but is very sensitive to moisture making biofoam ideal for trays of dry food products (Sunarti et al. 2016).

\subsection{Conclusion}

Sago palm (Metroxylon sagu) is a species from which starch-rich flour can be extracted from the pith of the trunk. Sago hampas is a fibrous by-product from the wet extraction process. Although it is inefficient for starch production, sago hampas consists of starch and fiber as major components. Some conclusions can be summarized about acid modified treatment of hampas:

1. Direct hydrolysis of starch and fiber using dilute acid and heat treatment (autoclaving or microwave-assisted treatments) degraded the starch into glucose and oligosaccharide and increased the amorphous region of fiber.

2. Slow or mild acid hydrolysis of starch and fiber attacked the amorphous region. Mild acid hydrolysis did not change the crystallinity pattern but increased the degree of crystallinity.

3. Products revealed from acid hydrolysis of starch and fiber in sago samples (starch, sago pith, and sago hampas) can be applied as sweetener, substrate for fermentation, and raw materials for food and nonfood industries.

Acknowledgments This publication is part of the research funded by the Osaka Gas Foundation of International Cultural Exchange (OGFICE) Research Grant FY 2012/2013 through Bogor Agricultural University, Research Institute for Environment, and from Southeast Asian Regional Center for Tropical Biology fiscal year 2010. The authors thank Ms. Fitri Ana Sari, Mr. Imam Muttaqiem, Mr. Taufiqurrahman, and Mr. Martin Dwiko for their technical assistances in this research.

\section{References}

Abd-Aziz S (2002) Sago starch and its utilization. J Biosci Bioeng 94:526-529

Ahmad FB, Williams PA (1999) Effect of salts on the gelatinization and rheological properties of sago starch. J Agric Food Chem 47:3359-3366

Awg-Adeni DS, Bujang K, Hasan MA et al (2013) Recovery of glucose from residual starch of sago hampas for bioethanol production. J Biomed Biotechnol http://dx.doi.org/10.1155/2013/935852

Bej B, Basu RK, Ash SN (2008) Kinetic studies on acid catalyzed hydrolysis of starch. J Sci Ind Res 67:295-298

BeMiller JN (1967) Acid-catalyzed hydrolysis of glycosides. Adv Carbohydr Chem Biochem 22:25-108

BeMiller J, Whistler R (eds) (2009) Starch chemistry and technology, 3rd edn. Academic Press, New York 
Chung YL, Lai HM (2006) Molecular and granular characteristics of corn starch modified by HClmethanol at different temperature. Carbohydr Polym 63:527-534

Englyst HN, Cumming JH (1984) Simplified method for the measurement of total non-starch polysaccharides by gas-liquid chromatography of constituent sugar as alditol acetate. Analyst 109:937-942

Fujii S, Kitahara S, Komoto M (1985) Studies on improvement of sago starch quality. In: Proceedings of the 3rd international sago symposium. Tokyo, Japan, 20-23 May 1985, pp 186-192

Gabriel C, Gabriel S, Grant EH et al (1998) Dielectric parameters relevant to microwave dielectric heating. Chem Soc Rev 27:213-223

Gerard C, Colonna P, Buleon A et al (2002) Order in maize mutant starches revealed by mild acid hydrolysis. Carbohydr Polym 48(2):131-141

Hebeda RE (1987) In: Watson SA, Ramstad PE (eds) Corn chemistry and technology. American Association of Cereal Chemists, St. Paul, pp 501-534

Hermiati E, Azuma J, Mangunwidjaja D et al (2011) Hydrolysis of carbohydrates in cassava pulp and tapioca flour under microwave irradiation. Indo J Chem 11(3):238-245

Jenol MA, Ibrahim MF, Phang LY et al (2014) Sago biomass as a sustainable source for biohydrogen production by Clostridium butyricum A1. Bioresources 9(1):1007-1026

Khan AR, Johnson JA, Robinson RJ (1979) Degradation of starch polymers by microwave energy. Cereal Chem 56:303-304

Kunlan L, Lixin X, Jun L et al (2001) Salt-assisted hydrolysis of starch to D-glucose under microwave irradiation. Carbohydr Res 331:9-12

Lai JC, Rahman, WAWA, Toh, WY (2013) Characterisation of sago pith waste and its composites. Indust Crops Prod 45:319-326

Lingga S, Phang LY, Wasoh MH et al (2012) Sago pith residue as an alternative cheap substrate for fermentable sugars production. Appl Biochem Biotechnol 167(1):122-131

Lorenz K, Johnson JA (1972) Starch hydrolysis under high temperatures and pressures. Cereal Chem 49:616-628

Luo Z, He X, Fu X, et al (2006) Effect of microwave radiation on the physicochemical properties of normal maize, waxy maize and amylomaize V starches. Starch/Starke 58:468-474

Matsumoto A, Tsubaki S, Sakamoto M et al (2011) A novel saccharification method of starch using microwave irradiation with addition of activated carbon. Bioresour Technol 102:3985-3988

Modig T, Liden G, Taherzadeh J (2002) Inhibition effects of furfural on alcohol dehydrogenase, aldehyde dehydrogenase and pyruvate dehydrogenase. J Biochem 363:769-776

Nigam JN (2001) Ethanol production from wheat straw hemicellulose hydrolysate by Pichia stipitis. J Biotechnol 87:17-27

Ning L, Villota R, Artz WE (1991) Modification of corn flour fiber through chemical treatment in combination with twin-screw extrusion. Cereal Chem 68(6):632-636

Odeku OA, Schmid W, Picker-Freyer KM (2009) Characterization of acid modified Dioscorea starches as direct compression excipients. Pharm Dev Technol 14:259-270

Palav T, Seetharaman K (2006) Mechanism of starch gelatinization and polymer leaching during microwave heating. Carbohydr Polym 65:364-370

Pancoast H, Junk WR (1980) Handbook of sugar. AVI Publishing, Westport

Pukkahuta C, Varavinit S (2007) Structural transformation of sago starch by heat-moisture and osmotic-pressure treatment. Starch/Starke 59:624-631

Rao PP, Kumar BR (2015) Characterisation and processing of sago particle reinforced composite. Intl J Eng Trends Tech 24(3):151-154

Sathaporn S, Sunarti TC, Mishima T et al (2005) Starches from different botanical sources I: contribution of amylopectin fine structure to thermal properties and enzyme digestibility. Carbohydr Polym 60:529-538

Shinghal RS, Kennedy JF, Gopalakrishnan SM et al (2008) Industrial production, processing and utilization of sago palm derived products. Carbohydr Polym 72(1):1-20 
Sunarti TC, Dwiko M, Richana N et al (2011) Effect of microwave treatment on acid hydrolysis of sago pith for the preparation of fermentable sugar in bioethanol production. In: Proceedings of the 1st international conference on chemical innovation, Kemaman, Malaysia, 23-24 May 2011, pp 155-158

Sunarti TC, Dwiko M, Derosya V et al (2012) Effect of microwave treatment on acid and enzyme susceptibility of sago pith. Procedia Chem 4:301-307

Sunarti TC, Derosya V, Taufiqurrahman A et al (2015) Acid modification of starch and fiber in Sago Hampas for improving the mechanical and physical properties of biodegradable foam. In: Proceedings of the 12th international Sago symposium 15-16 September 2015. Rikkyo University, Tokyo

Sunarti TC, Derosya V, Taufiqurrahman A et al (2016) Acid modification of starch and fiber in sago hampas for improving the mechanical and physical properties of biodegradable foam. In: Proceedings of the 12th international sago symposium, Rikkyo University, Tokyo, 15-16 September 2015, pp 117-121

Thirathumthavorn D, Charoenrein S (2005) Thermal and pasting properties of acid-treated rice starches. Starch 57:217-222

Tsubaki S, Sakamoto M, Azuma J (2009) Application of microwave heating for utilization of agricultural biomass. Res Adv Agric Food Chem 1:1-12

Utami AS, Sunarti TC, Isono N et al (2014) Preparation of biodegradable foam from sago residue. Sago Palm 22:1-5

Wang L, Wang YJ (2001) Structures and physicochemical properties of acid-thinned corn, potato and rice starches. Starch 53:570-576

Wang YJ, Truang VD, Wang L (2003) Structures and rheological properties of corn starch as affected by acid hydrolysis. Carbohydr Polym 52:327-333

Warrand J, Janssen HG (2007) Controlled production of oligosaccharides from amylose by acidhydrolysis under microwave treatment: comparison with conventional heating. Carbohydr Polym 69:353-362

Yatsugi T (1985) Problem of sago starch manufacturing. In: Proceedings of the 3rd international sago symposium, Tokyo, Japan, 20-23 May 1985, pp 201-207

Yiu PH, Loh SL, Rajan A et al (2008) Physicochemical properties of sago starch modified by acid treatment in alcohol. Am J Appl Sci 5(4):307-311

Yoshida T, Tsubaki S, Teramoto Y et al (2010) Optimization of microwave assisted extraction of carbohydrates from industrial waste of corn starch production using response surface methodology. Biores Technol 101(20):7820-7826

Yu HM, Chen ST, Suree P et al (1996) Effect of microwave irradiation on acid-catalyzed hydrolysis of starch. J Org Chem 26:9608-9609

Open Access This chapter is licensed under the terms of the Creative Commons Attribution 4.0 International License (http://creativecommons.org/licenses/by/4.0/), which permits use, sharing, adaptation, distribution and reproduction in any medium or format, as long as you give appropriate credit to the original author(s) and the source, provide a link to the Creative Commons license and indicate if changes were made.

The images or other third party material in this chapter are included in the chapter's Creative Commons license, unless indicated otherwise in a credit line to the material. If material is not included in the chapter's Creative Commons license and your intended use is not permitted by statutory regulation or exceeds the permitted use, you will need to obtain permission directly from the copyright holder. 
Part VII

New Carbohydrate Resources 


\title{
Chapter 21 \\ Starch Properties and Uses as Food for Human Health and Welfare
}

\author{
Kazuko Hirao, Tomoko Kondo, Keiji Kainuma, and Setsuko Takahashi
}

\begin{abstract}
Sago palm is a highly efficient starch-producing plant found in humid tropical zones. In the areas where sago palms are cultivated, its plantation methods and food cultures have been conveyed from generation to generation. Recently, it is increasingly seen as an important agricultural product and crop whose cultivation can lead to more fulfilling lives for local people. However, there are very few food uses for sago starch as a main ingredient in Japan. In order to increase sago starch usage across Japan, it is exceedingly important to introduce high-quality sago starch. Also it is crucial to publicize its attractiveness, positive characteristics, and its specific and potential usages. Accordingly, in this report, the physicochemical characteristics and optimal cooking properties of sago starch were examined through investigating sago starch usage in the cooking processes of udon, Chinese noodles, Chinese vermicelli, kuzukiri (fen pi), gomadofu, kamaboko, warabimochi, kuzuzakura nama-yatsuhashi, mushiyokan, pie filling, blancmange, and biscuits.

In terms of gelatinization behavior, sago starch was found to be similar to potato, cassava, and sweet potato starch. Also, in terms of retrogradation and amylose content, sago starch was close to cornstarch. It was proved that sago starch could be used in various types of cooking and food manufacturing by replacing other starches. Sago starch gel has satisfactory elasticity, softness, flexibility, and less adhesiveness. Furthermore, sago starch usability in puffed foods was proven. In sensory evaluations for all foodstuffs in this report, the sago starch-replaced foods had superior physical properties and were valued to have favorable tastes and textures in sensory evaluations. The possibility of further development of sago starch became apparent. In Japan, the appeal of the up-to-now unused resource, that is, sago starch, is being widely disseminated, and its potential use in cooking and manufacturing foodstuffs is being further considered.
\end{abstract}

\author{
K. Hirao $(\bowtie)$ \\ Aikoku Gakuen Junior College, Edogawa, Tokyo, Japan \\ e-mail: hirao@aikoku-jc.ac.jp \\ T. Kondo $\bullet$ S. Takahashi \\ Kyoritsu Women's University, Chiyoda, Tokyo, Japan \\ K. Kainuma \\ Tsukuba Science Academy, Tsukuba, Japan
}




\subsection{Introduction}

The sago palm (Metroxylon sagu and M. rumphii) is a highly efficient starch- producing plant found in humid tropical zones (Sato et al. 1979). Sago starch accumulates in the trunk of the sago palm. It takes over 10 years from the period of planting for sago starch to accumulate and be ready for harvest. However, this long maturation period can be countered through placing a sago palm plantation under proper sucker management to enable harvesting to be carried out more frequently (Kainuma 1982).

Sago starch has been used in a variety of ways across sago-producing areas. For example, it can be kneaded into a porridge (kurupun) or paste-like state (papeda, rendang), and it can be baked in a similar fashion into cakes and breads (lempeng, keropo, sinoli). It is also processed to make sago pearls (Hirao and Takahashi 1996), noodles (mie sagu), and crackers (kerupuk, sagu) as secondary products (Takahashi and Hirao 1992). In recent years, in addition to conventional usage of sago starch as a staple food and in desserts (Hirao et al. 2008; Nishimura 2008; Yamamoto et al. 2008), new usages in different food products are being considered (Bujang and Ahmad 2000; Puchongkavarin et al. 2000). Also, in the areas in which sago starch is cultivated, it is increasingly being seen as an important agricultural product and as a crop whose cultivation can lead to a more fulfilling life for local people. Accordingly, local people are trying to pass sago starch food culture down to their younger generations.

In Japan, sago starch is mainly imported from Indonesia and Malaysia with modified sago starch being largely used as dusting flour for noodles such as udon, ramen, and soba or for dumpling skins such as gyoza and shumai (Kondo 2015). However, in Japan there are very few foods that use sago starch as a main ingredient.

A possible reason for this could be that Japan is blessed with a multitude of starches which all have their own conventional unique food cultures. Examples of this include potato starch and sweet potato starch, both of which have a desirable degree of whiteness and are affordable, and kudzu starch and bracken starch which are a bit more expensive. It must also be mentioned that the usage of cornstarch extracted from imported corn is becoming more common in Japan.

In order to increase the usage of sago starch across Japan, in addition to the acquisition of high-quality sago starch, promotion of the attractiveness and positive characteristics of sago starch and its specific and potential usages is exceedingly important. Accordingly, it was decided that the physicochemical, cooking, and processing properties of sago starch were to be investigated in this report.

\subsection{The Physiochemical Characteristics of Sago Starch}

1. The shape, surface construction, and color of sago starch.

One of the unique characteristics of sago starch is the shape of its particles, which are elliptical or bell-shaped with part of the ellipse missing. The relatively large particle size of $10 \sim 65 \mu \mathrm{m}$ (average of $35 \mu \mathrm{m}$ ) is similar to that of tuber-root starches such as sweet potato and potato. 
Furthermore, observations using an X-ray photoelectron spectrometer and an atomic force microscope have shown that the structure of the outermost surface of sago starch particles has a myriad of small protuberances, thus resembling the surface structure of potato starch (Hatta et al. 2002).

Due to the fact that harvested sago palm logs are often stored in water for prolonged periods of time before starch extraction, damage and discolorization of the particles, possibly related to microbial growth or enzymatic reactions during storage, are frequent occurrences (Takahashi et al. 1981).

In terms of whiteness, when a plate of magnesium oxide $(\mathrm{MgO})$ is set at 100 , cornstarch and potato starch have ratings of 100 and 95.3, respectively. Comparatively, the whiteness rating of 80.1 for sago starch is low.

Recently, the number of new modern starch factories has increased. Accordingly, improvements in hygiene have been observed, and the whiteness rating of sago starch has risen to 83 or above.

\section{Amylose content and amylopectin chain length distribution of sago starch.}

The amylose content, determined by amperometric titration, is $24.5 \%$ for sago starch and $19.7 \%$ for potato starch. Due to the fact that the physicochemical properties of sago starch depend not only on its type but also on its cultivation environment, a high amylose content rating of $26 \%$, similar to that of cereal starches such as corn and mung bean, could also be attained.

Furthermore, the long-chain fraction Fr. II in the amylopectin chain length distribution, which was obtained by the gel filtration method, and Fr. III/Fr. II, which are considered to be very important physical properties, closely resemble those of cassava starch (Takahashi and Hirao 1994).

\section{Swelling power and solubility.}

Swelling power refers to how many grams of water are absorbed by $1 \mathrm{~g}$ of dry starch at $60 \sim 90{ }^{\circ} \mathrm{C}$. Solubility refers to the amount of starch that dissolves in hot water. Compared to potato starch which has a high swelling power of 100 as well as a high solubility of $100 \%$ at $90{ }^{\circ} \mathrm{C}$, cornstarch, with a swelling power of 22 and a low solubility of $26 \%$, swells and dissolves with difficulty even at $90{ }^{\circ} \mathrm{C}$. The swelling power and solubility of sago starch are 40 and $53 \%$, respectively, meaning sago starch can be valued between tuber-root starches and cereal starches (Takahashi et al. 1995).

4. The gelatinization and retrogradation properties of starch.

(i) Viscosity measured by a Rapid Visco Analyzer (RVA)

The changes in viscosity caused by heating and cooling of various starch types using an RVA (Newport Scientific Pty. Ltd) are shown in Fig. 21.1.

Sago starch (commercial sago, spineless sago palm, and spiny sago palm) showed a temperature at which viscosity begins to rise of $71 \sim 74{ }^{\circ} \mathrm{C}$ and a maximum viscosity of $195 \sim 248 \mathrm{RVU}$. When cooling at $50{ }^{\circ} \mathrm{C}$, its final viscosity was $115 \sim 165$ RVU. The viscosity of sago starch was the second highest behind potato starch and showed a similar viscosity to kudzu starch. In contrast to this, sugar palm 


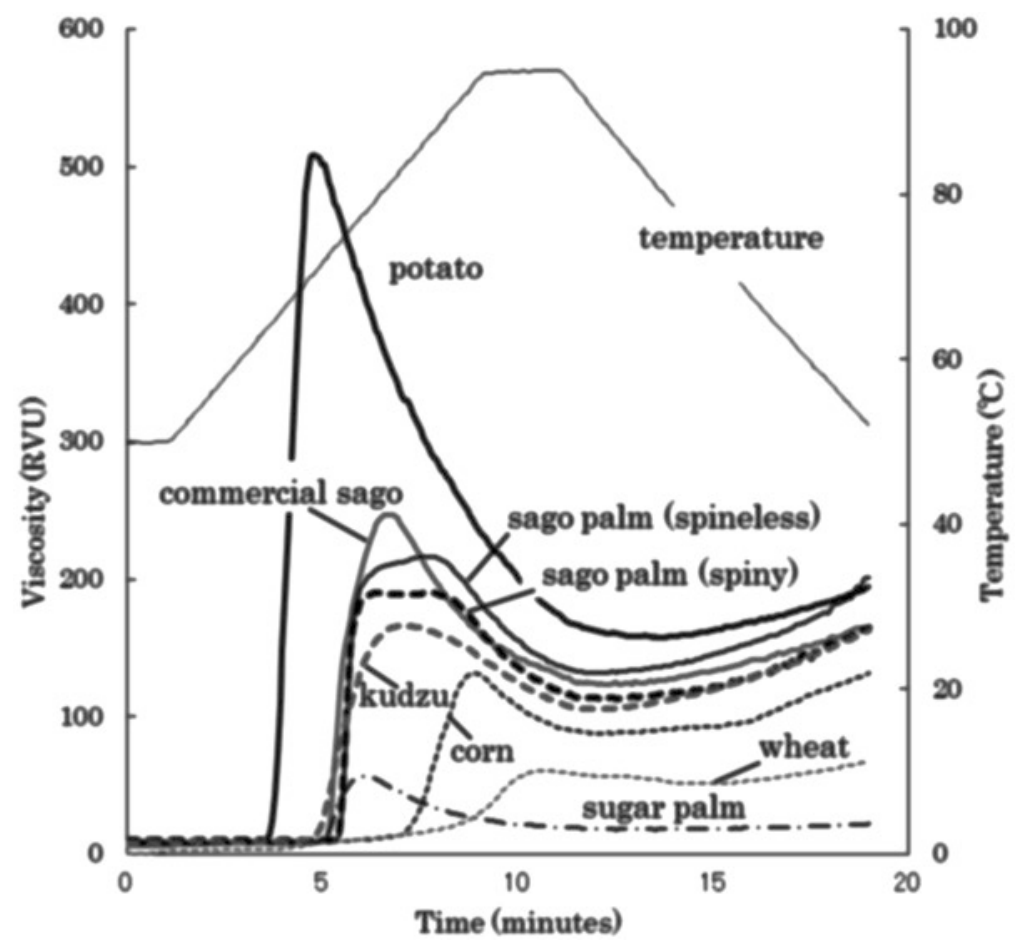

Fig. 21.1 Rapid Visco Analyzer (RVA) curves of various starches (Source: Hamanishi 2002)

starch (represented in this study by Arenga pinnata), which like sago starch is derived from tropical palm trees, showed the lowest viscosity with results similar to wheat starch (Hamanishi et al. 2002a).

(ii) Gelatinization behavior observed by photopastegraphy

The transmittance change of starch slurry during heating was determined using photopastegraphy (Hirama Scientific Machinery ART-3). After declining for a while, the transmittance then increased again (Fig. 21.2). It was concluded that this decline was due to the starch particles starting to swell with water. The gelatinization temperature at which the increase of transmittance occurred was $56{ }^{\circ} \mathrm{C}$ for potato starch, $58{ }^{\circ} \mathrm{C}$ for sago starch, $64{ }^{\circ} \mathrm{C}$ for cornstarch, and $65^{\circ} \mathrm{C}$ for mung bean starch (Takahashi et al. 1995).

(iii) Degree of gelatinization determined by $\beta$-amylase-pullulanase method (BAP method) and thermal analysis

When using the BAP method to determine the degree of gelatinization (Kainuma et al. 1981), it was found that the rate for sago starch quickly increased at around $70{ }^{\circ} \mathrm{C}$. This, being the lowest temperature after potato starch, proved that sago starch 


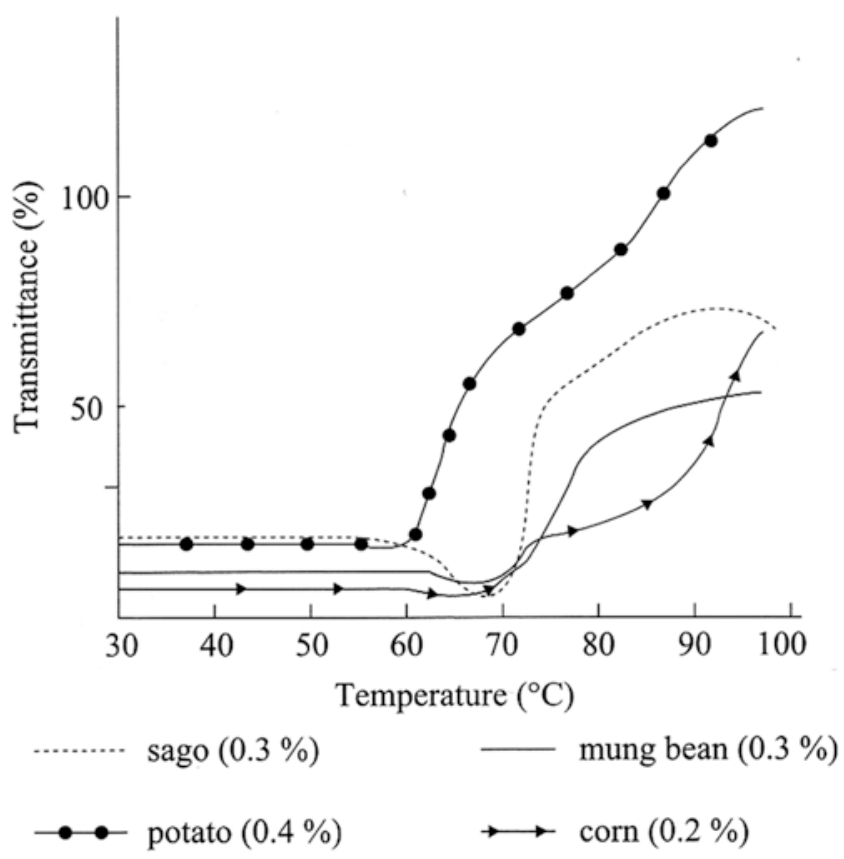

Fig. 21.2 Photopastegram of sago, mung bean, potato, and cornstarches (Source: Takahashi et al. 1981)

gelatinizes easily. After that, as the temperature rose, sago starch showed a slow gelatinization process resembling that of corn and mung bean starch (Takahashi et al. 1983). Based on the DSC determinations of the various types of starch at a sample concentration of $30 \%$, the onset temperature of gelatinization for sago starch was $60.4{ }^{\circ} \mathrm{C}$, and the peak and finishing temperatures of gelatinization and the heat of gelatinization $(\Delta \mathrm{H})$ were similar to that of potato starch.

(iv) Dynamic viscoelasticity of starch gel

According to static viscoelasticity measurements attained by a creep meter (Yamaden Plc.), when compared to sweet potato starch, sago starch was softer and had higher viscosity. By the same measurements, sago starch gel showed lower fluidity than that of potato starch gel.

According to dynamic viscoelasticity measurements using Rheolograph Gel (Toyoseiki Plc.), the E' and E" (corresponding to hardness and viscosity, respectively) ratings of sago starch were the lowest, indicating it is softer than potato, sweet potato, and cornstarch gels. Also, sago starch gel had a strong internal viscosity element with a large $\tan \delta$ (E'/E'), as opposed to the small $\tan \delta$ of cornstarch, which was found to have elasticity elements (Takahashi and Hirao 1994).

(v) Physical properties of sago starch gel 

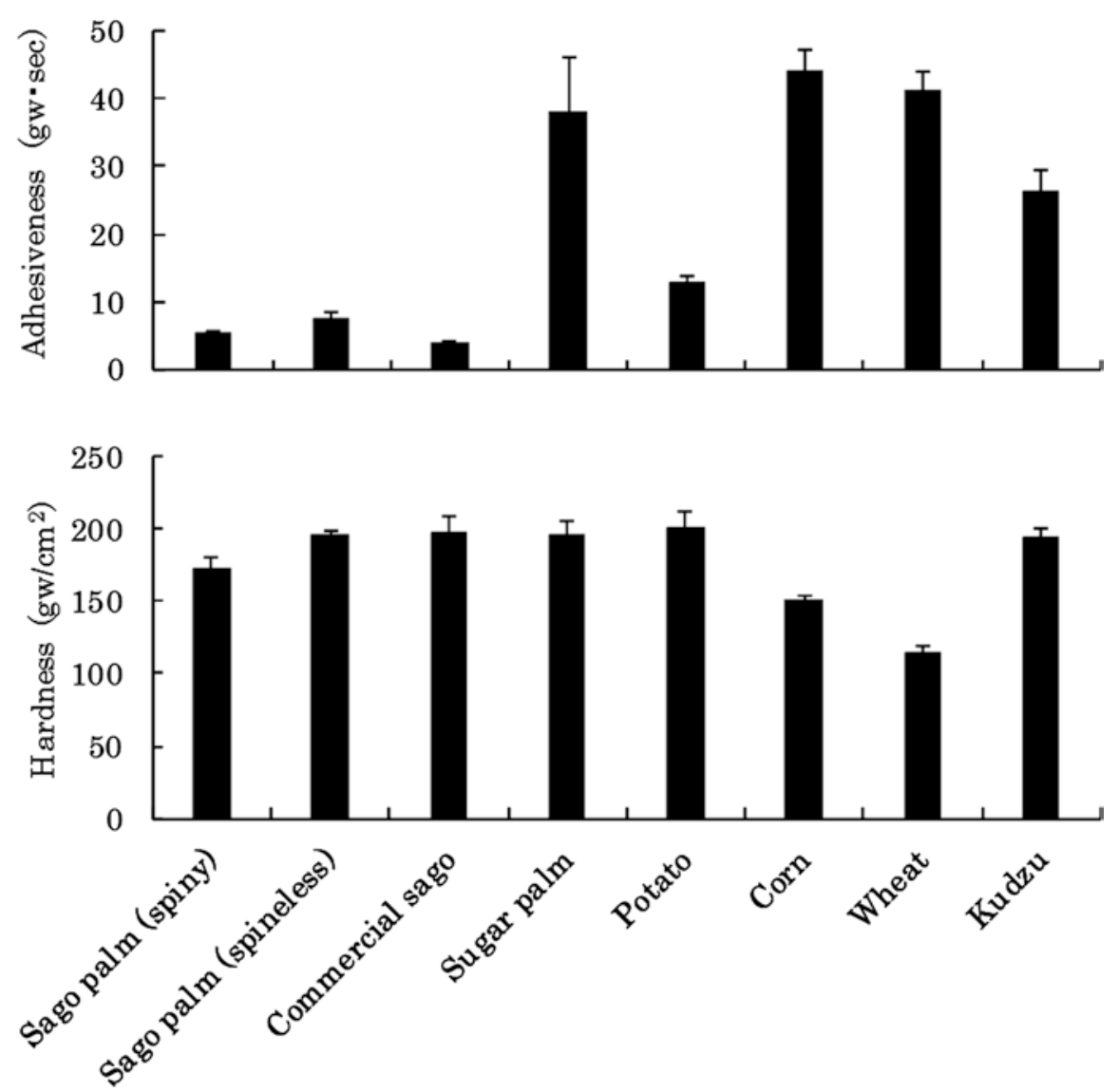

Fig. 21.3 Gel hardness and adhesiveness of various starches measured by Tensipresser (Source: Miyazaki 1999)

Texture measurements for hardness, cohesiveness, and adhesiveness were conducted using a Tensipresser (Taketomo Electric TTP-50BX). As shown in Fig. 21.3, the hardness of sago starch gel was similar to potato, sugar palm, and kudzu starch gels. Immediately after preparation, the physical property of the gel was soft but became hard after being cooled at $5{ }^{\circ} \mathrm{C}$ for $2 \mathrm{~h}$ (Miyazaki 1999). Furthermore, by cooling the gel for $2 \mathrm{~h}$ at $5{ }^{\circ} \mathrm{C}$, its adhesiveness greatly decreased, and its cohesiveness, which shows the degree of internal binding force, did not change from the original large value (Hamanishi 2002).

(vi) Changes of syneresis and whiteness in starch gels

The retrogradation of starch is followed by determining the change of syneresis and whiteness of the gel. Mung bean starch and cornstarch gels, which contain a higher amount of amylose, showed the largest amount of syneresis. Sago starch gel was second only to potato starch gel in terms of low syneresis (Fig. 21.4). Potato 
Fig. 21.4 Syneresis of starch gels determined by released water (Source: Takahashi et al. 1981)

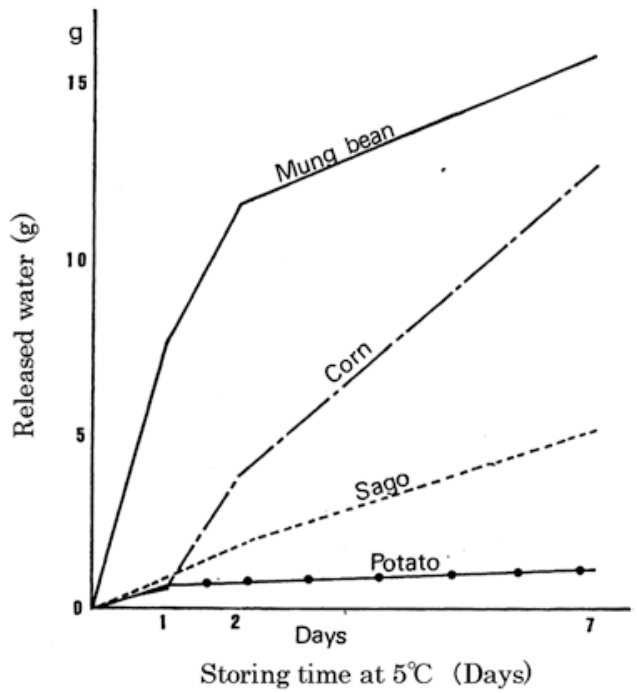

starch gel proved to have low whiteness showing less change from immediately after preparation until $4 \mathrm{~h}$ later. Sago starch gel had high transparency and little change in whiteness, being second only to potato starch gel. Cornstarch gel, however, immediately after preparation, showed apparently higher whiteness which increased as time passed (Takahashi et al. 1981).

Based on the above, it can be seen that the good points of sago starch are that it is a transparent, soft, and flexible gel with low adhesiveness and a low syneresis. Furthermore, sago starch contains a similar amount of amylose as cornstarch and its physical properties are similar to those of potato, sweet potato, kudzu, and bracken starches. Due to this evidence, it is thought that sago starch can be used in food products that contain the aforementioned starch types.

\subsection{Sago Starch as an Ingredient in Cooking}

\section{Udon (Japanese noodles)}

Udon was prepared using five types of starch: sago, potato, sweet potato, kudzu, and cassava. The starches were mixed to a ratio of $50 \%$ with non-glutinous rice flour. For comparison, udon made from $100 \%$ non-glutinous rice flour and from wheat flour was processed and examined. Udon made using non-glutinous rice flour was softer than wheat flour udon. However, adding starch to non-glutinous rice flour udon caused firmness to increase producing a firmer noodle than when using wheat flour. Cassava udon was the hardest followed by sago udon. In the sensory evaluation, udon made using sago starch was preferred in the parameters of smoothness and stickiness and overall evaluation. When the appropriate amount of substitution (with non-glutinous rice flour) of cassava and sago starch was investigated, it was 
found that as the substituted amount was increased, the udon became harder. In the sensory evaluation, udon made using a replacement rate of 50\% sago starch and 50 or $70 \%$ cassava starch was favored the most (Yokota et al. 2015).

\section{Chinese noodles}

In the preparation of Chinese noodles, starch was used as a partial substitute for wheat flour, and the effects of this replacement were investigated. The boiled Chinese noodles increased in hardness and became stretchy as the substituted amount of starch was increased. When comparing Chinese noodles made using sago starch and potato starch, the former was found to be harder and expanded to a greater degree. Furthermore, it was clearly found that by making Chinese noodles using sago starch, the amount of solid material lost in the water during the boiling period decreased dramatically. Based on sensory evaluation, it was proved that replacing wheat flour with sago starch to a degree of 10 or $20 \%$ produced Chinese noodles that were more transparent, were less sticky, and had a more favorable taste compared to the reference sample (0\% starch) (Kondo et al. 2013).

\section{Bread and muffins}

Bread and muffins were prepared to investigate the potential usage of sago starch in puffed foods. Muffins made using sago starch were found to expand better and have a more uniform texture and more springiness than muffins made using cornstarch or potato starch. It was found that when sago starch replaced $30 \%$ of the bread flour and vital gluten (10\% of the bread flour and sago starch) was added, the bread expanded to a degree of $1.3 \sim 1.5$ times. In the sensory evaluation, sago bread was found to be springier and have more uniform texture than bread made with other starches (Ohya and Takahashi 1987). Based on the above evidence, it can be concluded that sago starch is a perfectly viable ingredient in puffed foods.

\section{Chinese vermicelli}

Based on its physiochemical properties, sago starch was considered to have excellent noodle-making qualities and was therefore used in the production of Chinese vermicelli (cellophane noodles) using the pressurized extrusion method (Takahashi et al. 1985). Chinese vermicelli made from sago starch was found to be transparent, desirably firm, and nonsticky. In the sensory evaluation, sago starch vermicelli was rated higher than commercially available vermicelli in terms of appearance, texture, and overall evaluation. Due to this, sago starch can be considered as a viable ingredient in Chinese vermicelli. The addition of soybean protein isolate $(5 \%)$ to sago starch had further positive effects. It was found to inhibit solubility and produce noodles that resembled commercially available Chinese-made vermicelli (Takahashi and Hirao 1992).

\section{Kuzukiri/fen pi}

Fen pi is a mung bean starch sheet that is used in Chinese cooking. In Japan it is known as kuzukiri or suisen and is eaten as a chilled dessert with black honey or roasted soybean flour. Generally, kudzu, potato, or sweet potato starches are used as 
primary ingredients with characteristics such as quality of texture, chewiness, and ability to blend well with required toppings or seasonings. Based on this information, fen pi made from sago starch, which gels easily and has a strong internal binding force, was investigated. The product was found to have a hardness that was similar to potato starch fen pi, harder than kudzu starch fen pi, and approximately half that of mung bean fen pi. In the sensory evaluation, it was favored in terms of adhesiveness, ease of expansion, and in the overall evaluation (Ohya et al. 1990).

\section{Gomadofu (sesame curd)}

Gomadofu is made of kudzu starch and ground sesame seeds, which are heated and gelatinized. It is one of the most essential dishes for a vegetarian diet. Samples were prepared with sago starch or kudzu starch and 30\% soybean flour, instead of ground sesame seeds. It was found that sago starch was a good substitute for kudzu starch (Takahashi and Hirao 1994).

\section{Kamaboko (boiled fish paste)}

In order to determine the effects of heating on the physical properties of gel, sago starch and potato starch were added to frozen Alaska pollack paste and prepared in two ways - heating at $80^{\circ} \mathrm{C}$ for $20 \mathrm{~min}$ and heating at $30^{\circ} \mathrm{C}$ for $30 \mathrm{~min}$ and then $80^{\circ} \mathrm{C}$ for $20 \mathrm{~min}$. The network structure of fish paste gel was investigated using a low vacuum scanning electron microscope. In the gel containing sago starch, the starch particles could be observed, but they were smaller than those of potato starch. This proved that the ability of sago starch to gelatinize is lower than that of potato starch (Sompongse et al. 2006a).

Sago starch frozen fish paste gel was additionally examined by comparing two two-step cooking methods $\left(90 / 80{ }^{\circ} \mathrm{C}\right)$. At $90{ }^{\circ} \mathrm{C}$ the gel was harder and the starch particles in the gel were larger than when heated at $80^{\circ} \mathrm{C}$. Due to this, it was clearly determined that when sago starch is added to frozen fish paste, it should be heated at a final temperature of $90{ }^{\circ} \mathrm{C}$ in order to attain a gel with a similar structure to that of frozen fish paste containing potato starch (Sompongse et al. 2006b).

\section{Warabimochi (bracken starch pastry)}

Warabimochi is a Japanese dessert that is popular for its transparent appearance and its smooth texture both on the tongue and when swallowing. Traditional warabimochi is made from bracken starch. However, due to its recent rise in price, nowadays commercially sold bracken starch consists mostly of sweet potato starch. For this reason it was decided to use sago starch to prepare sagomochi. The end product had better color, cutting quality, firmness, and biting quality than traditional warabimochi. As previously mentioned, transparency is an important aspect of warabimochi, and in this parameter too, sago starch was superior to sweet potato starch as its distinctive pink tinge went well with the yellowish soybean flour which is sprinkled on top of the dessert. Sagomochi can be readily prepared at home. The key point in preparation of sagomochi from sago starch is to keep stirring it at high temperatures to promote gelatinization so that the end product has favored characteristics such as high viscoelasticity, good texture on the tongue, and slow retrogradation (Takahashi and Hirao 1994; Hamanishi et al. 2002a). 


\section{Kuzuzakura (kudzu starch pastry)}

Kuzuzakura is a transparent dessert that is eaten in early summer. It is necessary for the starch pastry to be easy to make and for it to form well around the adzuki bean paste filling. Usually kudzu starch is used in making kuzuzakura; however, as has previously been reported, by mixing kudzu starch and potato starch to a ratio of 3:1, a highly workable kuzuzakura can be produced (Teramoto and Matsumoto 1966). Using the aforementioned kuzuzakura as a reference, it was decided to make kuzuzakura using $100 \%$ sago starch. The sago starch product was found to be superior in terms of ease of production, formability, and shape retention. In the sensory evaluation, sago starch was found to produce a kuzuzakura that was smoother and springier than the reference and highly preferred in terms of transparency, color, and cutting quality. The low fluidity and syneresis plus the high viscoelasticity and transparency of sago starch give it the maneuverability, formability, and shape retention that are required for kuzuzakura production. Sago starch forms a soft gel that achieves the right balance of firmness between the pastry and the filling (Takahashi and Hirao 1994).

\section{Nama-yatsuhashi (raw cinnamon-flavored dumplings)}

Yatsuhashi is a popular confection in Kyoto. There are two basic forms, namayatsuhashi which has a soft mouth feel and yaki-yatsuhashi, which is baked yatsuhashi and is hard and cookie-like. Nama-yatsuhashi are thin squares of cinnamon-scented sticky rice dough with non-glutinous rice flour or glutinous rice flour being key ingredients. The effect of partially substituting these ingredients with sago starch was investigated. It was found that as the amount of substituted sago starch was increased, a harder gel was created with both non-glutinous rice flour and glutinous rice flour. It was also found that when sago starch replaced 30\% of non-glutinous rice flour and $50 \%$ of glutinous rice flour, a product with more adhesiveness resulted. Furthermore, in the sensory evaluation, when 50 or $70 \%$ of non-glutinous rice flour was replaced with sago starch, differences in color, firmness, and elasticity were revealed, and it was preferred in terms of elasticity and overall evaluation. This clearly proved that the usage of sago starch in namayatsuhashi is effective (Kondo et al. 2013).

\section{Mushiyokan}

Mushiyokan, which is made from kudzu starch or wheat flour mixed with adzuki bean paste, is enjoyed for its thick texture. Mushiyokan made using sago starch is softer and less sticky than that made of kudzu starch and rated on a par with kudzu mushiyokan in terms of color, sweetness, taste, springiness, and overall assessment (Hamanishi et al. 2002b).

\section{Pie filling}

Pie filling refers to the contents that are poured into baked piecrust. It requires good shape retention and it is important for it to be able to be cut cleanly. Conventionally, cornstarch or wheat flour is used to gain these characteristics, but 
they have a shortcoming for fast retrogradation and syneresis during low-temperature storage. Due to these facts, the potential for sago starch to be used as a substitute for cornstarch and wheat flour was investigated. Filling made from sago starch with the addition of egg yolk powder (equivalent to $20 \%$ of sago starch) had low syneresis and good shape retention. Furthermore, it rated better than cornstarch filling in terms of firmness, springiness, and overall evaluation, thus proving that sago starch can also be reliably used as an ingredient in pie filing (Hirao et al. 2005).

\section{Blancmange}

The English-style blancmange is a pudding made of a mixture of cornstarch, sugar, and milk which is heated and gelatinized. When sago starch was substituted for cornstarch, it gave the blancmange less syneresis, better shape retention, less stickiness, and a better feel on the tongue (Hirao et al. 1998). Immediately after preparation, the sago gel was soft, was supple, and lacked adhesiveness. However, by cooling the gel at $5^{\circ} \mathrm{C}$ for $24 \mathrm{~h}$, it retained its shape to a much more sufficient degree (Hirao et al. 2002, 2003a). The addition of cocoa or green tea powder improved shape retention of the sago starch blancmange, and its taste, hardness, smoothness, and overall rating in sensory evaluation were valued highly (Hirao et al. 2003b).

\section{Biscuits}

Biscuits are a baked confection with flour, butter, sugar, and milk used as basic ingredients. Some biscuits are made with starch acting as a partial replacement for flour. When $50 \%$ of the flour was replaced with sago starch, the biscuits exhibited higher swelling ability, softness, and fracturability than potato or cornstarch biscuits. These characteristics intensified as the ratio of sago starch increased, with $50 \%$ showing the highest improvement. Sensory evaluation found that biscuits with partial sago starch substitution were more crumbly than wheat-only biscuits and were given significantly higher preference in terms of form, taste, hardness, fracturability, feeling on the tongue, and overall evaluation. The 50\% substitution was especially preferred. Furthermore, even when a low amount of butter was used, as the amount of substituted sago starch used was increased, the biscuit became less crumbly. This condition was maintained until the amount of butter used was reduced by as much as half. Sago starch cookies using egg instead of baking powder and milk were found to have the same level of hardness but were 3-4 times more crumbly (Hirao et al. 2004).

\subsection{Conclusion}

In terms of its gelatinization behavior, sago starch was found to be similar to potato, cassava, and sweet potato starch. In terms of retrogradation and amylose content, sago starch was similar to cornstarch. It was clearly proved that sago starch could be used in various types of cooking and food manufacturing, as when it was used as a replacement for other starch types, the products attained had an agreeable taste. Gel 
made from sago starch had satisfactory degrees of elasticity, softness, flexibility, and adhesiveness. Furthermore, the usability of sago starch in puffed foods was clearly proven. In all the foodstuffs in this study, the sago starch versions had superior physical properties and in sensory evaluations were valued to have favorable tastes and textures. The possibility of the further development of sago starch-based foodstuffs is increasing (Hirao 2015). Presently, in Japan, sago starch is imported and used in the production of foodstuffs such as oxidized starch and as a dusting powder for various noodle types. However, research on the usage and effects of processed sago starch is now underway.

Sago palm and sago starch are now being widely seen as a valuable natural food resource and a plant resource that can help maintain the natural environment of planet earth. Sago is being increasingly considered to be an essential plant for overcoming many twenty-first century problems such as global warming, environmental destruction, and rampant deforestation in the tropic regions and for combatting hunger problems that frequently occur in developing countries and due to rapid world population increase (Kainuma 2015; Yamamoto 2015).

In Japan too, the appeal of the up-to-now unused resource, that is, sago starch, is being widely spread, and its potential use in cooking and manufacturing foodstuffs is being further considered (Kondo 2014; Hirao 2016). Sago starch is an ingredient that has the potential to make the lives of people all over the world more fulfilling and colorful. Research into sago starch deserves to be continued.

\section{References}

Bujang KB, Ahmad FB (2000) Production and utilization of sago starch in Malaysia. Sago Comm 11:1-6

Hamanishi T (2002) Studies on physicochemical properties of sago starch obtained at different growth stages of the trunk and cooking characteristics of sago starch. Kyoritsu Women's University ph. D. Thesis, pp 73, 95 (in Japanese)

Hamanishi T, Hirao K, Nishizawa Y et al (2002a) Physicochemical properties of sago starch compared with various commercial starches. In: Kainuma K, Okazaki M, Toyoda Y, Cecil JE (eds) New frontiers of sago palm studies: proceedings of the international symposium on sago. Universal Academy Press, Tokyo, pp 289-292

Hamanishi T, Matsunaga N, Hirao K et al (2002b) Cooking and processing properties of the traditional Japanese confection, kudzumushbiyokan, made from sago starch. J Cook Sci Jpn 35:287-296. (in Japanese)

Hatta T, Nemoto S, Hamanishi T et al (2002) Uppermost surface structure of sago starch granules. In: Kainuma K, Okazaki M, Toyoda Y, Cecil JE (eds) New frontiers of sago palm studies: proceedings of the international symposium on sago. Universal Academy Press, Tokyo, pp 349-354

Hirao K (2015) Development of sago starch foods using sensory evaluation. Jpn J Sens Eval 19:2_ 11. (in Japanese)

Hirao K (2016) The physicochemical properties and cooking aptitude of the sago starch. Sugar Starch Info 45(6):40-51. (in Japanese)

Hirao K, Takahashi S (1996) Studies on cooking of pearl-type starch. Part 3. Cooking method of sago pearls. Sago Palm 4:14-20 (in Japanese) 
Hirao K, Igarashi Y, Takahashi S (1998) Cooking and processing quality of sago starch gel. Part 3. Effects of ingredients ratio of soybean protein isolate and soybean oil on the rheological properties of starch gel. Sago Palm 6:1-9 (in Japanese)

Hirao K, Hamanishi T, Igarashi Y, Takahashi S (2002) Effect of the ingredient ratio of sago starch, soybean protein isolate and soybean oil on the physical properties and sensory attributes of blancmange. J Home Econ Jpn 53:659-669 (in Japanese)

Hirao K, Watanabe T, Takahashi S (2003a) Effects of added soybean protein isolate and soymilk powder on the physical properties and sensory evaluation of a blancmange type of starch gel (part 1) effects of additive concentration and addition method. J Home Econ Jpn 54:457-468 (in Japanese)

Hirao K, Watanabe T, Takahashi S (2003b) Effects of added soybean protein isolate and soymilk powder on the physical properties and sensory evaluation of a blancmange type of starch gel (part 2) effects of adding cocoa and powdered green tea. J Home Econ Jpn 54:469-476 (in Japanese)

Hirao K, Kanamori K, Yoneyama Y, Takahashi S (2004) Physical and sensory properties of biscuits containing partially replaced sago starch. J Home Econ Jpn 55:715-723. (in Japanese)

Hirao K, Takei F, Yoneyama Y, Takahashi S (2005) Effect of adding egg yolk powder on the physiochemical properties of sago starch. J Home Econ Jpn 56:49-54. (in Japanese)

Hirao K, Tanaka H, Konoo S et al (2008) The present condition of sago starch using method and processed foods in Riau, Indonesia. In: Proceedings of the 17th conference of the society of sago palm studies, pp 75-78 (in Japanese)

Kainuma K (1982) Utilization of sago palms in Sarawak, South Kalimantan and Papua New Guinea. Jpn J Trop Agri 26:177-186

Kainuma K (2015) Potential use of sago starch. In: The sago palm, the food and environmental challenges of the 21st century. Kyoto University Press, Tokyo, pp 289-295

Kainuma K, Matsunaga A, Itakawa M, Kobayashi S (1981) New enzyme system - $\beta$-amylase andpullulanase-to determine the degree of gelatinization and retrogradation of starches or starch foods. J Jpn Soc Starch Sci 28:235-240 (in Japanese)

Kondo T (2014) Properties of sago starch and utilization to prepared foods of sago starch. Prep Foods Techn 20:65-79 (in Japanese)

Kondo T (2015) Utilization of sago palm starch. In: The sago palm, the food and environmental challenges of the 21st century. Kyoto University Press, Tokyo, pp 259-289

Kondo T, Hirao K, Takahashi S (2013) Effect on Chinese noodles of using sago starch. J Cook Sci Jpn 46:93-99 (in Japanese)

Miyazaki T (1999) Cooking characteristics of sago starch: its physical properties by sago starch types and the breaking properties of sago noodles. Kyoritsu Women's University Faculty of Home Economics 1999 graduation thesis

Nishimura Y (2008) Present sago palm situation in Mindanao, Philippines. Proceeding of the 17th conference of the society of sago palm studies, pp 31-36 (in Japanese)

Ohya C, Takahashi S (1987) Application of sago starch to baked foods. J Cook Sci Jpn 20:362370. (in Japanese)

Ohya C, Takahashi S, Watanabe T (1990) Texture evaluation of fenpi made of sago starch by physical and sensory method. J Cook Sci Jpn 23:293-301. (in Japanese)

Puchongkavarin H, Shonbsngob S, Nuyim et al (2000) Production of alkaline noodles produced from the partial substitution of wheat flour with sago starch. Sago Comm 11:7-14

Sato T, Yamaguchi T, Takamura T (1979) Cultivation, harvesting and processing of sago palm. Jpn J Trop Agri 23:130-136. (in Japanese)

Sompongse W, Morioka K, Yamamoto Y, Itoh Y (2006a) Comparison of the effect of sago starch and potato starch on the texture properties of gels cooked from walleye pollack frozen surimi. Sago Palm 14:45-52

Sompongse W, Morioka K, Yamamoto Y, Itoh Y (2006b) Effect of the heating temperature on the of textural properties of sago starch-containing gels cooked from walleye pollack frozen surimi. Sago Palm 14:53-58 
Takahashi S, Hirao K (1992) Food-cultural studies on cooking and processing properties of sago starch. Bull Facul Home Econ, Kyoritsu Women's University 38:17-23 (in Japanese)

Takahashi S, Hirao K (1994) Studies on the physical and the chemical properties of sago starch, and its performance when used in the preparation of Japanese sweets. Bull Facul Home Econ, Kyoritsu Women's University 40:59-64 (in Japanese)

Takahashi S, Kitahara H, Kainuma K (1981) Chemical and physical properties of starches from mung bean and sago. J Jpn Soc Starch Sci 28:151-159 (in Japanese)

Takahashi S, Kobayashi R, Watanabe T, Kainuma K (1983) Effects of addition of soybean protein on gelatinization and retrogradation of starch. J Food Sci Techn 30:276-282 (in Japanese)

Takahashi S, Hirao K, Kawabata A, Nakamura M (1985) Effect of preparation methods of starches from mung beans and broad beans and preparation method of noodles on the physico-chemical properties of harusame noodles. J Jpn Soc Starch Sci 30:257-266 (in Japanese)

Takahashi S, Hirao K, Kainuma K (1995) Physicochemical properties and cooking quality of sago starch. Sago Palm 3:72-82 (in Japanese)

Teramoto Y, Matsumoto F (1966) Studies on the cooking quality of various starch (pt.1) kudzu dumpling. J Home Econ Jpn 17:384-388. (in Japanese)

Yamamoto Y (2015) Preface. In: The sago palm, the food and environmental challenges of the 21st century. Kyoto University Press, Tokyo, pp 29-32

Yamamoto Y, Yoshida T, Yanagidate I et al (2008) Sago palm and its utilization in Ambon and Seram Island, Maluku Province, Indonesia. In: Proceedings of the 17th conference of the society of sago palm studies, pp 17-22 (in Japanese)

Yokota T, Kondo T, Hirao K, Takahashi S (2015) Physical properties and sensory attributes of Japanese udon noodles made from sago starch, the 12th international symposium 2015. Sago Palm 23:46

Open Access This chapter is licensed under the terms of the Creative Commons Attribution 4.0 International License (http://creativecommons.org/licenses/by/4.0/), which permits use, sharing, adaptation, distribution and reproduction in any medium or format, as long as you give appropriate credit to the original author(s) and the source, provide a link to the Creative Commons license and indicate if changes were made.

The images or other third party material in this chapter are included in the chapter's Creative Commons license, unless indicated otherwise in a credit line to the material. If material is not included in the chapter's Creative Commons license and your intended use is not permitted by statutory regulation or exceeds the permitted use, you will need to obtain permission directly from the copyright holder. 


\title{
Chapter 22 \\ Production, Purification, and Health Benefits of Sago Sugar
}

\author{
Kopli Bujang
}

\begin{abstract}
Previous works on the conversion of sago starch and sago hampas into sago sugar, production of cellobiose from sago fronds, and the current studies on the health benefits from consumption of brown sago sugar are presented in this paper. Hydrolysis of sago starch into sugar generates total (100\%) recovery, containing glucose (94\%), maltose, and other impurities at 3\% each. Purification of the brown sago sugar is achieved using powdered activated charcoal to remove all impurities and color. Drying of the purified and concentrated white sago sugar is best performed in an oven (minimum $60{ }^{\circ} \mathrm{C}$ ), producing high $(100 \%$ ) yield of sugar crystals after several days. Analysis of sweetness revealed that the sago sugar is as sweet as $50 \%$ glucose. Brown sago sugar is preferable to white sago sugar due to the presence of antioxidant, analyzed based on total phenolic content (TPC) at $300 \mathrm{mg} / \mathrm{kg}$ sugar. Some residual of the TPC can be detected even after purification of the brown sugar. Sago sugar is also obtainable through enzymatic hydrolysis of physically treated sago hampas, generating substantial amount of sugars $(70 \% \mathrm{w} / \mathrm{w})$. Current research also reveals the feasibility of producing cellobiose (approx. 12\% w/w) from fresh sago frond, a type of pharmaceutical sugar which commands a higher price than glucose. It is obvious that sago palm has tremendous potential to be adopted as the new source of sugars to replace cane sugar.
\end{abstract}

\subsection{Introduction}

In a world starch market dominated by corn, potato, and tapioca, the world production of starch has been estimated to be 27.5 million $\mathrm{mt}$, with an insignificant amount of sago starch consumed, about 3\%, 200,000-300,000 mt per annum. Clearly, there is a need to enhance the importance of sago as a major crop in Southeast Asia for global recognition.

The common knowledge about sago is that it thrives in swampy areas or on shallow peat soils without needing copious amounts of pesticides or herbicides

\footnotetext{
K. Bujang $(\bowtie)$

Centre for Sago Research, Faculty of Resource Science and Technology, Universiti Malaysia Sarawak, Kota Samarahan, Sarawak, Malaysia

e-mail: bkopli@unimas.my
} 
(Pei-Lang et al. 2006), quite unlike the cultivation of oil palm. Sago is also a hardy palm, only minimally affected by floods and forest fires. More than $90 \%$ of all sagoplanting areas in Malaysia are found in Sarawak, East Malaysia. Sago is the world's highest starch producer per unit area at $25 \mathrm{mt} / \mathrm{ha}$. This is 4 times higher than rice, 5 times wheat, 10 times potato, and almost 17 times that of tapioca (Ishizaki 1997). Since the average annual intake of starch per person is approximately $250 \mathrm{~kg}$, a 1000 ha sago farm could support and save 100,000 people from starvation (Ishizaki 1997).

The most significant agronomic aspect of sago palm is that it multiplies from suckers; hence replanting is not necessary. The author has had the opportunity to visit a sago field owned by a small community of farmers near Pusa in Sarawak, allegedly planted by their great grandparents, over 300 years ago.

Table sugar is derived from sugarcane, a relatively easy and profitable plant to grow but rather ineffective in reproducing naturally (Braun 1999). On a per capita basis, the amount of sugar consumption in Malaysia is about $50 \mathrm{~kg}$ (raw equivalent), one of the highest in the region. Cultivation of sugarcane in Malaysia is relatively small, and although the annual production of sugarcane is relatively high at 1.31.6 million $\mathrm{mt}$, the sugar recovery is rather low at only $7-10 \% / \mathrm{kg}$ of fresh weight.

Lack of local raw materials induces heavy dependency of the sugar industry on imported materials (over 90\%). Increases in industrial applications of cane sugar naturally lead to a higher price of this commodity (Adam 2010). Hence, a cheaper alternative which can be obtained locally and in abundance is imperative for sugar production.

\subsection{Production of Sugars from Sago Starch}

Initial studies on the production of sugars were performed in $1 \mathrm{~L}$ lab-scale vessels on hydrolysis of various types of starch (sago, corn, tapioca, and sweet potato flour). A modified procedure for enzymatic hydrolysis of sago starch at the optimum parameters is detailed elsewhere (Bujang et al. 2000a).

Typical enzymatic hydrolysis uses Termamyl-12OL (a thermostable $\alpha$-amylase from Bacillus licheniformis, $120 \mathrm{KNU} / \mathrm{g})$ for liquefaction $(0.5 \mu \mathrm{l} / \mathrm{gram}$ of starch) and incubated at $90{ }^{\circ} \mathrm{C}$ for $2 \mathrm{~h}$. This is followed by Dextrozyme (a mixture of glucoamylase from Aspergillus niger and pullulanase from $225 \mathrm{AGU} / \mathrm{ml}$ ) for saccharification $\left(0.6 \mu \mathrm{l} / \mathrm{gram}\right.$ of starch) and incubated at $60{ }^{\circ} \mathrm{C}$ for another $4-6 \mathrm{~h}$ to produce hydrolyzed sago sugars, or HSS (Bujang et al. 2000b; Bujang and Jobli 2002). This period may be extended for larger volumes of hydrolysis (Bujang and Law 2006). This method generates a $100 \%$ recovery of glucose from sago starch.

It was confirmed earlier that $20 \%(\mathrm{w} / \mathrm{v})$ sago starch is the optimum starch concentration (Bujang et al. 2000a, 2004), at the ideal pH of 6.5 for liquefaction and 4.5 for saccharification, for producing sago sugars at over $100 \%$ recovery. The same procedure was performed on other types of starch, and, comparatively, the highest concentration of sugars was obtained from sago starch at $100 \%$ recovery, followed 
by sweet potato $(75 \%)$, corn $(65 \%)$, and tapioca starch at $60 \%$ (Booty and Bujang 2009).

Increasing the amount of starch from $200 \mathrm{~g} / \mathrm{L}$ to $10 \mathrm{~kg} / 50 \mathrm{~L}$ reduces the glucose recovery by $20 \%$, mostly due to the constraints and capacity of our lab equipment. These results confirmed that it is possible to scale up the process of enzymatic hydrolysis of sago starch with some loss in glucose yield (Booty and Bujang 2009).

\subsection{Purification of Sago Sugars}

Powdered activated charcoal (PAC) has been used extensively in purification and filtration processes due to its ability to absorb odorous or colored substances from gases or liquids. HSS is centrifuged and filtered to produce brown sago sugar (BSS). Purified sago sugars (PSS), or white sugar, is obtained by PAC filtration of BSS under gravity $(2.5 \mathrm{ml} / \mathrm{min})$ which showed a higher $(85 \%)$ recovery of sugars at a lower amount of PAC (5 g) compared to $10 \mathrm{~g}$ PAC (75\%). A high recovery of almost $90 \%$ was achieved when filtration was enhanced using a pump with a flow rate of $460 \mathrm{ml} / \mathrm{h}$ (Bujang et al. 2012).

Ang et al. (2006) reported that adsorption between PAC is lower toward glucose and lactate, but higher toward protein and color. However, the purification process to eliminate other impurities will inadvertently adsorb some sugars, albeit at small concentrations. This was amplified when purification was performed at a higher amount of PAC (10 g) where the yield of sugars recovery was lower.

Purified (white) sago sugar contains mostly glucose (94\%), with maltose and other impurities, each at 3\%, as shown in Fig. 22.1 (Bujang 2012; Monib 2015). The hydrolytic enzymes used contain $\alpha$-amylase, which attacks gelatinized starch randomly, thereby producing several types of mono- or oligosaccharides as impurities $(3 \%)$.

\subsection{Drying of Sago Sugars}

The crystallization of PSS was studied by several methods, freeze drying, spray drying, and oven drying, resulting in different degrees of success and yield. Spray drying gave the lowest recovery at less than $20 \%$, while both freeze drying and oven drying yielded about $100 \%$ - all measured based on weight of the dried sago sugars (DSS) at the end of the process.

Although oven drying $\left(60^{\circ} \mathrm{C}\right)$ clearly requires longer time (3-5 days), this method was adopted for our preliminary and future research at lab-scale processes (Monib 2015). However, the heating process creates a slightly yellow color of the sugar crystals. 


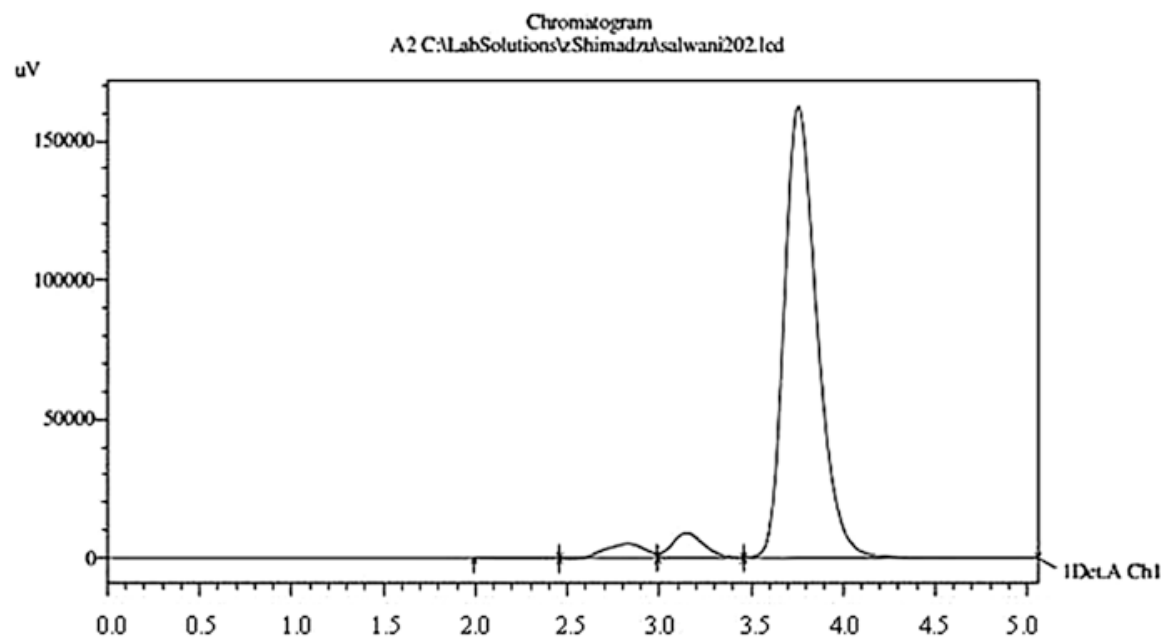

Detector A Chl

\begin{tabular}{|l|l|l|l|r|l|l|}
\hline Peak\# & Name & Ret. Time (min.) & Area $(\mathrm{mV})$ & Height (uV) & Conc. & Units \\
\hline 1 & & 2.292 & 1,661 & 84 & 0.000 & \\
\hline 2 & & 2.827 & 81,211 & 5.283 & 0.000 & \\
\hline 3 & & 3.143 & 112,629 & 9.210 & 0.000 & \\
\hline 4 & & 2.752 & 202,9875 & 162,435 & 0.000 & \\
\hline Total & & & 222,5377 & 177,013 & & \\
\hline
\end{tabular}

Fig. 22.1 HPLC analysis of purified or white sago sugar showing maltose and glucose peaks at retention times of 3.1 and $3.7 \mathrm{~min}$, respectively

\subsection{Sweetness Test}

Sweetness was measured by making a 10-70\% solution of the tested compound in distilled water and then requesting a test panel to taste it. If necessary, the solution was diluted and tasted again until the taster could confirm the sweetness (Yau et al. 1989). The relative sweetness of the various sugars or sweetening agents was compared to sucrose at certain dilutions, compared to the sweetness of sucrose as 100 (Godshall 1996).

The sweetness test was performed by dissolving white crystals of sago sugar in water $(20 \mathrm{~g} / \mathrm{L}$ to $100 \mathrm{~g} / \mathrm{L})$ and comparing this to a standard solution of $5 \%$ sucrose (Godshall 1996), performed by a panel of 15 volunteers. The panelists were required to taste several times-without actually drinking - the sweetness of the standard solution, which is of known concentration, and compared to the test solution. The panelists were then required to record whether one solution was sweeter than the other, or if they are of the same sweetness, in the appropriate column of the score sheet. The tests concluded that white sago sugar (containing $94 \%$ glucose) is $50 \%$ less sweet than sucrose, which is the main component in cane sugar (Monib 2015). 


\subsection{Flavonoids in Brown Sago Sugars}

Naturally occurring flavonoids have been known to occur in numerous plants. Flavonoids are classified according to their chemical structure and subdivided into three subgroups: (a) flavones; (b) flavan-3-ols, flavan-4-ols, flavan-3,4-diols, and proanthocyanidins; and (c) anthocyanidins. Flavonoids (e.g., catechins) have been shown to be the most common group of polyphenolic compounds in the human diet and are found universally in foods of plant origin.

Preliminary analyses show the part flavonoids play in affecting the role of allergens, viruses, and carcinogens. In vitro studies reveal that flavonoids also have antiinflammatory (USFDA 2013a), antimicrobial (USFDA 2013b), and anticancer properties (USFDA 2013c). Chemical analyses have been performed on brown sago sugars in order to determine potential benefits from its consumption.

Antioxidant assay is based on total phenolic content (TPC) and total flavonoid content (TFC). TPC analysis (gallic acid standard) was done on brown and white sago sugars. At $20 \%$ (w/v), white sago sugar is still much healthier than cane sugar, while brown sago sugar has the highest total phenolic and total flavonoid contents as shown in Table 22.1 (Bujang et al. 2015). The types of flavonoids identified so far in brown sago sugar are gallic acid, quercetin, and kaempferol. Only the latter remains after purification into white sugar. Obviously, the purification process using PAC removed most of the antioxidant properties.

\subsection{Production of Sugars from Sago Hampas}

Sago hampas is composed of the solids (fibers and vascular bundles) separated by filtration from sago effluent, also a highly potential source of raw material to produce sugar generated by the sago industry (Fig. 22.2a,b). It has been shown that for $1 \mathrm{mt}$ of dried sago starch produced, at least $1 \mathrm{mt}$ of dried hampas is discharged into the river (Bujang et al. 1996).

It was reported earlier that in some older sago mills, sago hampas can harbor as much as 60-70\% starch, trapped within its fibers (Abd-Aziz 2002). Fresh hampas also has high moisture content (70-80\%) and needs to be dried if it is to be trans-

Table 22.1 Types and amount of flavonoids in cane and sago sugars

\begin{tabular}{l|l|l|l}
\hline $\begin{array}{l}\text { Types of sugar } \\
(20 \% \mathrm{w} / \mathrm{v})\end{array}$ & $\begin{array}{l}\text { Total phenolic }{ }^{1} \text { compound } \\
(\mathrm{mg} / 100 \mathrm{~g})\end{array}$ & $\begin{array}{l}\text { Total flavonoid }{ }^{2} \text { content } \\
(\mathrm{mg} / 100 \mathrm{~g})\end{array}$ & $\begin{array}{l}\text { Radical scavenging } \\
\text { activity }(\%)\end{array}$ \\
\hline White cane & 0.647 & 0 & 17 \\
\hline White sago & 0.865 & 0.213 & 33 \\
\hline Brown sago & 39.599 & 61.064 & 85 \\
\hline
\end{tabular}

Values are expressed in ${ }^{1}$ gallic acid and ${ }^{2}$ quercetin equivalent $(\mathrm{mg})$ in every $100 \mathrm{~g}$ of glucose 


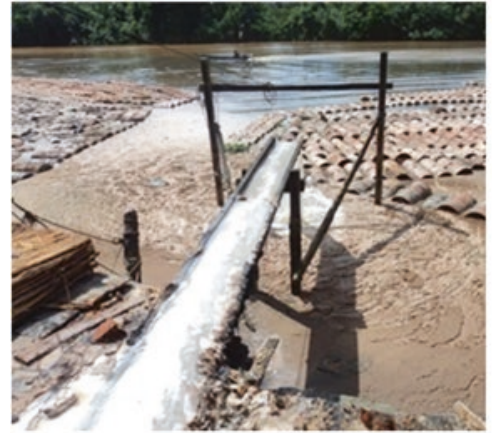

(a)

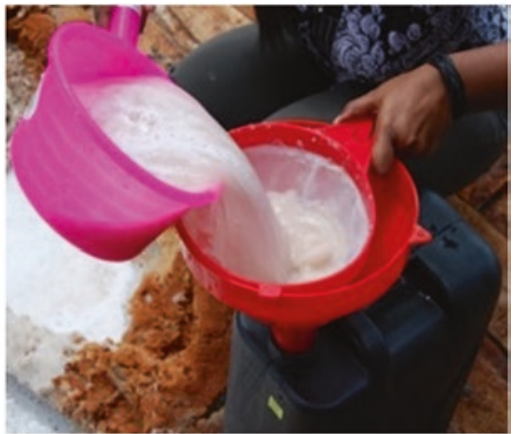

(b)

Fig. 22.2 (a) A typical view of release of sago effluent into the river. (b) Collecting sago hampas by filtering the sago effluent using a normal sieve

Table 22.2 Contents of sago hampas

\begin{tabular}{l|l}
\hline Composition & $\%$ (dry basis) \\
\hline Starch & $30-45$ \\
\hline Moisture & $5-7$ \\
\hline Ash & $3-4$ \\
\hline Protein & 1 \\
\hline Fiber & $30-35$ \\
\hline Fat & Not detected \\
\hline pH & $4.6-4.7$ \\
\hline
\end{tabular}

ported to a processing center. In modern factories, with efficient extraction facilities, waste sago hampas contains less starch (30-45\%), as shown in Table 22.2 (Adeni et al. 2009).

Sago hampas has been treated using steam and hydrolyzed using cellulase, $\beta$-glucosidase, and an enzyme complex at the optimum concentration of 20 and $1.5 \%(\mathrm{v} / \mathrm{w})$, respectively. The optimum digestion period was $20 \mathrm{~h}$ for cellulase and 16 for $\beta$-glucosidase. At the maximum substrate concentration of $6 \%(\mathrm{w} / \mathrm{v})$, enzymatic hydrolysis under these optimum conditions generated $30 \mathrm{~g} / \mathrm{L}$ of sugars or a recovery of 50\% from dried sago hampas (Janggu and Bujang 2009).

Adeni et al. (2013) reported that recycling the hydrolysate in enzymatic hydrolysis of sago hampas for production of sugar greatly increased the yield from one cycle $(27.8 \mathrm{~g} / \mathrm{L})$ to two cycles $(73.0 \mathrm{~g} / \mathrm{L})$ and three cycles $(138.5 \mathrm{~g} / \mathrm{L})$, a recovery of $70 \%$ from sago hampas (w/w). Fermentation of this sugar using baker's yeast generated $40.3 \mathrm{~g} / \mathrm{L}$ of ethanol after $16 \mathrm{~h}$ or $93.3 \%$ theoretical yield based on glucose concentration. 


\subsection{Cellobiose from Sago Leaves}

Apart from sago starch, a current study is looking at the possibility of producing cellobiose, a type of non-table sugar from sago leaves. Cellobiose can be obtained from enzymatic hydrolysis of cellulosic by-products, in this case sago leaves. The hard epidermis from fresh sago leaves is removed, and then the leaves chopped into $2 \mathrm{~cm}$ cubes, pulverized, and boiled for $30 \mathrm{~min}$. The mixture is filtered and the tender solid hydrolyzed using a cellulase enzyme complex (containing cellobiohydrolases, endoglucanases, and $\beta$-glucosidases). Preliminary results showed the yield of cellobiose and glucose from fresh sago at 12 and 5\%, respectively (Ahmad 2015). Cellobiose is a disaccharide, formed from 2 glucose molecules. Although it is not appropriate table sugar, and generally not consumed, it has several prebiotic properties especially in fermented dairy products, including bifidobacteria. Due to this, the market price for refined cellobiose (about USD 2000/kg) is much higher than glucose.

\subsection{Conclusion}

The main and only disadvantage of the sago crop is that the initial waiting period for harvest is $8-10$ years, which could be one of the reasons for hectares of sago land being cleared for oil palm farming. The main benefit of producing cellobiose is that sago farmers would no longer have to wait so long to receive income from the first cycle of sago harvest, since pruned leaves and suckers have been shown to be potential raw materials to yield cellobiose. Sarawak exported 63,000 mt of food-grade sago starch in 2014, with a total value among the different starch types and prices at USD 29.3 million.

Locally, sago starch is sold at USD 500/mt ex-factory price. Converting this even into unrefined sugar can be profitable when compared to cane sugar at USD 800/mt. Bioconversion of sago starch into pure glucose would be much more lucrative since it fetches a higher price to sago starch at USD 12,600/mt. The overall cost for such enzymatic hydrolysis (excluding electricity and labor) has been approximated to be about USD 10/mt of starch, with a calculated profit of about USD 12000/mt.

Acknowledgments The author wishes to acknowledge assistance from the Sago Chair of UNIMAS, NEDO Grant and JSPS Programs from Japan, and IRPA and MOSTI grants from Malaysia, together with cooperation from the State Government of Sarawak and the Sarawak Sago Association, for their financial and logistics support of these studies over the past 15 years. 


\section{References}

Abd-Aziz S (2002) Sago starch and its utilization: a review. J Biosci Bioeng 94(6):526-529

Adam (2010) Parliament: Malaysia imports 99\% sugar supply. Kuala Lumpur, Kuala Lumpur

Adeni DSA, Janggu U, Abd-Aziz S et al (2009) Glucose recovery from sago hampas for ethanol fermentation. In: Proceedings 1st ASEAN sago symposium. Kuching, Sarawak, Malaysia, pp 54-57

Adeni DSA, Bujang KB, Hassan MA, Abd-Aziz S (2013) Recovery of glucose from residual starch of sago hampas for bioethanol production. Biomed Res Int 2013:935852

Ahmad MN (2015) Production of cellobiose from sago frond as antimicrobial agent. Progress report MSc Project. Department of Molecular Biology. Faculty of Resource Science and Technology. Universiti Malaysia Sarawak. Kota Samarahan, Sarawak, Malaysia

Ang SY, Bujang KB, Adeni DSA (2006) Purification of lactic acid from hydrolysed sago starch fermentation by powdered activated carbon (PAC): Adsorption isotherm and kinetic Studies. In: Proceedings 31st Annual conference Malaysian Society Biochem \& Mol Biol, 17th August 2006

Booty HB, Bujang KB (2009) Maximising production of sugars from enzymatic hydrolysis of various starch sources, compared to sago starch. In: Proceedings of the 1st ASEAN sago symposium. Kuching. 29-30 October 2009, pp 70-73

Braun T (1999) Sugarcane. Retrieved October 1, 2010, from Ethnobotanical Leaflets. http://www. ethnoleaflets.com

Bujang KB (2012) A holistic approach to maximise productivities of the sago industry. Plenary speaker. In: Proceedings 2nd ASEAN sago symposium. Co-organised by UNIMAS, CRAUN, IPB \& FAO. 29-30 October 2012, pp 25-27

Bujang KB, Jobli S (2002) Effects of glucose feed concentrations on continuous lactate production from sago starch. In: International symposium tropical natural bio-resources and green chemistry strategy. ICBiotech (Osaka, Japan). October 27-30, 2002, pp 358-363

Bujang KB, Law PL (2006) Pilot-scale production of sugars from sago starch. Bio-Malaysia 2006 Kuala Lumpur Convention Centre 6-8 December 2006

Bujang KB, Apun K, Salleh MA (1996) A study in the production and bioconversion of sago waste. In: Proceedings 6th international sago symposium. Sago: the future source of food and feed. Universitas Riau, Pekanbaru, Sumatra. 9-12 December 1996, pp 193-200

Bujang KB, Adeni DSA, Jolhiri P (2000a) Effects of starch concentration and pH on enzymatic hydrolysis of sago starch. In: Biotechnology for sustainable utilisation of biological resources in the tropics, vol 14. ICBiotech, Osaka, pp 32-35

Bujang KB, Jolhiri P, Ishizaki A (2000b) Effects of $\mathrm{pH}$ on production of lactate from hydrolysed sago starch utilising Lactococcus lactis IO-1. ICBiotech (Osaka Japan) 14:27-31

Bujang KB, Bujang S, Adeni DSA (2004) Effects of calcium carbonate in fermentation of L-lactic acid from hydrolyzed sago starch, vol 26. ICBiotech, Osaka, pp 637-643

Bujang KB, Monib NJ, Nolasco-Hipolito C (2012) Production and purification of sago sugar. In: Proceedings 2nd ASEAN sago symposium. Coorganised by UNIMAS, CRAUN, IPB \& FAO. 29-30 October 2012, pp 171-176

Bujang KB, Hussaini AASA, Adeni DSA et al (2015) Total phenolic, flavonoid content, and antioxidant activity of sago sugar. R\&D Expo 2015. Organised by RIMC. Universiti Malaysia Sarawak, Kota Samarahan, Sarawak, Malaysia

Godshall MA (1996) Flavour components of cane sugars. Sugar Processing Research Institute, Inc, New Orleans

Ishizaki A (1997) Concluding remarks for the 6th international sago symposium. Riau Indonesia Sago Comm 8(2):22-24

Janggu U, Bujang KB (2009) Maximizing sugar production from enzymatic hydrolysis of sago fiber for ethanol fermentation. In: Proceedings 1st ASEAN sago symposium. Kuching, Sarawak, Malaysia. 29-30 October 2009, pp 30-33 
Monib N J (2015) Development on sago sugars recovery and purification by filtration on powdered activated carbon (PAC). Master's Thesis. Dept. of Molecular Biology. Faculty of Resource Science and Technology. Universiti Malaysia Sarawak. Kota Samarahan, Sarawak, Malaysia

Pei-Lang AT, Mohamed AMD, Karim AA (2006) Sago starch and composition of associated components in palms of different growth stages. Carbohydr Polym 63:283-286

USFDA (2013a) FDA approved drug products. US Food and Drug Administration. Retrieved 8 November 2013

USFDA (2013b) Health claims meeting significant scientific agreement. US Food and Drug Administration. Retrieved 8 November 2013

USFDA (2013c) Inspections, compliance, enforcement, and criminal investigations (flavonoid sciences). US Food and Drug Administration. Retrieved 8 November 2013

Yau NJN, McDaniel MR, Bodyfelt FW (1989) Sensory evaluation of sweetened flavoured carbonated milk beverages. J Dairy Sci 72:367-377

Open Access This chapter is licensed under the terms of the Creative Commons Attribution 4.0 International License (http://creativecommons.org/licenses/by/4.0/), which permits use, sharing, adaptation, distribution and reproduction in any medium or format, as long as you give appropriate credit to the original author(s) and the source, provide a link to the Creative Commons license and indicate if changes were made.

The images or other third party material in this chapter are included in the chapter's Creative Commons license, unless indicated otherwise in a credit line to the material. If material is not included in the chapter's Creative Commons license and your intended use is not permitted by statutory regulation or exceeds the permitted use, you will need to obtain permission directly from the copyright holder. 


\title{
Chapter 23 \\ New Sago Palm Starch Resources and Starch Pith Waste Properties
}

\author{
Takashi Mishima
}

\begin{abstract}
Generally, Metroxylon sagu Rottb. contains about $400 \mathrm{~kg}$ of dried starch in the pith of each tree. The starch stored in the pith exceeds $300 \mathrm{~kg}$ according to Ehara et al. (Environmental factors limiting sago production and genetic variation in Metroxylon sagu Rottb. In: Karafir YP, Jong FS, Fere VF (eds) Sago palm development and utilization: proceedings of the 8th international sago symposium. Universitas Negri Papua Press, Manokwari, pp 93-103, 2005). However, only 50\% of starch from the deposits can be extracted using current methods, and one-half remains behind in the residue. In this chapter, the characteristics of sago pith residue and features of these unused resources are described. Specific utilization of starch residue by establishing a conversion method as a sweetener is proposed. The food security of sugar from sugarcane may be helped by a sweetener made from sago starch. The genus Metroxylon has two sections. One is Metroxylon and the other one is Coelococcus. Section Coelococcus is a relict crop. The starch content and physicochemical properties of section Coelococcus are presented. It is anticipated that section Coelococcus will be available as a future source of biomass.
\end{abstract}

The cellulose contained within sago palm trunks is a major carbohydrate resource. However, because of its crystallinity, which makes it very difficult to digest, it presents a challenge to process and use in other products. In contrast, sago starch is an important bioresource and can be eaten, is used as feed for animals and microorganisms, and has industrial applications.

Generally, Metroxylon sagu Rottb. contains approximately $400 \mathrm{~kg}$ of dried starch in the pith of a single tree. According to Ehara et al. (2005), more than $300 \mathrm{~kg}$ of starch is stored in the pith. However, only $50 \%$ of the starch from the deposits can be extracted with current methods, and the other half remains in the residual pith waste.

Starch in sago pith waste occurs in the parenchyma cells (Fig. 23.1). Therefore, it is difficult to extract all of the starch from the pith using mechanical processing,

T. Mishima $(\triangle)$

Graduate School of Regional Innovation Studies, Mie University, Tsu, Japan

e-mail: mishima@bio.mie-u.ac.jp 


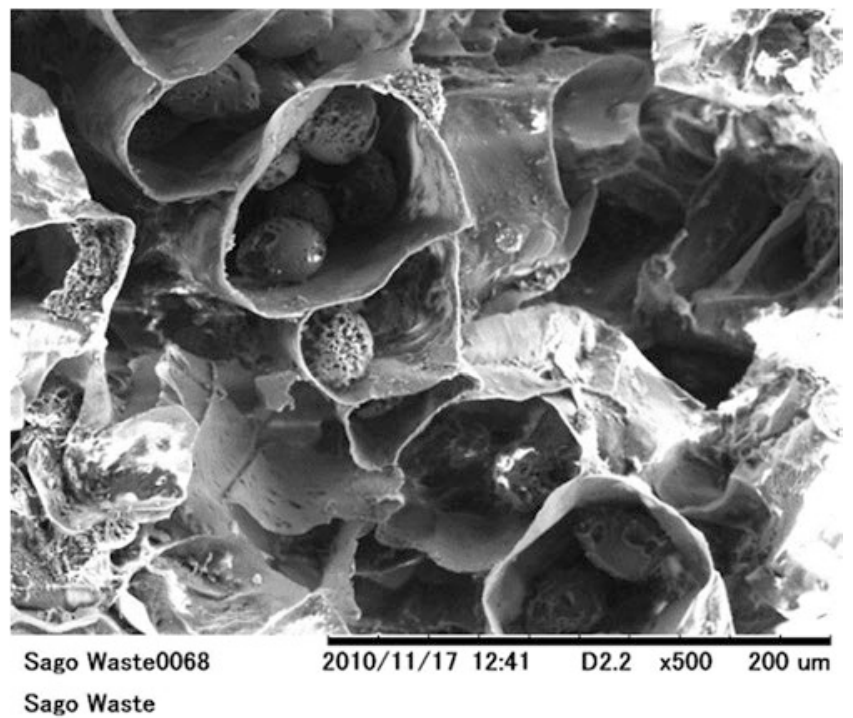

Fig. 23.1 Scanning electron microscope image of sago pith waste Acceleration voltage: $10 \mathrm{kV}$

Note: Holes in the starch may be the result of microorganism digestion

such as a rasper. In this chapter, we propose specific utilization of the starch residue by establishing a conversion method to make it into a sweetener. We also hope that the food security of cane sugar may be improved by producing a sweetener made from sago starch derived from pith waste.

\subsection{Starch in Sago Pith Waste}

The sago palm has a large trunk and grows more quickly than many woody plants. The palm requires approximately 12 years to reach maturity when it is harvestable (Jong 1995). Sago palm has the potential to become an important carbohydrate provider.

From the perspective of industrial starch production, sago palm pith contains approximately $26 \%$ (dry weight) in pith waste (Fig. 23.2). When we measured the starch content using a rasper and also comparatively determined the true starch content using chemical extraction, the pith content was found to be 37 and $77 \%$ in dry weight, respectively (Fig. 23.3). This result confirms that approximately onehalf the volume of starch is left in the pith waste. If we can develop a new extraction technique, it will be possible to use sago pith waste as a biorefinery raw material. 


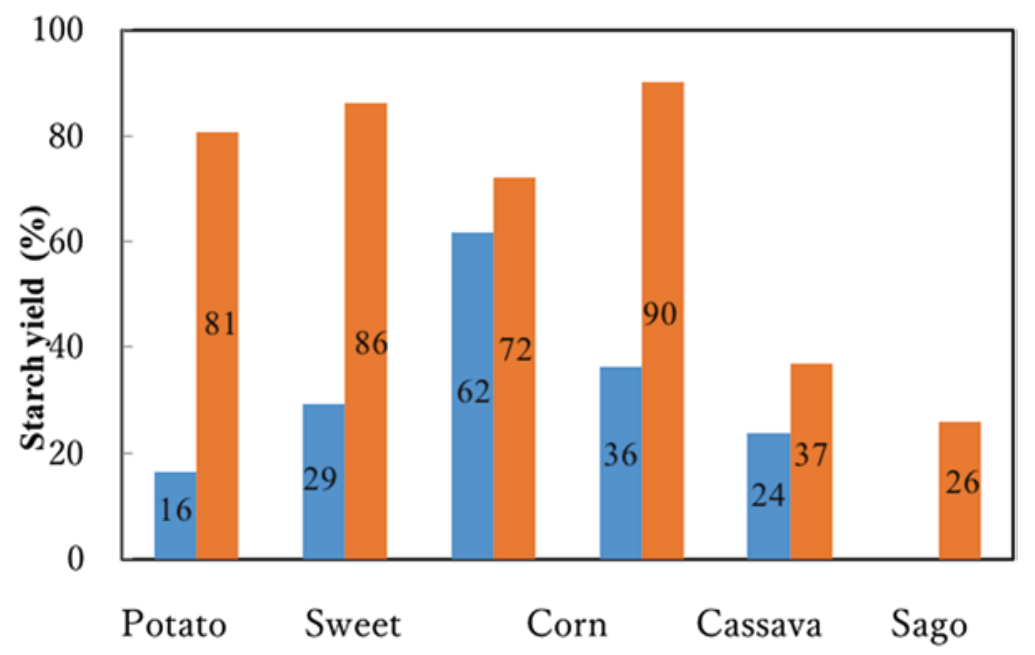

Fig. 23.2 Starch yield of each crop

: Dry starch wet weight

: Dry starch dry weight

Considering the actual processing, the sago palm, like grains, has less water content as compared to the potato

Source: Agriculture and Livestock Industries Corporation 2004, 2008; Jong 1995; Ministry of Agriculture, Forestry and Fisheries, Japan 2009

\subsection{Pith Waste Starch as a Possible Biorefinery Material}

Native starch has a strong crystalline structure that allows it to be stored for a long time. When sago starch is used in the food industry, it is usually treated with water and heat. The process of melting the crystalline structure to make starch is called gelatinization. Gelatinization is an important treatment. Liquefaction and saccharification are important treatments as well. Starch is a glucose polymer with $\alpha-1,4-$ and $\alpha-1,6$-glycosidic bonds. After gelatinization, starch can be easily hydrolyzed by enzymes or acid. The products after liquefaction consist of glucose and maltooligosaccharides. Saccharification makes glucose from liquefaction products. Glucose is an important raw material for sweeteners, ethanols, polyols, organic acids, and amino acids (Whistler 2009).

Simple mechanical treatment of sago pith is an easy and low-cost method. However, the starch yield is quite low. Santoso et al. (2015) proposed a high-level milling treatment for sago pith waste to effectively recover the starch. Please see Chap. 19. This method allows recovery of additional starch from sago pith waste.

As a different method of recovering starch from sago pith waste, a direct liquefaction and saccharification method for sago pith waste is proposed. This method is useful for obtaining maltooligosaccharides and glucose from sago pith waste; 


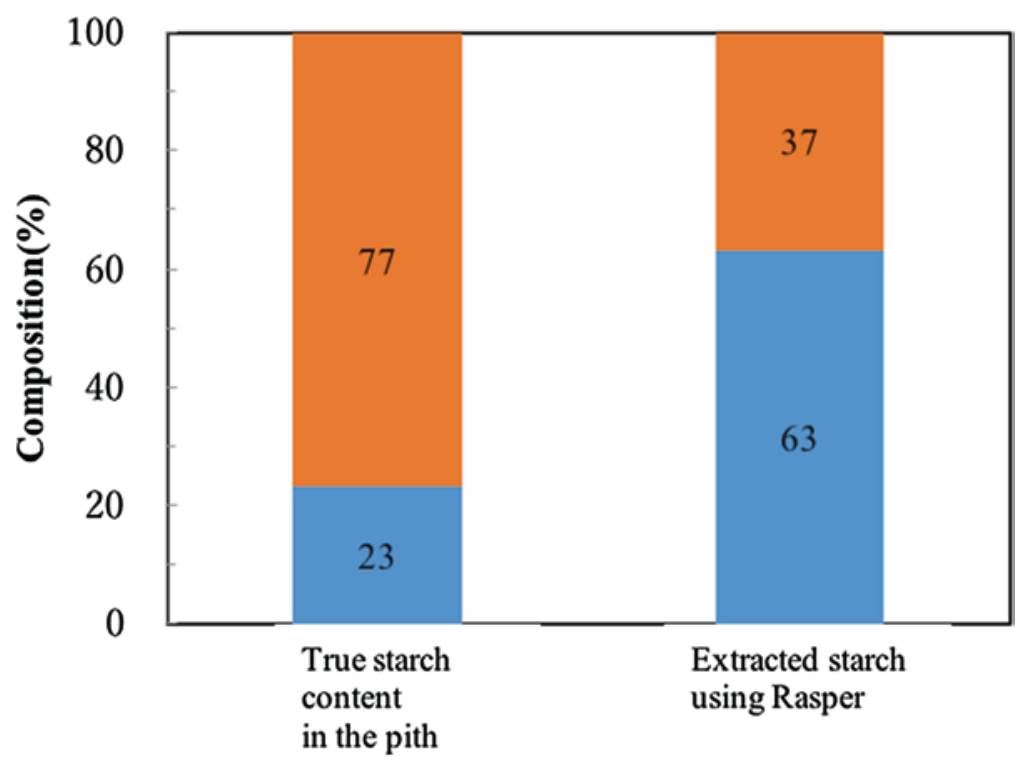

Fig. 23.3 Sago pith and the composition of the extracted substances

: Extracted starch

Others

The starch content was measured and calculated by the solvent extraction method using perchloric acid extraction in order to measure the true starch content

Table 23.1 Viscosity properties of major starch sources

\begin{tabular}{l|l|l|r|r|r|l}
\hline \multirow{2}{*}{ Sample } & \multirow{5}{*}{ Viscosity $($ RVU $)$} \\
\cline { 3 - 7 } & P.T. $\left({ }^{\circ}\right.$ C) & P.V. & F.V. & M.V. & B.D. & S.B. \\
\hline Corn & 76.1 & 114 & 78 & 41 & 72 & 36 \\
\hline Wheat & 84.4 & 108 & 125 & 55 & 54 & 70 \\
\hline Sago & 75.6 & 263 & 192 & 112 & 151 & 80 \\
\hline Potato & 68.9 & 636 & 273 & 204 & 432 & 69 \\
\hline
\end{tabular}

Viscosity measured by Rapid Visco Analyzer RVA-3D (FOSS)

The concentration of the sample was $6 \%$

$P . T$, peak viscosity temperature; $P . V$., peak viscosity; F.V., final viscosity; M.V., minimum viscosity; B.D., breakdown (P.V.-M.V); S.B., setback (F.V.-M.V.)

Source: Kako (2004)

however, some problems must be resolved. Generally, cornstarch is used to make high-fructose corn syrup consisting of fructose and glucose.

The gelatinization process requires agitation, and viscosity is one effective parameter for it. Table 23.1 shows the viscosity of major starch sources. Cornstarch shows the lowest viscosity, and sago starch shows a viscosity twice that of cornstarch. When we directly gelatinize the sago pith waste, the viscosity is so high that we cannot agitate it. Therefore, we tried direct liquefaction, expecting that the 
Table 23.2 Glucose yield treated with micro-powdering, heating, and the addition of Termamyl $120 \mathrm{~L}$

\begin{tabular}{l|l|l}
\hline & With micro-powdering treatment & Without micro-powdering treatment \\
\hline Yield $(\%)$ & 101 & 87 \\
\hline
\end{tabular}

Source: Sakakura (2013)

viscosity would decrease by starch hydrolysis. However, our expectation was not realized because the gelatinization temperature, at approximately $75^{\circ} \mathrm{C}$, was lower than optimal enzyme temperature of approximately $95^{\circ} \mathrm{C}$. Therefore, we combined micro-powdering treatment, direct gelatinization, and direct liquefaction. The micro-powdering treatment of sago pith waste was done using a Super Masscolloider (Masuko Sangyo Co., Ltd., Japan) with tap water. After the treatment, the slurry was heated with Termamyl $120 \mathrm{~L}$ (Novozymes). Table 23.2 demonstrates that the combination of the three treatments makes glucose from the starch in the pith waste.

\subsection{Properties of Metroxylon spp. Sago Palm Starch}

The genus Metroxylon is divided into two sections: Metroxylon and Coelococcus (see Chap. 4). In this chapter, we explain the starch properties of three species of the Coelococcus section: M. vitiense, $M$. warburgii, and M. amicarum.

Scanning electron microscopy images of six sago starches are shown in Fig. 23.4. All starch shapes have a bell or oval form. The results of the starch size distribution show that $M$. sagu and $M$. warburgii are similar in size but that $M$. vitiense and $M$. amicarum are smaller than $M$. sagu (Table 23.3).

The crystalline types of these starches are similar, showing a $\mathrm{C}$ type and approximately $30 \%$ crystallinity (Table 23.3). These data indicate that all samples have similar properties.

The starch contents of four species are shown in Table 23.3. Metroxylon sagu shows the highest starch content, followed by $M$. amicarum and $M$. warburgii; the lowest starch content was found in M. vitiense. The gelatinization properties of these starches are also similar (Table 23.4).

These results demonstrate that the starch properties of palms of the Coelococcus section are similar to those of the Metroxylon section. However, the starch yields of the Coelococcus species are about one-half those in the Metroxylon section; interestingly, the Coelococcus palms reflect a different non-swampy natural habitat. 
Viti Levu, Fiji (M.vitiense)

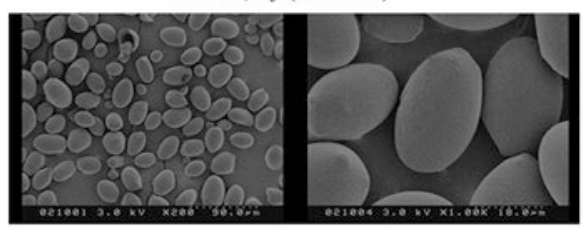

Santo, Vanuatu(M.wagurgii)

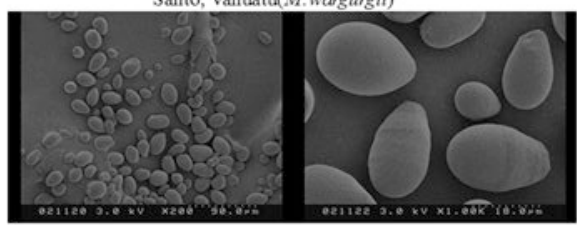

Moen, Micronesia (M.anicarum)

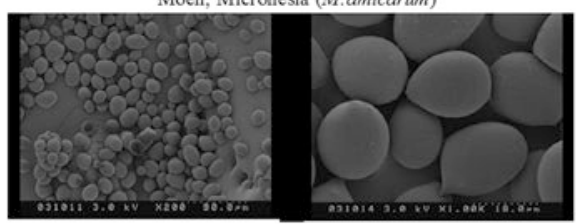

Vanua Levu, Fiji (M.vitiense)

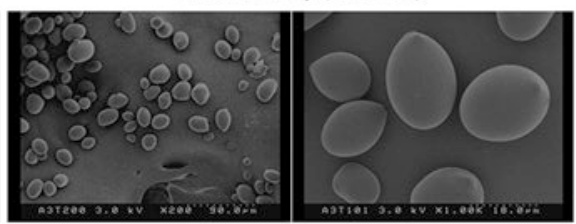

Upolu, Samoa (M.warburgil)

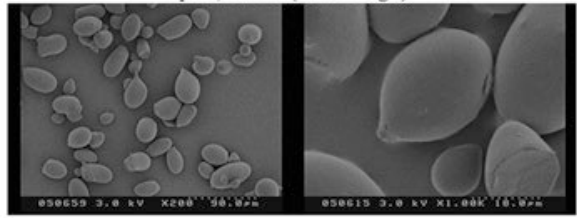

Central Karimantan,Indonesia ( $M . s a g u$ )

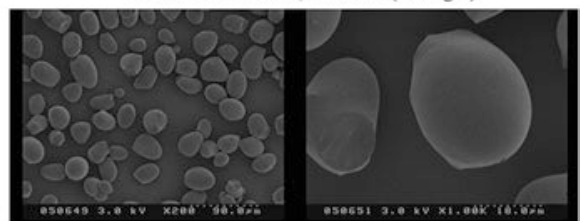

Fig. 23.4 Scanning electron microscopy image of sago starch Acceleration voltage: $3 \mathrm{kV}$. (Source: Mamiya 2005)

Table 23.3 Physicochemical properties of sections of various sago starches

\begin{tabular}{l|l|l|l|l|l}
\hline & $\begin{array}{l}\text { Long diameter } \\
(\mu \mathrm{m})\end{array}$ & $\begin{array}{l}\text { Short diameter } \\
(\mathrm{mm})\end{array}$ & $\begin{array}{l}\text { Crystallinity } \\
(\%)\end{array}$ & $\begin{array}{l}\text { Crystalline } \\
\text { type }\end{array}$ & $\begin{array}{l}\text { Starch } \\
\text { content }(\%)\end{array}$ \\
\hline $\begin{array}{l}\text { Metroxylon } \\
\text { vitiense }\end{array}$ & 21.6 & 15.7 & 29.4 & $\mathrm{C}$ & 27 \\
\hline M. warburgii & 29.2 & 19.3 & 28.7 & $\mathrm{C}$ & 36 \\
\hline M. amicarum & 19.0 & 15.5 & N.T. & $\mathrm{C}$ & 39 \\
\hline M. sagu & 30.5 & 21.8 & 32.3 & $\mathrm{C}$ & 77 \\
\hline
\end{tabular}

Source: Kako (2004)

Table 23.4 DSC properties of various sago starches

\begin{tabular}{l|l|l|l|l}
\hline & $\mathrm{To}\left({ }^{\circ} \mathrm{C}\right)$ & $\mathrm{Tp}\left({ }^{\circ} \mathrm{C}\right)$ & $\mathrm{Tc}\left({ }^{\circ} \mathrm{C}\right)$ & $\Delta \mathrm{H}(\mathrm{mJ} / \mathrm{mg})$ \\
\hline Metroxylon vitiense & 66.1 & 69.5 & 73.8 & 13.7 \\
\hline M. warburgii & 65.4 & 69.2 & 73.7 & 13.7 \\
\hline M. sagu & 66.6 & 71.7 & 76.9 & 15.4 \\
\hline
\end{tabular}

Source: Kako (2004) 


\section{References}

Agriculture \& Livestock Industries Corporation (2004) Sugar trivia. About isomerized glucose syrup http://sugar.alic.go.jp/tisiki/ti_0408.htm [in Japanese]

Agriculture \& Livestock Industries Corporation (2008) The situation regarding tapioca starch in Thailand http://www.alic.go.jp/starch/world/country/200802-03.html [in Japanese]

Ehara H, Naito H, Mizota C (2005) Environmental factors limiting sago production and genetic variation in Metroxylon sagu Rottb. In: Karafir YP, Jong FS, Fere VF (eds) Sago palm development and utilization: proceedings of the 8th international sago symposium. Universitas Negri Papua Press, Manokwari, pp 93-103

Jong FS (1995) Distribution and variation in the starch content of sago palms (Metroxylon sagu Rottb.) at different growth stages. Sago Palm 3(2):45-54

Kako S (2004) Physicochemical properties of starch from Metroxylon section Coelococcus. Master's thesis, Mie University [in Japanese]

Mamiya K (2005) Physicochemical properties and molecular shape of sago starch. Master's thesis, Mie University [in Japanese]

Ministry of Agriculture, Forestry and Fisheries, Japan (2009) The situation regarding potatoes and starch http://www.maff.go.jp/j/study/denpun/h210710/pdf/data3.pdf [in Japanese]

Sakakura K (2013) Study on production of isomerized sugar using sago palm starch extraction residue. Master's thesis, Mie University [in Japanese]

Santoso B, Sakakura K, Naito H et al (2015) Effects of micro powder milling on physicochemical properties of sago starch. J Appl Glycosci 62(2):73-80

Whistler RL (2009) Development of specialty starches. In: BeMiller J, Whistler RL (eds) Starch: chemistry and technology, Third edn. Academic Press, London, pp 6-9

Open Access This chapter is licensed under the terms of the Creative Commons Attribution 4.0 International License (http://creativecommons.org/licenses/by/4.0/), which permits use, sharing, adaptation, distribution and reproduction in any medium or format, as long as you give appropriate credit to the original author(s) and the source, provide a link to the Creative Commons license and indicate if changes were made.

The images or other third party material in this chapter are included in the chapter's Creative Commons license, unless indicated otherwise in a credit line to the material. If material is not included in the chapter's Creative Commons license and your intended use is not permitted by statutory regulation or exceeds the permitted use, you will need to obtain permission directly from the copyright holder. 
Part VIII

Conclusion 


\title{
Chapter 24 \\ Outcomes and Recommendations \\ from the 12th International Sago Symposium
}

\author{
Yoshinori Yamamoto
}

\begin{abstract}
The 12th International Sago Symposium took place in Tokyo, Japan, in 2015. This chapter reviews the recent and advanced information presented at the symposium. All symposium presentations are categorized under eight topics and summarized, and the outcomes and recommendations described.
\end{abstract}

\subsection{International Sago Symposium}

Since the First International Sago Symposium was held in Kuching in 1976, a sago symposium has been convened each 2-6 years thereafter, and the 12th International Sago Symposium took place in Tokyo (venue: Ikebukuro Campus of Rikkyo University) in 2015. The countries where the symposia have been held are those where sago palms grow, such as Malaysia, Thailand, Indonesia, Papua New Guinea, and the Philippines, except Japan. In Japan, the sago palm and sago research were promoted by the enthusiastic efforts of the late Dr. Isao Nagato who provided financial support to fund the Society for the Sago Palm and Sago Culture (presently the Society of Sago Palm Studies) in 1992 and for young Japanese researchers to conduct sago palm research in the sago palm-growing countries. Dr. Nagato also gave financial support to international sago symposia not only in Japan but also in other countries. The research results from Japan and the Southeast Asian countries have been presented at the annual meeting of the Society of Sago Palm Studies and the papers published in the Society's journal SAGO PALM. In 2010, the research results appeared in the publication of Sagoyashi (in Japanese) (Kyoto University Press), and in 2015 the English version The Sago Palm (Kyoto University Press and Transpacific Press) was published with the financial support of the Japan Society for Promotion of Science.

In this chapter, first, all the presentations at the 12th International Symposium are summarized (The Society of Sago Palm Studies 2015) and categorized under seven topics to share the information presented at the symposium, and then the

Y. Yamamoto $(\square)$

Kochi University, Nankoku, Kochi, Japan

e-mail: yamayosi@kochi-u.ac.jp 
outcomes and recommendations are described. Some of the presentations are included in this book, providing more information. Please refer to the proceedings (Ehara et al. 2016) for more information about the presentations not included in this book.

\subsection{Summaries of Presentations at the 12th International Sago Symposium}

\subsubsection{Sago as a Resource in Its Growing Areas}

Jong (Malaysia) reviewed the changes in the scale of processing and starch extraction techniques of sago starch factories, starch production rates, and utilization of sago starch in Malaysia and Indonesia from the 1980s to 2015. He also reviewed the development of sago palm plantations established in Selat Panjang, Riau, and conversion of wild sago forests into sago plantations in South Sorong, West Papua, Indonesia, based on his experience related to those developments. He concluded that sago plantation development and industrialization of sago factories are considerably behind in realizing their potentials and upcoming actions should be implemented in a way to be attractive to future investors.

Mofu and Abbas (Indonesia) of the University of Papua founded the Sago Palm Research Consortium (SPRC) which includes governmental organizations and the private sector to promote the industrial utilization of sago palm, which is the traditional starch crop in Papua. They reported on mechanization trials of starch extraction, utilization of sago starch as ingredients in various kinds of cakes and cooked dishes, to make feedstock for fish, etc. Haska (Indonesia) reported the necessity of sustainable development of the natural sago forests in Papua, considering preservation of the ecosystem and biodiversity in view of the increased interest in sago palm as a profitable business commodity in recent years. Quevedo and Lina (Philippines) reviewed the history of sago palm research in the Philippines and the current status of sago palm-growing areas and utilization. Sago palm research in the Philippines began in Mindanao, at the University of Philippines Mindanao, where sago palm grows, followed by the Visayas area (Aklan State University). Considering the current status of sago palm-growing areas, they proposed the need to develop sago palm plantations to assure that enough raw materials would be available for starch extraction if the industrialization of sago palm proceeds later in the Philippines. Pue et al. (PNG) reported that the consumption of sago starch as a staple food in PNG is decreasing, brought about by the introduction of new staple crops, such as rice, to PNG and the misunderstanding of sago palm in relation to hemolytic disease. He pointed out the importance of sago palm in the future as a staple food in PNG, especially in the areas where high population increase is predicted and crop yields are low due to limited areas of fertile soils. Sago is also important from the viewpoint of food security caused by climate change. 
Watling (Fiji) reported about Metroxylon vitiense traditionally growing in Fiji since ancient times, which is rapidly decreasing in population through clearance of land for agriculture, fires, large-scale coastal drainage schemes, and residential development; the palm is now restricted to less than 20 isolated populations. Moreover, in the past 20 years, populations continue to decrease due to the utilization of leaves for roofing materials for tourism structures and tree destruction for palm heart consumption. To preserve the palm under these conditions, a species recovery plan was agreed to and is being implemented by landowners, government agencies, and users.

Djodikusumo et al. (Indonesia) estimated the annual potential sago starch production in Papua at 150 million $\mathrm{mt}$ ( 500 million ha $\times 30 \mathrm{mt} / \mathrm{ha} / \mathrm{year}$ ) which theoretically could sustain 1.5 billion people ( $100 \mathrm{~kg} \mathrm{starch} / \mathrm{capita} / \mathrm{year})$; therefore, the sago forests in Papua are significant not only to Indonesia but also represent a world asset. However, to realize this there need to be policies to prevent conversion of natural sago forests to agricultural land for other crops and to develop modern equipment for starch extraction and drying to reduce labor requirements. Wulan et al. (Indonesia) carried out a sustainability analysis of three food commodities, rice, oil palm, and sago palm, on peat land. The analysis consisted of environmental analysis using a life cycle assessment (LCA), an economic analysis with environmental life cycle costing (LCC), a social analysis using social life cycle assessment (SLCA), a sustainability assessment using life cycle sustainability dashboard (LCSD), and a life cycle sustainability assessment (LSSA). The results revealed that sago palm is the most sustainable commodity among the three crops cultivated on peat land.

Hasada (Japan) examined the economics of sago starch production at the cottageindustry level using semi-cultivated sago stands and the possibility and constraints of expanding sago starch production in Southeast Sulawesi, Indonesia. The results suggest that, in order to succeed in promoting the sago starch production industry, the following concerns must be addressed: (1) diversification of market channels to expedite stable income generation, (2) provision of financial services that promote capital investment, and (3) development or improvement of processing equipment and overhaul of the current sago palm cultivation and utilization systems to reduce labor needs. Girsang et al. (Indonesia) discussed the possibility of enlargement of starch factories in Seram and Ambon Islands, Maluku Province, Indonesia, comparing the current small-scale sago factories with traditional, semi-modern, and modern technologies. The results revealed that the modernization of sago factory promoted starch production, labor absorption, and profit, but it was difficult to sustain because of raw material preparation, uncertain market demand, and fragile institutional development. 


\subsubsection{Diversity of Sago Resource in Asia and Pacific}

Johnson (USA) reviewed the history, geographic distribution, habitat characteristics, and classification of the palms of the genus Metroxylon. Ehara et al. (Japan) reported on the geographic distribution, starch productivity, and current status of utilization of the palms belonging to the Metroxylon and Coleococcus sections of Metroxylon. The report showed that the starch productivity of the palms belonging to the Coleococcus section were lower than those of Metroxylon. Moreover, the genetic diversity of sago palms growing in the eastern areas of the Malay Archipelago was greater than that of the western areas. The study used the RAPD (random amplified polymorphic DNA) method and divided the sago palms of the Malay Archipelago into four broad groups. Abbas et al. (Indonesia) recognized the intraspecific variation among 11 accessions collected in Papua Province, Indonesia, through the DNA analysis of the mitochondrial genome. Moreover, Matanubun (Indonesia) and Dewi et al. (Indonesia) reported the morphological differences among the sago palm folk varieties growing around Lake Sentani, Papua, Indonesia, and the relationship between the genetic differences and starch productivity among 12 accessions of wild sago palms growing in South Sorong, West Papua, Indonesia, respectively. In addition, Bilbao and Novero (Philippines) researched the genetic difference between suckering and non-suckering sago palms by SSR (simple sequence repeat) analysis, applying the primer sets used to establish genetic differences in date palm. Also, Ibrahim et al. (Malaysia) reported the minimal inhibitory concentration of Basra ${ }^{\mathrm{TM}}$, as a selection agent of transformed cells, for the sago palm transformant selection in the future.

\subsubsection{Agricultural Botany of Sago Palm}

Nakamura et al. (Japan) analyzed the growth pattern of sago palm suckers after transplanting and divided the growth pattern into three stages: (1) creeping (horizontally elongating) growth stage (4-5 years), (2) transition (shifting) growth stage from horizontal to vertical (1-1.5 years), and (3) trunk elongation (vertical) growth stage (6-7 years). Nabeya et al. (Japan), from the same research group in Nakamura (Japan), showed the same growth pattern of suckers emerging from the mother stem (primary suckers) and the suckers emerging from the primary suckers (secondary suckers) as the mother stem, as shown by Nakamura. Besides, they showed that the horizontal growth rate of the stem was closely related to the leaf production rate and that the rates were slower with the increasing order of suckers. Miyazaki et al. (Japan) reported the differences of root development (root weight at different vertical and horizontal positions from the palm trunk) by palm age, growing regions, and varieties. The total root weight and the root weight ratio of deep soil layers increased with palm age, and varietal differences in root weight at the same growth stage were clearly observed. 
Yamamoto (Japan) reported the total biomass production and of each part or organ of shoots (aboveground part) in two sago palm varieties growing in Southeast Sulawesi, Indonesia, with palm age and factors related to biomass production, that is, leaf area, photosynthetic rate of leaf, and growth duration. The results revealed that the varietal difference in biomass production is closely related to the leaf area per palm, and it was mainly determined by the leaf area per leaf compared to the number of leaves. Moreover, the leaflet width contributed most to the leaf area per leaf. Based on these data, he analyzed the varietal difference in starch production from the viewpoints of biomass production, distribution ratio to harvesting portion (pith), and starch percentage in pith. The varietal difference in starch production is mainly based on the difference in biomass production.

Delima et al. (Philippines) and Acaso (Philippines) reported research on embryo culture of sago palm seeds. Delima et al. succeeded in producing plantlets by embryo culture irrespective of the degree of seed maturity and seed size. Acaso et al. obtained plantlets with $10.5 \mathrm{~mm}$ shoots and $13.5 \mathrm{~mm}$ roots after 4 weeks by embryo culture under one-half MS medium with kinetin (3 mg/L) + ABA $(0.01 \mathrm{mg} / \mathrm{L})+\mathrm{GA}(0.1 \mathrm{~m} / \mathrm{L})$.

To determine the tolerance of sago palm to high Al concentration in soil, Chuchimanukul et al. (Japan) grew sago palm seedlings under different $\mathrm{Al}$ concentrations in the medium $(0,150,300 \mathrm{ppm})$. The results showed that the top growth was not affected by $\mathrm{Al}$ concentrations at 8 weeks after treatment, but the root growth was severely affected, the diameter decreased, and color darkened with the increase of $\mathrm{Al}$ concentration. From these results they concluded that a high concentration of $\mathrm{Al}$ in soil first affects root growth, in the early growth stage.

In addition, Amarillis et al. (Indonesia) and Ahyuni et al. (Indonesia) reported the effects of sucker size and plant hormones on the early growth of suckers and the effects of nursery periods on the early growth of suckers, respectively.

\subsubsection{Growth Environment}

Mori et al. (Japan) and Sasaki et al. (Japan) reported on microclimatic and soil environmental effects on the conversion of wild sago palm forests into sago palm plantations, respectively, as initial findings. For the microclimatic changes, air temperature, humidity, wind direction, and air pressure in the wild sago forests were compared with those in an open field. Light absorption, transmittance and reflectance, and soil moisture was monitored in the wild sago palm forests. For the soil environment, changes of peat thickness, underground level, soil subsidence, decomposition rate of organic matter, and so forth, after development of wild sago forests, were measured.

Yusuf et al. (Malaysia) analyzed growth results and starch production of sago palms cultivated on deep peat soil; Anderson series 3 ( $>2 \mathrm{~m}$ peat depth), in relation to the sago palm plantation development in Sarawak, Malaysia (LCDA/PERITA 19,063 ha), could not grow well even with fertilizer application. In the experiments, 
suckers grown under the same conditions were planted on the deep peat ( $>5 \mathrm{~m}$ peat depth) and mineral soils, with the thinning of suckers and application of sufficient fertilizer following $\mathrm{P}^{32}$ isotope experimental procedures. Consequently, the sago palm suckers growing on the peat soil showed good growth, comparable to those growing on mineral soil, but growth was gradually retarded after 5 years, and only $36 \%$ of palms (cf. 100\% on mineral soil) reached harvesting stage and had starch yields of only $20 \mathrm{~kg}$ starch yield (cf. starch yield of sago palms grown on mineral soil of $150 \mathrm{~kg}$ per palm). From these results, it was concluded that it is impossible to cultivate sago palms economically on peat soil; cultivation should be restricted to mineral and shallow peat soils.

Watanabe et al. (Japan) estimated the carbon balance within a sago palm garden on peat soil in Sarawak, Malaysia, through the comparison of carbon income by carbon fixation by sago palms and weeds and carbon supply to the soil by fallen leaves and carbon expenditure by emission of carbon dioxide and methane from the soil. Results revealed that the carbon expenditure was higher than the carbon income in the peat soil where sago palms were growing.

With regard to the nutrient acquisition of sago palm in relation to microorganisms, there were two papers presented. Toyota and Shrestha (Japan) isolated nitrogen-fixing bacteria from all parts of sago palm and extracted starch; all the isolates preferred simple carbon compounds as their carbon sources and their activities markedly increased when they were co-cultured in starch or hemicellulose medium with starch or hemicellulose-degrading bacteria. On the other hand, Chan (Malaysia) discussed how to change the relationship between the sago palm and the arbuscular mycorrhiza (AM), which contribute to $\mathrm{P}$ absorption, by soil drainage and $\mathrm{P}$ application, and showed the possibility of reducing the colonization of AM due to lower $\mathrm{pH}$ by $\mathrm{P}$ application, although the relationship did not change by the drainage and $\mathrm{P}$ application.

Umemura et al. (Japan) reported that the people living around Lake Blackwater located in the Central Sepik Plain, PNG, where sago palms are growing on peat soil, adapted to the oligotrophic environment through application of minerals such as $\mathrm{Fe}$, especially from well water and mineral-rich plants.

\subsubsection{Development of Technology in Starch Extraction and Utilization}

\subsubsection{Starch Extraction}

Regarding the starch extraction methods in sago palm-growing areas, Nishimura (Japan) pointed out that they changed from the traditional manual method in the original location (New Guinea Island) to an effective mechanical method (the western area of Malay Archipelago), corresponding to the change of utilization from staple food to commercial industrial commodities. Darma et al. (Indonesia) investigated the effect of cylinder teeth density and rotation speed on power requirements 
and specific energy consumption of a cylinder-type sago rasper. The results showed that the power requirements and specific energy consumption increased with higher teeth density and higher cylinder rotation speed.

Supriyanto et al. (Indonesia) and Haryanto et al. (Indonesia) reported on the dry processing of sago starch instead of wet processing. The dry process involves debarking the trunk, chipping the pith into thin strips, drying, sieving, grinding, and cyclone separation. The starch extracted by this method contains a slightly higher fiber content (about 3\%) than that from the wet method (about 1\%), but this method can save great amounts of water and avoid the pollution by waste water; Suprianto et al. called this method Green Technology. The fiber content in flour derived from the dry method could be reduced by yeast fermentation treatment before drying the sago pith to about $1 \%$ fiber content (Harianto et al.).

\subsubsection{Starch Utilization}

Yokota et al. (Japan) tried to utilize sago starch to make udon noodles, a traditional Japanese food usually made from wheat flour, to enable wheat allergy sufferers to eat the noodle. Udon noodles made from sago starch were highly rated for smoothness, stickiness, and sensory quality, although it was assessed to be a harder noodle as compared to the noodles made from rice, wheat, potato, or kudzu flour. In the sensory test evaluation, sago starch noodles were favored when $50 \%$ of the nonglutinous rice flour was substituted.

\subsubsection{Sago Hampas (Waste) Utilization}

According to reports (Shuiling 2006; Yamamoto et al. 2007), about one-half of the starch in sago palm pith is not extracted and gets discarded as hampas without any utilization. Therefore, the intent of researchers to extract the starch from the hampas and to develop its utilization for many purposes is increasing. One paper related to the starch extraction method from sago hampas and four papers related to the utilization of sago hampas were reported. Santosa et al. (Japan) reported that $21 \%$ of starch (dry weight basis of the hampas) was recovered from the sago hampas through wet milling by using a super mass colloidal mill; the physical properties of the starch are the same as those of starch directly extracted from the pith. Sudiana et al. (Indonesia) and Rachmat et al. (Indonesia) reported the possibilities to produce charcoal briquettes and high-quality silica and waste briquette, respectively; the charcoal and waste briquettes could replace fuel wood. Freddy et al. (Indonesia) suggested sago hampas as an appropriate material for making ethanol due to the high content of carbohydrates (82.4\%). Sunarti et al. (Indonesia) reported that the mechanical characteristics of biodegradable foam, in terms of moduli in rupture and in elasticity produced from the sago hampas, were improved through acid modification by soaking the hampas in $0.144 \% \mathrm{HCl}$ solution and methanol. 


\subsubsection{Sago Starch Properties}

Nitta et al. (Japan) used electron microscopic observations to clarify the type, multiplication, size, and distribution of starch in the sago palm pith in relation to its accumulation. Quanytah et al. (Indonesia) reported the characteristics of sago starches collected from 16 accessions in South Sorong, West Papua, including CIE $1976 \mathrm{~L} * \mathrm{a} * \mathrm{~b} *$ color difference, water, ash, fat and amylose contents, granular size of starch, X-ray diffraction, etc.

Okazaki (Japan) reported that the type of crystalline structure of sago palm starch was $\mathrm{C}$ type, containing both A- and B-type crystalline structure, from the X-ray diffraction patterns, and it showed the flexibility of moisture and heating in the gelatinization processes up to $80{ }^{\circ} \mathrm{C}$. In relation to this report, Katsumi et al. (Japan) proposed using the crystalline index (CI) to evaluate the regularity and deficit of crystalline components in starch from the X-ray diffraction. The results showed that the CI of sago starch is lower than that of corn and potato starch and that the CI is related to the gelatinization temperature and retrogradation of starches.

\subsubsection{New Carbohydrate Resources}

Bujang (Malaysia) reviewed long-term research on production of sugars from sago starch and cellobiose production from sago palm leaves. Sago starch can be enzymatically hydrolyzed into sugar with total $(100 \%)$ recovery and the syrup purified using powdered activated charcoal under gravity to remove all impurities and color. The sweetness of the sugar is about 50\% that of glucose. The brown sugar, without removing impurities and color, has health benefits due to the presence of antioxidants (phenols $300 \mathrm{mg} / \mathrm{kg}$ ). Another product, cellobiose, is a pharmaceutical sugar and commands a high price. From these results, he concluded sago palm is a highpotential crop and a substitute for imported cane sugar in Malaysia.

\subsection{Outcomes and Recommendations}

\subsubsection{Sago as Resources in Its Growing Areas}

Recognition of sago palm as a high-potential starch crop (a food energy crop) appears to be making steady progress in the countries where it grows, from the viewpoints of food security in relation to the projected population increase and global climate change. In addition, research on the impact of sago starch industrialization to economic development of rural area is being promoted. Under such circumstances, it is noteworthy that the University of Papua started to mechanize the starch extraction processes and to develop new commodities made from sago starch, 
by organizing the SPRC (Sago Palm Research Consortium). The Consortium is made up of governmental institutions and the private sector in Indonesian Papua, where wild sago palm area are widespread and starch from the palm has long been utilized as a staple food. It is hoped the activities of SPRC are successfully advanced.

\subsubsection{Diversity of Sago Resource in Asia and Pacific}

Many types of sago palms with different morphological characters, starch productivity, etc. are recognized in the sago palm-growing areas, especially in Papua, Indonesia, and in PNG which is considered the center of diversity of the sago palm. However, the ways in which these differences of sago palms are related to genetic makeup are not clear. There is an urgent need to establish varietal criteria in sago palm taxonomy and to clarify the varietal differences of morphological characters, starch yield, etc., under the same growing conditions such as soil type, groundwater level, management of suckers, and so forth, to evaluate properly the varietal differences of these characters.

\subsubsection{Agricultural Botany of Sago Palm}

To harvest sago palms sustainably, there is a need to develop a management system for sago palm gardens. Sucker control is the core technique for developing the management system. The growth patterns of primary and secondary suckers as well as the mother suckers reported in the symposium provide guidance on how to control the suckers. The report, Miyazaki et al. (Japan), on the root system development of sago palm related to palm age also provides useful information to manage water and fertilizer application in a sago palm garden. The report, Yamamoto (Japan), on the changes in biomass and dry matter distribution to each organ or part (above ground) with palm age and the factors related to the biomass production in varieties with different starch productivity provides not only basic valuable information about the development and growth of sago palm but also essential information for breeding high-yielding varieties. Moreover, the establishment of a high-probability technique for embryo culture may contribute to create new varieties and mass production of seedlings of excellent varieties.

\subsubsection{Growth Environment}

The reports, Mori et al. (Japan) and Sasaki et al. (Japan), on microclimatic and soil environmental conditions of wild sago forests are noteworthy in considering the sustainable development during a time when the concerns of governments and 
private companies for the development of wild sago forests is increasing. The report, Watanabe et al. (Japan), of carbon balance in peat soil where sago palms grow provides useful information for the contribution of sago palm-growing areas to greenhouse gas emission in relation to global warming. This environmental research is expected to continue in the representative sago-growing sites for many years following the same methods. The conclusion of the report by Yusuf et al. (Malaysia) that economic cultivation of sago palm is very difficult on deep peat soil $(>5 \mathrm{~m}$ thick) in Sarawak, Malaysia, and should be restricted to mineral and shallow peat soils may affect the future development of sago palm plantations on deep peat soil because it has been believed that sago palm is the only crop which can grow well on deep peat soil and be cultivated economically on the soil without any improvement. The area of peat soil is estimated at about 30 million ha in Southeast Asia (Kyuma 1986) and may differ in depth and physicochemical properties from site to site. Therefore, detailed research into how the soil depth and the physicochemical properties affect the growth and starch yield of sago palm should be conducted in typical deep peat areas in Indonesia, Malaysia, PNG, etc. Studies should also address how to improve deep peat soil as appropriate land for the cultivation of sago palm, based on the results of characteristics of peat soil in the future. Two interesting research studies, Toyota and Shrestha (Japan) and Chan (Malaysia), in relation to sago palm and microorganisms, nitrogen-fixing bacteria, and arbuscular mycorrhiza, were reported at the symposium. These studies show the possibility of nutrient supply to sago palm by the microorganisms, so it is expected to clarify quantitatively the contribution ratio of these microorganisms to the nitrogen and phosphorous absorption of sago palm.

\subsubsection{Development of Technology in Starch Extraction and Utilization}

In relation to starch extraction from sago palm pith, the dry sago flour making method, in which sago flour is produced through the process of drying the pith, crushing the dried pith, and sieving for fibers, as an alternative to the wet extraction method, was called Green Technology, because it makes it possible to avoid pollution from extraction waste water. It appears to be necessary to develop methods to remove the fibers from the flour, for example, by using yeast before drying the pith, as reported by Haryanto et al. (Indonesia), and to clarify the physicochemical properties of the sago flour. Regarding starch extraction from sago hampas (waste), in which one-half of the total amount of starch remains in the pith (Shuiling 2006; Yamamoto et al. 2007), the wet-milling method using a super mass colloidal mill makes it possible to extract a considerable amount of starch from the hampas without deforming the physical properties of the starch. The reports by Indonesian researchers on utilization of sago hampas as a material for fuel and biodegradable plastic show developing interest in sago hampas. Regarding the development of 
sago starch utilization, udon noodles made with sago starch, a traditional Japanese food usually made from wheat flour, enables wheat allergy sufferers to eat the noodle and was rated highly in a sensory test evaluation. It could contribute to develop the utilization of sago starch as an allergy avoidable food material.

\subsubsection{Sago Starch Properties}

The multiplication, distribution, and amount of sago starch in the pith were reported by observations with a scanning electron microscope. In addition, the characteristics of sago starch collected from 16 accessions in South Sorong, West Papua, Indonesia, were reported. It is desirable to clarify the differences of starch characteristics of sago palms growing under different conditions, as well as the varietal differences. The physical characteristic of sago starch from the X-ray diffraction pattern was clarified, and the crystalline index (CI) evaluated the regularity and deficit of crystalline components in starch from the X-ray diffraction, which was proposed to clearly show the differences of characteristics of starches from various crops. Clarification of the relationship between the physical and chemical properties of sago starch to promote the utilization should be performed.

\subsubsection{New Carbohydrate Resources}

The sago starch utilization research group at UNIMAS (University of Malaysia, Sarawak) has succeeded in producing sugars from sago starch and sago hampas and cellobiose from sago leaves. The results showed the possibility of industrialization of sugar production from sago starch in place of cane sugar and cellobiose production from sago leaves as a pharmaceutical sugar of high value.

\subsubsection{Other Palms}

The starch-accumulating palms belong to 12 genera among about 200 genera of the Arecaceae family. However, thus far research has been predominantly focused on palms in the genus Metroxylon, especially sago palm (M. sagu Rottb.). In such circumstances, Ehara et al. (Japan) reported the starch yield of the palms in the Coleococcus section of Metroxylon (M. salomonense, M. warburgii, M. vitiense, M. amicarum) in this Symposium. Ishima et al. (Japan) and Pasolon et al. (Indonesia) reported research on sugar palm (Arenga pinnata Merr.). The former report revealed the maximum starch yield (100-150 kg dry starch/palm) could be harvested at the growth stage from just before the emergence of female and male inflorescences. The latter reports discussed the relationship between the quantity of sap produced and 
growth characters of the palm. The research group organized by Yamamoto has reported the starch yields of several starch-accumulating palms including Arenga microcarpa, Corypha utan, Caryota mitis, as well as sugar palm (Yamamoto 2010, 2015) which was reported by Ishima et al. in this Symposium. The research on starch-accumulating palms, not only sago palm, but also other minor palms, which are adapted to various environmental conditions, need to be assessed for their possible contribution to the food security under the predicted global climate change.

\section{References}

Ehara E, Toyoda Y, Mishima T et al (eds) (2016) Proceedings of the 12th international sago symposium - the sago supports human planet welfare. The sago palm studies, Tokyo, pp 1-161. (CD version)

Kyuma K (1986) Organic soils in wetland forests: tropical peat soils. In: Lowland swamps in Southeast Asia. Tropical Agricultural Research Center, Norin Tokei Kyokai, Tokyo, pp 79-103. (in Japanese)

Shuiling DL (2006) Traditional starch extraction from the trunk of sago palm (Metroxylon sagu Rottb.) in West Seram (Maluku, Indonesia). In: Karafir YP, Jong FS, Fere VE (eds) Sago palm development and utilization: proceedings of the 8th international sago symposium. Universitas Negeri Papua Press, Manokwari, pp 189-200

The Society of Sago Palm Studies (2015) Abstracts of the 12th international sago symposium, Sago Palm 23 (1):4-57

Yamamoto Y (2010) Strategy for bio-fuel, community to world. Res Trop Agric 3:98-102. (in Japanese)

Yamamoto Y (2015) Studies on the productivity of starch accumulating palms in the tropics - miscellaneous palms. Abstract, Meeting of the Crop Science Society of Japan 239:56 (in Japanese)

Yamamoto Y, Omori K, Nitta Y et al (2007) Efficiency of starch extraction from the pith of sago palm: a case study of the traditional method in Tebing Tinggi Island, Riau, Indonesia. Sago Palm 15:9-15

Open Access This chapter is licensed under the terms of the Creative Commons Attribution 4.0 International License (http://creativecommons.org/licenses/by/4.0/), which permits use, sharing, adaptation, distribution and reproduction in any medium or format, as long as you give appropriate credit to the original author(s) and the source, provide a link to the Creative Commons license and indicate if changes were made.

The images or other third party material in this chapter are included in the chapter's Creative Commons license, unless indicated otherwise in a credit line to the material. If material is not included in the chapter's Creative Commons license and your intended use is not permitted by statutory regulation or exceeds the permitted use, you will need to obtain permission directly from the copyright holder.

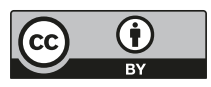




\section{Erratum: Addressing Food Insecurity in Papua New Guinea Through Food Safety and Sago Cropping}

Aisak G. Pue, Mary T. Fletcher, Barry Blaney, Andrew R. Greenhill, Jeffery M. Warner, Atagazli Latifa, and Jack C. Ng

\section{Erratum to:}

Chapter 9 in: (C) The Author(s) 2018

H. Ehara et al. (eds.), Sago Palm, https://doi.org/10.1007/978-981-10-5269-9_9

Co-author Jack M. Ng's middle initial was mentioned wrongly as "M" in the old version. The correct middle initial is " $\mathrm{C}$ ". This has been updated in this version as "Jack C. Ng". 